NEW

ZEALAND

PLANTS

AND

THEIR

STORY.

9s

torron. 



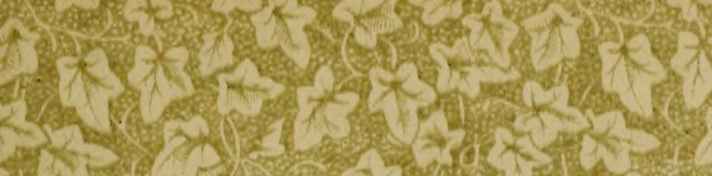

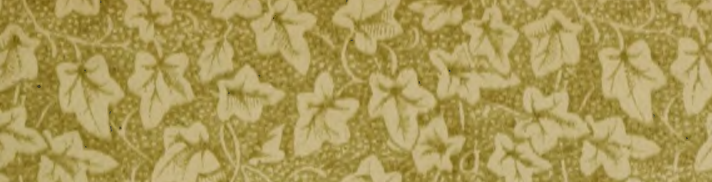

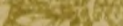

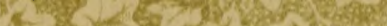

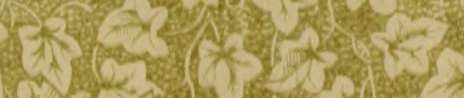

(2)

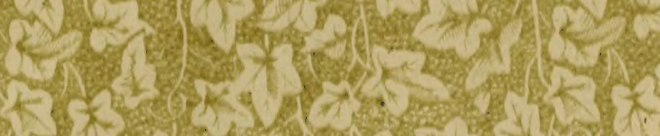

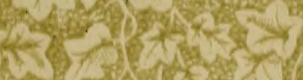

(1)

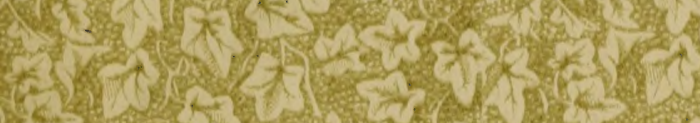

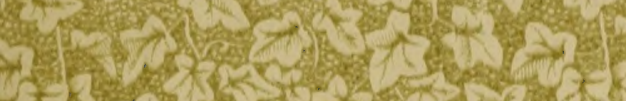

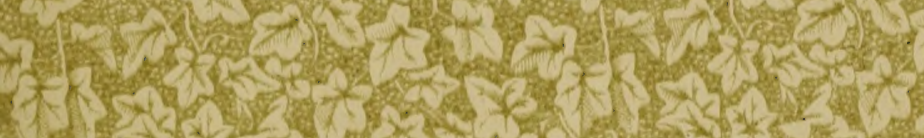

-4.

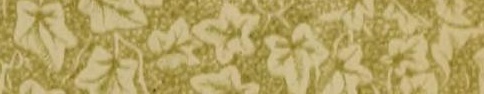

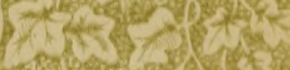

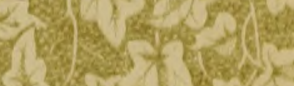

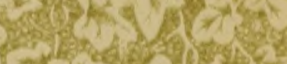
(1) (2)

(1) (F) a (f)

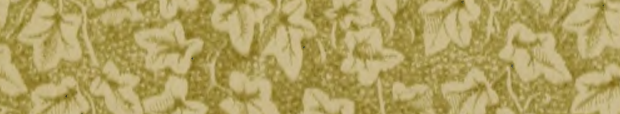
toly $x \rightarrow x^{2}$ (3)

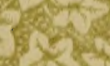

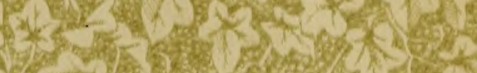

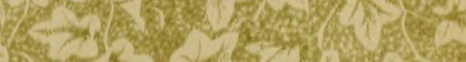

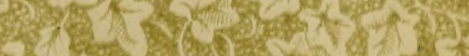

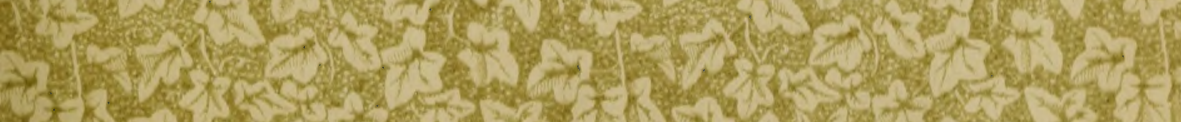

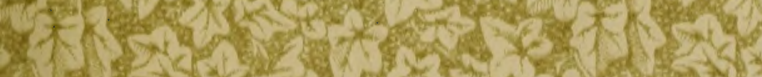
intore 18 A

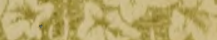

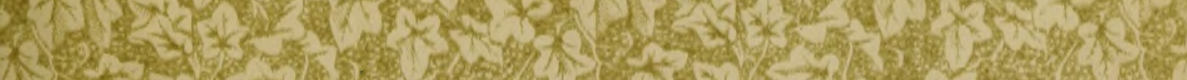

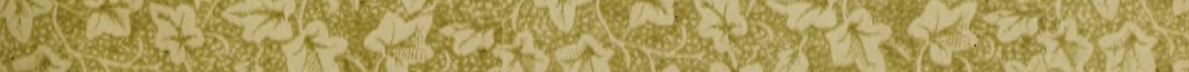

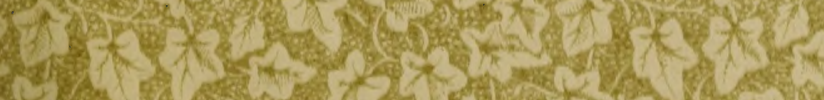






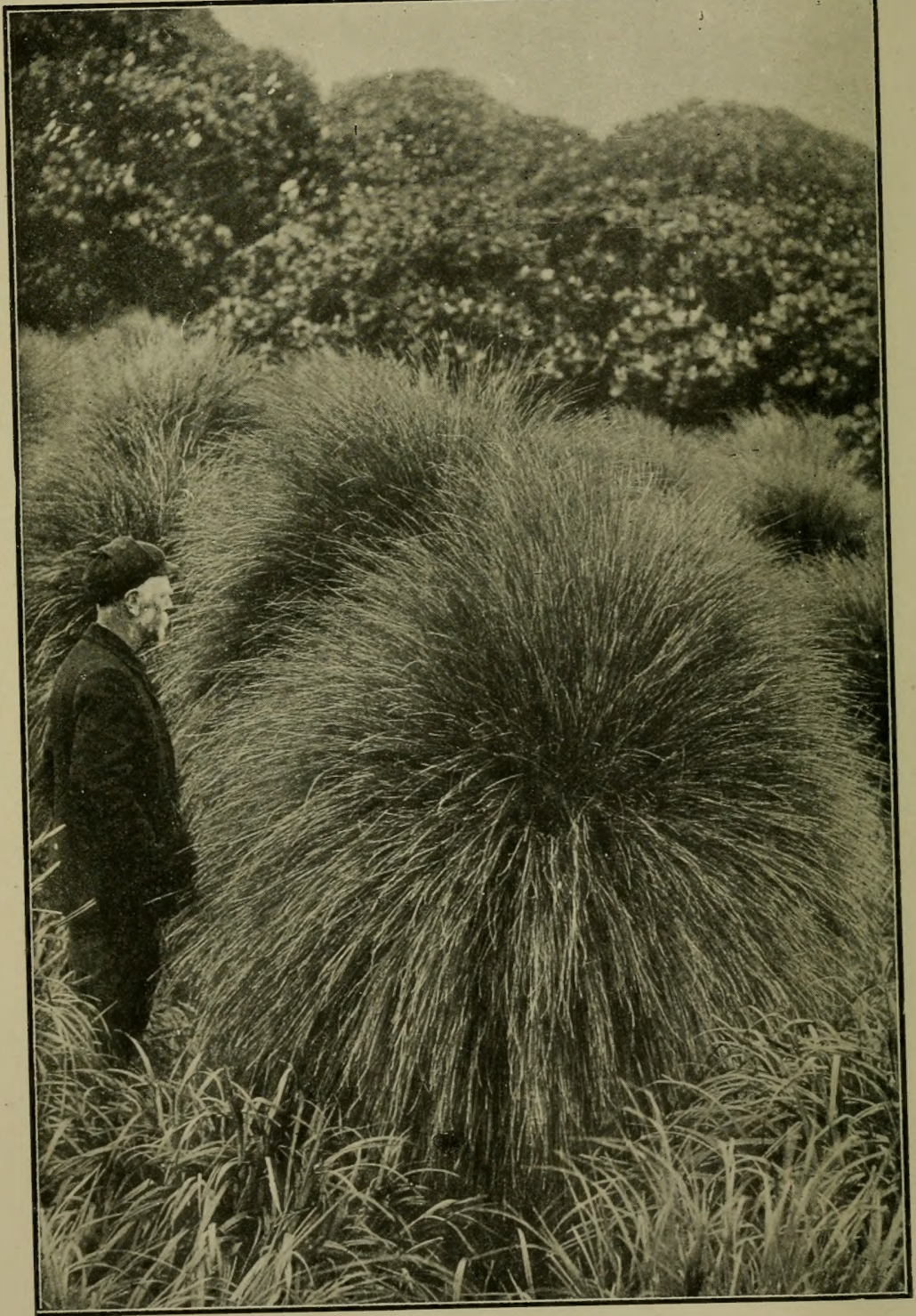
Tussocks of the subantaretic poa (Poa litorosa) growing in wet ground on the
outskirts of the Olearia Lyallii scrub-forest of Ewing Island (Lord Auckland Jslands).

Phil. Inst. Canterbury.]

[Photo, S. Page. 


\title{
NEW ZEALAND BOARD OF SCIENCE AND ART.
}

Manual No. 1.

\section{NEW ZEALAND PLANTS AND THEIR STORY.}

\author{
BY

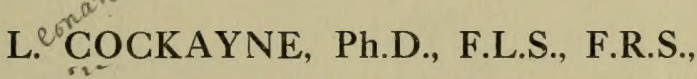

Corresponding Fellow Botanical Society of Edinburgh, President of the New Zealand Institute, Hector Memorial Medallist and Prizeman in Botany (N.Z. Inst.), Hutton Memorial Medallist (N.Z. Inst.).

Illustrated With 99 Photographs and 14 Text-Figures.

Published under the authority of the Hon. G. W. Russell, Minister of Internal Affairs.

SECOND EDITION, REWRITTEN AND ENLARGED.

\author{
LIBRARY \\ NEW YORK \\ BOTANICAL \\ GARDEN
}

WELLINGTON, N.Z. :

BY AUTHORITY : MARCUS F. MARKS, GOVERNMENT PRINTER. 
"The traveller, from whatever country, on arriving in New Zealand, finds himself surrounded by a vegetation that is almost wholly new to him, with little that is at first sight striking, except the Tree-fern and Cordyline of the northern parts, and nothing familiar, except possibly the Mangrove; and as he extends his investigations into the Flora, with the exception of Pomaderris and Leptospermum, he finds few forms that remind him of other countries."-J. D. HookER, "Flora Novae-Zelandiae," Vol. i; Introductory Essay; Nov., 1853. 


\section{PREFACE TO THE FIRST EDITION.}

THIS little book is based on a series of ten articles written by me for the Lyttelton Times, Dunedin Evening Star, and Auckland Star, which appeared during the months of April and May, 1907. To the above journals I here tender my hearty thanks for permission to reproduce those parts of the original articles that seemed suitable.

The text as it now appears has been changed in no small degree-much has been rewritten and amplified, and several additional chapters have been added, parts of two being founded on a paper I published originally in the Young Men's Magazine; while Chapter IX, dealing with introduced plants, is altogether new.

As for the book itself, it is the first attempt to deal with the plant-life of the New Zealand biological region as a whole on ecological lines. The subject is purposely treated in the most elementary manner; technicalities are studiously avoided as far as possible, the scientific names of the plants excepted, as the use of these is obviously unavoidable.

In the chapter dealing with the cultivation of New WZZealand plants special reference is made to school -gardens, for the guidance of such teachers as may use -this book.

W The subject-matter is, in part, the outcome of my $\mathbb{W}$ delightful wanderings for many years over the length and breadth of the Dominion, studying the while the 
plants as they grow naturally; but, on the other hand, I owe much to the writings of my predecessors and contemporaries, especially those of Sir Joseph Hooker, F.R.S., the late Mr. T. Kirk, F.L.S., and my friend Mr. T. F. Cheeseman, F.L.S., F.Z.S.

Besides the photographs taken personally, a few were generously given by Messrs. J. Crosby Smith, F.L.S., W. C. Davies, M. C. Gudex, M.A., F. G. Gibbs, M.A., J. J. Collins, A. Hamilton, and W. H. Field, M.P., and to these gentlemen my sincere thanks are due. I am also much indebted to Mr. W. C. Kensington, I.S.O., for permission to make use of any photographs published in my reports on botanical survey to the Department of Lands and Survey; and to the Philosophical Institute of Canterbury for the use of .three photographs from the important work just issued by that body on the Subantarctic Islands of New Zealand. My friend Professor C. Chilton, M.A., D.Sc., has most generously assisted me in revising the proofs, and I thank him most sincerely.

The book is published under the auspices of the Department of Education, and I gladly take this opportunity of thanking the Hon. G. Fowlds, Minister of Education, for having arranged for the publication of the work. My thanks are likewise due to Mr. W. E. Spencer, M.A., M.Sc., of the Education Department, who has rendered valuable assistance in various ways. Finally, it gives me much pleasure to express my obliga: tions to the Government Printer, Mr. John Mackay, and to the photographic branch of his Department.

Christchurch, 15th August, 1910. 


\section{PREFACE TO THE SECOND EDITION.}

The first edition of "New Zealand Plants and their Story" having been exhausted for some considerable time, and the insistent demand for a second edition by many interested in the wild plants of this country, has led to the book appearing under a new guise as the first of a series of Manuals to be published by the Board of Science and Art.

This second edition is virtually a new book. The subject-matter has been rearranged and so much additional information added that a far more connected account of the vegetation of New Zealand is presented than in the original work.

Although the first edition early on became a textbook in the University colleges, this fact need not in the least alarm the non-scientific reader, for whom the book is primarily prepared. On the contrary, the original popular style has been carefully maintained; technical terms, as before, are reduced to a minimum, and where used are explained, while the idea of the plants telling their own story is more strongly emphasized than in the first edition.

The number of photographs has been increased from seventy-one to ninety-nine, of which fifty did not appear in the original book, and there are fourteen new text-figures.

The reader will find certain statistics in some of the chapters. These figures I have not had an opportunity to carefully check, so some errors may have crept in. 
The book has been produced by direction of the Hon. G. W. Russell, Minister of Internal Affairs, to whom my warmest thanks are here recorded, not merely for his Ministerial sanction for its production, but for the kindly interest he has taken in its preparation and for his many important suggestions.

Let me take this opportunity of expressing my great obligation to the following gentlemen: Professor C. Chilton, D.Sc., C.M.Z.S., who assisted in reading the proofs and gave much welcome advice on certain topics; Mr. H. Baillie, who prepared the exhaustive indexa wearisome task-for which assistance I cannot be sufficiently grateful; Mr. Esmond Atkinson, who drew several excellent text-figures; Major A. A. Dorrien Smith, D.S.O., Messrs. B. C. Aston, F.I.C., E. Bruce Levy, and C. E. Christensen, and the Board of Governors of the New Zealand Institute, who supplied photographs or half-tone blocks.

Finally, I must record my thanks to the Government Printer for the eminently satisfactory manner in which the book has been produced, as also to his staff, especially to the Reader, whose critical reading of the proofspainstaking to the last degree-has been beyond praise.

Wellington, N.Z., 14th August, 1919. 


\section{TABLE OF CONTENTS.}

\section{CHAPTER I.}

\section{How the Plants have told their Story.}

How the plants are made to "tell their story"-Banks and SolanderBanks's love of natural history-The Forsters, father and son-Cook's second voyage-Why Banks did not accompany Cook-MenziesDumont D'Urville and Richard-“Essai d'une Flore de la Nouvelle Zélande" - - The Cunninghams and the plant-life of northern Auckland -Raoul, the French botanist-The Rev. William Colenso-Colenso's discovery of alpine plants on the Ruahine Mountains-The wonderful work of Sir Joseph Hooker-Darwin's remarks on Hooker's work-The botanical exploration of the Southern Alps-Sinclair, Bidwill, Haast, Hector, and Buchanan-Lyall, surgeon on the "Acheron "-The botanical exploration of the Chatham Islands by H. H. Travers and F. A. D. Cox -Modern New Zealand botany and Thomas Kirk-Cheeseman's " Manual of the New Zealand Flora"-D. Petrie and the flora of Otago-.The

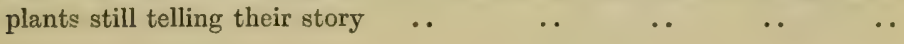

\section{CHAPTER II.}

Some Preliminary Considerations regarding Vegetation and Living Plants.

Special botanical interest of New Zealand-Changes wrought by the European settler-Explanation of the term "flora"-What is meant by the term "vegetation"-Definition of the expression "plant-community"-Some plant-communities of a farm-The plant-formation and the plantassociation-Explanation of the term "growth-form "- Some characteristic New Zealand growth-forms-More about growth-forms-Plasticity in plants-Effect of change in outer circumstances on the manukaStimuli and their effect in changing form - Natural changes in a plantcommunity - Topographical and biological succession-Climax and migratory formations-The struggle for existence-The growing-place of a plant-The meaning of the term "adaptation"-Adaptations with regard to the water-supply 
CHAPTER III.

The Flora and Vegetation of the Sea-coast.

General remarks-Statistics regarding the flora-Inland plants on the coast -Salt and succulence--The ice-plant and other succulents-Growthforms of coastal plants-Muehlenbechia Astoni-A coastal climbing-plant -Seaweeds-The sea-grasses-Sandy and rocky shores-Sandhills, their plants and plant-associations-Sand-binders - The spiny rolling-grassPlants of sand-hollows-The mangrove and its strange habits - Saltswamps-Salt-meadows-Peaty salt-meadow-Vegetation of rocks and cliffs - The pohutukawa-Phormium associations-Coastal shrubberiesCoastal forest-The kohekohe-The home of the tuatara and of a New Zealand frog-The wind-swept Open Bay Islands . . . . .

\section{CHAPTER IV.}

The Story of the Forests.

General remarks-Distribution of the forest-Composition of the forestTwo classes of forest-Special characteristics of rain-forest-The kohekohe-Origin of special forest-plants-Climbing-plants-ScramblersThe climbing-apparatus of the bush-lawyers-Root-climbers-The climbing-ratas - Climbing-ferns - Winding lianes-The mangemangeA leaf yards in length-Explanation of the term "spore"-Tendrilclimbers-The species of Clematis-Perching-plants-Seedling trees as perching-plants-Filmy ferns-The flowers of the forest-PollinationThe kauri forest-Life-history of a kauri forest-Mixed taxad forestWestland taxad forest-Kahikatea swamp-forest-Southern-beech forest -Lowland southern-beech forest-Identification of the southernbeeches

.

..

CHAPTER V.

Lowland Shrob-associations, Heath, and Rock Vegetation.

New Zealand shrubs in general--Relationship between the shrub form and the tree form-The ramarama-Persistent juvenile forms--Statistics regarding juvenile forms-The case of Pennantia-The behaviour of the kowhai-The pokaka, the mountain-currant, and koromikos in general -What experiment can do-The dwelling-places of the manuka-Manuka thicket-Tuberous-rooted orchids-Plants of the Auckland gumlandsThe pumice shrublands-The new vegetation after a volcanic eruption -Manuka thicket of the South Island- "Wind-scrub"-River-terrace scrub--Fern-heath-Rock-plants in general-Species common on rocks -Rock association of the East Cape Botanical District-The cliffs of the Wanganui River-The Olcaria insignis association-Rock association of Banks Peninsula-A remarkable case of plant-distribution 


\section{CHAPTER VI.}

\section{The Story of the Grasslands.}

General remarks-Samuel Butler's opinion of New Zealand flowers-Distribution of the grassland-Classification of the grassland-Composition and distribution of low tussock-grassland-The silver-tussock and hardtussock associations-Statistics regarding the growth-forms of low tussock-grassland-List of species of low tussock-grassland-The "stupid gentian"--Shrubs of the grassland-The dwarf brooms-The spaniard -Drought-resisting structure of many low tussock-grassland plantsEvolution of low tussock-grassland-Tall tussock-grassland-The growthform of the red-tussock-Appearance and constituents of certain tall tussock-grassland associations-The Danthonia australis associationTussock-grassland from the economic aspect-The question of burning -A valuable tall tussock

\section{CHAPTER VII.}

\section{The Flora and Vegetation of the High Mountains.}

General remarks-Statistics dealing with the alpine and lowland florasGenera peculiar to, or common in, the high mountains-Latitudinal distribution of the high-mountain flora--The alpine dwellers of $\mathrm{Te}$ Moehau-From Mount Hikurangi to Egmont and the Tararuas--Distribution in the South Island-The altitudinal belts of regetation and their limits-Conditions of life for the high-mountain plant inhabitants -Adaptations of the high-mountain plants-The flowers of the high mountains - The eyebrights, ourisias, buttercups, forget-me-nots, celmisias, and edelweiss-High-mountain rock plant-associations-The rock-veronicas-The vegetable-sheep-Assuciations of stony debrisA jet-black daisy-Fell-field-The coral-broom--Plants of the Mineral Belt-Herb-field-Flowers of Mount Egmont-The subalpine scrubShrubby veronicas and tree-daisies-High-mountain plants at sea-level -Winter coloration

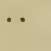

\section{CHAPTER VIII.}

\section{Plant-communties and Plants of Inland Waters, Swamps, AND Bogs.}

General remarks-The water-ferns-Azolla rubra-The pond-weeds-The water-milfoil-Changes in swamp wrought by man-Fresh-water algaeAlgae of hot-water springs-Definition of term "swamp"-Species and growth-forms of swamp-Conditions for plant-life in swamp-The root of Phormium tenax-Breathing-roots of the pukatea-Relations of swamp to other plant-formations-Vegetation of swamps-Swamp of Auckland - Special South Island swamp-plants-Bogs-Sphagnum moss and its peculiarities-Dryness of [sphagnum-cushions-Origin and distribution of bogs-Life-conditions for bog-plants-Growth-forms of bog-plantsThe species growing in bogs-Some bog associations-Sundews and bladderworts-The species of Gunnera-The false snow-grass (Schocnus pauciflorus) plant-association.

.




\section{CHAPTER IX.}

The Flora and Vegetation of the Outhying Islands.

A goblin forest-.The subantarctic flora-Composition of the subantarctic forest-Remnant of an ancient subantarctic tree-formation-Plants of the seashore-The splendid herbaceous plants-Subantarctic tussocks -Vegetation of Antipodes Island-Vegetation of Macquarie Island-A "wind-desert"-Vegetation of the Snares-A natural rotation of crops -The Bounty Islands-Flora of the Chatham Islands-The Chatham Island forest-Chatham Island bogs-The giant forget-me-not--Some interesting Chatham Island plants-Flora of the Kermadec IslandsLack of tropical species in the Kermadees-Plants peculiar to the group -Rock associations-Ngaio scrub-The two kinds of forest and their trees-The two tree-ferns-Luxuriance of New Zealand trees on the Kermadecs

$\cdots$

\section{CHAPTER X.}

\section{The Evolution of a New Flora and Vegetation.}

General remarks-Number of foreign plants growing wild in New ZealandOrigin of the plant aliens-Statistics regarding the families, genera, and species of the invaders - The comparative rareness of most introduced plants-No foreign plants in the primitive plant-formations-Classification of plant-associations at the present time-Names for the different classes of associations, and their definition-Subdivisions of the induced associations - Some modified associations - Modified grassland - Modified dune-hollows-Modified salt-meadow-Modified forest-Indigenous induced associations - Danthonia grassland-The depleted grassland of Central Otago-Rejuvenation of subalpine scrub-History of commercial phormium swamp-Other indigenuus induced associations -Adventitious associations - Tree, shrub, herb, and water associationsHakea on the gumlands-Origin of a gum-tree association-The foxglove spreading-Distribution according to habitat-Something about weeds ..

\section{$\begin{array}{ll}\because & \cdots \\ & \\ & \text { CHAPTER XI. }\end{array}$}

\section{The Classification of the Plants.}

Popular names of plants-English names and Maori names-Scientific names of plants-Some objections to the use of scientific names-Meaning of the term "species"-Little species-Aggregate species-Meaning of terms "genus" and "family"--The leading families and genera of the seed-plants - Seed-plants with only one seed-leaf-Plants with naked seeds-Ferns-Lycopodiaceae-Tmesipteris-Mosses and liverworts-Fungi-The black fungus of Nothofugus-Algae-BacteriaSlime-fungi 


\section{CHAPTER XII.}

The Distribution of the Plants in New Zealand.

General remarks-What the plants could tell of their wanderings - The botanical districts-The Three Kings Botanical District-The North and South Auckland Botanical Districts-The Volcanic Plateau Butanical District-The East Cape Botanical District-The Egmont-Wanganui Botanical District-The Ruahine-Cook Botanical District-Cook Strait no barrier to the wandering of plants-General considerations regarding distribution throughout the South Island-The North-western Botanical District-The North-eastern Botanical District-The Western Botanical District-The Eastern Botanical District-The North Otago Botanical District-The Fiord Botanical District-The South Otago Botanical District-The Stewart Botanical District-The botanical provincesHow plants travel long distances-Discontinuous distribution-Species known in only one locality

CHAPTER XIII.

The Affinities, Origin, and History of the Flord.

General remarks-Distribution of the kowhai-The endemic element of the New Zealand flora-Different degrees of endemism-The Australian element of the New Zealand flora-The Fuegian element of the New Zealand flora--List of species common to New Zealand and subantarctic South America-The Malayan element of the New Zealand flora-The European element of the New Zealand flora-The cosmopolitan element -Relation of the flora of Lord Howe and Norfolk Islands to that of New Zealand-The fossil fiora of Antarctica-The New Zealand Tertiary fossil flora-How plants change their form-The history of the New Zealand flora-The New Zealand glacial period _. _ . . 202

\section{APPENDIX.}

Differences in Nomenclatere of Plants cited in this Book from

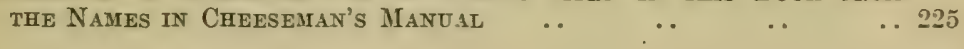

$\begin{array}{lllllllllll}\operatorname{INDEX} & \ldots & \ldots & \ldots & \ldots & \ldots & \ldots & \ldots & \ldots\end{array}$ 



\section{LIST OF ILLUSTRATIONS.}

Frontispiece-Tussocks of subantarctic poa (Poa litorosa).

Fig.

1. The mountain-lily (Ranunculus Lyallii).

2. The giant forget-me-not (Myosotidium nobile).

3. The pygmy pine (Dacrydium laxifolium).

4. The white clematis (Clematis indivisa).

5. The Rev. William Colenso, F.R.S.

6. Memorial to Sir Joseph Dalton Hooker, O.M., F.R.S., K.C.S.I.

7. Tree-ferns (Hemitelia Smithii).

8. Persistent juvenile form of the common kowhai.

9. Entanglement formed by the supplejack (Rhipogonum scandens).

10. The wild-irishman (Discaria toumatou).

11. Effect of wind and "sour" soil on the growth-form of the manuka (Leptospermum scoparium).

12. Stream undermining a migratory river-bed association.

13. Low tussock-grassland, a climax plant-formation.

14. The Australian glasswort (Salicornia australis).

15. The shrubby pohuehue (Muehlenbeckia Astoni).

16. Cushion form of the pohuehue (Muehlenbeckia complexa).

17. The sand-convolvulus (Calystegia Soldanella).

18. A wandering dune which has buried good agricultural land.

19. Natural fore-dune near Waikanae.

20. The erect breathing-roots of the mangrove (Avicennia officinalis).

21. A pohutukawa (Metrosideros tomentosa) growing as an erect bushy tree.

22. Flowering shoot of the teteaweka (Olearia angustifolia).

23. Interior of coastal scrub, Stewart Island.

24. Kohekohe (Dysoxylum spectabile) coastal forest.

25. Gully in a mountain southern-beech (Nothofagus cliffortioides) forest.

26. Lichens (species of Sticta).

27. The kahakaha (Astelia Solandri) growing on the vertical trunk of the taraire.

28. Climbing-stem of the semi-leafless lawyer (Rubus subpauperatus).

29. Rounded buttresses at base of trunk of a kahilsatea (Podocarpus dacrydiodes).

30. Roots of the broadleaf (Griselinia littoralis) descending from a young broad. leaf tree perched in the crown of a tall rimu (Dacrydium cupressinum).

31. Interior of the Waipoua Kauri Forest.

32. The giant moss (Dawsonia superba). "

33. Interior of a rain-forest, showing the abundance of ferns.

34. Taxad rain-forest of the Puketoi Range.

35. The prickly shield-fern (Polystichum vestitum).

36. Pahau-tea (Libocedrus Bidwillii) subalpine forest.

37. Moss cushion of Dicranoloma Billardieri. 
Fig.

38. The false mountain-holly (Olearia macrodonta).

39. Effect of cultivation in moist air of the common whipcord koromiko (Veronica lycopodioides).

40. Juvenile and adult leaf-forms of the mountain-wineberry (Aristotelia fruticosa).

41. Juvenile Coprosma retusa.

42. Two forms of leaf of the climbing hard-fern (Blechnum filiforme).

43. Parent tree of the double white manuka "Leonard Wilson."

44. New vegetation as in 1905 on the volcanic ash from the Tarawera eruption of 1886.

45. Portion of the rift on Mount Tarawera.

46. Vegetation of lower slopes of Mount Tarawera in 1913.

47. Bank of the long hard-fern (Blechnum capense).

48. Bank covered with the paritaniwha (Elatostema rugosum).

49. Senecio lagopus.

50. The hard-leaved tree-daisy (Olearia nummularifolia).

51. General view of a portion of low tussock-grassland.

52. Tall tussock-grassland.

53. Raoulia lutescens.

54. The green raoulia (Raoulia Haastii).

55. General view of the Rakaia River bed at an altitude of some 2,800 feet.

56. The spaniard (Aciphylla Colensoi).

57. Flowers of the North Island edelweiss (Leucogenes Leontopodium).

58. The alpine eyebright (Aciphylla Monroi).

59. Flowers of the North Island eyebright (Euphrasia tricolor).

60. Colony of the mountain-foxglove (Ourisia macrophylla).

61. The wet-rock koromiko (Veronica linifolia).

62. Flower-heads of the common cotton-plant (Celmisia spectabilis).

63. The white mountain-musk (Celmisia incana).

64. The common vegetable-sheep (Raoulia eximia).

65. Bringing specimens of the vegetable-sheep for the Christchurch International Exhibition of 1906-7.

66. The small vegetable-sheep (Raoulia bryoides).

67. The green vegetable-sheep (Raoulia rubra).

68. The penwiper-plant (Notothlaspi rosulatum).

69. Cushion of the North Island edelweiss (Leucogenes Leontopodium).

70. The mountain-cotula (Cotula pyrethrifolia).

71. Fell-field on scoria slopes of Mount Tongariro.

72. The false edelweiss (Helichrysum bellidioides).

73. Herb-field of Arthur's Pass, with Celmisia Armstrongii in abundance.

74. Boggy herb-field of Table Hill.

75. Portion of a cushion of Celmisia linearis.

76. Horizontal branching of Olearia Colensoi in subalpine scrub.

77. Adult and seedling of the coral-shrub (Helichrysum coralloides).

78. The giant spaniard (Aciphylla maxima).

79. Remains of an ancient swamp-forest.

80. Breathing-root of the pukatea (Laurelia novae-zelandiae). 
Fig.

81. The bog-cushion (Gaimiardia ciliata).

82. Close view of a piece of Stewart Island lowland bog.

83. View of a piece of false snow-grass (Schoenus pauciflorus) bog.

84. Subalpine bog on the Tararua Mountains.

85. Outskirts of Olearia Lyallii scrub-forest on the Snares.

86. The green tree-fern (Hemitelia Smithii) in the most southerly locality in the world for tree-ferns.

87. Penguin-rookery killing the vegetation of the Snares:

88. Herb-field of Adams Island.

89. Adventitious induced association of Eucalyptus numerosa.

90. Bush of the purple-flowered tree-daisy (Olearia semidentata).

91. The Kermadec tree-fern (Cyathea kermadecensis).

92. Moriori figure on the kopi-tree (Corynocarpus laevigata).

93. The mountain willow-herb (Epilobium chloraefolium).

94. Fruiting shoot of Cyathodes robusta.

95. The New Zealand violet (Viola Cunninghamii).

96. The small-leaved kohuhu (Pittosporum obcordatum).

97. The umbrella-fern (Gleichenia Cunninghamii).

98. The U-shaped Park Valley-a proof of former glaciation in the Tararua Mountains. 


\section{CORRECTIONS.}

On page 173 transpose that portion of lines 23 and 24 commencing with the word "concludes" and ending with the word "It" to line 10 of the same page. after "(Typhaceae)." Also, delete the word "the" in line 11, and the word "species" in line 12.

Paragraph 3 of page 173 as amended will read,-

"The raupo family (Typhaceae) concludes this abbreviated list of the families of New Zealand monocotyledons. It contains the genus Typha, which also is of high physiognomic importance, since it is characteristic of primeval swamp."

On pages 189 and 198, in addition to the localities mentioned, Angelica trifoliata is now known to occur near Lake Tennyson (North-eastern Botanical District).

On page 206, line 20, for 6 read 3 . 


\section{NEW ZEALAND PLANTS AND THEIR STORY.}

\section{CHAPTER I.}

\section{HOW THE PLANTS HAVE TOLD THEIR STORY.}

How the plants are made to "tell their story" - Banks and Solander-Banks's love of natural history-The Forsters, father and son-Cook's second voyage -Why Banks did not accompany C'ook-Menzies-Dumont D'Urville and Richard-"Essai d'une Flore de la Nouvelle Zélande "-The Cunninghams and the plant-life of northern Auckland-Raoul, the French botanist-The Rev. William Colenso-Colenso's discovery of alpine plants on the Ruahine Mountains-The wonderful work of Sir Joseph Hooker-Darwin's remarks on Hooker's work-The botanical exploration of the Southern Alps-Sinclair, Bidwill, Haast, Hector, and Buchanan-Lyall, surgeon on the "Acheron" - The botanical exploration of the Chatham Islands by $\mathbf{H}$. H. Travers and F. A. D. Cox-Modern New Zealand botany and Thomas Kirk-Cheeseman's "Nanual of the New Zealand Flora"-D. Petrie and the flora of OtagoThe plants still telling their story.

THe plants of any country, could they speak, would have not only a surpassingly wonderful story to tell, but one which, when applied, would profoundly modify the destiny of mankind. But they remain for ever silent, gracing the earth with their beauty and fragrance, and above all making it a place where man can exist, for without plants there would be neither man nor animals of any kind. Notwithstanding their silence, many ways have been devised to learn their secrets. First of all, they have been classified with something like completeness, and the all-necessary names given to their various groups of individuals. Much further than this have their interrogators gone-their relationship to one another has in many instances been made out; their habits have been more or less found out; with the aid of the microscope their minute structure has been revealed; their methods of reproduction and of growth have been laid bare; the communities which they form are now being eagerly investigated; 
their travels have been recorded; something even has been learnt of their position in the world in the dim past and of the remote ancestry of the present-day plants, for the commonest weed is no parvenu. Much more could be said regarding what in the mass is known of their story.

Notwithstanding all the above, the story is full of gaps-indeed, there is infinitely more lacking than is known. Only a portion of a chapter here and there is available. The beginning, the end, and much of the middle is wanting. A good deal is mere guesswork; only a little is truth without suspicion. If all this applies to the plants of the Old World, how much less have the plants of our own land told us! For the plant-historians here, and the plantquestioners, have been but few in number; nor at any time have they been properly equipped for their work, either with books, instruments, or the all-important money. But, as will be seen, they were furnished with what is better than all-love for their self-appointed tasks and true enthusiasm, armed with which success is certain. And surely that enthusiasm was fully justified, for the flora of New Zealand is remarkable enough-nay, "remarkable" is too weak a word for a plant population which can boast of including amongst its members the largest buttercup in the world (fig. 1), a forget-me-not with leaves as big as those of rhubarb (fig. 2), a speedwell 40 feet in height, the smallest member of the pine-tree family (fig. 3), tree-like daisies, arborescent lilies, plants of the carrot family with stiff leaves sharp as bayonets, mosses more than a foot tall (fig. 32), a brown seaweed hundreds of feet in length, and those strange anomalies of the plant-world, the vegetable-sheep (fig. 64).

Now, though the plants of New Zealand are of long descent, and, if this counts for anything, rank amongst the aristocracy of the vegetable kingdom, their first historians became acquainted with them only 149 years ago.

Sir Joseph Banks and Dr. Daniel Charles Solander, during the month of October, 1769, found themselves in a new world, whose plant-life was all strange, and where every tree and shrub and herb was a fresh surprise and a great joy. And yet for ages before these intrepid naturalists had ventured forth, and for ages, likewise, before the remote ancestors of the Maoris had completed their most perilous voyage, year by year unseen the alpine herb-fields of the Southern Alps had decked themselves with a wealth of flowers, 
the pohutukawas of the northern cliffs had been each summer a crimson glory, and at the margin of the swamps the lurid blossoms of the flax had attracted countless bell-birds and tuis with their nectar.

Even from boyhood Banks had shown much taste for natural history. The story goes that, walking along an English lane gay with wild flowers, he exclaimed, "How beautiful! It is surely more natural that I should be taught to know all these productions of nature in preference to Latin and Greek!" From that time onwards natural science was his occupation, and during a long lifetime he devoted his wealth and energies to its advancement. Thus it was that, at his own expense, he presided over the natural-history investigations of Captain Cook's ever-famous first voyage, accompanying that illustrious navigator, and taking as his colleague Dr. Solander, as well as several assistants.

Banks and Solander, whose names are always bracketed together in New Zealand botany, investigated only a comparatively few places on the coast. These were: Queen Charlotte Sound and Admiralty Bay, in the South Island; and, in the North Island, Poverty Bay, Tolaga Bay, Anaura, Mercury Bay, the Thames River (near its mouth), and the Bay of Islands. They collected in all 360 species of seedplants and ferns, a remarkably large collection considering the difficulties they had to encounter-a land without roads, and Natives who at any moment might prove hostile. One of their "finds" deserves a passing word. This is the beautiful shrubby groundsel (Senecio perdicioides), which they collected at Tolaga Bay, but of which no other specimens were gathered for more than a hundred years. But now, since its rediscovery some time ago, it has been introduced into cultivation, and may be admired in many gardens.

Banks caused about two hundred fine folio copperplate engravings to be prepared, and descriptions of more than three hundred plants were written by Solander. Plates and descriptions both are preserved in the British Museum, but, marvellous to relate, they have never been published !

Sir Joseph Banks's explorations in the vast unknown lands of the south spurred him on to fresh exertions. He accordingly made arrangements to join Cook's second voyage, which was to leave England in 1772, the Government accepting his services, as well it might. So extensive were the preparations he made that, his wealth 
notwithstanding, he was obliged to specially raise money to meet the expenses. He engaged, so we read, "Zoffany the painter, three draughtsmen, two secretaries, and nine servants acquainted with the nodes of preserving animals and plants." The Comptroller of the Navy, however, succeeded in putting so many obstacles in Banks's way that he withdrew in disgust from the project. Notwithstanding all this, Banks, to his everlasting credit, took great interest in the new adventure, and succeeded in getting Dr. John Reinold Forster, a man said to have been possessed "of vast information in natural science, philosophy, and general literature," and his son John George appointed naturalists to the expedition.

This second voyage of Captain Cook was of special interest to the botany of New Zealand, since a portion of the real South Island vegetation was investigated for the first time, for that of Queen Charlotte Sound, examined by Banks and Solander on the previous voyage, has closer affinities with that of the North Island. A lengthy stay was made at Dusky Sound in 1773, and Queen Charlotte Sound was revisited. Only 160 ferns and seed-plants were collected, a small gathering for areas so rich in plant-life as the area near the Marlborough Sounds and the western fiords of Otago.

The remains of Captain Cook's hut at Dusky Sound still stand, and the spot was visited by the author some years ago. There nature is exactly as it was at the time of Cook's visit. The same rich shrubbery marks the shore; kidney-ferns now, as then, clothe the forest-floor and climb up the southern-beech and taxad trees, from whose boughs, too, depend the long dark-green shoots of the pendulous club-moss (Lycopodium Billardieri).

The elder Forster published an account of some of the plants in a work bearing the ponderous title, "Characteres Generum Plantarum quas in insulis Maris Australis collegit. J. R. Forster." This was followed by a work by the son, "Florulae Insularum Australium Prodromus," a small book of 103 pages which gives descriptions in Latin of about 170 New Zealand plants; but these descriptions are altogether too short to be of any real use.

Forstera, a small group of pretty alpine plants, keeps the name of the two Forsters green for New Zealand botanists.

In 1791, Captain Vancouver, of Arctic fame, visited Dusky Sound, and in the dripping forests Mr. Archibald Menzies, the surgeon of the expedition, reaped an abundant harvest of the lower plants, 
the mosses and liverworts, which there grow in the richest profusion. Many of these are beautifully figured in Sir W. J. Hooker's fine work, "Musci Exotici," which appeared in 1818-20. For twenty-seven years to have elapsed between the collecting and publishing of these plants speaks volumes for the leisurely methods pursued by scientific men a hundred years ago as contrasted with the haste of the present day.

And now the French come into our story, for science is cosmopolitan. In 1824, Lieutenant Dumont D'Urville and René Primeverre Lesson, of the corvette "Coquille," collected plants at the Bay of Islands. With what enthusiasm Lesson set out on his adventurous voyage may be gathered from his words: "Un voyage autour du monde!!! ces mots magiques ébranlent toutes mes idées: le vou le plus ardent de mon cœur est done accompli!"* Three rears later D'Urville, then captain of the same ressel, which had been renamed the "Astrolabe," occupied himself on the shores of Cook Strait in making collections, again in company with René Primeverre Lesson, the naturalist. The plants they gathered were described by Achille Richard in a sterling work bearing the title, "Essai d'une Flore de la Nouvelle Zélande." So well did Richard perform his task that the book is a necessary adjunct to the library of any New Zealand botanist at the present day, especially as it deals also with the Forster collection and so clears up certain points left in considerable doubt by those workers. The names of $\mathrm{D}^{\circ} \mathrm{Urville}$, Lesson, and Richard remain embalmed in the New Zealand flora in Rapanea Urvillei, Pseudopanax Lessonii, and Polystichum Richardi; while D'Urville Island, the French Pass, and Astrolabe Harbour tell of this important expedition.

Allan Cunningham, His Majesty's Botanist, of New South Wales, who must not be confused with his namesake the Scottish poet, visited New Zealand in 1826. The scene of his labours was the Bay of Islands and the district adjacent. Cunningham, accompanied by the Natives, spent some five months collecting plants while wandering through those virgin kauri forests, so soon to be destroyed. In 1833 his ill-fated brother Richard $\dagger$ proceeded to New Zealand in

* A voyage round the world!!! these magic words disturb all my thoughts: the most ardent wish of my heart is fulfilled! (Opening words of "Voyage autour du Monde," 1839, by René Primeverre Lesson.)

t He was botanist to Mitchell's expedition to the interiur of New South Wales in 1835, and, getting separated from the party, was lilled ly the Natives. 
H.M.S. "Buffalo," presumably to assist in procuring spars for maintopmasts. This duty performed, Richard Cunningham left the ship at Whangaroa, remaining alone, solely in the interests of science, according to his biographer, "on the shores of a harbour densely inhabited by savages, who had but a few years before massacred the crew of the ship 'Boyd,' and more recently had seized upon the houses and property of the Wesleyan missionaries, who, after much fatigue, privation, and insult, had effected a settlement among them." But, as luck would have it, the Maoris remembered his brother Allan, with whom they had been on most friendly terms, and so they welcomed the venturous botanist, and assisted him to the utmost of their power.

The two Cunninghams found many "new" plants-i.e., such as had not been described in any publication. These, together with a description of the other known New Zealand plants, were published by Allan Cunningham in his "Florae Insularum Novae Zelandiae Praecursor; or, A Specimen of the Botany of the Islands of New Zealand "-an important work containing valuable details as to the actual stations of the plants, indispensable information so frequently not given by many authors.

The visit of the French to Akaroa in 1840, and the settlement in that town and its vicinity of a number of colonists of that great nation, are matters of general history. Less well known is the fact that accompanying the expedition was an enthusiastic botanist, Raoul by name, the surgeon of the corvette "L'Allier." He collected most thoroughly the plants of Banks Peninsula, and also those of the Bay of Islands. His services to New Zealand science have a fitting monument in the name of that genus of most interesting plants, Raoulia (figs. 53, 54), bestowed on them in his honour by Sir Joseph Hooker. Raoul's results were published in a splendid work, written by himself, and illustrated with fine plates, entitled "Choix de Plantes de la Nouvelle Zélande." One of the species, Pittosponum obcordatum, a curious small tree, discovered by Raoul in the neighbourhood of Akaroa, has not been found there since his visit, but some fourteen years ago a few trees were discovered near Kaitaia, in northern Auckland (fig. 96). Most likely the species has long been exterminated on Banks Peninsula, where probably it was not common, while most of the Kaitaia trees have been cut down, so that possibly the example figured in this book is the sole survivor; if so, it must be the rarest wild plant in the world! 
Six years before Raoul's visit, the Rev. William Colenso (fig. 5), then a young man of twenty-three, landed at the Bay of Islands, and from that time on, for a space of sixty-five years, he was a most ardent investigator in ethnology, the Maori tongue, zoology, and botany. This last alone is of moment here.

As a missionary amongst the Natives in the very early days of the colony, Colenso travelled much in the wilds, and was brought face to face with nature. He collected most industriously plants of all kinds, sending them in large quantities to Kew. Before Colenso's explorations comparatively little was known regarding the alpine vegetation, which is, perhaps, in more ways than one, the most interesting of all. Enduring considerable hardships, in company with several Maoris he crossed over the Ruahine Mountains, being the first European to accomplish this feat. On the summit the alpine vegetation in all its beauty met his delighted gaze. But here are the explorer's own words: "When we emerged from the forest and the tangled shrubbery at its outskirts on to the open dell-like land just before we gained the summit, the lovely appearance of so many and varied beautiful and novel wild plants and flowers richly repaid me the toil of the journey and ascent, for never did I behold at one time in New Zealand such a profusion of I'lora's stores. In one word, I was overwhelmed with astonishment, and stood looking with all my eyes, greedily devouring and drinking in the enchanting scene before me. . . Here were plants of the well-known genera of the bluebells and buttercups, gowans and daisies, eyebrights and speedwells of one's native land, closely intermixed with the gentians of the European Alps and the rarer southern and little-known novelties-Drapetes, Ourisia, Cyathodes, Abrotanella, and Raoulia."

Further on, sentiment exhausted, the naturalist sought the practical. "But how was I to carry off specimens of these precious prizes, and had I time to gather them? These mental pictures completely staggered me, for I realized my position well. We had left our encampment that morning, taking nothing with us, so we were all empty-handed, and no New Zealand flax grew there. However, as I had no time to lose, I first pulled off my jacket, a small travelling-coat, and made a bag of that, and then, driven hy. necessity, I added thereto my shirt, and by tying the neck, \& (', $^{\circ}$ got an excellent bag; whilst some specimens I also stowed in th: crown of my hat." 
Colenso's botanical writings are voluminous, and consist chiefly of papers published in the "Transactions of the New Zealand Institute," dealing with new species of plants, or what he considered to be new. Nany New Zealand plants were named in his honour, including the genus Colensoa.

Sir Joseph Hooker was botanist to that famous Antarctic Expedition which left England in 1839 under the command of Sir James Ross. So far as the Dominion is concerned, Hooker visited the Lord Auckland and Campbell Islands, and also the Bay of Islands, where he and Colenso met. He published his splendid results in several magnificent volumes, as a part of the botany of the Antaretic voyage, with lifelike coloured plates, under the titles "Flora NovaeZelandiae" and "Flora Antarctica."

Hooker's work as a field naturalist in the subantarctic islands was most thorough. Only one who has been to that place of wind and rain, and has attempted to make a botanical collection, can appreciate the completeness of his collections, and marvel at the immense amount of work accomplished in so brief a time.

But Hooker's labours on the New Zealand flora do not end here. By an arrangement with the New Zealand Government he wrote the classical "Handbook of the New Zealand Flora," published in 1864-67, which deals not only with the seed-plants, but with the ferns, mosses, liverworts, fungi, and seaweeds. This was no mere reproduction of his former works, for many New Zealand collectors, as detailed in this chapter, had been hard at work, and a vast quantity of fresh material awaited examination. Indeed, the task was of no small magnitude, and when the remarkable accuracy of the descriptions is considered it is hard to believe the fact that they were drawn up from dried plants alone. Assuredly, well might Darwin exclaim, "Oh, my heavens! to get up at second hand a New Zealand flora--that is work!" How original the treatment was is shown by the fact that sixteen endemic genera and half the species had no botanical names until Hooker described them.

The great botanist died in 1911. He had seen almost the beginning of New Zealand botany. He himself had laid truly and well an enduring foundation; during more than seventy years he had watched the building rise, until at the time of his lamented death he saw it well advanced, and its labourers men either 


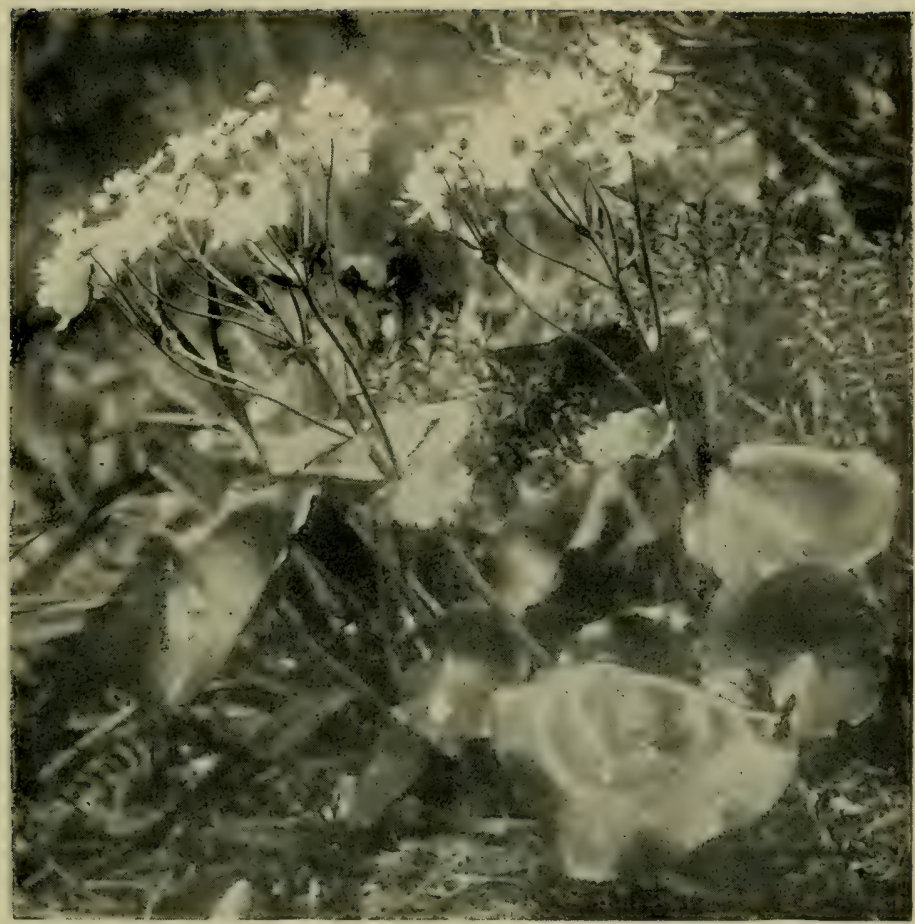

Fig. 1.-The mountain-lily (Ranunculus Lyallii), the largest buttercup in the world, growing at outskirts of subalpine scrub at head of the Otira Gorge (Westland).

[Photo, L. Cockayne.

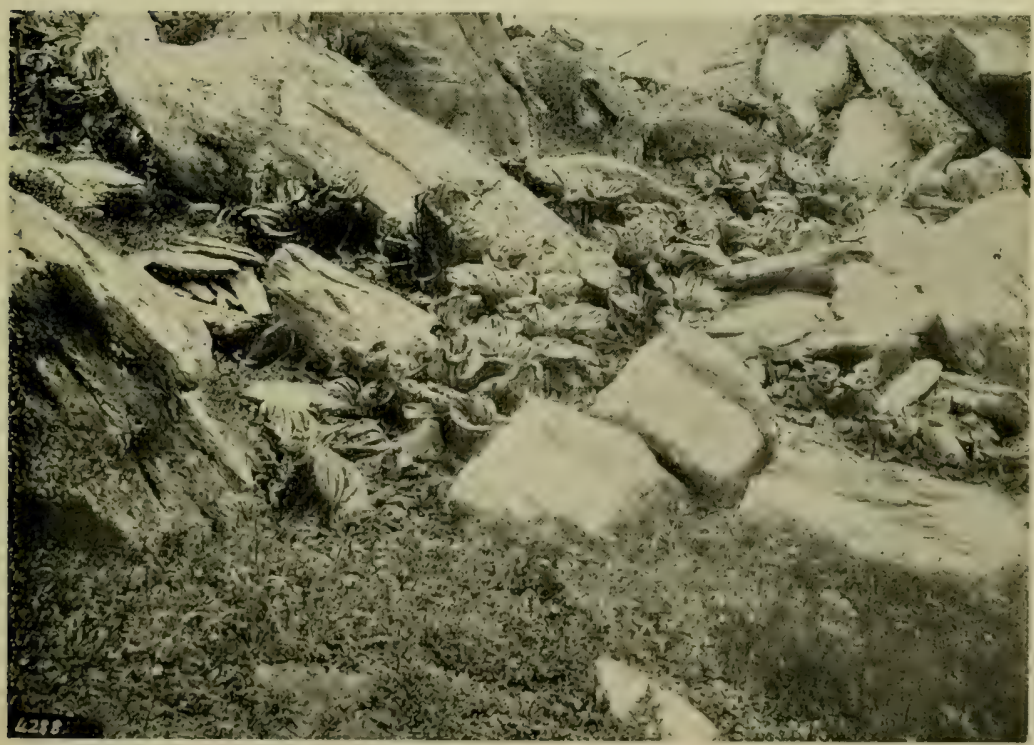

FIG. 2.-The giant forget-me-not (Mynsotilium unbile), growing on the rock coast of the north-east corner of Chatham Island. 


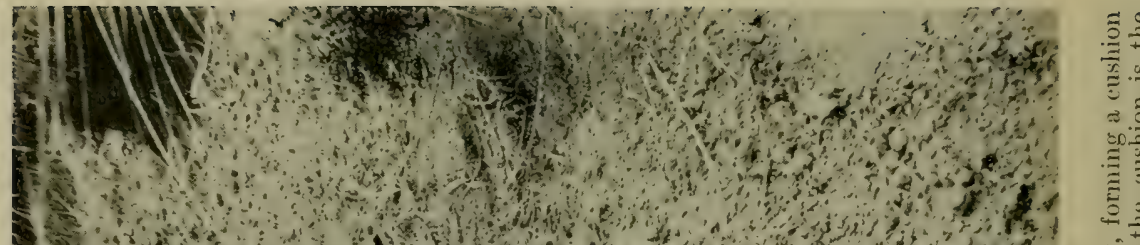

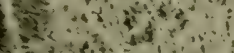
20

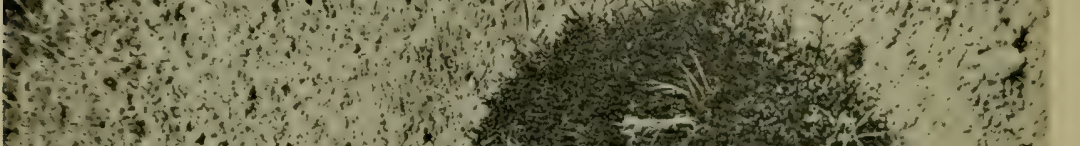
St iv 50 s.

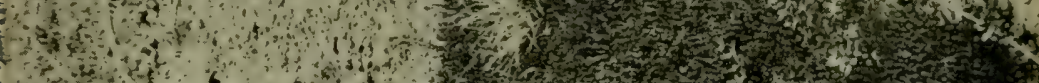

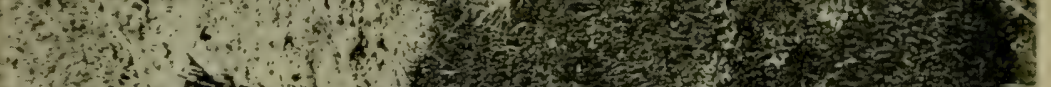

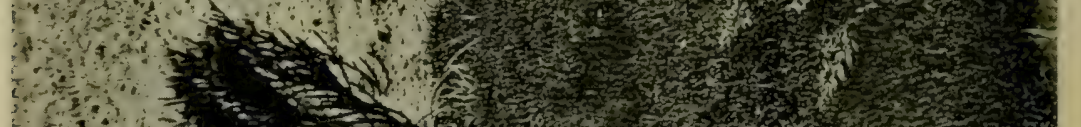

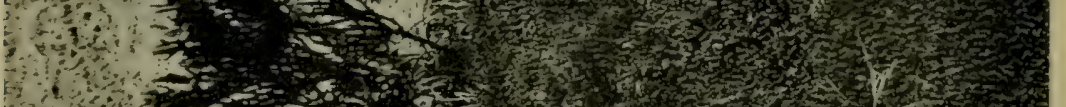
1

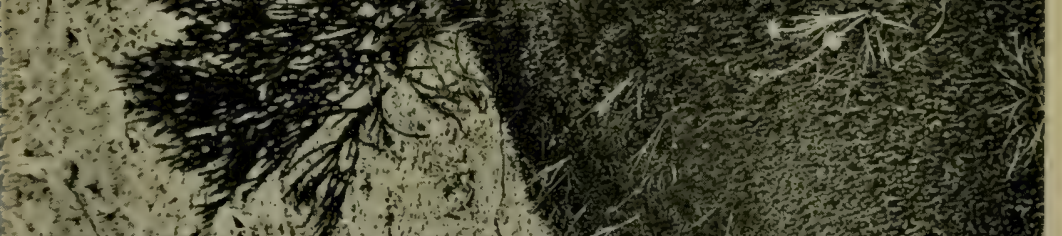

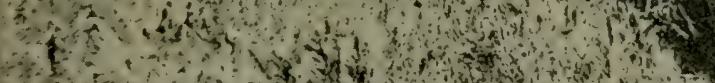

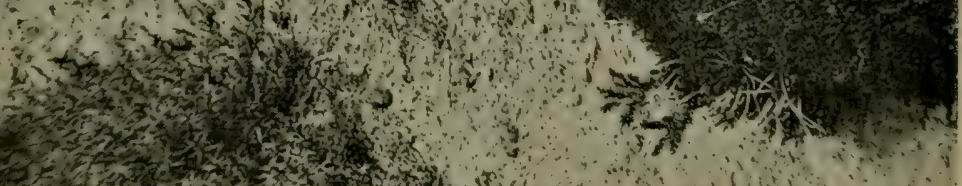

(1)

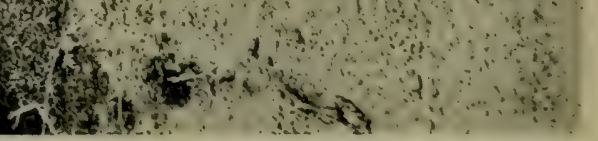




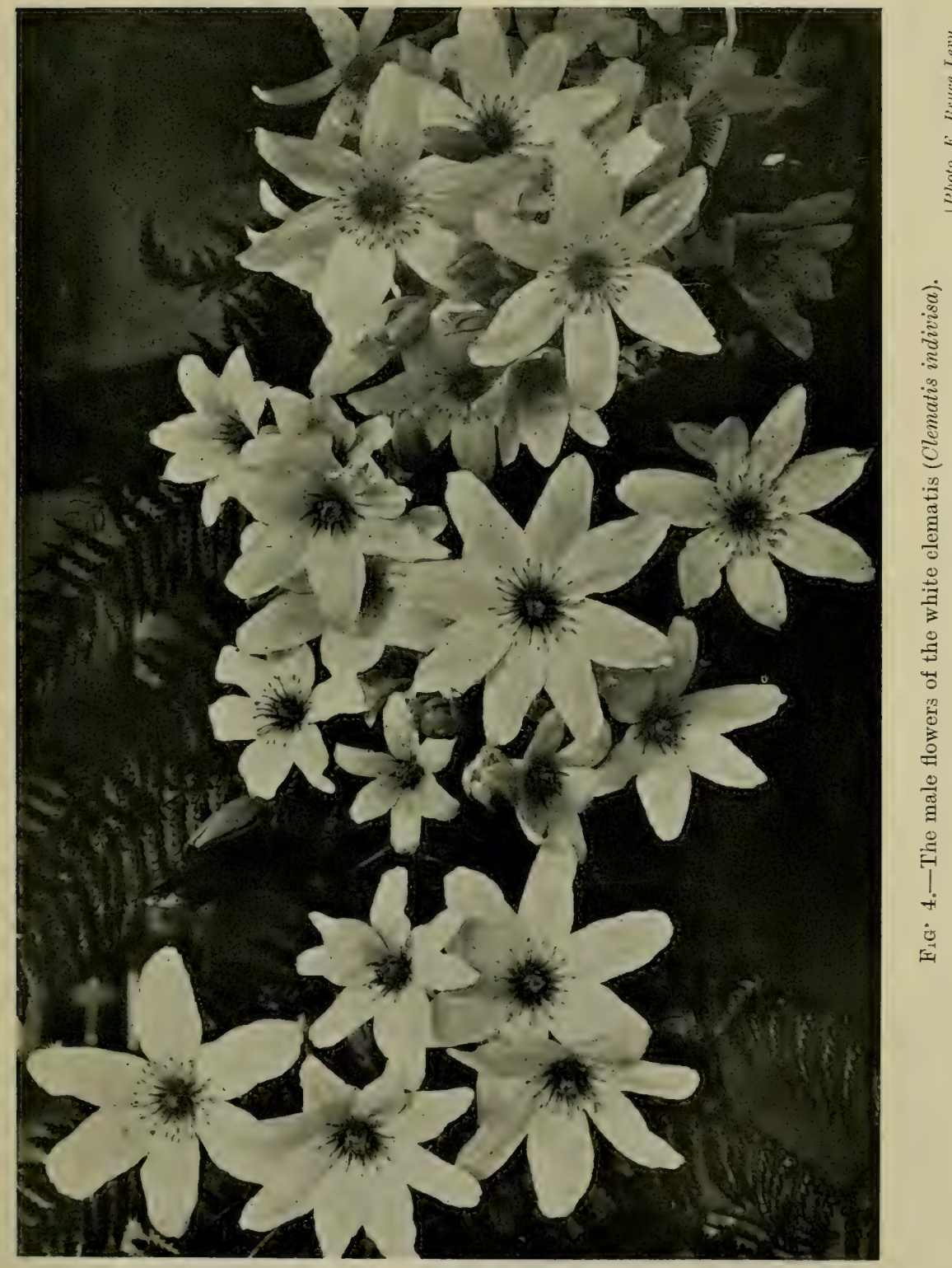




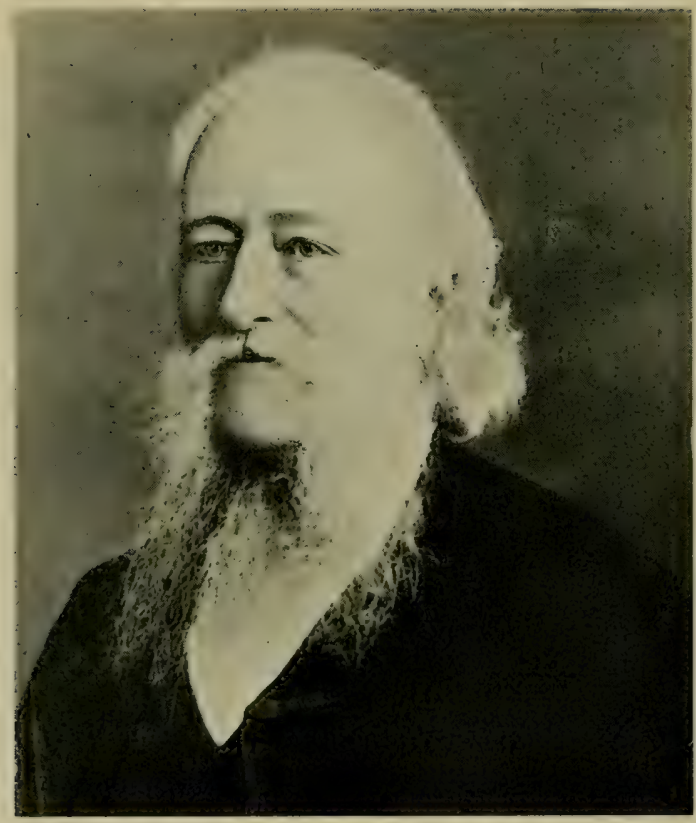

Fif, 5,-The Rev. William Colenso, F.R.S., the most celebrated New Zealand botanical explorer.

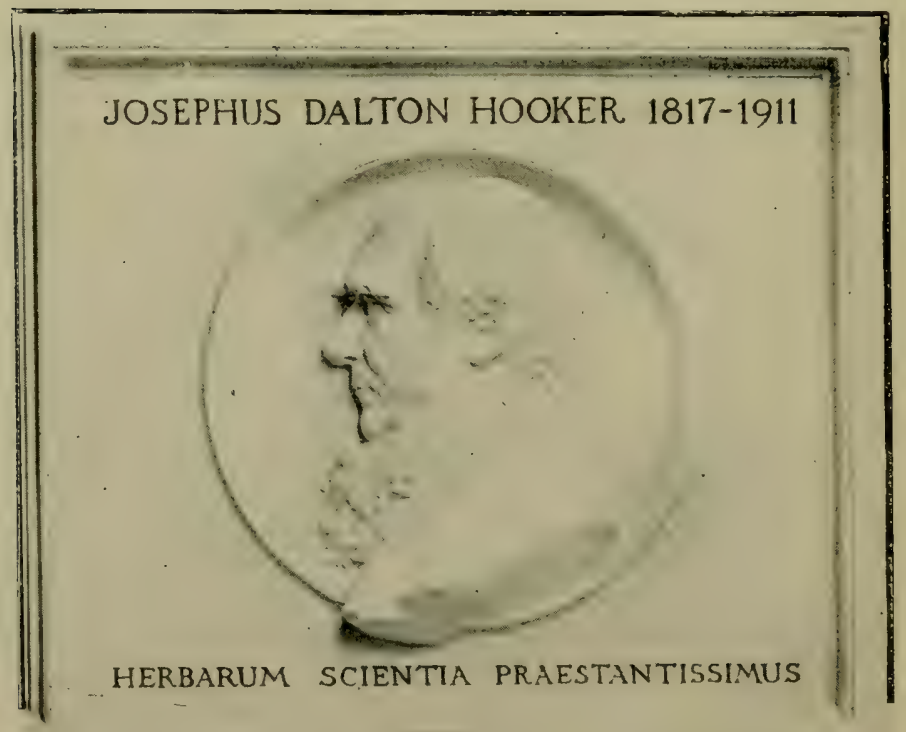

Fir. 6.-The memorial to Sir Joseph Dalton Hooker, O.M., F.R.S., K.C.S.I., in Westminster Abbey. 
New-Zealand-born or who for many years had made that land their home. To many of these men he was a friend, a guide, a counsellor. There is, indeed, no worker of real moment in the later botanical investigation of New Zealand but is deeply indebted to Hooker's influence and assistance, generously given.

The effigy of Hooker shown in this book (fig. 6) is a photograph of his memorial in Westminster Abbey, regarding which Leonard Huxley writes as follows:-

"Kew has his personal memory, but Westminster Abbey enshrines another memorial for the nation. . . . It is of marble, a profile medallion in ligh relief, slightly over life-size

a presentment of him in old age, at once strongly conceived and delicately executed; in form and expression admirably lifelike, save in the small point that the exigencies of sculpture demand a greater fullness of beard than he habitually wore. It is placed in the north aisle of the nave, where the Abbey honours modern science. Here is the Darwin memorial, erected some thirty years before; then a group of men famous beyond their own generation; last the memorial of Hooker himself. But though this group includes other contemporaries and friends of his, the understanding eye overleaps them, and sees closest in commemoration, as closest in affection, those lifelong fellow-workers."

The work of David Lyall must not be omitted. In 1847-49, when surgeon to the survey ship "Acheron," he made large collections on the New Zealand coast, paying especial attention to the lower plants. It is a remarkable fact that a plant originally discovered by him, and extremely plentiful on the shores of Foveaux Strait, Euphrasia repens, is very poorly represented in herbaria. The genus Lyallia, of Kerguelen Land, was founded in his honour; but to New Zealand botany his name is better known through the magnificent buttercup Ranunculus Lyallii.

Between the publication of the "Flora Novae-Zelandiae" and the "Handbook of the New Zealand Flora" many important botanical explorations were undertaken in New Zealand, and the alpine flora of the South Island stood especially revealed in all its richness. This result was brought about in large measure by the labours of Dr. Andrew Sinclair, R.N., Mr. J. C. Bidwill, Sir David Monro, Mr. W. T. L. Travers, Sir Julius von Haast, Sir James Hector, and Mr. John Buchanan. Other collectors and botanists also did 
excellent work not only in the alpine belt, but in other parts of the region; but space forbids further details, with the exception of mentioning the work of Dr. Lauder Lindsay, who botanized in eastern Otago, and published a most interesting account of that area.

Dr. Sinclair collected plants in various parts of the North Island and in the mountains of Nelson. He was associated with Haast in an exploration of the Rangitata, but was drowned in attempting to ford its treacherous waters. "Near the banks of the river, just where it emerges from the Alps, with the perpetual snowfields glistening in the sun, amidst veronicas and senecios, and covered with celmisias and gentians, there lies his lonely grave," writes Haast. Sir Joseph Hooker considered Sinclair as second only to Colenso as a botanical explorer, which is indeed high praise

Mr. Bidwill's explorations began so early as 1839. He made the first collection of alpine plants in New Zealand, in what is now the Tongariro National Park and its environs, and an interesting account of his travels appears in his little book, "Rambles in New Zealand," which was published in 1841. Forstera Bidwillii and other plants bear his name.

The extremely interesting mountains of Nelson, whose flora differs in many respects from that of the dividing range farther south, and has some affinity with that of the North Island mountains, were explored, independently of one another, by Monro and Travers, and also by Bidwill, each adding considerably to our knowledge of the species of the alpine seed-plants. The name of Monro is seen in many species of plants (e.g., Celmisia Monroi), and after Travers was called the genus Traversia, which by some is now merged in Senecio.

Sir Julius von Haast first made known the alpine flora of Canterbury, and, in part, of Westland, which is still largely a terra incognita, making every use of his opportunities as Provincial (ieologist. According to Hooker, he contributed more new species to the flora than any collector since Colenso. The name of a genus, II aastia, is a slight tribute to his exertions. As Cheeseman states, Haast's botanical results "cast a flood of light on the nature and distribution of the alpine flora."

Farther south, Sir James Hector and Mr. John Buchanan performed a large amount of careful and arduous work, and collected for the first time the alpine plants of the Fiord Botanical District. 
Buchanan also published many observations on botanical matters, and wrote a work on the grasses of New Zealand, in which lifesize figures of all the species of that family, as then known, are given. He also paid a short visit to Campbell Island.

In 1863 Mr. Henry H. Travers, who is still an industrious collector of New Zealand plants, made a botanical exploration of the Chatham Islands, the flora of which was unknown, save for a few species collected in 1840 by Dieffenbach. Travers, who stayed some months on the islands, with Pitt Island as his headquarters, made a most valuable collection of the plants. This was examined by Baron von Mueller, who published the results in his "Vegetation of the Chatham Islands" (1861). Mr. F. A. D. Cox, who resided in Chatham Island for many years, spent much of his leisure in studying the plants of that island, and brought to light many new facts regarding their distribution and habits. He also collecterl assiduously, sending much valuable material to Kirk, Cheeseman, and the author. In his honour Cheeseman founded the genus Coxella.

The publication of Hooker's Handbook brings us to what may be called the modern stage of New Zealand botany. Here the late Mr. Thomas Kirk and Mr. T. F. Cheeseman stand foremost. For many years Kirk held the position of leader of botanical thought in New Zealand. He was not only an industrious collector, visiting many parts of both Islands of New Zealand as well as the subantarctic islands, but a prolific writer, as is proved by the 140 papers to his credit in the "Transactions of the New Zealand Institute," to say nothing of publications elsewhere. He also wrote the "Forest Flora of New Zealand," which is the classic so far as New Zealand trees are concerned. At the time of his lamented death he was engaged on a new Flora of New Zealand, which, to the great loss of science, he did not live to complete. Fortunately, one-half was finished, and, although it lacked the correcting hand of its author, it will stand as one of the foremost publications on New Zealand floristic botany.

Mr. T. F. Cheeseman's botanical researches began in the early "seventies" of the last century, his first paper being published in 1873. Since that time he has been a most ardent and successful investigator of the New Zealand flora. Were his shorter papers alone to be considered he would always rank as one of the Dominion's foremost botanists. But in 1906 his "Manual of the 
New Zealand Flora" appeared, which at once stamped him as one of the foremost floristic botanists of the day. This work, like Hooker's "Flora Novae-Zelandiae," the Handbook, and Kirk's Forest Flora, is one of New Zealand's botanical milestones, and no milestone has ever urged more strenuous endeavour to those weary with journeying on the botanical path. Later, Cheeseman has published two fine volumes, entitled "Illustrations of the New Zealand Flora," giving beautiful figures together with semi-popular descriptions of typical plants. Finally, not the least important of his works is a philosophical essay dealing with the New Zealand subantarctic flora, the most valuable publication in the domain of New Zealand floristic plant-geography that has appeared since Hooker's classical essay in the "Flora Novae-Zelandiae."

Another worker, still full of activity, whose work must not be overlooked, is Mr. Donald Petrie. The flora of Otago had been investigated to some extent by Hector and Buchanan, as already noted, but wide areas remained unexplored. From the end of the "seventies" until the begimning of the "nineties" of the last century Petrie worked hard in his spare time to fill the blank, and so well was the work done that no part of New Zealand has experienced such a searching botanical investigation as Central Otago. His results appeared in a most useful paper published in 1896. Since that time he has travelled extensively in various parts of New Zealand, and hardly a year has passed but he has published descriptions of new species of seed-plants. Petrie also gave the first description of the flora and vegetation of Stewart Island, a much-needed botanical study.

There are other botanical workers now with us, most of them full of enthusiastic activity in finding out and recording the story of the plants, but their work must speak for itself. New branches of botanical science have been developed and the plants are being questioned in many novel ways undreamed-of by the early botanists, so that, ere long, many ner pages of their history should be unfolded, while facts of fundamental importance for the great farming community that we are should come to light and our prosperity be abundantly increased. This is no idle dream, for more intense devotion to botany - that great science on which agriculture primarily depends-will surely lead to new and better methods now altogether unknown. 
SPECIAL IMPORTANCE OF NEW ZEALAND FOR BOTANICAL STUDY. 13

\section{CHAPTER II.}

SOME PRELIMINARY CONSIDERATIONS REGARDING VEGETATION AND LIVING PLANTS.

Special botanical interest of New Zealand-Changes wrought by the European settler-Explanation of the term "flora" - What is meant by the term "vegetation"-Definition of the expression "plant-community"-Some plant-communities of a farm-The plant-formation and the plantassociation-Explanation of the term "growth-form "- Some characteristic New Zealand growth-forms-More about growth-forms-Plasticity in plants - Effect of change in outer circumstances on the manuka-Stimuli and their effect in changing form-Natural changes in a plant-communityTopographical and biological succession-Climax and migratory formations - The struggle for existence-The growing-place of a plant--The meaning of the term "adaptation"-Adaptations with regard to the water-supply.

OCCUPYING a most varied land-surface lying isolated from neighbouring land-masses, far out in the broad Pacific, the plants of New Zealand had for ages controlled their own destinies unhampered by competition with new arrivals, the destructive action of grazingmammals, or, most antagonistic of all, the interference of man, save only, very late indeed in their history, that of a quite primitive race, few in numbers. Thus several factors, common in other lands, of supreme moment with regard to the vegetation were lacking. When, then, not much more than one hundred years ago the European commenced to colonize his new heritage, the plant-covering, almost in its entirety, was truly virgin, and during its later years had reached a definite stage of development under the influence only of climate, soil, and the other conditions of its environment. Hence in New Zealand certain fundamental phases of plant-life can be somewhat more easily investigated than in the great majority of other lands, where the conditions on which its existence depends are more complex. This statement applies specially to that openair study of plants, as they grow naturally, which has called forth most of the story-fragmentary enough, it is true - of New Zealand plants as told in this little book. 
With the advent of the European came many of his animals and plants, which soon reacted upon a plant population unused to such invaders. Also, the settlement of the country, with its draining of swamps, its cutting-down or burning of forests, its ploughing of arable land, and its turning thousands of sheep on to the natural grasslands, rapidly brought about great changes in the vegetation, so that much of it has been profoundly modified or altogether replaced. At the present time, indeed, though happily considerable areas of primitive New Zealand still exist, much of the land is occupied by a new flora and vegetation akin to that of central Europe. Nevertheless, in this book, when dealing with the various classes of vegetation, it is, unless the contrary be stated, the virgin plant-covering which is the theme, so that the pictures here presented are of primeval New Zealand and not of the neighbourhood of cities or of the country seen on most railway journeys.

The terms "flora" and "vegetation" have already been used. It is necessary to distinguish between the two, for they are very different conceptions. The flora of a country simply means the species of plants as a whole which occupy that country. If they occur as truly wild plants they are said to be indigenous; if they have been brought by man, intentionally or unintentionally, they are called introduced. No matter how short a time a plant has been in the land, if it arrived without human aid it is equally as indigenous as its ancient brethren which came long ago. Indigenous plants found in no other land are called endemic. But the word "flora" has also another meaning-namely, that of a catalogue, with or without descriptions, of the known species of plants growing wild in any particular country-a work, when accompanied by descriptions, primarily intended to enable any plant of that country, when encountered, to be readily identified. In such a descriptive flora the species are arranged according to their families and natural relationships. Also, there will be a brief statement regarding their distribution. Investigations dealing with matters concerning a flora are called floristic. Frequently the word "flora" is used inaccurately when "flowers" would be the correct word, and it is not unusual to read such a sentence as "The hall was tastefully decorated with native flora"!

Vegetation refers not to the species but to the plant-covering of a country. The plants, too, from the standpoint of vegetation, are 
looked upon as living organisms with special forms more or less suited to the circumstances under which they live. Swamps, forests, bogs, and grassland, as will shortly be explained, are examples of distinct kinds of vegetation, and some of the units of such are the tussocks, the trees, and the shrubs. For the names and genetic relationship of these in the first instance a flora must be consulted. It is from a study of regetation and its components rather than from floristic investigations that the story of a plant may be gathered.

Those striking features of the landscape which stamp our country as New Zealand-swamps, forests, grassland, bracken-clad slopes, and manuka thickets-impress upon one the fact that the plants do not grow haphazard, but that some combination of conditions allows only definite sets of plants to occupy definite stations. These combinations of plants are called plant-communities - a comparison, but not very elose, with human communities. Many plantcommunities are less easy to recognize than are the swamps, forests, and so on-their delimiting requiring close observation combined with special knowledge and experience.

A student investigating the regetation of a fairly large area will soon perceive that plant-communities are not all of one kind. Unfortunately, there is as yet no recognized consensus of scientific opinion as to how they should be classified or what the names of the classes should be. In this book the conception of Professor Warming, as expressed in his "Oecology of Plants," is, with some modification, followed. The method to be adopted is, however, of no great moment, as long as the terms proposed are used with a definite meaning, so that their signification can be clearly understood.

Taking the case of New Zealand, it has been found that those specially common botanical features of the landscape, the forest for both Islands, and the tussock-grassland for the South Island, when examined by one who knows the names or appearance of a majority of the plants, differ considerably in their constituent members according to the latitude or altitude above sea-level of the plant-community in question. In other words, though the general appearance of a piece of either plant-community may be almost the same everywhere, it is the result of different combinations of species which, however much they differ in their relationship, are, when in combination, similar in outward aspect to those of other parts of the community, no matter where they may be situated. The forest of northern Auckland and 
that of Stewart Island, though similar in appearance, have, excepting ferns, but few species in common; also, the number of species in the latter is considerably smaller than in the former. This fact, then, stands out clearly: that the general appearance of a plantcommunity throughout its range need not depend upon its having a uniform floristic composition. It follows, then, that for such widespread plant-communities as forest and tussock-grassland the primary classification cannot be based upon their floristic composition, since there is no floristic uniformity, but upon their always consisting of plants of certain forms. Combinations of trees, shrubs, climbingplants, and ferus make up the forest for the most part; while tussock-grasses and other herbs of various kinds, together with certain shrubs of rather unusual form, make up the grassland community.

Perhaps the matter of classification of plant-communities may be made clearer to the general reader by a consideration of an area of farmland. Taking, then, the case of an ordinary mixed farm, the plant-covering falls into the two categories of grassland and crop. Also, there may be a plantation of pine-trees near the farmhouse. The crop may consist of cereals or "roots." In the case of the grassland, the dominant grass of the meadow may be rye-grass, cocksfoot, meadow-foxtail in drained swamps, or danthonia on a rather barren hillside. Now, all these grass-communities resemble one another to no small extent, but they differ in their general appearance so completely from the grain or root crops or the plantation of pines that they must be united into a community distinct from all these, to be known as meadow, whose special characteristic is that the dominant plant is of the ordinary grass form. On the other hand, the smaller communities of this meadow are distinguished by the fact that their dominant members are different--rye-grass, cocksfoot, \&c. So, too, in the case of the crop, it might be wheat, or oats, or barley; or, if of roots, swedes, soft turnips, or mangolds. Here, too, the cereals would form as a whole the large plantcommunity, their general form being the same; and so, too, with the roots as a whole, for a similar reason; but wheat, oats, or swedes would each be a smaller community, because each is a distinct kind of plant.

The large and the small communities cited above may be called plant-formations and plant-associations respectively. A plant-formation is distinguished by its general appearance- $-\mathrm{a}$ result of the special 


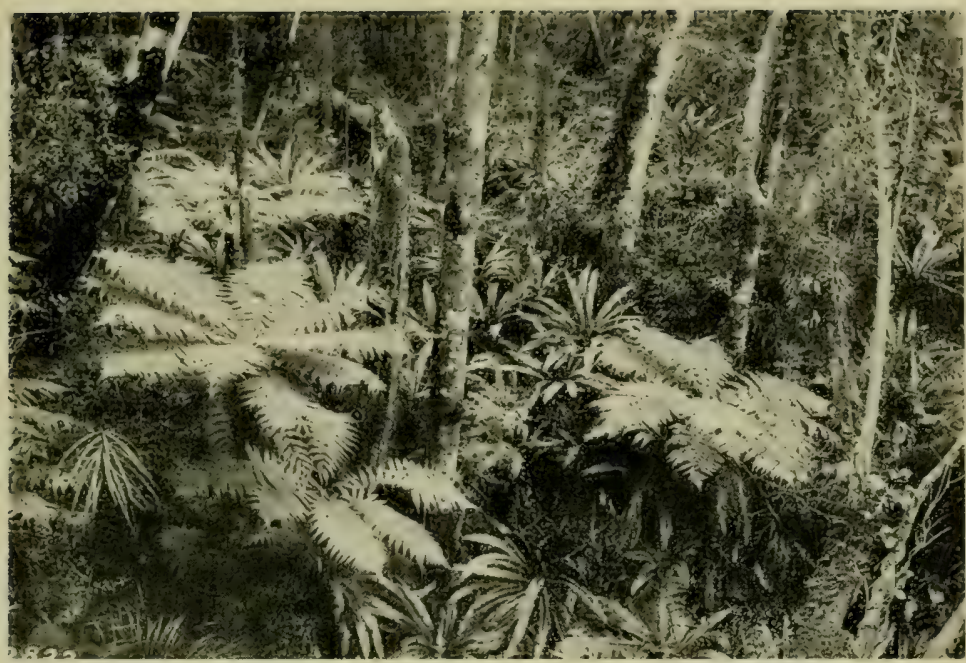

FIG. 7.-Tree-ferns (Hemitelia Smithii) in forest of Ulva, Paterson Inlet (Stewart Island).

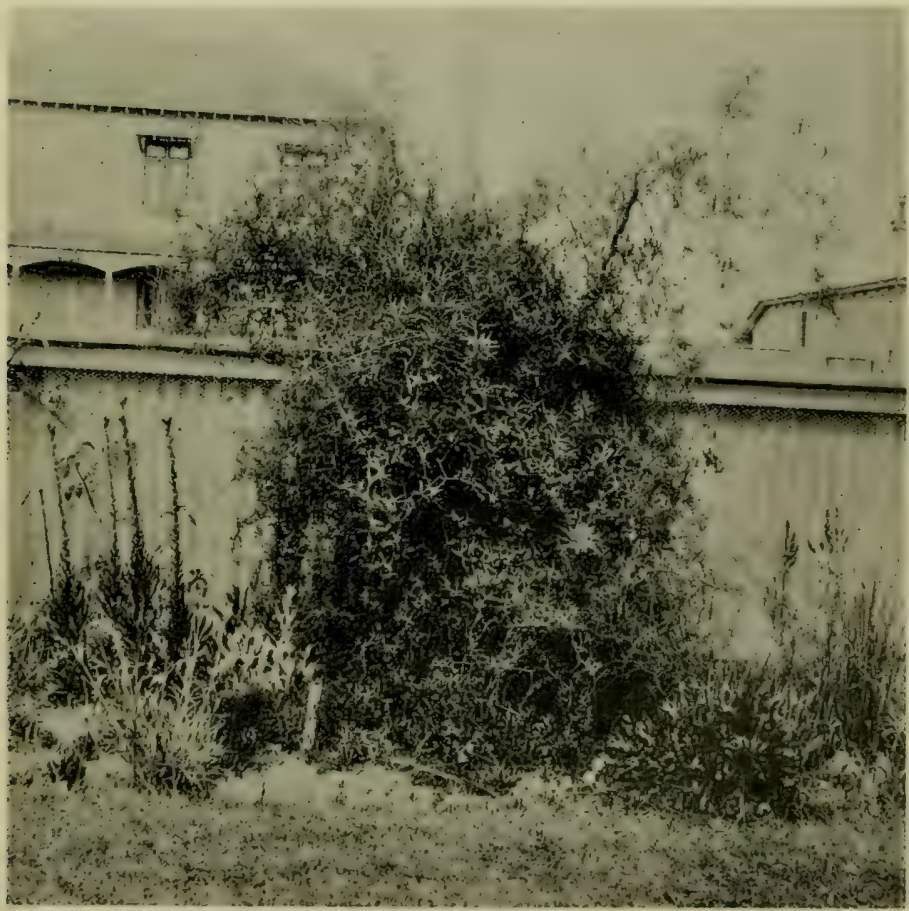

Fit. 8.- The persistent juvenile form of the common kowhai (Sophora microphylla), at this stage a divaricating shrub. 


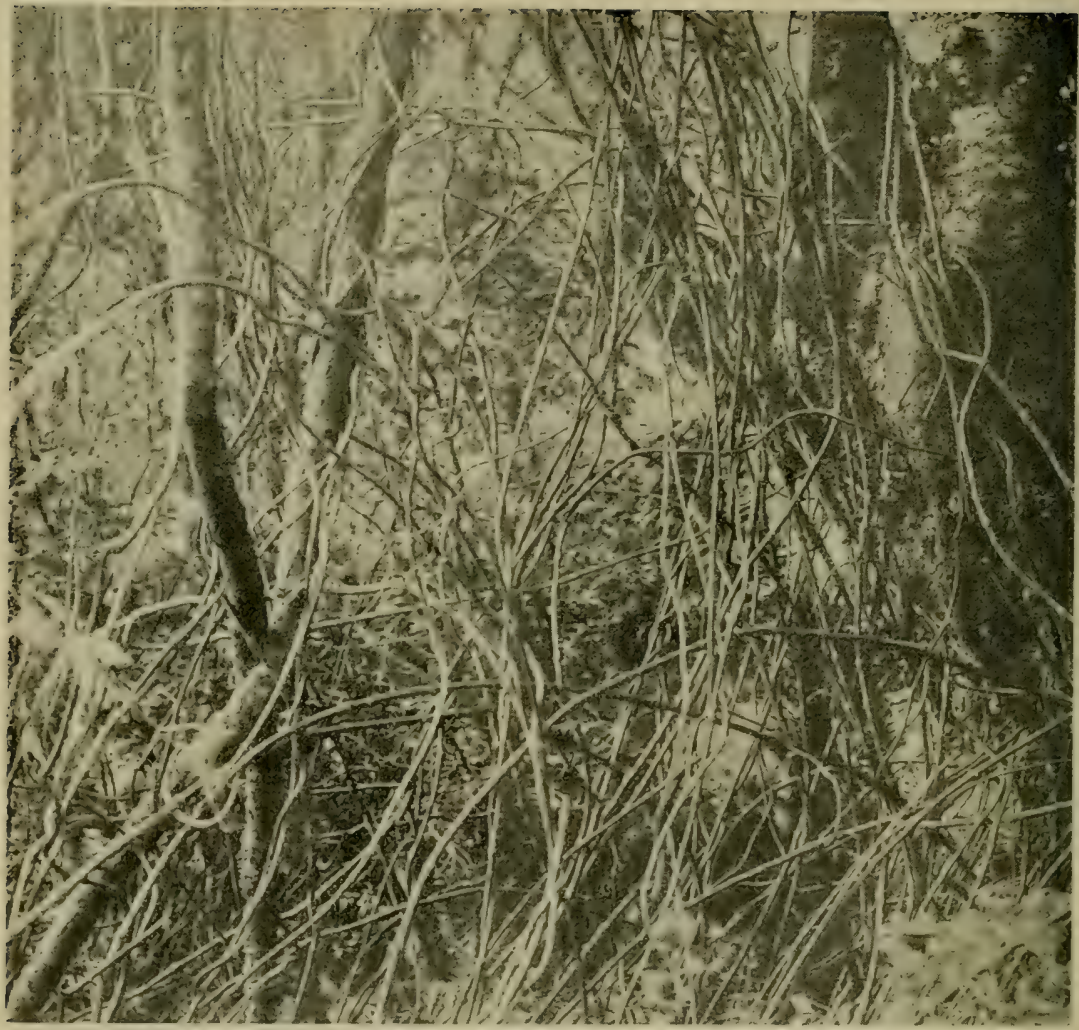

EIc. 9.- Entanglement in taxad rain-forest, formed by the originally twining stems of the supplejack (Rhipogonum scandens).

[Photo, L. Cockayne.

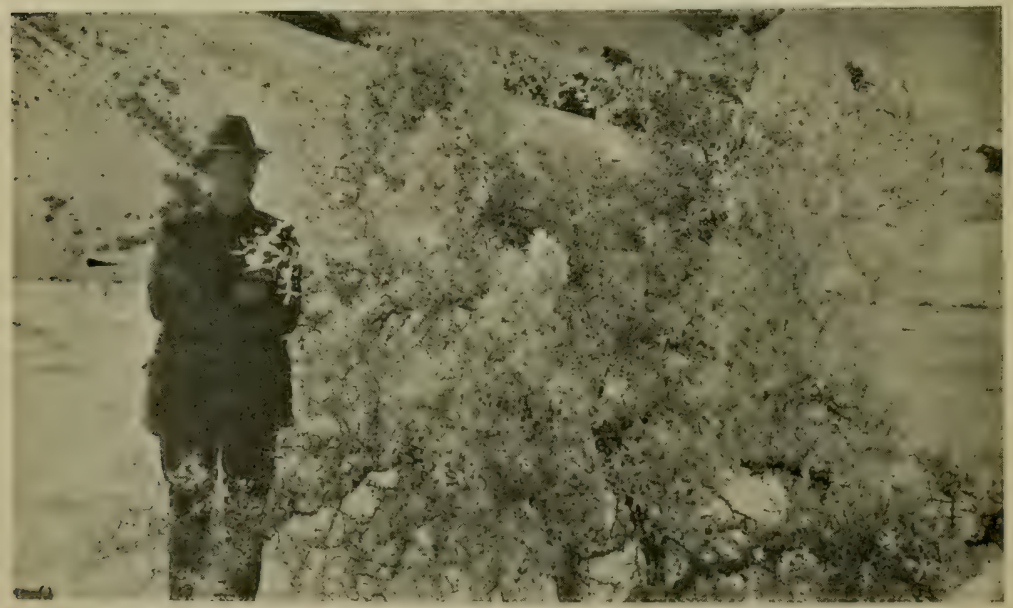

FIG. 10.-A rather large example of the spiny shrub, the wild-irishman (Discaria toumatou). Photographed at Cass (Canterbury) after a heavy snowfall. 
grouth-forms of its members, this term being explained below; and a plant-association, though resembling in general appearance any other association forming a part of the formation, is distinguished by possessing a different combination of species.

In the case of the farm the distinguishing forms of the leading members of the artificial plant-formations stand out clearly. The urass form, the swollen-root form, and the annual-cereal form are all special plant-forms (growth-forms) which can maintain that form-and this is of prime importance-nuly under certain definite conditions, which the farmer of his own accord supplies.

Thus plants may be classified not merely according to floral structure and relationships, but according to their outward form, such form being the outward expression of the plants' behaviour under the spur of their environment, and, indeed, determining their existence. This particular form of a plant is known as its growth-form or life-form, and it is all-important with regard to the plant's behaviour as a living organism, but has little to do with its status as a species, this latter being a matter of genetic relationship. In short, the growth-form is a biological* conception, while the specific form is floristic and genetic.

As an illustration of a growth-form, all tall trees with spreading branches may be cited as belonging to one growth-form, whereas there are thousands of species of such trees, belonging to hundreds of families. Or a tree may have a rery slender pyramidal form, wich the branches not spreading-e.g., the Lombardy poplar (Populus fastigiata), or the rewarewa (Knightia excelsa). Such different growthforms as that of the beautiful white Clematis indivisa, a tendrilclimber (fig. 4), and that of the noble mountain-lity (Ranunculus Lyallii), a summer-green herb with great saucer-like leaves and a thick succulent underground stem (fig. 1), belong to the same "family" - a term explained in Chapter XI.

It is clear that the growth-form is an all-important matter to be considered in regard to the living plant, while a classification of plants according to their growth-forms must he a necessary preliminary to the study of vegetation. In other words, it would be of great advantage were definite terms available for use when seeking

* In this book the term "biological" refers not to all the phenomena of zoology and botany, but only to that portion of these scienees which drals more particularly with vital processes and the relation of the organism to it: surroundings. 
to find out the methods employed by Nature when planting the great garden of the world. Nor did she plant it merely, but she keeps it in such perfect order that each group of growth-forms (these she also fashioned) shall be in harmony with its surroundings, so that each plant can carry on its life-work - the procuring of food and air and the reproduction of its kind.

Unfortunately, no one, as yet, has put forth a really satisfactory classification of growth-forms, for amongst the host of difficulties to be overcome there is amazing diversity of form amongst plants, and many connecting-links exist between forms otherwise distinct enough. In any case, an attempt to classify the seed-plants of New Zealand according to their growth-forms is far beyond the scope of this book; here it is only necessary to call attention to the following growth-forms, which are common enough to affect the physiognomy of the New Zealand landscape, and to a few others which are easily recognizable and will be frequently met with.

(a.) The Excrgreen Canopy-tree.-This is to be distinguished by its erect trunk, its crown of spreading branches, and its evergreen rather thick leaves. Examples: the tawa (Beilschmiedia tawa), the various species of southern-beech (Nothofagus), and the kamahi (Weinmannia racemosa) - this latter the commonest tree in New Zealand.

(b.) The Bushy Tree.-This has a comparatively short trunk, which gives off many more or less erect branches, these branching freely. Examples: the broadleaf (Griselinia littoralis), various species of Pittosporum, and the tree-coprosma (Coprosma arborea).

(c.) The Bushy Shrub.-This is much the same as the bushy tree, but there is virtually no trunk. Examples: the ramarama (Myrtus bullata), the hangehange (Geniostoma ligustrifolium), and the hupiro (Coprosma foetidissima). If the branches are very slender, then there is the twiggy-shrub form-e.g., the rohutu (Myrtus pedunculata).

(d.) The Divaricating Form.-This consists of a shrub forming a close, unyielding, often cushion-like mass, with its numerous. extremely wiry or rigid, much interlaced branches and twigs which are given off at a wide angle (fig. 15.) Examples: the mountainwineberry (Avistotelia fruticosa), the common kowhai (Sophora microphylla) in its juvenile stage (fig. 8), and many species of Coprosma. Altogether about 55 species, belonging to 23 genera and 18 families, possess this growth-form. 
(e.) The Tussock Form.-This is so well known that it requires no description. It occurs chiefly amongst the grasses and sedges, though probably the New Zealand flax (species of Phormium) should come here. Some species build fairly tall, solid trunks out of their dead stems and other parts. Examples: the silver-tussock (Pou caespitosa), the red-tussock (Danthonia Raoulii var. rubra), and the trunk-building niggerhead (Carex secta). About 40 species, belonging to 19 genera and 5 families, possess this form.

(f.) The Cushion Form.-Dense crowding of short branches spreading out from a centre and leaves inserted extremely closely on the stems lead to the building of more or less dense cushions. Examples : the vegetable-sheep (species of Hastia and Raoulia) (fig. 64), the common scleranth (Scleranthus biflorus), and the silvery celmisia (Celmisia argentea). About 55 species, belonging to 22 genera and 14 families, are cushion-plants or semi-cushion plants.

(g.) The Rosette Form.-The leaves, crowded at the ends of the branches, form rosettes of various shapes and sizes, some being flattened close to the ground. Examples: various plantains (species of Plantago) and the common New Zealand groundsel (Senecio bellidioides). The rosette form is frequently associated with some other growth-form.

(h.) The Tree-fern Form.-There is a fairly high trunk covered more or less with aerial roots, and a crown of huge, spreading leaves. Examples: the slender tree-fern (Dicksonia squarrosa) and the black tree-fern (Cyathea medullaris).

(i.) The Liane Form.-This includes all the climbing-plants, of which the following classes may be distinguished: (1) Scramblers; (2) twining climbers; (3) tendril-climbers; (4) root-climbers. Examples: the supplejack (Rhipogomm scandens), twiner (fig. 9); the scarlet climbing-rata (Melrosideros florida), root-climber. There are 47 climbing-plants, belonging to 16 families and 22 genera: 12 are scramblers, 13 root-climbers, 13 twiners, and 9 tendril-climbers. (of this total, 33 are woody and 14 herbaceous. Lianes are dealt with at some length in Chapter IV.

(j.) The Mistletoe Form.--This is the form of the semi-parasites, which take part of their nutriment from the tres, shrubs, lianes, or even other parasites to which they are attached, and part is manufactured in their green leaves from carbonic acid and water. All are shrubs. Examples: the red mistletoe (Elyticulle tetrapetula). 
the pirita (Tupeia antarctica), and the common New Zealand mistletoe "(Loranthus micranthus).

Parasites must not be confused with perching-plants (epiphlytes), which simply grow perched upon trees or other plants, but do not draw upon them for food. Perching-plants in New Zealand have usually growth-forms identical with plants rooted in the ground, but the perching (epiphytic) orehids have a special growth-form of their own, which is dealt with on pages 25 and 56 .

There are many other growth-forms, some exceedingly common and some much rarer, not a few of which present "adaptations" wanting in many floras other than that of New Zealand. Attention must be paid, in the first place, as to which of the great biological classes of seed-plants the species belongs - tree, shrub, semi-woody. plant, herb (in a restricted sense), or grass form (including many sedges). Trees and shrubs may be evergreen or deciduous; they may also be tall, of medium size, or small. Shrubs may also be erect or prostrate, and the latter either with their stems below or above ground, and rooting or non-rooting. The size and texture of the leaves must be taken into consideration. Semi-woody plants and herbs have much the same growth-forms. They may be tall, medium-sized, or small; erect or prostrate, the latter below or above ground, and rooting or non-rooting; tufted; much or little branched; succulent; and so on. The grass form (though grasses are really herbs, but owing to their special growth-form they are better kept separate) falls into various growth-forms-e.g., the tufted, the turf-making, and the tussock.

The following are interesting but rather uncommon growth-forms. The tuft tree-e.g., the cabbage-tree (Cordyline australis) and the mountain-neinei (Dracophyllum Trarersii); the leafless flat-stemmed or round-stemmed shrub-e.g., the New Zealand brooms (species of Carmichactia); the erpress-like shrub-e.g., the whipeord veronicas; the spiny shrub-e.g., Discaria toumatou (fig. 10); the summer-green herb (as opposed to evergreen), very common in most temperate countries but comparatively rare in New Zealand, its parts which are above the ground dying to the ground in autumn. The above and other growth-forms receive a good deal of attention in many of the chapters which follow. The -study of growth-forms is both important and interesting, and no small degree of ingenuity is required in order to bestow appropriate names. 
Many species are readily changed in form according to change in the conditions to which they are exposed; in other words, they are plastic. The manuka (Leptospermum scoparium) when not exposed to excess of wind, and growing in fairly good soil in an area where the rainfall is abundant, may be a small tree, 30 feet high, with a trunk 1 to 2 feet in diameter. When growing in its usual station in poor soil as a member of the manuka-thicket plant-formation, it is a rather tall shrub with its branches more or less erect and not spreading. On a sour, wet, cold soil in the mountains it creeps over the ground with its slender stems, which root into the soil; indeed, it may form a veritable turf.(fig. 11). Finally, it may bloom as a seedling when only an inch or two high. Thus one and the same plant, according to circumstances, can assume four growth-forms which are absolutely distinct from one another both in appearance and in physiological requirements. Were the case of the manuka a solitary one it could not be taken as an argument in support of any theory; but, as will be seen, such extreme plasticity is so common amongst New Zealand plants as, after a time, to occasion no surprise; and the question arises, Is there no true fixity, and are the forms of all the plants only maintained so long as the environment remains more or less constant?

The change in form of a growth-form or of an organ is the outward mark of a physiological response of a plant to some stimulus, which may be in the nature of a greater or lesser amount or intensity of light, heat, or moisture reaching it. Hore or less of a certain sait in the soil, the "sting" of an insect, or the presence of a fungus may also act as stimuli.

How far such action of a stimulus to which a plant has not been accustomed, carried on for a long time, can make itself felt so as to produce a more or less permanent change of form is a matter in great dispute. Be that as it may, the New Zealand flora offers no small amount of evidence that such changes as the environment can bring about may become very deep-seated. Further than this it is not safe to go in an elementary book, where speculation should take a quite minor place.

Heat, light, moisture, the soil-this a remarkable complex; the animals with which the plant comes in contact, as also the plants with which it is associated-all these are factors operating upon the plant which may be either beneficial or harmless, otherwise it must 
go to the wall. Nor, in most cases, can the plant escape from its surroundings. It is bound to its dwelling-place, where, or in the immediate neighbourhood-in the case of the higher plants - it must remain. But, as a member of a plant-association, its history has been that of a portion of the association; it has, in fact, become a nember of the association as the result of rigorous selection. Its ancestor, as a seedling from a chance seed which fell upon a spot where the conditions allowed it to germinate, would depend for its subs.stence upon its power to make the best of the circumstances. Were other better-equipped plants present, the plant in question would assuredly be wiped out in the struggle for existence. As time went on, the plants with which it was associated, together with itself and its brethren, would modify the environment for the better or for the worse, so far as the plant in question was concerned, and its power of survival might quite likely depend altogether upon its inherent plasticity. So with the changing years, as generation after generation of the plant held its own and its fellow-plants of other species were slowly being winnowed by the sieve of selection, a community specially suited to the conditions offered would finally be segregated.

The permanence of such a plant-community would depend partly upon the rapidity of the changes brought about by the plants themselves, such as the "exhaustion" of the soil or the increase in its amount of vegetable matter, and partly upon topographic changes caused, for example, by erosion, or sinking or rising of the landsurface. If the topographical change was extremely slow, apparent stability would come and a plant-community of wide range governed chiefly by climate be the result, such as the rain-forest or the tussock-grassland of New Zealand. If, however, rapid changes of the land-surface were in progress there would be many formations apparently of a temporary character, such as those of rocks, of stony river-beds (fig. 12), of steep gullies (fig. 25), of debris-slopes (figs. 51, 68, 70), and so on ; but which, if wiped out by topographic change in one place, would reappear in another so long as similar changes in the land-surface went on.

From the above it is clear that there are two kinds of formations to be considered-the one, apparently fixed, which may be called a climax formation, and the other, apparently of short duration, which, following Dr. C. B. Crampton, of H.M. Geological Survey, may be called a migratory formation. 
A climax formation is evidently in large part governed by climate (climatic), while a migratory formation in large part depends upon the nature of the soil, though, of course, in both formations soil and climate must count. Each of the plant-associations which taken together make up a migratory formation may be comparatively young, but the migratory formation as a whole must have existed longer upon the earth than the climatic formation of which it was and is a topographical phase.

Each formation has, indeed, its life-history, which consists, after its beginning, in a series of changes, one transitory association giving place to another, and so on, until the final apparent stability comes. This interesting phenomenon is known as succession. Succession is of two quite distinct kinds, but only one of these is true biological succession. This is where the plants themselves during their competition lead to changes in the association apart from any topographic change, as when the open association of stony river-bed is finally transformed into tussock-grassland (fig. 13), or the debris-field of the high mountains into that plant-formation described in Chapter VI under the name "fell-field" (figs. 69, 71).

In the case of topographical change there is often no gradual progress, but rather the wiping-out of a complete association and the beginning again--i.e., there is a series of migratory formations leading up to a climax association. The early association of rock-faces in a gully has but little to do with the final vegetation of the valley-floor. Succession of this kind may be called topographical succession.

With regard to succession, the struggle for existence between the plants is a matter of prime importance. Such a strife is somewhat analogous to that which takes place, even in civilized human communities, between the individuals of the State, each of whom is either aided or burdened by characters, good or evil, handed down to him from his more or less remote ancestors. Thus under the environment created by civilization some become rich or famous, while others remain poor or may even become degraded. This latter misfortune could in no small measure be remedied were the teachings of biology not ignored and a more suitable environment provided. But it must not be forgotten that too much interference with the laws of nature must spell disaster.

Every one who cultivates a garden, however small, has to cope with what are called "weeds"-i.e., with plants not wanted which 
are equipped in some special manner for occupying the soil at the expense of others. A species that can rapidly reproduce itself from seed, or by suckers, creeping stems, and the like, has a great advantage over one of slower propagating-power, and will soon smother it out by force of numbers alone. Some plants have large leaves which they flatten against the ground, and so occupy at once more than their share of the soil. Others have a peculiar taste, making them objectionable to suails, slugs, or insects, and so triumph over plants liable to the attacks of such animals. But there is no need to multiply instances; any one interested can search for examples, and a most fascinating quest it is. The advantages in some cases are so small as not to be appreciable by the observer; but, however slight the benefit, the plant possessing it must conquer in the long-run.

In nature this strife between plants is always in progress - a silent but nevertheless a deadly conflict. The calm aisles of a forest are a battlefield where the trees, shrubs, and more lowly plants strive for the mastery, while at the same time the forest itself wages incessant war with the adjoining grassland-the one or the other aided by climatic changes, an abundant rainfall favouring the forest and drier conditions the grassland.

Speaking generally, the "struggle" is not so much a physical one between plant and plant, but rather is it a competition for light, heat, moisture, and nutritive salts. The matter, in fact, resolves itself largely into a struggle for food - and here again the human simile is not far-fetched.

When the general conditions governing a plant-community are known, it might quite well be thought that those conditions affecting individually the various members of the community are also known. No conclusion could be more false. Each species has, as already stated, its special bome, which may be called its growing-place. Now, no two species of a community have exactly the same growingplace - the more alike are their growth-forms, the more alike their growing-place; and the converse holds good also. Thus each species is under special conditions of its own with regard to moisture, light, heat, \&c., and it is these conditions which must be known before a plant can truly tell its story. The New Zealand brooms (species of Carmichaelia), with their long roots deep down into soil that is wet, are in a very different environment to that of a short- 


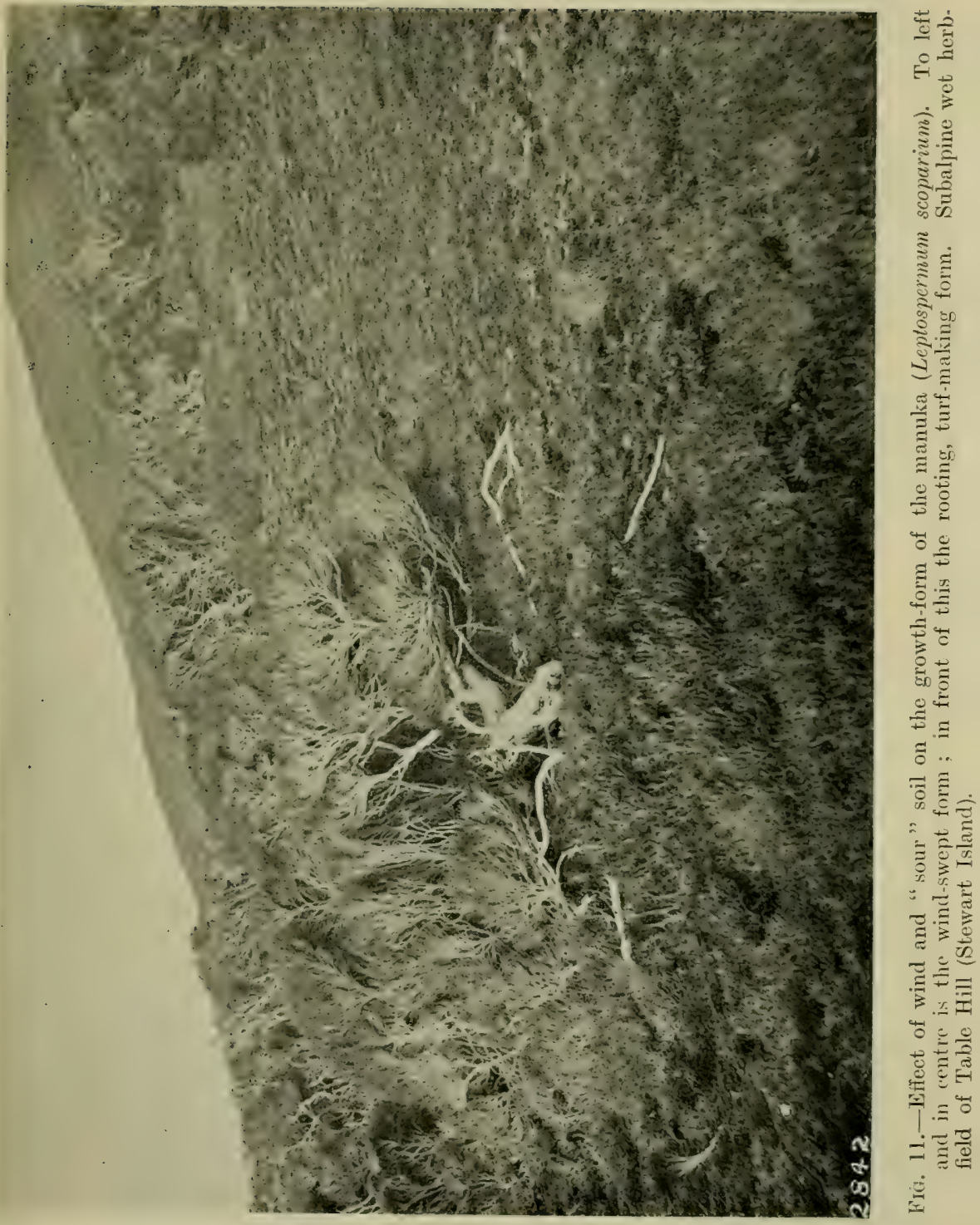




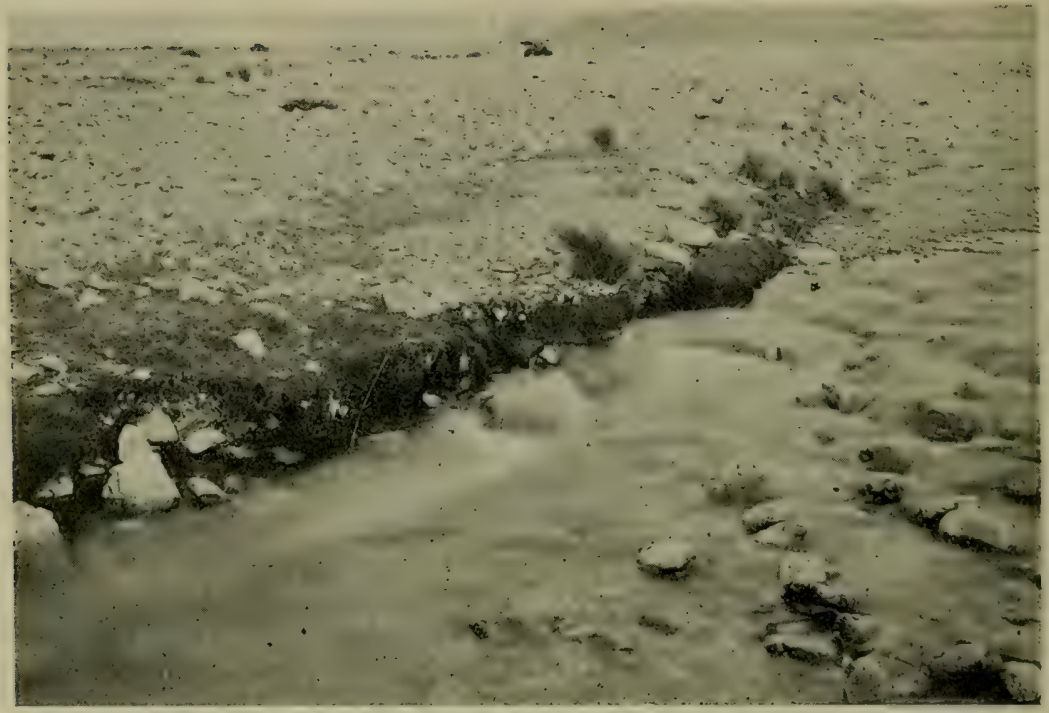

Fifi. 1:2.-One of the streams of the River ('ass (C'anterbury) undermining the migratory river-bed association of the mat-raoulia (Raoulia tenuicaulis).

Trans, N.Z, Inst.]

[Photo, L. Cockayne.

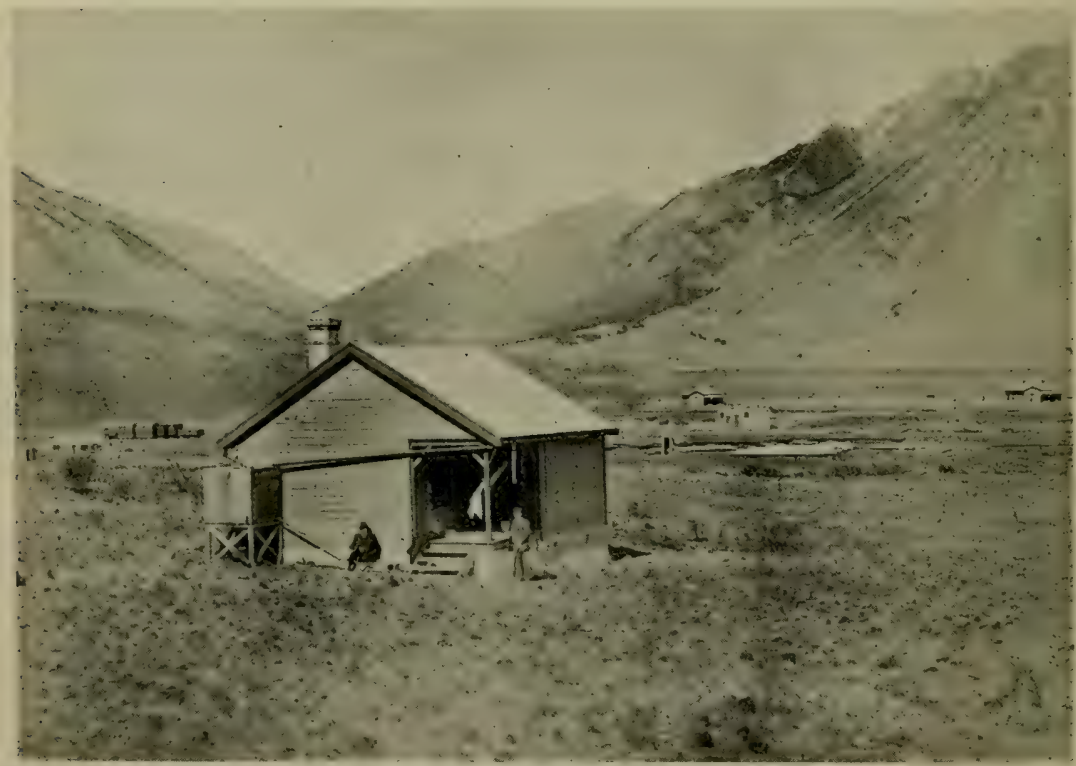

FIc. 13.-The low tussock-grassland at Cass (Canterbury), a climax plant-formation.

The small cottage belongs to the Canterbury College IIountain Biological Station.

Trans. N.Z. Inst.]

[Ploto, C. F, Foweraker. 


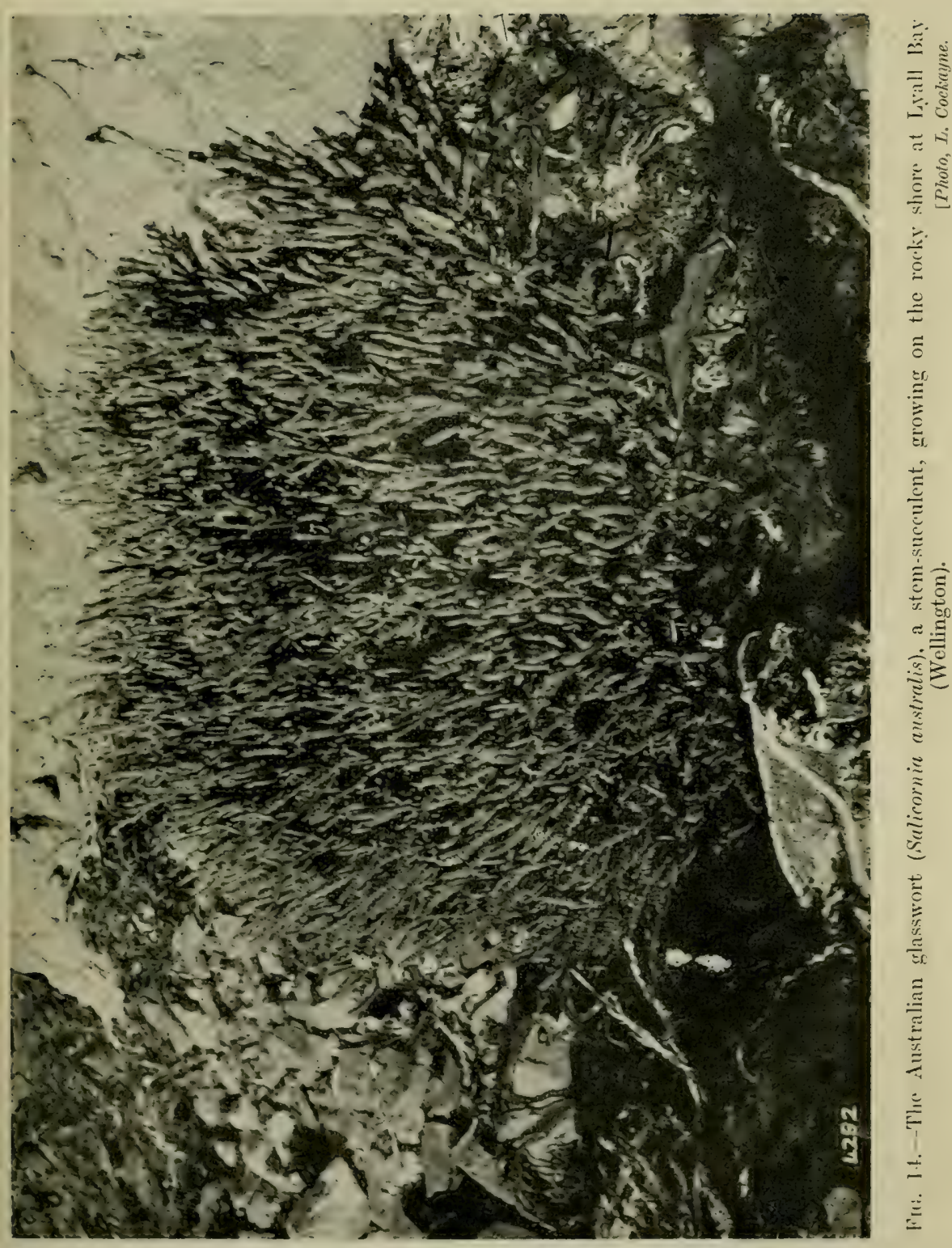




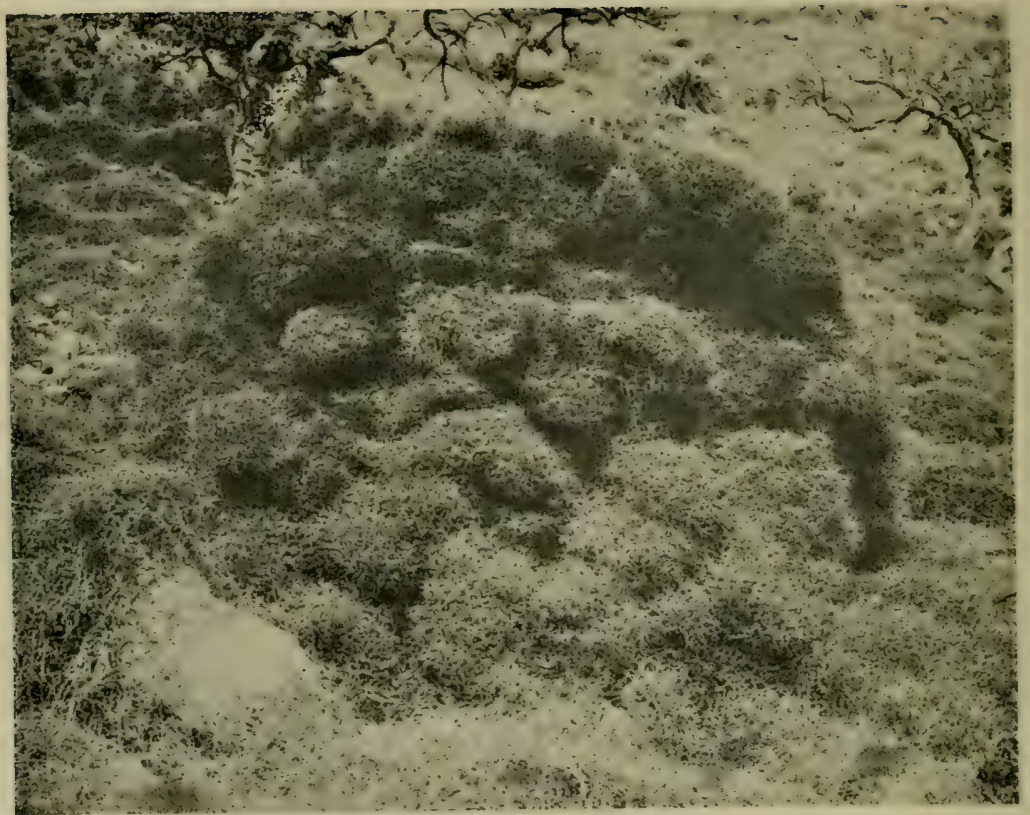

Fic: 15.-The shrubby pohuehue (Hullenbelie Astoni). a divarieating shrub, growing on the shingly beach near the mouth of the Wainuiomata River (IVellington).

[Photo, E. Bruce Ler?.

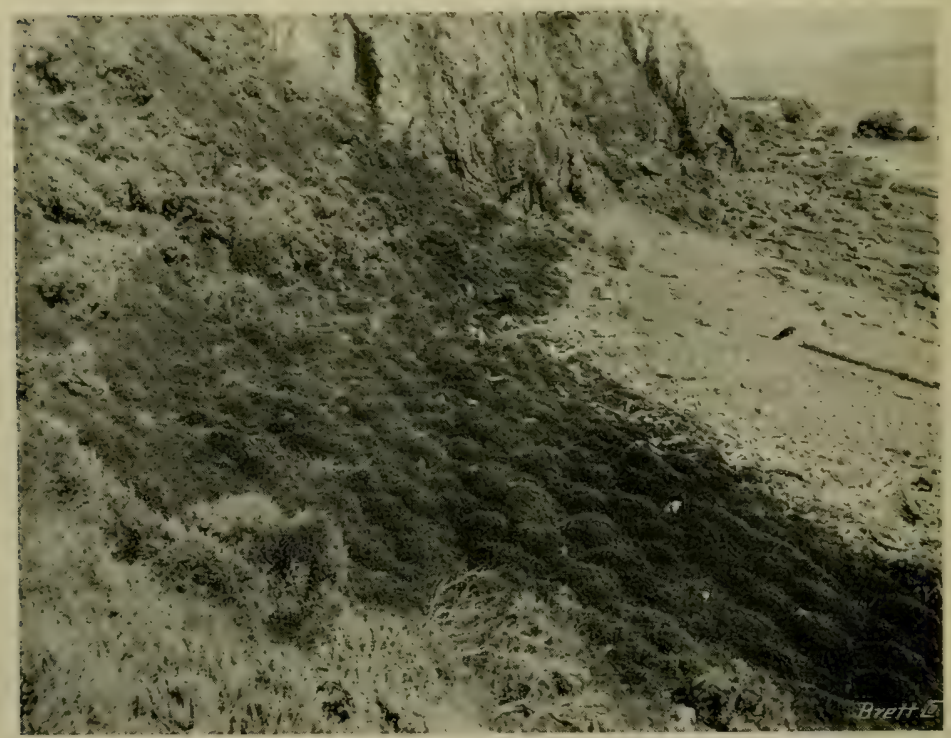

FI: 16.-An almost pure association of the pohuehue (IIuchlenbeckia cumplexa). a twining liane which by its "plasticity" has assumed the cushion form, growing at Titahi Bay (Wellington). 
rooted annual grass of the same community during a period, even short, of drought. Nor in the rain-forest can the housekeeping of the tall tree be the same as that of the low tree growing beneath its shade. So, too, in a swamp - the conditions with regard to light differ greatly according to the size of the plants. The New Zealand flax (Phomium), whose leaves need be thick to battle with the breeze, lives under conditions quite unknown to the creepingherb, Gratiola peruviana, of the wet ground beneath.

The term "adaptation" has been already used in this chapter; it requires some explanation. First of all, as used here, there is no idea of "purpose" underlying the expression. A root, for instance, is not an organ for the purpose of fastening the plant to the ground and taking water from the soil and conducting such water to the stem: it is an organ which functions in that manner. If it appears well suited both in form and action to carry on its special work, then it may be said to be an adaptation whose function it is to play the triple role indicated above. In some cases roots may play quite different parts. Thus the various lianes which climb by means of special roots put these forth from their elongated stems and so anchor the latter to the support. Here the root does not go downwards, nor has it any relation to water; indeed, when its anchoring function is no longer necessary it dies-not because it is no longer required, its "purpose" being fulfilled, but because the conditions under which such roots are given off have ceased to be, through the thick growth of the liane's stem, which no longer closely hugs the tree. Such fastening-roots are an adaptation, but not a special one, any more than the usual root form is special; commonness does not degrade either a function or the form of an organ. There are many other adaptations found amongst roots, and some receive attention in other parts of this book.

The relation of a plant to its water-supply is one which stands very plainly reflected in many plants, so that adaptations are readily studied in this regard. Thus, to refer to the root again, roots may be short (as in many annuals); they may go straight down for a great depth (as in the cultivated lucerne-Medicago sativa); they may extend laterally just beneath the surface of the soil (as in the New Zealand flax-Phormium tenax); they may consist largely of a spongy, water-absorbing tissue (as in the perchingorchids); they may possess an abundance of root-hairs (as in many 
plants of dry ground); they may have no root-hairs at all (as in many swamp-plants): all the above are adaptations connected with the water-supply.

The size, thickness, position with regard to the sun, flatness, degree of closeness at which they are given off from the stem, hairiness, glossiness, and other characteristics of leaves have a special bearing with regard to the amount of water which evaporates from them or which they have stored up in their tissues. Many of the different degrees of development which leaves assume with regard to the characters cited above can frequently, with some degree of confidence, be looked upon as adaptations. It is very easy to carry the idea of adaptations too far, and to use the imagination rather than reason based on observation and-best of all-on experiment. Even with the latter, where living plants in their natural habitats are concerned, it is almost impossible to devise experiments which can say that one particular agent is the actual cause. Nore satisfactory experiments can be carried out in the laboratory; but it must never be forgotten that the conclusions derived from such refer only to the plant under the laboratory conditions and not to the plant in the field. All this might make one feel rather pessimistic regarding studies of the living plant in nature; but pessimism need not raise its horrid head-in general, plants have already told a good deal. Observation pure and simple is a tool of power which lies ready to the hand of all. Nature is carrying on her work now as in days primeval; much can be learned by an ardent student in her workshop. 


\section{CHAPTER III.}

\section{THE FLORA AND VEGETATION OF THE SEA-COAST.}

General remarks-Statistics regarding the flora-Inland plants on the coastSalt and succulence--The ice-plant and other succulents--Growth-forms of coastal plants - Muehlenbeckiu Astoni-A coastal climbing-plant-Seaweeds -The sea-grasses-Sandy and rocky shores-Sandhills, their plants and plant-associations-Sand-binders-The spiny rolling-grass--Plants of sanctlollows-The mangrove and its strange habits-Sait-swamps-Salt-meadows - Peaty salt-meadow-Vegetation of rocks and cliffs-The pohutukawaPhormium associations - Coastal shrubberies-Coastal forest-The kohekohe - The home of the tuatara and of a New Zealand frog-The wind-swept Open Bay Jslands.

A const-line between four and five thousand miles in length, extending from nearly the latitude of Sydney in the north to far beyond that of the southernmost point of Tasmania in the south, may well furnish a great deal of diversity in both species and plantcommunities. The varieties of stations for plant-life are also augmerted by the physical features of the shore. In some places calm fiords, flanked by towering, precipitous mountains, stretch far inland; in others an ironbound coast faces the ocean storms. There are long stretches of level shore of shingle, gravel, or of sand-extensive estuaries, and tidal rivers. In short, the two main Islands of New Zealand, together with Stewart Island, present a diversified coast not surpassed in variety of physical features by any other of equal size.

The flora consists of three classes of plants-namely, those which always occur near the sea, those which generally occur near the sea but which occasionally are found inland, and those which are found equally both near and at a considerable distance from the coast. Leaving out of consideration the last-named class, the total number of species, considering only the seed-plants, the ferns, and fern-allies, are about 190, and these belong to 54 families and 107 genera. Of the above about 144 are confined to the coast-line or its immediate neighbourhood, and the remainder occur in a few localities inland, but generally speaking they are of but slight importance as constituents of the lowland vegetation. Nine families and 35 genera 
are confined, or almost so, to the coast-line. The commonest of the latter are: Zostera, Spinifex, Atropis, Salicornia, Mesembryanthemum, Tetragonia, Spergularia, Euphorbia, Corynocarpus, Aprum, Samolns, and Avicennia. The species of these genera are, for the most part, dealt with farther on, and their popular names and characteristics are given.

The species common both to the coast-line and farther inland are numerous enough. Their coming to the coast depends a good deal on the conditions offered both of climate and soil. Where there are true coastal conditions there are few non-coastal plantsthat is, where the sea-wind strikes fair, bringing with it at times a considerable amount of sea-spray, or where a flat area is subject to the invasion of brackish water.

The following inland plants, amongst others, are common in many places on the sea-coast: The kiekie (Freycinetic Banksii); the toetoe (Arundo conspicua); the toetoe-whatumanu (Mariscus ustulatus), as far south as Bankis Peninsula and near Kumara in Westland; the tuhara (Cladium Sincluirii), in the northern part of the North Island only; the two species of New Zealand flax (Phormium tenax and 1 . Colensoi); the tree-nettle, or ongaonga (Urticn ferox); the two pohuehues (Muehlenbeckic complexa and $M$. australis); the red and the white tea-tree (Leplospermum scoparium and $L$. cricoides); the sonthern rata (Metrosideros lucida) in the south of the South Island and in Stewart Island; certain ferns-e.g., the common maidenhair (Adiantum affine), the common climbing-polypody (Polypoclium diversifolium), and the thick-leaved polypody (Cyclophorus serpens).

The chief factor operating upon coastal plants different from those to which inland plants are exposed is a greater amount of sait in the soil. This factor may easily be overestimated, since plenty of soils close to the sea contain very little salt indeed. Other factors affecting the distribution and forms of the plants are frequent high winds (perhaps charged with salt), bright sunlight, and a mild climate.

The effect of salt in the soil is reflected in the plant by succulence of stem, of leaf, or of both. Such succulence is found in plants exposed to excess of salt the world over. This succulence is caused by the presence of special tissues which serve for waterstorage. Certain New Zealand coastal plants exhibit this feature. The ice-plant, or horokaka (Mesembryanthemum australe), which so 
frequently drapes the coastal 'clifts with its succulent reddish or palegreen leaves, and bears rather large rose-coloured or white flowers. according usually to the colour of the leaf, is a pleasing and familiar (xample. This species must not be confused with the Hottentot fig $(\boldsymbol{M}$. edule), a native of South Africa, now naturalized on many sandhills, but which possesses leaves still "fatter" than those of its indigenous sister, and bears larger and yellow-coloured flowers. Other common coastal succulents are the leafless Australian glasswort (Salicorvia australis) (fig. 14), a stem-succulent common in saltmeadows and on rocks close to the sea, and the sea-blite (Sucter maritima), a leaf-succulent, usually growing in rather wetter ground than the glasswort and not nearly such a common plant.

Succulence has been shown experimentally to be brought about by excess of salt in the soil, and certain plants to which salt is not a deadly poison can be made artificially succulent. Some of the introduced plants of this country, as, for example, the spotted catchfly (Silene anglica var. quinquemlnera), acquire much fatter leaves when growing near the sea than when growing inland.

The amount of succulence in coastal plants must not be overestimated. The great majority are not succulent at all ; but, then. they are usually not exposed to much salt. Even certain saltmeadow and salt-swamp plants are not succulent. Drought, in general, is combated in many foreign plants by means of succulence. Thus there are the numerous species of the succulent Caciu: family--e.g., in Mexico-and the host of South African succulent; helonging to various families. New Zealand, as will be seen, has also its succulents of dry stations in the subalpine and alpine belts.

With regard to the growth-forms of the coastal plants, they fall into the familiar categories of trees, shrubs, lianes, herbs and semiwoody plants, and water-plants. The trees number about 28. Excepting the karaka (Corynocarpus laevigata) and the pohutukawa (Metrosideros tomentosa). the other trees rarely exceed 20) feet in height. But the tree form is unsuited to coastal conditions, and about 24 of the trees frequently do not develop a distinct trunk, but as shrubs bear abundant flowers and fruit. Even the pohutukawa, which attains a height of 70 feet or more in the forest, on Rangitoto Island blossoms freely when only a foot or so in height. In many cases the leaves of the coastal trees are more or less leathery or thick, as well might be expected. 
There are about 40 shrubs, of which 12 are more or less prostrate in habit. Nost are of the ordinary bushy-shrub form. A quite remarkable shrub is the shrubby pohuehue (Muehlenbeckia Astoni), which is of the divaricating form, and builds on stony shores irregular rounded masses 4 feet or more in height (fig. 15). All this would be nothing were it not that the genus consists otherwise of climbing or creeping species, and that the liane-like main stems of this plant betray its relationship to its climbing relatives. One of these. however, the pohuehue ( 1 . complexa), when it occurs near the shore, frequently assumes the cushion form (fig. 16). M. Astomi so far has been noted only from near Cape Turakirae (Wellington) and one or two places in Marlborough e.g., near the mouth of the Flaxbourne Stream and in the lower portion of the Awatere Valley.

The only liane to be mentioned is the Australian gourd (Sicyos austratis), a plant not unlike the vegetable-marrow, but now quite rare except on the small islands to the north-east of Auckland.

There are about 109 herbs and semi-woody plants, which belong to the various growth-forms common to such plants. Regarding th: leaves of these, 75 species have small or very small leaves, and in $7 t$ species they are succulent, thick, or leathery.

The coastal plant-formations are of a diverse character, and consist of a great many plant-associations. The most important communities are: Seaweed associations, shore vegetation, dune regetation, rock associations, salt-swamp, salt-meadow, coastal scrub, and coastal forest.

Where rocks jut out into the sea, forming pools, there the beautiful red seaweeds have their home; but where the sea dashes with fury, the huge brown ones are found in abundance. As two of these are so frequently cast up on the shore, they, at any rate, must be known to most who are acquainted with the seaside. The one (Macrocystis pyrifera) grows to an immense size, and its "leaves" float upon the surface of the sea by means of their small bladders full of air, while, dozens of feet below, the cord-like stems are anchored firmly to the rocky floor of the ocean. The other. the bull-kelp (Durvillaea utitis), is found in rougher water, its long strap-like "leaves" showing, when cut into, a honeycomb-like structure, while the main "trunk" is solid. Durrillaea gets its name from Dumont D'Urville, mentioned in Chapter I. By the Stewart Island Maoris the "leaves" of the bull-kelp are made into bags for holding the preserved mutton-birds. 
Seaweeds are green, brown, or red, the colour being in harmony with the amount of sunlight to which they are exposed. The green plants occur in the shallowest water, where they are left high and dry for some hours at a time; the brown are found in shallow rock-pools near low-water mark and on rocks exposed at low tide; and the red have their homes in deep pools, or far down in still water, as in the Otago fiords. Seaweeds, although apparently exposed to uniform conditions when growing side by side, are of many most distinct forms. Codium adhaerens forms thick, fleshy, dark-green masses on stones in rock-pools; Chaetomorpha Darwini consists of beautiful translucent strings of green beads; Hormosira Banksii covers rocks with its large, brown, wrinkled, bead-like masses. The red seaweeds differ greatly in their texture, those in the deepest water being exceedingly fragile.

Although they are not seaweeds but true seed-plants, the seagrasses (Zostera nana and Z. tasmanica) may receive mention here. Zostera nana is extremely common in shallow estuaries, and covers the muddy floor with its flat grass-like leaves for many square rards at a time.

Sandy shores are common enough on the New Zealand coast: and as these, when sufficiently firm, are patronized as playgrounds for our children and ourselves, something as to their plants may be of interest. Such a shore may sometimes be quite without plants, except for the remains of seaweeds which mark the high-tide limit. Where the shore is sheltered, the sand-convolvulus (Calystegia Soldanella) (fig. 17), with its whitish flowers striped with lilac, and kidney-shaped or heart-shaped fleshy green leaves, is often present. Here, too, is the home of the shore-buttercup (Ramunculus acaulis), its leaves of three small succulent leaflets flat on the sand, and its little yellow flower buried right up to its neck. As the seeds ripen, this plant has the curious property of bending its flower-stem into the sand and thus sowing its own crop. The New Zealand spinach (Tetragonia expansa), the succulent New Zealand orache (Atriplex Billardieri), and the prickly saltwort (Salsola Kali) are also plants of the shore, but the latter is perhaps not indigenous.

Gravelly and rocky shores are richer in plant-life than sandy ones, since, for one thing, they are much more stable. On them, especially in Southland and Stewart Island, the shore-dock (Rumex neglectus) is common. This has a rather stout creeping stem, which 
enables the plant to make considerable patches on the gravelly shore, where it grows far more luxuriantly than on the peaty ground which it also inhabits. On the stony shore of Foveaux-Strait a small plant of the cress family, the shore-cress (Lepidium tenuicaule), puts down an exceedingly long root in quest of the fresh water which flows seaward beneath the stones. In the same locality a forget-me-not with small white flowers (Myosotis pygmaea var. Traillii) is also common. On the shores of Cook Strait two rather unexpected mountainplants, the spear-grass (Aciphylla squarrosa) and the striking silvery mats of a variety of Raoulia australis, are common. In similar stations two usually erect shrubs, the shrubby ribbonwood (Plagianthus divaricatus) and the common coprosma (Coprosma propinqua), form veritable mats. This happening certainly is not due to wind alone, as erect plants in the same neighbourhood testify, but the heat from the stones and the bright light may be controlling factors.

On many parts of the coast. sand is continualiy being brought on to the shore by the advancing waves. In the neighbourhood of high-water mark the shore soon becomes dry, and the sand is then borne landwards by any wind coming from the sea. Where the sand accumulates faster than it is hlown away, a hill, or dune as it is frequently called, is formed. Any obstacle in the path of the blown sand will also arrest its progress and cause its heaping-up. The dunes of New Zealand are of great extent, and occupy an area of more than three hundred thousand acres. In some parts of the coast the belt of dunes is more than six miles in width, and in the north of the Auckland Provincial District, on the west of Stewart Island, and elsewhere, the sandhills attain a height of several hundred feet, though usually they are much lower.

Frequently the dunes are very unstable, and in some places so much so that great areas of moving sand exist. These "wandering dunes," as they are called (fig. 18), insidiously advancing inland, do great damage - burying fertile fields, filling up valuable flaxswamps, choking watercourses, and overwhelming forests, plantations, pasture-lands, and even human dwellings. Happily nature has done much to stop such inroads, and the wandering dunes of New Zealand are chiefly the result of damage done by grazinganimals breaking the surface of the sand, and by fire removing the natural safeguard, its plant-covering. 


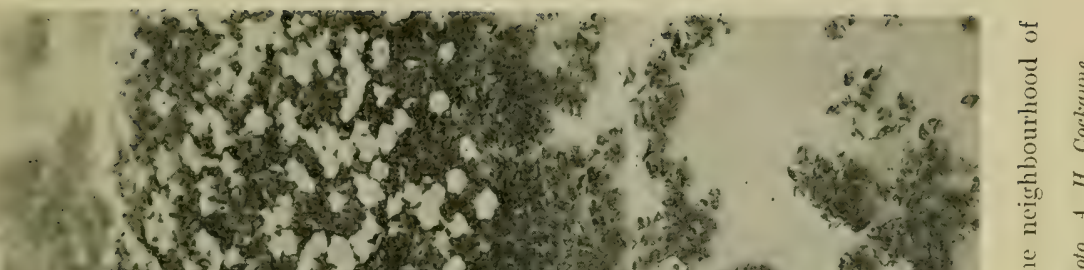

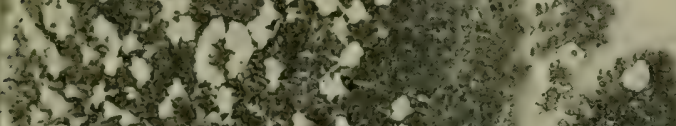

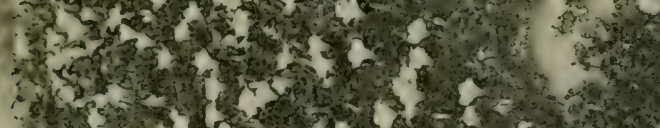

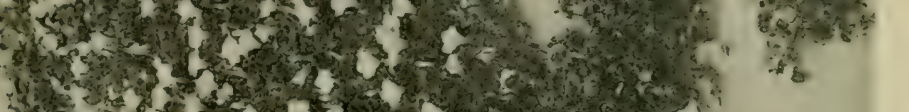

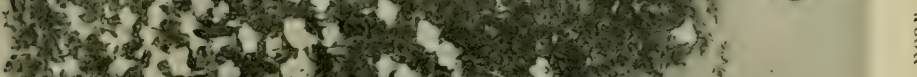

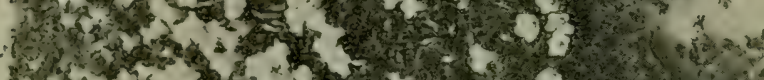

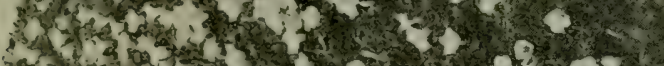

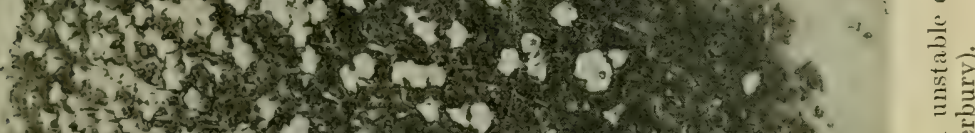

$$
\begin{aligned}
& \text { H. }
\end{aligned}
$$

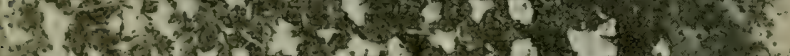

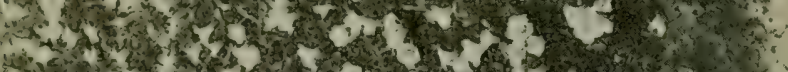

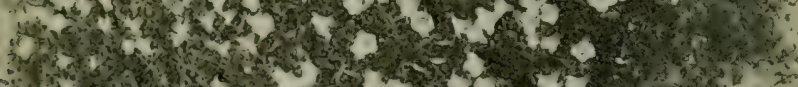

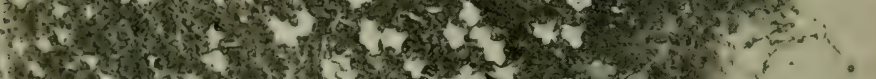

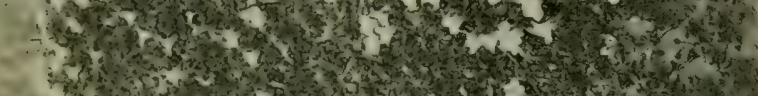

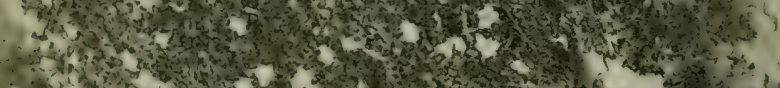

$$
\begin{aligned}
& \text {...2. }
\end{aligned}
$$

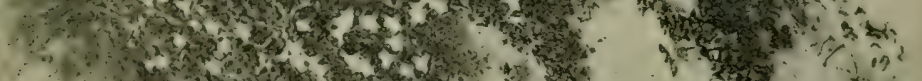

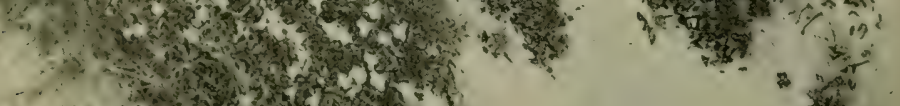

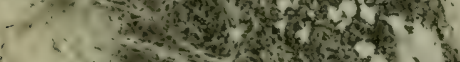

$$
\begin{aligned}
& \text { (4) }
\end{aligned}
$$

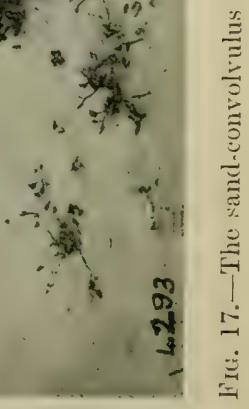




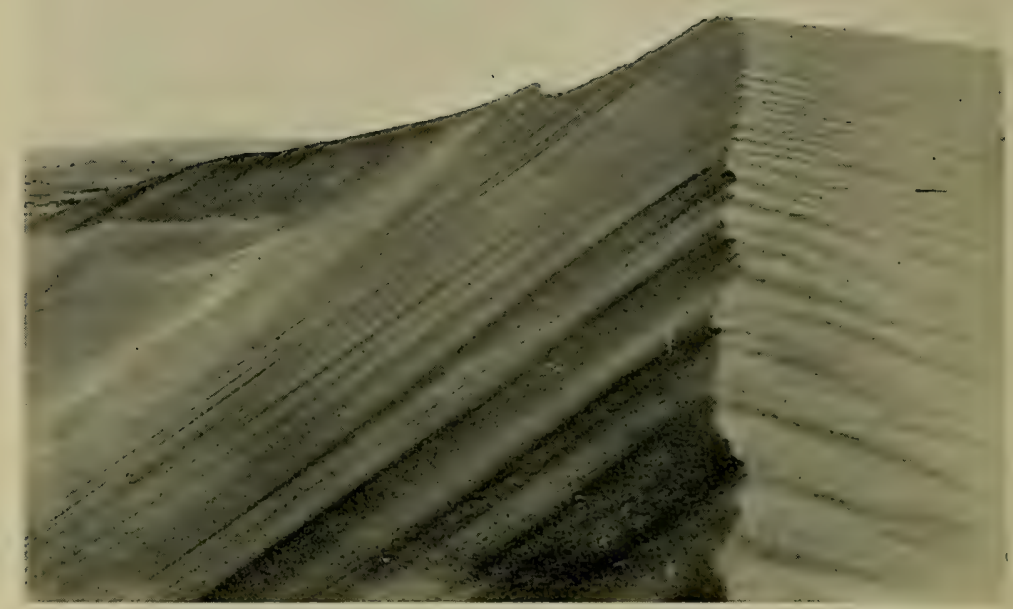

Fr:. 18.- Wandering dune which has buried good agricultural land near Turakina (west coast of IVellington).

[Photo, L. Cockrtyne.

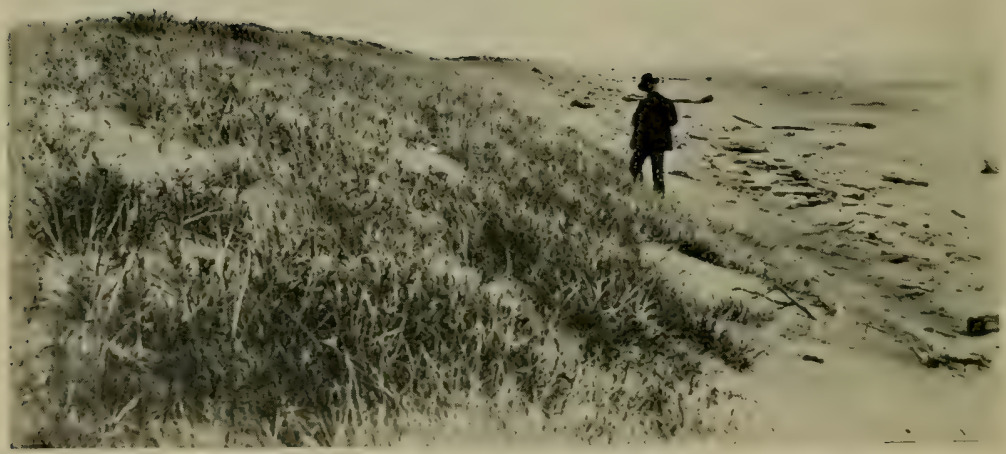

Fra. 19. - Natural fore-dune with a very even surface held by the silvery sandgrass (Spinifex hirsutus), near Waikanae (west coast of Wellington). 


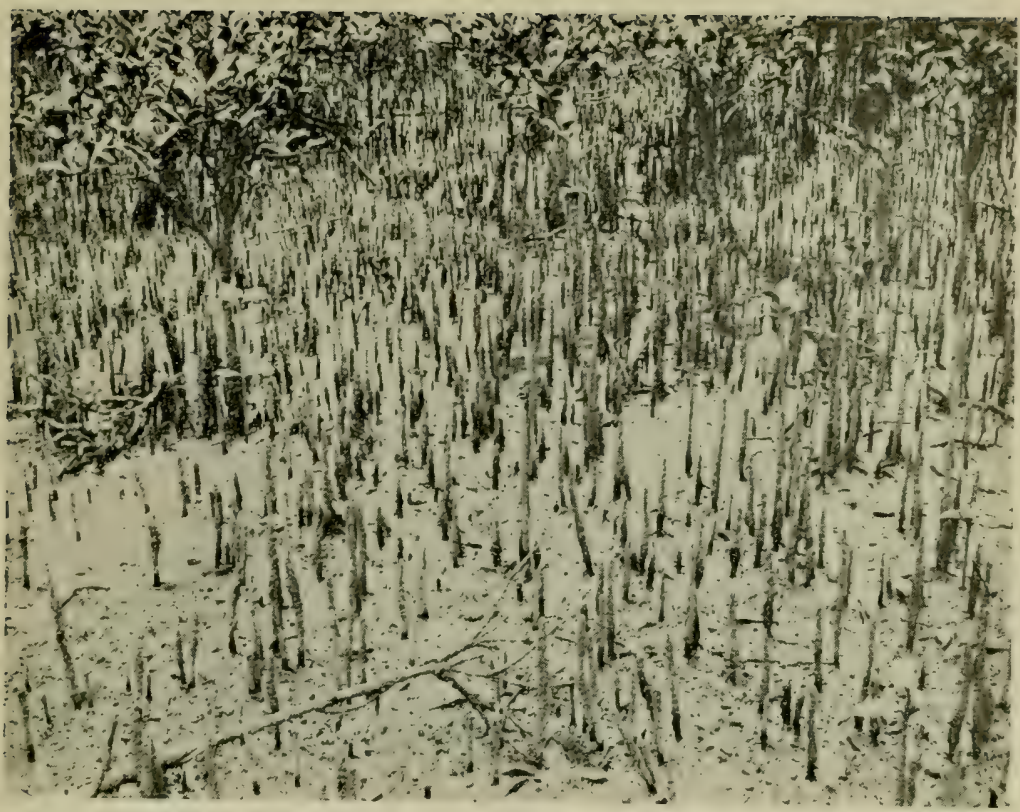

FIG. 20.-The erect breathing-roots of the mangrove (Avicennia officinalis) projecting out of the muddy floor of a tidal river near Mangonui (North Auckland). In the background are young plants of the mangrove.

[Photo, L. Cockuyne.

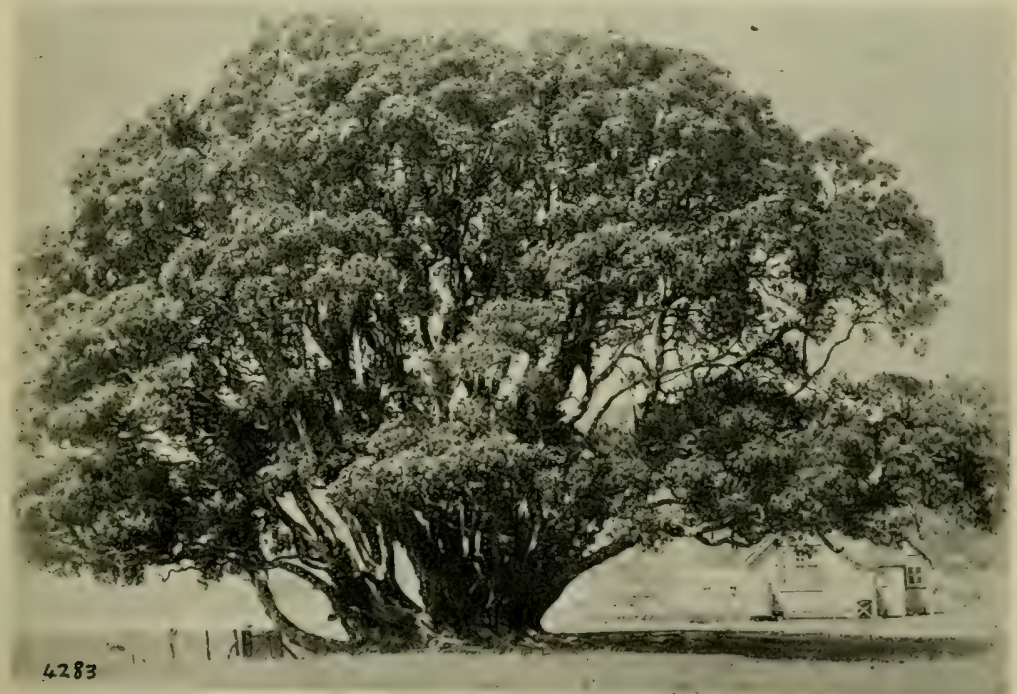

Fig. 21.-A pohutulawa (IItrosideros tomentosa) growing as an erect busly tree in the school-grounds at Te Araroa, near the East Cape. 


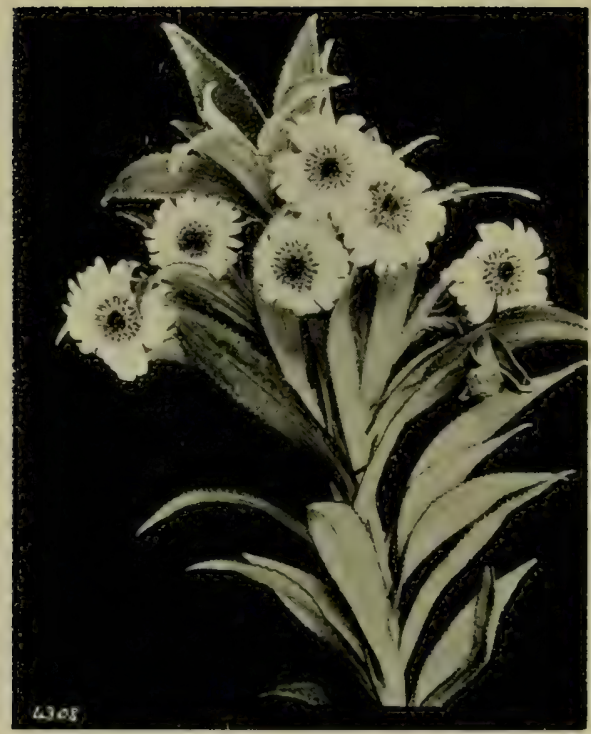

III. 22.-Flowering shoot of the teteaweka (Oleariu angustifolia). The outer florets are white and the inner florets are purple.

[Photo, J. Crosby Smith.

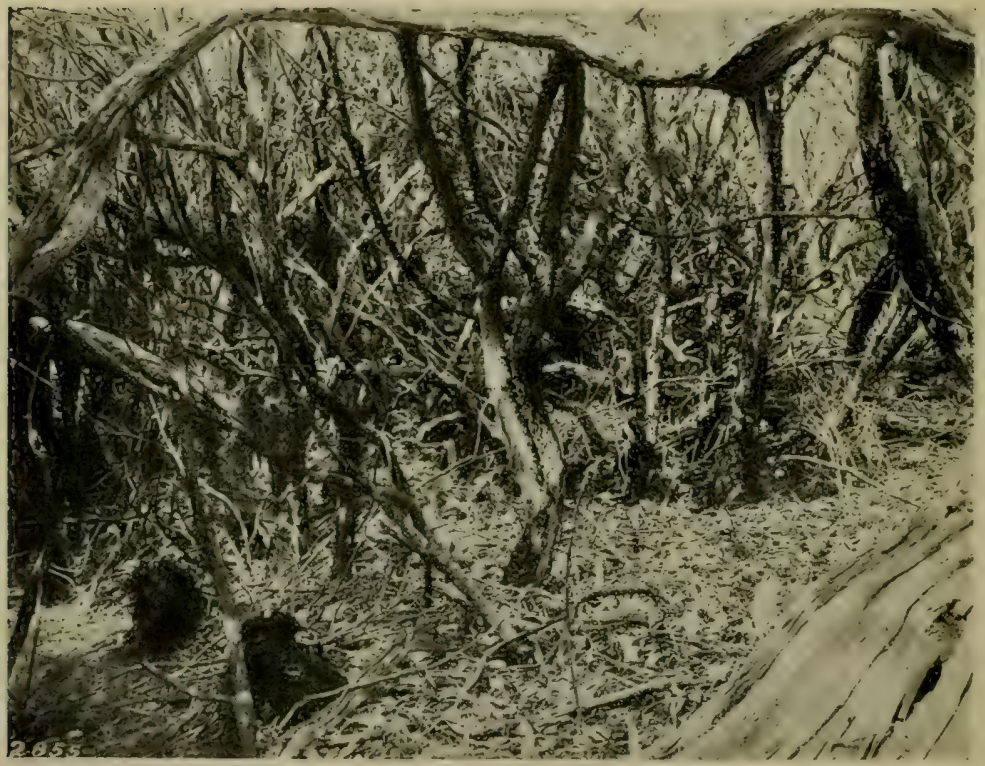

FIG. 23.- Interior of coastal scrub composed of a large-leaved variety of Olearia Colensoi growing near the Old Neck (Stewart Island). 
In order that a plant can live on drifting sand it must have the power of binding that unstable compound into a firm mass. Plants with rapidly growing underground stems, which have the power of rooting near the tips of the branches and putting forth new shoots as fast as the old ones are buried, are sand-binding plants par excellence. With few exceptions, wherever sandhills exist on the globe, such plants accompany them.

In New Zealand there is a most excellent example in the pingao (Scirpus frondosus). Its thick, rope-like stems, commonly called roots, form a perfect entanglement inside the dune, and its semitussocks of stiff, golden-coloured leaves crown many sandhills from the North Cape to Stewart Island and the Chathams. Unfortunately, rabbits and some other animals do not despise this plant, notwithstanding its most unappetizing-looking leaves. In consequence they destroy this natural protector of our shores, which came into being in a land where grazing-animals, the moa excepted, were unknown. It is of great interest biologically that sandhill conditions have called forth a sand-binding endemic plant of the same growth-form as that of sand-binders the world over. Also, the pingao must be a plant of long descent, since it has no near relative in any part of the earth, belonging, as it does, to an endemic subgenus of Scirpus, Desmoschoenus by name.

The silvery sand-grass (Spinifex hirsutus), which grows wild in Australia as well as in New Zealand, is another very important sandbinder. Its stout stems, often many feet in length, at first creep over the surface of the sand, firmly fixing themselves by means of many roots. Finally they are buried, and the tufts of long flexible leaves, covered densely with soft silvery hairs, project out of the sind. The pollen-bearing and ovule-bearing plants are distinct. When the seeds are ripe, the mature inflorescence breaks off, and, borne by the wind, hops on its long spines over the sandy shore like some huge insect, until, at last falling to pieces, the "seeds" are deposited and finally buried. S. hirsutus naturally builds up fairly stable dunes, which in some places have a surface so even as to look like a railway-embankment (fig. 19), as in the case of the dune fronting the shore near Waikanae, in the Wellington Provincial District. Spinifex, being less tolerant of frost than the pingao, reaches only the northern parts of the South Island, but it is present on all dunes of the North Island.

3-Plants. 
In Europe, America, and elsewhere plants and grazing-anınals assumed their present forms side by side. The marram-grass of Europe (Psamma arenaria) is a case in point. This, although naturally little better as a sand-binder than our Scirpus or Spinifex, is of infinitely more value for "reclaiming " our moving sands, since it is not relished as food, and grows rapidly and luxuriantly. With the marram may be used the lyme-grass (Elymus arenarius), another European sand-binder.

Besides grasses, trees and shrubs are of great service for sandfixing. Of the latter, the tree-lupin of California (Lupimus arboreus) is a splendid weapon in the hands of the dune-reclaimer if properly used: that is to say, this shrub is not a sand-binder, and will be worse than useless if planted where subject to sand-invasion, but it cannot be equalled when used so as to form a dense cover which will hinder the sand so covered from becoming the sport of the wind.

Where the dunes are more stable, other special "sand-plants" are common. Of these, the sand-coprosma (Coprosma acerosa), with wiry, reddish-coloured, interlacing twigs, is found everywhere; and so, too (with the exception of Southland and Stewart Island, where the pimelea is Pimelea Lyallii), is the autetauranga (Pimelea arenaria), a low spreading shrub, with flexible interlacing branches, pretty silvery leaves, and white flowers. Certain species of Cassinia, which genus belongs to the daisy family, are very frequent features of this association, but they are different in various parts of New Zealand. In the Auckland Botanical Districts it is the tauhinu-korokio (Cassinia retorta); Taranaki, Hawke's Bay, the shores of Cook Strait, and northern Marlborough and Nelson have the tauhinu, or cottonwood (C. leptophylla); while farther south the golden cottonwood (C. fulvida) is the sole representative. The two first-named tauhinus are so like one another that even an expert may find it sometimes difficult to draw the line. C. fulvida, too, strongly resembles some forms of the tauhinu, but it is generally to be distinguished by its yellow appearance.

Where the force of the wind is less felt, shrubland may make its appearance, and the manuka (Leptospermum scoparium in one or other of its varieties), the cabbage-tree (Cordyline australis), the toetoe (Arundo conspicua), the New Zealand flax (Phormium tenax), and, from the shores of Cook Strait southwards, the wild-irishman (Discaria toumatou) occur in force. 
In the Auckland Botanical Districts such sand shrubland would also contain the tall mingimingi (Leucopogon fasciculatus), growing as a prostrate shrub; the white tea-tree (Leptospermum ericoides), similarly prostrate, though in a forest it would be a good-sized tree; the heath-like pomaderris (Pomaderris pluylicaefolia), and perhaps the austral broom (Carmichaelia australis), distinguished by its broad flat green stems, absence of leaves, and pods with red seeds. Cassinia retorta, mentioned already, is, of course, abundant; but, strange to say, it remains erect where most of its fellow-shrubs hug the sand. In Southland the manuka association appears absent. In Stewart Island the puheretaiko (Senecio rotundifolius) forms dense thickets.

Hollows in the dune areas are very frequent, the sand being blown away until the ground-water is almost reached, for wet sand is not moved by wind. Where the water cannot get away there will be swamps, and even shallow lakes.

In sand-hollows the pioneer plant is the sand-sedge (Carex pumila), which soon builds miniature dunes. The sand-gunnera (Gunnerc arenaria), forming close mats of small pale-green leaves flattened to the ground, is also very abundant in many localities. Such hollow's finally become occupied by introduced grasses and plants of the clover family. These hollows, where circumstances permit, may be made truly profitable through growing lucerne (Medicago sativa), but the grazing by sheep or cattle would be almost certain in time to cause fresh drifting of the sand. Such grazing needs, then, to be conducted with extreme caution. Dune-hollows must not be looked upon as having any close relationship to sand-grass dune, but they may rightly be considered different plant-formations, the beginning of a dune-hollow association being due to a topographical change.

Let us leave the dunes, and, in imagination, sail up one of those wide estuaries in the west of the North Auckland Botanical DistrictHokianga or Kaipara Harbour - or one of the tidal rivers of the east -the Whangarei, for instance. If it is high tide, we shall see on either side of the stream a belt of close-growing, dull-coloured, small trees, rising out of the turbid water. These consist of the mangrove (Avicennia officinalis), and the sight is one almost unknown in any other land outside the tropies. It is, in fact, one of the natural wonders of New Zealand.

Now, quite undeservedly, the mangrove has got a bad reputation. A mangrove swamp is supposed to represent all that is most 
hideous on earth-alligators in crowds, a fearsome odour, crabs waiting to pick such of the victim's bones as are left by the alligators, malaria, and deadly "microbes" in vast abundance. Even in the tropics this picture has been shown to be absurd, but in New Zealand the mangrove belt is quite a pleasing feature of the northern rivers. The mangrove is also a beneficial plant, as it materially assists in turning muddy useless shores into good dry land.

Moreover, the mangrove is one of the most noteworthy plants in nature. As our boat proceeds up the river the tide has turned, and the slimy flats where the mangrove is rooted come into view. There, projecting out of the mud, are thousands of upright bodies, 6 inches or so in height, looking much like stout asparagus-shoots (fig. 20). One might feel sure these were young mangroves; but they are nothing of the sort, strange as it may seem: they are, in fact, roots which, instead of passing downwards to anchor the trees, grow upwards into the air. On being examined, these erect roots are found to consist largely of a very porous tissue. Plants, like animals, cannot live without oxygen. They need to breathe just as much as we human beings do; without air they would die of suffocation, nor would they get energy to carry on their work. In the soft mud is little of the life-giving gas, hence the necessity for the mangrove to obtain a supply for its ordinary roots. This it does with these erect organs, which are the veritable lungs of the tree. Of course, the aerial parts of the mangrove, like those of any other tree, procure oxygen by means of the small pores in the leaves and minute openings in their bark.

The mangrove, too, has another peculiarity of even greater interest than that just described. If a seed were to fall on the muddy floor of a tidal estuary, being washed hither and thither by the ebb and flow of the tide, it would have little chance of germinating. While still on the tree, however, the seed has germinated. The little mangrove (embryo) has emerged from its seed-coat, awoke from its heavy sleep, and become a fair-sized seedling plant with rudimentary roots. At this stage it somewhat resembles a broad-bean which has just germinated. Therefore it is not a seed which falls from the tree, but a young growing plant, whose roots rapidly increase in length, pass downwards and outwards from near the tip of the stem below the seed-leaves, and anchor the plantlet firmly in 
the unstable ground. The green seed-leaves, with which the little plant was also provided while attached to the tree, can manufacture food-material; but this is not all, for they are also fleshy and full of nourishment, so the young mangrove can live until the time when, provided with foliage, it is in a position to manufacture for itself in sufficient quantity the sugary foods it requires from the carbonic acid of the atmosphere and water. Surely none need cast contumely on such a plant as this!

Much more common than mangrove salt-swamp, or, as it may also be called, "tidal forest" or "tidal scrub," is that plantformation which occurs on the floor of tidal rivers and lagoons subject to flooding during the highest tides. The plants concerned are usually more or less of the rush form, and, seen from a distance, present the appearance of a dark, even surface. Extremely extensive swamps occur at Havelock (Pelorus Sound), Invercargill, and many other places. The Invercargill salt-swamp is now being reclaimed and turned with surprising speed into well-grassed dairyland of first-class quality.

The first plant to settle on the clayey or loamy sandy ground, so soon as it is able to support salt-swamp plants, is the three-square (Scirpus americanus), which on the wetter ground can at first hold its own against the subsequent arrivals, thanks to its far-spreading underground stems; but finally the next-comers, the jointed rush (Leptocarpus simplex) and the sea-rush (Juncus maritimus var. australiensis) exclude the light, and the three-square is exterminated. In many salt-swamps either the Leptocarpus or the Juncus are dominant, but only as far south as Timaru and Okarito; farther south the sea-rush does not go, and Leptocarpus reigns alone.

There are also other members of the formation-e.g., the seasedge (Carex litorosa), which is found only in salt-swamp; the swamp twig-rush (Cladium junceum), but this only in the north of the North Island, though the species extends to Foveaux Strait; the succulent Australian glasswort (Salicomia anstratis); the slender New Zealand celery (Apium filiforme); and the shore-cotula (Cotula dioica) forming green mats, the leaves highly aromatic when bruised. In deep pools is the grass-like sea club-rush (Scirpus robustus), a summergreen grass-like sedge; and on the driest ground a black ball-like divaricating shrub of more or less deciduous habit, the shrubby ribbonwood (Plagianthus divaricatus), takes complete possession. 
As the salt-swamp gets drier owing to its members arresting the mud, its biological conditions change, and the environment becomes less suitable for the jointed rush and the sea-rush, but eminently fitted for turf-making plants which can tolerate salt, most of them provided with small thickish leaves. The chief species are the southern water-pimpernel (Samolus repens var. procumbens), a white-flowered plant of the primrose family, but not a bit like a primrose; the creeping selliera (Selliera radicans), which has a curious corolla, looking as if a portion had been removed, also white; the shore-cotula (Cotula dioica), with aromatic leaves and yellowish button-like flower-heads; and the salt-grass (Atropis stricta). In some places, but by no means everywhere, growing in the pools or streams, is the beautiful New Zealand musk (Mimulus repens). Its flowers are bright lilac in colour, with an orange throat. Extremely abundant also in some localities (e.g., on the northern shores of Cook Strait), dotting the ground everywhere, is the pretty relative of the last-mentioned, the dwarf false musk (Mazus pumitio). The curious Australian sea-holly (Eryngium resiculosum), a plant of the carrot family, which ean increase at a great rate by means of rumners, and so become a pasture weed, is an occasional saltmeadow plant.

Other species of the salt-meadow are: A plant of the fat-hen family, the spreading-orache (Atriplex patula); the three-ribbed arrow-grass (Triglochin striatum var. filifolium); the succulent Suacda maritima (but frequently absent); the two kinds of wild celery (A pium prostratum and A. filifolium); and the swamp-cotula (Cotula coronopifolia).

In parts of Southland, Stewart Island, and the small islands of Foveaux Strait the ground is very peaty. Here are different conditions and a very different association. The plant-covering makes a turf of such density as to encourage those who love so to do-and many there ar: in the world of that disposition-- to carve their names thereon. Selliera radicans, Cotula dioica (in certain of its forms), or the shining green rosettes, flattened close to the ground, of the glossy plantain (Plantago Hamiltonii), may in turn be the leading species. The lovely white shore-gentian (Gentiana saxosa) may dot the meadow everywhere. Soft cushions of the shoreeyebright (Euphrasia repens)--balls of snowy whiteness-stand out distinctly when in blossom, making a delightful spectacle. There are 
green colonies of the shore-dock (Rumex neglectus); the tiny creamywhite stars of the dwarf bedstraw (Asperula perpusilla) are everywhere; red mats of the shore-stonecrop (Crassula moschata) occur abundantly; and in the wet pools is the water-chickweed (Montia fontana).

The varied coast-line, combined with the mountainous character of portions of the coast, to say nothing of the geological structure of the rocks, has led to a considerable variety of coastal-rock associations, as well as to a rich rock-flora. About 100 species, belonging to 37 families, are more or less common on coastal rocks, but only about 30 species are found where there is much sea-spray, and there is not one which is confined to pure rock alone.

The ice-plant (Mesembryanthemum) association is truly coastal; it occurs in all parts of New Zealand proper. The plant itself ( $M$. austrule) frequently forms green masses hanging downwards on the cliff-face so that they can be raised like a curtain. There may be little else than the ice-plant, but generally the succulent Australian glasswort (Salicomia australis) this the first-comer on rocks just left bare by the sea-the wild celery (Apium prostratum), and the shore-groundsel (Senecio lautus) are present. When less exposed to spray, in the North Island, there is the taupata (Coprosma retusa), its extraordinarily thick, fleshy, polished leaves closely rolled, and the plant itself hugging the rock. In the north of the North Island and the Marlborough Sounds the rock-lily (Avthropodium cirratum), called in the latter locality the "Mabel Island lily," its broad green leaves 2 feet in length, forms pure colonies. The shorespleenwort (Asplenium obtusatum) is sometimes a member of this association. Less spray, and many other plants invade the rock, some of them common lowland shrubs-e.g., the manuka (Leptospermum scoparium).

One rock association is dominated by a tree, the pohutukawa or Christmas tree (Metrosideros tomentosa), of which the Aucklanders are so justly proud. It was formerly much more abundant than at present. It grows frequently on the faces of cliffs, stretching outwards over the oyster-covered rocky shore. Some of its roots are fixed in the solid rock, and creep for long distances over the surface-a most remarkable sight - while others are given off quite high up the trunk or from the branches; but these do not usually reach the ground. Not infrequently the pohutukawa is of a quite 
erect growth, as may be seen in many coastal forests (fig. 21). It occurs on the coast from the Three Kings Islands to Poverty Bay and Taranaki, and inland on the shores of Lakes Taupo, Waikaremoana, Rotorua, Roto-iti, and other lakes of the Volcanic Plateau.

Associations in which the yellow-flowered, drooping-leaved mountain-flax (Phormium Colensoi) is the leading plant occur at various points on coastal rocks. On the soft papa clifts of Hawke's Bay the flax is accompanied by the handsome papa-koromiko (Veronica macroura). Another plant peculiar to that association is the East Cape groundsel (Senecio Banksii). On the northern shore of Cook Strait, and on rocks in Pelorus and Queen Charlotte Sounds, an allied association occurs, but the reronica is the Cook Strait koromiko ( $Y$. salicifolia var. Athinsonii). In Stewart Island and the Otago fiords Phormium Colensoi clothes the rock, but hardly where facing the actual ocean. In the last-named localities, as also in Southland, peat is readily formed in the semi-subantarctic climate. On such a soil there is a coastal fern-association of the shorespleenwort (Asplenium obtusatum), the thick-leaved hard-fern (Blechnum durum), and its smaller-leaved relative, the shore hard-fern (B. Bankisii). Here will be also the fine white shore forget-me-not (Myosotis albida), a plant suitable for rock-gardens. Old morainic matter facing the sea in Westland-e.g., the Okarito Bluff-has its special rock association, distinguished especially by great green sheets, where water drips, of the handsome everlastings-the three-nerved cudweed (Gnaphalium trinerve) and the rock-cudweed (G. Lyallii), the latter to be distinguished from the former by its larger leaves. There is also abundance of the clinging climbing-rata (Metrosideros scandens). Another cudreed (Guaphalium keriense) occurs on volcanic coastal rocks of Taranaki. It is accompanied by an unnamed veronica allied to V. Cookiana, a thick-leaved prostrate form of the shorelobelia (Lobelia anceps), an unnamed grass, and the fine thick-leaved rosettes of a variety of the New Zealand plantain (Plantago Raoulii).

One of the most remarkable plant-associations of New Zealand is that combination of shrubs, \&c., growing on Rangitoto Island, in the Hauraki Gulf. The soil is entirely composed of huge blocks of scoria. There is apparently no water, but, of course, a sufficiency there must be. All the same, there is not enough, as a rule, for the shrubs and other plants to assume their usual development. Notwithstanding the barren dwelling-place, 180 species at least of 


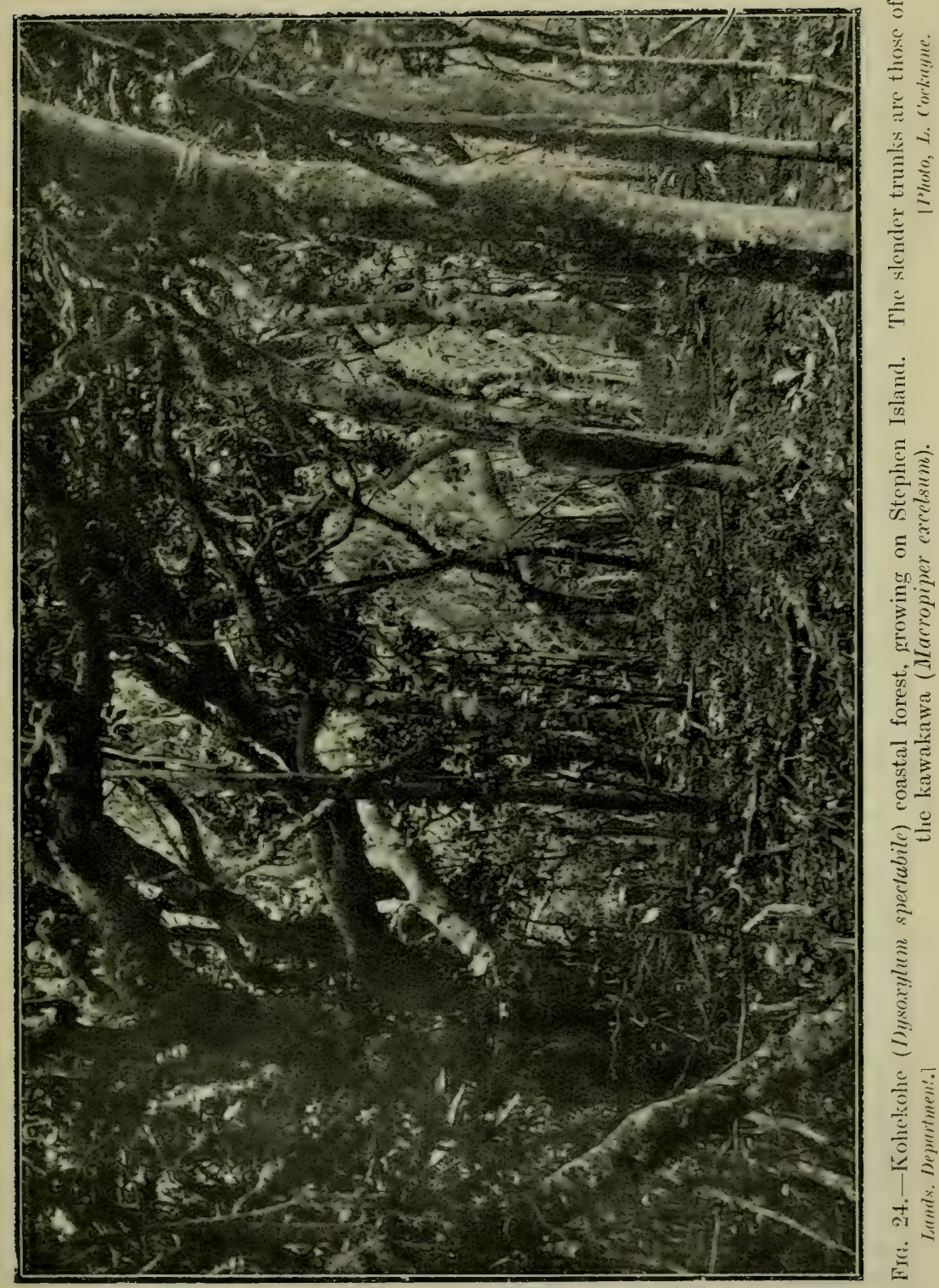




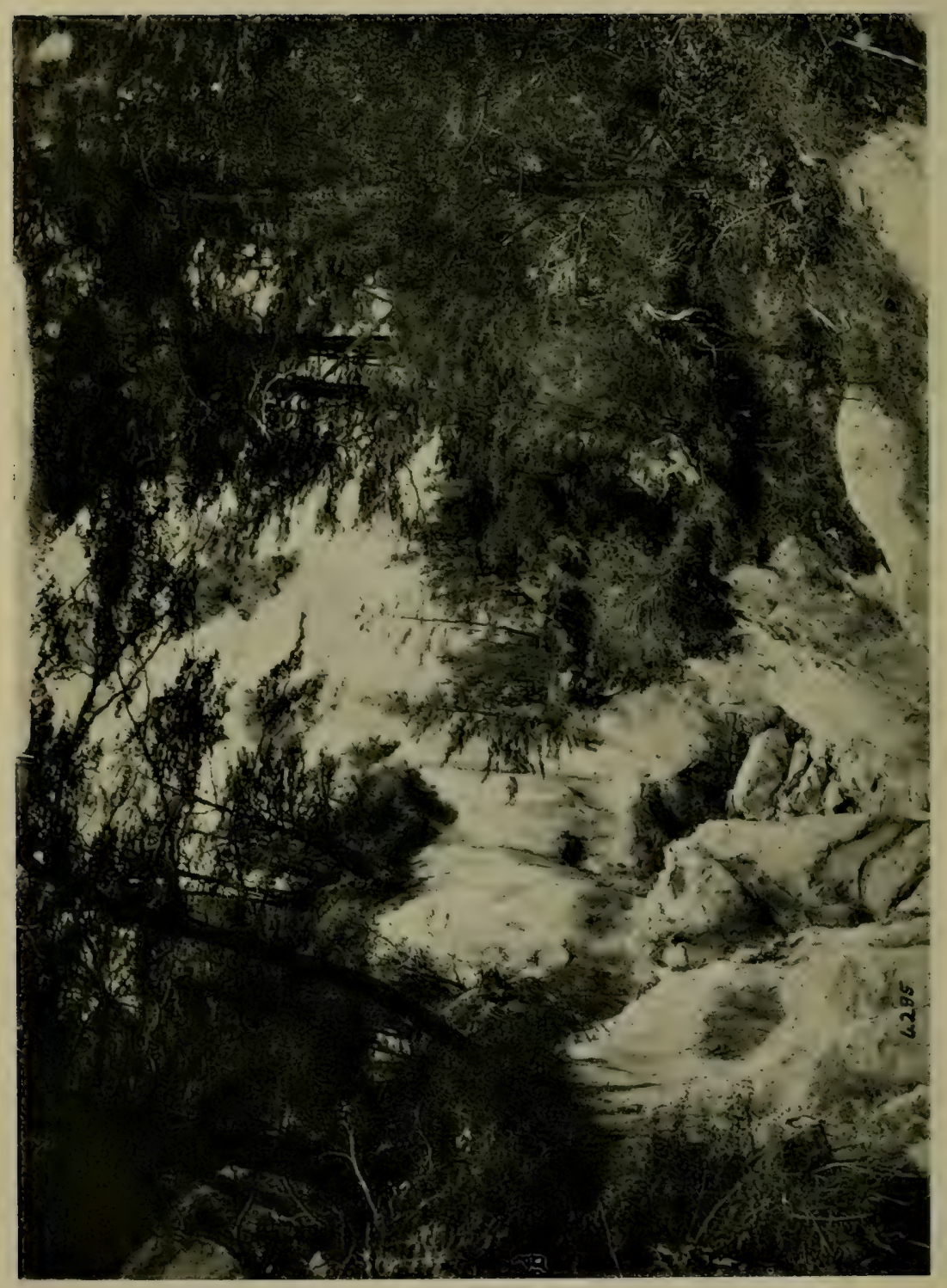

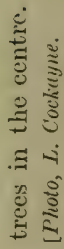

Eo

ఏ

$$
\text { . }
$$

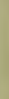

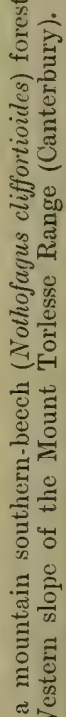

$\because$

ह5

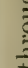

吾 


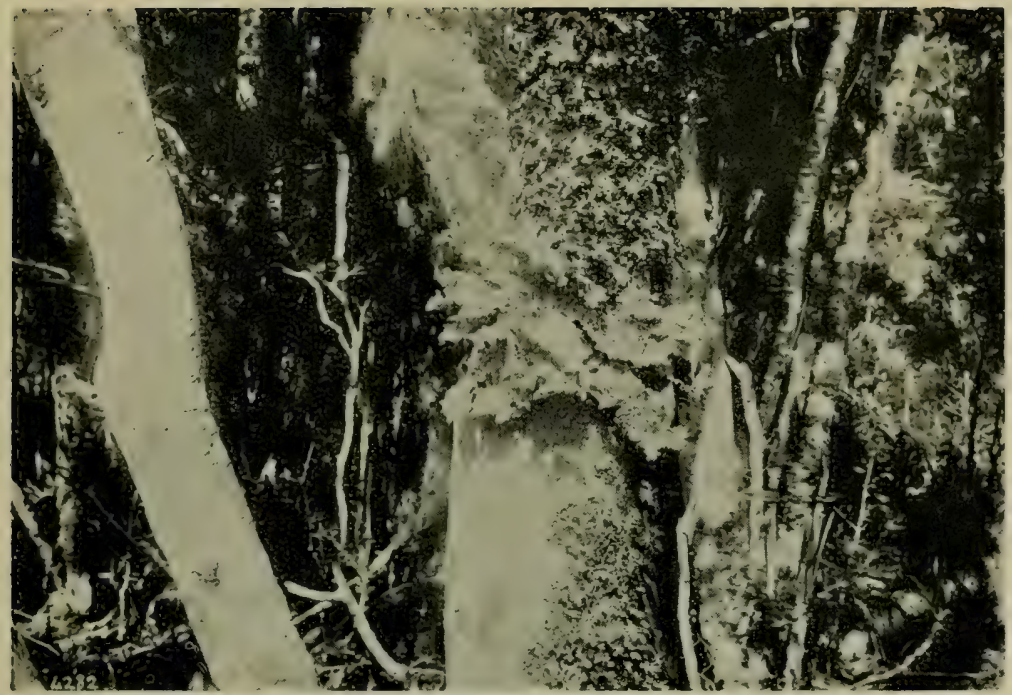

Fra. 26.-Lichens (species of Sticta) epiphytic on the trunk of the kamahi (Weinmannia racemosa) in the rain-forest near Milford Sound (Otago).

[Photo, L. Cockayne.

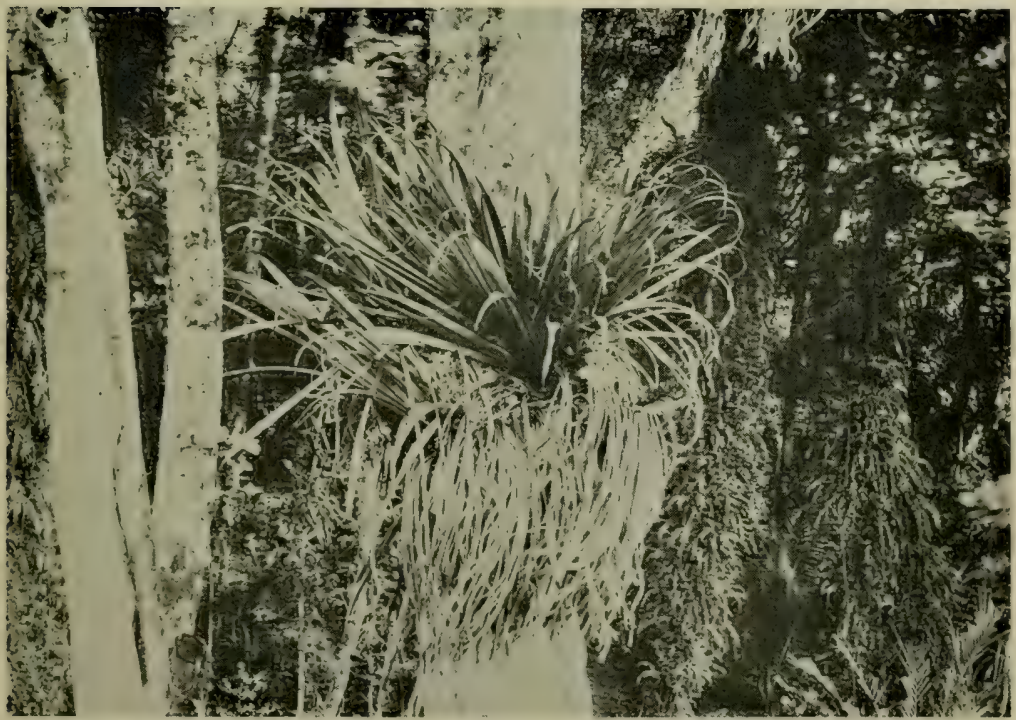

FIG. 27.-The kahakaha (Astelia Solandri) growing on the vertical smooth trunk of the taraire (Beilschmicdic taraire) in the Waipoua Kauri Forest (North Auckland). The indistinct vegetation on the right is the climbing hardfern (Blechnum filiforme).

[Photo, I. Cockayne. 


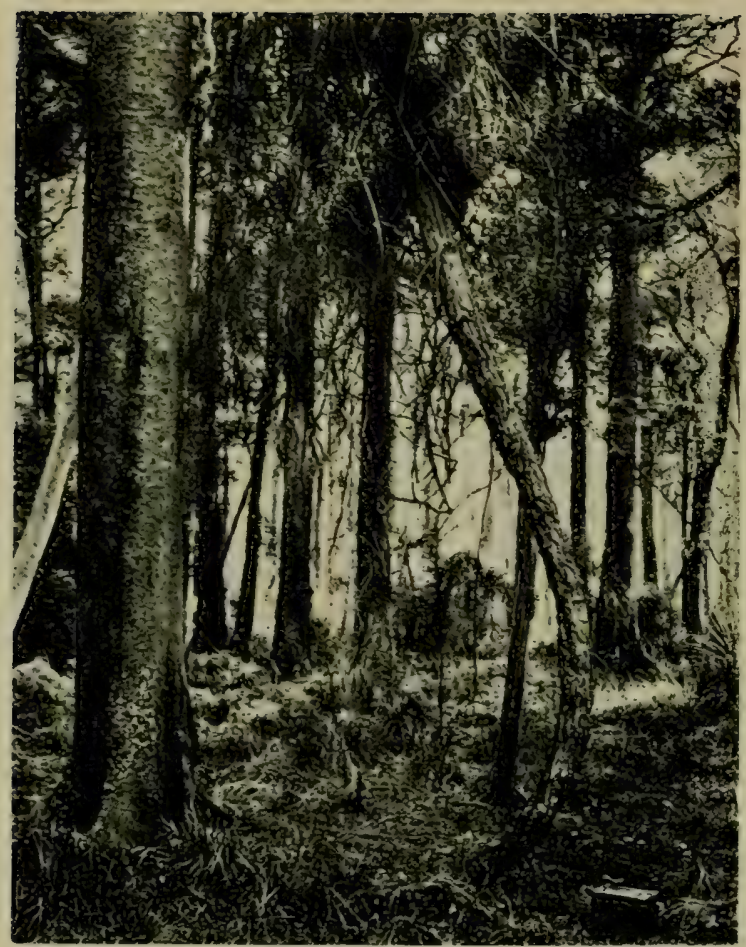

FIG. 28.- In the centre the climbing-stem of the semileafless lawyer (Rubus subpauperatus), but now quite detached from its original support. On left, trunk of kahikatea. Riccarton Bush, near Christehurch.

Trans. N.Z. Inst.]

[Photo, J. W. Birl.

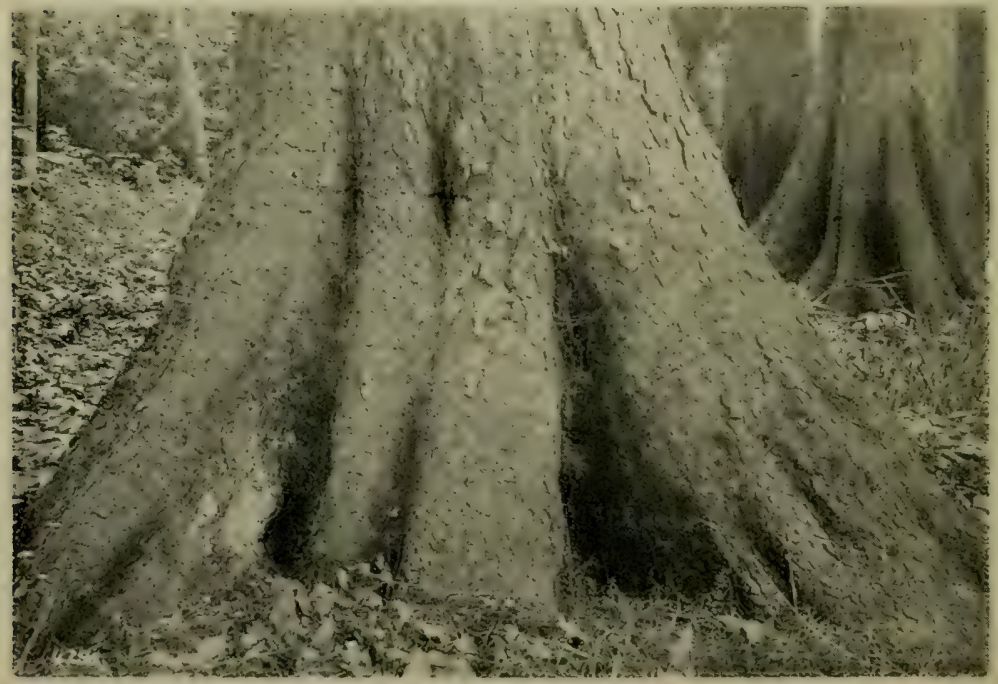

Fit. 29.--Base of the trunk of a kahikatea (Podocarpus dacrydivides), showing its rounded buttresses. Riccarton Bush, near Christchurch. 
seed-plants, ferns, and fern-allies live on the small island. Every stage of plant-colonization can be seen, from the occupation of the rock by mosses, lichens, liverworts, and filmy ferns to actual forest-but this does not get established until humus has collected in sufficient quantity to aci as a water-reservoir. Two astelias, the shorekowharawhara (Astelia Banksii) and the kowharawhara (A. Cunninghamii var. Hookeriana), are abundant. These are well enough suited to the surroundings. So, too, is the puka (Griselinia lucida), usually a perching-plant. But hardly so suited to its position is a rain-forest shrub, such as the hangehange (Geniostoma ligustrifolium) or the two coprosmas-the glossy karamu (C. robusta) and the karamu (C. lucida). These and other shrubs or stunted trees (e.g., the pohutukawa) have had their plasticity called into play, and so developed thick leaves, which are less liable to be damaged by drought, containing as they do an extra supply of water.

The beautiful inlets of Stewart Island derive their charm in large measure from the assemblage of trees and shrubs along the water's edge, especially when the southern rata (Metrosideros lucida), its boughs almost dipping into the water, has burst into flaming crimson. In similar situations the inaka. (Dracophyllum longifolium) and the mountain-flax (Phormium Colensoi) are common.

Where the coastal scrub of Stewart Island is densest it has received the name of "mutton-bird scrub." This consists largely of the puheretaiko (Senecio rotundifolius), a very fine shrubby groundsel, which makes an excellent garden-plant even as far north as Auckland. The leaf is frequently 4 inches or more in diameter, and covered so closely with a mat of buff-coloured hairs on the under-surface that it can be written upon. The leaf may thus be made to serve as a post-card, which can be posted at the most southerly post-office in Australasia - that on the Isle of Ulva, in Paterson Inlet.

In the West Coast Sounds this groundsel forms thickets, associated with some other shrubs, of which the principal are the charming Olearia operina, the shore-koromiko (Veronica elliptica), and the common koromiko ( $V$. salicifolia). A close relation of $O$. operina, the teteaweka ( $O$. angustifolia) (fig. 22), occurs in Stewart Island, and has flower-heads 2 inches or so in diameter, with violet centres. There are also a few plants at the base of the Bluff Hill. These latter, unfortunately, are badly attacked by an indigenous 
parasitic fungus, one of the rusts, those protean plants which in some instances, totally changing their form and habits, spend a part of their existence on one plant and another part upon quite a different species.

Growing in a similar situation to the teteaweka is a form of the common mountain tree-daisy (Olearia Colensoi), very like the subantaretic tree-daisy (O. Lyallii). The interior of such coastal scrub presents only a view of naked, irregular trunks and branches (fig. 23), but it is a remarkable sight nevertheless.

The shore-koromiko (Veronica elliptica), mentioned above, deserves a few words. In the first place, it is one of our South Americin connections, for it grows in southern South America as well as in New Zealand. When fairly sheltered it is a fine upright-growing shrub, covered closely on its outer twigs with rather thick palishgreen small leaves. Like all the other veronicas, its flowers have only two stamens. The corolla is at first bright purple, but soon fades to white. The scent of the flowers is delicious. It is abundant in the Lord Auckland and Campbell Islands, the Snares, Stewart Island, the west coast of the South Island, and the east coast to about as far north as Dunedin; then on that coast it does not occur again until on one of the northern islands of Pelorus Sound. It appears again, but as a different variety, on the shore of Cook Strait at Titahi Bay, near Wellington. Finally, it was discovered recently by Mr. P. G. Morgan to the west of Mount Egmont, on the coast of Taranaki; but, strange to say, it extends no farther to the north, though it grows freely from seeds, and may be cultivated at any point on the New Zealand coast.

Forests of various kinds are more or less common near the coast, but their distribution is governed by the sea-wind, as also by the degree of cold of the area where they occur. Thus there are treeless portions of the coast-line and other parts where the forest is reduced to scrub or where coastal scrubs occupy what would be its site.

Frequently coastal forest does not greatly differ from that of the adjacent lowland: but there are certain coastal trees which appear in such a coastal community, and their presence both reveals the character of the forest and affects its appearance. The special coastal tree-associations are commonest in the Auckland Botanical Districts, but become less marked the farther south one goes until, with the 
exception, in most places, of the ngaio (Myoporum laetum), a lowland forest pure and simple comes almost to the water's edge.

The following trees are fairly common in coastal forest, but those with an asterisk are confined, or almost so, to the Northern Botanical Province. The kawakawa (Macropiper excelsum), the karo (Pittosporum crassifolium), ${ }^{*}$ its near relative $P$. umbellatum, ${ }^{*}$ the karaka (Corynocarpus laevigata), the akeake (Dodonaea viscosa), the shor(panax (Pseudopanax Lessonii), * the ngaio (Myoporum laetum), the taupata (Coprosma retusa). There are certain other trees, not strictly coastal, of equal importance. Some of these are: The kohekohe (Dysoxylum spectabile), the mahoe (Melicytus ramiflorus), the kaikomako (Pennantia corymbosa), the titoki (Alectryon excelsum), the mapou (Rapanea Urvillei), and the ubiquitous manuka (Leptospermum scoparium).

In northern coastal forest the pohutukawa (Metrosideros tomentosa) is frequently the most important tree. With it will be the other coastal trees mentioned above and a number of the ordinary trees and shrubs of the adjacent area. There will be abundance of treeferns. Various species of Coprosma, and the rangiora (Brachyglottis repanda), may form a considerable proportion of the undergrowth.

In the south of the North Island, and along the east coast of the South Island as far south as Cheviot, there is karaka forest. Whether this is an indigenous association, or whether it has originated, so far as the karaka goes, from trees planted near Maori settlements as its nucleus, is not known, but probably a good deal is the original work of nature.

A forest of considerable interest is the kohekohe (or, as it is called in Marlborough, the "cedar") forest, with Dysoxylum spectabile as the principal tree. This interest is not, as one might suppose, derived on account of the timber it contains, or its peculiar biological characteristics, but rather because it is an indication of excellent land for grazing purposes when the forest is removed. Consequently very little of this beautiful primitive association now remains; in its stead are prosperous homesteads, sheep, and cattle!

The kohekohe itself is a most beautiful tree, of tropical appearance, 20 to 50 feet high, its trunk 1 to 4 feet in diameter, its branches spreading and covered with pale, smooth bark. The leaves consist of about four pairs of leaflets 3 to 7 inches long and a terminal one, the whole compound leaf being up to 7 inches long. 
The flower-stalk is branched, pendulous, and more than 10 inches long, and, strange to relate, it is given off not, as one would reasonably expect, from the twigs, but from the actual naked trunk of the tree. The flowers, waxy-white in colour, are produced only in the winter. The species belongs to the same family as the tropical mahogany, the satinwood, and the Australian cedar. The genus is Asiatic, Polynesian, Malayan, and Australian.

On Stephen Island, in Cook Strait, doubly famous as the home of the tuatara lizard (the last representative of an otherwise longvanished race) and of a second New Zealand frog, is a piece of the forest under consideration. Now, on that islet can be seen every stage of human interference with the "forest primeval" to its replacement by a cabbage-garden, a most necessary adjunct to a lighthouse-keeper's home. This forest is quite a remarkable one, and, from what has gone before, it seems clear enough that such portion as still remains should be preserved from further destruction. It consists, besides the kohekohe (Dysoxylum spectabile), of the largeleaved milk-tree (Paratrophis opaca), the kawakawa (Macropiper excelsum), and the nikau-palm (Rhopalostylis sapida). The trees are stunted, some of them have many spreading branches (fig. 24), and are garlanded by that most elegant of climbing-ferns, the climbing hard-fern (Blechnum filiforme).

A remnant of a coastal forest which has disappeared through natural means is found on the Open Bay Islands, which lie off the coast of south Westland. It would be an unpleasant experience to pass a night there, since in their peaty soil, honeycombed by the holes of petrels, veritable leeches and wetas of huge size and formidable aspect abound. The vegetation of the largest island consists of an impenetrable scrub of kiekie (Freycinetia Banksii), one of the last survivors of a forest which must have clothed these islands long ago, when connected with the mainland of Westland. At that time the area of the forest would be sufficient to secure it from damage by wind; but as the land gradually shrank in size, so would the forest be more and more exposed until the sole survivors would be those plants which could tolerate the most wind.

Only a brief reference can be made to the Poor Knights Islands, visited some years ago for the first time by Captain Bollons and the author, where the big snail, Placostylus Hongii, is still abundant; where the arborescent vegetation consists largely of a large-leaved 
form of the wiry matipo (Suttonia divaricata), an unexpected plant: and where there is a very fine koromiko with glossy leaves (Veronica Bollonsii), which, according to Mr. Petrie, is also found on the Hen and Chickens Islands. Nor can the cliff-vegetation of the Nuggets be described, where an alpine celmisia (Celmisia Lindsayi) clothes the barren rock; nor many other charming spots, lapped by the many-voiced ocean. Sufficient, however, has been said to show that we need not climb into the clouds to find our wild flowers, and that those who are wont to take their pleasure sadly by the seashore may find there a field of new interest. 


\section{CHAPTER IV.}

\section{THE STORY OF THE FORESTS.}

General remarks-Distribution of the forest-Composition of the forest-The two classes of forest-Special characteristic's of rain-forest-The kohekoheOrigin of special forest-plants-Climbing-plants - Scramblers-The climbingapparatus of the bush-lawyers - Root-climbers - The climbing-ratas Climbing-ferns - Winding lianes - The mangemange-A leaf yards in length-Explanation of the term "spore"-Tendril-climbers-The specie: of Clematis - Perching-plants -- Seedling trees as perching-plants - Filmy ferns - The flowers of the forest-Pollination - The kauri forest-Lifehistory of a kauri forest-Mixed taxad forest-Westland taxad forestKahikatea swamp-forest-Southern-beech forest-Lowland southern-beech forest-Identification of the southern-beeches.

However little the average New-Zealander may know about the plants of his country, few there are who cannot raise some enthusiasm regarding the "bush," as the forest is everywhere called. To old and young it is a delight: the stately trees; the birds, fearless of man; and, above all, the wealth of ferns, appeal to all. But that this forest is a unique production of nature, found in no other land, is not a matter of common knowledge, though truly it has many claims to be considered a priceless possession.

Although so large a part of the forest has been destroyed, usually for economic reasons - either that the land could be put to a better use or that the timber was required-but partly through fires, sufficient remains, often quite virgin, to give a fairly correct idea of the vast tree-covering of primeval New Zealand.

In the lowlands this great forest extended almost unbroken throughout the North Island, and, in the South Island, over all the area west of the Dividing Range. The Marlborough Sounds area, too, was densely forest-clad; thence going south along the east coast only small areas occurred here and there, until forest once more asserted its supremacy on the Seaward Kaikouras. Farther south, on Banks Peninsula, was noble forest, whence until a little to the north of Dunedin the land was treeless, save for isolated areas amongst the foothills of the Southern Alps. In the south of the 
South Island, however, the great forest of the west already mentioned extended almost unbroken to the east coast. Stewart Island, too, was green or black with forest. Not in the lowlands only was this mighty tree-community; it swept over the lower hills and climbed high on to the flanks of the great ranges.

Leaving out of consideration the species peculiar to the high mountains, the New Zealand forest, as a whole, is made up of some 381 species, which belong to 62 families and 150 genera. The ferns, with their allies, and the seed-plants number 91 and 290 respectively. At the head of the list of families that of the ferns come first with 88 species, followed at a considerable distance by the coprosma family ( 27 species), and the sedge and the orchid families (22 species each); then come the taxad (pine) and myrtle families (16 species each), the daisy family (14 species), the lily family (11 species), and the araliad family (10 species). No genus is represented by more than 24 species (Coprosma), and most have fewer than 6. If the ferns are omitted, nearly 90 per cent. of the species belong to New Zealand alone. Well may we glory in our "bush" !

Coming next to the growth-forms of the forest, there areTrees, 99 ; shrubs, 63 ; herbs, 51 ; grass-like plants, 26 ; ferns, 88 ; climbing-plants (excluding climbing-ferns), 26 ; perching-plants, 15 ; and parasites, 13. The ferns include 8 tree-ferns, 23 filmy ferns, 7 climbing-ferns, and 17 perching-ferns (excluding such filmy ferns as live in that manner).

There are two distinct forest-formations in New Zealand - the rain-forest and the southern-beech forest, the former with tropical affinities, and the latter related to the forest of western Patagonia and Tierra del Fuego.

The rain-forest gets its name from the fact that its existence and presence is not determined by the water stored up in the soil, but by there being an abundance of rainy days. Nothing brings this out more clearly than a railway journey from Christchurch to Greymouth. At first the train traverses the gradually ascending Canterbury Plain, where with the exception of the Riccarton Bush there are few trees except those planted by the settler. Leaving the plain, the train winds its way through the upland valleys into the mountains, the view on either side being yellow tussock-clad slopes, with here and there patches of forest in gullies or shady situations. After Cass Station is passed, and the River Waimakariri crossed, 
the area of frequent rainy days is entered, and at once the train plunges into the black forest-mass, which at that point stands out like a wall, forbidding the tussock to advance farther west. So is it throughout the South Island, until the wet climate of southern Otago favours forest and allows it to extend from coast to coast.

The southem-beech forest can thrive, it is true, with a smaller rainfall than the rain-forest, and can occupy drier ground and more inhospitable stations. Still, it, too, has frequently more or less a rain-forest character. Its chief distinction is, indeed, floristic and geographical, for its leading trees belong to the southern-beech genus (Nothofugus), which is peculiar to New Zealand, subantarctic South America, Tasmania, and eastern Australia, and has no tropical Asiatic or Polynesian relatives. It also differs from true rain-forest in its tall trees being all of one kind, whereas in rain-forest there is a mixed assemblage, although one or two species may be in special abundance. Further, though there is a considerable similarity between the two classes of forest, and they are connected by intermediates, taxad rain-forest at one end of the series contrasts markedly with subalpine southern-beech forest at the other end, so greatly do the two differ in their composition, physiognomy, lifehistory, and biological characteristics.

All the New Zealand rain-forest associations have a number of characters in common. With one or two exceptions, the trees are evergreen. Sometimes the bases of the trunks develop buttresses (fig. 29), which may be plank-like, and their uppermost roots frequently stretch over the forest-floor, half-buried, or at times raised high above the ground. Such roots and irregular bases of the trees in general are closely covered with mosses, liverworts, or perhaps filmy ferns. In their interstices humus lodges, in which many ferns and seedling plants find a fitting home.

The forest is made up of different layers, if the general level of the foliage be considered. The tall trees form the uppermost layer: the smaller trees and tallest shrubs the second, or between this layer and the first may come the crowns of the medium-sized trees; smaller shrubs, tree-ferns, sedge-tussocks, and juvenile trees the third; and finally comes the forest-floor, with its carpet of $110 \mathrm{osses}$, liverworts, and filmy ferns, through which grow the smaller ferns (fig. 33), herbs; grass-like plants, and seedling trees and shrubs. A most important feature of the forests is afforded by the climbing-plants, or lianes, 


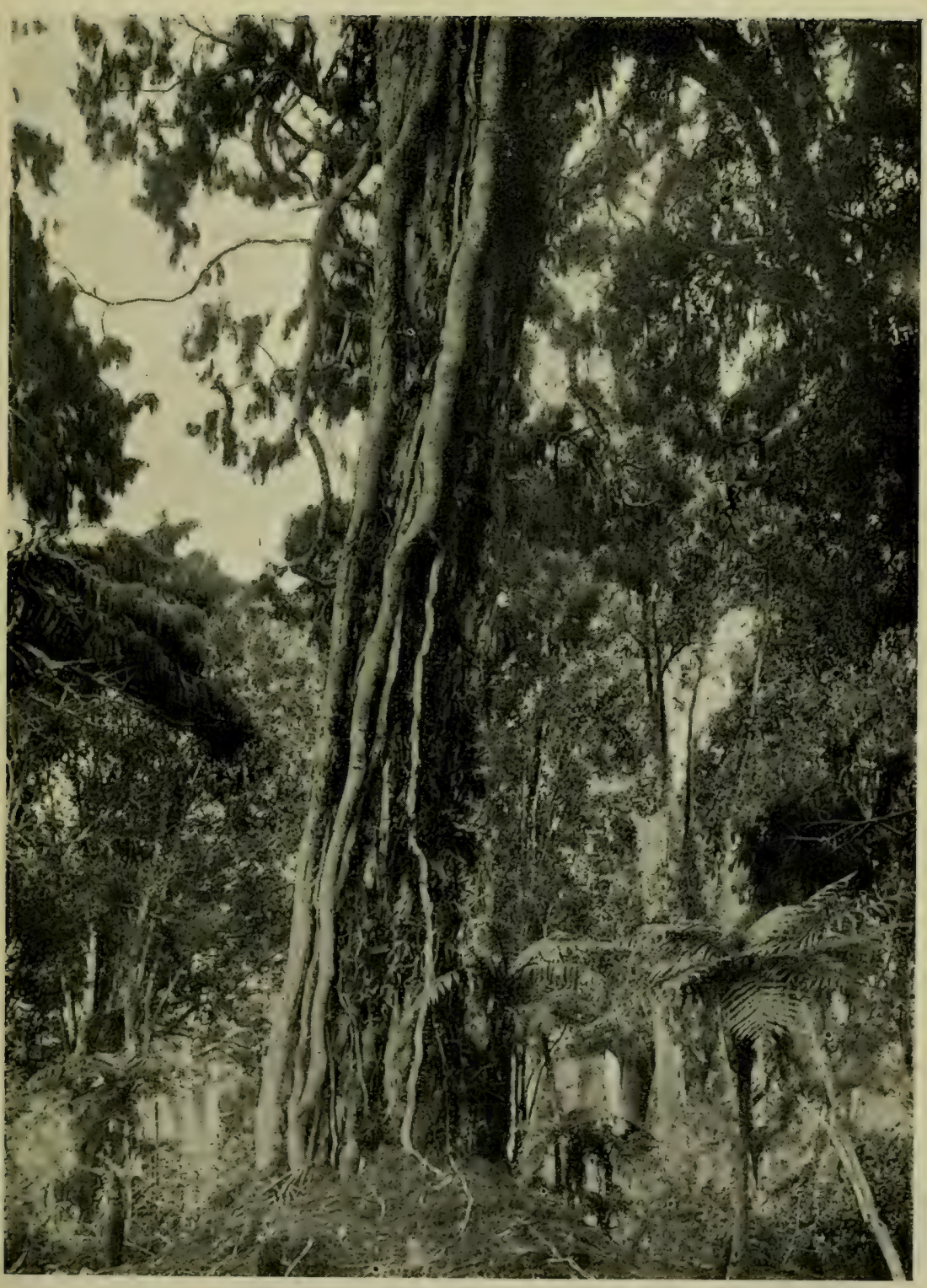

FIG. 30. - Roots of the broadleaf (Girisclinia littoralis) descending from a young broadleaf-tree perched high in the crown of a tall rimu (Dacryrlium cupressinum) entering the ground. Rimu-kamahi forest-association of Stewart Island. 


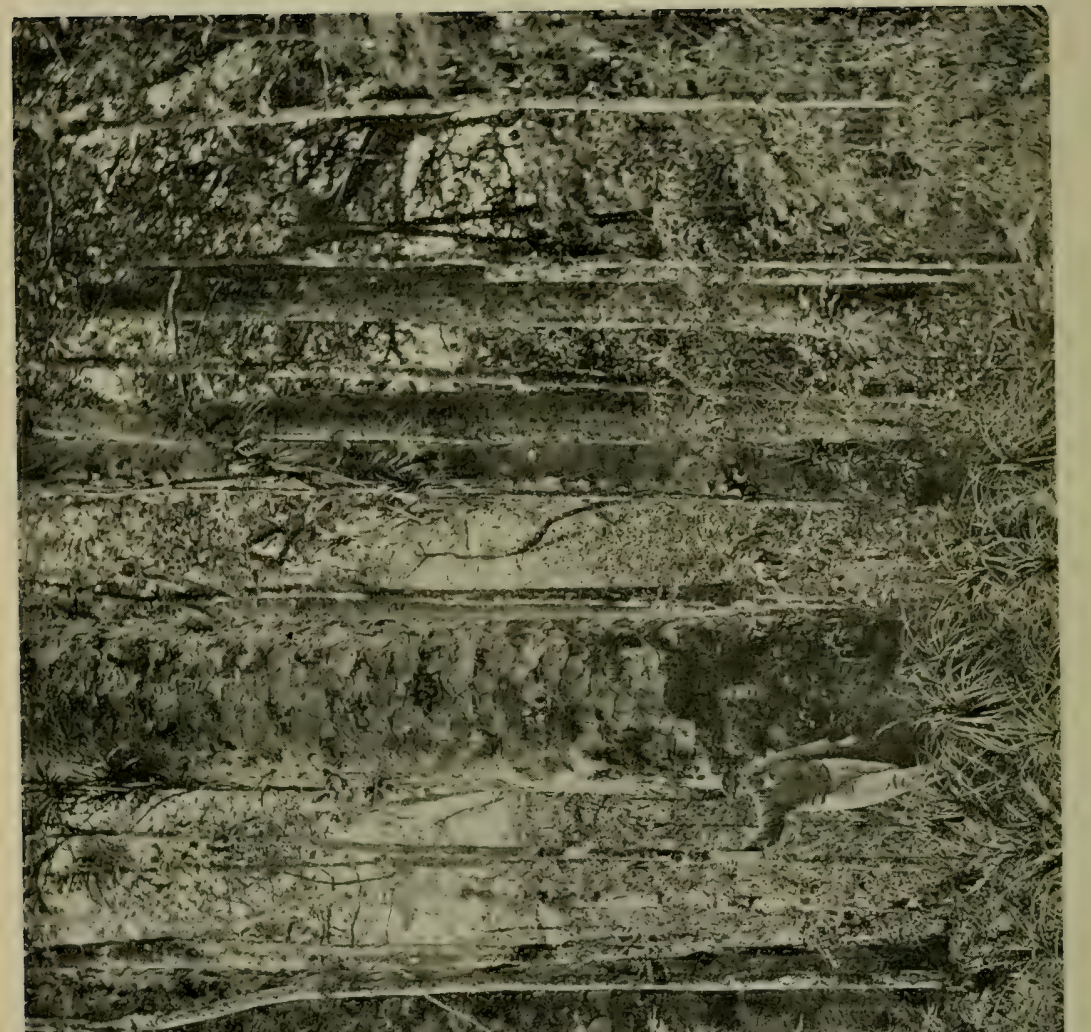

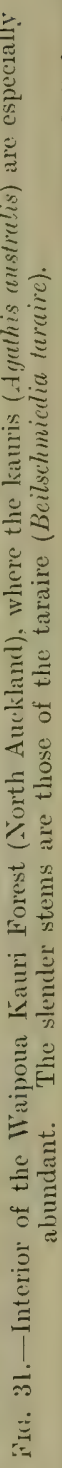




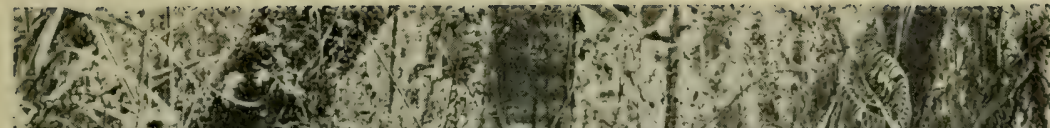

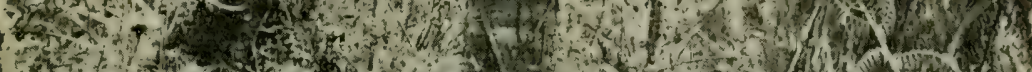

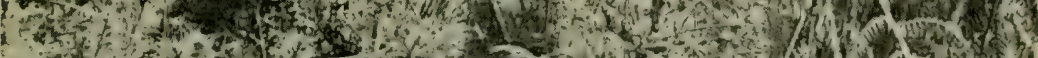

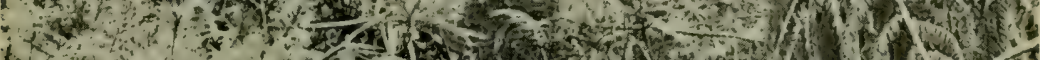

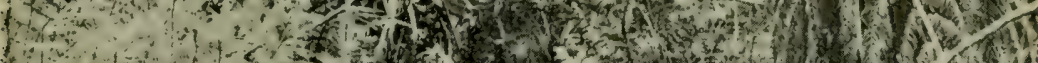

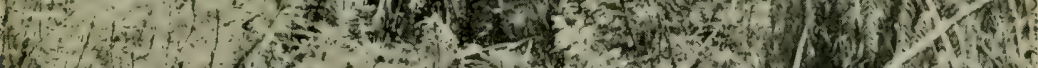

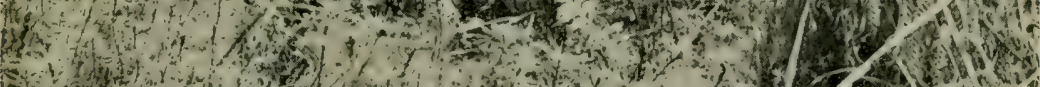

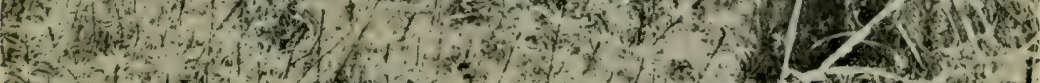

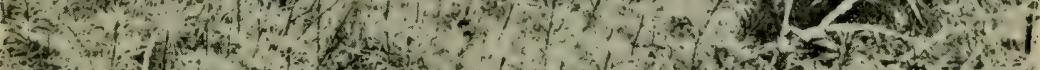

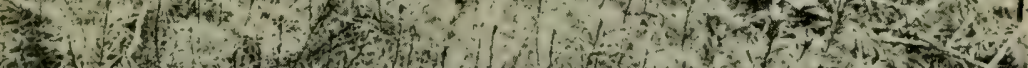

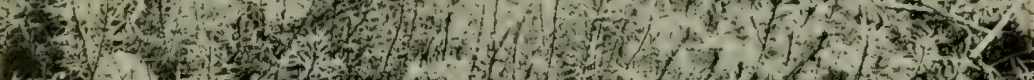

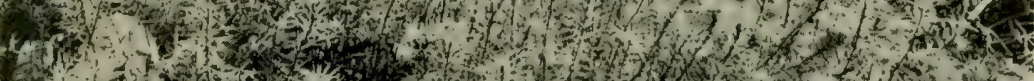

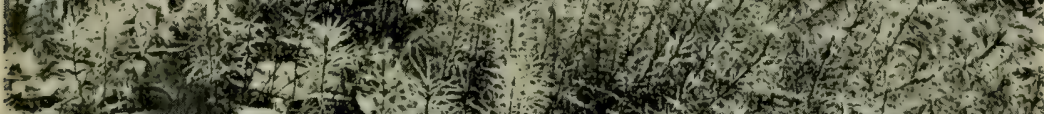
$3(1+2)$

FI(. 32.- The giant moss (Dausonia superba), 2 feet high, growing on the floor of the Waipoua Kauri Forest (North Auckland). The trunk in centre of background is that of the nikau-palm (Rhopalostylis sapida).

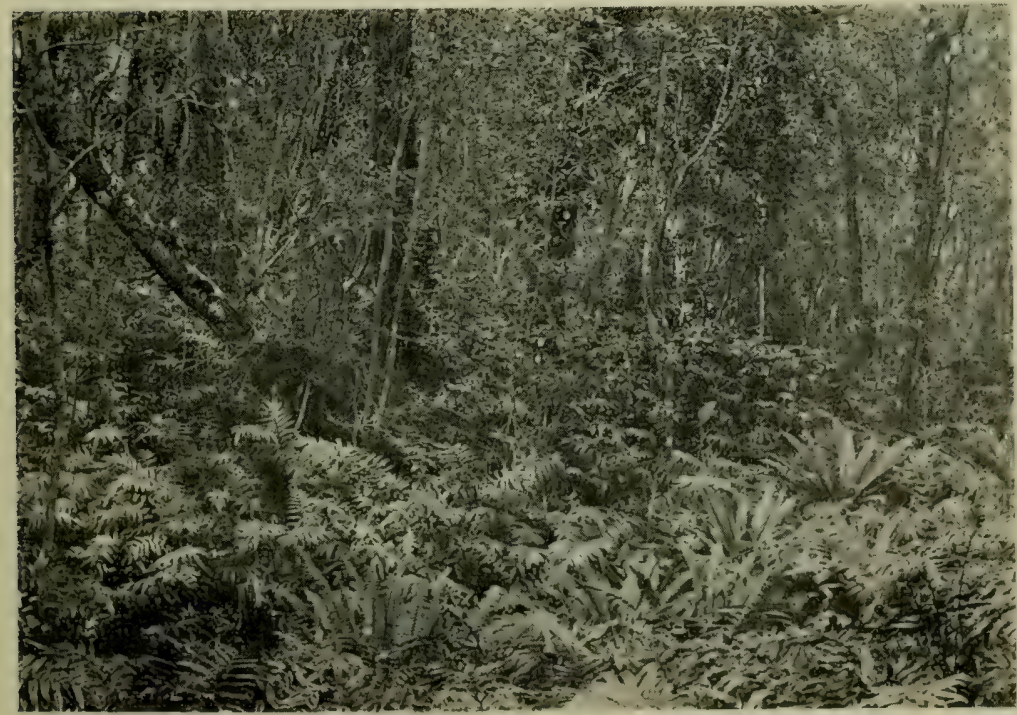

Fig. 33. - Interior of rain-forest at the base of the Longwood Range (Southland), showing the abundance of ferns. Those in the centre are the common hard-fern (Blechnum discolor).

[Photo, L. Cockayne. 


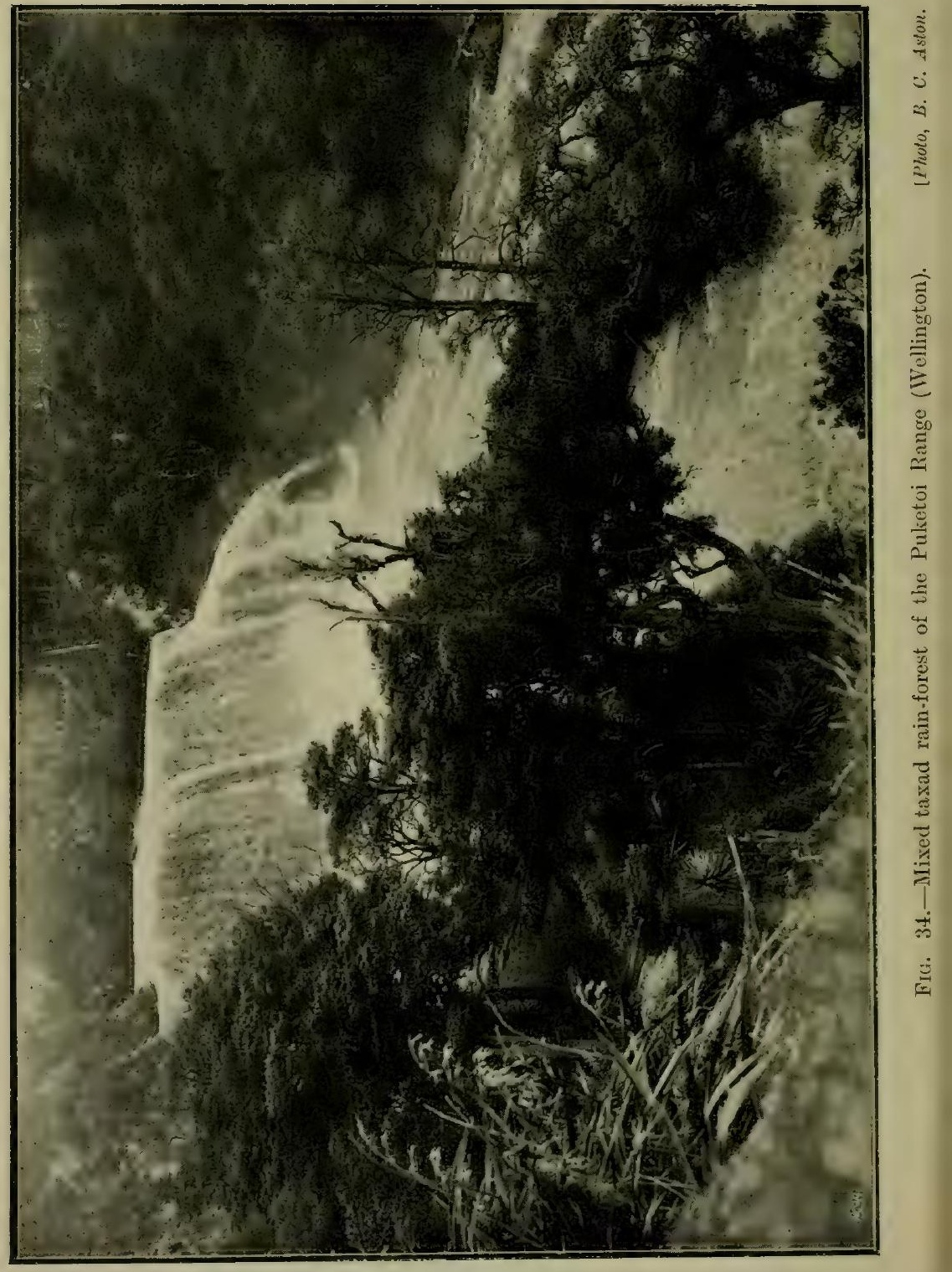


as they are often called, which, rope-like, hang from the tree-tops, form an impenetrable tangle (ing. 9), or gracefully entwine the smaller trees and shrubs.

Groups or groves of tree-ferns, sometimes 20 or 30 feet in height, with enormous feathery leaves like giant umbrellas, are a most pleasing feature of the forest (fig. 7). Close-growing, small-leaved shrubs of dense habit form thickets. On tree-fern stems, on fallen trees, and even on the forest-floor are sheets of delicate filmy ferns. Lichens of great size, milk-white or golden or dusky, abound (fig. 26). Perched high up in the forest-roof, in the forks of the branches are bird-nest-like masses, several feet in circumference, of plants of the lily family - the kahakaha (Astelia Solandri) (fig. 27), or the kowharawhara (Astelia Cunninghamii). Long fronds of ferns and shoots of lvcopods several feet in height hang drooping from the boughs, and rertain orchids with aerial roots which can absorb water, and shrubs of various kinds too, grow high up on the trees, whose boughs thus support veritable gardens. In some few cases the flowers of a tree are produced on the thick branches, or even on the trunk, as in the kohekohe (Dysoxylum spectatile), and not, as usual, from amongst the leaves. Now, should a botanist knowing nothing of New Zealand read this description, he would at once conclude it was no account of the forest of a temperate climate, but of one in the tropies. And this is quite true : the common forest of New Zealand, owing partly to its origin, but far more to the moist and equable climate, must be classed with the tropical, not with the temperate forests.

The forest also can tell a good deal about the evolution of the apparently wonderful adaptations of certain plants to the conditions it provides. On walking through the interior of the forest one cannot fail to notice the subdued light, which is so much less intense than in the open. Above all things, most plants require sunlight. Without this they cannot manufacture in their leaf laboratories their necessary food from the "carbonic acid" of the air and the water from the soil. In a forest, then, there is what may be called a "struggle" for the sunlight. The tall trees meet the difficulty by raising their tops high into the heavens. But with the smaller plants it is another matter, for these must either become attuned to a minimum of light or grow in some special way so as to get their fair share. Consequently a spindling habit of growth occurs in many young forest-trees - long, straight, thin stems, and few lateral branches; "drawn up to the light" is the gardener's phrase. 
Carry out this idea a little further. and you have certain plants putting out long shoots, which, too weak to stand alone, lean against other trees for support. Go a little further still, and such long shoots develop certain organs which assist them to cling to the supporting tree. So, by slow degrees, modification after modification has been evolved, until the remarkable brotherhood of lianes or climbingplants has come into existence, whose roots can enjoy the cool, rich soil of the forest-floor, but whose crowns dispute with the tree-tops
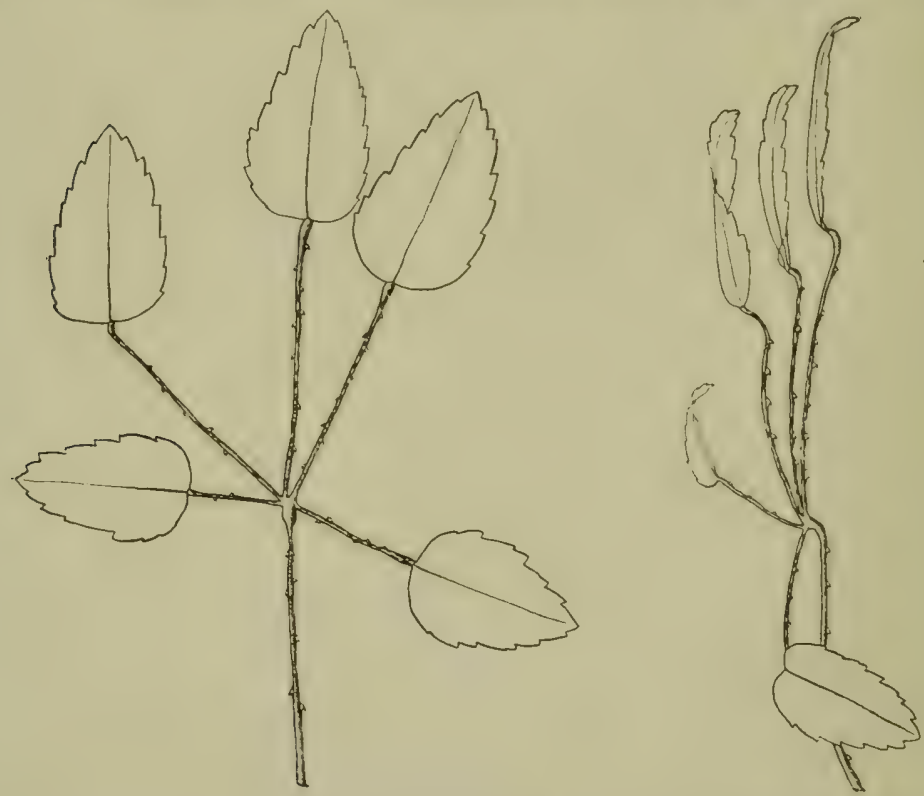

Climbing-leaves of the bush-lawyer (Rubus australis), showing the midribs

Trans. N.Z. Inst.]
for the light of l provided with hooked prickles.

[J. W. Bird del.

for the light of heaven, and under its beneficent influence bring forth their flowers, ripen their fruits, and manufacture stores of food within their green leaves.

Lianes, as explained in Chapter II, may be conveniently and naturally divided into scramblers, root-climbers, twiners, and tendrilclimbers-nanes which speak for themselves. The shrub-fuchsia (Fuchsia Colensoi), a much more slender plant than the tree-fuchsia ( $F$. excorticata), offers a transition to the scrambling habit, being frequently merely a shrub in the open, but in the forest at other 
times a true liane, its thin shoots being thrust amongst the branches of another tree for support. Here there is no special differentiation of climbing-organs; but in the various species of Rubusalso scramblers -it is different. On their leaf-stalks and midribs these have developed special curved hooks (see text-fig., p. 50), which serve for climbing purposes, and grip so tenaciously whatever they touch that they have earned for these plants the sarcastic term of "lawyer." Frequently the leaf-blades are much reduced in size, and the midribs are elongated, so that the leaf is changed in function, and has become a special climbing-apparatus, as in the yellow-prickled lawyer (Rubus cissoides) (see text-fig. below).

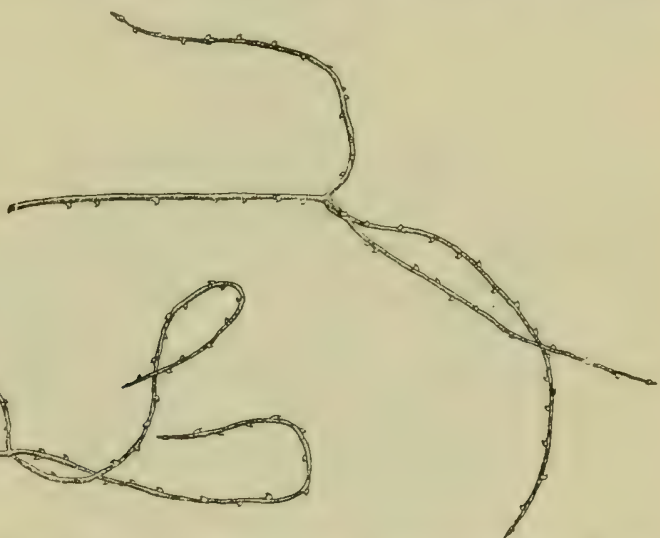

The leaf of the yellow-prickled lawyer (Rubus cissoides), consisting only of midribs, provided with hooked prickles, and forming a special climbing-apparatus.

Trans, N.Z. Inst.]

[J. W. Bird del.

In New Zealand there are other species of Rubus, which differ considerably from one another in shape of leaf, size of flower, and colour of fruit, the commonest and the one with the largest leaves and most showy flowers being the bush-lawyer ( $R$. australis), while that of wet forest is the swamp-lawyer ( $R$. schmidelioides), a creeping ground-plant in its juvenile form and not a climber except in its much later adult stage. Finally, there is a species which does not climb, but creeps on the ground, the creeping-lawyer (R. parvus) of Westland; but this is not a forest-plant.

One of the commonest root-climbers, which with its leathery, green, sword-like leaves gives a characteristic appearance to the North Island forests, is the kiekie (Freycinetia Banksii), whose fleshy bracts, called "tawhara" by the Maoris, are sweet and edible. The 
roots fasten this plant very firmly to its support, being given off at right angles, or thereabouts, to the stiff climbing-stem, and, passing right round the support if slender, finally put forth many rootlets, which are parallel, or nearly so, to the main roots, and close together. Other root-climbers, one or other of which is
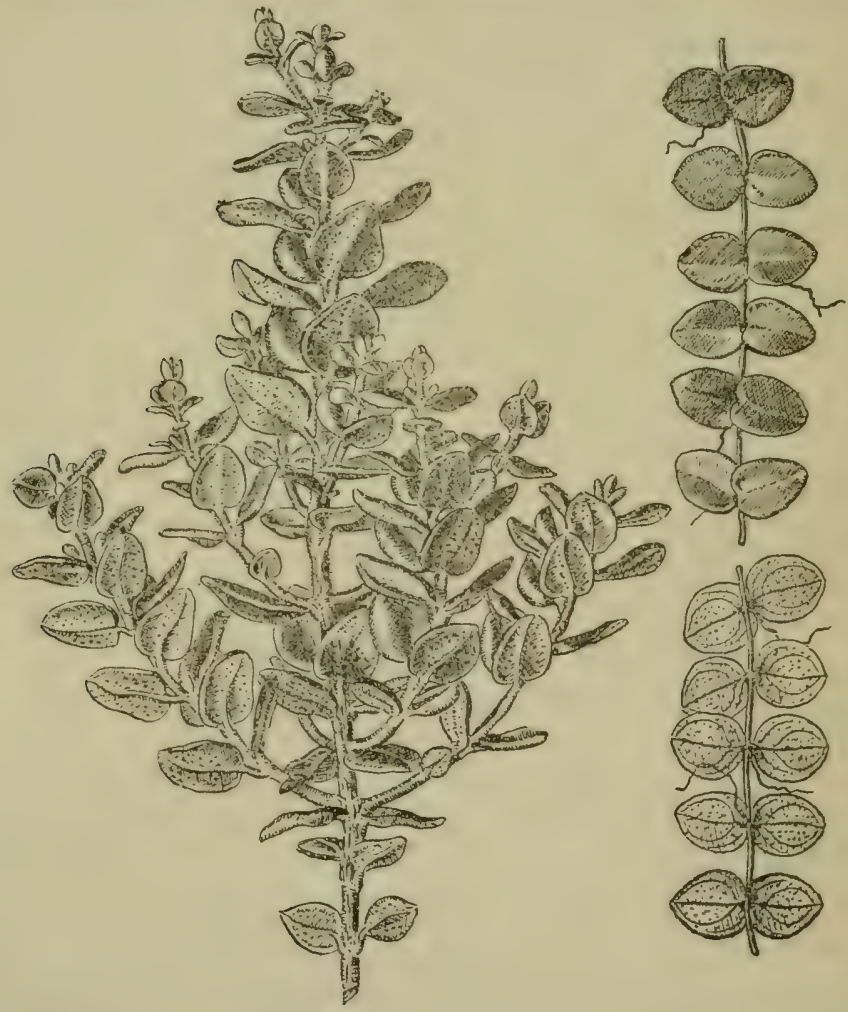

On the left a non-climbing shoot of the clinging climbing-rata (Metrosideros scandens), and on the right a climbing-shoot.

[Esmond Atkinson del.

characteristic of most New Zealand forests, are the various species of climbing-ratas. These, when young, cling most closely to the treetrunks by means of numerous short roots, their leaves more or less flattened against the bark, but finally, as the stems become cord-like, or rope-like, the roots wither away, and the stem is no longer pressed against its support. For the different species the Maoris had the 
general name "aka," but here a few popular names are suggested. The scarlet climbing-rata (Metrosideros florida), the giant of the group, has cable-like stems, sometimes 6 inches or more in diameter, covered with loose bark. It bears splendid scarlet flowers. The white climbing-rata ( $M$. albiflora), the clinging climbing-rata ( $M$. scandens) (see text-fig., p. 52), the hairy climbing-rata (M. Colensoi), and the common climbing-rata ( $M$. hypericifolia) have white flowers, or, in the case of the two latter, pinkish. The last-named is especially common, being found in both the main Islands and in Stewart Island, growing not only on trees but also on the ground, where its stems may creep for many yards at a time and put forth roots at intervals into the soil. The crimson climbing-rata ( $M$. diffusa), with beautiful rosy-crimson flowers, is practically confined to the Northern Botanical Province, as is also $M$. albiflora.

With one exception the climbing-ferns are root-climbers: e.g., the climbing-polypody (Polypodium diresifolium), whose leathery, dark-green, broad leaves, most diverse in form, are to be seen in abundance in most New Zealand forests, and the climbing hardfern (Blechum filiforme), with its woody stem and two quite distinct forms of foliage-leaves on the one plant (fig. 42), a fern which is very common in all the drier lowland forests of the North Island and of those of northem Nelson and Marlborough. This species, before climbing, frequently creeps over the forest-floor, and at this stage the leaves are small. Later, as a liane, the much larger, differently shaped leaves are produced in great abundance (fig. 42).

Coming next to the twining climbing-plants, there is the wellknown supplejack (Rhipogonum scandens), a plant of the lily family, which forms close entanglements in most lowland forests (fig. 9). Originally many of these stems have wound round young trees, which have been strangled to death, while other stems have broken away from the branch to which they have clung. The two species of pohuehue (ILuehlenbeclica), relatives of the common dock, are also winding-plants. They are easily recognized by their abundant soft, green leaves, and, when in fruit, by the small black nuts seated on a fleshy and almost transparent cup. Very frequently, as bush boys and girls well know, their rope-like stems hang swaying from the forest-roof, the original support long since vanished. The same thing happens, too, in the case of the bush-lawyer (Rubus australis) and its relatives by the time their stems have reached their full size 
(fig. 28). The New Zealand jasmine (Parsonsia heterophylla), a pretty plant producing abundance of small sweet-scented flowers, is another very common twining liane. It occurs especially on the forestoutskirts, or where the forest has been partially cleared. It and its near relative, the small-flowered New Zealand jasmine ( $P$. capsularis), may be recognized by the curious long green fruit, something like a kidney-bean in outward appearance. These plants are especially remarkable for the diversity of forms assumed by their leaves at different stages of the plants development. These may be arranged into three series-viz., small round or oblong, long narrow,

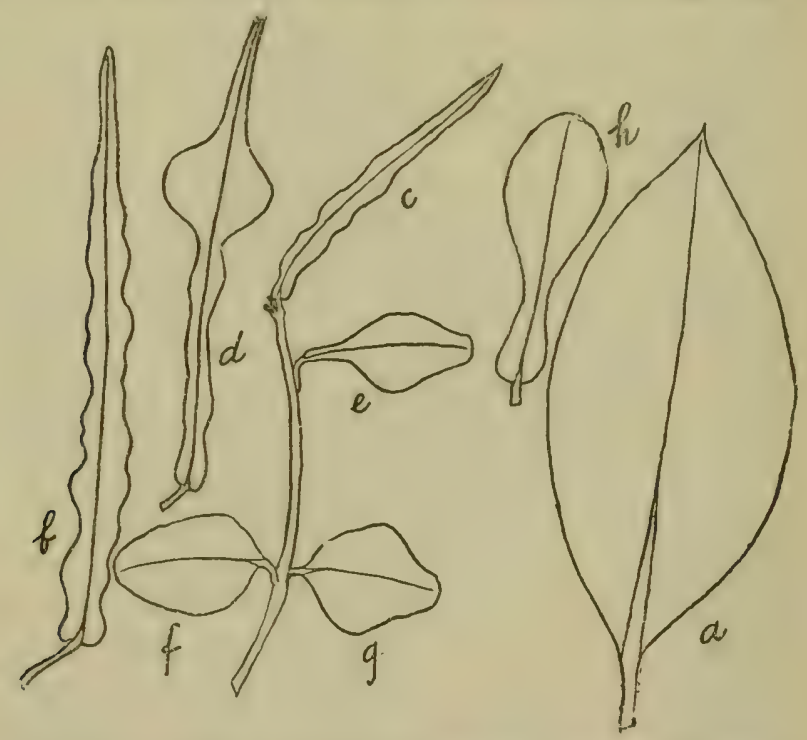

Outline of leaves of the New Zealand jasmine (Parsonsia helerophylla): $a$, the adult leaf; $e, f$, and $g$, the small, more or less round seedling leaves; $b$ and $c$, the long narrow seedling leaf; $d$ and $h$, the transitional forms of the seedling leaves.

Trans. N.Z. Inst.]

[L. C. del.

and finally moderately broad and of an oblong type. Between the small round and the long narrow are all kinds of transitional forms. One variety of $P$. capsularis, as yet undescribed, never reaches the final adult stage, but produces flowers while in the narrow-leaved condition, and so it may perhaps be considered a fixed juvenile form of Parsonsia helerophylla.

The mangemange (Lygodium articulatum) is an elegant climbingfern, whose masses of tough slender stems twined round one another 
make a substitute for a wire-wove mattress by no means to be despised. The leaf of an ordinary fern consists of a stalk and blade, the continuation of the former being called the midrib. The blade may be divided or undivided; in the former case the divisions may be little leaves, each with its own stalk. In nearly all cases a leaf continues to increase in length for a certain time, when its growth is concluded. There is usually no further increase year after year. But the remarkable fern here being considered (Lygodium) is regulated by no such rule, for its midribs may continue to grow until the leaf is so long as to reach the tops of tall trees, thanks to its twining habit. The midrib has thus become a climbing-organ, and a leaf many yards in length is different altogether from what one imagines a leaf to be. At regular intervals lateral leaflets, which are also capable of great extension, are given off from the midrib, one at a time, and distant from each other about 4 inches, each being furnished with a very short stalk. As with the leaves of certain other ferns, so here two different kinds of leaflets may be noted-those which bear spores and those which function as ordinary leaves-but between the two are all kinds of transitional stages, interesting to observe.

The term "spore" needs some explanation'. It is a single cell that becomes free from the parent plant and is capable of developing into a new individual. The spores of ferns are contained in little bags (spore-cases), and groups of these make the dots or round patches on the under-surfaces of some of the leaves of ferns. Spores are frequently spoken of as "seeds," but they are quite different, for no tiny plant ready for development is present in a spore, as there is in a seed.

Those much-prized climbing-plants, the clematises, are tendrilclimbers, the tendrils being modified leaf-stalks. The white clematis (Clematis indivisa) is the large white-flowered species (fig. 4); the small white clematis (C. hexasepala) has also white but smaller flowers; the yellow clematis (C. Colensoi) produces masses of yellow flowers in the spring, and is especially abundant in Wellington and Taranaki. 'The leafless clematis $(C$. afoliata - not, however, a forestplant-is a curious form which looks rather like a mass of rushes. It has few or no true leaves; but such would be a harm rather than a benefit, for the plant grows in extremely dry places, making dense bushes of entwining stems, which in the early spring are covered closely with their yellow flowers. All the New Zealand species of 
Clematis have male and female flowers on separate plants, the male being much the more showy (fig. 4).: The New Zealand passion-flower (Tetrapathaea australis) is another tendril-climber, the tendrils in this case being modified flowering-shoots. In autumn its orange or red fruits, containing numerous black seeds, are very showy. It is not found in every lowland forest, nor does it extend farther south than Banks Peninsula.

All the lianes are worthy of the closest study, and not the least interesting point is to observe the differences between the climbing and non-climbing shoots (see text-fig., p. 52). Also, it is remarkable how certain species, such as some of the lawyers, the leafless clematis, the small-leaved pohuehue, and Metrosideros scandens, are lianes under one set of conditions and virtually shrubs under another. It is interesting, too, to grow this class of plants from seed, and to observe how the climbing habit is not shown at all, or very little, by the seedling at an early stage of development.

Another method by which plants seek the light is to boldly leave the ground and perch high on the trees. Most instructive transitions between this perching habit and the ordinary method of growth may be observed in any New Zealand forest. The perching-lilies (Astelia) also grow on rocks or form huge tussock-like clumps on the ground. Many ferns live indifferently either on trees or the forest-floor, as does also the lovely forest tree-groundsel (Sinecio Kirlii). Certain plants are almost exclusively perchers (epiphytic). Thus the perching-kohuhu (Piltosporm comifolium) and the thick-leaved kohuhu (P. Kirkii) are of this class, and it is interesting that all the other members of the genus are ordinary terrestrial trees or shrubs. The puka (Griselinia lucida), with its great leathery shining green leaves, is frequent high up in the forks of some forest giant; but it also grows on rocks near the sea, and under cultivation makes a most handsome shrub for the open border. Some of the orchids are perching-plants-e.g., the common dendrobe (Dendrobium Cunninghamii) - and these have a special root-tissue which is quite spongy, and can absorb whatever moisture drips on to it. Some of these perching-plants build up great spongy masses of soil on the tree-trunks, and it is the water-holding capacity of this soil which in part enables epiphytes in general to live under what appear such adverse circumstances. Certain ferns and lycopods are generally epiphytic-e.g., a variety of the drooping-spleenwort (Asplenium 


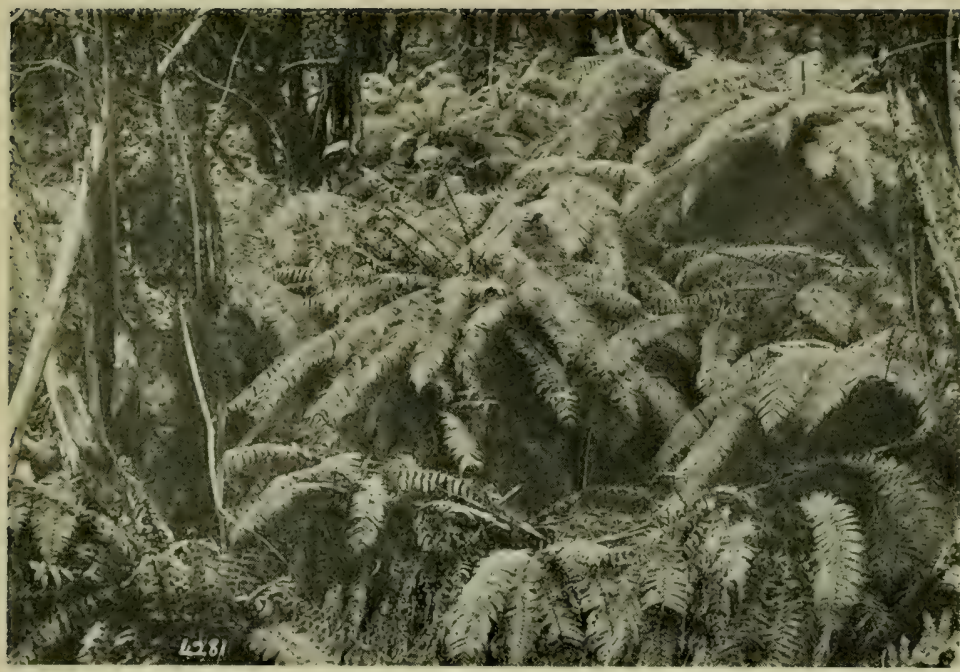

Fid. 35. - The prickly shield-fern (Polystichum vestitum), an important constituent of the undergrowth growing at the outskirts of a mountain southern-beech (Nothofagus cliffortioides) forest. The leaves of the fern are 3 feet long. Base of Big Ben (Canterbury). [Photo, L. Cockayne.
[P

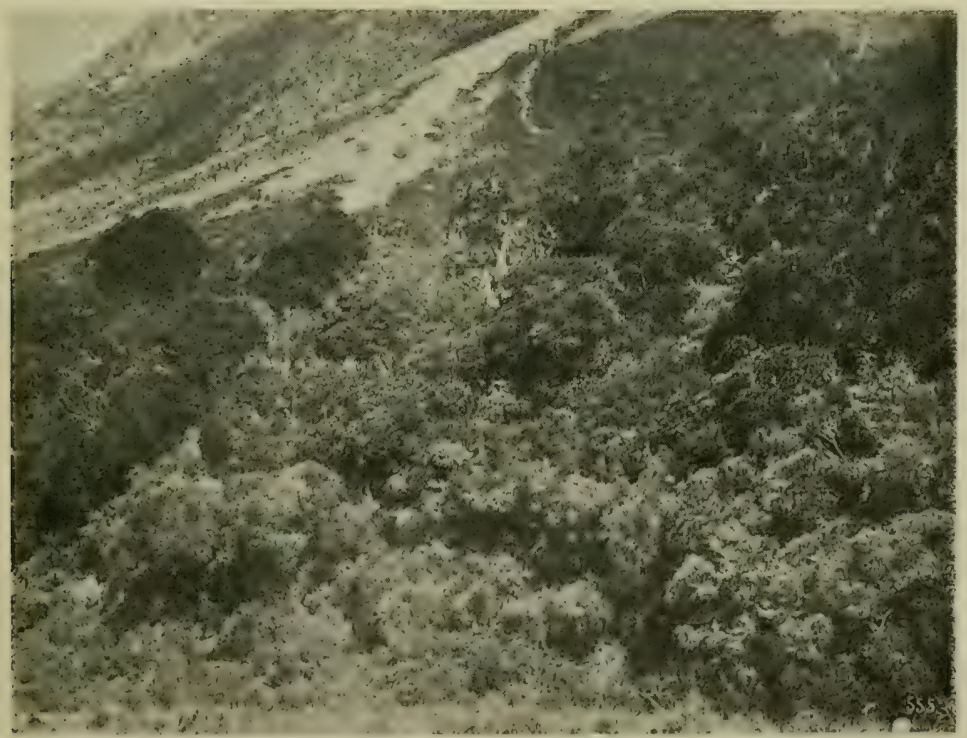

Fic. 36.-Pahau-tea (Libocedrus Bidwillii) subalpine forest, from 3,100 feet altitude upwards to the subalpine scrub, at base of Mount Murray, not far from the source of the River Rakaia (Canterbury). 


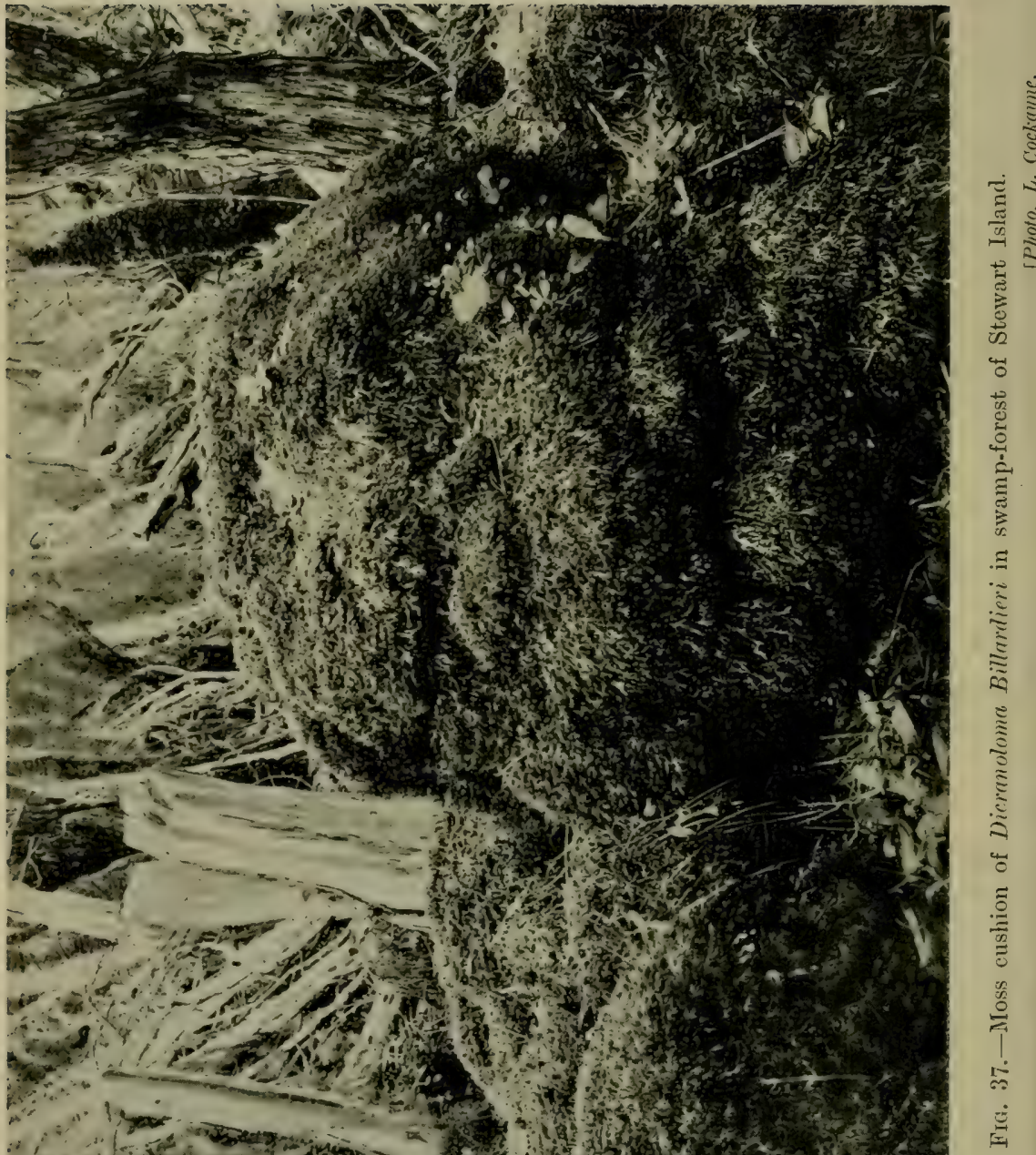




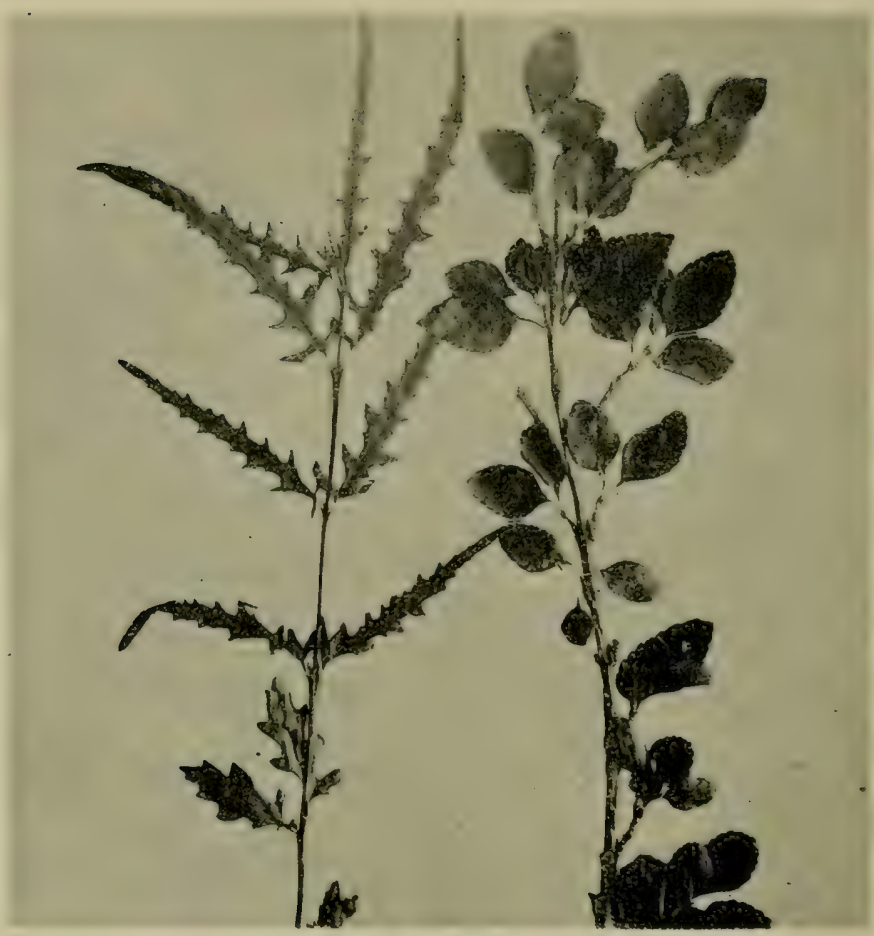

FIG. 40.-On the left the juvenile leaf-form and on the right the adult leaf-form of the mountain-wineberry (Aristotelia fruticosa).

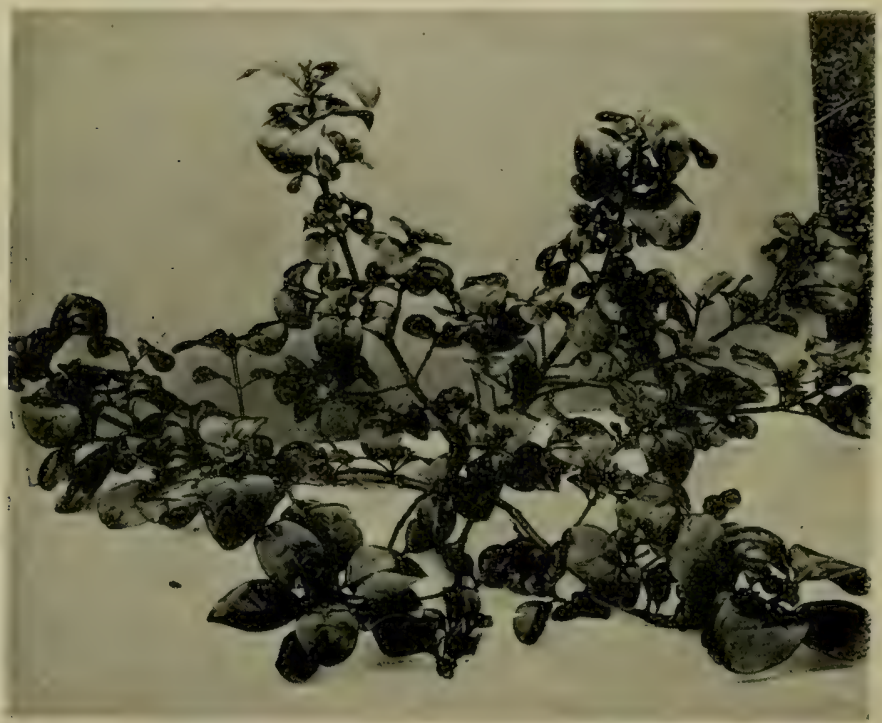

FIG. 41.-Juvenile Coprosma retusa, showing early prostrate shoots Trans. N.Z. Inst.] and taller erect ones. 
flaccidum), the shining-spleenwort (Asplenium adiantoides), many of the filmy ferns, and the pendulous club-moss (Lycopodium Billardieri).

Seedling trees are very common as perching-plants, or epiphytes, to use the scientific term, and some of the forest giants begin their career in this manner. These finally send down to the ground roots which grow into a solid "root-trunk"; the former host is locked in their embrace and stifled. The northern rata (Metrosideros robusta), the Chatham tree-heath (Dracophyllum arboreum), and in the southern parts of New Zealand the broadleaf (Griselinia littoralis) frequently behave in this most ungrateful manner (fig. 30). So, too, the puka $(G$. lucida) may behave similarly, though such is not its usual custom. With regard to the northern rata (Metrosideros robusta), the popular but erroneous belief is that the descending roots are ascending climbing stems, and that these eventually grow together and stifle the tree. This error has arisen through mistaking the climbing stems of the scarlet climbing-rata $(M$. florida) for the descending roots of the northern rata (M. robusta).

Though many plants are "eager" to get into the fresh air and sunlight, others are the reverse, and have developed different adaptations which enable them to lead their special life. The interior of a thick forest has an atmosphere charged with vapour not altogether unlike that of a glasshouse. Plants living under such conditions are subject to much the same environment as submerged water-plants, and have developed similar leaves, which are quite thin and able to absorb any water which may fall upon their surfaces. Such, amongst others, are the filmy ferns (species of Hymenophyllum and Trichomanes), the beautiful crape-fern (Leptopteris superba), and its relative the single crape-fern (Leptopteris hymenophylloides). Plants like these can exist only in a moist atmosphere; the full rays of the sun or a dry atmosphere cause them to shrivel up, and they soon die when removed from their forest home. Many mosses and liverworts also belong to this category, and mimic in their forms the smaller ferns, to which, of course, they bear no relationship. Although possessing much thicker leaves than those of the filmy ferns, the black hard-fern (Blechnum nigrum) is confined to the moistest, most shady parts of the forest, and is never found under other circumstances. It may be pointed out here that leaves of ordinary trees and shrubs are more or less impervious to water, and, as a rule, the more drought-resisting the plant, the more impervious the leaf. 
New Zealand forests are not distinguished for their brilliant flowers. On the contrary, most of the forest blossoms are inconspicuous and of a dull colour. But there are some notable exceptions. The northern and the southern ratas (Metrosideros robusta and 1 . lucida) bear multitudes of crimson blossoms. The yellow kowhai (Sophora grandiflora and S. microphylla) has been fitly termed the New Zealand laburnum. The various species of trees known as lacebark (Hoheria populnea, H. sexstylosa, and $H$. angustifolia) are, in their season, dense masses of white. The kaikomako (Penuantia corymbosa) vies in its purity with any bridal flower. The putaputaweta (Carpodetus serratus) is a rival of the English may. The tawari (Ixerba brexioides) of the Auckland upland forest is so showy that the Maoris had a special name, " whakou," for the tree when in bloom. The white tea-tree (Leptospermum ericoides), with its multitude of white or pinkish flowers, quite equals the popular Spriraen Thunbergi of gardens.

The heketara (Olearia Cunninghamii) and the rangiora (Brachyglottis repanda) produce multitudes of daisy-like flowers in the spring. The wineberry, or makomako (Aristotelia racemosa), has distinctly pleasing rosy-coloured flowers. The hinau (Elaeocarpus dentatus) has numerous white drooping flowers. The white clematis (Clematis indivisa) is esteemed by all, but not always treated as it deserves, for its snowy blossoms (fig. 4) are frequently torn from their forest home only to wither.

The terms "pollination" and "fertilization" must next be considered. Pollination relates only to the transfer of the yellow dust known as "pollen" from the anther of the flower to the stigma, while fertilization denotes the actual act of fertilizing, which consists in the coalescing of a male and a female cell. By subsequent growth of this fertilized cell a tiny plant, called an "embryo," is formed within the roundish or oval body (the ovule) within which was situated the above-mentioned female or egg cell. The male cell, on the contrary, is the result of the development of a pollen-grain (microspore), which by means of its prolongation (the pollen-tube) enters the ovule and so allows fertilization to take place. The ovule eventually develops into a seed-i.e., a tiny plant-surrounded, it may be, first by food material, and then externally by a more or less stout covering (the seed-coat).

In some instances the stamens and pistil are close together on the same flower, and pollen and stigma are ready the one for the other 
at the same time, in which case the flower can pollinate itself. But in a considerable number of instances self-pollination is impossible; and the pollen of one flower must be applied to the stigma of another. Such cross-pollination, as it is called, has been proveri to be beneficial for many plants. A large percentage of New Zealand trees and shrubs have the pollen-bearing flower on one plant and the ovule-bearing flower on another. Others, again, are so constructed that the pollen is ripe before the stigma of the same flower is ready to receive it, or the stigma may in other species be developed before the pollen. In all these cases cross-pollination is alone possible. This may take place in two ways: either the wind may carry the pollen-light as dust-from one flower to another, as in the genus Coprosina and in many other cases, or animals may convey it dusted on some part of their bodies. In accomplishing this work, insects play a very important role. Birds also pollinate a few New Zealand plants, amongst others the puriri (Vitex lucens), the waiu-atua (Rhabdothamms Solandri), and the New Zealand flax (Phormium tenax) - this latter not a forest-plant.

The story of how New Zealand plants are pollinated yet remains to be told by the plants. Certainly in a calm forest-interior the wind can have but little effect, yet the coprosmas-so abundantare apparently suited for wind-pollination alone. Nor are there many showy flowers, as already seen, which could on that account attract insects. On the other hand, there is abundant honey in some species, and usually plenty of pollen, both of which many insects love, and it may be that honey or pollen alone, without brilliant coloration to guide the insect visitors, is a sufficient attraction.

There are many distinct forest-associations in New Zealand. Here the most important-the kauri, the mixed taxad, the kahikatea, and the southern-beech groups of associations-are dealt with in quite a general manner

The kauri forest extends from the north of the North Auckland Botanical District to almost latitude $38^{\circ}$. It is probably the noblest tree-community of the temperate zone. The kauri (Agathis australis) is not a close relation of the old World pines, but is nearer to trees of the monkey-puzzle (Araucaria) family.

A kauri forest by no means consists of that tree alone, for the taraire (Beilschmiedia taraire)-very handsome, with its rather large leaves, darkish-green above and bluish-white beneath-- is often 
dominant in the north of its range, while farther south its place is taken by its quite different-looking relative, the tawa (Beilschmiedia lawa). The kauris form smaller or larger clumps. The kauritrees themselves are some distance apart, and the spaces between are filled up with a close growth of the huge tussocks of the kaurigrass (Astelia trinervia)-which, of course, is not a grass at all, but belongs to the lily family-and a sedge, the giant gahnia (Gahnia xanthocarpa), with leaves sharp as a razor; while growing through these are certain shrubs or small trees, especially the aromatic-leaved maireire (Phebalium nudum), the spiderwood (Dracophyllum latifolium), young plants of the tawhero (Weimmannia sylvicola), the ivy-tree (Nothopanax arboreum), the white climbing-rata (Metrosideros albiflora), the shrubby honeysuckle (Alsenosmia macrophylla), the forest tree-groundsel (Senecio Kirliii), bearing in its season large white laisy-like blossoms, and the silver tree-fern (Cyathea dealbata). Where the undergrowth is more scanty the stately kauris appear in all their srandeur, their huge, grey, shining, columnar trunks rising up 60 and maybe 80 feet without a branch, and dwarfing altogether the other trees (fig. 31).

High above the general forest-roof tower the great spreading branches of the kauri, themselves equalling forest-trees in size. At the base of each tree is a pyramidal mound of humus caused by the shedding of the bark. Common in the kauri forest is the fantastic and irregular trunk of the northern rata (1Letrosideros robusta), its base covered with sheets of translucent kidney-ferns (Trichomanes reniforme) and white cushions of the moss Leucobryum candidum. Seen from without, a kauri forest is equally remarkable. The spreading heads of the hauris rise so high above the general forestroof that it looks as if one forest were superimposed upon another. Very frequently there is found in the undergrowth a miniature treefern (Blechnum Fraseri), which has a very slender trunk, 1 inch or less in diameter-not thicker, indeed, than a stout walking-stickand rarely more than 3 feet high, which spreads into large colonies by means of long, slender, creeping stems. The stumpy tree-fern (Dicksonia lanata), another small tree-fern, with leaves of a metallic sheen, is frequently plentiful in some places, and may then form much of the undergrowth. On the forest-floor are the usual ferns and mosses of taxad forest, and the giant moss (Dawsonia superba) may form colonies, the plants being 1 to 2 feet high (fig. 32). 
A kauri forest really consists of two distinct associations-the kauri association, as briefly described above, and a mixed forest association with the taraire or tawa as the leading trees, but with other tall or medium-sized trees also-e.g., the tawhero (Weinmanniu sylvicola), the totara (Podocarpus totara), the miro ( $P$. ferrugineus). the rewarewa (Knightia excelsa), the rimu (Dacrydium cupressinum), and the tanekaha (Phyllocladus trichomanoides). Kauri forest generally speaking, is in a condition of progression or retrogression. There may be many large trees and little undergrowth, or a powerful undergrowth ready to develop into taraire or tawa forest. These two stages are o. distinct expression of the amount of light available, the dense undergrowth denoting a maximum, and the close forest-roof made by the tall trees, with the consecquent scanty undergrowth, a minimum. As the illumination increases, forest will eventually be replaced by manuka shrubland. Were the climate to remain constant, the forest would slowly change and reach its climax with tall trees and little undergrowth; then, as tree by tree died, light-intensity would increase, seedlings would grow, and rejuvenation gradually take place. Should, however, conditions too dry for rainforest arise, then, if they continued, the forest would give place to shrubland.

The mixed forest (fig. 34) varies in composition according to latitude and altitude, but a general groundwork of plants is always present. Many species of northern New Zealand are wanting in the centre and south of the South Island, and, conversely, the more important southern species are less frequent in the north at a similar elevation. Latitude $38^{\circ}$ forms a fairly definite boundary for quite a number of trees and shrubs, and latitude $42^{\circ}$ a second boundary, though the former, and to a greater extent the latter, is overstepped in several instances.

The pines (species of Podocarpus and Dacrydium), as they are popularly called, but more correctly designated taxads, since they are related to the yew (Taxus), are evervwhere important members of the society under discussion. Confined to the far north of New Zealand are--the taraire (Beilschmiedia taraire), the mangeao (Litsaea calicaris), the makamaka (Ackama rosaefolia), the tawhero (Weinmannia sylvicola), the toatoa (Phyllocladus glaucus), the kawaka (Librocedrus Doniana), the tree-coprosma (Coprosma arborea), two plants of the true honeysuckle family (Alseuosmia), and some other trees and shrubs. 
Amongst the trees not extending much beyond latitude $12^{\circ}$ are some very common ones of the northern forests. Some of these are-- the nikau-palm (Rhopalostylis sapide), the karaka (Corynocarpus laevigata), which reaches Banks Peninsula; the tawa (Bcitschmiedia lawa); the kohekohe, or New Zealand cedar (Dysoxylum spectabile); the rewarewa (Knightia excelsa); the pukatea (Lavelia novae-zelandiae); the tanekaha (Phyllocladus trichmanoides); and some of the New Zealand olives (Oleat). Certain shrubs belong to the same category-e.g., the rangiora (Brachyglottis repanda), the kanono (Coprosma grandifolia), and the wharangi (Mclicope temata).

Each tree-association takes its name from the dominating tree. The best-marked associations are-the rimu (Dacrydium cupressinum) association, the totara (Podocarpus totara) association, and the tawa (Beilschmiedia tawa) association. It is possible that in many parts of the North Island the latter is the climax association towards which the other associations are progressing.

On the west of the Southern Alps, going south from the Taramakau River in Westland, there is a continuous mixed taxad forest, distinguished especially by the absence of the tarata (Pittosporum eugenioides) and the presence in great abundance of the glossy ascarine (Ascarina lucida), a most handsome low tree with black bark and green, extremely glossy, oblong, toothed leaves 1 to 2 inches long, and of the mountain-tawheowheo (Quintinia acuifolia), a small tree of slender habit with abundant oblong leaves, yellowish in colour but with green veins and midrib. In the undergrowth there is the evil-smelling hupiro (Coprosma foetidissima) and juvenile pokaka (Elaeocarpus Hookerianus). The lianes Freycinetia Banksii and Metrosideros florida, and the perching-kowharawhara (Asteliu Cunninghamii), are abundant, and their presence at a glance distinguishes this Westland forest from that of Banks Peninsula, Dunedin, Southland, or Stewart Island.

At an altitude of some 2,500 feet the lowland forest of Westland is succeeded by one in which the pauhau-tea (Libocedrus Bidwillii) and the mountain-totara (Podocarpus Hallii) are dominant. Similar forest also occurs near the source of the River Rakaia, on the eastern side of the Dividing Range (fig. 36). At a still higher altitude in Westland various tree-daisies (Olearia ilicifolia, $O$. macrodonta, $O$. lacunosa, O. excorticuta, and $O$. avicenniaefolia), together with the mountain-neinei (Dracophyllum Traversii), form the uppermost forest, the latter giving a remarkable appearance to the association. 
The mixed taxad forest of Southland (fig. 33) and Stewart Island consists of the rimu (Dacrydium cupressinum) and the kamahi (Weinmannia racemosa) as the leading trees. Rhipogonum scandens and the common climbing-rata (Metrosideros hypericifolia) are the most important lianes. There are no perching-lilies. Considering the Stewart Island forest only, Hemitelia Smithii is the principal tree-fern. 'The kohuhu (Pittosporum tenuifolium), the tarata ( $P$. eugenioides), the mahoe (Melicytus ramiflorus), and the ivy-tree (Nothopanax aboreum) are absent, but instead of the latter and the tarata are the mountain ivy-tree (Nothopanax Colensoi) and Pittosponum Colensoi var. fasciculatum. The hupiro (Coprosma foetillissima) is the leading shrub of the undergrowth, but C. Colensoi and C. Banksii, both small straggling shrubs, are also common. All the abovementioned trees noted as being wanting in Stewart Island occur, however, in the taxad forest of Southland and near Dunedin.

Kahikatea (Podocarpus dacrydioides) forest may frequently be the climax association of swamp, but if the floor got drier the other taxads, \&c., would come in and ordinary mixed rain-forest result. ()bviously, as the habitat of this forest is true swamp, where water lies for almost all the year round except during a time of drought, this class of forest can become established with a general climate too dry for rain-forest proper, such as the Canterbury Plain, where there were originally limited areas of this plant-formation.

The kahikatea forest consists, so far as tall trees go, almost exclusively of Podocarpus dacrydioides - multitudes of long, straight trunks, like masts of ships, rising from the swampy ground. High up some of the stems, except in the south of its range, climbs the New Zealand screw-pine, the kiekie (Freycinetia Banksii), which also everywhere forms a rigid entanglement along the forest-floor. Dead trees bridge the ever-present pools of water, and certain shrubs, of which; up to northern Westland at any rate, the swampcoprosma (Coprosma tenuicaulis) is one, form more or less dense thickets. Dicksonia squarrose is the commonest tree-fern. The swamp-asteliad (Astelia nervosa) is characteristic.

Day by day this association becomes smaller and smaller, since it occupies land which is suitable for dairy-farming. Large areas still occur in Westland. In Stewart Island there are only a few kahikateas, the remarkable swamp-forest of that island being dominated by the yellow-pine (Dacrydium intermedium), a small taxad, 
and being also especially distinguished by the enormous number of huge moss and liverwort cushions of the forest-floor (fig. 37).

The southern-beech forests (incorrectly called "birch" by the settlers), consisting of species of Nothofagus, are quite distinct from all those which have been dealt with hitherto, although they have some species in common. The dense growth of the evergreen foliage shuts out a large percentage of light, and in consequence the undergrowth is scanty. Some South Island subalpine forests of pure mountain southern-beech ( $N$. cliffortioides) contain in many parts little but seedling beech-trees (fig. 25). Woody lianes, too, are represented only by the white-leaved lawyer (Rubus schmidelioides var. coloratus), and the more highly organized perching-plants are absent. Nor are ferns nearly so plentiful as in the mixed taxad forest, though one, the prickly shield-fern (Polystichum vestitum), is frequently abundant (fig. 35). The tree-trunks are often covered completely with a black fungus (Antemaria). Parasitic on the southern-beech trees are two mistletoes, the one, Elytranthe tetrnpetala, having most showy scarlet flowers, and the other, E. flavida, having yellow flowers. The small mountain club-moss (Lycopodium fustigiatum) is sometimes very plentiful on the forest-floor. In moist places there are frequently large colonies of the tree-moss (Polytrichum dendroides), looking rather like a pine-tree in miniature, and equalling Dawsonia superba in stature. Where the forest comes to an abrupt termination in the subalpine belt it is invaded by some of the high-mountain shrubs.

Besides the mountain southern-beech (Nothofagus cliffortioides): the silver southern-beech ( 1 . Menziesii) and the red southern-beech ( $I$. fuscu ) also make pure associations on the high mountains, the first-named occupying the uppermost belt and driest localities; the silver southern-beech comes next highest, while the red southernbeech ascends only to the lowest part of the subalpine belt. Silver southern-beech forests occur on Mount Ruapehu, in western Nelson, and in the Fiord Botanical District.

The red southern-beech (Nothofagus fusca) and its var. Colensoi are tall, massive trees, with larger leaves than any of the other species. They form, mixed or unmixed with Nothofagus Mlenziesii, magnificent forests in the montane belt of many of the North Island mountains, but $N$. fusca and the other southern-beeches are absent on Mount Egmont, the subalpine forest there having either the kamahi 


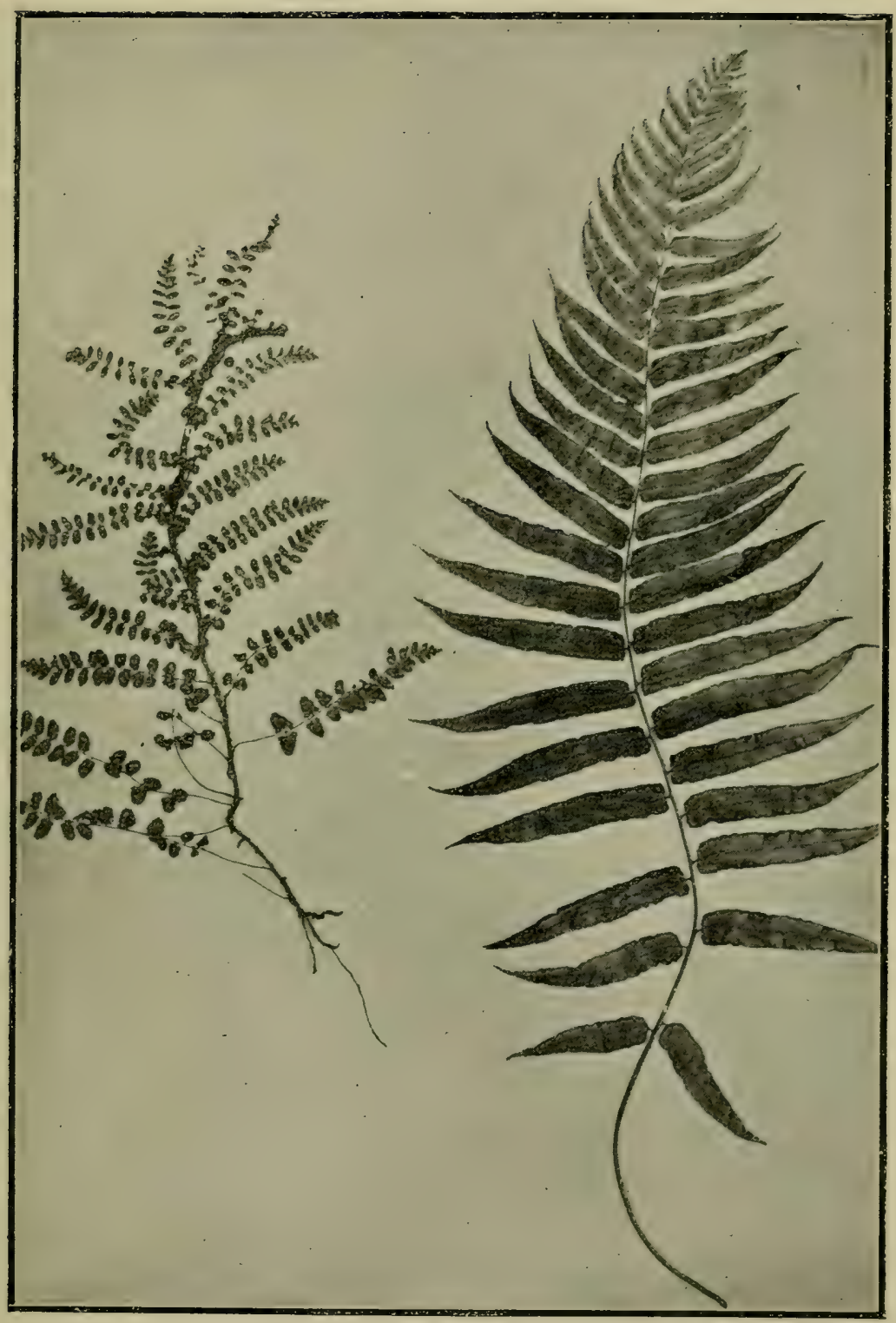

FIG. 4:- On the left the form of the climbing hard-fern (Blechnum filiforme) when growing on the ground, and on the right the much larger and differently shaped leaf of the climbing form of this fern. The sporebearing leaves are different again. 


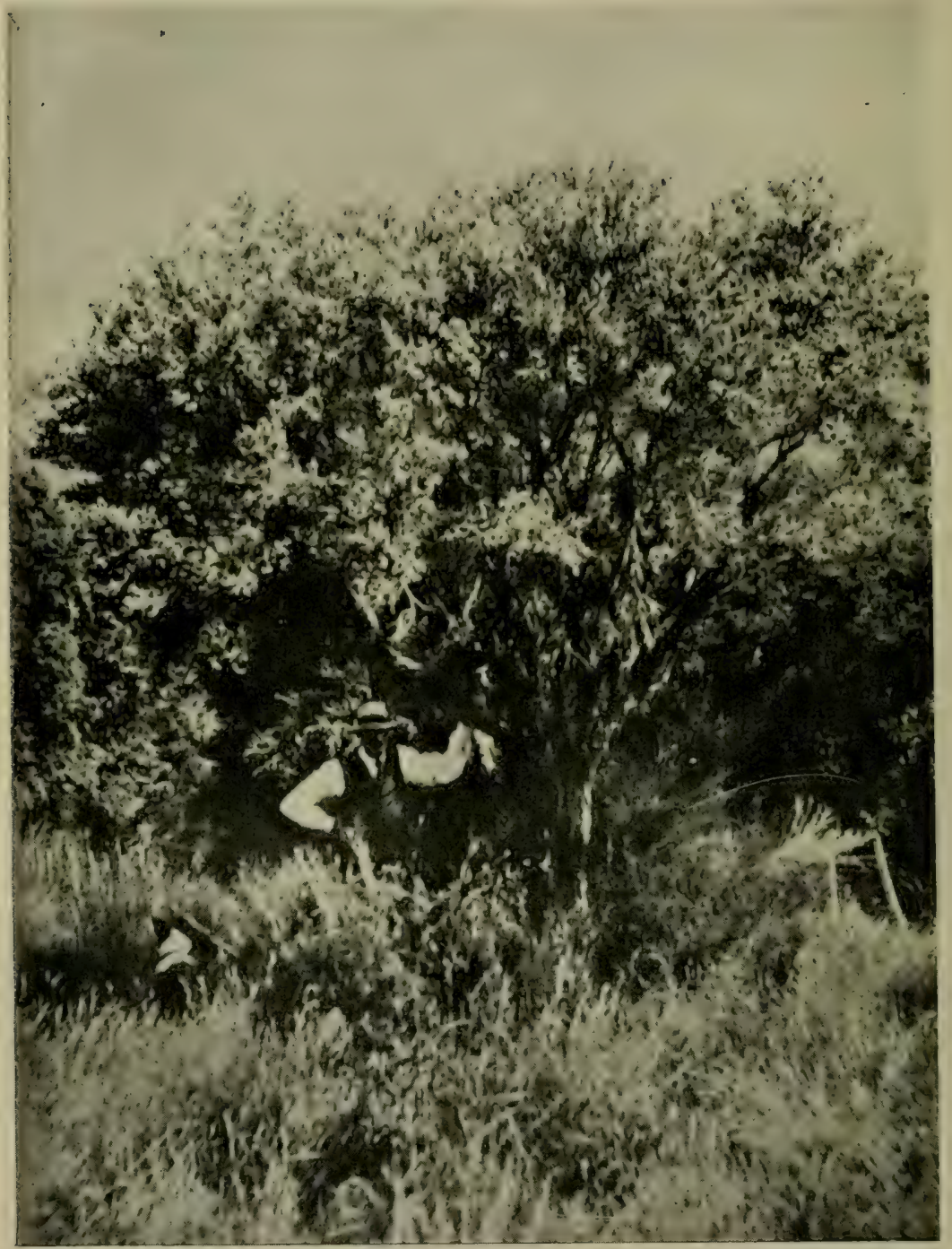

Fir: 43.--The parent plant of a recently discovered double white manuka, now named "Leonard Wilson," growing wild near Port Levy (Banks Peninsula).

Truns. N.Z. Inst.]

Photo, J. E. Young. 


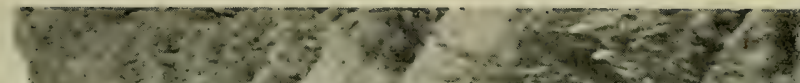

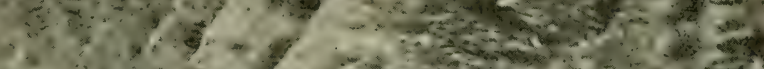

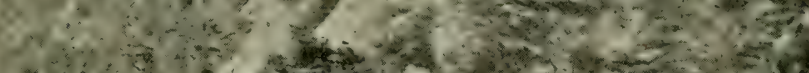

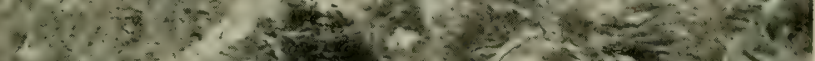

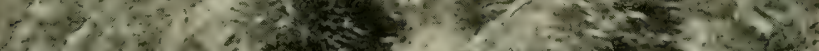

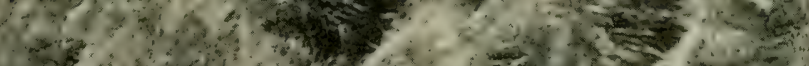

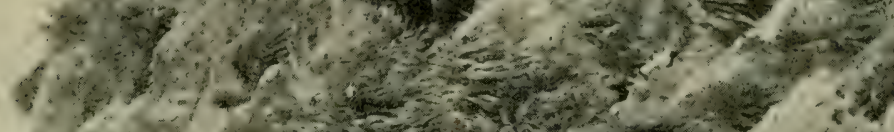

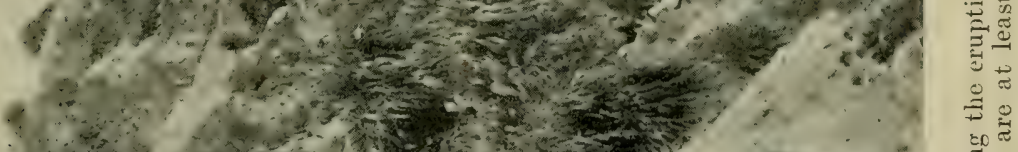

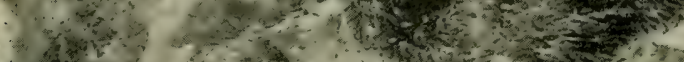

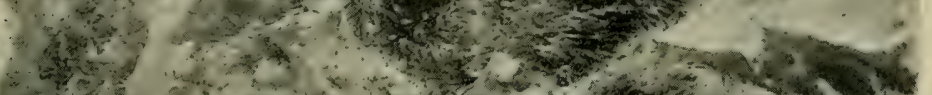
2.25,

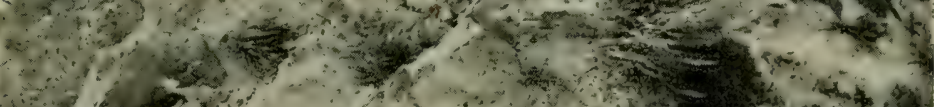

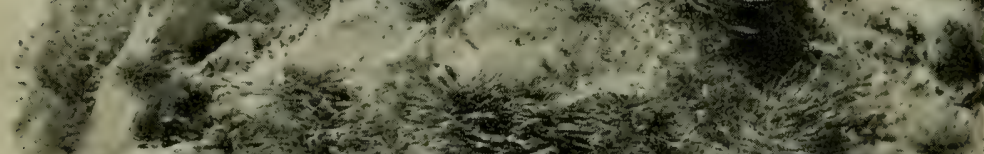

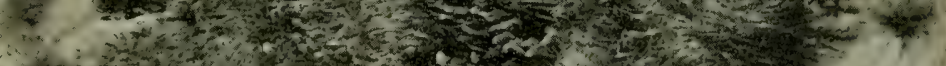

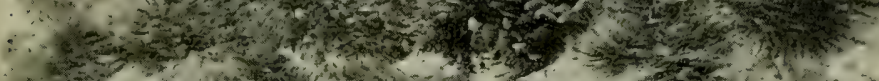

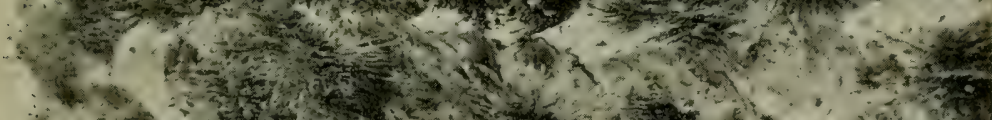

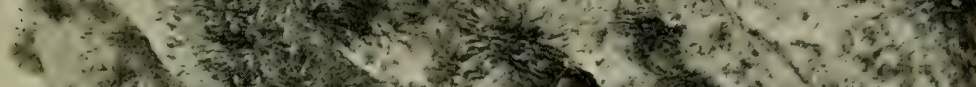

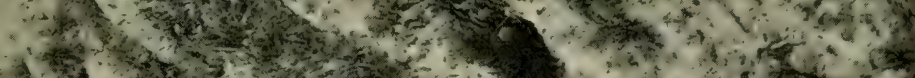

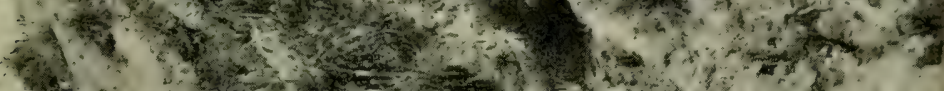

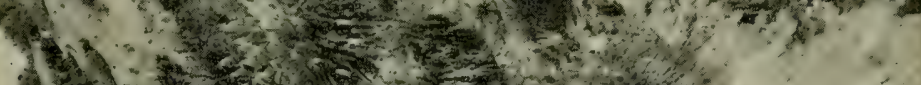

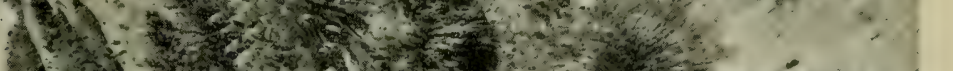

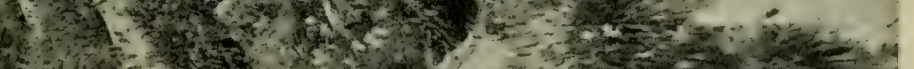

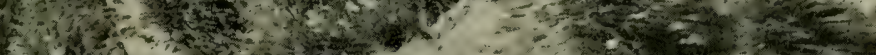

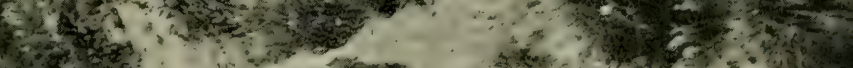

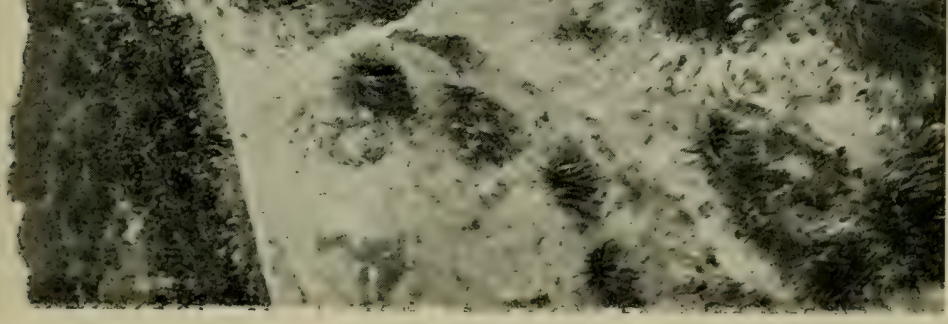

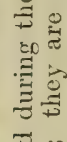

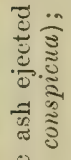
证 苛苛 $\stackrel{\circ}{*}$ $\exists$ 5 100

ถิํำ . 코

है $\triangle \frac{\pi}{8}$

है

도 迅 -

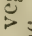

क

沗

$\pm$

离 


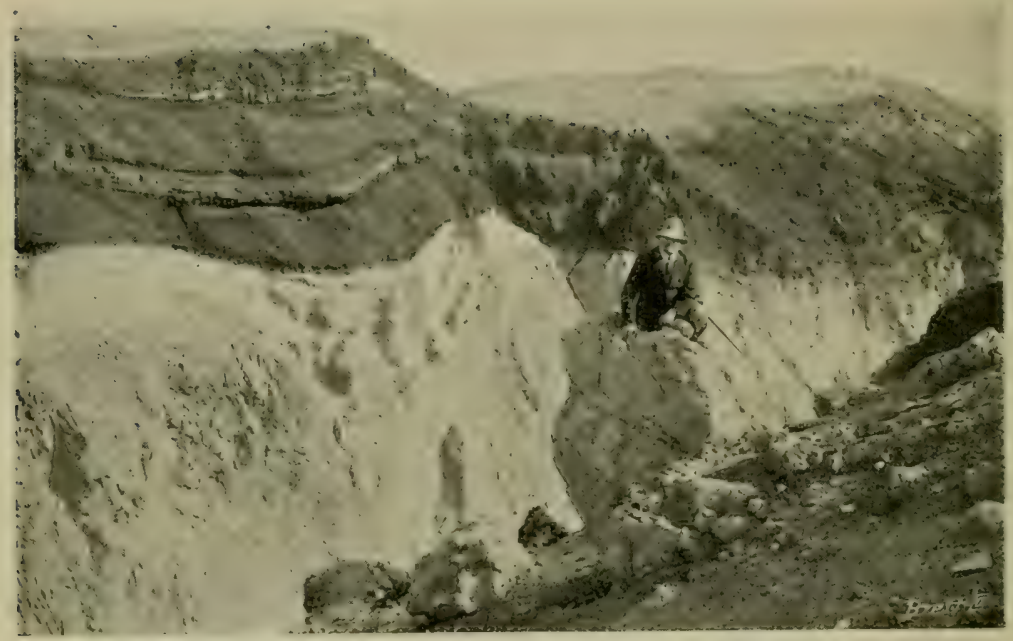

Fig. 45.-Portion of the rift made by the eruption of 1886 at a height of 3,400 feet on Hount Tarawera.

[Photo, B. C. Aston.

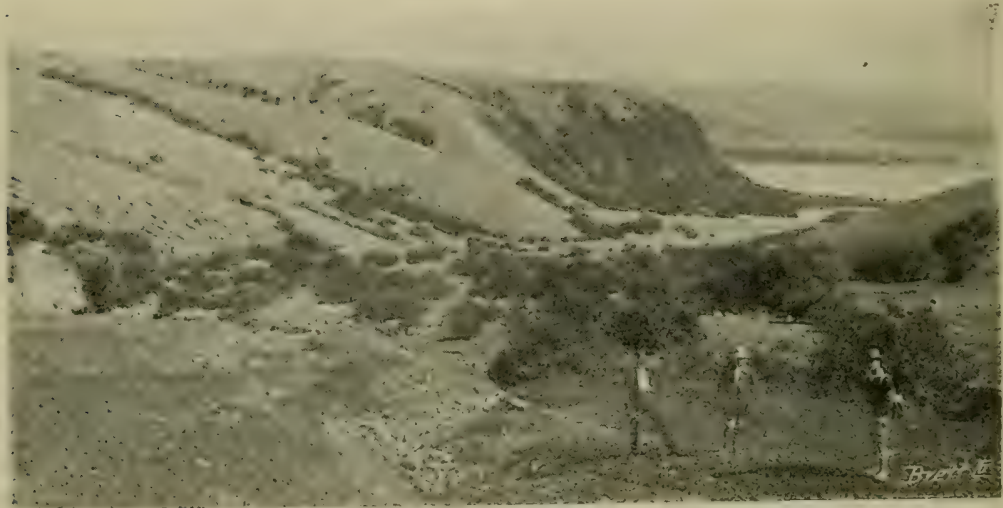

FIG. 46.-Lower slopes of Mount Tarawera as in 1913. The bushes are the N.Z. Farmer.] tutu (Coriaria sarmentosa).

[Photo, B. C. Aston. 
(Weimmannia racemosa) or the pahau-tea (Libocerlrus Bidwillii) as the dominant tree.

Nothofagus forest occurs at sea-level at Day's Bay, Wellington, and in certain parts of Nelson and the Marlborough Sounds area. The dominant species is $N$. fusca or the black southern-beech $(N$. Solenderi), as the case may be, the last-named never ascending as high as the other species. At Oxford, Canterbury, there was originally a most extensive forest of the black southern-beech ( $N$. Solanderi). In the west of Nelson and the Otago fiords there are extensive areas of ordinary rain-forest mixed with Nothofagus forest.

It is possible to identify the above species of southern-beech from their leaves alone. Nothofagus fusca and N. Menziesii have respectively toothed or crenate leaves, but those of the first-named are much larger, thinner, and of a vivid green. The other two species have entire leaves; those of $N$. Solanderi have a tapering leaf-base, while those of $N$. cliffortioides are heart-shaped and do not taper at the base. But it is not always easy to identify the two last-mentioned trees, especially if working only with dried specimens, for the leaf-character is not always satisfactory, and the general habit of the living tree and, for purposes of identification, its juvenile form are much better guides. 


\section{CHAPTER V.}

\section{LOWLAND SHRUB - ASSOCIATIONS, HEATH, AND ROCK VEGETATION.}

New Zealand shrubs in general-Relationship between the shrub form and the tree form-The ramarama-Persistent juvenile forms-Statisties regarding juvenile forms-The case of Pennantia-Tha behaviour of the kowhaiThe pokaka, the mountain-currant, and koromilos in general - What experiment can do-The dwelling-places of the manuka-Manuka thicketTuherous-rooted orchids-Plants of the Auckland gumlands-The pumice shrublands-The new vegretation after a volcanic eruption-Manuka thicket of the South Island-"Wind-scrub"-River-terrace scrub-Fern-heathRock-plants in general-Species common on rocks-Rock association of the East Cape Botanical District-The cliffs of the Wanganui Rirer-The Olearia insignis association - Rock association of Banks Peninsula -A remarkable case of plant-distribution.

Is all gardens where a specialty is made of our indigenous plants it is not the trees which are there to be found, but rather the shrubs of the open country. Obviously, these latter are more easy to cultivate than forest-plants. But this in not the sole reason: it is special beauty of form or flower that has marked them out as of peculiar merit. In any large garden in the world New Zealand shrubs would deservedly occupy a prominent place. Moreover, they belong, in many instances, to families which have no shrubby representatives in the Old World, whence nearly all ideas as to botanical form are derived.

The germander speedwell is a pretty little creeping-plant of English lanes, with bright-blue flowers. It has relatives in the Old Country, and in other places in both hemispheres; but, with the exception of its Ner Zealand cousins, two others in Fuegia, and a couple in Australia and Tasmania, all are herbs, or at best only woody in part. Of the 120 or so New Zealand speedwells (called throughout this book "koromikos"), 112 are woody; they vary in habit from plants a few inches high to forest-trees. Plants of the daisy family are usually herbaceous; but in a few regions, especially oceanic islands, shrubby forms occur, New Zealand being comparatively rich 
in such. Shrubby plants of the heath family are also frequent in the natural shrubberies, and some are of large size and quaint form.

There is a close relationship between the tree form and the shrub form. A number of tall shrubs stand on the border-line, so that a comparatively slight change of outer circumstances will turn the scale. Thus the round-leaved coprosma (Coprosma rotundifolia), one of the commonest of the forest-coprosmas, described in Cheeseman's Manual as "a laxly branched shrub 4-12 ft. high," when growing as a constituent of low river-bed forest in Westland is the dominant tree, often forming pure "stands," to use an expressive forestry term, and reaching a height of 20 feet or more. But in Stewart Island, for example, when growing outside the forest in an exposed position, this coprosma is of the dense divaricating growth-form.

Still more remarkable is the case of the wild-irishman (Discaria (oumatou). For miles and miles the dark mass of this shrub a ferw feet high-its form almost that of a divaricating shrub -is an important physiognomic feature (fig. 10) of the low tussock-grassland plant-formation throughout the South Island. Even when growing in the same climate where certain trees flourish it keeps its apparently fixed and certainly highly-differentiated form. No one seeing this shrub in its thousands under the above circumstances would ever dream that it could, did circumstances favour, grow into a tree 20 feet high with a distinct trunk. Yet in the river-valleys of Nelson subject to the excessive western rainfall it does become a veritable tree, with an actual trunk more than 1 foot through.

Generally speaking, it is the bushy trees which readily acquire the shrub habit-e.g., the broadleaf (Griselinia littoralis) - while those shrubs with an altogether different growth-form from trees in general, such as the divaricating, do not become trees.

Dwarfing does not of necessity change a tree into an ordinary shrub. The giant rimu (Dacrydium cupressinum) when a member of the subalpine scrub of Stewart Island is dwarfed to 6 feet in stature, but the trunk and tree form persist. Still more remarkable is the case of the pahau-tea (Libocedrus Bidwillii), which, an ordinary erect tree of the subalpine forest on certain parts of Mount Egmont, on the adjacent Pouakai Range, where exposed to the western gales, is dwarfed to about 4 feet, and on its leeward side maintains its form, resembling a toy tree, but on the windward side its branches have disappeared. 
As in the case of the trees, so, too, with the New Zealand shrubs: nearly all are evergreen. This might well be expected in a region possessing a climate devoid of extremes of any kind. The deciduous habit is essentially bound up with severe winters or hot summers combined with a dry climate. Some New Zealand trees and shrubs are deciduous throughout their range, but others exhibit every transition from the evergreen to the decidums habit according to the amount of frost they have to encounter. The following list embraces most of the deciduous or semi-deciduous trees and shrubs and lianes: The large-leared pohuehue (Muehlenbectia austratis), the pohuehue ( $M$. complerrt), the creeping-pohuehue (M. axillaris), the large-flowered New Zealand broom (Camichactia gramliflora). the tall New Zealand hroom ( $C$. oflorata), the climbing New Zealand broom (C. gracilis), the various kinds of kowhai (Sophora), the wildirishman (Discaria toumatou), the wineberry (Airstotelia racemosa). the lowland riblonwood (Plugianthus betulimes), the shrubly ribbonwood ( $P$. divaricatus), the hybrid ribhonwod ( $P$. cymosus), the hoary mountain-ribbonwood (Gayge ribifolia), the mountain-ribhonwood (G. Lyallii), the narrow-leaved lacebark (Hoheria angustifolia), the long-leaved lacebark (H. sexstylosa), the tree-fuchsia (Fuchsin excorticata), the shrub-fuchsia ( $F$. Colensoi), the shore-fuchsia ( $F$. procumbens), the fragrant tree-daisy (Olearia fragantissima), the thinleaved tree-daisy $(O$. Hectori $)$, the odorous tree-daisy $(O$. odorata), the swamp tree-daisy $(O$. virgatu and its varieties), the twiggr treedaisy $(O$. lineat $a)$, the divaricate tree-daisy $(O$. divaricata $)$, and the deciduous tree-groundsel (Senecio Hectori).

In the case of the kowhai the deciduous habit has nothing to do with frost, for the leaves are shed only just before the plant comes into bloom. On the other hand, in the case of the shrubby ribbonwood, leaves will persist all winter on twigs within the shrub when on its periphery not a leaf can be seen. Plagianthus betulinus, Gaya ribifolia, Senecio Hectori, the various tree-daisies, the New Zealand brooms, and probably some of the other plants listed above are truly deciduous, no matter where they may grow.

Shrubs differ greatly in their demands on nature. Some-for instance, the species of Alscuosmia, a genus of four species of the honeysuckle family, all of which are confined to New Zealand-can live only in the forest shade. Others-e.g., many of the New Zealand brooms-luxuriate in the full blaze of the sun. Others, again, 
are eminently plastic, certain of their organs-or, indeed, the whole plant-responding to change of enviromment. Thus the beautiful ramarama (Myrtus bullata) when exposed to the sun has its leaves Ereatly blistered and stained with red or purple, but when sufficiently shaded, as in thick forest, they are almost smooth and quite green. Nore remarkable still are those shrubs or trees now to be dealt with, but all too briefly, which have a juvenile form not only distinct from that of the adult, but which persists at the former stage for a long time, even for many years.

The number of New Zealand seed-plants which differ in a more or less striking degree at various stages of their growth according to the age of the individual is about 200 , belonging to 32 families and 53 genera. In about one-half of the above the actual growth-forms of the juvenile and adult are difterent-i.e., they are adapted for conditions more or less different. With the exception of three or four species, the plants which exhibit this remarkable phenomenon are endemic, while of the endemic genera no fewer than ten possess species of the above character. Nor is this all: certain species which exhibit the phenomenon in New Zealand do not do so elsewhere. There appears, then, ground for a shrewd suspicion that this state of affairs is connected in some way with New Zealand itself, and may be referred to conditions of the past provided by changes in the land-surface and the climate. This appears the more likely since certain strongly marked juvenile forms appear rather out of place at the present time. There seems, for instance, no reason for the great differences between the young and adult forms of the New Zealand jasmine (Parsonsia heterophylla). (See text-fig., p. 54.)

If the growth-forms of the above class of plants be analysed it appears that 48 are trees, 114 shrubs, 13 herbs, 6 water-plants, and 19 climbing-plants These estimates could easily be made higher if distinctions somewhat slighter were recognized From the standpoint of their water-requirements, the juvenile state of 125 is less tolerant of drought than the adult, in 16 it is able to bear drought better, and in 59 there is no striking difference.

The most important eases are where the juvenile stage not only remains juvenile for many years, but actually flowers and bears fruit. This has been observed in no fewer than 19 species. Thus the kaikomako (Pennantia corymbosa) remains in its young state for many years as a divaricating shrub. Finally it grows into an ordinary 
tree, but the divaricating form persists in its lower part. The juvenile and adult of such a tree may both bloom at the same time. Such flowering has not been observed in the cases of the narrowleaved lacebark (Hoheria angustifolia) and the lowland ribbonwood (Plagianthus betulinus), though both pass through a juvenile form almost identical with that of Pcnnautia; but, on the other hand, juvenile Hoheria sexstylosa flowers when three or four years old. If any of the above species remained at the juvenile stage it would

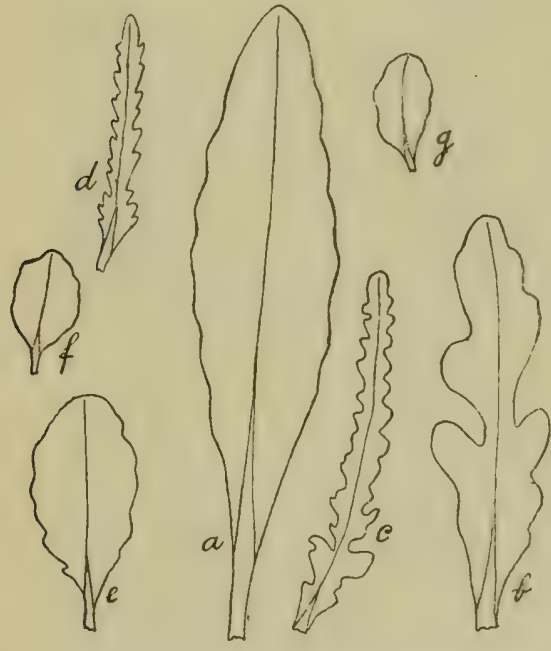

Juvenile and adult leaves of the pokaka (Elacocarpus Hoolierianus): a, adult leaf ; $b$, transition between adult and juvenile leaf; $c, d$, narrow form of juvenile leaf; $e, f, g$, obovate form of juvenile leaf.

Trans. N.Z. Inst.] be in the same category as any ordinary divaricating shrub ; also, it would be quite as distinct a species as the plant of which it was once a part. This phenomenon actually does happen in the genus Sophora, the species of which are known as "kowhai." The common kowhai (Sophora microphylla), when young and for many years afterwards, is a divaricating shrub, but it has not been observed to bloom at that stage (fig. 8). However, in the montane belt of Marlborough and Canterbury there is the prostrate kowhai (S. prostrata), which almost exactly resembles the juvenile divaricating form of S. microphylla, and, though it blooms and fruits freely, never becomes a tree. Now, in the

East Cape Botanical District, the large-flowered kowhai (S. grandiflora) has no divaricating juvenile form, but resembles that of the adult throughout its development.

How strongly the effect of habitat may be impressed upon a plant can perhaps be seen in the case of the taupata (Coprosma retusa). This species when growing on coastal rocks is more or less flattened against the rock. This prostrate habit is reflected in the early prostrate shoots of the young shrub (fig. 41), but the later upright shoots show a transition towards its final tree form. Yet 
even as an erect shrub or a small tree many branches may show the "weeping" habit, which is possibly a reversion to the juvenile stage.

Another tree with an early divaricating-shrub stage is the pokaka (Elacocarpus Hookerianus). Its various leaf-forms may be seen in the text-figure on p. 70. Even when this tree has reached its ultimate height of some 40 feet or more, shoots of the juvenile form may appear quite high up in the tree. This is also the case with the kahikatea (Podocarpus dacrydioides) and the Chatham tree-heath (Dracophyllum arboreum). Juvenile shoots which thus reappear on adult plants may be termed "reversion shoots."

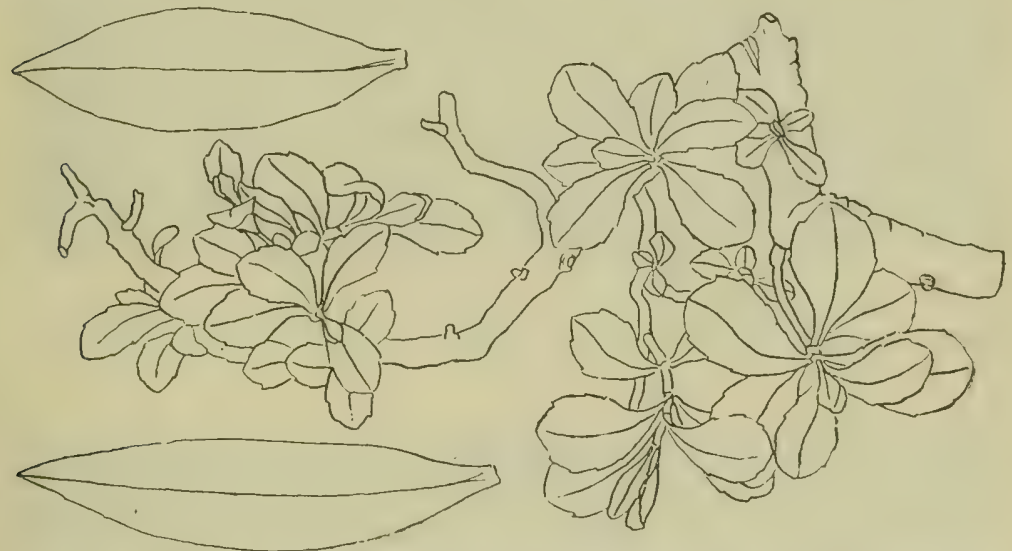

The branch with the small toothed leaves is a reversion shoot of Veronica salicifotia var. Atkinsonii. The two larger leaves without teeth on the margin are those of the adult.

[Esmond Atkinson del.

The mountain-wineberry (Aristotelia fruticosa) does not commence its career as a divaricating shrub, but such is its final destiny. The seedling for some time puts forth leaves of various forms, not at all like those of the adult, as may be seen in fig. 40 . Also, these leaves, as well as the form of the young plant, denote that the latter is far more dependent upon an abundant supply of water than is the adult; for this, indeed, may, in its almost leafless habit and rigid spinous stems, be peculiarly fitted to resist drought.

Many of the koromikos (Veronica) differ considerably in their early stage of growth from the final adult form. The commonest distinction is the toothing of juvenile leaves. Such is well shown in the text-figure of Veronica salcifolia var. Attinnsonii shown above, 
where the plant has reverted to the juvenile stage. The whipcord koromikos exhibit the phenomenon under discussion to an extreme degree. The juvenile has extremely thin leaves, which could not tolerate desiccation; whereas in the adult the leaves are reduced to thick scales, which are pressed close to the stem, and thus adapted to resist drought.

Experiment shows that in some cases the juvenile and adult stages are dependent upon the environment, and can be produced or suppressed. Cultivation in moist or in dry air is one agent which brings about the change. The juvenile spineless wild-irishman (Discaria toumatou) can be kept for many years in that condition by moist-air culture; but a week or two in dry air and the spines appear. In a similar manner, leaves can be called forth on the leafless common New Zealand broon (Carmichaclia subulata); the whipcord veronicas can be made to put forth true, thin leaves (fig. 39); and the strongly concavo-convex leaf of the boat-leaved tree-daisy (Olearia cymbifolia) can be flattened out.

The extreme plasticity of the manuka (Leptospermum scoparium), referred to in Chapter II, must suggest to any one that this species can get on very well in the world. This is true enough, for the plant in question can live and enjoy the best of health in forest, in swamps, on dry rocks, on river-bed, on cold subalpine moorlands, on sandhills, near the seashore, and exposed to sulphur-fumes near hot springs.

The manuka produces yearly its wealth of snowy flowers in the greatest abundance. Their white colour renders them exceedingly conspicuous. They are more or less bisexual, even on the same branch, and so depend to no small extent for pollination upon insects in search of their honey and pollen. The seeds are ininute, produced in great profusion, readily germinate, and so light that they are easily blown up from the ground along with the dust. Fire does not destroy the seeds to any extent, enclosed, as they are, in their stout woody capsules. If the above facts are borne in mind, it would seem remarkable indeed if the manuka did not form a most widespread plant-association of its own, which was not only capable of holding its place against the attacks of man, his grazing-animals, and fires, but could increase and become extremely bard to get rid of. It may be pointed out that Leptospermum scoparium itself is not composed of a definite set of individuals forming one biological 


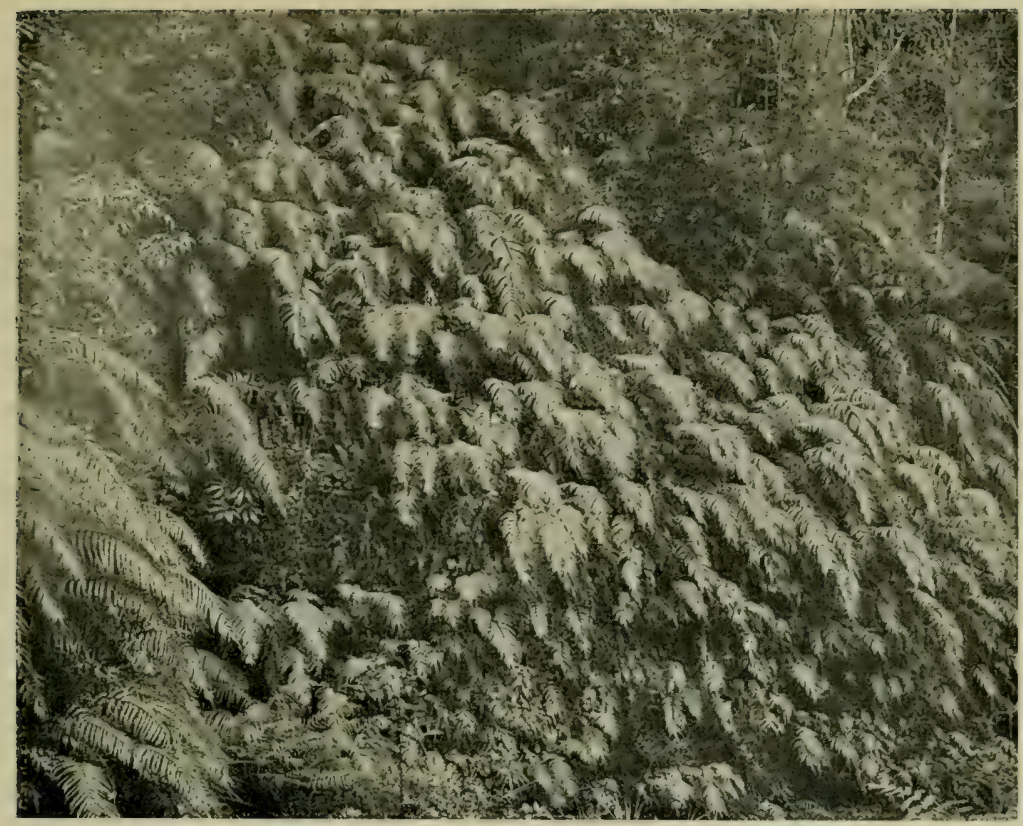

FiG. 47.-Bank of the long hard-fein (Blechnum capense) with the leaves averaging about 3 feet in length and forming a "leaf-mosaic." On the roadside going to the Fox Glacier (Central Westland).

[Photo, L, Cockayne.

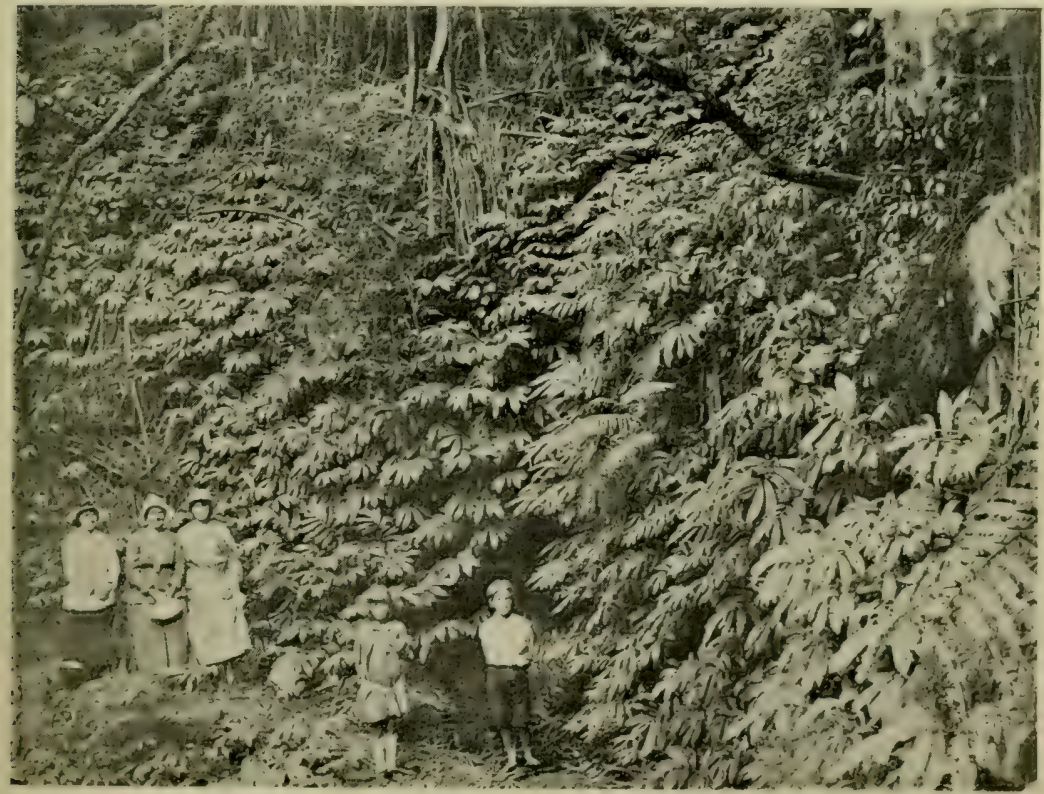

Fig. 48.-Bank covered with the paritaniwha (Elalostema rugosum).

Waitakerei Range (Auckland).

[Photo, E. Bruce Levy. 
I. $m$ -

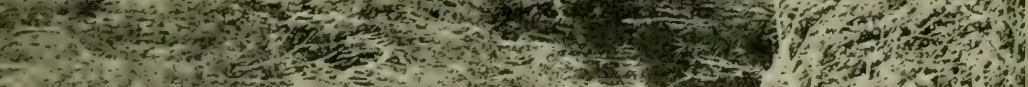

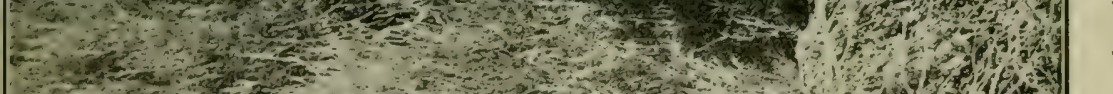

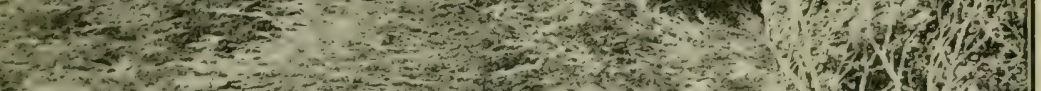

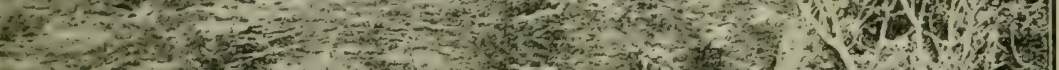

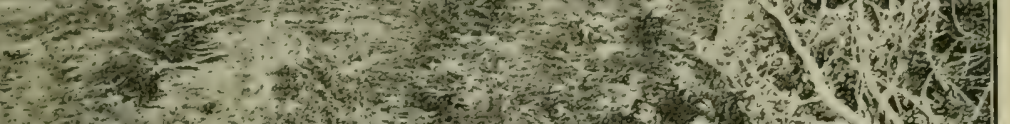
3. 3.5.

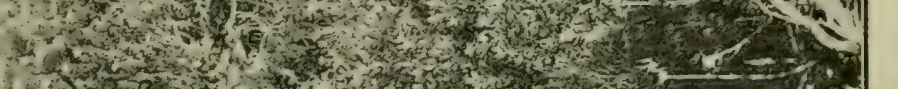

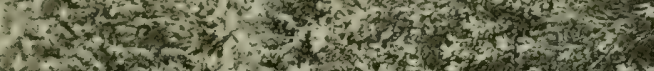

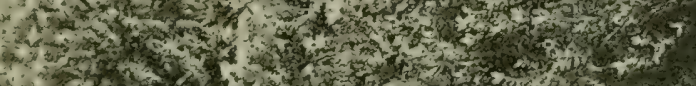

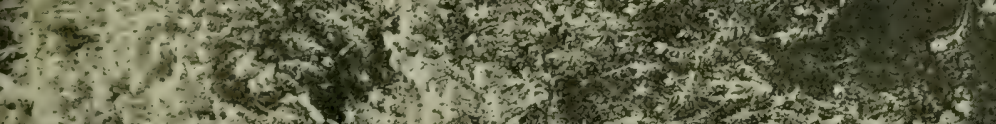

F.

1.3.

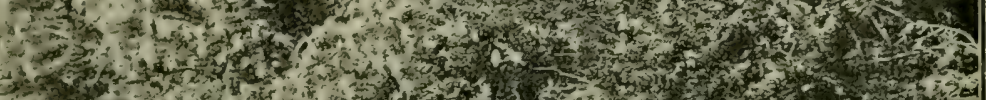

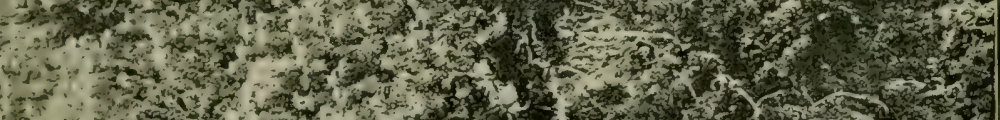

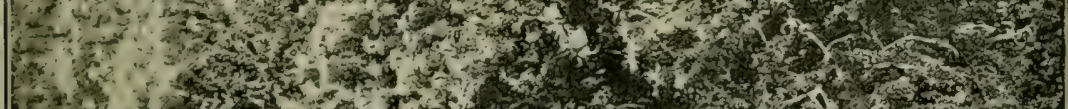

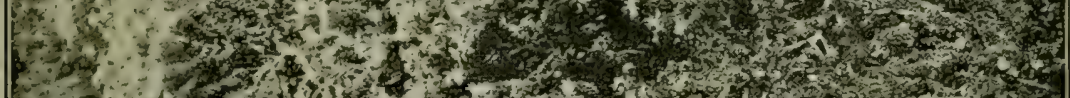

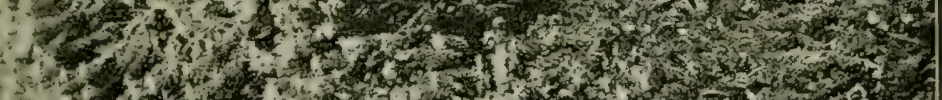

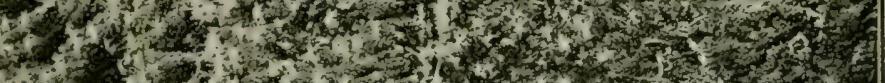

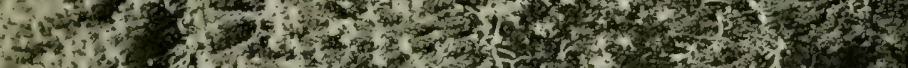

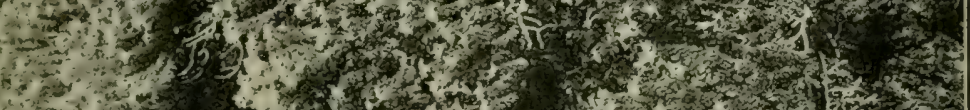

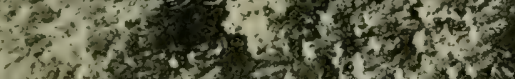

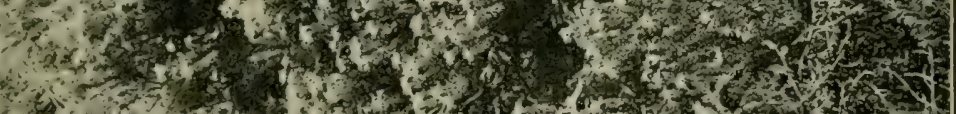

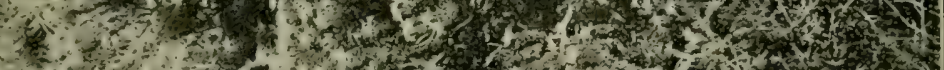

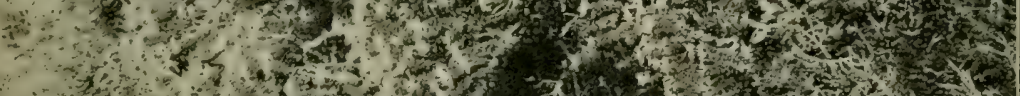

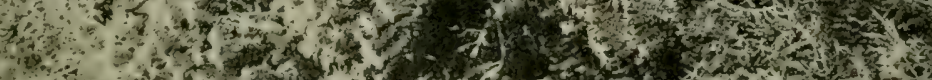

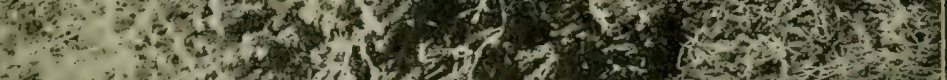

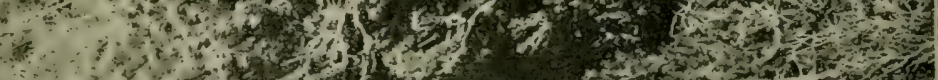

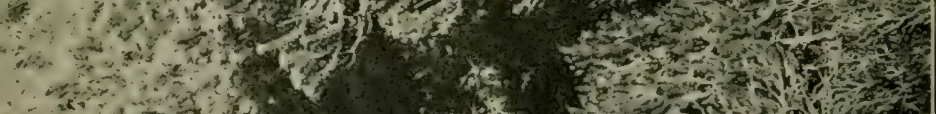

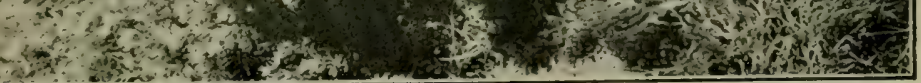




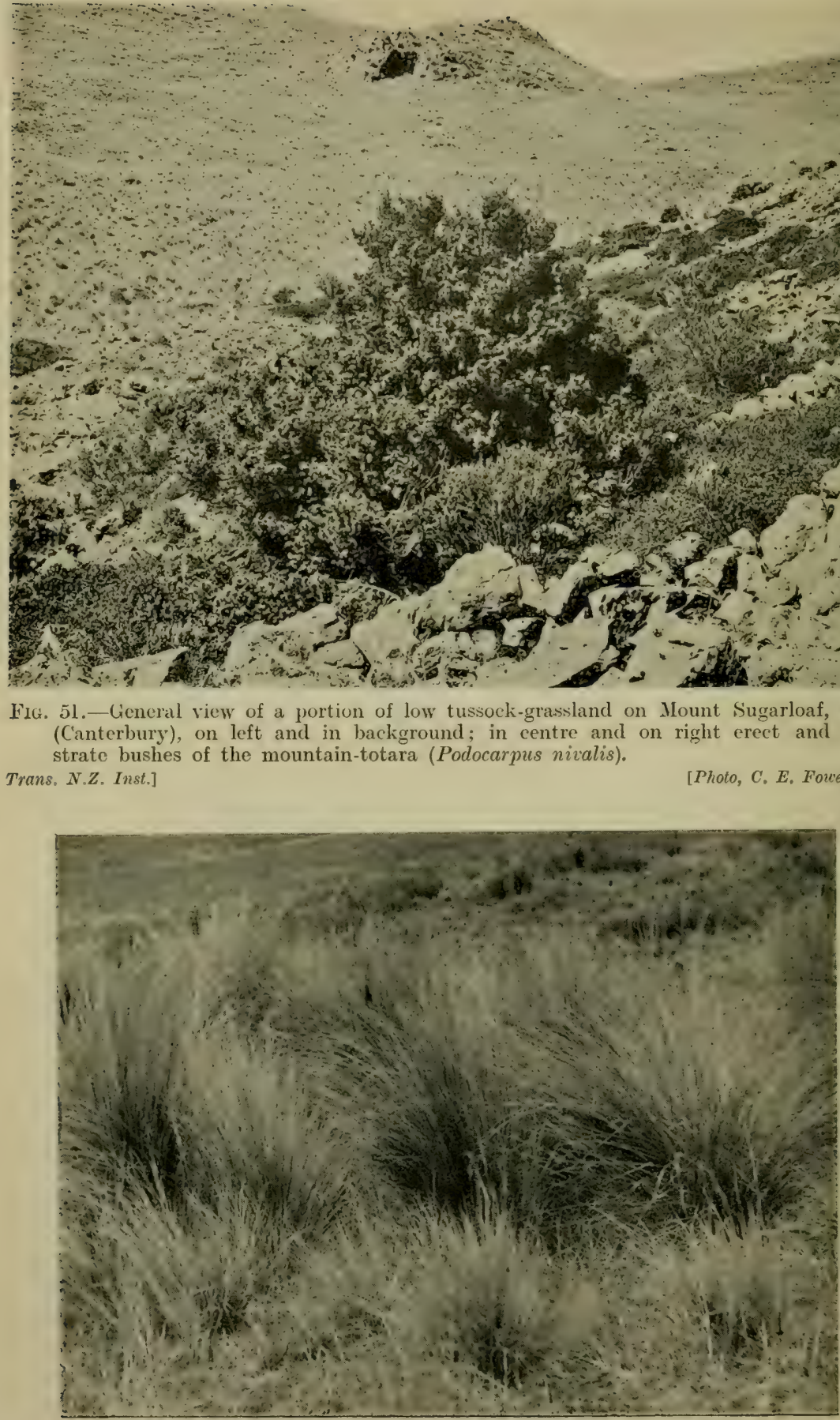

Fic. 52.-Tall tussock-grassland of the red-tussock (Danthonia Raoulia var. rubra) growing in the montane belt of the Malvern Hills (Canterbury). 
race which reproduces its like. On the contrary, it presents a diversity of forms which are semingly impossible to classify. Some, it is true, are distinct races, but most are probably unfixed hybrids between races not yet defined by the plant-classifier. There are also occasionally individuals with beautiful double flowers (fig. 43), and others with crimson blossoms, of which the form known in gardens as Leptospermum Vichollsii (in general incorrectly spelt "Nichollii") is one of the most handsome shrubs in cultivation.

Wherever the soil is extremely poor, as on dry gravel plains, or particularly "sour," as that sterile clay, wet in winter and baked hard in summer, which forms the Auckland gumlands, a more or less dense association of manuka occurs. At the present time it is impossible to say what was the primitive physiognomy or composition of the latter association, for repeated burning must have greatly altered the original arrangement of its members as well as their relative abundance. In any case, it seems safe to assume that a plant with such habits and potentialities as the manuka would formerly, as now, stamp the association with its own remarkable individuality.

The manuka formation, described below under the designation " manuk thicket," is of varied origin. It may be a natural successor to rain-forest, or a stage of succession in the development of riverbed, swamp; or bog vegetation, and certainly it can take the place of forest which man has destroyed.

A great many members of the formation are shrubs with small leaves of a heath-like character. There are generally a good many tuberous orchids to reward careful search if looked for at the season when they may be expected to flower; indeed, amongst the manuka is the dwelling-place par excellence of these curious plants, so greatly esteemed by many, partly for their beauty, partly for the rarity of certain species, and partly because they are frequently considered to be extremely valuable.

The number of orchids provided with tuberous roots enabling them to grow in the soil, as distinguished from the perching-orchids, with their water-absorbing, aerial roots, is 57 , belonging to 21 genera. Compared with their gorgeous tropical relatives grown in hothouses, the New Zealand orchids are the most modest of country cousins, yet their attractions are not to be denied. Some have flowers so constructed that cross-pollination by insects is 
essential before seed can be produced; but so much has been written on this subject that no details need be given here. Other orchids, again, are self-pollinated.

Coming next to the manuka-thicket plant-associations, the most varied is that of the Auckland gumlands, where the number of species is about 81 . As one proceeds south the species gradually become fewer in number. In gumland thicket, beneath the manuka there is frequently a dense growth of the green rush-like Schoenus Tendo or S. brevifolius mixed with the yellowish-green pine-like clubmoss Lycopodium densum, or each of these may form colonies of its own. Other common plants of this association are-- bracken-ferm (Pteridium esculentum); the three species of Pomaderris (P. phylicaefolia, $P$. elliptica, and $P$. Edgerleyi), all of them small shrubs with inconspicuous flowers - the first-named having very small, rolled, hairy leaves, the second a more erect plant with bluish-green oblong leaves covered beneath with whitish hairs, and the third is of more spreading habit, with narrower leaves covered beneath with a rustcoloured dense mat of hairs; the tall mingimingi (Leucopogon fasciculatus), a shrub very like the manuka, but of the heath not the inyrtle, family; the northern needle-leaved heath (Dracophyllum Urille(mun), an erect, grass-like shrub of slender habit with long needle-like leaves; flat-stemmed tussocks of Lepidosperma laterale; another heath with very small overlapping ovate sharp-pointed leaves (Epacris pauciflora), pleasing from its abundant small white flowers; yellowish young non-flowering trees of the tawhero (Weinmannia sylvicola), extremely hard to distinguish from the adult of the makimaka (Ackuma rosafolia), a plant of the margin of kauri forest or near streams; that showy tree-daisy, with large broad stiff shining leaves, silvery beneath, the akepiro (Oleario furfuracea); a miniature cabbage-tree, at most 3 feet high but generally smaller, the ti-rauriki (Corlyline pumitio); and, in some localities, the toru (Persoonia toru), a small closely-branched tree with thick leathery polished brownishgreen narrow leaves, 6 inches long, more or less. In the association towards its northern limits the curious climbing leafless parasite, Cassytha paniculata, spreads its yellow cord-like stems from shrub to shrub, like the web of a monstrous spider, thus forming a little above the ground veritable entanglements, which may cause one to stumble.

On the pumice-covered tableland towards the centre of the North Island the thicket changes its character. Certain of the northern 
plants are wanting, and some peculiar to the area, or nearly so, appear. Here is that exquisite shrub the niniwa (Gaultheria oppositifolia), with a profusion of flowers like a glorified lily of the valley. Here also is a peculiar brownish-leaved erect shrub of the heath family, the monoao (Dracophyllum subulatum), usually a sign of very bad land. Manuka is, of course, in abundance as usual. There is sometimes a good deal of the mountain-flax (Phormium Colensoi).

In 1886 the eruption of Tarawera led to the burying of large areas of this plant-association by volcanic ash. So thickly did this fall that in some places an actual new land-surface was formed for repopulation (figs 45, 46). This was of great interest, since opportunities for observing the settlement of a large area of virgin soil under natural conditions are rarely afforded; and in this case there is a clue to what may have taken place long ago in the evolution of the plant-covering of the adjacent country.

Where the heath was but thinly covered with ashes it reappeared almost in its original form; but where the covering was many feet in depth there is quite a different story. Very shortly after the eruption heavy rain occurred, and the comparatively loose soil was cut into innumerable deep but narrow gullies, with many lateral ones opening into them. The sharp ridges between these gullies are bare, but on their sides wave masses of toetoe-grass (Arundo conspicu(t), a plant not very abundant in the adjacent shrubland (fig. 44). The "seeds" of this grass would, of course, be brought by the wind. Another common nember of the new society is the tutu (Coriaria samentosa) (fig. 46), its "seeds," of course, having been brought by birds from the plants of the adjacent heath, where it is a common plant.

On Tarawera itself and its immediate neighbourhood multitudes of the flat silvery cushions of a variety of the common raoulia (Raoulia anstralis) have occupied the ground, thanks to their easy distribution through wind-blown "seeds," and, in addition, the absence of competition with other plants. Exactly the same thing has happened on the man-made desert of Central Otago and in parts of Marlborough. It is of special interest that, notwithstanding the general belief that seeds are readily carried long distances by the wind and by birds, all the Tarawera colonists have come from the immediate neighbourhood-they have simply "increased their holdings." But, as might well be expected, a large majority of the 
species have made use of the wind as their conveyance, those that have employed birds being very few. In some places where there was forest the plants were not altogether destroyed, and various species have regrenerated from the bases of the burned trees.

In the South Island the manuka thicket, so far as the shrubs go, frequently consists of pure Leptospermum scoparium. Sometimes other shrubs occur in varying quantities, of which the tumatakuru or wild-irishman (Discaria toumatou), the pungent minginingi (Cyathodes acerosi), and the golden cottonwood (Cassinia fulvida) are frequent, while the mountain-cottonwood (C. V'aucilliersii) is not uncommon. The ground-plants vary according to the altitude, soil. and climate. On the Bluft Hill the thicket is richer in species than that just described; and specially noteworthy are the large bushes of a very robust form of the pungent mingimingi (Cyathodes acerosa), some with abundance of white and others with pink drupes.

Where the ground is very wet, as on those dreary wastes, the pakihis of the North-western Botanical District, the heath approximates to hog, and would be so reckoned but for the small amount of peat on the surface. The plant-covering consists of various rushlike sedges (Clatium glomeratum, C. teretifolium, C. capillaceum); the bog umbrella-fern (Gileichenia dicarpa); a creeping club-moss (Lycopodium ramulosum), which in full sunshine produces abundance of spore-bearing stems, but in the shade these are wanting: the beautiful white bog-gentian (Gentiana Tounsoni), which flowers late in the year; the bog-epacris (Epacris pauciflora); the slender-flowered eyebright (Siphonidium longiflorum)-a very rare plant, the only representative of this endemic genus; some orchids and sundews; and, of course, abundance of manuka.

In contradistinction to thicket is that type of shrubland where the divaricating growth-form and other stiff-stemmed or especially dense-growing shrubs frequently make a more or less impenetrable mass. Such an association can be designated by the expressive word "scrub."

In Australian plant-geography the term "scrub" has an unfortunate application. In eastern Australia there are two quite different tree-communities-the one consisting principally of Eucalypti, often growing some distance apart, which forms "savannah," and the other a true rain-forest. For this latter the Australian vernacular is "scrub," and this has been inadvisedly followed in Australian 
plant-geography, notwithstanding the accepted dictionary meaning of the word and the failure to bring home to the student the important fact that the so-called "scrub" belongs to "rain-forest," a scientific term of precision and general application.

"Scrubs," in the sense used in this book, are the result of dry soil (frequently stony), high winds, wet swampy soil with a low oxygen content, the rlimate of high altitudes. and absence of a certain amount of sunshine, with the resulting " sour " soil: but these different factors need not all be present.

On the hills near Wellington there was originally a good deal of scrub whose origin may be traced to wind alone. Some still exists on the Kaukau Range, at its junction with the C'row's Nest. This scrub is simply the adjacent semi-coastal rain-forest reduced to scrub under the dwarfing action of frequent gales, the wind also selecting the colonists, or, rather, killing out the unfit. In addition a species from the neighbouring rocks, Veronica pariflora-not in the original forest-- has entered the community. Nor, being a small tree, has it been able to get rid of its trunk, which, if used, would make its new dwelling-place impossible to live in ; consequently the trunk is got out of the way by being laid prostrate for many yards upon the ground. Very conspicuous in this scrub are the supradivaricating whatwhaupaku (Nothopenas (momelum), and the three myrtles-the ramarama (Mytus bullata), the rohutu ( $M$. obcorlata), and their hybrid, M. Ralphii.

Another interesting wind-scrub occurs on the North Cape Promontory, where the tanekaha (Phyllocladus trichomanoides), usually a forest-tree 60 feet or so high, is dwarfed to 4 feet in height.

In Westland extensive scrubs occur on the faces of the riverterraces of the lowland belt, and follow the river-valleys until they merge into the subalpine scrub of the high mountains; indeed, the two associations are closely allied, containing as they do many of the same species. This terrace-scrub is not so dense as its subalpine relative. It consists of--the sharp-leaved totara (Podocarpus acutifolizes; the New Zealand holly (Olearia ilicifolia); the mountainakeake (Olearia aricenniafolia); the false New Zealand holly (Olearia macrodonta) (fig. 38); the lancewood (Pseulopanax crassifolium var. unifoliutum); the glossy karamu (Coprosma robusta): the mountain ivy-tree (Nothopanax Colensoi); the mountain-wineberry (Aristotelia fruticosa); various (oprosmas of the divaricating form c.g.. the common coprosma (C. propinqua), the leafy coprosma (C. pariffora), 
the heath-like coprosma (C. rugosa); the whauwhaupaku (Nothopanax anomalum), of similar form to the coprosmas; two New Zealand brooms, the large-flowered broom (Carmichaetia grandiflora) and the swamp-broom (C. paludosa). In the shade grow the creekfern (Blechnum fluviatile), the triangular hard-fern (B. vulcanicum), and the prickly shield-fern (Polystichum vestitum). The white-leaved lawyer (Rubus schmidelioides var. coloratus) climbs over the shrubs.

Manuka shrubland has strong affinities with fern-heath, one of the most widespread plant-formations in New Zealand. Probably most of the present fern-heath has resulted from the action of man in burning the forest. Thus in the neighbourhood of the Marlborough Sounds, in many parts, it is quite uncertain whether an area of burnt southern-beech forest, after the sowing of grasses, may not be replaced by agriculturally worthless fern-heath, the extermination of which is extremely difficult.

The leading plant of the formation is the bracken-fern (Pteri(lium esculentum). This fern cannot grow in the forest shade; but as soon as forest is burnt, the spores of the fern being already in the ground, thousands of plants appear, and, thanks to the rapidly growing underground stem, full of plant-food which had been manufactured by the leaves, the area in an astonishingly short time becomes bracken-fern, frequently many feet in height. Where the fern reaches its full development nothing else can grow, but usually some of the manukia-thicket plants of the immediate neighbourhood are present, while the tutu (Coriaria samentosa) is almost certain to be a constituent. The effect of overstocking with cattle on fern after it has been burnt is remarkable; indeed, without their aid it would usually be impossible to grass the land. Were it not that a bracken plant-covering consists entirely of fern-leaves, and that the destruction by cattle of the rolled-up end of the leaf stops further growth of that leaf, the fern would invariably conquer. Its one weakness leads to its downfall.

The weathering of rocks prepares in the talus-slope at their base new soil for colonization, which in part is peopled by those shrubs which grow on the rock, so that an open shrub-association or a dense scrub may eventually be formed. This is the topographical, not biological, succession mentioned in Chapter II, the rock association not turning into scrub by slow degrees. Nevertheless, as shrubs are extremely common denizens of rocks, there is a kind of relationship between the associations of the two stations. 
Rock-plants may be divided into those which are fixed to the actual surface of the rock and those which nust commence their existence in a crevice or hollow where more or less soil has accumulated. The former class consists of algae, lichens, mosses, and liverworts; the latter embraces the seed-plants, the ferns, and certain club-mosses (Lycopodium). As the soil of the rock-face, hollows, or crevices increases in amount through decay of the vegetation the conditions less and less resemble those of an early stage of settlement, and an association may arise through biological succession having little to do with rock-conditions. Naturally, too, there are great differences between the associations of dry and wet or of sunny and shady rocks, while even apparently dry rocks may contain no small amount of water. Rocks readily weathered favour plants; in New Zealand their chenical nature is usually of little moment, though a few indigenous plants have, so far, been seen only on limestone - e.g., the lime-spleenwort (Asplenium obtusatum var. anomolon), the rock-anisotome (Awisotome Enysiz), and A. patula. The serpentine rocks of the Mineral Belt in Nelson also have a selecting-power.

Considering lowland rocks alone, the total number of species occurring on them throughout New Zealand is about 180, distributed amongst 43 families and 95 genera. With regard to their growthforms, shrubs and herbs are nearly equal, and make up about 62 per cent. of the total; ferns come next in number. Only 20 of the 180 species are purely or almost rock-plants; the remainder are largely drought-enduring plants of other formations-i.e., considering dry rocks only.

The following species are more or less common on lowland rocks generally: The two species of New Zealand flax; the bush-lawyer (Rubus australis); the manuka (Leptospermum scoparium); the snowberry (Gautheria antiporla); the tall mingimingi (Leucopogon fasciculatus); the common koromiko (Veronica salicifolia); the broad-leaved poa (Poa anceps), in the North Island; species of piripiri (Acaena Sanguisorbae, various forms); the wild-irishman (Discaria toumatou), but this latter is not found in the North Auckland Botanical District or on North Island rocks in general.

Coming now to details, on certain North Island, Nelson, and even Marlborough rocks the otherwise perching kahakaha (Astelia Solandri) may form pure colonies. In the East Cape Botanical District shady 
rocks, dripping with water, are frequently draped with the New Zealand calceolaria (Jovellana Sinclairii), its pretty flowers white spotted with purple; with it may be wide breadths of the pleasing "everlastings," Gnaphalium subrigidum or G. keriense. On wet rocks in Westland the creeping New Zealand calceolaria (Jovellana repens) is often present, accompanied by Nerrera depressa, conspicuous through its red "berries," and Gumera albocarpa. On limestone rocks in North Canterbury is the common maidenhair (Adientum affine), the lime-spleenwort (Asplenium obtusatum var. anomodon), the anise (Angetica montruna), the mountain-akeake (Olearia aricenniaefolic $\iota$ ), and the yellow-flowered leafless clematis (Clematis afoliat $($ ).

The exquisite scenery of the Wanganui River owes its special charm to the plant-covering of its soft papa (calcareous mudstone) rocks. Above the perpendicular or, it may be, sloping cliff's is the low forest of tawa (Beilschmiedia luwe); beneath this there may be a belt of shrubs, and beneath this again masses of the pale-green, drooping, flat, grass-like leaves, more than a yard in length, of Cladlium sinclairii; and with this, but dominating the scene, great breadths of the huge pimnate leaves, scme up to 10 feet in length, of the long hard-fern (Blechnem capense), each leaf spread out to its full clear of its neighbours - the whole forming a perfect mosaic. Where especially wet and shaded, pure yellowish-green or glistening bronze colonies of the parataniwha (Elatostema rugosum) add a special charm to the scene. Nearer the base of the cliff there will be an abundance of Gnaphatium keriense mixed with the pretty Veronica cataractre, and beneath this stunted maidenhair fern (Adiantum affine). As the river is descended, the elegant Euphrasia cumeata enters the association, and where the rock is wet a groundsel, Senecio latifolius, with its showy yellow heads of blossom. Such banks of Blechnum capense as the above are characteristic of New Zealand generally, and are not confined to rock, their presence being rather determined by excess of moisture (fig. 47). So, too, is it with the parataniwha (Elalostema mesum) (fig. 48).

Amongst the most prized of New Zealand plants for garden purposes are the rock tree-daisy (Olearia insignis) and the New Zealand lilac (Veronica Hulkeana), a most floriferous plant with soft lilac flowers; but few would guess that two plants so dissimilar grew side by side on dry rock! Both shrubs have been illustrated more than once, and described many times in the English gardening 


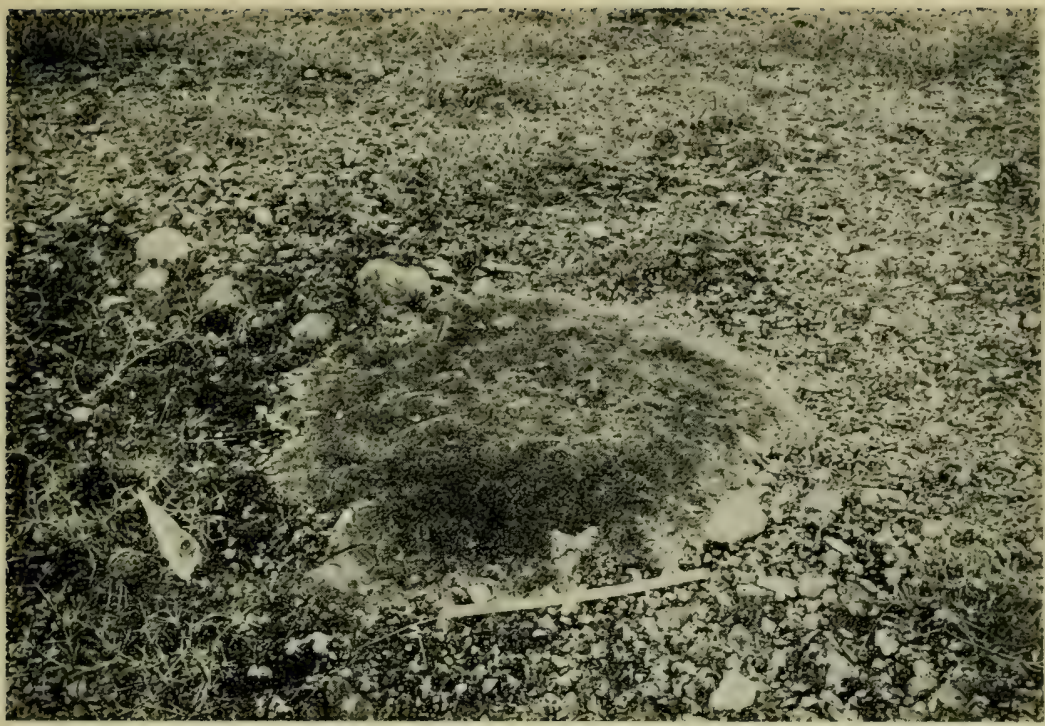

FIc. 53.-Raoulia lutescens, a low cushion-plant which forms a seed-bed for other plants in the development of low tussock-grassland.

Trans, N.Z, Inst.]

[Photo, C, E. Foweraker.

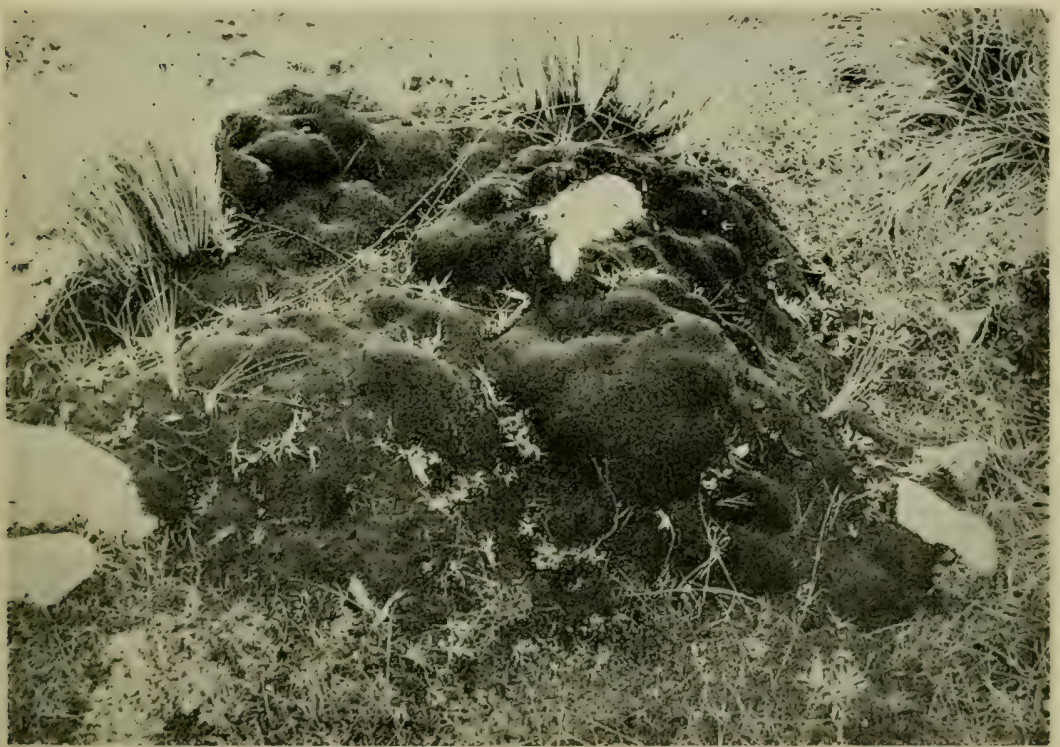

Fig. 54.-Cushion of the green raoulia (Raoulia Haastii) with tussock-grass settled on it. Bed of the River Cass. 
papers. With them there may also occur two other plants admirably suited for gardens - the rock shrub-groundsel (Senecio Monroi) and a truly charming bell-flower (Wahlenbergia Mathewsii) with large pale-lilac flowers, this latter not yet introduced into cultivation.

Olearia insignis is a low-growing, straggling shrub with stout branches which in their younger parts are covered with a mat of buff-coloured hairs. The leaves are extremely thick and fleshy; they are bright-green above, but beneath are covered densely with a thick mat of whitish hairs. Fach leaf is 4 to 6 inches long, and the leaves are arranged in rosettes at the ends of the otherwise leafless branches. These latter are always bent so as to bring the rosettes into as much light as possible. The large, hemispherical flower-head is 2 to 3 inches through, and covered with many scales, hairy as leaf and stem. The outer little flowers of the head are very numerous, and white in colour, but the inner ones are yellow. The form and structure of the plant is in harmony with its dry, rocky home-i.e., it is specially adapted to tolerate drought. The flower-head differs in important characters from that of any other Olearia, and probably a genus should be constituted in which to place this truly remarkable and most handsome plant. Veronica Hulkeana is too common as a garden-plant to need any special description, but it may be pointed out that the species is an aggregate, containing a number of different races quite distinct for garden purposes.

The other members of this association are: The mountain-flax (Phormium Colensoi), but only where the rocks are shaded; the nao (Linum monogynum), an elegant plant with fine white delicate flowers, which is a real flax or linseed, very common on the coast; the anise (Angelica montana); the tutu (Coriaria sarmentosa); the leafless clematis (Clematis afoliata); a variety of the common anisotome (Anisotome aromatica); and the rock cotton-plant (Celmisia Monroi); but rarely are all present in any one place. The association is not purely lowland, but ascends to about 3,000 feet; it also occurs, but considerably modified, on the actual coast.

The rocks of Banks Peninsula have a distinct vegetation of their own. Its fullest development is on rocky faces with a southern aspect. The association is distinguished by the presence of the lovely Veronica Lavaudiana, a small shrub-confined to the peninsulaof rather straggling habit, with beautiful substantial dark-green 6-Plants. 
leaves edged with red, and bunches of many small white flowers slightly rosy in the bud. Also two other plants characterize this association-herbaceous groundsels with leaves of great size, white underneath - Senecio lagopus (fig. 49) and S. saxifragoides. The distribution of these two species is one of the most remarkable cases of plant-distribution in the world. It has recently been most carefully investigated by Professor Arnold Wall. The two species, or more properly varieties of an aggregate species, differ

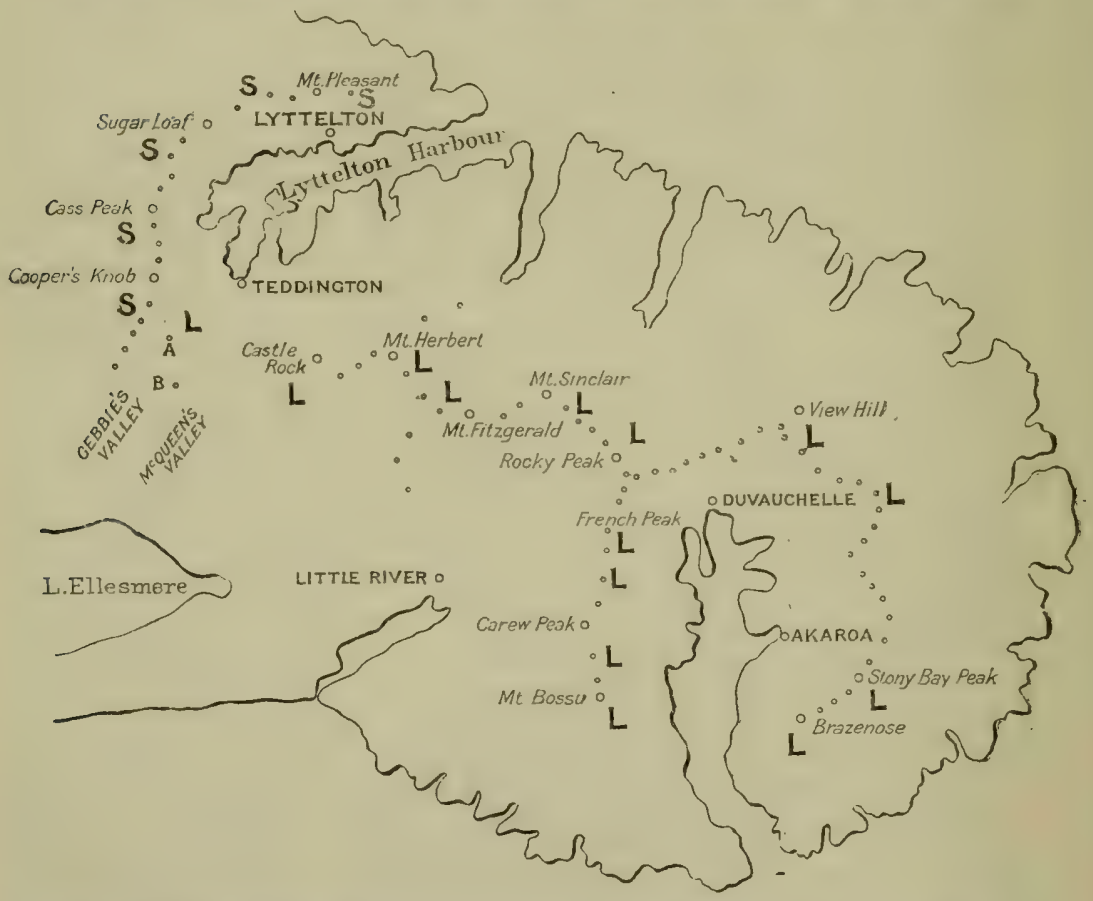

Map of Banks Peninsula and Port Hills, showing distribution of the two species of Senecio. L. Seneciolagopus ; S. Senecio saxifragoides ; A, rhyolite escarpment where S. lagopus occurs; B, rhyolite escarpment where neither species occurs.

only in the degree of certain characters common to both-namely, the presence of "bristles" on the leaf-blade and silky hairs on the leaf-stalk; but these differences hold good for each species. Now, as the above map shows, S. lagopus is confined to Banks Peninsula proper, and S. saxifragoides to the Port Hills. Such a 
"selecting-power" of the habitat, each part of the peninsula " choosing" the plant it likes best, is almost beyond belief ; and yet for some reason or other the two species keep quite separate, their areas of distribution being separated only by a gap of barely a mile, where neither grows!

A species of Anisotome not yet bearing a name, it having been mistaken for A. Enysii, confined likewise to Banks Peninsula, is also a member of this rock association. The other constituents are various shrubs or dwarfed trees which tolerate the rock lifee.g., a variety of the smooth-leaved koromiko (Veronica leiopliylla), the broadleaf (Griselinia littoralis), the mountain-korokio (Corokia Cotoneaster), and the rock-akeake (Olearia Forsteri); the nao (Linum monogynum); the hard shield-fern (Polystichum Richardi); some grasses; a wood-rush (Luzula campestris), one or more of its many varieties; and some other plants. 


\section{CHAPTER VI.}

\section{THE STORY OF THE GRASSLANDS.}

General remarks-Samuel Butler's opinion of New Zealand flowers-Distribution of the grassland-Classification of the grassland-Composition and distribution of low tussock-grassland - The silver-tussock and hard-tussock associations-Statisties regarding the growth-forms of low tussock-grassland -List of species of low tussock-grassland-The "stupid gentian"-Shrubs of the grassland - The dwarf brooms - The spaniard-Drought-resisting structure of many low tussock-grassland plants-Evolution of low tussockgrassland-Tall tussock-grassland-The growth-form of the red-tussockAppearance and constituents of certain tall tussock-grassland associationsThe Dunthonir australis association-Tussock-grassland from the economic aspect-The question of burning-A valuable tall tussock.

I'HEN the early settlers reached their antipodean home they must have been struck by the absence of green meadows gay with buttercups, daisies, coltsfoot, and oxeyes; regretfully, too, would they call to mind the wealth of wild hyacinths and white anemones of the spring-time woods, the stately foxglove, or hillsides yellow with the cowslip. Samuel Butler, erstwhile sheep-farmer, but afterwards a philosophical writer, voiced this feeling when he wrote, "Summing up, then, the whole of the regetable and animal products of the settlement [Canterbury], I think that it is not too much to say that they are decidedly inferior in beauty and interest to those of the Old World." And, again, "I do not know one pretty flower which belongs to the plains," and "We have one very stupid white gentian." Later, when Butler had read Darwin's "Origin of Species," and had contributed in 1863 a eulogistic article on that immortal work to the Christchurch Press, he might have written differently; for he surely would have learnt, as he did afterwards, that the interest in plants or animals is not aesthetic merely, but biological, and he would have comprehended that the monotonous array of tussocks, the despised spear-grass and wild-irishman, and the herbs with insignificant flowers were just as important members of organic nature and had stories of their own as sensational and fascinating as those of their more gaudy sisters of the Swiss Alps, which he admired so greatly. 
Butler's contempt for the Canterbury flora was derived from his observation of the tussock-grassland; evidently he knew little of the much more showy denizens of the highlands. He was certainly right, too, in his estimate of the plants as "wild flowers," except in the case of the "stupid gentian." But the British meadow is an artificial creation, and its pretty flowering-plants are weeds, the signs of indifferent farming. On the other hand, much of the New Zealand grassland even yet is almost virgin, and its plants are those which Nature banded together, to their mutual benefit, after years of wandering and change. Evidently, then, information of much more moment is to be reached from the study of New Zealand natural grassland than from that of European aitificial meadow, and its plants at once stand forth as living organisms with special stories of their own to tell.

According to the teaching of present-day plant-geography, a war is ever being waged between forest and grassland. Nowhere is this better illustrated than in New Zealand, where even man has come as the ally of the grassland, and with axe, fire, and foreign grasses and clovers has changed into green lush meadows hundreds and hundreds of square miles of virgin forests. But with the natural grasslands, usually at a leight of 1,000 feet and upwards, it is different. These for nearly serenty years have been occupied by millions of sheep; the tussocks have been repeatedly burned; rabbits exist on them in uncountable numbers; many foreign plants have secured a permanent footing; and yet these tussock-grasslands, with but one exception, remain virtually unchanged. This speaks volumes as to the suitability of the tussock growth-form for its New Zealand enviromment. With a host of enemies arrayed against it, the tussock still stands supreme, except in the lowlands where it has fallen before the plough, or in Central Otago, with the dry climate and man arrayed against it.

The headquarters of the tussock-grassland is in the South Island. There the Southern Alps cause the water-bringing clouds from the Tasman Sea to deposit their burden on the snowy alpine heights and on the strip of lowiand between them and the Tasman Sea. Much rain also falls upon their eastern slopes, but the amount gradually lessens in proceeding eastwards, until at a certain point the minimum amount demanded by forest for its welfare under the special soil and other climatic circumstances provided is not 
available. Then, all of a sudden, the advance of the great treecommunity is stopped; and from this point, except at those areas mentioned in Chapter IV, the brown tussock extends to the east coast, its ranks unbroken, save by swamp, or scrub, or river-bed, or dune.

In the North Island the formation is much more local, its main habitat being the lofty pumice tableland in the centre of the North Island and the adjacent mountain-slopes.

The great tussock-grassland plant-community falls into two distinct classes, according to the conditions the dominant tussocks and their companion plants can and cannot tolerate-the relative amounts of light, of rain, and of the degree of "sourness" of the soil being perhaps the determining factors. Where the soil is specially "sour," the rainfall fairly heavy, and cloudy skies frequent, the red-tussock (Danthonia Raoulii var. rubra*) dominates; but where the climate is drier--often very dry indeed-the soil well drained, and sunny days abundant, one or the other of two tussocks -the silver-tussock (Poa caespitosa) or the hard-tussock (Festuca novae-zealandiae) - is the physiognomic plant. As the Danthonia is a much taller tussock than either of the other two, the two plantformations may be known as "tall tussock-grassland" and "low tussock-grassland" respectively.

Low tussock-grassland (fig. 13) is found, in the South Island, on the east of the Dividing Range, beginning at the eastern margin of the western subalpine or montane forest, from Nelson to the northem part of the Fiord Botanical District inclusive. The formation ascends from sea-level to about 4,000 feet altitude, but its altitudinal limit depends altogether upon the aspect of the slope, one facing north permitting it to climb very much higher than one facing south. These limitations concern only the plant-formation and not the tussocks themselves, or many of the accompanying plants, for, having joined other associations, they ascend into the alpine belt.

The plant-formation consists of two well-defined plant-associations. In one the silver-tussock (Poa caespitosa) is the dominant tussock; it may be called the "silver-tussock association." In the other

* The "type" of Danthonia Raoulii is the tall tussock-grass of Banks Peninsula, and not the red-tussock, though elsewhere the latter is by far the commoner plant. 
the hard-tussock or fescue-tussock (Festuca novae-zealandiae) is dominant; it may be called the "hard-tussock association" or the "fesene-tussock association," either name being suitable. In certain areas, especially in the lowland belt, both tussocks occur in the association, but usually one is more abundant than the other.

The other plants which make up the plant-formation are a mixture of shrubs, grasses, sedges, semi-woody plants, and herbs, many of them small and more or less insignificant. Some of the species are confined to the lowlands and some to the montane belt; nevertheless, the transition from one belt to the other is so gradual, and the members which they have in common so many, that it is hard to draw a line between the two.

The number of lowland species is about 80 . Their growth-forms are-trees and shrubs, 10 ; herbs and semi-woody plants, 50 ; grasslike plants, 15 ; rush-like plants, 2 ; ferns, 3 . To go into details, some of the more common grasses are--the common oat-grass (varieties of Danthonia semianmilaris); danthonia (varieties of Danthonia pilosa)-this not ascending, so far as is known, to more than 3,000 feet altitude; the blue-grass (varieties of Agropyron scabrum); the long-haired plume-grass (Dichelachne crinita); the desertdanthonia (Danthonia Buchanani); the mountain-twitch (Triodia exigua). There are several sedges, the small grass-like Carex breviculmis being especially common, while two other small sedges (C. Colensoi and C. inversa) are frequently present. The following low-growing herbs or semi-woody plants have flowers large enough to be noticeable: The grassland-buttercup (Ranunculus multiscapus); the small-leaved cranesbill (Geranium microphyllum); the shortflowered cranesbill (Geranium sessiliflorum var. glabrum, and probably other varieties) - this especially in the mountains; the yellow oxalis (Oxalis corniculata, in various varieties); several varieties of the long-stalked willow-herb (Epilobium pedunculare); the pale willowherb (Epilobium novae-zelandiae); the dichondra (Dichondra repens); the common convolvulus (Convolvulus erubescens); varieties of the slender bluebell (Wahlenbergia gracilis); the New Zealand bluebell (IV. albomarginata) - in the mountains chiefly; the slender New Zealand daisy (Lagenophora pumila); the grassland-daisy (Brachycome Sinclairii) - chiefly in the mountains; the false edelweiss (Helichrysum bellidioides) (fig. 72) -in the mountains; the slender everlasting (Helichrysum filicaule); the common celmisia (varieties 
of Celmisia longiflora); the turfy raoulia (Raoutia subsericea); and the common New Zealand groundsel (varieties of Senecio bellidioides).

One plant, on account of its beauty, deserves special mention. This is the snow-gentian (Gentiana corymbifera)-Butler's "stupid gentian." The plant itself has an open rosette of a few brownish, smooth leaves, and a tap-root which descends deeply into the clayey, stony soil. In summer the plant puts forth a stout flower-stalk, which above branches closely into numerous branchlets bearing crowded together many large white blossoms, each about threequarters of an inch in diameter. These plants dot the ground for acres at a time, and when in full bloom are a charming spectacle.

Some of the shrubs of the low tussock-grassland at once attract attention from their bizarre appearance. Such are the wild-irishman (Discaria toumatou), a semi-divaricating deciduous shrub, some 3 or 4 feet high, bearing abundant sharp green spines, and producing in early spring small sweet-scented white flowers (fig. 10) : various species of New Zealand broom according to the locality. the commonest tall species being the common New Zealand broom (Carmichaelia subulata); a small heath, Leucopogon Fraseri, formins: mats of slender stems furnished with short brownish sharp-pointed small leaves which frequently overlap, and bearing in abundance its white sweet-scented flowers, which are succeeded by yellowishorange " berries"; various dwarf brooms, one cushion-forming and found only in the mountains, the stout dwarf broom (Carmichaelia Monroi), and the others spreading greatly by underground stems, and forming mats of erect flattened green branches an inch or two high; of these, the common dwarf broom (C. nana) occurs in the lowlands, but the two others (C. Enysii and C. uniflora) belong to stony, flat ground in mountain-valleys, where the last-named may grow associated with the mountain-twitch (Triodia exigua) and a dwarf koromiko with blue flowers (Veronica pimeleoides var. minor). The cabbage-tree (Cordyline australis) is a feature of the association, both in the lowlands and the lower montane belt; so, too, is the tutu (Coriaria sarmentosa), which, in the grassland, dies yearly to the ground, and may not be identical with the tall evergreen forest-shrub.

In the early days of sheep-farming there were great colonies of the spaniard (Aciphylla Colensoi). This plant consists of a circular mass of thick hard extremely sharp bayonet-like yellowish-green leaves forming an erect open rosette 2 feet or more high, out of 


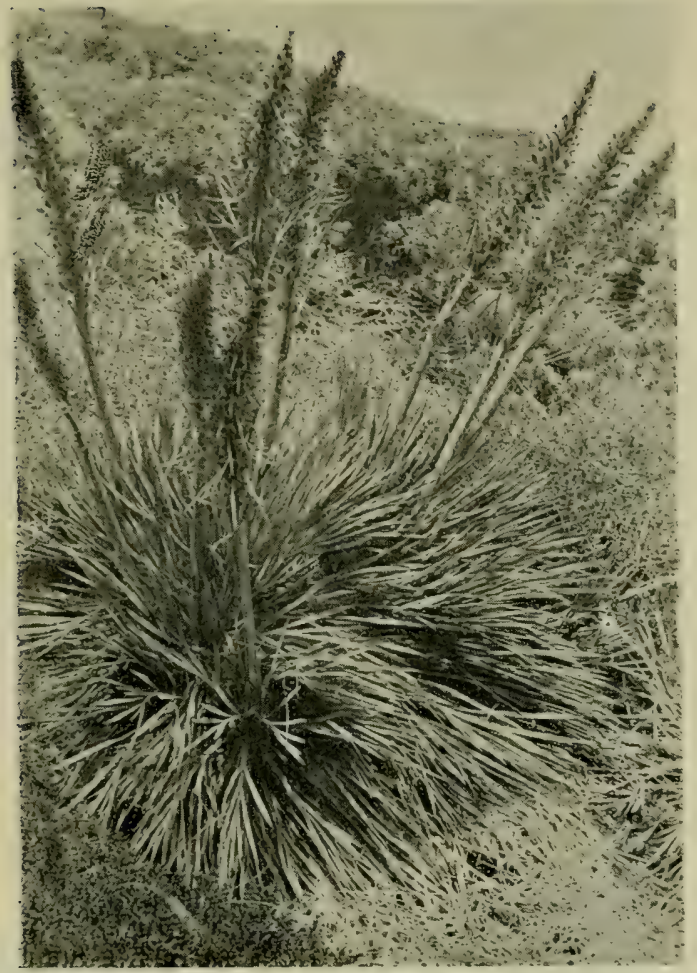

Fra. 56.-The spaniard (Aciphylla Colensoi) growing in scrub on Mount Perceval, near Hanmer.

¡Photo, C. E. Christensen.

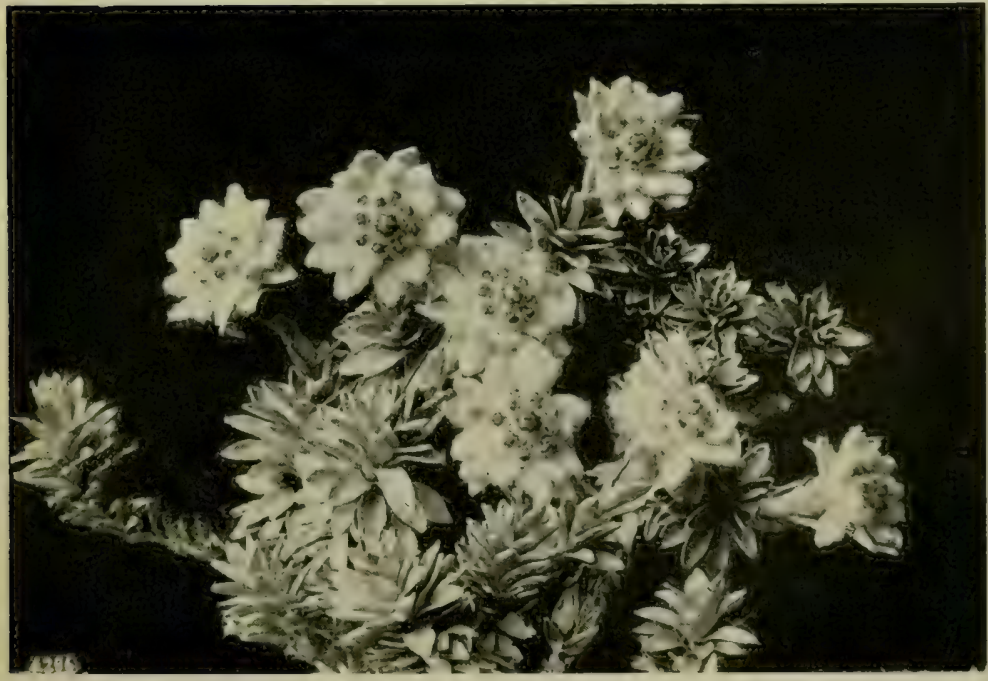

Fug. 57.-The flowers of the North Island edelweiss (Lucogenes Leontopodium). [Photo, W. C. Daries 


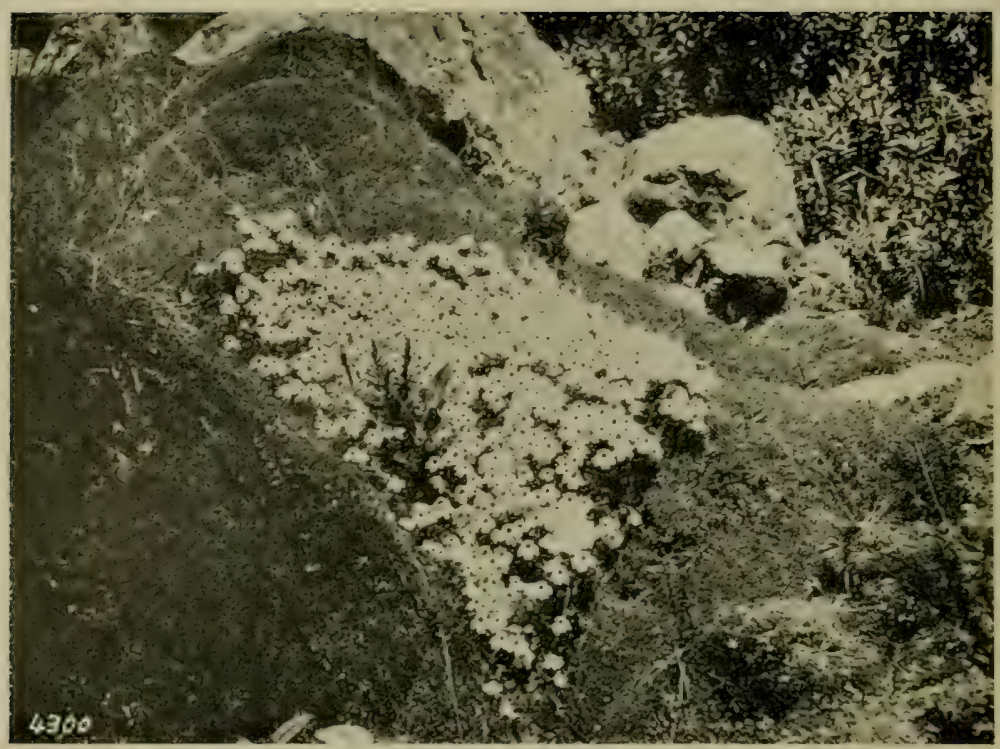

FiG. 58.- In centre the alpine eyehright (Euplerusia Monrui), and surrounding it a dense mat of the mat-raoulia (Raoulia tenuicaulis). Bed of the Punch Bowl Creek, Bealey Valley (Canterbury).

[Photo, L. Cockayne.

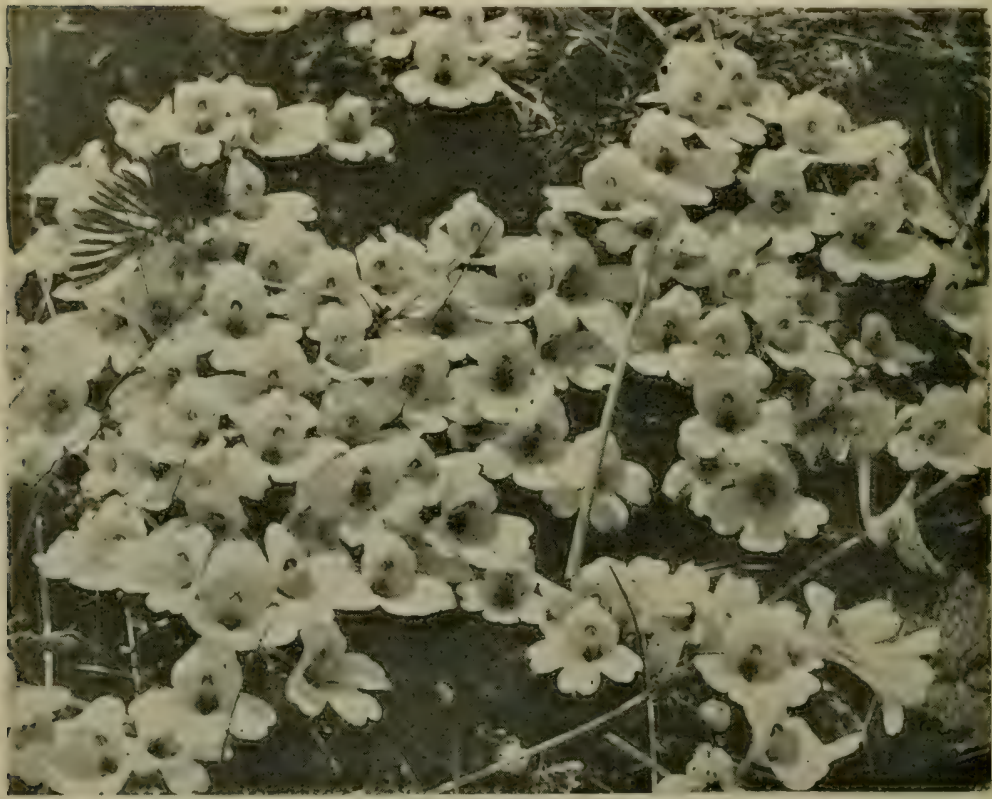

EIG. 59.-Flowers (about life-size) of the North Island eyebright (Euphrasic tricolor), from plants collected at Mount Hector (Tararua Mountains). 


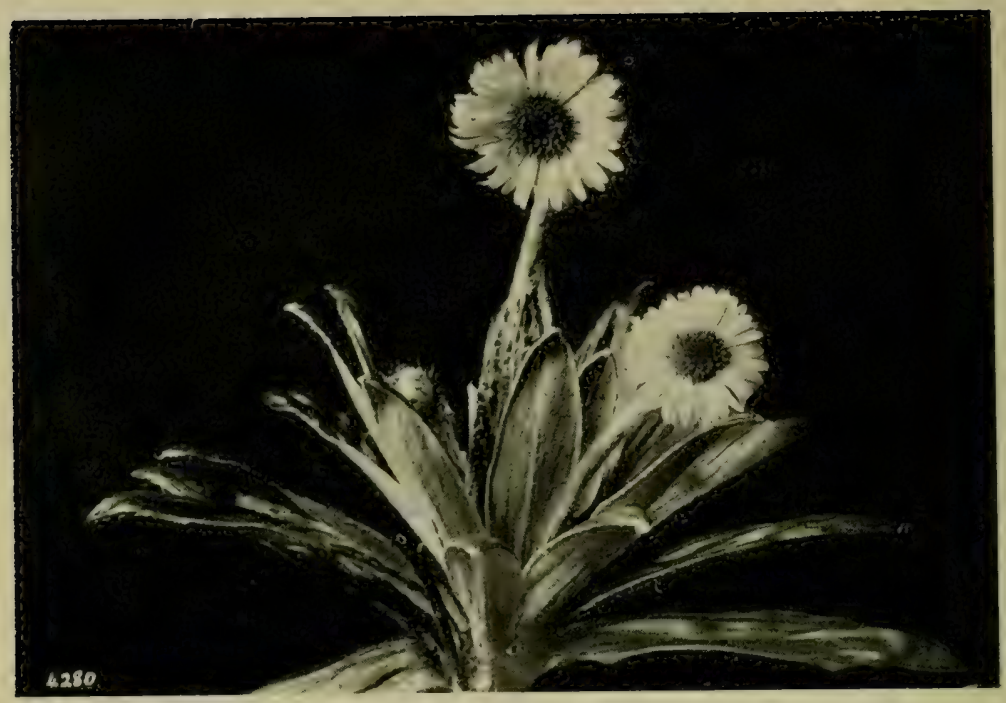

FiG. 62.-Flower-heads of the common cotton-plant (Celmisia spectabilis).

[Photo, W. C. Davies.

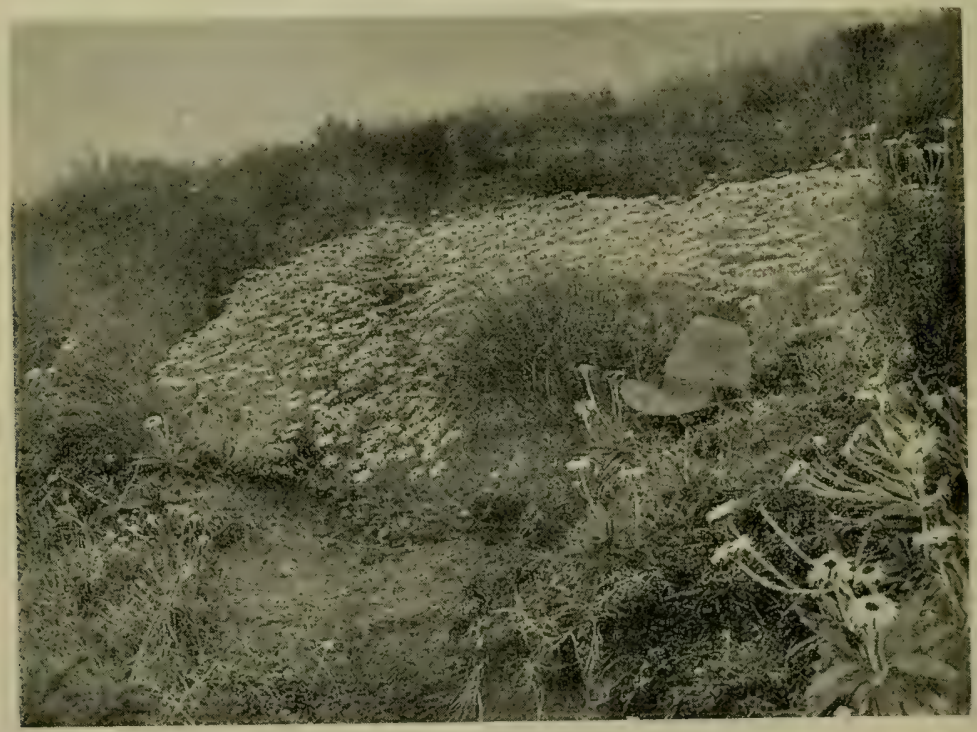

Fra. 63.- In centre, the white mountain-musk (Celmisia incana) growing as a member of the fell-field association of the Ruahine Mountains at about 3,000 feet altitude.

[Photo, B. C. Aston. 
the centre of which rises the huge stout flower-stalk furnished with similar but much smaller leaves, the small whitish carrot-like bunches of flowers arising from their junction with the flower-stalk (fig. 56). So rigid are the leaves that they are almost motionless in a heavy gale. Even yet this remarkable plant is common in the the mountains, as in the Hooker Valley; but its numbers have greatly decreased since the early days, owing to the attacks of rabbits, hares, fire, and even sheep. The horseman now can ride through his sheep-run without being troubled by this formidable plant; also, it has a natural enemy - a beetle-which feeds upon its leaves.

This special form of the Aciphylla, that of the tussock-grasses, that of the wild-irishman, that of the flat-stemmed leafiess brooms, that of the little heath, are all suited for reducing the plants' demand for water in a dwelling-place where that essential commodity may at times be rather short. The frequent winds, with their great evaporating-power; the hot sun of the summer; the stony nature of the ground; as also the cold of winter, which may render the soilwater of no use to the plant - all these things and others demand drought-resisting structure in the plants. On the other hand, many of the small members of the association are not so well equipped to resist drought, nor do they need such an adaptation, but, safe from wind and sun in the shelter of the tussocks, they live in security. In other words, the well-being of the tussock-community depends upon the tussocks themselves, just as the delicate forestferns depend for their very existence on the tall trees which give them shade and shelter. Also, it must not be forgotten that both the drought-resisting structure and that which cannot tolerate desiccation are equally adaptations when each performs its special function.

A very common feature of many parts of New Zealand, especially in the mountainous areas, is a broad shingly river-bed, bounded on either side by high terraces, or sometimes filling up a narrow valley. The water of these rivers is not usually confined to one channel, but meanders in several streams over the wide stony bed (fig. 55), which in consequence is in places quite dry and ready for plant colonists. These are not slow to avail themselves of the chance to "take up land," and, like their confrères of Tarawera, engage the wind or the birds to convey them to their new holdings, while some even travel by water. 
Amongst the earliest settlers are the willow-herbs (Epilobium), thanks to their light seeds furnished each with a tuft of hairs and so readily the sport of the wind. Various species of Raoulia come in a similar manner, and large, circular, moss-like cushions or patches of silver and green result (Raoulia australis, $R$. lutescens, $R$. tenuicaulis, R. Haaslii) (figs 53, 54). Lichens cover the stones with curious markings, and mosses spring up on the silt. As these earlier plants decay, humus is added to the silty, sandy soil, and, as already explained, various drought-resisting shrubs-Discaria toumatou (this frequently forming thickets of itself alone) (fig. 55), Cassiniu fulvida var. montana, species of Camichaelia - put in an appearance, together with grass-tussocks. Such shrubs may remain quite isolated, and the tussock become dominant, in which case the shelter will favour the settlement of many small herbaceous plants, including grasses, and grassland will result (fig. 55). Or, on the other hand, the conditions may favour arborescent growth --- a natural shrubbery of koromikos, coprosmas, and other shrubs, some with wiry branches, may appear, perhaps to be replaced finally in the mountains by a southern-beech forest. Grassland formed in this manner may be seen in process of evolution in many places, and it was in this way that the great river-made plains, equally with the "fans" of debris at the outlet of creeks, have been colonized by their plant inhabitants.

The red-tussock (Danthonia Raoulii var. rubra) is considerably taller than the silver or the hard tussock, being $2 \frac{1}{2}$ feet high or more. The stems and leaves are bunched closely together to form the base of the tussock, which is about 1 foot through; but they spread out above and bend downwards near their tips, and there the tussock will be more than twice the diameter of its base. The leaves are narrow, thick, and leathery; their sides are bent inwards, and they taper to a fine long drawn-out point. The colour is green tinged more or less deeply with orange or red. The stout leaf-sheaths remain part of the tussock after the narrow blades are decayed, forning a close covering round the stem many times larger than the living portion. There is a short woody rootstock, provided with rather long wiry roots.

The ground occupied by this grass and its associated plants is usually more or less wet; indeed, in Southland, where it still occupies fairly large areas, the plant-association follows after sphagnum bog. 
On the Southland Plain the reddish-coloured tussocks frequently stand so closely together that there appears to be nothing else. But between these colonies of tussock there are usually open spaces, varying in area. Growing on the wettish soil of such spaces there will be dark-coloured, entangled, shining masses of the stiff stems of the wiry snowberry (Gaultheria perplexa). A form of the mountainastelia (Astelia montana) often makes extensive colonies. The New Zealand flax (Phormium tenax) is frequently more or less abundant. A number of other plants, many of them elsewhere much more common in the mountains than in the lowlands, are generally present in this Southland association. Such are-the alpine hard-fern (Blechnum penna marina); the grass-lily (Herpolirion novae-zelandiae), a summer-green herb with short grass-like leaves an inch or two long, and, for the size of the plant, a rather large bluish flower ; the spear-grass (Aciphylla squarrosa); the mountain-snowberry (Gaultheria depressa); two small plants of the heath family (Cyathodes empetrifolia and Pentachondra pumila); the curious Oreostylidium subulatum, a stemless herb with very short, ncedle-like leaves in small rosettes, and inconspicuous flower sunk amidst the rosette; and the small craspedia (Craspedia minor), furnished with sticky aromatic soft leaves and whitish flower-head.

This remarkable plant-association, though occurring almost at sealevel, has a most decided subalpine stamp, the reason for which is briefly gone into in the next chapter. The plants, too, for the most part, are drought-tolerating, although growing in such a wet position. This curious state of affairs receives consideration when dealing with bog-plants in Chapter VIII.

Besides occurring in the lowlands, the above association ascends to the limit of the montane belt; it also extends to Stewart Island. The tussock itself, under the name of "snow-grass," is well known by shepherds for its worthless character as sheep-feed. Unfortunately, they call at least two other plants by the same name.

Tall tussock-grassland differing in composition from the above is more or less common in the high mountains (fig. 52). On the Voleanic Plateau of the North Island it occupies considerable areas at an altitude of 3,000 to 4,000 feet. In that botanical district, besides the red-tussock the more important plants are the following: The common celmisia (a variety of Celmisia longifolia), dark-coloured erect bushes 1 foot 6 inches high of the monoao (Dracophyllum 
subulatum), that pretty eyebright Euphrasia tricolor, circular mats of the prostrate shrub Coprosma depressa, the small creeping bluishgreen shrub Pentachondra pumila, and the ubiquitous pungent heath (Leucopogon Fraseri).

Other classes of grassland also ascend high into the mountains, but only one can be mentioned here-the hassock-grass (Danthonia australis) association. This occurs on rather gentle slopes where the snow lies long in winter. The grass forms dense mats, green above, but with rotting stems and leaves beneath. The mats are more than 2 inches thick; they consist of the very wiry stems of the grass and the numerous short leaves flattened to the ground, and all pointing in one direction. More than 4 inches of the basal part of the stem is covered by old leafsheaths. The leaves themselves are from 2 to 6 inches long; the sheath equals the blade in length; this latter is green, stiff, hard, and needle-like. For hundreds of feet the mountain-slopes may be covered with the close yellowish-green mantle formed by the hassock-grass, the general appearance being that of a well-kept lawn. So slippery is the surface that it is hard to keep one's feet when struggling up the slope. So vigorous is the growth of the grass that it rapidly buries its competitors, which in consequence are few in number. Several species of Celmisia are the most common, especially the common cotton-plant (C. spectubilis), the snow-celmisia $(C$. viscosa), the hoary mountain-musk (C. intermertia), and the needle-leaved celmisia $(C$. laricifolia). There may also be the large-flowered raoulia (Raoulia grandiflora), the little spaniard (Aciphylla Monroi), and an occasional tussock of Festuca novaezealandiae. The association occurs in the North-western Botanical District and in the North-eastern Botanical District where the two districts adjoin, while southwards it occurs in the north-western part of the Eastern Botanical District.

It is low tussock-grassland which must specially be considered from the economic aspect; tall tussock-grassland of Danthonia Raoulia var. rubra is worthless, though the soil on which it grows may be rich enough when drained, as Southland can testify.

As mentioned at the beginning of this chapter, the association under consideration has supported millions of sheep for nearly seventy years. During that by no means inconsiderable space of time, a period during which an artificial pasture would have had 
to be renewed again and again, no means of any kind worth mentioning have been used to improve this natural pasture, out of which so many thousands of tons of wool have been made. Certainly the number of sheep grazed per acre is very small, perhaps one to four acres being quite a liberal estimate. In the Mackenzie country more than thirty years continuous grazing has not lessened the carrying-capacity of the whole area-in fact, if the number of rabbits also grazing on the land be considered, its carrying-capacity has increased. And yet over a good deal of that pasture-land the tussock has been wiped out.

Evidently the tussocks Poa caespitosa and Festuca novae-zealandiae are not relished by sheep. 'i'his was discovered in the early days of sheep-farms, and recourse was had to burning the tussock in order to make it put forth young palatable leaves, which, though they are produced in the ordinary course of things, are so surrounded by the old, dry, unpalatable leaves that the sheep cannot reach them. At the present time the consensus of opinion amongst sheep-farmers appears to be that the tussock should be burnt at the end of winter, or as soon after as possible, since late burning is apt to cause the death of the tussocks. Obviously, too, the aspect of the slope with regard to the sun must be taken into consideration, the late burning of sunny faces being much more harmful than that of shady faces. Much burning in the past has been harmful, for in no few places slopes of stony debris have arisen through this cause.

Another grass-this of great reputed palatability-is the small blue-tussock (various varieties of Poa Colensoi). This in many places is extremely abundant, and obviously on the increase. Probably its palatability is greatly overestimated. This is the more likely since various quite poor introduced grasses growing side by side with it-e.g., Yorkshire fog and sweet-vernal-in winter are eaten to the ground. Nor are even sorrel (Rumex . Icetosella) and catsear (Hypochaeris radicata) neglected by the sheep.

The above indigenous grasses do not stand alone as lacking palatability. It seems probable that, with the doubtful exception of the blue-grass (Agropyron scabrum), and at lower levels danthonia (varieties of Danthonia pilosa), the other pasture grasses are more or less worthless in this regard. Where a really high-class fodderplant has been present it is now gone. According to the early historians of sheep-farming, the anise (Angelica montana) was 
abundant, and a mark of "good country." But it has been eaten out years ago, and is now to be found only in inaccessible spots - a tribute to its palatability. In the subalpine belt, especially of Central Otago, the Mackenzie country, and parts of Marlborough, the broad-leaved snow-grass (Danthonia flavescens) is dominant in many places. This is probably the most palatable of all the tussocks. On the other hand, Danthonia australis is probably absolutely worthless. So, too, is the mountain-twitch (Triodia exigua) of the stony river-valleys. 


\section{CHAPTER VII.}

\section{THE FLORA AND VEGETATION OF THE HIGH MOUNTAINS.}

General remarks-Statistics dealing with the alpine and lowland floras -Genera peculiar to, or common in, the high mountains-Latitudinal distribution of the high-mountain flora-The alpine dwellers of Te Mochau-From Mount Hikurangi to Egmont and the Tararuas--Distribution in the South Island - The altitudinal belts of vegetation and their limits-Conditions of life for the high-mountain plant inhabitants-Adaptations of the high-mountain plants-The flowers of the high mountains-The eyebrights, ourisias, buttercups, forget-me-nots, celmisias, and edelweiss-High-mountain rock plantassociations - The rock-voronicas - The vegetable-sheep - Associations of stony debris-A jet-black daisy-Fell-field-The coral-broom-Plants of the Mineral Belt-Herb-field-Flowers of Mount Egmont-The subalpine scrub-Shrubly veronicas and tree-daisies-High-mountain plants at sealevel-Winter coloration.

To the average New-Zealander the only vegetation with which he is acquainted is that of the neighbourhood of city or village, or such as is viewed from the railway-train. Even from the latter, at best, he may see some forest-mostly damaged remnants, flax growing unnaturally in drained swamps, or, if he travel by the Main Trunk or Midland railways, a fair amount of tussock-grassland. Even if acquainted with all the lowland vegetation, no one not in the secret could guess that on the high mountains there existed a floral world very different from that of everyday New Zealand, or, indeed, from that of any other land. But a few figures quickly show this to be the case. Thus a careful comparison of the lowland and high-mountain plants brings out the fact that there are about 520 purely lowland species (not counting those confined to the coastline), and rather more than 500 species which belong exclusively to the high mountains. In addition, the flora of the latter is strongly reinforced by about 100 species which occur in the lowlands under special circumstances only, so that there is virtually a true subalpine and alpine flora of about 600 species, which belong to 45 families and 123 genera. In addition, there are about 350 species found both in the lowlands and the high mountains. The whole highmountain flora, then, contains about 950 species. How specially a New Zealand production is this flora is emphasized by the fact that 
of the 600 special alpine species 94 per cent. are foumd in no other part of the world; of the remainder, 22 species also occur in Australia. 9 are subantarctic South American, and 6 cosmopolitan or nearly so.

One family and the following 15 genera, 7 of which are endemic, are confined to the high mountains: The Logania family (genera, Logania, a dwarf shrub, and Mitrasacme, very small tufted herbs); Marsippospermum, the species of the rush form; Exocarpus, the habit of which is shrubby, creeping, leafless; Hectorella (endemic), a small cushion-plant; Pachycladon (endemic), a rosette-plant; Notothlaspi (endemic), a rosette-plant; Corallospartium (endemic), stout leafless shrub; Swainsona, a rosette-herb; Pernettya, a dwarf heath; Phyllachene, cushion-plants; Forstera, small semi-prostrate herbs ; Leucogenes (endemic), mat-forming, low, woolly, semi-woody ; Haastia (endemic), huge cushion-plant $(H$. pulvinaris), or prostrate semi-woody woolly plants $(H$. Sinclairii, $H$. recurca and its var. Wallii) : Traversia (endemic), erect shrub with form of other tree-daisies.

Other genera possess far more high-mountain than lowland species. Perhaps the most characteristic of these are: Various grasses, especially Poa, Agrostis, Deschampsia, Trisetum, and Danthonia; Colobanthus; buttercups (Rammculus): spaniards and spear-grasses (Aciphylla); Anisotome; needle-leaved heaths (Dracophyllum); gentians (Ǵentiana); forget-me-nots (Myosotis); koromikos (Veronica); ourisias (Ourisia); tree-daisies (Olearia); celmisias, cotton-plants, mountain-musks (Celmisia); raoulias, vegetable-sheep (Raoulia): everlastings (Helichrysum); cotulas (Cotula); groundsels, both herbs and shrubs (Senecio).

There are also a number of other genera which play an important part in the flora, although some contain few or no strictly high-mountain species. The more important are: The grasses Hierochloe and. Festuca; the hooked sedges (Uncinia); the New Zealand flax (Phormium), represented by its species P. Colensoi: the southern-beeches (Nothofagus); the bog-lily (Chrysobactron); sundews (Drosera); New Zealand brooms (Carmichaelia); cranesbills (Geranium); tutu (Coriaria); snowberries (Gaultheria) ; various small heaths (Leucopogon, Cyathodes); coprosmas (Coprosma); lobelias (Pratia); bluebells (Wahlenbergia); cudweeds (Gnaphatium); cassinias (Cassinia); certain ferns and lycopods; and many taxads (Podocarpus and Dacrydium). Sedges (Carex) are represented by many high-mountain species. 
In proceeding from the north to the south of the main Islands of New Zealand the first hint that such a collection of plants as a high-mountain flora exists is afforded by a small area of open ground on Te Moehau, a mountain 2,750 feet in height, terminating the Cape Colville Peninsula. The late Mr. James Adams, the discoverer of this isolated patch of high-mountain vegetation, writes: "Lvery step in the open ground not only showed that the vegetation was a contrast to that on the ridge, but also that it was unlike that of any other high peak on the main range throughout the peninsula. I could scarcely believe my eyes, as each fresh plant that I saw seemed to show that I was on the top of one of the mountains in Nelson Province."

This unexpected association consists of Danthonia semiannularis var. setifolia, the mountain-totara (Podocarpus nivalis), the alpine colery-pine (Phyllocladus alpimus), the common oreobolus (Oreobolus pectinatus), the mountain-pine (Dacrydium Bidwillii), the common carpha (Carpha alpina), the little mountain-heath (Pentachondra pumila), the mountain-foxglove (Ourisia macrophylla), and the white mountain-musk (Celmisia incana).

It is more than 100 miles south from Te Moehau that, on Mount Hikurangi, the next high-mountain community appears-this also one of few members, but some of them the most beautiful of the alpine flora: e.g., the North Island edelweiss (Leucogenes Leontopodium) - a fine-sounding name for a noble plant (fig. 57); the common mountain-gentian (Gentiana bellidifolia) (fig. 71); the largeflowered raoulia (Raoulia grandiflora), with its silvery cushion and rather conspicuous flowers; a fine forget-me-not, Myosotis amabilis ; and one or two celmisias.

Then from Mount Hikurangi southwards, along the Kaimanawa, the Ruahine, and the Tararua Mountains, extends the gradually increasing band of mountain-dwellers, their ranks gradually swollen by those which have halted in their northern march. Then westwards on to the highlands of the Voleanic Plateau and of the great volcanoes (fig. 71), and having crossed the lower country, not without many difficulties, their ranks much depleted, in time the wearied travellers rested on Egmont's brow.

The headquarters of the high-mountain plants is not in the North Island but on the mountains of the South Island, about 71 per cent. of the whole high-mountain flora being confined 7-Plants. 
thereto. This happening is not unexpected, since there is far more room for high-mountain species in the latter Island, and many species undoubtedly of recent origin have not yet had time to spread far. The total North Island high-mountain flora numbers fewer than 180 species, of which only about 35 are confined to that Island. Finally, a considerable number have gained a permanent footing on Stewart Island, and some are confined thereto.

Any one at all observant when climbing a high mountain cannot fail to notice at certain points a rather sudden change in the general aspect of the vegetation. Thus, for example, in ascending Mount Egmont, the well-graded road, gradually rising, leads upward through the rain-forest, but at some 2,600 feet or so a treeassociation of a different character is encountered, composed largely of the kamahi (Weinmannia recemosa), its gnarled, twisted branches far outspreading, the scene reminding one of some of Dorés pictures. Passing one or other of the mountain houses, the path becomes steeper, the forest becomes lower, and then, almost on a sudden, it gives place to a subalpine scrub; this in its turn-at, say, 4,000 feet altitude-coming to a standstill and yielding place to what is there known as the "moss," but which in the language of this book may be called "herb-field" or "tall tussock-grassland," according to the combination of growth-forms. At a higher elevation still these formations are succeeded by a most open vegetation of a few lowly plants which can tolerate for their soil the loose scoria, and are exposed to the heavy winter snow. This description does not apply, however, to the whole mountain, since on the west the "moss" descends to a much lower altitude.

In order to speak with precision of these vertical changes the following names may be given to the different rings of vegetation which girdle a mountain, such rings being termed "belts." These belts are three in number-the lowland, the montane, the subalpine-and perhaps their most important delimiting factor is the winter snowfall.

For each botanical district the altitudinal limits of these belts must differ, and so, too, on every individual mountain according to the aspect of the slope. As soon as a height is reached upon a mountain where, in winter, snow has lain for some months at a time-say, 5,000 feet-certain plants, rare or wanting below, appear in abundance, and a new vegetation appears. Above this line is 
the alpine belt. It a lower altitude another line occurs, marking the point at which snow may lie for a week or two. This forms the boundary between the upper and lower subalpine belts, into which the subalpine belt may be conveniently divided, and it occurs at about 1,000 feet below the boundary of the alpine belt. At another 1,000 feet below this comes the lower boundary of the lower subalpine belt, it marking the line where snow generally lies for only a few days at a time. Two thousand feet below this again marks the lower limit of the montane belt, where snow falls more or less every year, but where it usually melts soon after it falls. This belt extends downwards from the subalpine belt to 1,000 feet altitude, when the upper limit of the lowland belt is reached.

If the whole high-mountain flora be considered, the lower subalpine belt contains approximately 700 species, the upper subalpine 750 , and the alpine 400; but only about 100 of the latter reach the highest summits suitable for plant-life.

The plant inhabitants of the high mountains have to endure much harder times than their relatives of the lowlands. Frost. occurs at all seasons of the year, and in winter may last for many days; the wind is frequently extremely violent; rain and mist abound, especially on the western mountains of the South Island and on Mount Egmont; the soil is frequently extremely cold, at which time the activity of the roots in bringing water to the leaves is greatly reduced; a dry and a moist atmosphere may follow one another closely; short periods of drought must be met equally with long periods; snow may fall during any month of the year, and from winter onwards it may lie for months, especially in gullies; in the middle of summer the soil-water may be extremely cold, even on the hottest days; many plants have a brief growing-period but a long daily illumination; the intensity of the sunlight increases with altitude; the soil may be very hot and the air comparatively cold; disintegration of the surface soil is always in progress; snow avalanches are not infrequent.

That the plants of the high mountains must live strenuous lives the foregoing paragraph clearly foreshadows. But they are well equipped by nature, and their growth-forms and organs are attuned to the alpine life. Evidently they must be prepared for lack of water at times; they must be able to resist the tempest; the tremendous pressure of the snow must have no permanent effect on 
them; the frost attacking them, even when they are growing rapidly, must be combated; for an unstable footing on the soil they must be provided: in short, they must be distinct in many ways from the plants of the lowlands.

Low stature is obviously of great advantage for various reasons. so Nature has selected for her mountain gardens many plants which either hug the ground or are veritable dwarfs. Thus out of 500 high-mountain species of herbs and semi-woody plants 138 are between 1 foot and 6 inches high, 199 are less than 6 inches high. - and 92 either closely hug the ground or are less than 2 inches high. Even a tall tree such as the kamahi (Weinmannia racemosa) becomes in the subalpine scrub a shrub well fitted to resist both snow and wind.

Cushion-plants (some of extreme density), mat-plants, turf-making plants, rosette-herbs pressed to the soil, rigid-stemmed plants, plants with rigid leaves (Aciphylla), leafless shrubs, shrubs with much reduced leaves--these are all more or less frequent on the high mountains.

Certain structures or characteristics are more or less common --e.g., hairiness, woolly, leathery, thick, or fleshy leaves: thus of 500 herbs and semi-woody high-mountain plants no fewer than 31; have leaves of this character (63 per cent. of the 500).

A rather curious feature is that of dead leaf-sheaths and other parts of a plant remaining attached to the living plant and turning into peat. Such peat is always sopping wet, and when the plant puts forth roots into it, as is often the case, it has a constant water-supply of its own-quite a useful possession during even a short drought. On the other hand, this phenomenon is also correlated with absence of sunlight and prevalence of rain and mist--just such a climate as exists in the subantarctic islands to-day. Such an adaptation perhaps indicates that part of the New Zealand alpine flora originated not on the high mountains at all, but in the sunless and wet climate of the south. This is the more feasible since the subantarctic and Andean plants of South America possess the same habit to an equal degree.

If Nature failed to deck the forest and the grassland with heautiful blossoms, she made ample amends in the high mountains, though she was not lavish with colour, for, with a few exceptions, the flowers are white or yellow. This peculiarity was first of all 
accounted for by the assumption that in New Zealand there was a great lack of insects capable of pollinating the flowers, and that bright colours can only come into existence through their attracting insects, for the bright-coloured flowers then would be pollinated, lear seed, and reproduce their kind, whereas the duller flowers would not be pollinated to the same extent, and in course of time would cease to be.

Here is not the place for supporting or condemning what is at best a theory, with much to be said on both sides. One point, however, stands out: this is that white flowers are more conspicuous than any others, and that they stand every chance of being pollinated by insects, of which the mountains contain an abundance, while they can also be seen at night and so be pollinated by moths. They have, in fact, a double advantage over blue or red flowers with regard to their chance of pollination by insects.

Coming now to a brief account of the plants with showy flowers: The eyebrights (Euphrasia) are real alpine gems (figs. 58, 59). The alpine eyebright (Euphrasia Monroi) has rather big flowers, considering the size of the plant, white with a yellow eye; the yellow eyebright ( $E$. Cockayniana) is yellow; the North Island eyebright (E. tricolor) has a large flower, white with a yellow throat and marked with purple lines-it is a most beautiful feature of Mount Egmont and other North Island mountains (fig. 59). Other pretty plants of this genus are $E$. Cheesemanii and the small eyebright (E. zealandica). The eyebrights are in part parasites, living attached to the roots of grasses. This habit renders them exceedingly difficult to cultivate.

To Ourisia, a genus belonging exclusively to South America, New Zealand, and Tasmania, belong perhaps the most charming of the mountain-plants (fig. 60). The mountain-foxglove (Ourisia macrophylla) of the North Island and the snowy mountain-foxglove (O. macrocarpa) (and its variety calycina) of the South Island are the tallest of the New Zealand species, and exceedingly handsome plants. O. Cockayniana looks rather like a stunted form of the latter, and forms large patches on the wetter mountains of Canterbury and Westland. The creeping mountain-foxglove (O. cacspitosa), forming glistening bright-green mats on stony ground, is in early summer a sheet of lovely blossoms. Also very beautiful are $O$. sessiliflora, $O$. glandulosa, and $O$. prorepens. 
"Eyes . . . Blue as the blue forget-me-not," sings Tennyson, and the more prosaic modiste calls a certain silk "forget-me-not" blue. And yet New Zealand's forget-me-nots behave with the mythical antipodean topsy-turviness, and frequently produce not blue but yellow flowers! Some of the yellow forget-me-nots that have their home in dim river-gorges or on wet shady rocks are of large size, and one, the bronze forget-me-not (Myosotis macrantha), is bronze-coloured rather than yellow. Other beautiful forget-menots are the yellow forget-me-not ( $\boldsymbol{M}$. australis), $M$. Goyeni (a rockplant), and the rock forget-me-not ( $M$. saxatilis), discovered only a year or two ago in subalpine Marlborough. In similar situations may grow the pretty little Veronica linifolia (fig. 61).

Of all the plants the buttercups most deserve mention. Of these there are quite a number, and they are far and away the finest buttercups on earth. The mountain-lily (Ramunculus Lyallii) is their queen (fig. 1). This world-famed plant raises great leaves from its very thick rootstock, each with a blade shaped like a saucer, sometimes more than 9 inches in diameter, and a stout stalk a foot or more in height, inserted in the middle of the blade, and lifting it high from the ground. The smaller $R$. Baurii, of South Africa, has the same leaf-form, and, under certain circumstances, the New Zealand Kaikoura buttercup ( $R$. lobulatus) produces leaves of this kind. In late November, December, and early January $R$. Lyallii puts forth a very tall stem, which, branching, bears numbers of blossoms of snowy whiteness, there being frequently more than thirty close together, each as big as a five-shilling piece. To behold this noble plant, an acre at a time in full bloom, is to a lover of beautiful flowers the sight of a lifetime. The yellow alpine buttercup (Ranunculus Godleyamus), found near the source of the Rakaia and farther south, is nearly as striking, and so also is the hairy alpine buttercup ( $R$. insignis) of the North Island and some of the Nelson mountains. The white cut-leaved alpine buttercup (R. Buchanani) of the Otago mountains is splendid also; and mention must be made of the more recently named $R$. Matthewsii (probably a hybrid between $R$. Lyallii and $R$. Buchanani), which worthily bears the name of its energetic discoverer. The goldenyellow Mount Egmont buttercup ( $R$. nivicola) is one of the features of that mountain, and is very plentiful also on the upper slopes of Tongariro. $R$. lobulatus, a plant of easy culture and of large size, 
very like $R$. Monroi, is confined to the North-eastern Botanical District. The silky alpine buttercup ( $R$. sericophlyllus) grows with great luxuriance amongst coarse stony debris from the Eastern to the Fiord Botanical District. There are also a number of smaller high-mountain buttercups, all of which are pretty enough-e.g., Ranunculus gracilipes, $R$. geraniifolius, $R$. Enysii, $R$. Monroi var. dentatus, $R$. Sinclairii, and $R$. novae-zealandiae.

Generic names are frequently hideous, but in Celmisia there is one dainty enough to take a foremost place among those feminine floral appellations now so common; and well does a race of plants so beautiful demand a fitting title. With one exception, all are true New-Zealanders, and probably a remnant of the long-vanished plants of sunken southern lands. Two principal classes occurthose with fine upright rosettes of lance-shaped or dagger-shaped leaves (the cotton-plants), and those which trail over a considerable area, forming round mats (the mountain-musks), these getting their name from the aromatic scent of their leaves, which frequently bathes the high slopes with fragrance. Some, again, have quite small rosettes, and form dense silvery cushions, such as the white cushion-celmisia (Celmisia sessiliflora), the silver cushion-celmisia $(C$. argentea), and the green cushion-celmisia (C. bellidioides), the latter different to most celmisias in its green, hairless leaves. The most handsome of the celmisias is perhaps the silvery cotton-plant (C. coriacea), a plant with large, stiff, broad, silvery leaves, and flower-heads several inches in diameter. C. Hookeri, a species of the North Otago Botanical District, with flowers even larger, has the merit of growing well in lowland gardens. The species of Celmisia number 51 or more; there are also some fine natural hybrids, especially where $C$. petiolata, C. Traversii (distinguished by its leaves, bright-green above, and edged with rust-coloured hairs), C. coriacea, C. Brownii, C. Lyallii, and C. spectabilis are present.

The snow-groundsel (Senecio scorzoneroides), notwithstanding its being burdened with its second name, is one of the most showy of New Zealand plants. The author will never forget the wet herbfield near the source of the River Poulter, gleaming like a snowfield with the multitudes of its pure blossoms. It also occurs as forms with bright-yellow, paler yellow, and cream-coloured flowers. Occasionally it grows on dry rocks. Its relative S. Lyallii has much smaller flower-heads and narrower leaves. 
There are a few other specially charming flowering-plants which must be mentioned. The two small trees, the mountain-ribbonwood (Gaya Lyallii) and the hoary mountain-ribbonwood (G. ribifolia), bear in due season their wealth of snowy blossoms, brightening the subalpine scrub or the outskirts of the gloomy southern-beech forest. Boggy or even stony ground of western mountains in the South Island is frequently decorated by the white flowers, three-quarters of an inch in diameter, of the straggling Veronica macrantha, its leaves glossygreen. Throughout the high mountains of the west of the South Island, in deep pockets of peaty soil on rocky ground, grows the alpine avens (Geum uniflorum), a creeping semi-woody plant raising its flowers, each one inch across, well above the foliage. Finally, the two species of edelweiss-Leucogenes Leontopodium (fig. 57) and L. grandiceps-far surpassing their Swiss namesake (Leontopodium (alpinum) in beauty, must not be forgotten, which, though concluding this list, might with more propriety stand at the very top.

The gradual change of rock into a soil more favourable for seedplants, by way of debris-slopes, and so on, is so striking that it seems most natural when dealing with the plant-communities to commence with those of rocks and to end with those where the plants themselves have built up most of their dwelling-place-so far as soil is concerned-out of their own dead parts.

Many of the most highly specialized plants have dry rock-faces as their habitations; indeed, they have assumed a form so suited to the circumstances that they cannot compete with their more plastic but less highly differentiated fellows for more hospitable abodes.

All the rock-species do not live side by side, but the locality is given in brackets where those of restricted range have their homes. Mosses and lichens are always present, a black tufted lichen being characteristic of the highest peaks (fig. 66).

The following shrubs are confined to dry rock-faces: The coralshrub (Helichrysum coralloides) (Marlborough) is a shrub up to 3 feet in diameter, with many stout branches, the outermost of which are closely covered with leaves closely pressed to the slender stem and increasing its apparent diameter fourfold. These leaves are densely covered with white silky hairs on the inner (upper) surface, but the outer (under) surface has its upper half thickened and forming a dark-green glossy boss. Thus the stem appears covered with green 


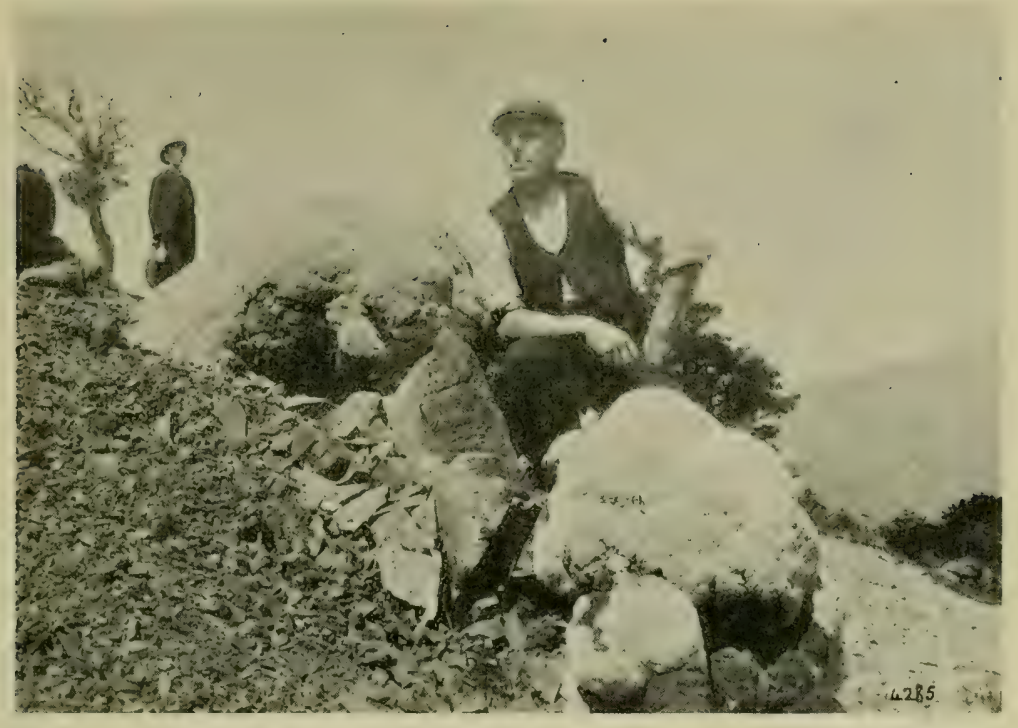

FIG. 64.-The common vegetable-sheep (Raoulia eximia) growing on rock surrounded by loose rock debris on the Mount Torlesse Range (Canterbury) at altitude of 3,500 feet.

[Photo, L. Cockayne.

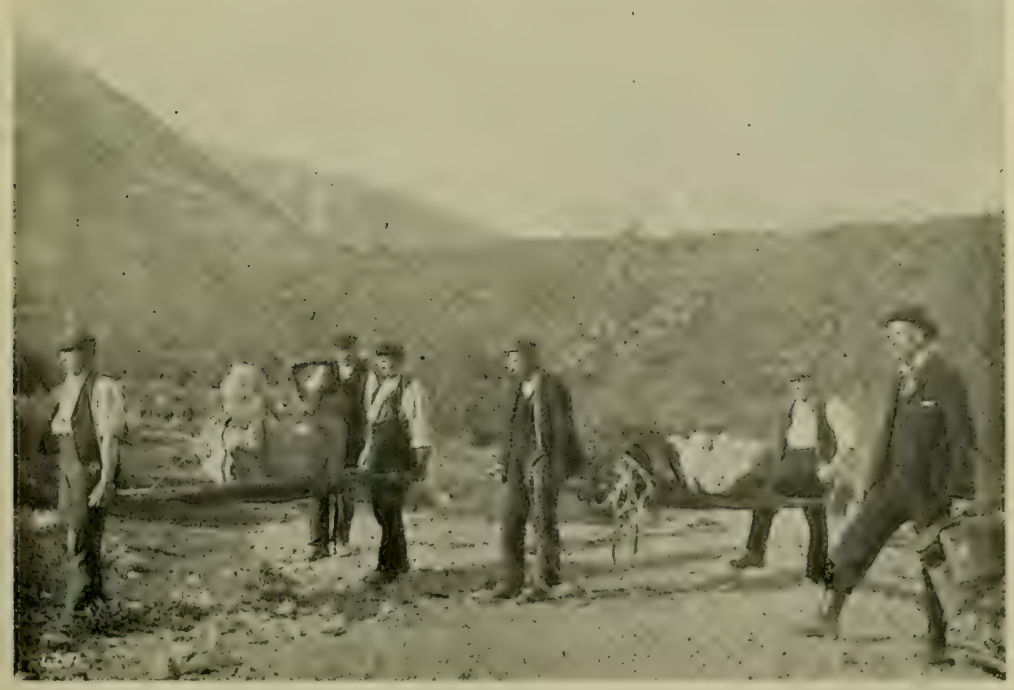

FIc. 65.-Bringing specimens of the vegetable-sheep (Raoulia eximia) for the International Exhibition held at Christchurch in 1906-7. One of these specimens is now to be seen in the Canterbury Museum (Christchurch).

[Photo, L. Cockayne. 


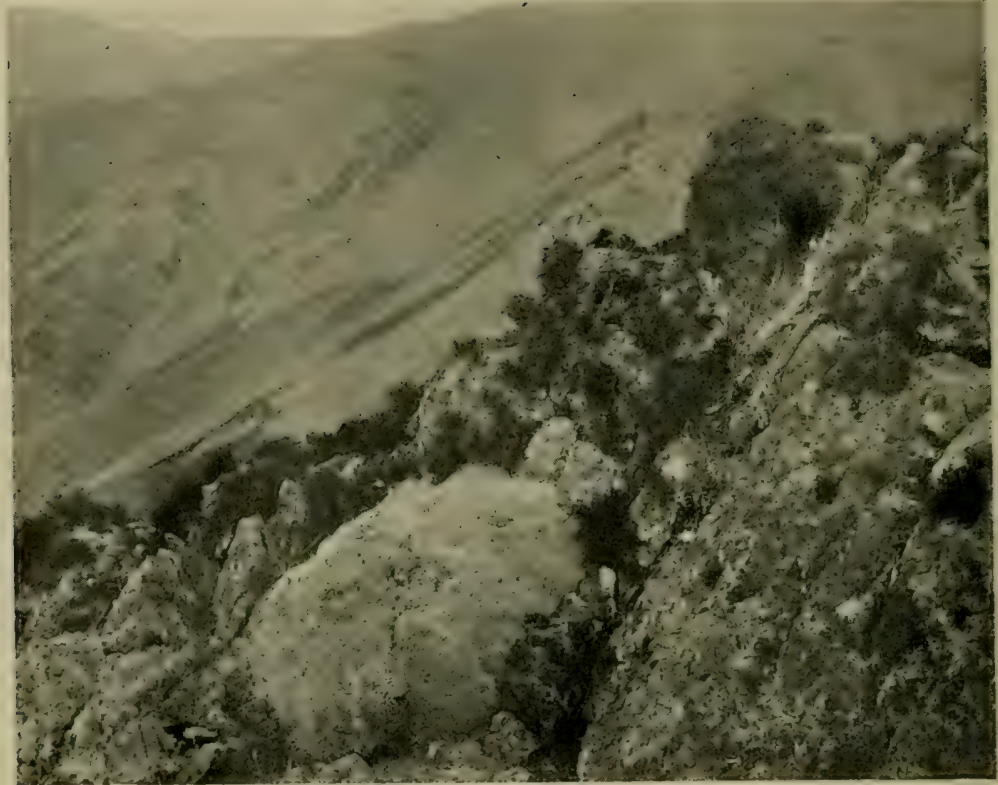

Fici. (66.-The small vegetable-sheep (Reoulic bryoides) growing on dry rock on Shingly Range (Marlborough) at an altitude of 4,000 feet. The black plant is a lichen common at high altitudes.

iPhoto, L. Cocknyne.

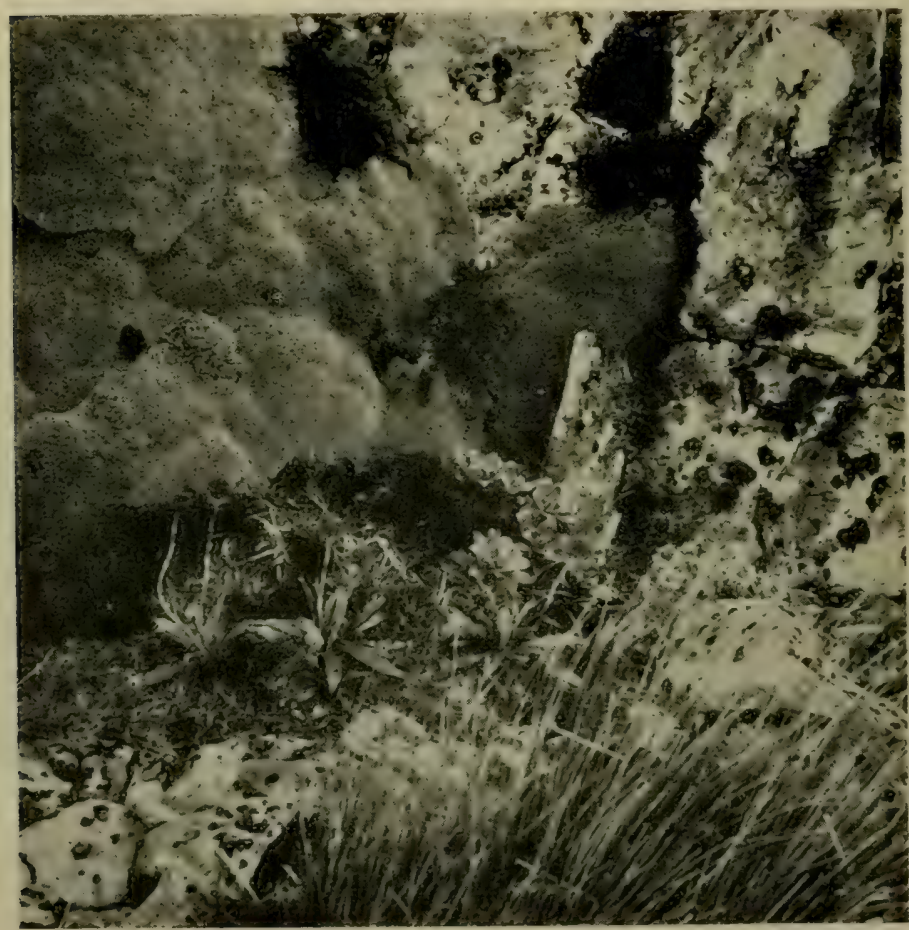

Fic. 67. - In top left-hand corner of the photograph is the green vegetable-sheep (Raoulia rubra) growing on rock on the Tararua Mountains.

[Photo, B. C. Aston. 


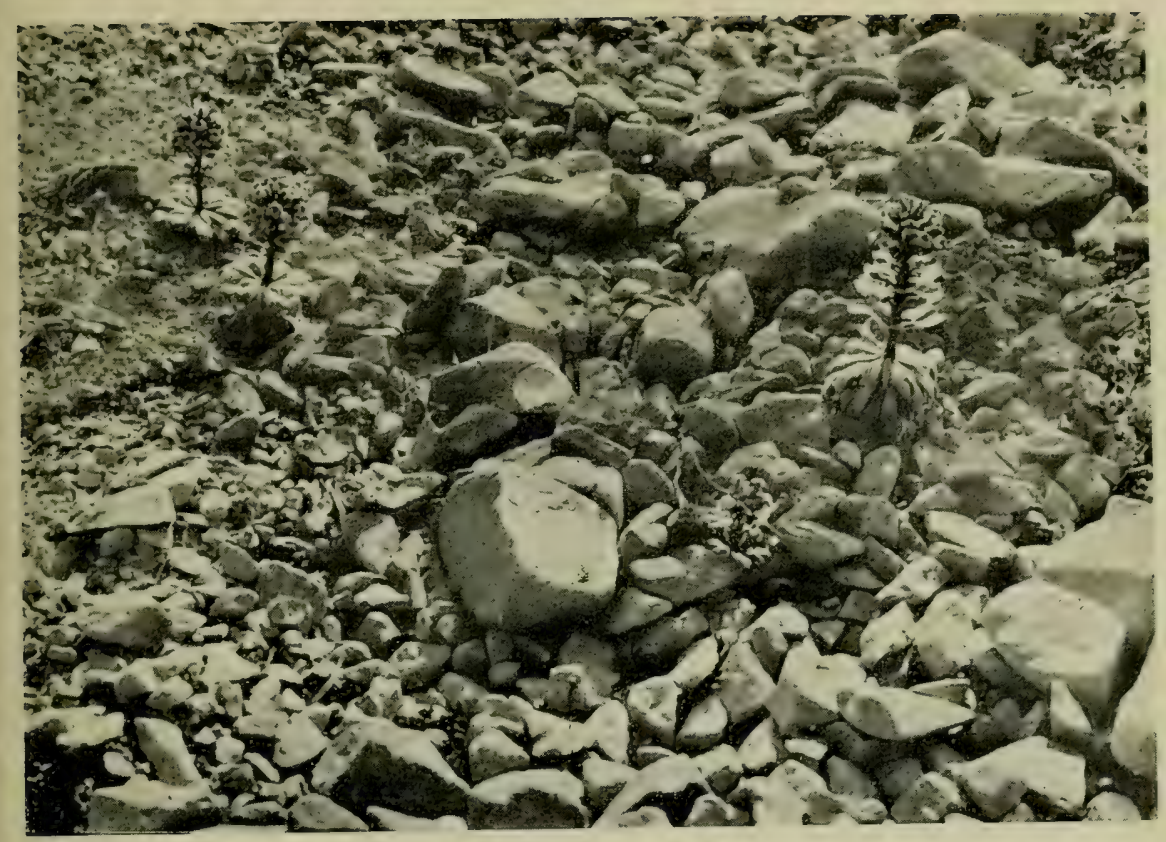

FIG. 68.-The penwiper-plant (Notothlaspi rosulatum) growing on stony debris of a riverterrace near Castle Hill (Canterbury).

[Photo, L. Cockayne.

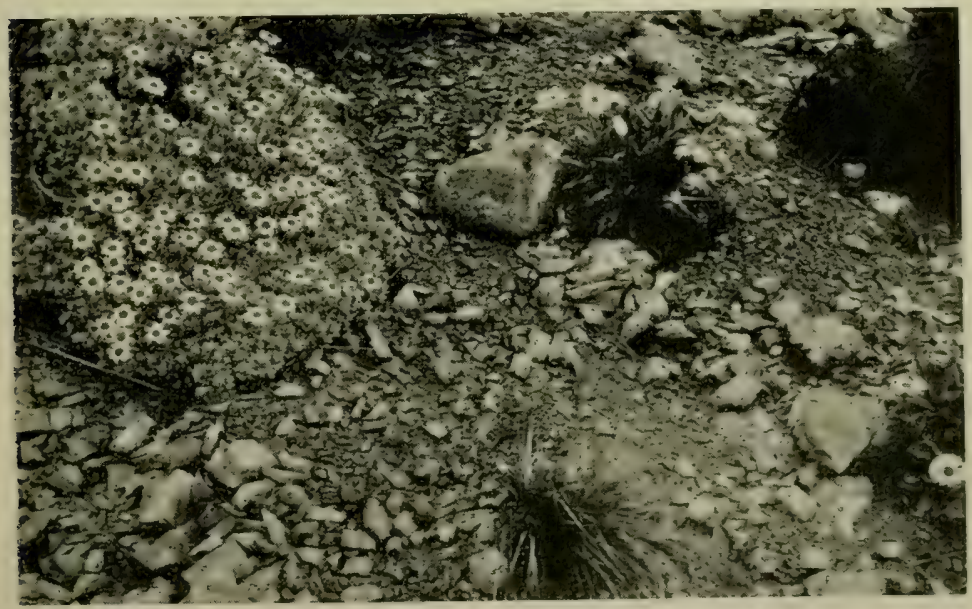

Fic. 69.-Cushion of the North Island edelweiss (Leucogenes Lcontopodium) growing as a member of the fell-field association on Mount Hector (Tararua Mountains).

[Photo, B. C. Aston. 
tubercles surrounded by white silky hairs (fig. 77). This shrub is either erect or drooping, much branched, and a foot or considerably more in height, or, where exposed to the wind, it is compacted into a rounded cushion. Much commoner, it being found throughout most of the eastern mountains of the South Island, is H. Selago, of similar form to the above, but more slender; then there is also the still more slender $H$. microphylla-this occasionally a plant of Marlborough subalpine scrub the three species affording an instructive example of gradation of form. Two willow-herbs are confined to rock-the thick-leaved willow-herb (Epilobium crassum) (Marlborough to Central Otago) and E. brevipes (Marlborough and northern Canterbury), the former with fairly large and the latter with small flowers; both have thick, polished, green leaves. There are some curious rock-koromikos of the whipcord or semi-whipcord type, but most of these occur also in other associations. These koromikos are: Veronica ammulata (Takitimu Mountains, Southland); V. tetrasticha (Marlborough and Canterbury); V. lycopodioides (eastern mountains generally) - this probably embraces several distinct varieties of local range, one, at any rate, being a plant of subalpine scrub; V. tumida (Nelson and Marlborough); V. Gilliesiana (inorth-west Nelson and throughout alpine Westland).

There are a good many more rock-koromikos: e.g., those with glaucous more or less Heshy small leaves-V. pinguifolia; $V$. Gibbsii (Mounts Rintoul and Ben Nevis, Nelson); V. Buchanani (the common Otago species of this class, an aggregate species made up out of several unnamed varieties); the remarkable $V$. epacridea-quite impossible to describe briefly in ordinary language; $V$. rupicola (Harlborough)-one of the ordinary small-leaved form of koromiko; V. Raoulii (Marlborough and Canterbury)--the small leaves with a red edge and the flowers bright pink and produced early in spring.

Perhaps the most striking denizens of rocks are the various kinds of vegetable-sheep (species of Raoulia), which form hard cushions, inostly white but occasionally green- $R$. rubra (fig. 67) of the Tararuas, $R$. Goyeni of Stewart Island, $R$. bryoides of wide range in the South Island (fig. 66), R. Buchanani of the Fiord Botanical District-and one of enormous size, $R$. eximia (figs. 64, 65). The raoulia-cushions are all constructed on the same plan. Above, the stems branch again and again, and towards their extremities are covered with small woolly leaves, packed as tightly as possible. 
Finally, stems, leaves, and all are pressed into a dense, hard, convex mass, making in the case of Raoulia eximia an excellent and appropriate seat for a wearied botanist (fig. 64). Within the plant is a peat made of rotting leaves and branches, which holds water like a sponge, and into which the final branchlets send roots. Thus the plant lives in great measure on its own decay, and the woody main root serves chiefly as an anchor. The vegetable-sheep are not inaptly named, for at a distance a shepherd might be misled.

The rocks of the alpine summits weathering away, and the rain not being sufficient to bear all the debris into the valleys, an enormous quantity of angular stones collects on the mountain-sides in many places, which may form steep slopes for thousands of feet. As the traveller wearily ascends these "shingle-slips," as they are called by those splendid mountaineers, the musterers, the stones constantly slip beneath his tread, and slide down the slope. Numerous large grasshoppers, grey as the shingle, leap from beneath his feet, an occasional black butterfly flits through the air or rests upon a rock, while overhead may fly screaning that famous bird the kea. All is a scene of utter desolation: it is, in truth, an alpine desert.

To the shingle-slip proper belongs a most peculiar series of plants. They have several characteristies in common. Some are true summer-green herbs. Most have long roots and are low-growing. Many are succulent. Not a few are of a colour similar to the shingle. Some have leaves of rather an indiarubber-like texture, and one (Craspedia albina), at any rate, is covered with an exceedingly woolly mass of hairs. These shingle-slips become burning hot in the sunshine, and yet in the evening of the same day may be icy cold. At some distance below the surface the stones are wet. The water at the plants' disposal is usually not much above freezing-point. Here are a few of the plants to be found in such situations: A stiff-leaved grass (Poa sclerophylla); three buttercups-Ranunculus chordorhizos, $R$. crithmifolius (see text-fig., p. 107), and $R$. Haastii; the snow-white woolly Craspedia alpina; a plant of the carrot family (Anisotome camosula); a daisy, jet black, and with stamens like golden pin-hẹads (Cotula atrata), and its near relative C. Dendyi, with larger flower-heads brown or almost yellow in colour; one of the pink family (Stellaria Roughii); the curious and sweet-scented penwiper-plant (Notothlaspi rosulatum) (fig. 68); a plant with pea- 
like flowers (Swainsona novae-zelandiae); great woolly mats of Haastia recurva; and a fleshy-leaved lobelia (L. Roughii). A piripiri, too (Acaena glabra), is frequently confined to this peculiar station. These plants do not grow closely side by side; they are few and far between, and without close observation the slopes look quite bare. Occasionally a trailing-veronica ( $V$. epacridea) sprawls over the stones, and it is frequently accompanied by a smaller species of the whipcord form, V. lycopodioides, while the semi-whipcord koromiko, V. tetrasticha, may also be present.

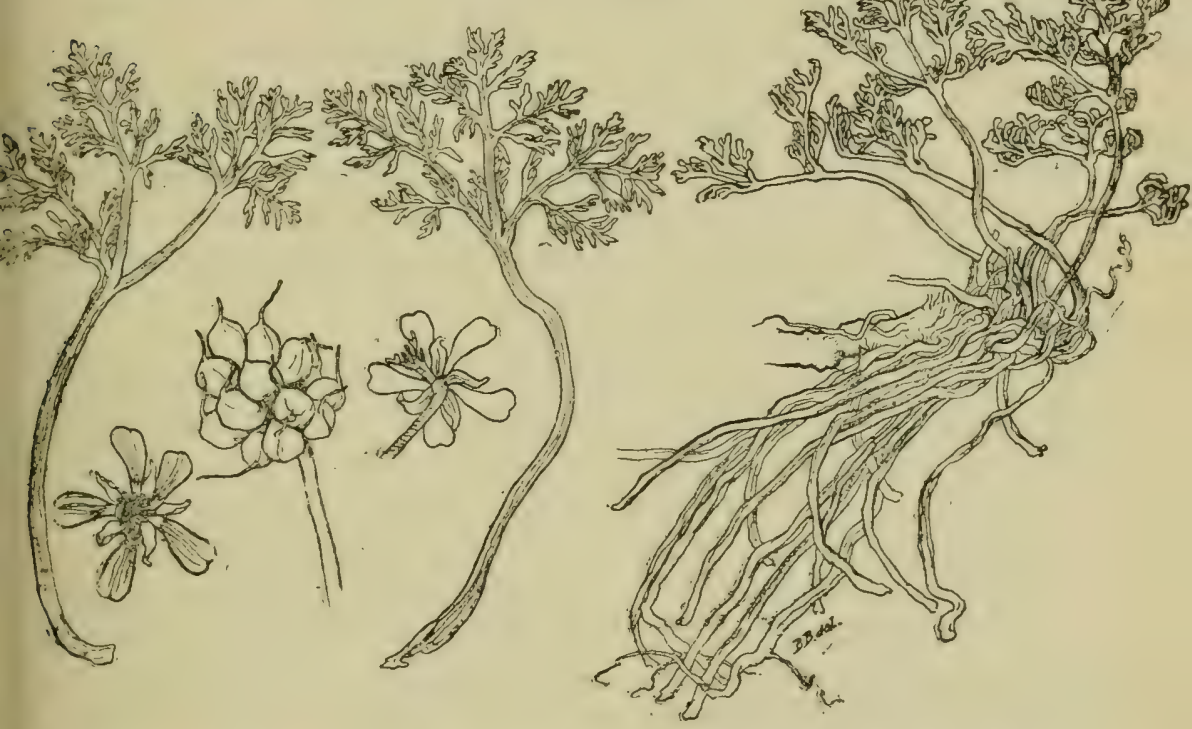

Ranunculus crithmifolius, a rare buttercup found sparingly in the North-eastern Botanical District, and then considerably to the south on the Mount Arrowsmith Range (Canterbury).

Trans. N.Z. Inst.]

[After Laing.

In the North-eastern Botanical District, in addition to the above, there are the rock-bluebell (Wahlenbergia cartilaginea), a plant rather like a European crusty saxifrage; the greyish Raoulia cinerea; and a convolvulus (Convolvulus fractosaxosa). In the western mountains of the South Island there are woolly mats of Haastia Sinclairii, and, confined to northern Westland, Veronica Haastii var. macrocalyx.

A vegetable-sheep of the largest dimensions, Haastia pulvinaris, grows on the shingle-slips of the North-eastern Botanical District, 
but only where the stones are very large, the result of quite recent disintegration. The cushions are even more woolly and sheep-like than those of Raoulia eximia. Probably H. pulvinaris may grow also upon actual rock, but it has not yet been recorded from such a habitat.

Closely related to the shingle-slips, so far as the conditions for plant-life go, are the scoria-slopes of the volcanoes of the central plateau of the North Island. But on these the plant-life is still more scanty. Except Claytonia australasica, which, strange to say, is also a plant found in shallow rumning water, all the South Island shingle-slip plants are wanting. In their place is a true alpine gen, the scoria-koromiko (Veronica spathulata), which possesses a root of great length, small succulent leaves close to the cinders, and in summer is altogether covered with multitudes of snow-white flowers, which quite hicte the foliage. Another koromiko of a rather more stable habitat is Veronica Hookeriana, a species allied to V. Lyallii. Both these species are absent on Mount Egmont, but their place is occupied by a species of Epitobium which is probably yet without a name.

Turning now to the flora of debris and scoria-slopes, it consists of 33 species, belonging to 14 families and 18 genera. No fewer than 22 of these species are confined to their inhospitable home.

The shingle-slips become more stable at their margins and where they are flatter; consequently species not specially adapted for the extreme conditions of existence which the shingle-slip offers are able to gain a footing, and these are the pioneers of that common plantassociation-" fell-field "- of the eastern greywacke mountains of the South Island which gives the special character to much of their scenery.

The name "fell-field" is a combination of "fell," which means a barren or stony hill, and "field," meaning a wide expanse. This name, chosen by Professor Percy Groom as a translation of the Danish "fjeldmark," fits admirably the New Zealand plant-formation, for it is barren enough, the plants forming at best small colonies here and there with bare stony soil between, the whole extending for miles along the dry mountain-slopes. Fell-field occurs principally in the eastern mountains of the South Island beyond the average reach of the western rain.

Amongst the growth-forms of the species are prostrate, creeping, and rooting shrubs; semi-woody plants and herbs; cushion-plants ; rosette-plants ; tussock-grasses ; and erect, stout-stemmed shrubs. 
A few specially common or remarkable plants easily observed may be noted. Celmisias of several species are abundant, especially the common cotton-plant (Celmisia spectabilis) (fig. 62) and the remarkable C. Lyallii, which has somewhat the form of a spaniard, with its stiff, erect, sharp-pointed leaves, which have also the anatomical structure of a desert-grass. There will be numerous circular mats of different kinds of mountain-musk-e.g., Celmisia Tiscolor, C. intermedia, and C. Sinclairii. Frequently the lovely creeping mountain-foxglove (Ourisia caespitosa) will form broad green mats. The coral-broom (Corallospartium crassicaule) occurs on a good many mountains; its extremely rigid leafless grooved stems. yellowish in colour, look hardly alive. There will be large tussocks of the broad-leaved snow-grass (Danthonia flavescens). At high altitudes the celmisias will be $C$. viscosa or $C$. Haastii. There will also be small moss-like cushions of Veronica pulvinaris-a gem when covered with its white flowers; tiny spear-grasses (Aciphylla Homoi and its near relatives); cushions of a forget-me-not, Myosotis pulvinaris (Central Otago); small glaucous veronicas ( $V$. pinguifolia and its allies); silvery cushions of the large-flowered raoulia (Raoutia grandiflora); various species of needle-leaved heath (Dracophyllum); and the mountain-totara (Podocarpus nivalis), a most characteristic fell-field plant (fig. 51).

A fell-field association which must not be neglected is that of the Dun Mountain (Nelson), which occupies a portion of the celebrated "Mineral Belt," the rocks of which are peridotite and serpentine. On the adjacent non-serpentine area there is luxuriant southernbeech forest, but the moment the serpentine appears the forest ceases, and a fell-field association or tall tussock-grassland, as the case may be, commences. The contrast between the forest and the Mineral Belt associations is most striking, and puts one in mind of the sudden appearance on the coast of salt-meadow-the result of an excess of salt, just as the Hineral Belt associations are due to an excess of magnesia. It is true that at the junction between the two there is a certain amount of shrubland, but what are trees outside the serpentine become at once shrubs when the influence of its soil is felt, as in the case of the broadleaf (Griselinia littoratis) and tall red southern-beech (Nothofagus fusca).

There are certain species absolutely confined to the serpentinee.g., the prostrate shrub Pimelea Suteri; the pretty forget-me-not. 
Myosolis Monroi; and Notothlaspi australe, related to the shingle-slip penwiper-plant ( $N$. rosulatum). Frequently shrubs are dotted about on the stony ground, especially a variety of the mountain-cottonwood (Cassinia Vauvilliersii); the leafless prostrate Exocarpus Bidwillii; a variety of the box-leaved veronica (Veronica buxifolia); a variety of manuka; the open, rigid cushions of Hymenanther dentata var. alpina, their ultimate twigs rigid and spine-like; a prostrate needleleaved heath (Dracophyllum rosmarinifolium); and, looking quite out of place amongst all these drought-resisting plants, a variety of Coprosma Cunninghamii with bright-green leaves.

The above association is certainly of a drought-resisting character, but not so much so as is to be seen in much of the primitive vegetation of Central Otago. But on the Mineral Belt the adaptations are in harmony with the serpentine soil, while in Central Otago they are in harmony with the dry climate.

On those mountains of the South Island particularly exposed to the western rainfall, and on many of the North Island mountains, the vegetation is far denser than that described for fellfield, and there is a continuous covering over greater or smaller areas. This may be termed "herb-field." According to the average amount of water in the soil, the species will differ to some extent, so that wet herb-field and dry herb-field are two distinct classes of the plant-formation. To do justice to either fell-field or herb-field many pages would be necessary: here only a few more or less striking plants will be mentioned.

On Mount Egmont the herb-field is distinguished by great colonies of the beautiful alpine foxglove (Ourisia macrophylla), accompanied by the noble Egmont buttercup (Ranunculus niricola). There are also considerable breadths of the bog-celmisia (Celmisic glandulosa var. latifolia).

On the Tararua and Ruahine Mountains a very striking feature is the prominent part played by the alpine astelia (Astelia montana), which forms enormous patches. Celmisia hieracifolia and the white mountain variety (C. incana) (fig. 63), making great mats, are abundant. But the special glory of these ranges are the sheets of the North Island edelweiss (Leucogenes Leontopodium) (figs. 57, 69).

In the South Island the glorious feature of herb-field is the acres and acres of the mountain-lily (Ranunculus Lyallii) when in full bloom (fig. 1). Almost equally beautiful is Ourisia macrocarpa 
in one or other of its varieties. There are, of course, a good many celmisias. Of these Celmisia Armstrongii of the Western Botanical District is very showy (fig. 73), with its sword-like leaves marked by an orange midrib. C. lanceolata of the South Otago and Fiord Botanical Districts is equally striking. Then there are the dense silvery cushions of $C$. sessitiflora or $C$. argentea, and the mats of $C$. intermedia and $C$. Sinclairii.

Thanks to the energy of Mr. D. L. Poppelwell, a good deal is now known of the herb-field of the Garvie Mountains, South Otago Botanical District. A very fine form of Celmisia peliolate is common. There are splendid hybrids between the above and C. Brownii, as also a bronze-leaved form of $C$. coriacea. Perhaps the most interesting plant is a spear-grass (Aciphylla pinnatificla), a beautiful rosette-plant, forming extensive patches in wet ground; lut, unlike other members of the genus, which are fixed to their home, this plant spreads over wide areas, thanks to its underground stems.

The wet Stewart Island herb-field is almost bog. A striking feature, especially on the Table Hill Range, is the close turf formed by cushion-plants growing into one another. Such are Donatia novae-zelandiae, Diacophyllum politum, and Oreobolus pectinatus. The grass-like Carpha alpina is also abundant (fig. 74). A grass with leaf-tips sharp) as needles (Danthonia pungens) is often an important feature. Here, too, will be silvery cushions of Celmisia argentea and $C$. linearis (fig. 75), and the Stewart Island spaniard (Aciphylla Traillii).

Many interesting plants and plant-associations have perforce to be left out of this account of the high-mountain vegetation, but a brief reference must be made to the subalpine scrub.

In many places on the high mountains of New Zealand, especially in an area where the rainfall is excessive, upon emerging from the upper forest one is confronted with a formidable natural fence, some chains in breadth, dividing the forest from the grassland or herb-field. On many mountains this girdle is absent, or represented by stunted southern-beech trees or isolated patches of shrubs. The above barrier, composed of a thick and varied growth of shrubs, is designated the "subalpine scmb," and if unprovided with a track inay be virtually impenetrable (fig. 76). The shrubs, dense in themselves, have such wiry or rigid branches interlacing one into another that no passage can be made between them. In many 
places where it is impossible to crawl on one's hands and knees beneath the close mass the only alternative is to walk upon the top.

At first sight it might seem that such plants would be worthless for garden purposes, and yet in that regard they are the very élite of the New Zealand flora. The scrubs of the montane and subalpine river-beds, moraines, and terraces may also be included here.

These latter scrubs are the headquarters of the shrubby koromikos (Veronica). Here is the cypress-koromiko (Veronica cupressoides), named most fittingly, for no one seeing it for the first time and out of bloom could dream it was not a cypress. Other veronicas met with here are- $V$. buxifolia var. odora, forming shining green bushes, round as a cricket-ball; V. Traversii, which is of similar habit, but with much less glossy foliage; $V$. glaucophylla, with sagegreen leaves; $V$. subalpina, an early-blooming species with bright-green leaves; V.monticola; V.remicosa--indeed, there is a superabundance of species, many of which strongly resemble one another.

Tree-daisies (Olearia) are much in evidence. The following may be noted: The native holly $(O$. ilicifolia), with musk-scented prickly crinkled leaves; the false mountain-holly ( $E$. macrodonta), somewhat like the above, but with broader and greener leaves; the smallleaved tree-daisy $(O$. nummularifolia), with small hard and leathery leaves; the boat-leaved tree-daisy $(O$. cymbifolia $)$, similar to the last-mentioned, but with the margins of the leaves much recurved; the musky tree-daisy (O. moschata), after the manner of $O$. nummularifolia, but with larger and paler-coloured leaves; the glossy treedaisy $(O$. arborescens), with rather large glossy leaves, covered on the under-surface with a shining mat of hair; and the large-leaved tree-daisy (O. Colensoi), with thick rather large leaves, much toothed, and covered beneath with a thick mat of white hairs. The remarkable $O$. lacunosa, with its leaves rather like those of a juvenile lancewood, and its relative $O$. excorticata, with broader and shorter leaves, are rarer, being confined to the Tararua Mountains in the North Island, and to the north-west and west of the South Island. There is also a true lancewood (Pseudopanax lineare). This, like its well-known relative of the forest, $P$. crassifolium var. unifoliatum, has also long narrow juvenile leaves, but instead of turning them downwards, as in the case of the latter species, they are held erect.

Other plants of the daisy family forming scrubs are the cottonwoods C. Vauvilliersii, C. fulvida var. montana, and C. albida, the first two 
of wide range, but the latter confined to the North-eastern Botanical District. To the same family belong also the shrubby groundsels, very common plants of the subalpine scrub, such as Senecio elaeagnifolius, S. Bidwillii, and S. cassinioides. Traversia baccharoides is also a shrubby groundsel, which is confined to the north of the South Island, with its southern limit in the north of the Eastern Botanical District.

The heaths are represented in subalpine scrub by various species of Dracophyllum and by Archeria Traversii and Gaultheria rupestris, the latter to be recognized by its lily-of-the-valley-like flowers, after the manner of those of $G$. oppositifolia of the Volcanic Plateau.

Diacophyllum Traversii is a magnificent small tree, with smooth, naked, brown stems extending candelabra-like from the summit of the trunk, and each stem crowned at its extremity with a rosette of stiff, reddish leaves, having long-drawn-out points arching downwards; it occurs both in the subalpine scrub of Westland and in the uppermost belt of the subalpine forest. Any one journeying over Arthur's Pass can hardly fail to observe this truly remarkable small tree. The mountain-flax (Phormium Colensoi), also a plant of sea-cliffis, is common in subalpine scrub, as is likewise, in some localities, one of the spear-grasses (Aciphylla Colensoi var. maxima), a most formidable plant with bayonet-like leaves a yard long (fig. 78). Manuka (Leptospermum scoparium) is often a constituent of certain subalpine scrubs. On the Longwood Range (Southland) it is much in evidence, while on certain Stewart Island mountains it forms a scrub of extreme density.

At the beginning of this chapter it was pointed out that about 100 of the high-mountain plants descended into the lowlands under special circumstances. The conditions under which the more important of these are found is where the climate of the lowlands is of a subantaretic character-i.e., where there is a considerable percentage of cloudy days in the year, a comparatively cool summer, and a good many piercing southerly winds at all seasons. Under such conditions peat is readily formed and accumulates, bog and semi-bog are abundant, and afford positions which most ordinary lowland plants abhor, but in which certain high-mountain species can get on excellently. Plants of this character are the common donatia (Donatia novae-zelandiae), a cushion-plant of mountain-bogs; Senecio Lyallii, a plant of both boggy ground and the banks of icy- 
cold streams; and the silvery cushion-celmisia (Celmisia argentea), a species of boggy herb-field. Other examples could be given, but these suffice to illustrate the class of plants which have come from the heights, or which, it may be, ascended thither from their original lowland stations.

There are two broad paths by which alpine plants can gain the lowlands without greatly changing their mode of life: they can follow the stony river-beds from their sources far in the heart of the mountains or they can descend by means of the tussock-grassland. There is thus no need for the alpine plants of such plant-formations to choose any means of progression other than the slow one of competition with their neighbours-not an uncommon method of getting on in the world, after all !

The beautiful autumn coloration of leaves exhibited by many trees of the Northern Hemisphere cannot be expected in a regetation whose trees are nearly all evergreen. Nevertheless. the highmountain plants of New Zealand show a considerable amount of winter coloration, the result of frost. Various evergreen shrubs have their leaves thus coloured-c.g., the manuka (Leptospermum scoparium), the mountain southern-beech (Nothofagus cliffortioides), and the mountain-korokio (Corokia Cotoneaster). The coloration is especially striking in bog or river-bed cushion-plants, so that in winter a river-bed may be a place of remarkable beauty. The most striking feature in this particular are the great cushions of Raoulia Haastii of the Waimakariri or Rakaia mountain-valleys, which in summer are bright-green, but in winter are of varions shades of rich chocolate-brown, and are indeed a delightful spectacle. Another raoulia (Raoulia temicautis) assumes many colours-e.g., yellowish-green, pale reddish-brown, and greys of different tints. The case of Pimelea prostrata var. repens is of special interest, since some plants are coloured and others in the immediate vicinity undergo no change. The green cushions of Donatia novae-zelandiae and Phyllachne Colensoi of the high-mountain bogs become more or less red in winter. Very few observations regarding winter coloration of New Zealand plants have been made, and doubtless many other's exhibit a distinct winter coloration. It may be pointed out, however, it is of just as much importance to observe those species which do not colour as those which do so when both are growing under apparently identical conditions 


\section{CHAPTER VIII.}

\section{PLANT-COMMUNITIES AND PLANTS OF INLAND WATERS, SWAMPS, AND BOGS.}

Goneral remarks-The water-ferns-Azolle rubre-The pond-weeds-Tho watermilfoil-Changes in swamp wrought by man-Fresh-water algae-Algae of hot-water springs -Definition of term "swamp" - Species and growth-forms of swamp-Conditions for plant-life in swamp-The root of Plormium lenax-Breathing-roots of the pukatea-Relations of swamp to other plantformations-Vegetation of swamps-Swamp of Auckland-Special South Island swamp-plants - Bogs - Sphagnum moss and its peculiaritios Dryness of sphagnum-eushions - Origin and distribution of bogs-Lifeconditions for bog-plants - Growth-forms of bog-plants - The species growing in bogs - Some bog associations - Sundews and bladderworts The species of Gunnera-The false snow-grass (Schoenus pauciflorus) plant-association.

IT has already been shown that in her forests, grasslands, herbficlds, shore vegetation, shrubberies, and on even her frowning cliffs New Zealand possesses plants which do not yield in beauty or interest to those of any other land. With her seaweeds, too, she is well able to hold her own. But when it comes to her fresh-water plants she must take a lower place. Rivers, lakes, and smaller sheets of water there are in plenty which offer first-class inducements for oceupation by aquatic plants, but none of the more beautiful kinds, except since the advent of the European, have accepted the offer; in vain do we look for indigenous water-lilies like those of the neighbouring island-continent. Still, for all that, New Zealand's inland waters are not without plant-life, some of which, from the biological standpoint, is interesting enough.

Take the case of the floating water-fern (Azolla vulic $t$ ). The red masses of this curious plant, covering still pools so thickly that one might think them dry land, must be known to all. The apparently upper surface of the upper leaf-lobe is covered with minute excrescences, so that it camnot be wetted, and, in consequence, drops of water frequently begem the floating mass and glitter in the sun- 
light like diamonds. An individual plant is quite small, and consists of a thin, much-branched stem, which puts down roots into the water from its under-surface, and bears overlapping leaves. Each leaf consists of two lobes, an upper and an under one, which, except on close examination, look like separate leaves. Each lobe is adapted for a totally different condition of life, so there is a distinct division of labour in the one leaf. The upper lobes overlap one another like tiles on a roof; they are comparatively thick, provided with leafgreen, and therefore carbonaceous-food producers, and they are never submerged. Each contains a large cavity full of slime, inhabited by a fresh-water alga, named Anabaena, belonging to the Nosloc family; which, however, does its host no damage, but, like a respectable lodger, probably pays for its accommodation. The under lobe is partly submerged, quite thin, and able on its outer side to absorb the necessary water. Noreover, the close arrangement of the leaves as a whole furnishes cavities where air can lodge, and thus provides the necessary buoyancy for the floating plant.

In most parts of New Zealand may be seen, floating on the surface of slow-flowing rivers or calm shects of water, the oval brown leaves, about 1 to 3 inches long, of some species or other of pond-weed (Potamogeton), the most abundant of which is the common pond-weed ( $P$. Cheesemanii). Besides the above leaves there are others (but not in all the species) which live always submerged, and differ considerably from the floating ones. These submerged leaves are very thin, translucent, erect, more or less ribbon-shaped, extremely numerous, and always moving. no matter how gentle the current. Since there can be no danger of want of water at any time, such leaves are entirely without any protection on that scure; on the contrary, they are so constructed as to be able to absorb) water over their whole surface just like the filmy ferins already dealt with, and thereby secure at the same time the oxygen which the water contains. Their ribbon-like shape is well adapted to withstand damage from the currents of water, while sufficient extent of leaf-surface is provided by increase in number of leaves. It is also an interesting fact that these submerged leaves are similar to the early seedling ones of the pond-weed, and that this particular shape of leaf is common even amongst the land members of that great division of plants (monocotyledons) to which Potamogeton belongs. Some of the pondweeds never produce floating leaves-e.g., Polumogeton ochreatu: 
and $P$. pectinalus. The last-named sometimes occurs in brackish water, and its leaves are 2 to 4 inches long, extremely narrow or almost thread-like.

The water-milfoils (Myriopllyllum) differ from the pond-weeds in that they have no floating leaves, but boldly raise the upper portion of their stems above the water-surface. They agree, however, in the fact that the aerial leaves, like the floating leaves of the pond-weeds, rliffer from the submerged ones. This is the more interesting because no line of demarcation on the erect stem separates the two kinds of leaves except the water-surface; that is to say, the same tissue (an produce quite different leaf-forms according to change of outer (ircumstances-a happening like that detailed for certain trees in Chapter V. The water-milfoils are graceful, feathery-looking plants, with four or more leaves frequently given off in whorls round the stem. The submerged leaves are cut into fine segments, a very rommon occurrence in many water-plants, whereas the aerial leaves are broader and much less cut. Some of the water-milfoils are bog-plants rather than aquatics-e.g., the small water-milfoil ( $M$. Votschii). Another species of water-milfoil, the stout water-milfoil ( $M$. robustum), attains 2 feet in height; but it is a swamp-plant, not :i water-plant. Its stems are stout, erect, and branched, fitting it for a kind of life different from that of its aquatic more slenderstemmed relative the common water-milfoil ( $M$. elatinoides) and it: near relative $M$. propinquum.

Certain plants are common in shallow mountain-streams. Such are: the water-chickweed (Montia fontana), which forms dense green masses or cushions of stems and leaves, and produces minute white flowers; a large-flowered, quite showy willow-herb (Epilobium macropus), which is dominant in many streams; and schizeilema nitens, which in mountain-streams of certain parts of the South Island is greatly in evidence with its green shining mats of slender stems and minute leaves of three leaflets.

It is probable that all aquatic seed-plants are descended from land-plants which took to the water by slow degrees, thanks to their innate plasticity, as their habitat gradually became wetter and wetter

a. common enough circumstance. This is no place to discuss this question at length, but it may be pointed out that some plants can live equally well on land and in water, and even do not mind being submerged. The water-starworts (Callitriche) are examples. 
In many streams the indigenous vegetation has been ousted by foreign competitors, and some beautiful flowering-plants have become established - e.g., the Cape pond-weed (Aponogeton distichum), an Australian water-lily (Ottelia ovalifolia), and the European waterbuttercup (Ranunculus aquatilis). On the other hand, certain very troublesome weeds have become rampant, especially the watercress (Radicula N'asturtium aquaticum) and the American waterweed (Elodea canadensis). The watereress differs greatly in form both of leaf and flower from the aquatic form when growing on dry ground.

Rivers, ponds, lakes, stagnant pools, moist soil, wet cliffs, and many other stations are the homes of the fresh-water algae, or the pond-scums, as one section of this important class of plants may be popularly called. These pond-scums frequently form green, slimy masses which float on the surface of the water. Common forms consist of what look like very fine, long, green hairs. Under a fairly strong power of the microscope these are seen to consist of long tubes, divided by thin walls into compartments, which contain plantgreen, sometimes in the form of bands.

The fresh-water algae are a very large group of plants, living uncler various conditions and of many forms, and, although occupying a low position in the plant-world, their structure is at times fairly complicated, and their methods of reproduction are quite elaborate. To this family belong the diatoms; the stoneworts (Chara, Nitella)-brittle plants up to a foot or more in height, with a peculiar odour, and growing submerged in extensive colonies on the beds of lakes and rivers; the desmids-tiny plants, often of star- or crescent-shaped solitary cells; the pond-scums, already mentioned; the red snowplant; and many other groups. In the hot springs of the North Island are some peculiar forms, belonging to the blue-green algae, which are able to exist in water of a very high temperature. These were studied some years ago by Professor Setchell, of the University of California, and in a letter to the author he states that none of the New Zealand forms can endure a temperature greater than $167^{\circ}$ Fahrenheit, which seems a bath quite hot enough in all truth!

These hot-water algae are sometimes cited to show how living organisms could exist in the early days of the earth, when cold water would be unknown, and how such organisms may have persisted since those distant ages, and that they or their congeners may be the ancestors of the plants of the present day. 
Where the water is not too deep, and is not flowing, many species of seed-plants can grow which are not specially adapted for the aquatic life. Communities of this character fall into the two classes of swamp and bog.

Dealing first with swamp, this term is here used to designate those plant-communities which have as their home loose soil, frequently consisting of peat - the remains of former generations of plantswhich is covered throughout the year more or less deeply by water. Except forest no New Zealand plant-formation has been so greatly modified by man, as will be seen in Chapter X.

The number of species found in swamps is less than 70 , belonging to 16 families and 32 genera. Their growth-forms include trees. shrubs, lianes, herbs, grass-like plants, rush-like plants, and ferns. At least 40 of the species are grass-like or rush-like. Many of the swamp-plants grow equally well under much drier conditions, while others are confined to swamp.

The conditions for plant-life differ considerably in different swamps according to the amount of nutritive salts they contain, the average depth of the water, the nature of the swamp-floor, the degree of stagnation of the water, the altitude above sea-level, the latitude of the swamp, and the combination of species.

When dealing with the mangrove (Chapter III), it was shown how that tree must provide for a supply of air for its roots. So, too, with various swamp-plants, which accordingly have a considerable portion of the outer part of their roots made up of a spongy covering full of air. This can be well seen in the roots of the New Zealand flax (Phormium tenax). This plant also avoids the wet ground, is far as it is able, by not sending its roots deep down, but rather extending them for long distances close to the surface of the soil. It is interesting also to note how the roots of $P$. tenax when growing in dry ground are furnished with an enormous number of root-hairs, these alone being capable of absorbing water from the soil. But when a root gets down to the actual water, or into very wet soil, no root-hairs are produced, but the root then is furnished with an outer thin "skin" which readily allows water to pass through it.

The case of the pukatea (Laurelia novae-zelandiae) may be considered here. This fine tree grows in swamp-forest, where the muddy substratum is deficient in oxygen. At the base of the tree the great plank-buttresses continue as roots which are raised high above the 
surface of the ground. Where the soil is wettest, prolongations from the root pass upwards above the water and probably function in the same manner as the breathing-roots of the mangrove (fig. 80).

Between lakes, swamps, bogs, grassland, and rain-forest there is a rather close connection. Sedges, raupo (Typha angustifolia), rushes, and rush-like plants growing in the shallow water near the margin of a small lake may in time, through their decay, turn by slow degrees that part into dry ground, and advance farther and farther into the lake until a water-surface is no longer visible, the whole having become a raupo or phormium swamp. From this the transition to grassland though tussock gaining a footing or to rain-forest by way of swamp (kahikatea) forest is in many cases only a matter of time.

The blocking of watercourses with aquatic plants (an soon convert grassland into a swamp. Even on shingly river-beds, swamps at various stages of growth may be observed, and toetoe-grass (Arundo conspicua), cabbage-trees (Cordyline australis), and New Zealand flax (Phormium tenax) break the monotony of the scene.

Sinking of the land may bring about great changes in the plantassociations, and remains of plant-life in hogs or swamps can teach much as to recent changes in the land-surface. In the swamps of the Canterbury Plain in the neighbourhood of Christchurch considerable numbers of fallen trees are found, the remains evidently of a large semi-coastal forest, which must have been replaced by swamp during a sinking of the land, or the swamp may have ultimately been buried by shingle (fig. 79). So, too, on that narrow peninsula in the far north of Auckland is much kauri-gum to be met with in the bogs, a sure sign that the land stood considerably higher at the time it was occupied by kauri forest, since that tree is most rare in swamps.

The changes noted above which are slowly taking place in swamps, owing to the gradual lessening in depth of the water, leads to the plants being arranged in more or less distinct belts or girlles, according to their being suited by structure or constitution to water of a certain depth, using the term "girdle," since "belt" has already been selected as a name for the rings of vegetation encircling mountains.

A journey on any of the New Zealand main railway-lines shows the traveller that swamps are even yet a very common feature of the landscape, for they can be recognized at a glance by the dense growth 


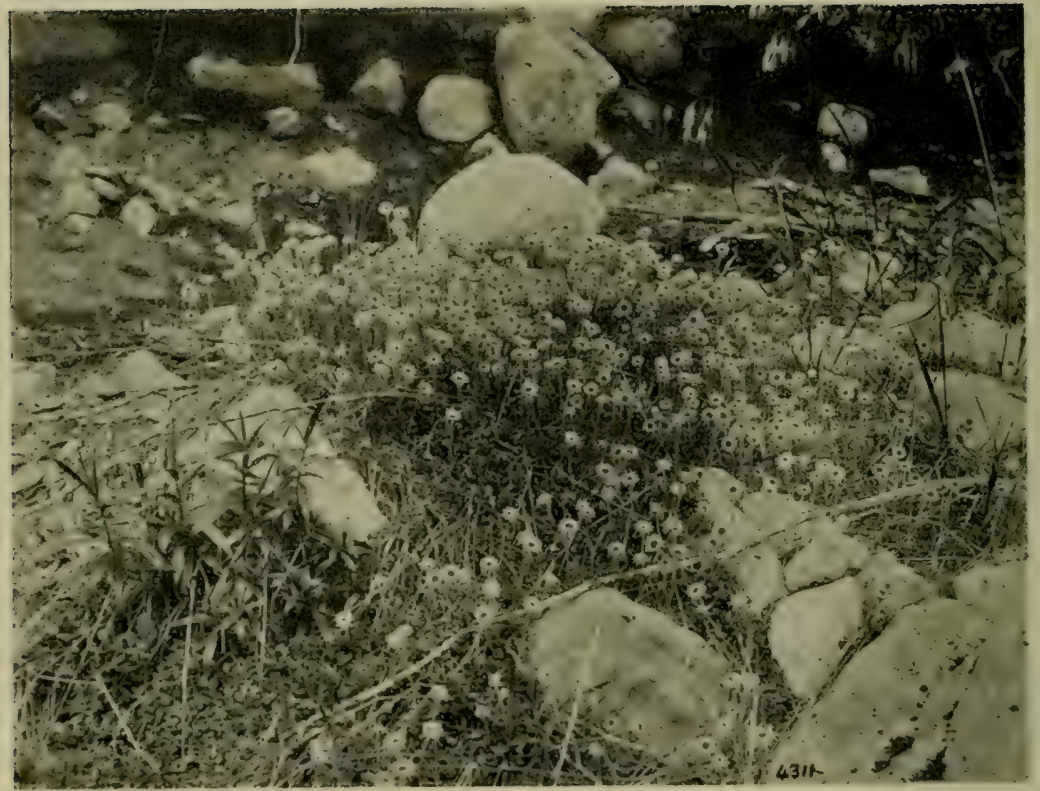

Fig. 72.-The false edelweiss (Helichyrsum bellidivides) growing on stony ground in the Bealey Valley (Canterbury).

[Photo, L. Cockayne.

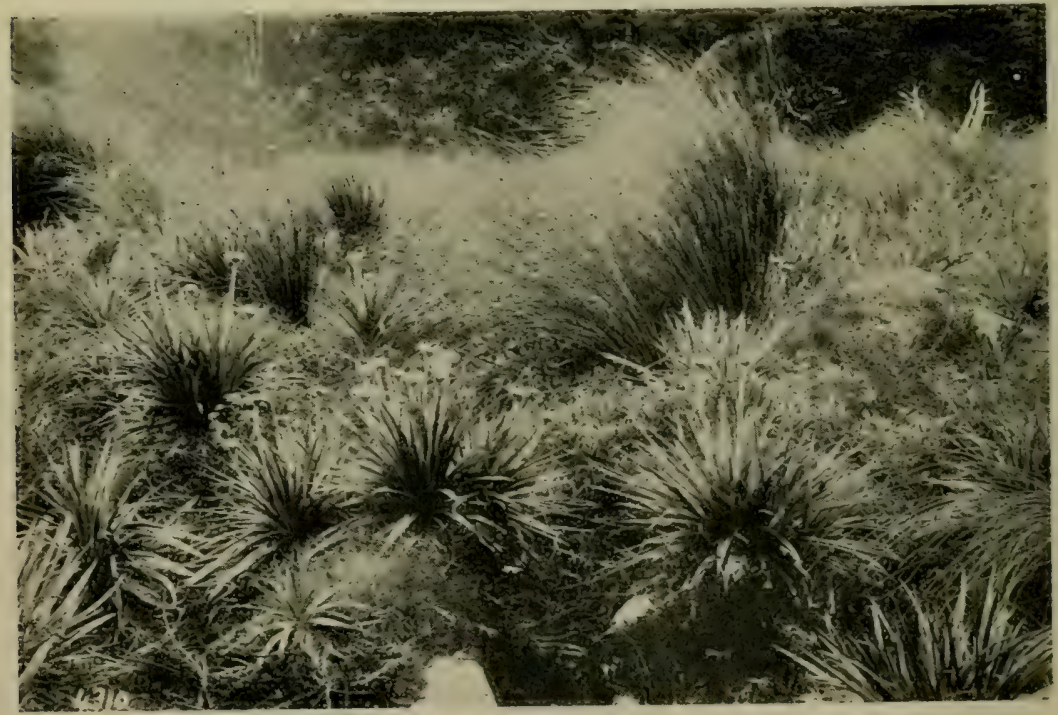

FIG. 73.-Herb-field of Arthur's Pass, with Celmisia Armstrongii in abundance.

[Photo, L. Cockayne. 


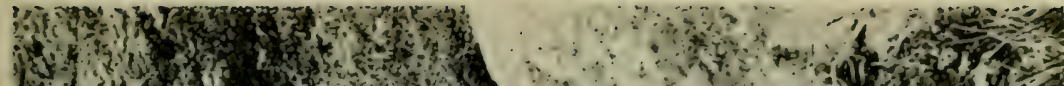

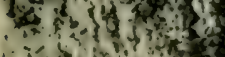

Whom $\therefore$.

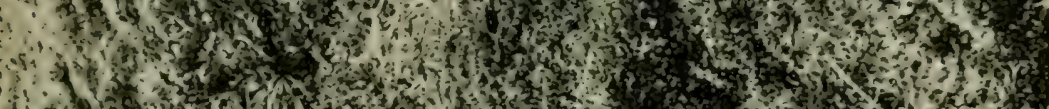

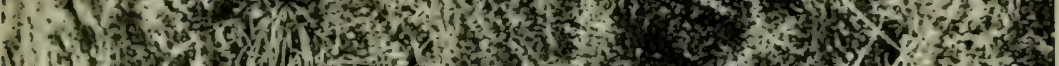

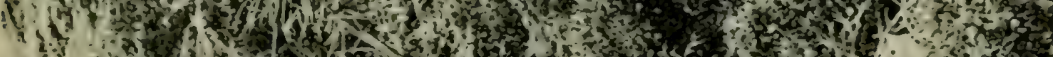

t d.

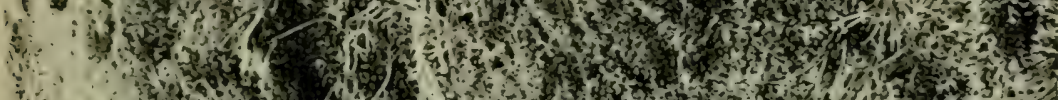

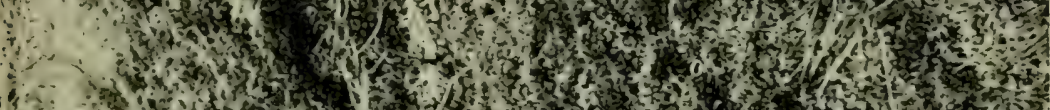

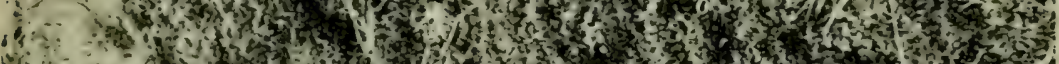
5.

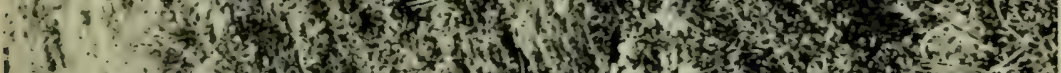

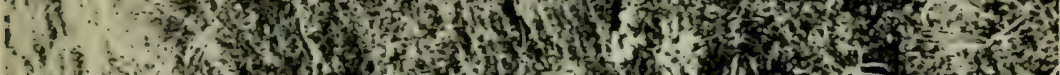
${ }^{3}(\mathrm{~m}$ )

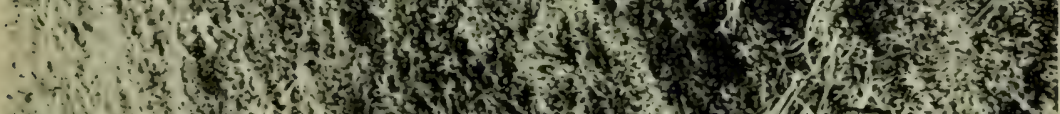
.

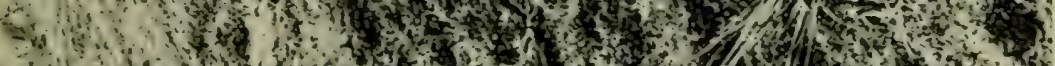

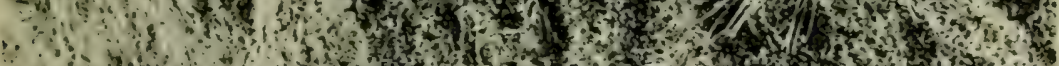

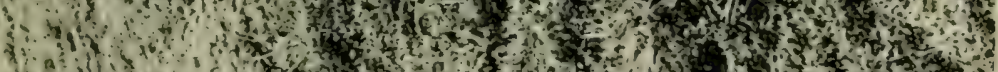

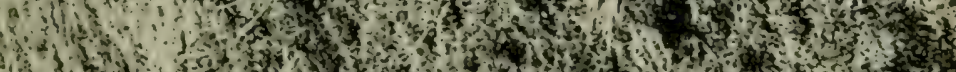

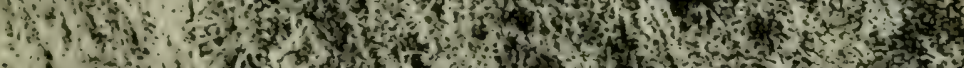

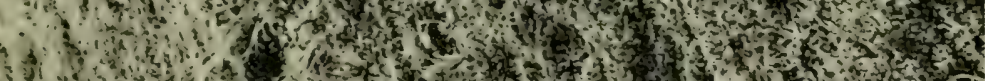

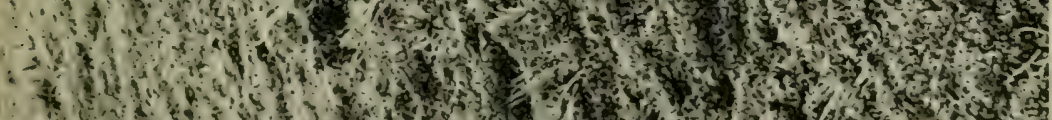

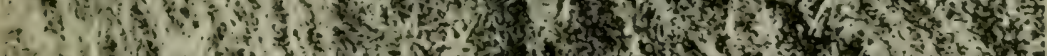

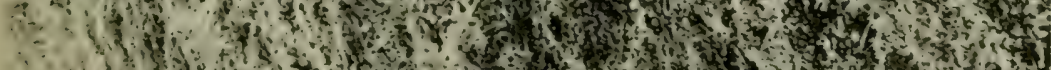

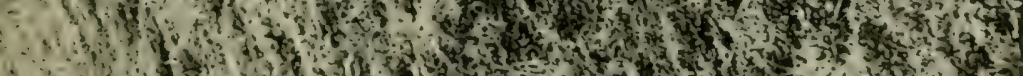

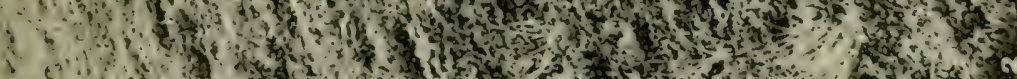

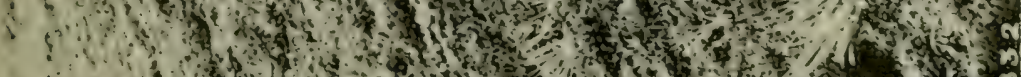

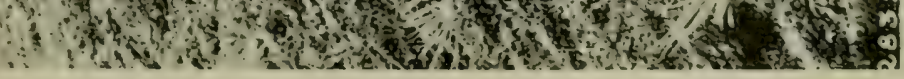




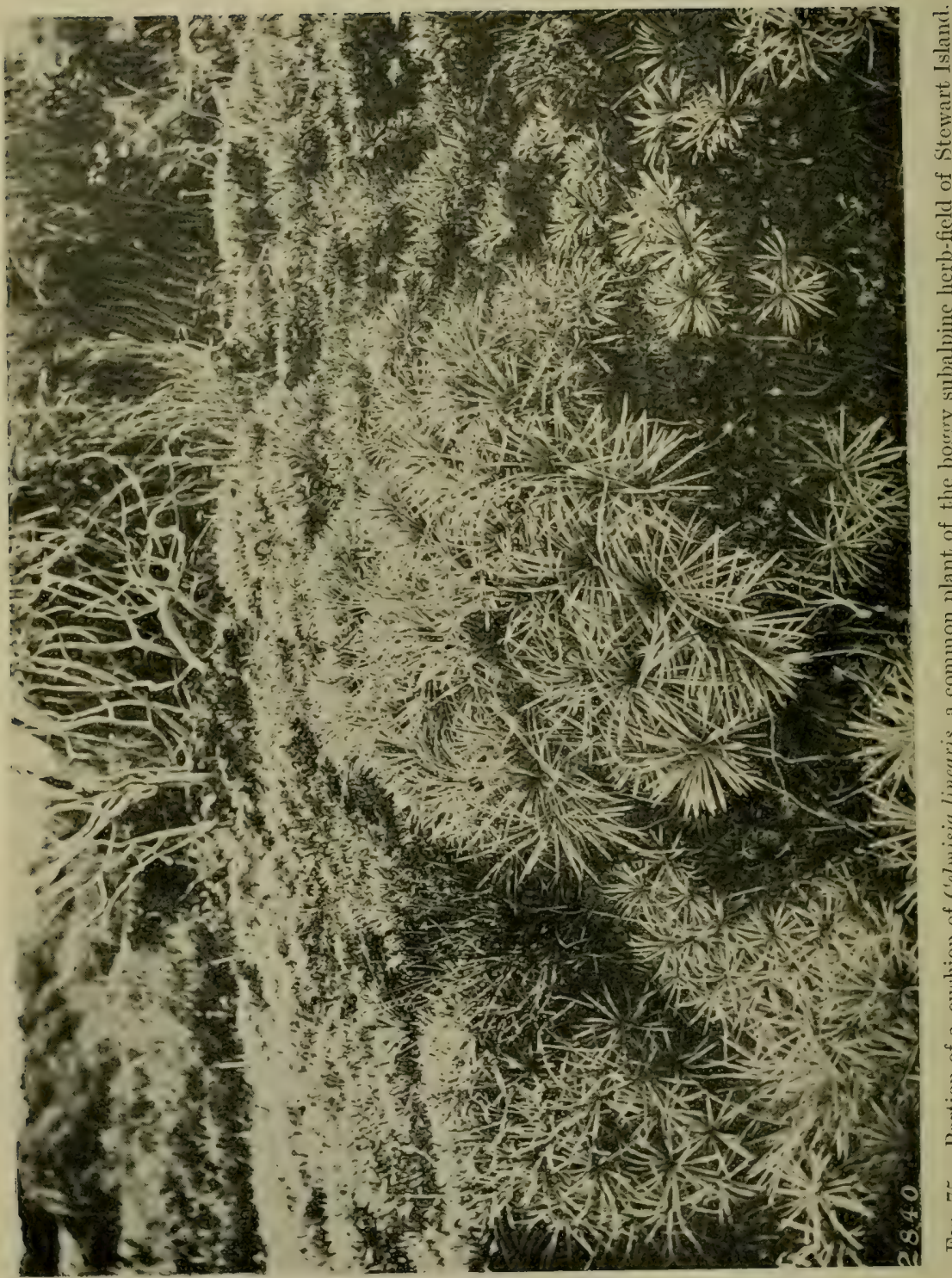


of New Zealand flax (Phormium tenax) or raupo (Typha angustifolia) and by those most curious plants the niggerheads (Cares secta). Even yet, too, in certain localities the scene is enlivened by the presence of that fine bird the pukeko (Porphyrio melanotus), gay with red legs and bill and blue breast. Before the days of settlement these swamps were much more extensive, but some of those reported by the early surveyors as being undrainable now bear rich crops of grain, potatoes, or " roots."

In the deepest swamps the raupo or bulrush (Typlea angusti foliu var. Muelleri or var. Brownii) is the sole plant, but where somewhat shallower there will be more or less stunted, yellowish Phormium tencix, looking most unhappy. This plant grows at its best alongside streams where it has an abundant supply of water full of oxygen and there is never stagnation. Frequently various shrubs are present, especially the manuka (Leptospermum scoparium); the common coprosma (Coprosma propinqua); the karamu (Coprosma robusta): a coprosma intermediate between the two former (C. Cuminghamii), various forms of which may quite well be hybrids; the common koromiko (one or other variety of Teronica salicifolia); and a treedaisy of the divaricating form (a variety of Olearia virgata). Cabbagetrees (Cordyline australis) are sometimes present in swamp, and may occur in considerable numbers.

The niggerhead (Cares sect $\boldsymbol{t}$ ) is a characteristic swamp-plant: forming extensive colonies. This sedge builds for itself tall and stout "trunks" out of its dead roots and rootstocks, from the summit of which, like shock heads of hair, the long leaves droop. In such a position the plant is raised high above the water of the swamp, having thus made for itself a dry position very much better for its well-being. On the "trunk" of the sedge the long hard-fern (Blechnum capense) finds a congenial home, as well as some small indigenous plants - e.g., the marsh-pennyworts, species of Hyitrocotyle. Swamps are rich in several species of willow-herb, of which the beautiful swamp willow-herb (Epilobium pallidiflonm), the more slender $E$. chionanthum, the creeping $E$. insulare, and the very tall $E$. erectum need mention. Two buttercups, Ranunculus macropus and $R$. rivularis, are common, the latter being distinguished from the former by its more finely cut floating leaves and shorter leafstalks. In the North Island more especially a variety of the common astelia (Astelia nerrosa) may form considerable colonies. 
In certain Auckland swamps there are various rush-like plantse.g., the great spike-rush (Elaeocharis sphacelata), 2 to 3 feet high, distinguished by its stout cylindrical hollow green stems, which are divided by partitions; the common twig-rush (Cladium teretifotium ; : the jointed twig-rush (C. articulatum), taller (up to 6 feet) than either of the preceding, and growing on rather drier ground, whre it forms pure colonies of cylindrical stout stems divided by transverse partitions and produces a brown drooping inflorescence a foot long. There will also be a good deal of the cyperus sedge (Carex pseudo-cyperus var. fascicularis), and the creeping New Zealand burr-reed (Sparganium subglobosum), with its long brightgreen almost three-edged leaves, and its flowers, some male, some female, crowded into rounded heads. The rather rare swampfern (Diyopteris Thelypteris var. squamulosa) may be occasionally met with, but the most common fern of swamps is the long hardfern (Blechnum capense).

South Island swamp contains fewer species than that of the North Island, but it has a few plants of its own, such as the swampbroom (C'armichaelia paludosa) (Westland), a divaricating species of the same genus, also occurring in Westland (probably C. grandiflora vir. diearicata), and the rare climbing-broom (C. gracilis), a scrambling liane. In Stewart Island the coastal jointed rush (Leptocorpus simples) occurs in fresh-water swamp. So, too, has this plant ventured farther inland, or been left behind at some period of its wanderings, on the gravel shores of Lakes Manapouri and Te Anau.

The bog-moss (species of Sphagnum) is the most characteristic plant of bogs. It forms great rounded soft cushions and hillocks of a whitish colour, into which one sinks when walking upon them, and on which many of the bog-plants make their home. Taking the whole New Zealand region, there are about 18 species of Sphagnum, some of which are also Australian.

Sphagnum possesses some characteristics which must be noted here. The outer part of its long stem consists of an external layer of large clear thin-walled cells, lacking leaf-green, but with their walls stiffened by thickenings, and communicating with one another and with the outer world by means of large holes in their walls. Cells similarly constructed are also present in the leaves, but there they are surrounded by a network of very narrow cells containing leaf-green whose colour is masked by the colourless cells. Water is 
rapidly drawn into the stems and leaves through capillarity and held firmly as in a sponge, the capillary spaces between the drooping branches also functioning in this regard.

The surface of a sphagnum-cushion becomes so dry during a period of drought that it is readily set on fire. This fact is strong evidence that a continuous stream of water is not being conducted upwards, by capillarity, from the wet moss or water below. Indeed, a sphagnumcushion is dependent for its water-supply on the rainfall, and can exist only where this is abundant, an excessive precipitation allowing the plant to occupy even a rock-surface. As the upper portion of a sphagnum-cushion grows, its lower part dies and is converted into peat, great masses of which frequently accumulate. Such peat is used for fuel in many parts of the world, and at Waipahi, in Southland, is cut to some extent for that purpose. New Zealand peat in general is formed by many other plants in addition to sphagnum, or this latter may be altogether wanting. The upper surface of a sphagnum hog continues to rise in height through the rapid elongation of the apices of the moss-stem, and any plants growing thereon must, like dune regetation, be able to grow upwards faster than they are buried. The small pine Dacrydium Biduillii, common on subalpine bogs, is frequently buried by the too rapid upward growth of the moss, and may be observed in all stages of burial. On the sphagnum-cushions themselves grow many plants which cannot live under the adverse conditions provided by peat itself, for here they have at their disposal purer water than that of the peat.

Coming next to bogs, it must be first explained that these differ from swamp in that, though the soil is saturated with water at all times of the year, and shallow pools may be present, the whole surface of the ground is not covered with water. Further, swampwater contains more or less lime, but this, of course, is absent in the acid bog-water. The soil consists of peat, which is sometines many feet in depth. The bog-water is coffee-coloured, and contains much organic matter. Those small plants termed "bacteria," some of which play such an important role in adding the all-important nitrogen-compounds to soil in general, are few or wanting in bogs.

Bogs originate in various ways, as, for example, from swamp; through formation of peat under the influence of a wet climate, and on which sphagnum gains a footing; from water lying in wet hollows; from mountain-streams frequently flooding the adjacent ground; 
and from an excessive rainfall in a climate of the subantarctic type. Hence in Westland, Southland, and Stewart Island bogs are common. In the North Island, before the land was drained, there were many bogs on the Waikato Plain, where they originated in the great swamps as peat accumulated. Hollows, too, of the Auckland gumlands are occupied by bog, so that two distinct plant-formations exist on these rather barren areas side by side. In the montane and subalpine belts of the high mountains bogs are a well-marked featire. though from the scenic stand point of little interest (fig. 84). Between swamp and bog there are many transitions. True sphagnum bog may form an " island " in raupo-phormium swamp, as in at virgin swamp near Levin (Wellington). There on the sphagnum the phormium is much more stunted than that in the swanp, and much browner, while species absent in the swamp are commone.g., bracken-fern (Pleridium esculentum).

Although a bog is a station of extreme wetness, for some reason not yet properly understoor the bog-water is not relished by the plants, so that in a considerable number of cases their growth-forms are similar to those of plants living under the driest conditions. To use the scientific term, the bog is " physiologically dry." It is a case of "Water, water, everywhere, nor any drop to drink." The peat of bogs, too, is deficient in such compounds of nitrogen, potassium, and phosphorus as the plant can use-three essential requisites.

Various theories have been put forth-some backed by experiment -to account for the physiological dryness of bogs. The following, amongst others, have been advanced as causes: (1) The lresence of free humous acids in the soil; (2) the lowering of the water-table during summer and the drying of the superficial larers of peat; (3) coldness of soil and evaporation from the leaves increased by drying winds and want of moisture in the air; (4) the low temperature of the soil and its lack of oxygen; (5) the poisonous nature of the peat itself. New Zealand experience shows that on a certain mountain-slope in the North-eastern Butanical District the only place where a koromiko (Veronica salicomioides) of the drought-tolerating whipeord form grew was where its roots could obtain the icy-cold water of a stream. Also, a sphagnum-cushion supports an assemblage of plants which are not nearly so strongly provided with drought-resisting structure 
as that of the adjacent wet peaty soil, probably owing to the moss being saturated with fresh water after rain. Against the theory of cold water being the cause of the physiological dryness of bogs there is the case of dronght-resisting plants being present on the comparatively warm bogs of North Auckland, where frost is unknown, and where the water can never become cold enough to check the action of the roots.

The special structure and many of the growth-forms of bog-plants, as mentioned above, are similar to those of plants of the driest stations. Thus dwarfing is frequent; the manuka, for instance, becomes at times an almost turf-making plant. The swamp-heath (Dracophyllum palurlosim) of the Chatham Islands, and even the purple tree-daisy (Oleariu semidentata) of the same group, bloom when a few inches in height. though under ordinary circumstances the stature of the former is 6 feet and of the latter 3 feet. The cushion form is common on mountain-bogs, as in the alpine donatia (Donatia novere-zelendiae) and the common phyllachne (Phyllache Colensoi). The tussock form, the rush form, the creeping form with an underground stem, and the rosette form all occur on bogs. These and other forms receive some consideration below.

Attention can next be called to certain bog-plants and to the composition of various bog associations. The wire-rush (Hypolaena lateriflorre, a brownish, wiry-stemmed, rush-like plant, is a most characteristic species, and forms from one end of New Zealand proper to the other end extensive pure colonies both on lowland and mountain bogs. So, too, one or other of the smaller umbrellaferns (Gileicheniu dicarpa, G. alpina) by its green colour makes a bog recognizable at a long distance (fig. 82).

Many subalpine bogs are occupied principally by the following: A green cushion-plant, Phyllachne Colensoi; Donatia novae-zelandiae, strongly usembling Phyllacher the common oreobolus (Oreobolus pectimutus), a sedge of similar habit to Donatia, with leaves arranged like a comb); a small celmisa (C'. longifolia var. alpina) and another with broader leares $(C$. glaudulosi $)$; the slender grass Degeuria setifolia: certain plants belonging to the rather rare family Restionaceae -Gaimarlia ciliata, G. setacea, and $(\dot{r}$. pallida, all cushion-plants (fig. 81), and looking like mosses. Here, too, will be in some localities a dense turf formed by a woody plant, the pygmy jine (Dacrydium laxifolium), that smallest species in the world of the pine-tree family: 
but when it grows away from its bog dwelling and has settled on the drier ground it becomes taller and more straggling, though in extremely dry situations it forms close cushions (fig. 3). The following sedges are common denizens of mountain-bogs: The grasslike, small Carex Gaudichaudiana; the common carpha (Carpha (alpince), its leaves 6 inches long, or less, grass-like and stiff; and, where the peat is wet and the conditions approximate to those of swamp, Carex slellulata and C. diandra.

Bogs oceur even on the scoria of the central plateau of the North Island, if water oozes out of the ground in sufficient quantity. In interesting plant of these bogs, but not confined thereto, by any means, is a member of the gentian family (Liparophyllum (iunnii), which has a very thick creeping stem and profusion of tiny whit star-like blossoms. It may be pointed out that this plant is the sole species of the genus, which is found only in this country and 'T'asmania.

The sundews (Drosera) are characteristic bog-plants, and deservi at any rate a passing word. As shown above, the bog-water larks available nitrogen. The small, spoon-like leaves of the sundews are provided with glandular hairs, at the end of which in shining drop of thid may usually be seen. This contains it substance which has the power of acting on animal matter in much the same manner as the gastric juice. Should a small insect alight on a drosera-leaf, it becomes entangled in the sticky fluid, and at the same time the hairs bend over and pin the victim fast. Thus does this tiny plant procure some of its nitrogenous food. All the sundews do not dwell in bogs, and in this case the advantage of the nitrogen-gaining carnivorous habit is greatly discounted. For example, $D$. auriculate is a plant of open manuka shrubland, and climbs over grass-stems and various plants. It can live quite well in a dry place, as it has an underground tuber containing a good deal of water. D. pygmaea may receive mention here on account of its remarkable distribution, it having so far been found only at the two extremes of New Zealand and in the centre of the North Island - viz., on the Bluff Hill, the Waimarino Plain, and in the far north of the North Island. It is a tiny plant, no bigger than one's littlefinger nail, and so may be easily overlooked.

Another plant which can use tiny animals for food must be mentioned, the bladderwort (Utricularia monanthos), a plant with 
small, showy, purple flowers. The bladderworts are quite without true roots, metamorphosed leaves functioning as such. In some instances the leaves develop in another unusual way: they construct themselves into small bladders, which are furnished with a lid, which can open only from without inwards. This leads to an arrangement like that of certain mouse-traps, so that a minute aquatic animal may easily enter the bladder, whence it cannot escape, and is digested in due course by the plant. A beautiful bladderwort ( $U$. delicatula), having white flowers with a yellow eye, grows in certain Auckland bogs. Another species, $U$. novae-zelandiae, found in North Island bogs generally, has pale-purple flowers with a yellow eye. U. protrusa and $U$. Mairii are aquatic species which float on the surface of the water; the latter was a plant found only in Lake Rotomahana, but it was destroyed during the Tarawera eruption, nor has it been since found either there or in any of the other lakes.

Species of the genus Gumera are frequent in lowland bogs. Those near Invereargill contain abundance of $G$. prorepens, which forms blackish mats. The New Zealand species of Gunnerc are quite small-mere pygmies, indeed, in comparison with their luge-leaved Chilian relation $(G$. chilensis) or that giant recently discovered by Skottsberg on the Juan Fernandez Group (G. masafuerae) with leaves 10 feet across. But, notwithstanding this, all equally afford houseroom to a species of Nostoc, a fresh-water alga, somewhat after the manner of Azolla, before described. Perhaps the prettiest denizen of these Southland bogs is the pale-blue grass-lily (Herpolirion novaezelandiae), which, when not in flower, may be mistaken for a grass. A companion plant is Oreostylidium subulatum, ${ }^{*}$ the only species of this purely New Zealand genus. A creeping club-moss (Lyycopodium ramulosum) is frequent in Stewart Island and on the west of the South Island, and farther north the somewhat sinilar $L$. laterale is encountered.

Where streams fiow through the montane low tussock-grassland sphagnum bog of a peculiar kind is common, its presence being at once recognized by the general grey colour given by its dominant species, a tussock-plant with reddish stems at a close view, the false snow-grass (Schoenus pauciflorus). Here, too, in due season, the Zealand. 
association may be resplendent through the multitude of yellow blossoms of the swamp-lily (Chrysobactron Hookeri) (fig. 83). Thr pretty little New Zealand violet (Viola Cuminghamii) grow freely on the sphagnum-cushions, accompanied by the false edelweiss (Helichrysum bellidioides), a pretty willow-herb (Epilobium chlorafolium), the rather insignificant Halorhagis micrantha, and the small Anisntome armmaticu, a rosette-plant of the carrot family with deeply cut leaves.

Montane and lower subalpine bog are easily invaded by tussock, especially the red-tussock (Danthonia Raoulii var. rubra), or shrubs, and then are rapidly converted into tussock-grassland or shrubland, as the case may be. 


\section{CHAPTER IX.}

\section{THE FLORA AND VEGETATION OF THE OUTLYING ISLANDS.}

A goblin forest-The subantarctic flora-Composition of the subantarctic forest -Remnant of an ancient subantarctic tree-formation-Plants of the seashore-The splendid herbaceous plants - Subantarctic tussocks-Vegetation of Antipodes Island-Vegetation of IIacquarie Island-A "wind-desert"Vegetation of the Snares - A natural rotation of crops-The Bounty Islands - Flora of the Chatham Islands-The Chatham Island forestChatham Island bogs-Tho giant forget-me-not-Some interesting Chatham Island plants-Flora of the Kermadec Islands-Lack of tropical species in the Kormadees-Plants peculiar to the group-Rock associations-Ngaio scrub - The two kinds of forest and their trees - The two tree-ferns -.. Luxuriance of New Zealand trees on the Kermadecs.

LANDS of mist and sleet and hail, of fierce squalls born in the icy south; cruel, rock-bound coasts, scenes of brave men's death or of fierce struggles with the angry sea; lands of brown hills, enclosed by thick woods, weird and grotesque-in very truth goblin forests, patrolled and sentinelled by uncouth monsters of the deep: such impression may our far-off subantarctic islands give at first.

A closer view, and scenes more pleasing greet the traveller. Despite the ever-present gales, fields of magnificent flowers clothe the hills in summer-time. Within the forest, beneath the thick entanglement of gnarled and twisted branches of the trees, multi tudes of ferns spread out their feathery leaves into the dim light. The knotted trunks, the fallen trees, the uneven ground--all are thickly covered with a mantle most delicate of translucent filmy ferns. Mounds of exquisite liverworts of many species adorn both forest-floor and boles of trees. Thickets of shrubs abound. All is one close mass of vegetation, save where long bare paths of dark peat lead from the dim recesses of the forest, along which a startled sea-lion may glide, fearful of the intruder, or one at bay greet him with angry roar and open jaws (fig. 85).

It is in the Lord Auckland Islands alone of these lonely southern lands that true forests are to be found. In Campbell Island trees are 
altogether absent; densely growing shrubs clothe the lower slopes and fill the gullies. In Antipodes Island a few lines or patches of shrubs show as dark spots amongst the all-prevailing tussock, while on Macquarie Island woody plants are wanting.

The islands mentioned in the foregoing paragraph, together with the Snares, the Bounty Islands, and Macquarie Island, form the New Zealand subantarctic islands. They lie in the South Pacific Ocean, between the parallels of $54^{\circ} 44^{\prime}$ and $47^{\circ} 43^{\prime}$ south latitude, and $159^{\circ} 49^{\prime}$ and $179^{\circ}$ east longitude. The distance and direction of each of these groups from the South Cape of Stewart Island are respectively: The Snares, 60 miles south-west; the Lord Auckland Islands, 190 miles south by west; Campbell Island, 330 miles south by east; the Antipodes Islands, 490 miles east-south-east; Macquarie Island, 570 miles south-west by south; the Bounty Islands, 490 miles east.

The total number of species of ferns, their kin, and seed-plants for the New Zealand subantarctic islands, taken together, is 188, belonging to $3 t$ families and 89 genera. Taking the groups of islands separately, the number of species in each is as follows: Snares, 22 ; Lord Auckland Islands, 155; Campbell Island, 112 ; Antipodes Islands, 56; and Macquarie Island, 34. With regard to the families, only 3 (the fern, grass, and daisy families) have more than 20 species each. The orchid and sedge families have 11 and 10 species respectively; the rush family has 9 species; the coprosma and carrot families have each 6 species; and the buttercup, willowherb, cress, and chickweed families have each 5 species.

There is a considerable number of endemic species, the total being 53 -i.e., almost 30 per cent. of the flora. Each group of islands possesses its own peculiar species-Snares, 2; Lord Aucklands, 6 ; Campbell, 5 ; Antipodes, 4 ; and Macquarie, 3 . One genus, Pleurophyllum, consisting of most distinct and remarkable species, is endemic. Taking the endemic species as a whole, some 32 have no really near relatives in any part of the earth, so must be considered extremely old. All the remainder have cousins in New Zealand proper, so they or their relatives are of no great age, so far as old age counts in the world of plants.

The forest of the Lord Auckland Islands consists for the most part of the southern rata (Metrosideros lucida), blazing with crimson in the summer-time. The other associated trees and shrubs are the haumakoroa (Nothopanax simplex), the evil-smelling karamu 
(Coprosma foetidissima), the inaka (Dracophyllum longifolium), the divaricating shrubs Coprosma ciliata, C. parviflora, Suttonia divaricata, and, where the forest changes into scrub, the yellow-leaved mountain-cottonwood (Cassinia Vaucillieisii). The extraordinary manner of growth of this association; the close, even foliage of its roof; the twisted, far-reaching branches, semi-prostrate and arching trunks, and consequent lowness of the trees, are plainly the expressions of the tempestuous climate-rigorous enough in many ways, but never really cold. Within the shelter of the forest quite other conditions exist, so here flourish those plants that can exist only in an atmosphere saturated with moisture. As for the affinities of the forest, they are subtropical and not subantarctic. Here, of all places, where a southern-beech (Nothofagus) forest might be expected, it is absent. Before leaving the forest it must be pointed out that at one spot it contains a certain amount of the tree-fern Hemitelia Smithii (fig. 86), and that this locality is the most southerly point in the world reached by tree-ferns.

Above the forest-line comes a scrub-association of the most extreme density, varying in height from 8 to 3 feet. The dominant shrub is Suttonia divaricata. With this is stunted southern rata (Metrosideros lucida), the coprosmas already mentioned, together with Coprosma cuneata, and stunted inaka (Dracopluyllum longifolium). It is thus largely forest stunted to scrub.

In some few parts of these subantaretic islands-namely, on Eming Island of the Lord Auckland Group, to an extremely limited extent on the north of Lord Auckland Island itself, and especially on the Snares-are small woods of another character. These are composed of the truly magnificent tree-daisy (Olearia Lyallii), found only in these islands, but closely related to O. Colensoi of Stewart Island, the Southern Alps, and the North Island mountains. O. Lyallii has great leathery leaves, up to 8 inches in length, which are green on the upper surface but pure white beneath, thus affording a delightful contrast when they are stirred by the wind. Perhaps for this treecommunity the term "scrub-forest" would be more fitting than "forest." Probably this association is a modified remnant of the ancient forest of that latitude and farther to the south, which during the problematical great expansion southwards of New Zealand in later Tertiary times was driven into its present narrow limits by the invading and more vigorous rata forest of the north. The community of herbaceous plants, too, is possibly to be similarly 
accounted for - that is to say, it is a remnant of a subantarctic plant-formation of long ago.

On the Snares, mixed with 0 . Lyallii, is the rare and beautiful small tree the Stewart Island tree-groundsel (Senecio Stevartiae). Strange to say, though this plant also occurs farther to the north, it has not been found on Stewart Island proper, but only on some of the small islands in its vicinity.

Some of the subantarctic seashore-plants are wonderful enough. Here, almost to high-water mark, comes a splendid tussock-grass, Poa foliosa, with broad, green, drooping leaves. On the rocks, almost where the sea washes, are large green cushions of Colobanthus muscoides, hard as those of the vegetable-sheep; and near by will be frequently seen the shining green rosettes of a species of plantainthe Plantago carnosa of the "Flora Antarctica." Close by, where the kelp (Durvillaea utilis) heaves on the restless waters, swims, quite fearless of man, as it has done for ages, the little flightless duck (Nesonetta aucklandica). From the cliffs droop green draperies of a most strange pale-green soft-leaved grass ( $P$ oa ramosissima), while their summits are crowned with great green bushes of the sweetscented shore-koromiko (Ieronica ellipica). On the flat rocks beneath stands, sentinel-like, the Auckland Island shag (Phalacrocorax Colensoi), conspicuous with its glistening black back, spotless white breast, and flesh-coloured feet; and accompanying it is the pretty little mackerel-gull (Larus scopulinus), with dove-coloured back, white head and breast, and brilliant red legs and beak.

The herbaceous plants are the special glory of the subantarctic islands as a whole. Sir Joseph Hooker declared long ago that outside the tropics no such floral display is to be seen in any area of the same size. Several of these plants have exceptionally large and handsome leaves, amongst which one wallis knee-deep (fig. 88). The monarch of all is a majestic plant of the daisy family (Pleurophyllum speciosum), this genus being purely subantarctic, though related to the asters of gardens. The leaves of this plant are of great size, and all are corrugated. In colour and general appearance they somewhat resemble pale-green velvet or plush, and are so arranged at times as to look like shallow goblets. These leaves alone are striking enough ; but when the beautiful purple flower-heads, each 2 inches in diameter, are raised 3 feet above the foliage, dozens at a time, side by side, the spectacle is magnificent. There are perhaps three other species 
of the same family. One of these ( $P$. criniferum) is a taller plant than $P$. speciosum, and has thinner, more erect leaves, which die to the ground in winter. The massive flower-stalk is 5 feet high, but the flower-heads are purplish-brown and not particularly showy (fig. 88). A third species (P. Hookeri), with silvery leaves just tinged with green, dotting the upland meadows as far as the eye can reach, is a charming-enough sight. But how intensified is the beauty of the herb-field when there are present in large numbers, and also in full bloom, a fine yellow buttercup (Ranunculus pinguis); gentians pink, violet, and crimson (Gentiana cerina); the straggling shrubby Veronica Benthami, exquisite with its blue flowers; the gorgeous orange-coloured swamp-lily (Chrysobactron Rossii); the prince of forget-me-nots, its blossom ultramarine (Myosotis capitata), perhaps the most beautiful plant in the New Zealand flora; and mats of the stiff rosettes of Celmisia vernicosa, bearing many fine flower-heads with purple centres and white rays, while the leaves are like polished greenstone. Other magnificent plants are two of the carrot family, with great masses of close-growing purple blossoms (Anisotome latifolia and $A$. antipoda), the former with leaves reaching to the middle of one's thigh; and the herbaceous araliad, Stilbocarpa polaris, whose massive creeping stem afforded, in 1907, a valuable food for the unfortunate castaways of the "Dundonald." Attention must also be called to Cotula plumosa, a plant with creeping stems and pale-green leaves, 6 inches long, feathery, and aromatic. There is also the closely allied $C$. lanata, which is frequently a plant of the seashore. Blackish patches of the prickly shield-fern (Polystichum vestitum) in many places contrast with the varied greens.

The tussocks rank with the forest and the herb-field as an astonishing feature of these New Cealand subantarctic islands (see frontispiece) Their habit is that of the niggerhead, described in Chapter VIII. On Antipodes Island and in some parts of the Lord Auckland Group they are in many places quite 4 feet high, and grow so closely that to make any progress at all one is compelled to walk upon their tops. On Antipodes Island these tussocks take the place of arborescent growth, and it is curious to see the little green parrakeet peculiar to the island (Cyanorhamphus unicolor) perched and swaying on the drooping grass-leaves. Where the tussocks are lower, the wandering-albatross (Diomedia exulans) rears its young, bringing daily from the ocean the supply of food. Here, too, the 
baby birds, clad in downy robes of snowy whiteness, each seated on its flat, cheese-shaped nest, brave for months the piercing antarctic blasts, until their time shall come to seek the white-topped waves and follow in the wake of the great ships.

Seen from the sea or from an eminence, a brown covering appears to clothe the whole surface of Antipodes Island, save where it is traversed by irregular dark lines-these indicating the presence of low coprosma scrub or of the prickly shield-fern (Polystichum vestitum) -almost a tree-fern with its short stout trunk. The brown covering denotes the close-growing tussocks of Poa litorosa, which, in dense ranks, occupy nearly the whole island. At first, as mentioned above, the tussocks are raised 4 feet high or more on their trunks, but they decrease in size according to the distance from the sea, while more and more abundant becomes the prickly shield-fern. When these dominating plants decrease to a reasonable size other species join the association, especially Anisotome antipoda, with its leaves bright green and much cut; the antarctic piripiri (Acaena Sanguisorbae var. minor), of a pale bluish-green hue; and the water-fern (Histiopteris incisa), of a tender green. Where there is open ground certain lichens put in an appearance-e.g., Sticta Freycinetii and other leafy species of that genus, together with several species of Cladonia, and Usnea articulata. Liverworts and mosses, and the filmy fern Hymenophyllum multifidum, are also abundant on the wet peat.

Perhaps the most interesting association of Antipodes Island is bog, since it so clearly demonstrates the selective power of deep peat saturated with water. This comes out in an especially striking manner, as the choice of plants is limited to the small flora of the island. In such bog tussock-grass is virtually absent; the great palegreen leaves of Pleurophyllum criniferum and the grass-like Carex ternaria - this the dominant plant-mark off, at a glance, bog from boggy tussock-grassland. Certain plants-some of stately form-are more abundant in the bog than in the grassland, especially Anisotome antipoda, Stilbocarpa polaris, Coprosma repens, and C. cuneata. The filmy fern Hymenophyllum multifidum forms close patches of greenery.

Where the ground is heavily manured by the giant petrel (Ossifraga gigantea) grows a fine herbaceous groundsel peculiar to the island and with no near relative elsewhere-Senccio antipodus. Associated with this striking plant are thick masses of the antarctic piripiri (Acaena Sanguisorbae var. minor) mixed with the water-fern 
Histiopteris incisa, and, on the barest ground, the Antipodes chickweed (Stellaria decipiens var. angustata).

Although Macquarie Island belongs to Tasmania, biology derides political boundaries, and emphatically declares the island in question to be three-fourths New Zealand and the rest Fuegian. This latter claim is specially emphasized by the immense cushions of Azorella Selago, the Fuegian rival of our vegetable-sheep, but a plant of the carrot family.

Although the number of species is considerably less-at most 34 - than that of any other subantarctic island except the Snares, the flat ground near the sea, the swamps, and the hillsides have, through the prevalence of Poa foliosa tussock, Stilbocarpa, and the silvery Pleurophyllum Hookeri, somewhat the same general appearance as that of the other islands. But at a height of some 300 feet the scene is changed-the wind has there the mastery. Here is the late Mr. A. Hamilton's description of this "wind-desert," as it may be called :-

"At about 300 feet you gain a plateau so swept by the antarctic gales that vegetation is reduced to compact closely growing mosses, small uncinias, and the compact cushion-like masses of Azorella. Selago. In the hollows of the uplands are countless little tarns or lakes, some of considerable extent. Round the tops of the hills the wind has cut out wonderful terraces from a few inches to a foot or two in height, with completely bare rock, much disintegrated at the top. In some of the more sheltered places or gullies stunted plants of Stilbocarpa and Pleurophyllum cover the ground."

Distant only 65 nautical miles from Stewart Island, the flora of the Snares is a connecting-link between that of Stewart Island and the flora of the other New Zealand subantarctic islands. It is an apology for a flora merely, the full number of its species of seed-plants and ferns being but 22. Still, two of these, both most striking plants-Anisotome acutifolia and Stilbocarpa robusta-occur nowhere else in the world. Further, though there are only so few species, climate, soil, and penguins have sorted them out into the welldefined plant-formations-scrub-forest, tussock-grassland, and several coastal associations.

On the Snares there are extensive colonies of the Victoria penguin (Cataractes pachyrhynchus), many hundreds being congregated into one place (fig. 87). Where a penguin colony has occupied the ground for some time it kills out every plant, and there is only an area of mud and filth encircled by a wall of tussocks. Ultimately the area 
is abandoned by the birds, and the highly manured ground stands ready for plant-colonization. This is evidently fairly rapid. The first plant to settle on the abandoned land is the succulent-leaved Crassula moschata, usually a plant dwelling on saltish ground, which, stimulated by the enormous amount of available nitrogen, forms great patches 12 yards or so across. There may also be a cushion or two of Colobanthus muscoides - a plant elsewhere growing only on rocks drenched by sea-spray! As the manure becomes less powerful, the tussock-grass Poa foliosa gains a footing, and in course of time grasstand is re-established. If the number of penguins in proportion to the size of the islands be taken into account, there can be no doubt that through their agency the plant-covering has been destroyed and restored again and again. Even the scrub-forest of Olearia Lyallii and Senecio Steuratiae can have no chance of reinstatement, when once the trees die, so long as the penguins are present.

These subantarctic islands offer another interesting example of a natural rotation of crops. Thus Disappointment Island, in the Lord Auckland Group, the scene of the terrible "Dundonald" wreck, is the home of countless mollymawks (Diomedia melanophrys). Cast your eye over the dreary landscape and you will see brown grassland dotted with wlite birds, and here and there patches of vivid green. This last arises from the presence of the antarctic piripiri (Acaena Sanguisorbae var. minor). As the tussock, with its accompanying plants, is slowly but surely destroyed by the many generations of birds, the piripiri takes complete possession of the bare ground, thanks to its colonizing-power, for the barbed fruits adhere to the feathers of the young birds, and so are spread broadcast. The antaretic piripiri is really quite a rare plant in the tussock-grassland, and so there is here a remarkable example of a plant originally of little importance becoming, in a virgin vegetation, virtually a weed. But tussock will finally again predominate, and gradual alternate destruction and rejuvenation of the vegetation will always be in progress - a natural rotation of crops indeed, thanks to the presence of mollymawks.

There yet remain for mention the Bounty Islands. So far as plant-life goes, their description is easy. Indiarubber-like masses of that great seaweed the bull-kelp (Duvillaea utilis), here yellow in hue, cover the rocks between the tide-marks, while, where the sea cannot reach, the glistening granite of these lonely isles is dimmed only here and there by the green stain of an alga, their sole land-plant 


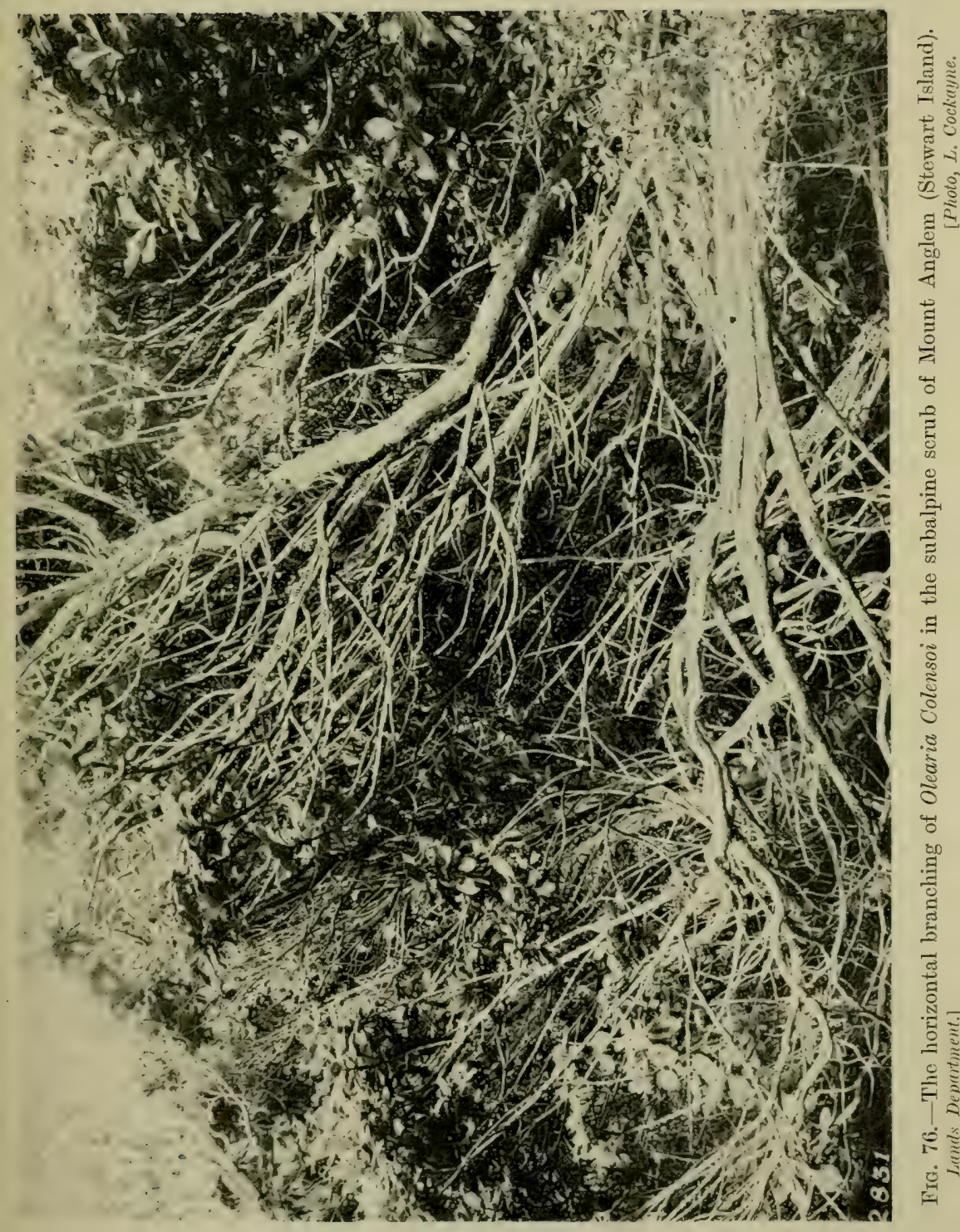




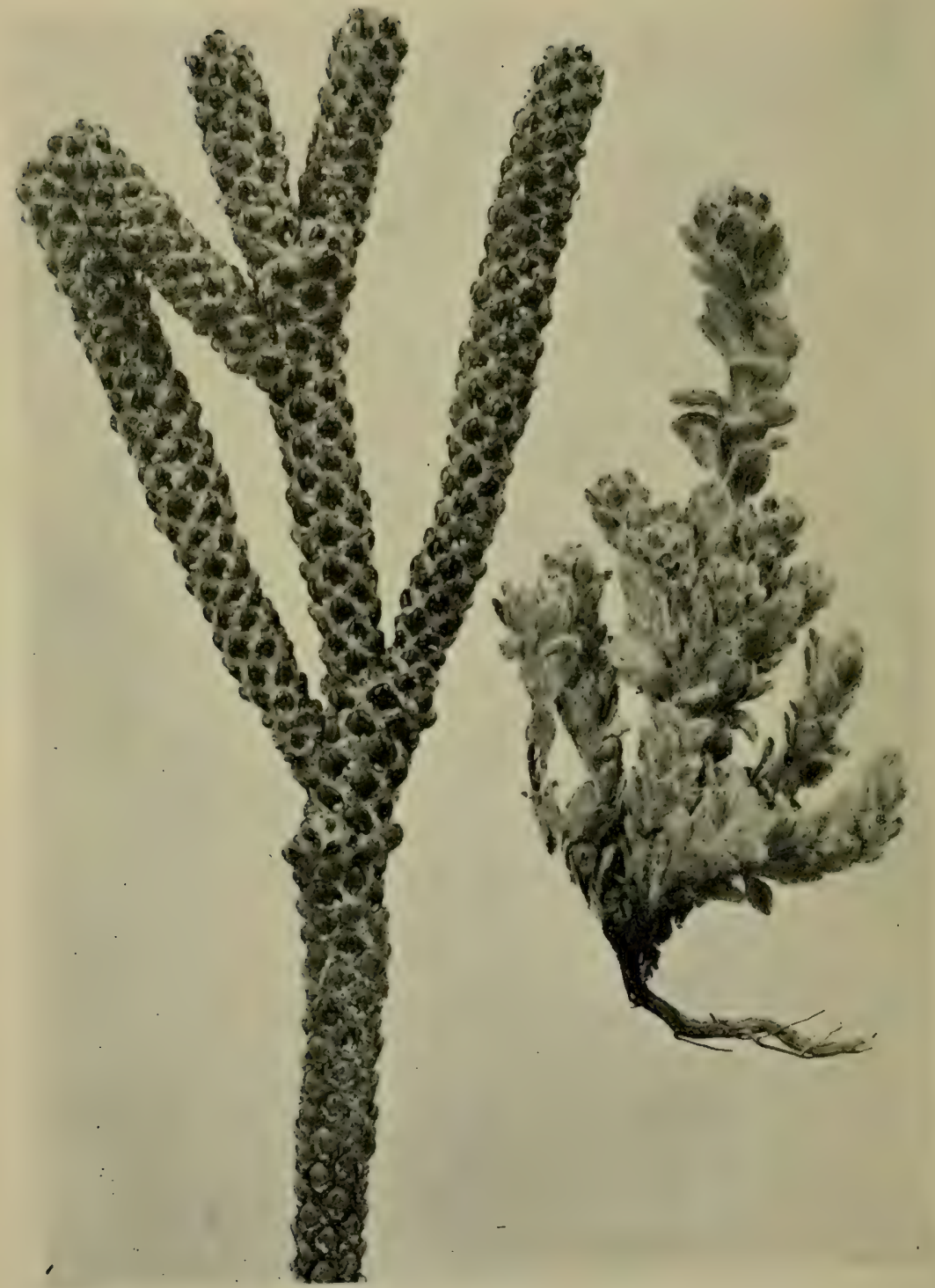

Fic. 77.-On left, adult shoot of the coral-shrub (Helichrysum coralloides), showing the greatly reduced leaves; on right, the young plant of the same species (recently discovered by the author on the Inland Kaikoura Mountains) with true spreading leaves.

[Photo, E. Bruce Levy. 


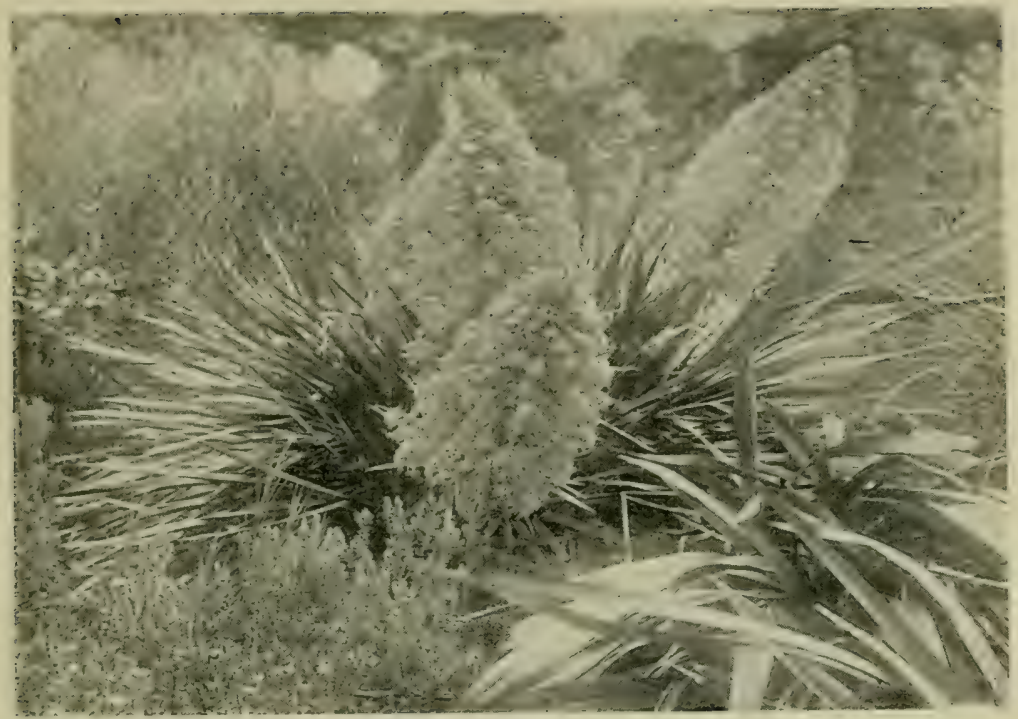

FIG. 78.-The giant spaniard (Aciphylla maxima) in full bloom. Subalpine serub of Arthur's Pass.

[Photo, L. Cockayne.

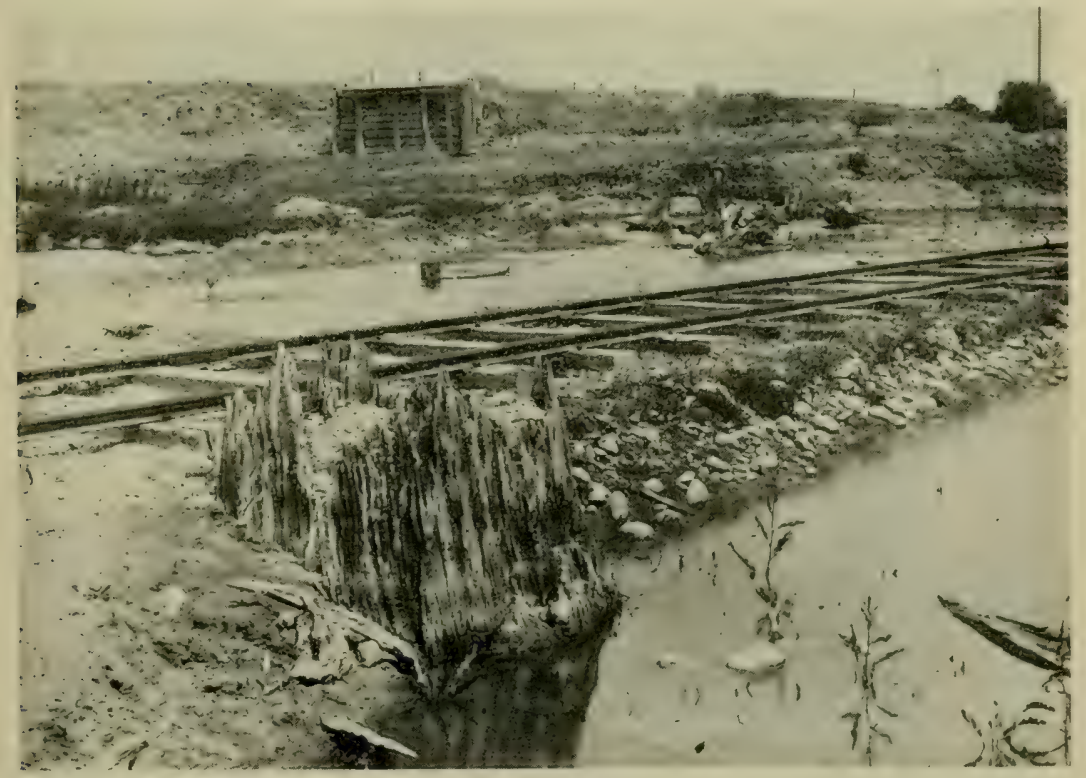

FiG. 79. - A tree-stump (one of many-the remains of an ancient swampforest) unearthed through digging a gravel-pit on the Canterbury Plain near Christchurch. 
visible to the naked eye. During part of the year these desolate rocks are a scene of busy life. Penguins in apparently countless hosts stand in close array from base to summit of the islands. Furseals (Arctocephalus Forsteri) bask on the warm rock, which everywhere by them and by the feet of former penguins is polished smooth as glass. Here, too, the mollymawk makes its curious nest of penguinquills and guano, and beneath the stones in the latter at winter-time, and perhaps all the year round, is teeming life of beetles, amphipods, and spiders. Probably these islets are a remnant of a much larger land area, and the alga not the forerunner of a future vegetation but the last survivor of one long passed away.

At a distance of about five hundred miles from the coast of New Zealand, and almost due east from the port of Lyttelton, lie the Chathams. This group has a flora and vegetation quite as interesting as its subantarctic sisters, but, owing in part perhaps to the milder climate and more northerly situation, of a different character. Subantarctic grassland, fields of herbaceous plants, rata forests-all these are absent. A tree-community of another character flourishes, distinct, too, from any other of New Zealand. The trees themselves have a very familiar appearance; they look like old friends, but one hesitates to greet them as such. Surely this is the common koromiko; but never did one see that as a tree 50 feet in height. Here is the lancewood, but where is the well-known juvenile form ? Here, too, is the korokio taranga of the northern North Island, yet its leaves seem larger and its yellow fruits bigger. The truth is that long isolation from the New Zealand mainland has, in some way or another, led to slight differences between many Chatham Island and New Zealand plants. They have certainly come from a parent stock-perhaps one or the other is the actual parent; but now, although most closely related, they are for the most part distinct enough to be considered species. The lancewood is neither of the two varieties of Pseudopanax crassifolium, nor is it $P$. ferox-it is $P$. chathamicum; the koromiko is not Veronica salicifolia-it is V.gigantea; while the korokio taranga is named Corolia macrocarpa, and in its larger fruit and broader leaves is distinct from $C$. buddleoides of the North Island.

Coming now to the flora of the Chatham Islands, the total number of species of ferns, their kin, and seed-plants is 236, belonging to 55 families and 140 genera. The most important 
families, together with the number of species in each, are as follows : The fern family (49), the daisy family (23), the sedge family (20), the grass family (13), the orchid family (12), the willow-herb and carrot families (each 10), and the koromiko, fat-hen, and coprosma families (each 5). With regard to endemism, there are 2 endemic genera-Myosotidium and Coxella, the latter genus belonging to the carrot family and allied to Aciphylla-and 31 species (including certain more or less well-marked varieties), but 20 of these are extremely closely related to species of New Zealand proper. This New Zealand relationship is emphasized by the fact that, with the exception of the comparatively few endemic species and one or two others, the remaining species belong to New Zealand, where a large majority are quite common.

Forest still occupies a good deal of the Chatham Islands, though much has been destroyed and replaced by artificial grassland. The commonest of the forest-trees is the karaka, called in the Chathams kopi (Corynocarpus laevigata), whose smooth bark was frequently adorned with a figure of a three-fingered man by the Moriori artists (fig. 92), who possibly, like children, found it simpler to draw three fingers than five. Then come the Chatham matipo (Suttonia chathamica), the Chatham mahoe (Hymenanthera chathamica), the Chatham akeake (Olearia Traversii), the tree-karamu (Coprosma chathamica), the Chatham lancewood (Pseudopanax chathamicum), the Chatham ribbonwood (Plagianthus chathamicus), and the nikau (Rhopalostylis sapida). There are two distinct classes of forests on the island-one, where the kopi is dominant, of a coastal character, and another, that on the higher ground, containing fewer species, and having the Chatham tree-heath (Dracophyllum arboreum) as its dominant tree and the kopi absent. The forest on limestone near the great lagoon (Te Whanga) is also somewhat different from either of the above classes of forest, since there alone is to be found the Chatham kowhai (Sophora chathamica).

There is no shrubby undergrowth in the Chatham Island forest, but tree-ferns and ferns of all kinds similar to those of New Zealand proper are very abundant. The only lianes are the supplejack (Rhipogonum scandens), the climbing-convolvulus (Calystegia tuguriorum), and the broad-leaved puliepuhe (Muehlenbeckia austratis). Many most characteristic New Zealand forest-trees are absentc.g., all the taxads (Dacrydium, Podocarpus, and Phyllocladus), the 
southern-beeches, the cabbage-trees, and the pittosporums. Even a shrub so ubiquitous as the manuka (Leptospermum scoparium) is extremely rare.

The despair of the settler and the delight of the flower-lover are the very numerous bogs of the Chatham Islands, in which there is frequently an abundance of sphagnum moss (Sphagnum antarcticum var. ericetorum). These are frequently occupied by a close growth of the purple-flowered tree-daisy (Olearia semidentata), a truly lovely shrub in every respect. Covered in the summer-time with flower-heads of the most intense purple, these olearia shrubberies are an entrancing spectacle (fig. 90). The Chatham tree-daisy (Olearia chathamica) is not so common, but it occurs in quantity on the summit of those precipitous cliffs forming the south coast of Chatham Island; it is taller and more robust than $O$. semidentata, and its flowers are white. Growing in company with $O$. semidentata is the swamp-heath (Dracophyllum paludosum), a needle-leaved shrub 3 or 4 feet high, of erect, tapering, rather pyramidal growth.

The wettest bogs are occupied by a restiaceous plant called Sporodanthus Traversii, the genus being confined to New Zealand. The plant itself increases at a great rate by means of its stout creeping stems; these put forth very smooth dull-brown stiff but flexible woody leafless rush-like stems 6 feet or more high, but sometimes so bent to the ground that one can walk upon them. Frequently the Sporodanthus is entangled with Olearia semidentata and Dracophyllum paludosum. Where the association is more open considerable breadths of the bog umbrella-fern (Gleichenia dicarpa) put in an appearance, as in New Zealand lowland bogs in general. In New Zealand proper, Sporodanthus was originally common in certain bogs of the Waikato; it is also to be found in the far north of the North Island, near Kaitaia.

In the neighbourhood of these olearia bogs the margin of the forest often consists entirely of the rautini (Senecio Huntii), a magnificent tree-groundsel related to $S$. Stevartice of the Snares, which produces pyramidal bunches of yellow flower-heads 5 inches long, and has fair-sized aromatic pale-green leaves 4 inches long in semi-rosettes of about twenty leaves at the ends of its stiff, bare, brittle twigs. For many hundreds of yards at a time this girdle of the tree extends, forming, when covered with its golden blossoms, a gorgeous mass of colour, for flowers and leaves are in about equal proportions. 
Within the forest is a second endemic needle-leaved heath, the tree-heath (Dracophyllum arboreum), remarkable in two ways; for, first of all, it usually begins its career as a perching-plant on a tree-fern, and next it has a juvenile form, which it maintains for many years, with leaves far broader than those of the adult. Moreover, from even high up in the tree, late in life, it may revert again to its broad-leaved juvenile stage. When fully grown it has a short, thick trunk, spreading branches, and is about 30 feet in height.

The most famous of all the Chatham Island plants is the giant forget-me-not (Myosotidium nobile) (fig. 2), usually called by the absurd name of Chatham Island lily, or, what is worse, Macquarie cabbage! This wonderful plant, found nowhere else in the world, is now almost extinct. Formerly it extended, according to the late Mr. F. A. D. Cox, almost round the main island, forming a broad belt on the seashore, just above where the dry seaweed marks the high-tide limit. The massive, shining, broad, green rhubarb-like leaf-blades, a foot or more in length, raised high from the ground on stout leaf-stalks, and the numerous blue flowers, each half an inch or so in diameter, render this plant a most conspicuous object. The seeds germinate rapidly if fresh, and seedlings are raised with the greatest ease. The author has long thought this noble plant might easily be naturalized on certain North Island shores-for instance, on those of the Little Barrier and Kapiti. Near the Portobello Fish-hatchery it has been introduced and is growing Iuxuriantly. Surely some effort could be made to fence a piece of the Chatham Island shore from sheep and pigs, so that this rare, interesting, and most beautiful plant could once more reassert itself in its natural station.

Other interesting Chatham Island plants which, except the sedge, are endemic are the mutton-bird plant (Cotula Featherstonii), which grows only near the holes of the petrels, and its near relative C. Renwickii, hitherto recorded only from the Forty-fours, a small group of rocky islets ; the shrubby speedwells, Veronica Dieffenbachii, $V$. Dorrien-Smithii, V. Barkeri, and V. chathamica, this latter a charming little plant, of which there are many distinct forms, which creeps over rocks close to the sea; the great sowthistle (Sonchus grandifolius), which grows on sand-covered ledges of rock near the sea, or at times on the dunes; the bog-poa (Poa chathamica) an important fodder plant; the Chatham cranesbill (Geranium Traversii), of which there 
are white and pink varieties; the swamp-matipo (Suttonia Coxii), a shrub with pretty mauve fruits; the Chatham gentian (Gentiana chathamica); two spear-grasses, Coxella Dieffenbachii, a genus confined to the Chathams, and Aciphylla Traversii; a sedge which is also subantarctic South American (Carex Darwinii var. urolepis); and the Chatham mingimingi (Cyathodes robusta), which forms rounded bushes on dry ground, and in autumn is covered with white or red "berries" (fig. 94).

Science is indebted to Mr. T. F. Cheeseman, in the first place, and, in the second place, to Mr. W. R. B. Oliver, who much more recently spent a year in the group, for a considerable amount of information regarding the Kermadec Islands, the only truly subtropical portion of the New Zealand Botanical Region.

From the subantaretic islands to the subtropical Kermadecs (lat. $29^{\circ} 15^{\prime}$ S.) is a long step, and yet the dominant tree in the latter is also a Metrosideros ( $M$. villosa), a near relation, however, of the pohutukawa and not of the southern rata. But with this the similarity between the two botanical provinces ends, except that both are of volcanic origin; and, generally speaking, there is no more outward resemblance between the plant-forms than there is between the climates.

As seen from the sea, there is nothing in the appearance of the plant-covering of the Kermadecs to recall the tropics. For instance, no feathery coconut-palms fringe the shore, nor is even the mangrove present. On the contrary, the rather dull hue of the ordinary New Zealand foliage, as seen from a distance, is everywhere manifest.

Sunday Island (distant from the North Cape of New Zealand about 625 miles), the largest of the group, is forest-clad, while Macauley Island is almost entirely without arborescent growth owing to the depredations of the goats placed there a number of years ago, and in its place is a close-cropped pasture of beard-grass (Polypogon monspeliensis). The whole group is of volcanic origin, as stated above, and the small Curtis Islands are still in the solfatara state, with hot mud, boiling pools, and sulphur.

A certain number of tropical plants have reached the Kermadecs, but not to the extent that might be expected. Amongst these are one or two ferns (e.g., Nephrolepis cxaltata, Asplenium caudatum, A. Shuttleworthianum), Cenchrus calyculatus, Ipomaea pes-caprae (which forms the well-known plant-formation on so many tropical shores), 
Metrosideros villosa, Canavalia obtusifolia (a climbing leguminous plant), Ageratum conyzioides (which bears the name of cherry-pie or wild heliotrope), Aleurites moluccana (the candlenut of the Polynesian Islands) - these last two introduced-and also some grasses.

Certain plants are peculiar to the group. Amongst these are two coprosmas, C. petiolata and $C$. acutifolia, the former closely related to $C$. chathamica of Chatham Island, C. retusa of the North Island of New Zealand, and C. Baueri of Norfolk Island; Suttonia kermadecensis, related to a Norfolk Island plant; Ascarina lanceolata, a tall shrub or small tree; Boehmeria dealbata, a small tree of the nettle family; the Kermadec nikau (Rhopalostylis Cheesemanii); the Kermadec koromiko (Veronica breviracemosa); Scaevola gracilis, a semi-woody plant with prostrate spreading branches; Homalanthus polyandrus, a tree of the spurge family; and two fine tree-ferns, Cyathea Milnei and one discovered by W. R. B. Oliver and named by him C. Kermadecensis (fig. 91).

The rank and file of the plants are such as would be met with in the North Island-for example, the karaka, ngaio, wharangi (Melicope temata), mahoe, tutu, ivy-tree (Nothopanax arboreum), and others mentioned below. In fact, about four-fifths of the small flora of $11 \pm$ species consists of ordinary New Zealand plants.

Coming now to the vegetation of the coastal rocks, the most important plants dwelling thereon number but fifteen, including the New Zealand ice-plant (Mesembryanthemum australe), the shorespleenwort (Asplenium obtusatum), the primulaceous Samolus repens var. strictus, the wild celery (Apium prostratum), the mariscus-sedge (Mariscus ustulatus), the New Zealand spinach (Tetragonia expansa), the shore-lobelia (Lobelia anceps), and the common club-rush (Scirpus nodosus) - a rush-like tussock. The New Zealand appearance is also increased by the shrubby Coprosma petiolata hugging the rock after the manner of the well-known taupata (C. retusa) of New Zealand.

Talus slopes at the foot of sea-cliffs are usually densely covered with tussocks of the mariscus-sedge (Mariscus ustulatus) 3 feet or so high-a stout sedge with broad, hard, shining leaves; a true sedge, Carex semi-Forsteri; certain ferns ; and the ngaio (Myoporum lactum), but only as a shrub. These talus slopes are far from being stable. Also, instability is brought about on other slopes, made up out of weathered volcanic tuffs, through the action of the burrowing petrels and shearwaters, these slopes being their breecing-ground. Hence on 
the latter the Mariscus and its associates again occur-one and the same association owing its distribution to two distinct causes, one geological, the other biological.

A rather important plant-association is the girdle of ngaio scrub along the coast, especially where there is a space for its occupation and development between the cliffs and high-tide mark. The principal members are-the ngaio (Myoporum laetum), the kawakawa (Macropiper excelsum var. major), the climbing-gourd (Sicyos austratis), the mariscus-sedge (Mariscus ustulatus), the leguminous Canavalla obtusifotia, Carex semi-Forsteri, the fern Pteris comans, and, close to the sea, tussocks of Scirpus nodosus.

By far the most important plant-formation of the group under consideration is the forest, which falls into two associations-viz., the one where the driest conditions provided rule, and the other occurring at higher elevations, where the climate is wetter. Dry forest is distinguished by the presence of Metrosideros villosa as the dominant tree, whereas in wet forest no special tree is dominant. The more important trees and shrubs of the Kermadec forest are the following: Metrosideros villosa, a tree 70 feet high or more (aerial roots pass off from the lower part of the trunk and finally enter the ground and function as stems); the karaka (Corynocarpus laevigata), also a tall tree; the ngaio (Myoporum laetum), equal in height to the other tall trees; the mahoe (Melicytus ramifloms), a small tree in dry forest but a massive bushy tree where rain is abundant; the endemic Rapanea kermadecensis, a small tree; the endemic Ascarina lanceolata, a tall shrub or small slender tree; the wharangi (Meticope ternata), a small tree with leaves larger than those of the same species in New Zealand proper; the endemic Coprosma acutifolia, a small slender tree; the Kermadec nikau (Rhopalostylis Cheesemanii). The two endemic treeferns are often in abundance, Cyathea kermadecensis, 70 feet high, sometimes making extensive colonies in wet forest (fig. 91), while C. Milnei is more characteristic of dry forest.

It will be seen from the above brief account of the forest that the warm, humid climate of the Kermadec Islands, to which the forest owes its existence and luxuriance, is reflected also in the luxuriant growth of certain trees-e.g. the karaka (Corynocarpus laevigata), the mahoe (Melicytus ramiflorus), and the ngaio (Myopomm lactum)-which far exceed the height they attain in New Zealand. 


\section{CHAPTER X.}

\section{THE EVOLUTION OF A NEW FLORA AND VEGETATION.}

General remarks - Number of foreign plants growing wild in New ZealandOrigin of the plant aliens-Statistics regarding the families, genera, and species of the invaders - The comparative rareness of most introduced plants-No foreign plants in the primitive plant-formations-Classification of plant-associations at the present time-Names for the different classes of associations, and their definition-Subdivisions of the induced associations - Some modified associations--.Modified grassland-Modified duno-hollowsModified salt-moadow-Modified forest-Indigenous induced associationsDanthonia grassland--The depleter? grassland of Central Otago-Rejuvenation of subalpine scrub--History of commercial phormium swamp-Other indigenous induced associations - Adventitious associations - Tree, shrub, herb, and water associations - Hakea on the gumlands - Origin of a gumtree association-The foxglove spreading-Distribution according to habitat —Something about weeds.

If the floras of Europe and temperate Asia be considered, where through century after century the influence of man has reacted on the plant-life, it seems clear that in a surprising number of cases it is impossible to say with any degree of certainty that such-and-such a species is truly indigenous. Take a flora of Great Britain for example, open it haphazard, and see what unnatural habitats are frequently cited for the species, such as fields and waste places, waste places near gardens, meadows and commons, river-banks and osier beds, wall-tops, sandy fields, hedge-banks and roadsides, copses, and cornfields. But there is no need to multiply instances. Evidently any attempt to explain how such European floras have attained their present proportions must be mainly guesswork. Still more difficult must it be to attempt in Britain or similar countries to reconstruct the primitive plant-covering such as it was before man had taken a hand in its distribution.

Now, in New Zealand the state of affairs is quite different. If an indigenous plant is found in a hedgerow, a meadow, or a waste place, every one knows it is growing in a situation into which it has been driven by the influence of man. It is also known, with only three or four exceptions at most, what species are truly indigenous, and so, too, what vegetation is really primeval. 
Since the advent of the British, however, a great change has overtaken the vegetation. The number of species growing wild, and which will continue to grow wild, has increased to such an extent that no one, however well versed in floristic botany, had he not New Zealand botanical literature for a guide, could possibly say whether this plant, or that, was indigenous or the contrary. To such a degree have certain foreign species entered into plantassociations of an apparently primitive stamp, such as tussockgrassland, swamp, rock associations, manuka thicket, or sandhill, to quote a few examples, that these foreign species appear just as much parts of the association as do the indigenous plants themselves.

Thus it is clear that, dating from the first visit of Captain Cook, a new flora and a new vegetation has been arising in New Zealand, at first slowly, but later by leaps and bounds, and that its evolution is still in progress. Carefully conducted inquiries into this matter are of the greatest scientific and economic interest not only with regard to New Zealand botany, pure and applied, but also because they may shed much-needed light upon the evolution of floras and vegetation in general.

The foreign plants now growing wild without cultivation have come from many lands, but by far the greater part are, as in the case of the human colonists, natives of Great Britain and Ireland. There are also Australians, North and South Americans, Africans, and Asiatics. Even some New-Zealanders have moved to distant parts of the botanical region far from their real home. Unlike the ancestors of the true New Zealand plants, the aliens were not borne hither by winds or birds over the ocean. Neither did they travel slowly over ancient land-extensions now submerged, nor have they originated in New Zealand itself, but the ships that conveyed the human immigrants or their goods brought the plants also. Some species were purposely introduced for their economic or ornamental vilue; others came unbidden as impurities in agricultural or garden seeds, in ballast of ships, in the hay or straw packing of goods, and in other ways. So thoroughly has the acclimatization of these plants succeeder that there are now about 520 species more or less firmly established, some 276 of these being more or less common from the North Cape to the Bluffi, while a few are quite at home even on the highest mountains. Other species may be expected to come in course of time, but some that have arrived may die out, whil 10-Plants. 
others will get a firmer hold upon the land; cases of these kinds are being recorded yearly.

The seed-plants which have gained a more or less firm footing are a most varied assemblage. They belong, indeed, to no fewer than 68 families and 279 genera. Certain of these families are not represented in the indigenous flora -c.g., the willow family (Sali('rceae), the poppy family (Papaveraceue), the mignonette family (Resedaceae), the valerian family (Valevianaceae), the teasel family (Dipsaceae), and some others. Most numerous of all with regard to the species they contain, as might perhaps be expected, is the grass family (Gramineae), 83 species, which surpasses in number even the great daisy family (Compositae), 67 species. Then come the pea family (Leguminosae), 44 species, and the ress family (C'rnciferae), 34 species. Other fairly large families are those of the chickweed (Caryophyllaceae), 26 species; sage (Labiatae), 21 species; koromikn (Scrophulariacene), 17 species; dock (Polygonacene), 14 species; buttercup (Rannonlacene), 13 species; rose (Rosacene), 13 species; potato (Solanaceac), 13 species; carrot (Umbellifercue), 12 species: and forget-me-not (Boraginaceae), 10 species. On the other hand, some families are represented by only 1 species -e.g., the gentian (Gentianaceae), the primrose (Primulaceae), the periwinkle (Apocynaceae), and the pokeweed (Phytolaccaceae).

With regard to the genera, the following contain the most species . Clovers and trefoils (Trifolium), 15; buttercups (Ranunculus), 11 ; brome-grasses (Bromus) and wild-turnips (Brassica), 8 each; docks and sorrels (Rumex), 7 ; and plantains (Plantago) and vetches (Vicia), 6 each.

At first thought, the idea of 520 different sorts of plants-some of them the most aggressive weeds in Europe-having not only been loosed to do their will, but also having established a secure footing, would lead to the conclusion that, if not the flora of New Zealand, at any rate the primitive vegetation was doomed. No conclusion could be more incorrect. Were it not that man has changed, and is changing, the face of nature by means of his farming operations, his grazing-animals, his fires, his drains, and his exploitation of the rain-forest and the flax-swamp, the host of foreign plant invaders would be powerless-the indigenous plants, attuned to the special life-conditions of their native land, would laugh these aliens to scorn. Why, even now, when the introduced plants have 
man as their potent ally, 66 per cent. of the species are rare or local, 40 per cent. being so rare as to be negligible, while merely 34 per cent. can be classed as extremely common, common, or fairly common, these being taken together.

In order to get a true estimate of the actual position of the plant invaders it is necessary to go into this matter of commonness and rarity from another standpoint-that of distribution with regard to soil and other conditions. Thus what is called "waste ground" -e.g., sides of roads, neglected building-sites, and rubbish-heapsis occupied by about 355 species, some 255 of which are confined thereto. Add to the latter 60 species restricted to cultivated lancl, and it is plain that 60 per cent. of the invaders do not molest in the slightest degree the indigenous plant inhabitants. But even this estimate is far too low, for there are 102 pasture-plants which do not invade the natural unploughed lands. In short, there are probably only about 100 species which are established on land where the vegetation would be, in their absence, exposed to modification only by grazing, fire, and other causes due to the influence of man. The warfare, indeed, between the primitive New Zealand plant inhabitants and the alien invaders is waged almost entirely under conditions where man takes a hand, for, except for certain rock formations, stony-debris formations, and water formations, with but one trifling exception. * no truly primitive plant-formation is desecrated by a single foreign invader! This is a very different version of the story to that current in biological literature, where it is affirmed ad nauseam that the New Zealand vegetation is powerless when it comes into compretition with the European plants, which by natural selection have become the very élite of the weed-world.

In order to gauge the effect of the invasion by alien plants, first of all a classification of the different kinds of plant-associations which exist in New Zealand at the present time must be made. These associations may be divided into the following natural groups: (1) Primitive-i.e. the unchanged indigenous associations; (2) modified-i.e., where the primitive associations are altered to some

* This is on the bed of the River Minchin just where it enters the little lake of the same name. Here the author in $18: 99$ observed one plant of chickweed. With this exception the author has never seen an introduced plant in what still remains of primitive New Zealand, and he, for yeurs past, has been making careful observations on this head. 
extent, but on the whole exhibit their primitive characteristics (e.g., low tussock-grassland on the eastern portion of the Southern Alps); (3) induced-i.e., where the action of man, intentional or otherwise, has brought into being without cultivation a plantassociation unknown, or extremely rare, in primitive New Zealand) : (4) artificial-i.e., where man has purposely suppressed the original primitive association and substituted one of his own making (e.q. a Pinus radiata plantation or a field of wheat). The induced associations are a large class, and must be further subdivided into: (a) Indigenous induced-.i.e., such induced associations as consist principally or entirely of indigenous plants (e.g., Phormium swamp. the result of draining); (b) adventitious-i.e., where by the indirect action of man certain introduced species have constructed associations in which they are dominant (such associations may consist entirely of foreign species-e.g., gorse thicket in river-bed-or some indigenous. species may also play a minor part).

So far as the vegetation of New Zealand is concerned, the artificial plant-associations obviously can give no information regarding the evolution of the vegetation of the future; on the other hand. the modified and induced associations have abundance of information to offer. There are, in fact, certain associations already settled firmly on the land which bid fair to be long-enduring features of the vegetation. Other associations are in process of evolution merely. Between the apparently stable associations and the first begimning; there are many transitions.

Modified associations are extremely common features of the landscape, but here only a few can be dealt with. Grazing-animals play a great part in modifying associations by reducing the quantity--even to extinction- of the most palatable plants, and so altering the relative abundance of the members of the particular association. In the early days of sheep-farming in Nelson the anise (Angetica montana) was extremely abundant in montane tussoek-grassland, but for years it has been almost altogether absent; indeed, except for the published writings of some of the early sheep-farmers, no one would hav. included it as a constituent of that association. Burning the tussock, if carried out year by year, will altogether eradicate the silver-tussock (Poa caespitosa) or the hard tussock (Festuca norae-zealandiae), but long before that happens bare ground suitable for plant-oceupation will arise. In this way the catsear (Hypochoeris radicata), various grasse's, 
especially Torkshire fog (Holcus lanalus) and sweet vernal (Anthoxanthum orloratum), have become common on many upland pastures, the seed from which such grasses originated having come in horse-feed, or been brought by the wind or the grazing-animals themselves, or even having been sown when grass-seed has been purposely scattered after a burn. Various unpalatable indigenous species have gr:atly increased on these upland pastures - e.g., certain turf-forming raoulias (Raoulia subsericea, R.glabra); the turfy coprosma (Coprosma Petriei), of similar habit; the common mountain-groundsel (Senecio bellidioides); the false edelweiss (Helichrysum bellidioides); the swamp-lily (Chrysobaction Hookeri); the mountain-piripiri (Acaena Sanguisorbae var. pilosa); the spineless piripiri (A. inermis); various gentians (Gentiana); and, perhaj) most abundant of all, the small sharpleaved heath (Leucopogon Fraseri).

The association of dune-hollows and even of the actual sandhills is considerably modified in many places by the establishment of white clover (Trifolium repens), suckling-clover (T. minus), haresfoot clover ( $T$. arense), the toothed medic (Medicago denticulata), the melilot (Melitotus arensis), and the harestail-grass (Laguius ovatus).

Salt-meadow is not a likely association to be interfered with, but in some places it has been heavily invaded by the curved snaketailgrass (Lepturus incurcatus) or the buck's-horn plantain (Plantago Coronopus), both European coastal plants.

Where cattle have penetrated rain-forest and let in the light the tutsan (Hypericum Audrosaemum) can gain a footing; also the elderberry (Sambucus niger) spreads readily in forest where the undergrowth has been more or less destroyed-e.g., on the Dunedin Town Belt. In the neighbourhood of Wellington City danaged semicoastal forest will contain the herb-robert (Geranium Robertianum) and the aromatic Cedronella triphylla, a Canary Island plant.

Perhaps the most interesting of all the new plant-associations are the indigenous induced, since they demonstrate the extreme aggressiveness of various indigenous species. The following is an especially interesting example.

A fairly pure plant-association, unknown in primitive New Zealand, is now one of the most striking features of the vegetation in certain parts of both Islands. It is also of great econonic importance. This is the now well-known "Dunthonia grassland." In the South Island, from Nelson to the south of Canterbury, it 
occupies large areas of the lowland and montane belts where the silver-tussock (Poa caespitosa) has been repeatedly burnt. Where tussock still persists, danthonia (one or other variety of Danthonic pilosa) occupies the ground between the tussocks.

Few plants in the world possess greater powers of aggression, even against well-equipped competitors, than this indigenous New Zealand grass. For example, the primeval forest of the RuahineCook Botanical District, growing on rather poor soil, has been felled, the fallen trees burnt, and an orthodox grass-seed mixture of various European grasses and clovers has been sown. This has led in a brief time (partly through the heary fertilizing of the ground by woorlashes) to the establishment of excellent pasture, on which sheep are srazed. For a few year's this pasture holds, but by degrees danthonia (nters in, and it is only a short time before it easily becomes the dominant grass.

Equally striking but more sensational has been, in Central Otago, the effect of burning the tussock, overstocking with sheep, and allowing the rabbit to take possession in its millions. For miles the tussock is gone; so, too, hive the other grasses and herbs. Gazing at the scene from one or other of the river-valler's-say, the Clutha near Cromwell-the mountains look like huge sandhills; at a distance there is no evident sign of plant-life. But a closer view shows this not to be the case. The ground, its surface no longer protected by the tussocks, covered with stones, scarred and carved by rain, is dotted everywhere with silvery patches of two raoulias

-Raoulia lutescens and R. Beaurerdii. These denizens of stony river-bed, thanks to the suitability of their freely produced seed for carriage by the wind, have speedily taken advantage of the situation and seized on the new ground. Nor would the attempt be a new one. For thousands of years their seeds must have flown on to the tussock-grassland in hope (speaking of the plants as though they were endowed with reason) of finding a nursery for the young plants; but the hope was vain-the competition with the well-equipped nembers of the primitive formation was too keen. So, too, the little grass Poa maniototo is there in its thousands, and an indigenous annual or biennial chickweed, Stellaria gracilenta. It is, however, certain foreign plants rather than the indigenous ones which can tolerate and perhaps enjoy the new conditions. Thus sorrel (Rumex Acetosella) is extremely common even where rabbits ate 
specially abundant. In spring there is plenty of the hemlock storksbill (Erodium cicutarium). In some places the Australian comb wheat-grass (Agropyron pectinatum) has gained a secure footing. The most important alien of all is the winged thistle (Carduns mycnocephalus), which, thistle though it be, is credited with supplying a large amount of nutritious food. Burning, and overstocking both with sheep and rabbits, have there been elsewhere in the mountain areas of the South Island, but there the climate has been wetter; it was the extremely dry situation-the driest in New Zealandwhich has turned for the time being so much of Central Otago into a man-made desert. Irrigation, however, will in part remedy this state of affairs, and the higher belts of the mountains, where the rain is more plenteous, are in no danger of becoming "depleted areas."

During the survey for the Midland Railway considerable areas on and near the summit of Arthur's Pass were burnt, the associations destroyed being in some cases subalpine scrub, and in other cases subalpine forest of tree-daisies, the pauhau-tea (Libocedrus Bidwillii), and the mountain-neinei (Dracophyllum Traversii). According to the aspect, the soil, and the original association, so differ the new associations, but all agree in the fact that they are composed of New Zealand plants. In some places the burning has led to almost a pure association of the mountain-flax (Phormium Colensoi) being established; in other places a scrub of the subalpine koromiko (Veronica subalpina) dominates. The interesting feature of the case is that the dominant plants of the regenerating vegetation are frequently not the dominant ones of the original plant-covering.

Draining raupo (Typha angustifolia) swamp leads in a very short time to the drained ground being covered thickly with densely growing bushes of New Zealand flax (Phormium tenax). Such drained swamp, although wet enough in winter, often becomes exceedingly dry in summer, and so, for much of the year, is a swamp no longer. Whoever first made this discovery of turning raupo swamp into dense Phormium brought millions of pounds sterling to New Zealand. Bonuses were offered again and again by various Governments to reward him who should devise better means of preparing the commercial fibre, but no reward was offered for what lay at the root of the whole matter - the establishment of a perennial supply of raw material. 
When the flax is established nature does not let it have all its own way. The law of plant-succession at once comes into operation. Various shrubs, their seeds already in the ground or brought by wind or birds, quickly put in an appearance-e.g., a divaricating small tree (a variety of Olearia virgata), the common karamu (Coprosma robusta), the common koromiko (a variety of Veronica salicifolia), and other swamp-shrubs. Nor must the cabbage-tree (Cordyline australis) or the toetoe-grass (Anundo conspicua) be omitted. Also very aggressive are certain lianes, especially the swamp-lawyer (Rubus schmidelioides) and the bell-vine (Calystegia sepium). Did not the flax-miller wage constant war on these robbers of his "swamp " his profits would decrease year by year.

There are many other indigenous induced plant-associations. Here, briefly, are a few of them: Fern-heath of bracken (Pteridium esculentum) - this plant is undoubtedly, though indigenous, the prince of "noxious weeds" so far as New Zealand goes : manuka thicketthe manuka is nearly as aggressive as bracken; tauhinu (C'assinia leptophylla) shrubland - the tauhinu is another potent weed, necessitating each plant to be pulled up by hand; wineberry (Aristotelia racemosa) thicket - this replacing certain classes of forest after burning, or even felling; colonies of the swamp-lilies (Chrysobactron Hookeri and C. Rossii), thanks in part to their being summer-green herbs - the former species in the montane belt of the eastern Southern Alps after the tussock or the bog is burnt, and the latter species after burning the tussock-grassland of Campbell Island.

Adventitious associations next claim attention. These are of various classes, according to whether they are composed of trees, shrubs, herbs, or water-plants; while each of these classes may be subdivided with regard to the origin and biological standing of such subdivisions.

The most important adventitious tree-associations are those formed by the following: Gum-trees (Eucalyptus), Australian acacias (Acacia), willows (Salix), pines (Pinus radiata and P. Pinaster), and the locusttree (Robinia pseud-acacia).

The following adventitious associations may also be mentioned: (1.) Those of leguminous shrubs-e.g., the gorse (Ulex europaeus), the broom (Cytisus scoparius), the Cape broom (Cytisus candicans), the tree-lupin (Lupinus arboreus). (2.) Those of rosaceons shrubs-e.g., the sweetbrier (Rosa mbiginosa), various kinds of black- 


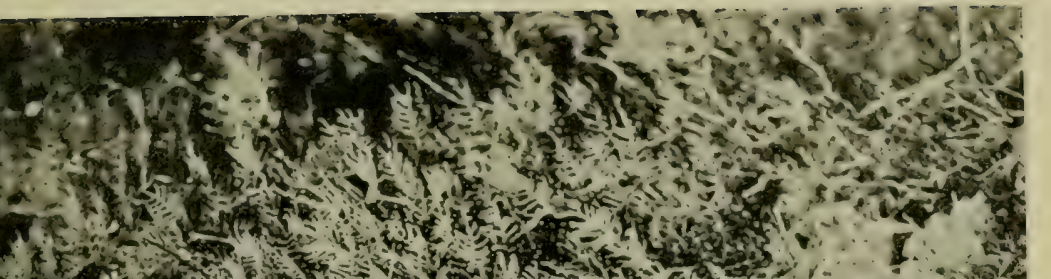

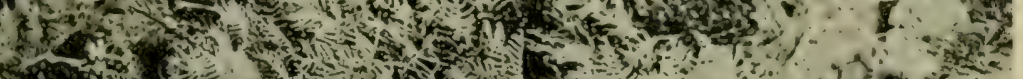

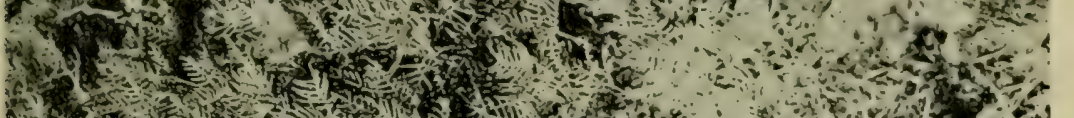

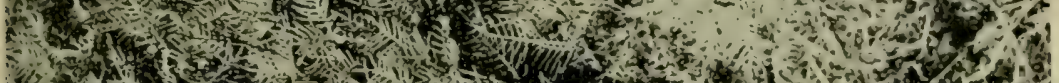

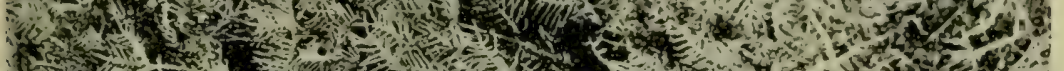

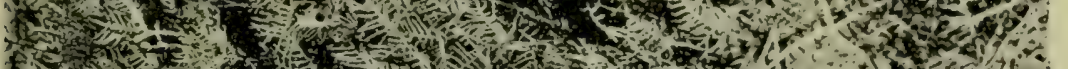

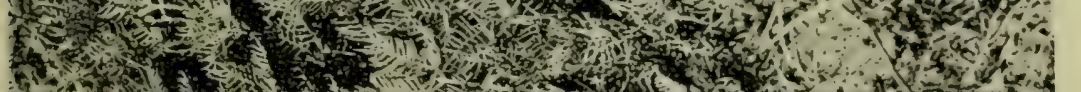

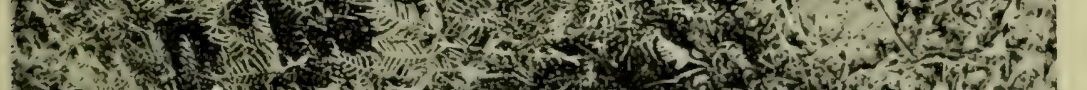

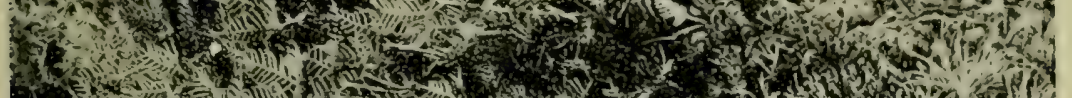

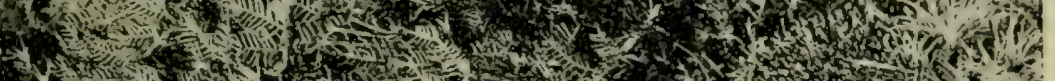

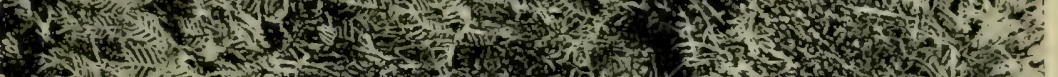

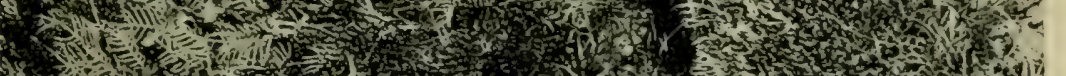

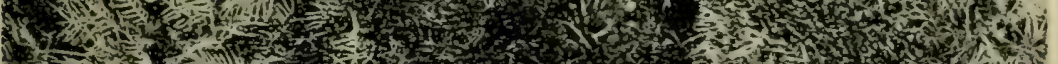
H.

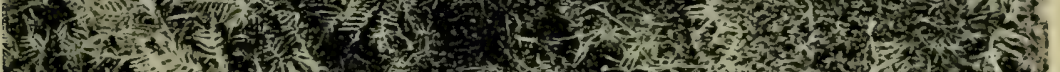
3tint AN

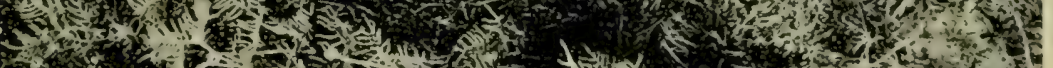
1.7.t.

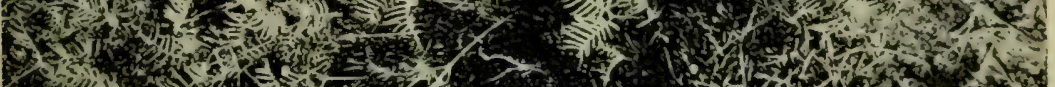
1.4. V.

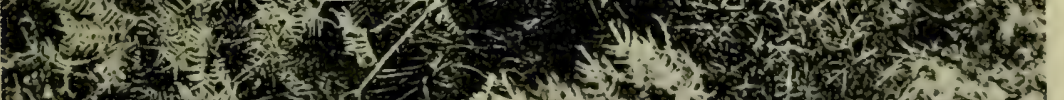

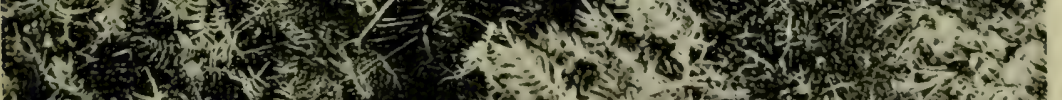
(1) 난. H.

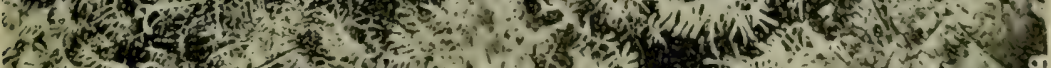
20

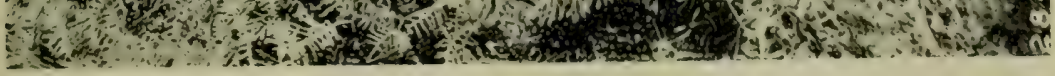




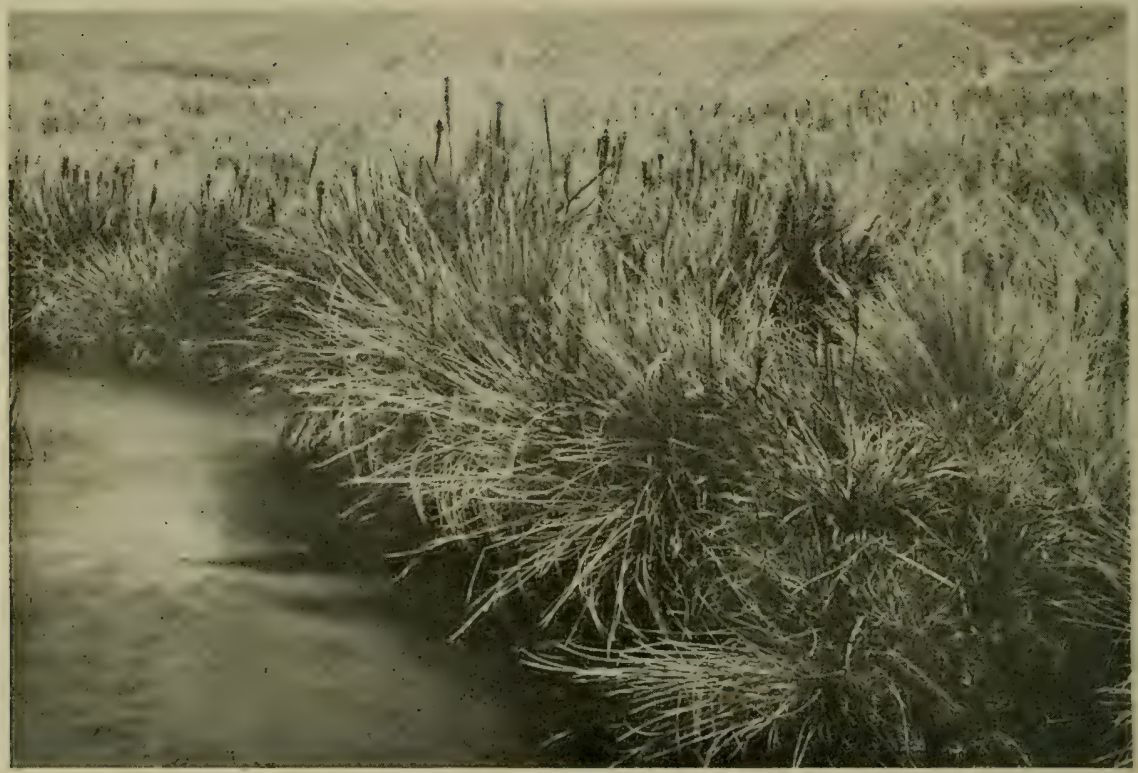

FiG. 83.- View of a picec of false snow-grass (Schoenus peuciflorus) bog oceupying an old river-bed near ('astle Hill ('anterbury). The ereet black stems are the flowers of the bog-lily (Chrysobactron Hookeri var. angustifolium).

[Photo, I. Cockayne.

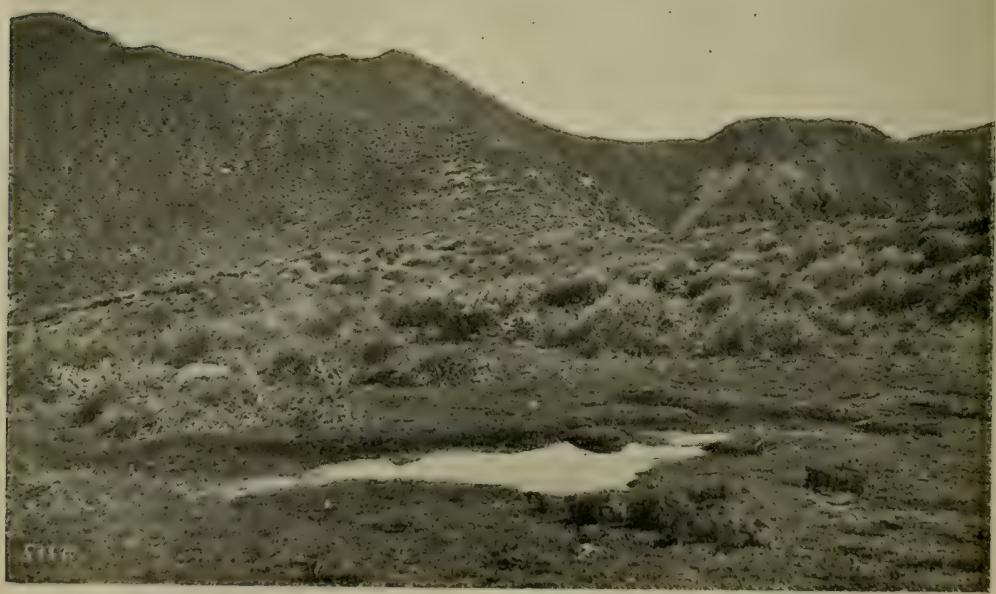

FIG. 84.-Subalpine bog on the Tararua Mountains.

[Photo, B. C. Aston. 


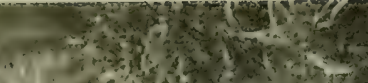
$8 \times 2 \times$

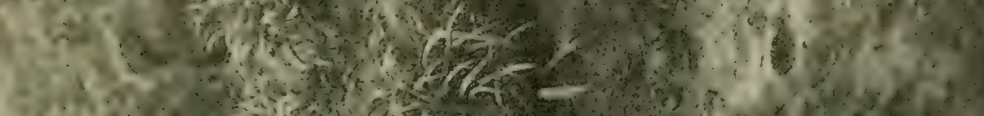

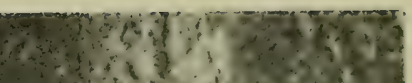

$\frac{\sqrt{2}}{2}$

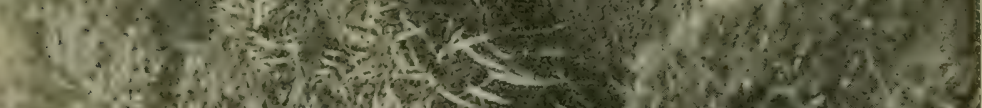

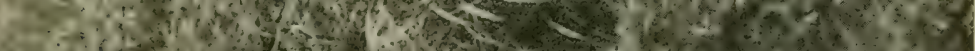

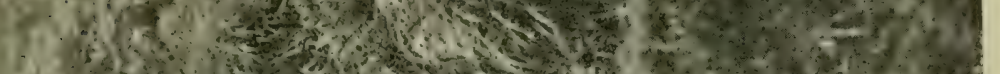

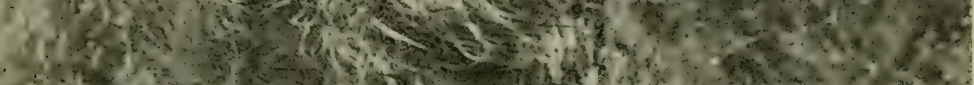

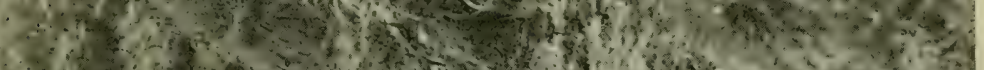

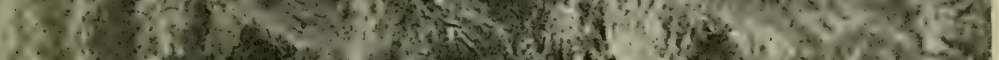

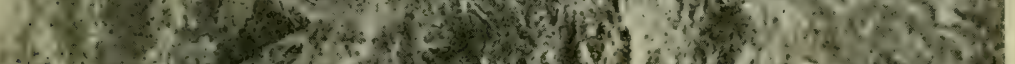

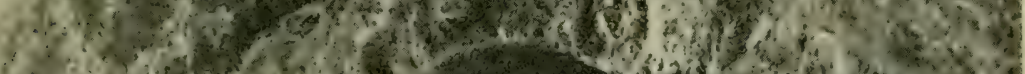

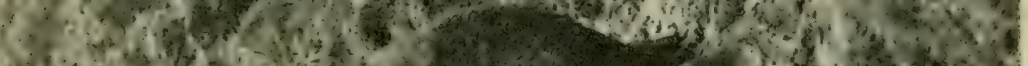

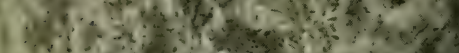

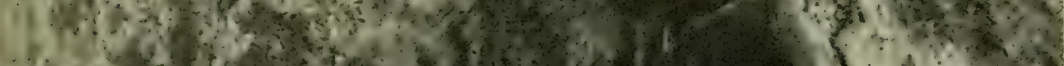
Wous

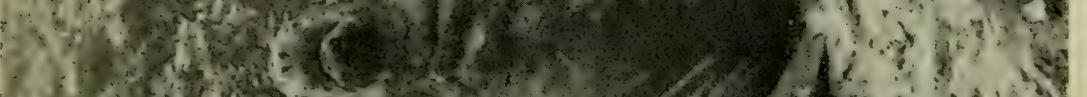

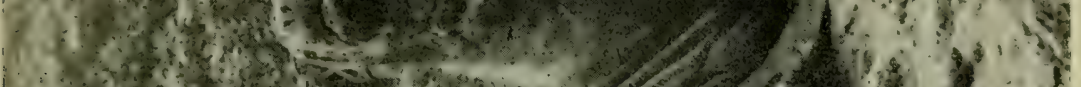

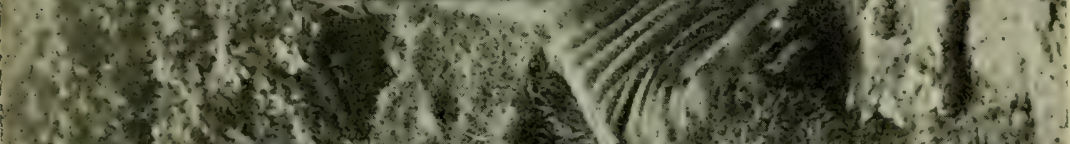
1.40 (3)

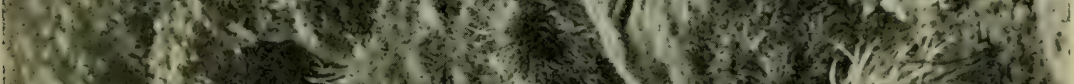

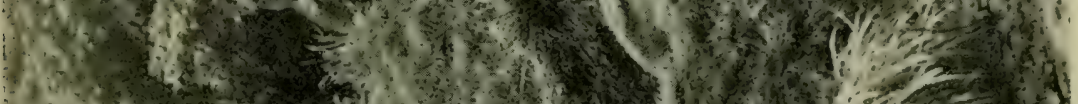

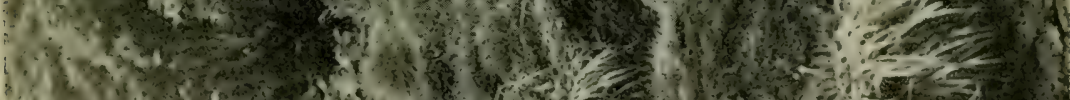

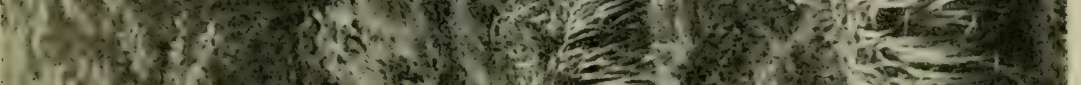

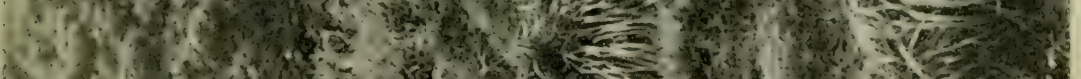

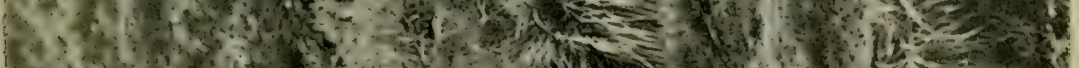

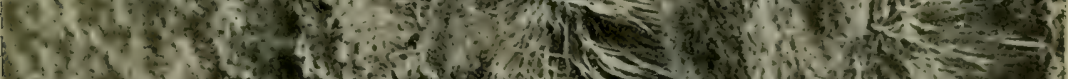

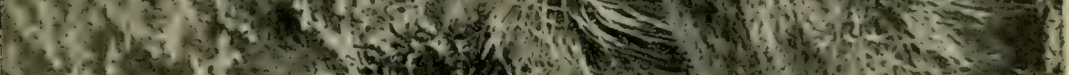

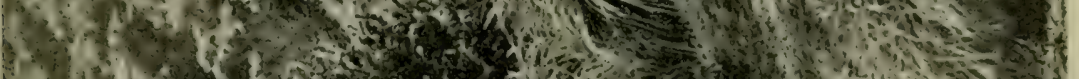

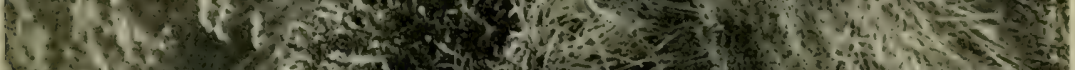

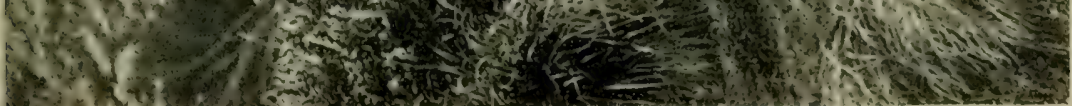




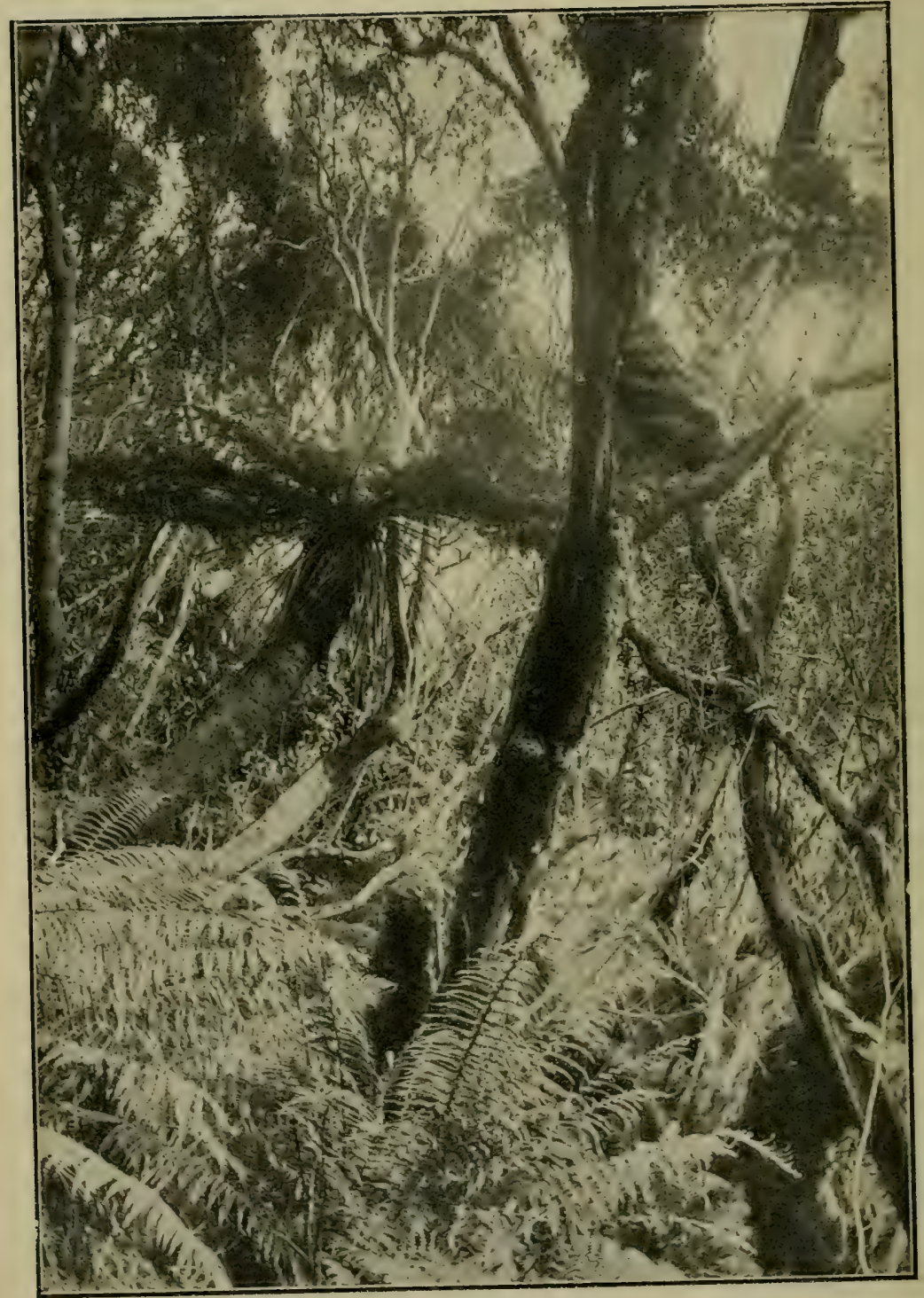

FIG. 86. - In the centre and to the left the green tree-fern (Hemitelia Smithii) in the locality farthest south in the world reached by tree-ferns. Fround at head of Norman's Inlet (Lord Auckland Island). the prickly shield-fern (Polystichum vestitum).

Phil. Inst. Canterbury.]

[Photo, S. Page. 
berry (Rubus fruticosus and its allies). (3.) Those of Australian shrubs-e.g., the hakea (Hakea acicularis), various Australian heaths (three species of Epacris). (4.) Those of herbs and grasses-e.g., the milk-thistle (Silybum Marianum), the white clover (Trifolium repens), the horned poppy (Glaucium flavm), the foxglove (Digitalis purpurea), the giant fescue (Festuca aruminacea), and the marram (Psamma arenaria) - this also frequently an artificial association. (5.) Those of intand waters-e.g., the watercress (Radicula Nasturtium rquaticum), the cursed crowsfoot (Ranunculus sceleratus), the Canadian water-weed (Eloden canalensis), the yellow monkey-flower (Mimulus luteus), and the water-buttercup (Ranunculus aquatilis).

A few of the above associations need some further consideration. In certain places where the manuka-association has been burnt out on the gumlands of Auckland the Australian Hatea acicularis now forms pure colonies, notwithstanding it had to compete with the manuka itself - a most aggressive plant. The exact circumstances of this case demand careful inquiry. One point of interest is that biological literature appears to accept as a fact that Australian plants cannot become naturalized to any extent in New Zealand. C'ertainly there are at most but 20 purely Australian species amongst the naturalized plants; but of these one-half are firmly established as colonies amongst the indigenous vegetation, even if in some cases such establishment is restricted at present to only one or two localities. Nor does the fact of a species being so limited in its distribution, or of its being exceedingly rare, prove that it is incapable of becoming really aggressive. Thus a plant may remain quite isolated for years and be apparently incapable of spreading, but an unlooked-for change of conditions may give it just what it requires. Dr. Truby King, some years ago, pointed out to the author a most interesting case. At Waitati, near Dunedin, on the land belonging to the Mental Hospital, stands a fine example of a kind of stringy-bark (Eucalyptus numerosa) more than fifty-eight years of age. Originally the vegetation of the area was mixed taxad forest, but this has been replaced by a close growth of manuka thicket. Some eighteen years ago this thicket was burned in the neighbourhood of the tree, and a young forest of gums several acres in extent has sprung up, the new ground and the potash from the fire being eminently suitable for the germination of the gum-tree seeds. In 1910 the gum-saplings grew extremely closely (fig. 89). Their height was from 40 to 50 feet. Some were half a font 
in diameter, while others were extremely slender. Thousands of manuka seedlings sprang up along with those of the gum; and it inust not be forgotten that manuka, far more than most of the indigenous plants, ean reproduce itself again and again after burning, and can exclude almost all other vegetation. But in this case the great rapidity of growth gave the gums the victory, and eight years ago only a little manuka remained near the margin of this remarkable and quite natural forest-growth. Nor is the above only interesting biologically : it is equally important from the point of view of cheap afforestation of unproductive areas covered with manuka thicket.

With regard to sweetbrier (Rosa rubiginosa) on the one hand, and blackberry (Rubus fruticosus) on the other, both form dense thickets, but their distribution is strictly limited by climatic conditions, the former demanding a dry and the latter a rain-forest climate.

The foxglove (Digitalis purpurea) has increased its area of distribution greatly of recent years. In those parts of Nelson and Marlborough, for example, possessing a forest-climate acres and acres of ground where southern-beech forest has been burnt are occupied closely by this plant, which with its purple and white flowers makes a wonderful display, as on the slopes bounding the Rai Valley. In places at present the strife is between the foxglove and the bracken-fern, but the latter is pretty sure to be the victor.

Every introduced species has what may be called its likes and dislikes with regard to its dwelling-place; so, too, for that matter, as has been seen in the previous chapters, have the indigenous species. A few examples may be of interest.

The horehound (Marumbium vulgare) is virtually confined to places on low tussock-grassland where sheep camp, where it forms a pure adventitious association. The goat's-rue (Galega officinalis) was observed for the first time in New Zealand about fifteen years ago near Woodville, on the bank of the Hanawatu River. At the present time it may be seen in great quantity almost anywhere on the banks of that river, and not there alone but on the adjacent ground, though only so far as the river has deposited silt in time of flood. The mullein (Verbascum Thapsus) grows on the loose stony ground of river-terraces or hillsides, on river-beds, and on the "depleted areas" of Central Otago and Marlborough. The viper'sbugloss (Echium vulgare), the Australian piripiri (Acaena ovina), 
the Californian stinkweed (Gilia squarrosa), and in some places the well-known garden annual Eschscholzia californica grow along the roadsides of Marlborough and Central Otago, two areas where the rainfall is low. The French honeysuckle (Centranthus ruber), originally a garden-escape, is now becoming a beautiful feature of the railway cuttings both on pure rock and the dry stony hillside between Wellington and Ngaio. The Himalayan Leycesterie formosa, another garden-escape, occurs in damaged rain-forest in both Islands, and is sometimes quite abundant. The oxeye daisy (Chrysanthemum Leucun(hemum) spreads to an amazing extent in pastures devoted to cattle or horses, and even replaces such vigorous grasses as cocksfoot (Dactylis glomerata); but where sheep are grazed on exactly similar ground it never becomes aggressive, and so well is this becoming known that in dairring districts sheep are put to graze in early summer on such infested pastures. The climbing-groundsel (Senecio mikanoides) invades more or less damaged forest, climbing over the plants of its outskirts. The common dandelion (Taraxacum officinale) is essentially a roadside weed of rather moist ground; it does extend into pastures, but is eaten freely by sheep. The Deptford pink (Dianthus Ameria) is dotted here and there on montane low tussock-grassland. The water-buttercup (Ranunculus aquatilis) was first noticed about fourteen years ago in South Canterbury. Since then it has spread to inland waters throughout much of the South Island, and to the south, at any rate, of the North Island. Its distribution must have taken place by aid of aquatic birds.

Amongst the introduced plants the most notorious are those known by the opprobrious term of "weed." All must know, though at the present time it is difficult to conceive such it state of affairs, that before the advent of the white man, and even for some considerable time afterwards, there were no weeds in New Zealand. IIr. T. W. Adams told the author how his land on the Canterbury Plain was at first weedless. A little further thought, and it is clear that in any virgin vegetation weeds must be unknown, for what is a weed but merely a plant growing where it is not wanted ? 'i'he mere presence of man in a new land, then, creates weeds. There is no occasion for a plant to be in itself useless to man to constitute it a weed. The best of plants, such as potatoes, if growing unbidden in a flower-garden may become weeds for the time being. Even in a New Zealand taxad forest all the trees not 
required for milling purposes are weeds, except such as benefit the association, or a forest occupying ground of greater value for grazing than for the growing of timber is a distinct weed-association.

On the other hand, a so-called "noxious weed" may be no weed at all. Where the unploughed ground close to the hedge of a paddock of lucerne in Marlborough is oceupied by Californian thistle (C'nicus arrensis) the latter is certainly not it "noxious weed," or, indeed, a weed at all, for it is unable to extend for even one inch into the lucerne; and in that position it is neither wanted nor unwanted - it does, in fart, neither harm nor good.

Foxglove is certainly a bad weed in certain parts of the Marlborough Sounds area, where the land it occupies conld lo profitably farmed; but for a borough situated in an area where it is impossible for this plant to spread to proclaim it it noxious weed which must be eradicated, when there could be none to eradicate, was not a wise measure. On the other hand, as a garden-plant the foxglove could do no harm.

Such well-known weeds as the sorrels, docks, fat-hens, and thistles would in the original primeval world each have its proper place in the primitive plant-association to which it might belong. and would be present in no extraordinary numbers. It was the changes brought about by cultivation in its various forms, fires, and the close grazing of domestic animals which upset the balance of nature. Then those plants whose structure and habits were most in harmony with the changed conditions would become more numerous at the expense of those not so well equipped, and as the conditions antagonistic to the plant-association as a whole increased, so would the species best suited to such conditions likewise increase. All this is to say that many plants are potential weeds, ready to become active ones as soon as suitable conditions arise. Thus, through the many centuries of cultivation in Europe, aided by the ever-expanding intercourse with other lands, the great army of now almost cosmopolitan weeds has been gathered together-the very pick of the vegetable world in temperate climes for thriving under the artificial conditions imposed by man. It is the old story that when one interferes with nature she exacts remorselessly her tribute.

It is only in a virgin vegetation that the evolution of a weed can actually be witnessed. The New Zealand flora has furnished some rather striking examples. Some of these cases have been 
already discussed-e.g., the bracken-fern, the manuka, the tauhinu, the swamp-lily, the sharp-leaved heath, and the raoulias of montane grasslind. Other New 'Zealand plants which have become weeds owing to their unpalatability and their occupying ground fit for palatable species are the piripiri (various varieties of Acaena Sanguisorbae and A. novae-zelandiue), the cotton-plant (Celmisia spectubilis) - -thanks to its leaf-buds being protected from burning by a covering of dearl, wet leaf-sheaths -the small sea-holly (Eryngium resicuInsum), the water-fern (Histiopteris incisa), the rough bracken (Paesiu scrtberula), and many plants which grow naturally in tussockgrassland.

The term "weed," then, is evidently merely relative, and depends upon the plant in its relation to man. If the human element is left out of the question, a weed is simply at living organism, like any other plant or animal, and its habits and structure are entirely for its own benefit, just as are the organs of all animate beings. In itself there is nothing "noxious" at all, nor in an undisturbed plant-society would it react upon its neighbours more than any other plant; nor is it "noxious" unless it is doing agricultural or horticultural damage, or certain to lead eventually to such damage.

Before leaving the question of weeds, those minute organisms may be mentioned which, settling upon other plants and livings as parasites, damage and not infrequently kill the host. To this category belongs that vast assortment of lowly plants commonly. termed "blights." Many of these are members of the great family. of fungi. For the most part their structure cannot be made out without the aid of the compound microscope, but their presence is often writ large on the unfortunate host-plant. The rusts and smuts, the so-called Irish potato-disease, the organism causing "damping off" in seedlings, and many other plant-diseases fall into the category of "blights." Right at the north-east corner of Chatham Island is an old orchard, planted before the middle of the last century. At the time of the author's visit to the Chathams, seventeen years ago, he was astonished to learn that blights of all kinds were quite unknown at that particular part of the island, the extreme isolation of the orchard having proved its salvation. And so, too, it was with New Zealand orehards in the early days, hefore the coming of the microscopic weeds. Many of the 
ills which aftlict humanity are due to the presence of extremely minute introduced plants, known as bacteria-the "microbes" of everyday language - and so various diseases now common in New Zealand were unknown to the Maori.

It may be asked whether there may not be introduced some day other plants which might become dangerous pests. So far as animals are enncerned, the experience of Ner Zealand with regard to accimatization has not been encouraging, and it is wise to consider long and carefully, and get the best advice available, before turning any animal loose. Dotibtless the same reasoning applies to plants; but, unfortunately, they do not wait to be set free. Probahly all the worst weeds of the earth have already arrived. and it cannot be expected that any new-comer will rival the couchgrass (Agropyron repens) - in certain situations an important fodderplant ; the sorrel (Rumex Acetosella)--also, in places, most valuable ; or the so-called "Californian thistle" (Cnicus arvensis), the common field-thistle of the British Islands. At the same time, any farmer who sees an unknown plant on his farm should look at it askaner, ohtain what information he can get respecting it-for it may he something useful-and eradicate it at once if he has any reason to suspect it of having the weed-assuming characteristics.

Finally, there comes in the question whether any of the indigenous plants are liable to extinction. So far as the opinion of the author goes, this, with one or two exceptions, should be answered in the negative. There is nearly always some haven of refuge, and it is most unlikely that any except those species of which only a very few individuals exist in one locality (e.g., Pittosporum obcordatum) will be entirely eradicated; but that the species as a whole will remain in anything approaching their present numbers is impossible, while some must become extremely rare. The new flora and vegetation are in their making. The future of the glorious New Zealand plants and the beautiful primitive regetation lies not in the lap of the gods, but in the good sense of us New-Zealanders and in our love for our beautiful New Zealand. So should we take care that abundant reserves are set aside as sanctuaries for our plantsnatural museums, indeed, where nature can carry on her work unmolested. Nor is the mere proclamation and establishment of these havens of refuge sufficient: they must be guarded with that zealous and loving care which such priceless possessions demand! 


\section{CHAPTER XI.}

\section{THE CLASSIFICATION OF THE PLANTS.}

Popular names of plants--English names and Maori names-Scicutific names of plants-Some objections to the use of scientific names-Meaning of the term "species" - Little species - Aggregate species - Meaning of terms "genus" and "family"-The leading families and genera of the seedplants-Seed-plants with only one seed-leaf-Plants with naked seedsFerns-Lycopodiaceac-Tmesipteris-Mosses and liverworts-Fungi - The black fungus of Nothofagus-Algae-Bacteria-Slime-fungi.

Noт the least interesting part of the story which plants can tell is that which concerns their relationships. Just as in luman society Nature has declared true equality to be impossible, so in the plantworld there are high and low, together with many intermediate grades, and all this rather through the labours of a plant s ancestors than from its own exertions. But before one can speak definitely of individuals of any kind names must be given them. With regard to plants these names are of two kinds-popular and scientific. The former for New Zealand plants are either English or Maori; the latter for all plants are Latin, or what counts as such. The English names are for the most part those which have been given by the early settlers, partly from some likeness, real or fancied, to the plants of the Old Country, and partly from some peculiar characteristic of the species in question. 'T'o this latter category belong such names as " lacebark," "ribbonwood," "spiderwood," " milk-tree, " " pincushionplant" ; and to the former, "birch," "ash," "honersuckle." Some names have been bestowed for jocular reasons- e.g., " lawrer, ". wildirishman," "spaniard," and "niggerhead." I few are the work of botanists who have sought, vainly for the most part, to bring into use a nomenclature that should have a more correct English equivalent for the scientific name-e.g., "speedwell " for "Teronica," "groundsel" for "Senecio," "palm-lily" instead of " cabbagetree," and "beech" instead of "birch." Some English namies are corruptions of Maori ones, as "biddy-biddy" for " piripiri," " cracker" for "karaka," "maple" for "mapou," " matagowrie " 
for "tumatakuru." Finally, some names have been deliberately coined by certain writers, including the author, where no popular name exists; a good many names in this book are of that kinde.g., the mountain-twitch, the false snow-grass, and the pygmy pine. The origin of the names of New Zealand plants is quite an interesting study in recent word-making, and is well worth investigating. Occasionally an English name is given a false Maori equivalent. Thus "tea-tree," an admirable name with a definite meaning, is oftener than not written "ti-tree." Worse than this is the name "Titri" on a flag station near Waihola, on the south line from Dunedin.

The Maoris, living as they did in constant touch with nature, possessed much more knowledge of the vegetable products of New Zealand than do most of their more enlightened, but in some respects more degenerate, white brethren. For all the more common trees and shrubs the Maoris had names. Unfortunately, both Maori and English names are used loosely, some being applied to more than one species, or having a different signification in different districts. "Akeake" is applied to Dodonea viscosa, Olearia Tracersii, and O. avicenniaefolia. The silver southern-beech (Nothofagus Menziesii) is called "brownbirch." "red-birch," " white-birch," and "silver-birch," according to the part of New Zealand where the tree is growing: nor would this greatly matter were it not that the above names are used equally loosely for other species of the genus Nothofagus. "Koromiko" is the name for several species of Teronica; "toetoe" is the name for a large number of grass-like plants, and " totara" for the lofty taxad Pordocurpus totara equally with the dwarf heath Leucopogon Fraseri. ()ther instances could be given, but these will suffice. Further. many plants have neither a Maori nor an English name.

From the above it may be seen that the popular names are of no use when it is desired to make an accurate list of even the seed-plants of any locality, and that names having a definite application must be used. For this reason the scientific names have been designed.

The scientific names are in Latin. The use of Latin dates, of course, from the time of the Romans; but its application to plants, as they are now known, began in the sixteenth century, when modern botany was born. Latin was then the universal written language of the learned, and the early botanical works were all written 
in that tongue. This usage of Latin has proved very convenient in practice, for it would lead to endless confusion did the plants bear the popular names of their respective countries alone. As it is, a definite scientific name is applied to one particular species, and to that one only, and such names-e.g., Ranunculus insignis-are recognized by scientific men, no matter what their nationality.

Each scientific name of a species consists of two words only, the first denoting the genus and the second the species to which the plant belongs, such names being called respectively "generic" and "specific." If the species is divided into varieties a third name is accorded the variety, and "var." is placed before it-e.g., Geranium sessiliflorum var. glabrum. In writing the name of a species the generic name must invariably begin with a capital letter, whereas the specific name must begin with a small letter unless it is (1) the latinized name of a person either in the form of a noun in the genitive case or of an adjective (e.g., Celmisia Hookeri, Asplenium Hookerianum), or (2) a generic name used specificially (e.g., Schoenus Apogon).

It is frequently objected that the scientific names are too difficult to remember for everyday use, and that English ones would be much easier to learn. There is a grain of truth in this. All the same, those who so object are usually people who do not intend to learn either name. Others, again, who urge the same plea, when speaking of their garden-plants, invariably call snapdragons " antirrhinums"; nor would they abolish the words "chrysanthemum," "geranium," or even "eschscholzia," for the world. Nor does the gardening public object to the names "viola," "narcissus," or even "lobelia" and "petunia," all of which, as those cited above in this paragraph, are valid generic names. It is rather the second name which is the stumbling-block; but here again there are cases where this has become the popular name of a plant, as "japonica" for Pyrus japonica, and "macrocarpa" for Cupressus macrocarpa. It is more frequent, however, to use the generic name in the above manner, as "danthonia" for Danthonia pilosa. Such generic names frequently answer excellently when used in this manner, so in this book a good many are so used.

To write down the word "species" is much easier than to define what a species really is. In fact, when it comes to fixing the limits of a species, scarcely two classifiers can agree. The individuals of 11-Plants. 
the plant-world form the starting-point for classification. Unfortunately, these individuals are not all equal from the biological standpoint. Some reproduce their like, and groups of these-each individual producing individuals almost exactly the same as those produced by the remainder of the group-are self-breeding entities, all of common descent. True-breeding groups of this kind may be called "little species." Other individuals are hybrids, and usually their offspring differ in certain characters from the parents. Other individuals, again, though really identical, may look so different from one another, owing to their growing under different conditions, that, without experiment, it may be mere guesswork to pronounce them either similar or dissimilar.

Frequently in certain groups of "little species" the individuals of these groups taken as a whole so greatly resemble one another that it is difficult to find good, easily recognizable marks by which the individuals of each group may be recognized and not confused with the individuals of the other groups. In order to meet this difficulty such closely related groups of "little species" are united into one large group, which, notwithstanding that such a groul) consists of two or more distinct entities, is called a species.

There are therefore in floras two distinct kinds of species, viz.: (1) The little species, which, however, is kept distinct as a species only if it has no extremely close relatives; and (2) the big or aggregate species, which is a combination of two or more little species. Between these two classes floras usually make no distinction, although they are obviously two quite distinct biological conceptions.

In giving a definition of an aggregate species frequently no one plant found in nature is meant, but the description includes the characters common to all the little species making up the group, and the species is said to be "variable." Thus such a species is not a reality, but merely an idea. The realities are the little species which make up the aggregate: these really exist in nature. Where these units (the little species) of the aggregate species are recognizable, names may be accorded them as varieties, the variety thus really corresponding biologically to those species composed of one little species alone. There is thus nothing derogatory in the rank of "variety," since it is equivalent to that type of species which comes true from seed but is kept by itself as a species since there are no closely allied little species with which it would be convenient to unite it. 
In the New Zealand flora the kauri (Agathis australis) is a little species, but as there is no other tree which comes at all close to it it stands by itself as a species. On the other hand, the lancewood (Pseudopanax crassifolium) is an aggregate species: there is nothing in nature which answers to its botanical description. What does exist in nature are the two varieties of which the "species" is composedthe varieties unifoliata and trifoliata - this last a rather rare plant. If a botanist who describes plants were so inclined he could "make" these into two species, but one would require to have for its second name "crassifolium," since this name has been already used, while to the other he could give a name of his own choosing. Cases such as this lead to differences of opinion as to what is called "specific rank." It matters, however, but little whether a plant be called a "species" or a "variety" so long as the name represents a distinct group of individuals which can be readily recognized.

If a number of species agree in certain particulars so that it seems likely they have descended from some common ancestor, they are said to belong to the same genus, the next wider group of plants. Suppose you find a number of plants which, although they differ much in stature, shape of leaves, habit of growth, size and colour of flowers, yet all have four petals, eight stamens, the calyx-tube attached to the ovary, and after flowering they produce a narrow elongated four-angled capsule which splits open from the apex downwards into four sections, revealing a large number of seeds each provided with a tuft of hairs at the apex, then all those plants will belong to the genus Epilobium (fig. 93). These plants, again, will differ greatly amongst themselves; but groups having distinguishing marks for each group can be found, and such groups will each represent a species, which may be either a little species or a collection of such, as is frequently the case in this genus. There are in New Zealand between thirty and forty species of Epilobium, which are distinguished from one another by distinctive marks, and each beare a name, the so-called specific name-e.g., glabellum, Hectori, pubenswhich is placed after the generic name Epilobium.

Originally the second, or specific, name of a species liad a meaning which was supposed to be appropriate to the particular plant, though frequently it was nothing of the kind; but the number of specific names has so greatly increased during the past hundred years that it is no longer possible always to find an appropriate appellation, 
while in some cases names at first thought to be suitable have proved to be quite the contrary. Notwithstanding this, the rules of modern botany demand that a specific name once given must stand for ever, even where the name is quite inappropriate; even if the plant had originally been put in a wrong genus-a common enough circumstance - the original specific name must be used. A name, then, is now considered merely as a label and nothing more, and need have no meaning whatsoever.

Another matter which must be remembered is that generic differences in the seed-plants generally depend on the structure of the flowers, and not on the form of the leaves. That a plant has leaves like a willow does not constitute it a willow; similar plant-form, as has been already shown in this book, occurs amongst plants quite unrelated. Leaves, however, amongst other characters, are made use of as marks of specific differences, and in many instances a plant can be readily identified from its leaves alone.

Classification goes still further. A number of related genera make a family-formerly called a "natural order" - and still wider subdivisions are established, until such fundamental divisions of the plant kingdom are reached as-slime-fungi, algae, fungi, liverworts, mosses, ferns, conifers, seed-plants with one seed-leaf in the seedling (monocotyledons), and seed-plants with two seed-leaves in the seedling (dicotyledons).

The families are now most frequently arranged according to the manner in which they are supposed by some to have originated, the more simple coming first and the more complex last. Thus amongst seed-plants th pine-tree family begins the list, and the daisy family completes it. It must not be forgotten that this arrangement is hypothetical only, and that, although the monocotyledons come early on in the list, there is a good deal of evidence that they have originated from the dicotyledons, and not vice versa. With but few exceptions the rules of botanical nomenclature order the names of families to end in aceae. Thus the student must write Violaceae, not Violariae; Scrophulariaceae, not Scrophularineae; and so on. But Compositae, Umbelliferae, Palmae, Cruciferae, Labiatae, Leguminosae, and Gramineae are allowed.

Considering the seed-plants alone, New Zealand has some 1,620 species, about four-fifths of which are found nowhere else in the world, the number varying according to the computer's conception of 
a species. Were an extremely conservative estimate of the species of the whole flora to be made, after uniting far more species into aggregates than has ever been done the total would be as high as 1,500. The families and the genera number 101 and 382 respectively.

It would be out of place here to go at any detail into technical matters pertaining to the families and genera, so, commencing with the most highly organized families and proceeding gradually downwards, only a few of the more interesting are mentioned. Neither can any attempt be made to define in popular language the families, genera, and other divisions of the plant-world-a task of extreme difficulty, and the result, when attained, harder for the beginner to understand than would be his learning the necessary technical terms, which have a definite meaning and can be used with precision.

The daisy family (Compositae) is the largest of our plant families. What is popularly called the flower is not a single flower, but it is really a collection of small flowers placed closely side by side upon the expanded summit of the flower-stalk, and forming a "head." The cotton-plants and mountain-musks (Celmisia), the groundsels (Senecio), the vegetable-sheep and its relatives (Raoulia), the cotulas (Cotula), the daisies (Lagenophora and Brachycome), the edelweiss (Leucogenes), the endemic tree-groundsel (Traversia), and the helichrysums belong to this order. Many are amongst the most striking of our plants, both in form and flower. The total number of species* in this family is about 260 .

The bluebell family (Campanulaceae) contains only 13 species, but many are exceedingly pretty. It contains the New Zealand bluebell (Wahlenbergia albomarginata), whose white or bluish flowers are so conspicuous a feature of the upland grasslands; the pretty white pratias (Pratia), which are related to the well-known lobelia of gardens; three lobelias (Lobelia)-one a pretty fell-field species (L. linnaeoides) and another confined to shingle-slips (L. Roughii); and the endemic Colensoa physaloides, a handsome plant, easily cultivated in gardens, with blue flowers.

The coprosma family (Rubiaceae) contains the large genus Coprosma, which is closely related to the coffee-plant. Coprosmas can always be recognized by the male and female flowers being on different plants, and by the berry-like fruit containing two plano-convex stones.

* The number of species given for the families in this chapter refers only to the number of New Zealand species. 
C. grandifolia has very large leaves and reddish-orange drupes, and is common in North Island forests, but extends south as far as Greymouth and Mount Grey (Canterbury). C. Petriei forms a close turf in the drier South Island mountains, and has large port-winecoloured drupes, but these are occasionally pale-blue or almost white and translucent. Many coprosmas are shrubs of a dense habit of growth, with slender interlacing branches. An interesting point is the recent discovery by Mr. B. C. Aston that several of the species yield adjective wool-dyes, showing, on suitable mordants, a great range of colour, fast to light and soap. In addition, the hot-water extract of Coprosina areolata is a good brown substantive dye on wool, requiring no mordant. The theoretical side of the work is interesting as showing that New Zealand plants allied to European and Asian dye-plants behave similarly. The scarlet uniforms of the French soldiers were originally dyed with madder (Rubia tinctorum), from which the important dyestuff alizarin was first obtained, and, if New Zealand were cut off from the supplies of dye from older countries, coprosmas could supply the colour for uniforms, even to the red tabs of staff officers. Other genera of this family are Nertera (plants with beautifully coloured " berries"), the bedstraw (Galium), and the woodruff (Asperula). The number of species of this family is 52 , most of which are coprosmas.

The plantain family (Plantaginaceae) contains only the genus Plantago with its 9 not-too-well-understood species. All of them are typical rosette-plants. One, Plantago aucklandica, is confined to the Lord Auckland Islands.

The Gesneriaceae, a tropical family of 70 genera, is represented by the endemic genus Rhabdothamnus, with only one species, the waiu-atua $(R$. Solandri), which is related to certain New Caledonian and Lord Howe Island plants.

The koromiko family (Scrophulariaceae) contains the very large genus Veronica and other genera of showy plants (Ourisia, Mimulus, Euphrasia, Jovellana, Mazus, and Gratiola). Veronica contains more than 100 species, many of which are difficult to define. Some of the most beautiful garden-plants belong to this family-e.g., the foxglove, snapdragon, calceolaria, pentstemon, and mimulus.

The forget-me-not family (Boraginaceae) comprises the forget-menots (Myosotis) and Myosotidium, which is confined to the Chatham Islands. 
The Tetrachondraceae is a very small family, containing only one New Zealand species, Tetrachondra Hamiltonii, and another species closely related to the above and found only in subantaretic South America.

The convolvulus family (Convolvulaceae) contains the beautiful climbing-convolvulus (Calystegia tuguriorum) and the lovely purple Ipomaea palmata of the shores of northern Auckland.

A little lower down the scale come the gentians (Gentianaceae). Owing to the bitter principle in their vegetative parts, these plants are not relished by stock. Possibly the root could be used as a tonic, like that of the European Gentiana lutea. Gentiana contains 24 New Zealand species. G. corymbifera, in full bloom, is one of the most striking plants of the flora. Other genera are Liparophyllum, with only one species, which is also Tasmanian, and Sebaea, which has but one species in New Zealand ( $S$. ovata), which is also Australian.

There is only one member of the primrose family (Primulaceae), Samolus repens, with 2 varieties, one of which is a prostrate, whiteflowered plant forming broad patches in salt-meadows, but the other is of erect habit.

The heath family (Ericaceae) is represented only by the snowberries (Gaultheria and Pernettya). The sole species of the latter in New Zealand ( $P$. nana) is a small wiry shrub forming mats on the ground and bearing rather large (for so small a plant) white flowers.

The Australian heath family (Epacridaceae) is of physiognomic importance, as it contains the large genus Dracophyllum with its 27 species. Other genera are Cyathodes (fig. 94), Leucopogon, and Pentachondra.

The carrot family (Umbelliferae) contains some of the most remarkable genera of the flora-e.g., the spear-grasses and spaniards (Aciphylla) (figs. 56, 78); the endemic genera Anisotome and Coxella ; Angelica, with several species, of which 2 are climbers-a remarkable occurrence in this family; the small rush-like Crantzia; and the remarkable Actinotus.

The araliad family (Araliaceae) contains the genera Nothopanax, Pseudopanax, the endemic Stilbocarpa (2 species), and the beautiful tree Meryta Sinclairii of the Three Kings Islands, with its immense shining leaves crowded at the ends of the branches, their blades 18 inches long or more. 
The willow-herb family (Onagraceae) must soon become known to the botanical student through the large genus Epilobium (40 species). The species of this genus are not yet well known, and they are difficult for a beginner to determine. Some are distinctly prettye.g., E. pallidiflorum, E. macropus, E. vernicosum, and $E$. chloraefolium var. kaikourense. Others become terrible weeds in an alpine garden -e.g., E. nummularifolium, various varieties of $E$. pedunculare, and $E$. linnaeoides. The fuchsias, of which there are 3 New Zealand species, belong to the same family.

The inyrtle family (Myrtaceae), with 20 species, contains the ornamental genera Metrosideros, Myrtus, Leptospermum, and Eugenia. this latter, with 1 New Zealand species (E. maire), found only in swamp-forest.

The pimelea fanily (Thymelaeaceae) should be known to all who love a garden, as containing the various species of Daphne. In New Zealand the family is represented by Pimelea (14 species), and Drapetes (3 species). Pimelea longifolia and $P$. Gridia are fine handsome shrubs; $P$. prostrata, in various varieties, is exceedingly common in open country; and $P$. arenaria is a rather remarkable duneshrub. Drapetes consists of 6 species only (1 Australian, 1 Fuegian, 1 Bornean and New Guinea, and 3 New Zealand). D. Dieffenbachii is a common moss-like plant of the high mountains whicli descends into the montane belt.

The violet family (Violaceae) contains in New Zealand not only ordinary violets (Viola) (fig. 95), but actual trees and shrubs. These latter, unlike violets proper, have flowers regular in form, and berries, not capsules, containing the seeds. It is hard to conceive anything more unlike the ordinary conception of a violet than is the divaricating shrub Hymenanthera crassifolia, or the malioe (Melicytus ramiflorus), a more or less bushy tree.

The mallow family (Malvaceae) is very showy, and contains some small trees most valuable for garden purposes, as the lacebarks and ribbonwoods (Hoheria, Plagianthus, and Gaya).

To the Elacocarpaceae belongs the wineberry (Aristotelia racemosa), one of the "fire weeds" of New Zealand-i.e., a plant whichi comes up abundantly after a forest is burned. Here also comes that fine tree the hinau (Elaeocarpus dentatus) and the pokaka (E. Hookerianus), both with distinct juvenile and adult forms, but of a very different type in each species. 


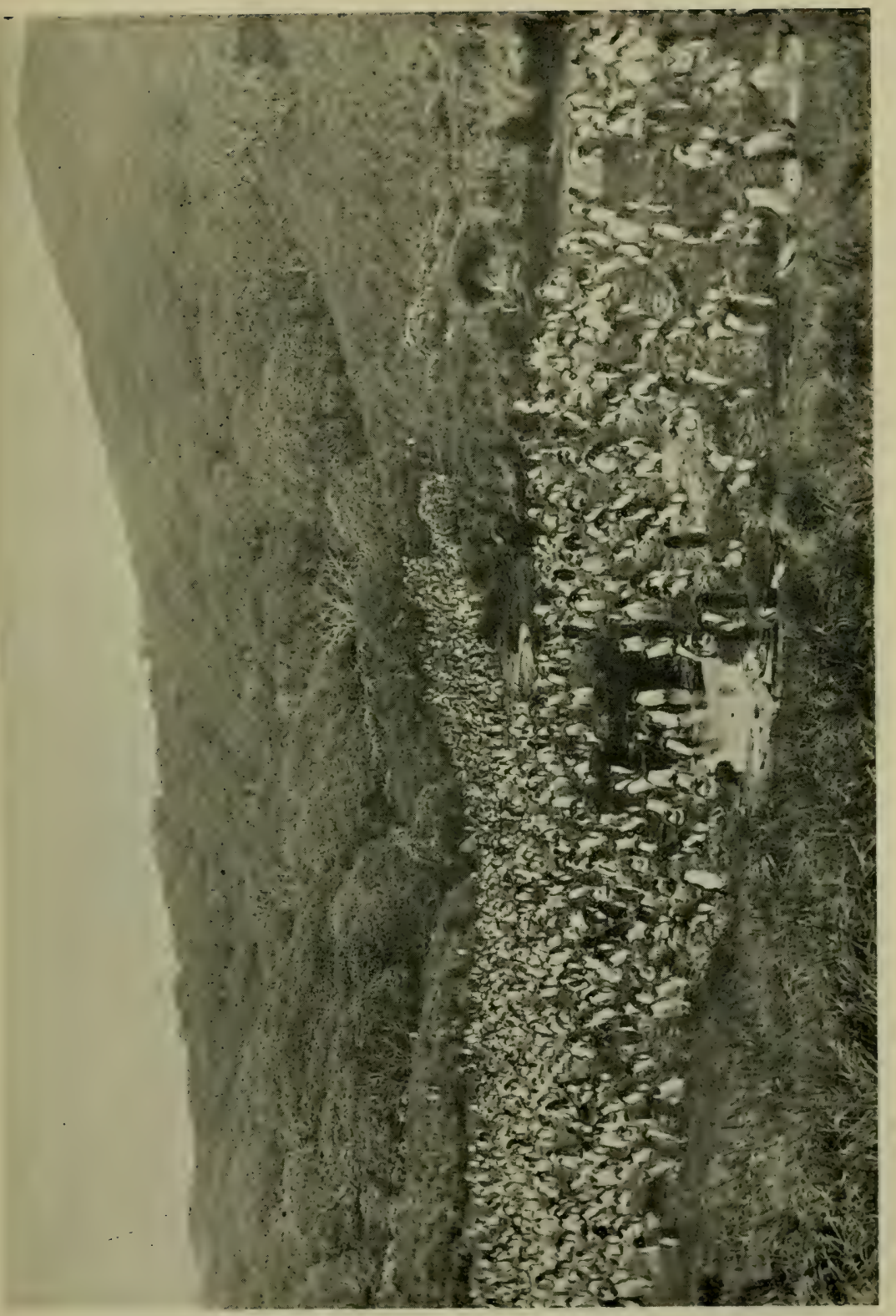

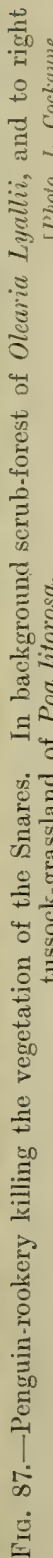




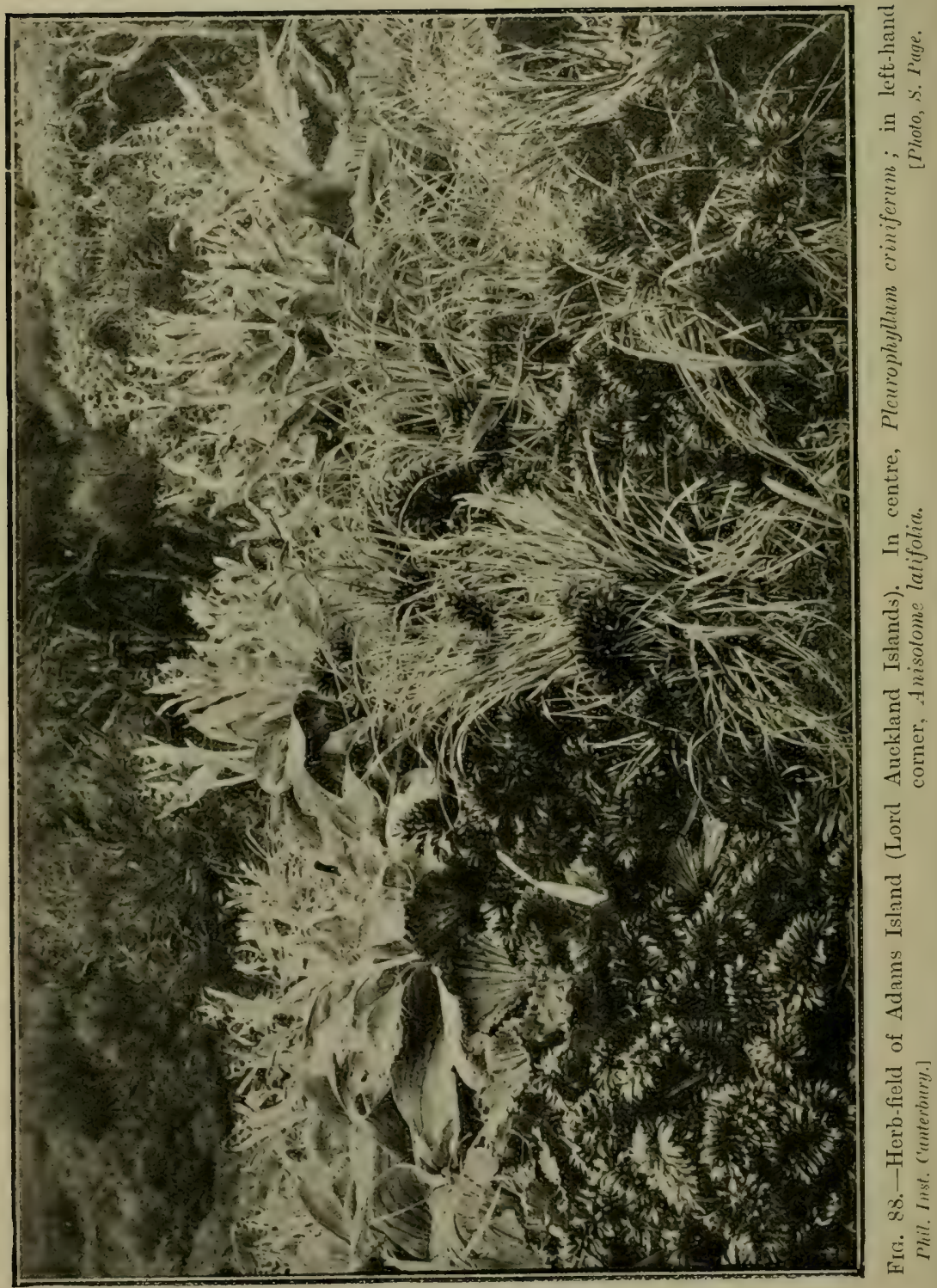




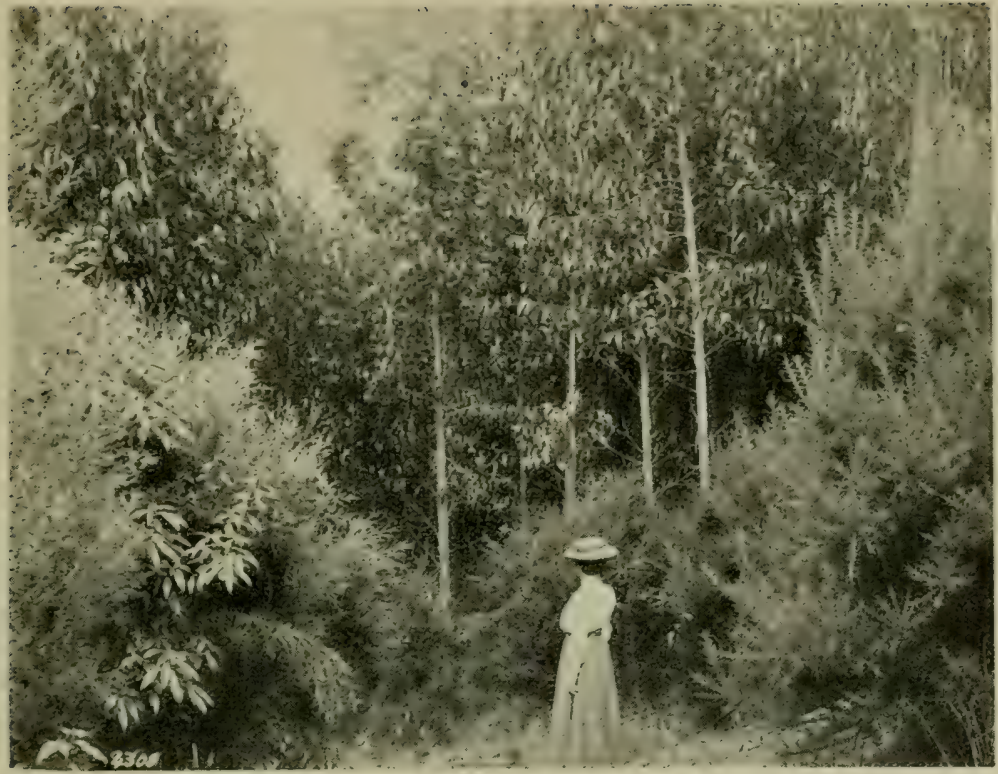

FIC. 84.-Adventitious induced association of Eucalyptus numerosa at Waitati (Otago).

[Photo, L. Cockayne.

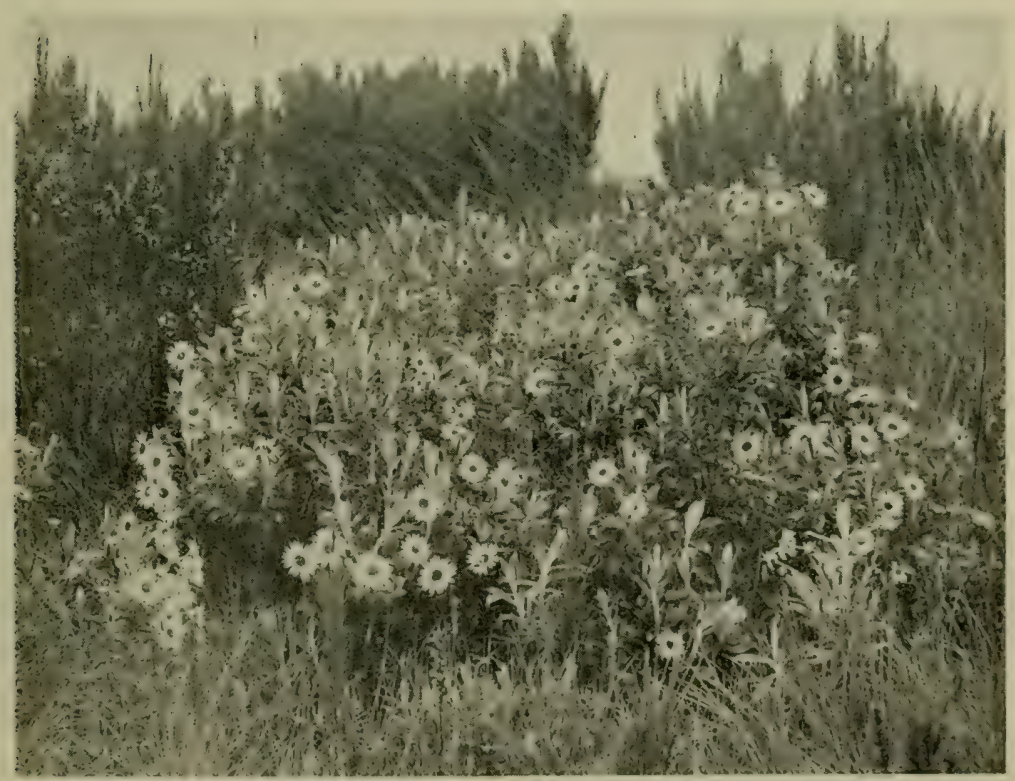

Fur. 90.-Bush of the purple-flowered tree-daisy (Olcaria semidentate) growing as a member of the upland bog association of Chatham Island. In background, the bog-heath (Dracophyllum paludosum). 


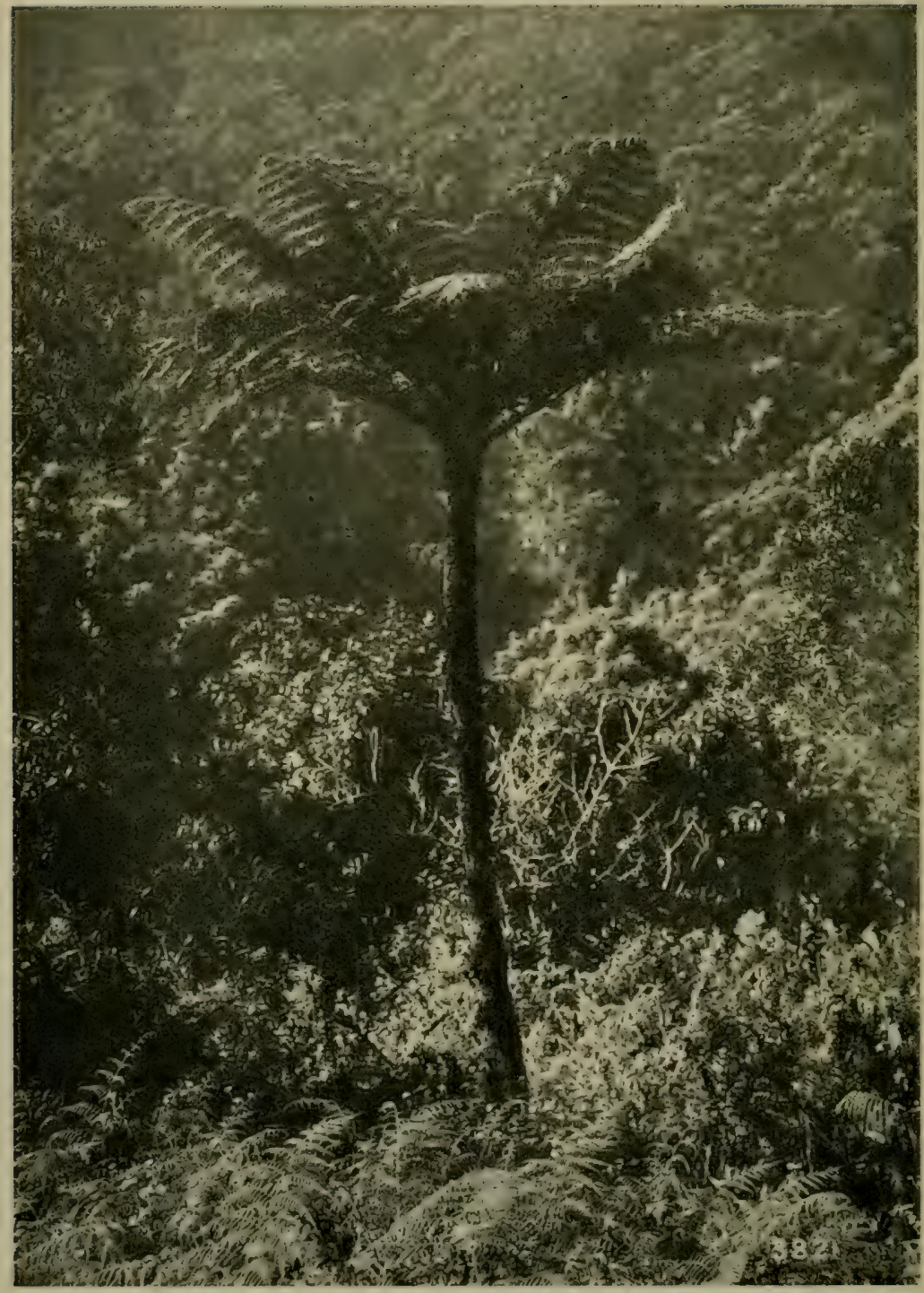

FIs. 91.-The Kermadec tree-fern (Cyathea kermadecensis), 70 feet high, growing in wet forest, Sunday Island (Kermadec Islands). 
The buckthorn family (Rhamnaceae) includes the thorny Discaria and the North Island genus Pomaderris.

Stackhousiaceae contains in New Zealand only a most tiny plant with yellow flowers, Stackhousia minima, which when in bloom fills the montane tussock-grassland for chains at a time with delicious fragrance.

The geraniums, or cranesbills, belong to the family Geraniaceae. They are generally rather insignificant, though their first cousins the pelargoniums of gardens, incorrectly termed " geraniums," are amongst the most showy of plants. Some authorities place the genus Oxalis in the above family, but others place it in a family by itself, the Oxalidaceae. New Zealand has only 2 species of Oxalis, the beautiful white Oxalis magellanica and a huge aggregate species, $O$. corniculata.

To the pea family (Leguminosae) belong the New Zealand brooms (Carmichaetia), of which there are 22 species, all with remarkable contrivances against drought. Closely related to Carmichaelia are the endemic genera Corallospartium, Notospartium, and Chordospartium. Here also comes the yellow kowhai (Sophora microphylla and its allies), and a rare mountain-plant, Swainsona novae-zelandiae, of Australian affinities. Then there is the parrot-bill (Clinathus puniceus), which is related to Sturt's desert-pea of central Australia.

The rose family (Rosaceae) lacks in New Zealand the true roses, but is represented by the genera Rubus (5 species or more), to which belong the bush-lawyers; Geum (7 species, all but one mountainplants); Potentilla (1 species); and Acaena, containing 9 species, to which belong the different species of piripiri-plants very unlike roses. The common piripiri (Acaena Sanguisorbae) is a large aggregate species made up of many varieties, some of which are easy to recognize.

The pitchy-seed family (Pittosporaceae) is common in forests. The genus Pittosporum can be recognized by the generally large capsules, which, when they open, contain black seeds embedded in a very sticky substance. The kohuhu $(P$. tenuifolium in several varieties), so largely used as a hedge plant, is wrongly called "matipo" by the gardeners, this being the name for various species of Suttonia.

Saxifrages (Saxifragaceae), plants so essentially alpine, are wanting in New Zealand; but there are some forest-trees belonging to the family-e.g., the putaputaweta (Carporletus serratus). The kamahi 
(Weinmannia racemosa), called "red-birch" in Westland, is very common, and belongs to the Cunoniaceue, a most closely related family.

The sundews (Drosera) belong to the family Droseraceae. There are 6 New Zealand species in the genus.

To the laurel family (Lauraceae) belong the genera Beilschmiedia (to which belong the tawa and taraire), Litsaea, and the parasitic Cassytha.

The mustard or cabbage family (Cruciferae), so important in horticulture and agriculture, contains, as a rule, plants with rather insignificant flowers. Lepidium is the most important New Zealand genus of this family, and $L$. oleraceum (Cook's scurvy-grass) the most famous plant of that genus. Attention may be called to the endemic Pachycladon, a genus consisting only of $P$. novae-zelandiae, a small high-mountain rock or debris plant of the rosette form.

The Monimiaceae is represented by only 2 species - that noble tree the pukatea (Laurelia novce-zelandiae), of South American affinity, and the pigeonwood (Hedycarya arborea).

The magnificent magnolias of America and Asia (Magnoliaceae) are absent from New Zealand forests, their representatives being shrubs with rather insignificant flowers, the pepper-tree (Drimys axillaris, $D$. colorata), and $D$. Traversii, of the North-western Botanical District, relations of the well-known Winter's bark (Drimys Winteri) of South America.

The buttercup family (Ranunculaceae) contains, besides the buttercups (Ranunculus), of which there are about 46 New Zealand species, the charming clematises (fig. 4) and an alpine genus (Caltha) containing 2 species, in each of which the leaf is most curiously lobed.

The chickweed family (Caryophyllaceae) includes the subantarctic genus Colobanthus (10 species), Spergularia, and Claytonia. There are at least 26 introduced species of this family in New Zealand.

The goosefoot family (Chenopodiaceae) comprises Chenopodium, Artiplex, and Rhagodia, with mostly coastal species.

The knotweed family (Polygonaceae) includes Muehlenbeckia, a genus of 4 species, two of which are lianes of physiognomic importance in the New Zealand landscape.

The mistletoe family (Loranthaceae) includes various closely related semi-parasitic genera (Elytranthe, Phrygilanthus, Loranthus, and Iorthalsella). The common mistletoe (Loranthus micranthus) is now 
found not only on various indigenous trees and shrubs, but on plumtrees, elms, hawthorns, laburnums, and some other introduced trees.

The Proteaceae, that great Australian and South African family, is represented by only the rewarewa (Knightia excelsa) and the toru (Persoonia toru).

The nettle family (Uricaceae) is remarkable for the great shrubby nettle (Urtica ferox). U. linearifolia is a scrambling climbing-plant.

The beech family (Fagaceae) contains the southern-beeches (Nothofagus), the subantarctic representative of the northern Fagus, this latter including the true beeches.

This concludes, so far as this book is concerned, that division of the seed-plants which in the seedling state have two seed-leaves (dicotyledons).

Among the division of the seed-plants which have only one seedleaf in the seedling state (monocotyledons) the following may be noted :-

The orchid family (Orchidaceae), with about 60 species in New Zealand, is divided into those which root in the soil and those with aerial roots provided with a special tissue for absorbing such water as falls on them. The most important genera are Pterostylis (13 species), Thelymitra (12 species), and Corysanthes (8 species).

The iris family (Iridaceae) contains the easily cultivated and rather pretty libertias. Libertia micrantha is a common plant of many montane and subalpine forests.

The lily family (Liliaceae) contains the different kinds of cabbagetree (Cordyline), and the New Zealand flax (Phormium), of which there are 2 species, $P$. tenax and $P$. Colensoi, as already noted. Here also come the genera Herpolirion and Astelia.

The palm family (Palmae) has two representatives-the nikau (Rhopalostylis sapida) and the Kermadec nikau (R. Cheesemanii).

The rush family (Juncaceae) is an extensive one, consisting of the alpine or subantarctic Roskovia, the true rushes (Juncus), and the wood-rushes (Luzula). This genus contains at least 8 species, but the aggregate species (Luzula campestris) can be split up into at least 10 more or less distinct varieties.

The sedge family (Cyperaceae) is of considerable physiognomic importance in New Zealand generally, since it includes the niggerhead (Carex secta) and those huge forest tussocks, various species of Gahnia. In New Zealand the family contains 124 species, which 
are usually either of the grass or the rush form. From rushes the rush-like sedges are distinguished by the former having flowers with small but nevertheless distinct floral leaves, while the distinction between grasses and sedges is that the former have hollow, jointed stems, and leaves with split leaf-sheaths, while the latter have solid stems, frequently angular, and the leaf-sheaths not split. The genera comprise Mariscus (1 species); Elaeocharis (5 species); Fimbristylis (1 species, which frequently grows near hot springs); Scirpus (13 species, including the sand-binding pingao, S. frondosus); Carpha (1 species-C. alpina-also found in Tasmania, Victoria, and the high mountrins of New Guinea); Schoenus (7 species, including $S$. brevifolius and S. tendo, plants of physiognomic importance on the Auckland gumlands, and the false snow-grass (S. pauciflonus), the characteristic plant of one bog association in the high mountains); Cladium (10 species, including the magnificent $C$. Sinclairii of certain North Island cliffs); C. teretifolium and C. glomeratum, characteristic swamp-plants, both closely resembling one another; Lepidosperma (2 species); Gahnia (8 species); Oreobolus (3 species)-all cushionplants; the hooked sedges (Uncinia), a genus of South American affinity, with 15 species; and the highly important genus Carex, the true sedges, with some 55 species, varying from huge tussocks crowning massive trunks to tiny grass-like tufts an inch or two high-e.g., Carex pyrenaica var. cephlalotes (also Australian) and C. acicularis, both species rock-dwellers on the highest mountains.

The grass family (Gramineae) is the most important economic plant-family in the world, since it supplies man and his grazing-animals with the great bulk of their food-c.g., pasture grasses, cereals (wheat, oats, barley, rye, maize), sugar (the sugar-cane), and also provides many. ornamental plants, some of which are economic, as the bamboos; nor must the value of grasses in the landscape of temperate countries be forgotten, giving, as they do, the restful green of the countryside, which is imitated in our garden lawns. The New Zealand species number 127, distributed into 28 genera, of which the largest are: Poa (30 species), Danthonia (15 species), Deyeuxia (11 species). The low tussocks (Poa caespitosa and Festuca novae-zealandiae), the tall tussocks (various forms of Danthonia Raoulii), and the toetoe-grass (Arundo conspicua) are of great physiognomic importance. The tussock form, the tufted form, the semi-climbing bamboo form, the turf-making form, the mat form, and the cushion form are all 
represented amongst New Zealand grasses, and afford an admirable example of the biological capabilities of a single family of plants.

The pond-weed family (Potamogetonaceae) includes the floating pond-weeds (Potamogeton), 5 species; the sea-grass (Zostera), 2 species; and the submerged aquatic plants of the genera Althenia and Zanichellia.

The screw-pine family (Pandanaceae) has only one representative in New Zealand, the kiekie (Freycinetia Banksii), but it is of considerable physiognomic importance.

The raupo family (Typhaceae) contains the genus Typha, which also is of high physiognomic importance, since it is the characteristic species of primeval swamp.

The pine family (Pinaceae), a very extensive family in the Old World, and of great economic value for its timber, is represented, and most worthily, by the kauri (Agathis australis) and two species of cedar (Libocedrus Bidwillii and L. Doniana). The kauri belongs to a subfamily (Araucarineae), and has as near relatives the Norfolk Island pine (Araucaria excelsa), the monkey-puzzle of the Andes (A. imbricata), a Brazilian species (A. braziliensis), the Australian A. Cunninghamii, and 6 New Caledonian species. Closer relatives still are some 6 species of Agathis itself found in Malaya, the Polynesian Islands, and Australia.

The taxad family (Taxaceae) concludes this abbreviated list of the families of New Zealand monocotyledons. It includes the genera Dacrydium (7 species), Podocarpus (7 species), and Phyllocladus (3 species). To these families belong many of the most important timber-trees, some yielding wood of extreme durability. Also here comes one of the plant curiosities of New Zealand mentioned in Chapter I, Dacrydium laxifolium - the smallest pine in the world (fig. 3).

The Pinaceae and Taxacece, together with the cycads of Australia, South Africa, tropical America, and the unique Welwitschia mirabilis of South Africa, form a fundamental division of the plant kingdom, the gymnosperms, distinct from other seed-plants in that their seeds are not enclosed in a chamber (the ovary) but stand uncovered upon the surface of scale-like leaves.

The seed-plants do not by any means comprise the whole of the New Zealand flora, nor even of those plants which stand out conspicuous in the landscape, for here come in the ferns. These, 
together with their allies the club-mosses (Lycopodium), and Tmesipteris, Psilotum, Isoetes, Pilularia, and Azolla, contain more than 150 species.

The ferns (Filices) bear their spores in little stalked bags, called sporangia, groups of which are plainly visible as circular brown patches or spots upon the back of the leaf. In some ferns-e.g., the hard-ferns (Blechnum) - only certain leaves bear spores, and these in that genus are of a different shape and narrower than the leaves without spores. In other ferns again-e.g., the moonwort (Botrychium) and the adder's-tongue (Ophioglossum)-there are also spore-bearing and sporeless leaves, very different in appearance, but both are given off from the same leaf-stalk. By some the two latter genera are not classed with the true ferns.

When a spore germinates it does not give rise to another fernplant, but to a small, flat, green body, frequently heart-shaped (the prothallus), which in course of time produces on its under-surface reproductive organs, so that an act of fertilization can eventually take place. By this means a young plant is produced which eventually grows into an ordinary spore-bearing fern.

New Zealand ferns are divided into 33 genera, one of which (Loxsoma) is endemic. The genera containing the most species are the filmy ferns (Hymenophyllum), the hard-ferns (Blechnum), the spleenworts (Asplenium), and the polypodies (Polypodium).

Generally the leaf-surface of a fern is more or less vertical, but in the genus Gleichenia it is horizontal, whence the species of that genus get the name of "umbrella-fern" (fig. 97).

The beautiful filmy ferns belong to the genera IIymenophyllum and Trichomanes. The leaves of these ferns are generally much divided, but those of the kidney-fern (Trichomanes reniforme) have a quite even margin. Many ferns can live only in a moist atmosphere; others, again, can tolerate extreme drought-e.g., the thickleaved Cyclophorus serpens and the woolly Gymnogramme rutaefolia.

The club-mosses (Lycopodiaceae) are represented by 11 species, one of which, $L$. ramulosum, is endemic. Although called "clubmosses," they bear no relationship to mosses proper. Like the ferns, these plants pass through a sexless (spore-bearing) stage and a sexual stage. The latter does not consist of a flat body which lives on the ground, \&c., as in the ferns, but of tiny "tubers," which have to be dug out of the ground, in appearance something like 
badly shaped potatoes. Up to a few years ago very few clubmosses had been found at this stage of development anywhere in the world, so there remained much to be learnt of the life-history of

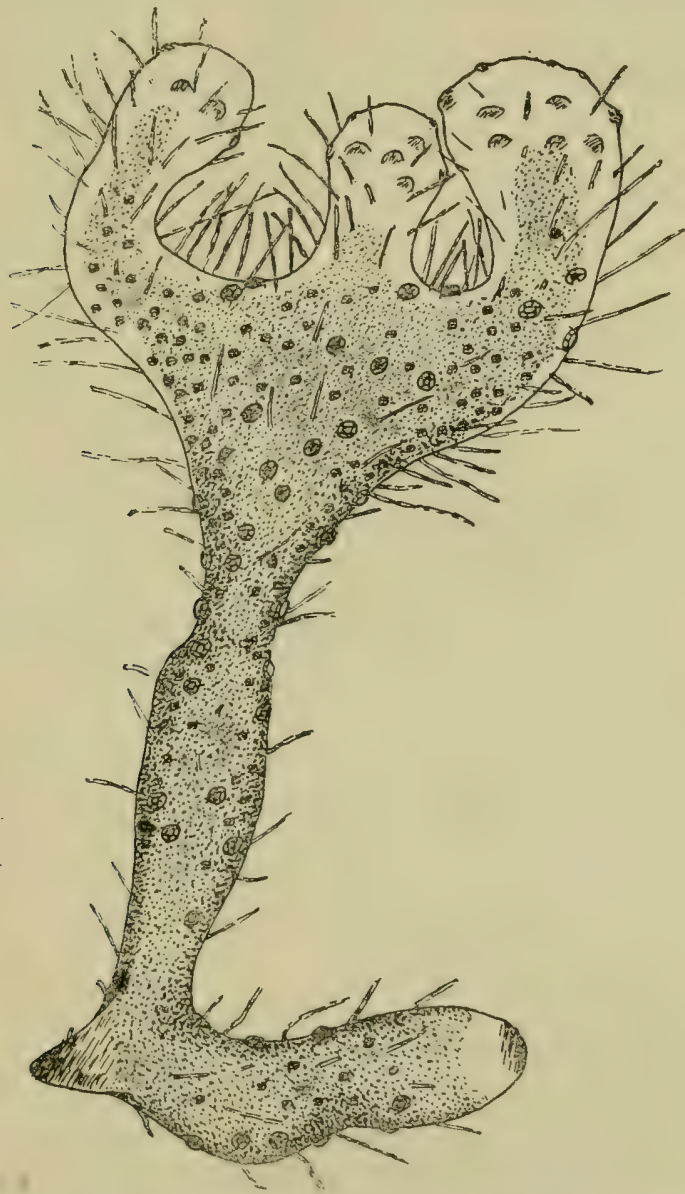

Complete branched early sexual stage of Tmesipteris of large size. Magnified 10 times. (After Holloway.)

the genus. The honour of having filled this blank has come to New Zealand. The Rev. John E. Holloway, D.Sc., of Hokitika, during the last few years has dug up hundreds of our club-mosses at all stages of their sexual development, and in a series of brilliant papers 
published in the "Transactions of the New Zealand Institute" has added greatly to what was previously known concerning the lifehistory of Lycopodium.

Tmesipteris, which closely resembles a club-moss in appearance, also passes the sexual stage of its career underground. Up to last year this stage of its development was unknown, but Professor

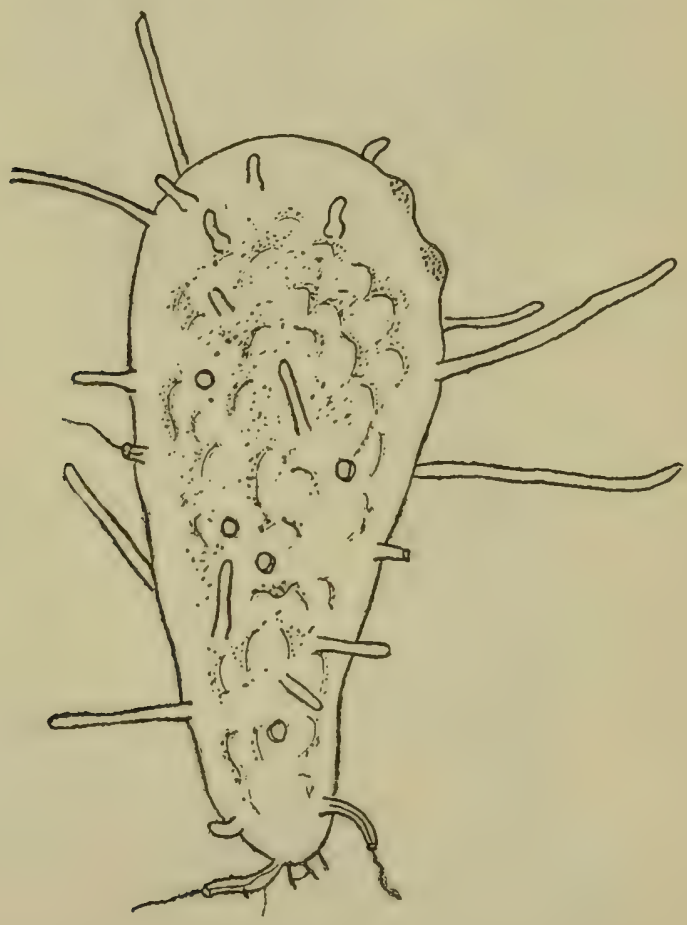

Very young complete early sexual stage of Tmesipteris. Magnified 45 times. (After Holloway.)

Anstruther A. Lawson, of Sydney University, from material he collected in New South Wales, had the honour of first making known to science a part of the life-history of this remarkable plant. Since then Holloway has confirmed and amplified Lawson's results, using a wealth of material he had discovered in the moist forests of Westland. He has also been able to trace the development of the young 
plant which appears as the result of fertilization. These club-mosses and Tmesipteris seem rather out of place on the earth at the present time, for their nearest relatives are plants of the long-ago which were quite common ages before the seed-plants which now beautify the earth came into existence. Of these relics of the dim past there are also in New Zealand two other genera-Phylloglossum and Psilotumeach with one species. The early stage of the latter was also unknown until last year, when Lawson discovered and described it ; the former earlier yielded up some of its secrets to Professor A. P. W. Thomas, of Auckland.

The mosses and liverworts embrace hundreds of species living under all kinds of conditions, and varying in size from the giant Dawsonia superba (fig. 32) and Polytrichum dendroides, 2 feet or more high, to tiny species of liverworts (Frulania, \&c.), which cling to the bark of trees. Very interesting is the way in which both mosses and liverworts build up great cushions in stations where the air is almost constantly saturated with moisture. In the forests of Stewart Island, but chiefly in the south and west, the cushions look just like moss-covered boulders (fig. 37).

Low down in the scale of the plant-world come those most wonderful of plants the fungi, whose life-histories are as marvellous as any fairy tale, and of which but little was known sixty years ago. At the present time their study is of the highest economic importance, and plant pathologists are employed by all progressive countries to find means of waging warfare on these microscopic plants and other "blights," both vegetable and animal. One example of a New Zealand fungus must suffice. In the montane Nothofagus forests more especially, the boles of the larger trees are covered in many instances with a thick coating of a coal-black hue, which gives the trunks the appearance of having been plastered thickly with soot, and tends to enhance the gloomy character of the interior of these forests. This coating consists of a fungus, Antennaria by name, which is especially interesting from the manner in which it gets its food-supply. Antennaria belongs to the group of "honeydew fungi," so named because they utilize as food the exudation excreted by certain insects. If a piece of the plant be examined carefully, there will be found embedded in its interior numerous reddish insects somewhat resembling tiny wood-lice, surrounded with white fluffy material like cotton-wool. These are scale insects related to the well-known Coccus Cacti, from 12-Plants. 
which the colouring-matter cochineal is made. This beech-coccus exudes considerable quantities of a sweet sticky fluid, on which the black fungus feeds; while at the same time the scale insect lives warm and snug under the protection of its sooty covering. Antennaria can also exist without its animal lodger and the rent which it pays in kind, but in this case the author has been informed that the fungus changes its habit of growth somewhat in accordance with its altered circumstances.

After the fungi come the algae, salt water and fresh. Macrocystis pyrifera, a brown seaweed, attains an enormous size, and lengths of many hundreds of feet are not unknown; indeed, this plant may be the famous "sea-serpent."

Then there are the bacteria--the "microbes" of the newspapersall infinitesimally minute plants, including some the greatest of benefactors and others the deadly enemies of mankind. And finally come the slime-fungi (IIyxomycetes), which may be seen as jelly on rotten wood, and, moreover, are at one period of their existence animals, and at another plants! Many are very small, and unless one knew exactly where to look for them, and what to look for, their presence would never be suspected. 


\section{CHAPTER XII.}

\section{THE DISTRIBUTION OF THE PLANTS IN NEW ZEALAND.}

General remarks - What the plants could tell of their wanderings-The botanical districts - The Three Kings Botanical District-The North and South Auckland Botanical Districts-The Volcanic Plateau Botanical DistrictThe East Cape Botanical District-The Egmont-Wanganui Botanicai District-The Ruahine-Cook Botanical District-Cook Strait no barrier to the wandering of plants-General considerations regarding distribution throughout the South Island-The North-western Botanical District-The North-eastern Botanical District-The Western Botanical District-The Eastern Botanical District - The North Otago Botanical District-The Fiord Botanical District-The South Otago Botanical District-The Stewart Botanical District-The botanical provinces-How plants travel long distances-Discontinuous distribution--Species known in only one locality.

THE story of the distribution of our plants is certainly one of the most thrilling they have to tell. Perhaps it might include their origin also-that mystery from which merely a corner of the veil has been raised, only to be dropped again before more than a shadowy glance has been gained. The story, some small part of which is told in this chapter and the next, would perforce deal with long journeys over land and sea; with mountains slowly rising and sinking, but all the time being carved into fantastic forms by water or moulded by ice; with land and sea replacing one another again and again-profound depths of ocean coming into being, but, with the moving years, changing into shallow seas or dry land; with fluctuations of climate from antarctic cold to tropic heat. Then would the plants tell of their constant struggle literally for " a place in the sun," or it might be in the shade; of the going to the wall of beings too highly organized to begin a new life; of the victory for those able to accommodate themselves to circunstances; of the selecting action of soil and climate; of the ills they had suffered at the hands of many animals and even of their fellows.

If much of the above the plants can only lint at, they certainly can tell where they reside at present; they can give some information as to their modes of travelling; they can teach us 
something about the ways by which their competitors have been worsted-indeed, their story as told in this book has chronicled some of these matters.

Before any question regarding distribution can be approached the first thing necessary is to get a true account of the distribution of the plants according to latitude and altitude throughout the New Zealand Botanical Region. This essential preliminary has been the business of the plant-collectors-an ardent brotherhood, far too little appreciated when their truly strenuous labours are considered. It is true that these labours will have to be continued for many years, since there are areas of considerable size still unexplored botanically, and no locality, as yet, has been thoroughly examined. All the same, the general details of New Zealand plant-distribution are now fairly well known.

It has been possible tentatively to divide the New Zealand Botanical Region into a number of fairly natural botanical districts. Each district possesses its peculiar plants (both indigenous and introduced), its special plant-associations, and, to some extent, its special agriculture and horticulture. ('limate, latitude, soil, and the age of the species partly account for some of the peculiarities of the districts, but they are also correlated with the geological history of the New Zealand archipelago.

The divisions as proposed by the author two years ago in the "Transactions of the New Zealand Institute," together with their names, may he seen upon the map on page 181; there is, then, no need to enumerate them here. The space will be better utilized by calling attention to a few interesting points concerning each district.

Beginning at the north with the Three Kings Botanical District, its flora is quite small, but no fewer than six species are confined to the group. These are the fern Davallia Tasmani, the Three Kings milk-tree (Paratrophis Smithii), the Three Kings karo (Pittosporum Fairchildii), Coprosma macrocarpa, and Teronica insularis. The puka (Meryta Sinclainii) and the cabbage-tree (Cordyline australis) are an important feature of the vegetation of the West King.

Surprising as it may seem, there are more than 100 species of plants which either do not extend past latitude $38^{\circ} \mathrm{S}$., or go beyond it only for a short distance. Some of these are trees, shrubs, and ferns characteristic of the forests of the North and South Auckland Botanical Distriets. The following may be noted: The handsone 


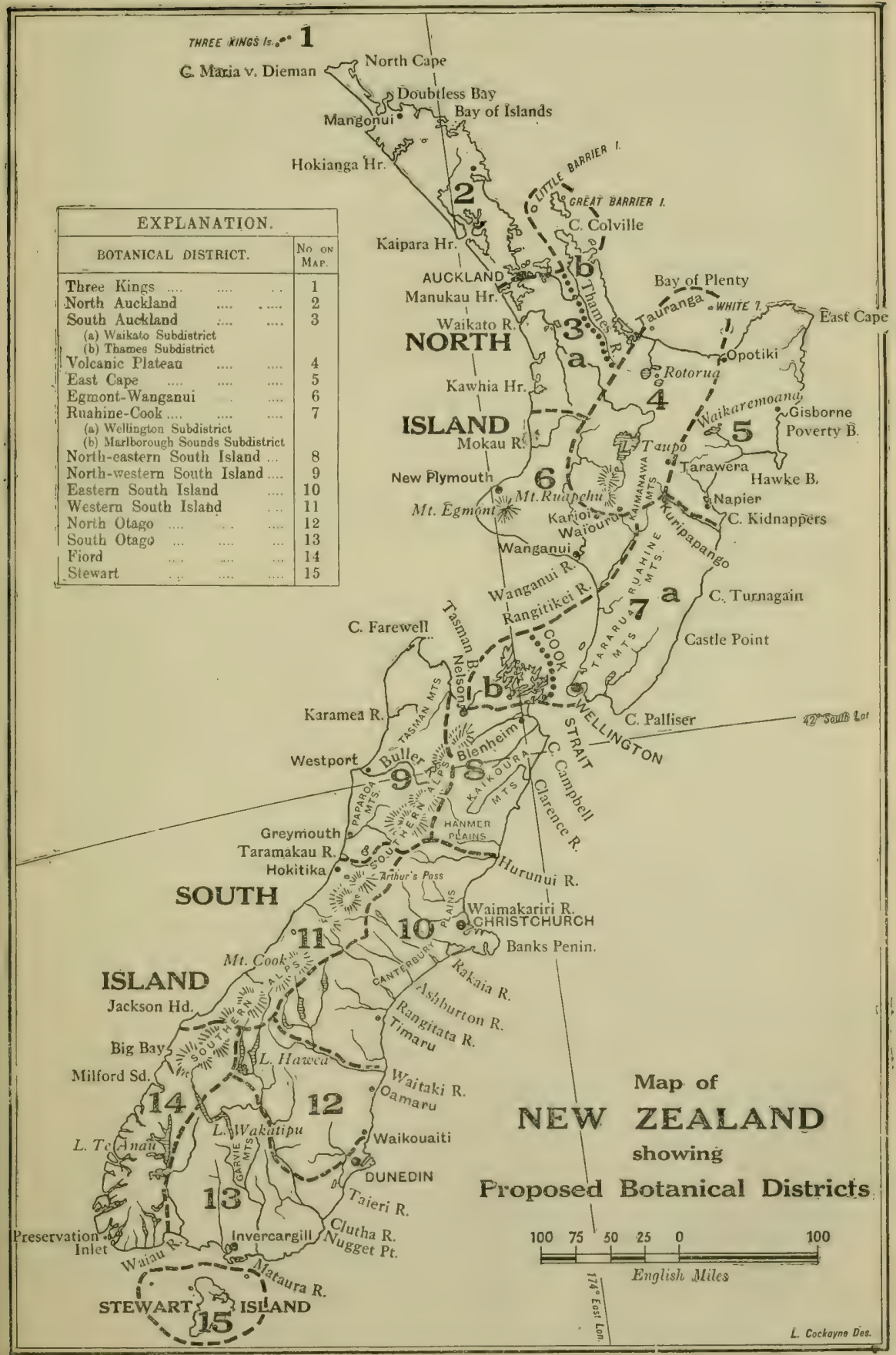


fern Loxsoma Cuminghamii (the genus endemic), which is found in certain localities only, there forming great colonies amongst manuka near the outskirts of kauri forests (in all floras it is placed with the filmy ferns, but the discovery of its juvenile sexual stage a few years ago showed this to be erroneous, so for the future it must be placed with the ordinary thicker-leaved ferns); the kauri (Agathis australis); the taraire (Beilschmiedia taraire); the tawhero (Weinmannia sylvicola); the makamaka (Ackana rosaefolia); the mairehau (Phebalium nudum); various species of Pittosporum, especially the karo ( $P$. crassifolium); one or two species of Coprosma-e.g., C. arborea and C. spathulata. Some species are confined to the far north-e.g., the king fern (Todea barbara); the parasitic Cassytha paniculata; the beautiful large thinleaved oru (Colensoa physaloides), able to endure much shade. Even the actual North Cape has its peculiar plants, limited to that wind-swept promontory; such are Cassinia amoena, Halorhagis curtilaginea, and a thick-leaved form of the hangehange (Geniosloma ligustrifolium).

Quite a number of species well known in New Zealand farther to the south have their northern limit in the South Auckland Botanical District--e.g., the filny ferns Hymenophyllum pulcherrimum and $H$. unilaterale, the alpine hard-fern (Blechmum penna marina), the prickly shield-feru (Polystichum restitum), the nodding club-moss (Lycopodium varium), the alpine club-moss (L. fastigiatum), and the mountain club-moss (L. scariosum). That plants which can travel so easily as can ferns and club-mosses by means of their spores, light as dust, should suddenly be arrested in their march northwards rather throws out of gear one's ordinary conception of the capacities of such plants for long journeys over the ocean and eventual settlement. Amongst other species with the same northern limit as the above are the mountain-toatoa (Phyllocladus alpinus), the pahau-tea (Libocedrus Bidwillii), the silver-tussock (Poa caespitosa), certain small sedges, the forest-snowberry (Enargea parviflora), the broadleaved cabbage-tree (Cordyline indivisa), the star-lily (Arthropodium candidum), the silver southern-beech (Nothofagus Menziesii), the wildirishman (Discaria toumatou), the slender broom (Carmichaelia flagelliformis), the haumakaroa (Nothopanax simplex), the mountain-foxglove (Ourisia macrophylla), Coprosma linariifolia, the hupiro (C. foetidissima). It is remarkable, too, that most of the above have come to a standstill here, since they are quite well fitted for dispersal. The 
broad-leaved cabbage-tree (Cordyline indivisa), for example, may be quite an aggressive plant where forest in its vicinity has been destroyed. A negative feature in the primitive vegetation is the absence of grassland, the place of which is taken by manuka shrubland.

In the farming areas of the North and South Auckland Botanical Districts there are splendid meadows of Paspalum dilatatum, and Lotus hispidus also forms pastures both artificial and adventitious. In orchards oranges and lemons are grown with success. It may be pointed out with regard to grassland generally that in these districts a greater diversity of primitive plant-associations are turned into grassland than is the case in any part of New Zealand. Certain introduced plants do not occur south of the Auckland Botanical Districts-e.g., Helenium quadridentatum, Tolpis umbellata, certain species of Epacris, Solanum sodomaeum, the ink-weed (Phytolacca octandra), the water-lily already mentioned (Ottelia ovalifolia), and the wild rice (Zizania aquatica).

Coming next to the Volcanic Plateau Botanical District, the monoao (Dracophyllum subulatum) is an extremely characteristic feature of the shrubland, as is its relative the red heath (D. recurvum) of the scoria deserts of the volcanic alpine area, where it forms reddish rounded bushes. Tussock-grassland, both tall and low, covers considerable areas, so that mountain shecp-runs are established. Totara (Podocarpus tolara) and mountain-totara (P. Hallii) are important constituents of the forest. The high-mountain flora assumes considerable proportions, and the following species, which do not reach the South Island, may be cited: The Egmont buttercup (Ranunculus nivicola), the box-leaved pimelea (Pimelea buxifolia). a small-leaved ball-shaped koromiko (Veronica laevis), the pumice whipcord koromiko (V. tetragona), two lovely low-growing koromikos (V. Hookeriance and $V$. spathulata), and the dainty North Island eyebright (Euphrasia tricolor) (fig. 59).

With regard to the East Cape Botanical District, attention may be called first of all to the fact that a number of well-known northern New Zealand trees have their south-eastern limit in its northern part. Such are the kawaka (Librocedrus Doniana), the toru (Persoonia toru), the parapara (Pisonia Brunoniana), the mangeao (Litsaed calicaris), the tawheowheo (Quintinia serrata), the tawari (Ixerba brexioides), the karo (Pittosporum crassifolium), the tawhero (Wcinmannia sylvicola), 
the pohutukawa (Metrosideros tomentosa), the puriri (Vitex lucens), the korokio taranga (Corokia buddleoides), the tawapou (Sideroxylon novo-zealandica), and the Auckland tree-daisy (Olearia albida).

There are thirteen species peculiar to the district: these include the large-flowered kowhai (Sophora grandiflora); two fine forget-me-nots - Myosotis amabilis and M. saxosa; three veronicas - V. macroura and $V$. Cookiana (coastal plants), and V. Darwiniana (high-mountain plant); and a tree-daisy Olearia pachyphylla, related to O. furfuracea.

In the northern part of the district there are extensive forests of both Nothofagus and taxads; in the south the climate is drier, forest is much less in evidence, and there fern-heath or manuka shrubland originally occupied considerable areas. Rivers are often fringed with groves of trees and shrubs, amongst which are the largeflowered kowhai (Sophora grandiflora), Pittosporum Ralphii (now so common in gardens or for hedges), and one of the lacebarks-Hoheria sexstylosa. The rose-leaved anise (Angelica rosaefolia-a climbing plant), the beautiful upright calceolaria (Jovellana Sinclairii), and the "everlasting" Gnaphatium subrigidum are frequent plants of the district, limited to special stations.

With regard to farming, sheep are depastured in large numbers on the rich artificial pastures. Danthonia pastures will support an astonishing number of sheep. The southern limit of maize as a grain crop is in the neighbourhood of Gisborne, though as a forage crop it is grown as far south as Cook Strait. In gardens subtropical plants similar to those cultivated in the Auckland Botanical Districts grow vigorously.

As in the district just denlt with, so, too, in the EgmontWanganui Botanical District certain trees-e.g., Libocedrus Doniana, Metrosideros tomentosa, and the puriri (Vitex lucens)-find a southern limit. On the coast west of Mount Egmont the shore-koromiko (Veronica elliptica) has its northern limit. Except one or two plants of Mount Egmont, which need further study before a definite pronouncement can be made, only the fine herbaceous groundsel, Senecio Turneri (a species closely related to S. latifolius), and Teronica salicifolia var. longeracemosa appear to be confined to the district. Indeed, the characteristics of the district are negative rather than positive, and based rather on the vegetation than on the flora. For example, the vegetation of river-gorges briefly described in Chapter $\mathrm{V}$ is a characteristic feature. The original forest was probably very largely 


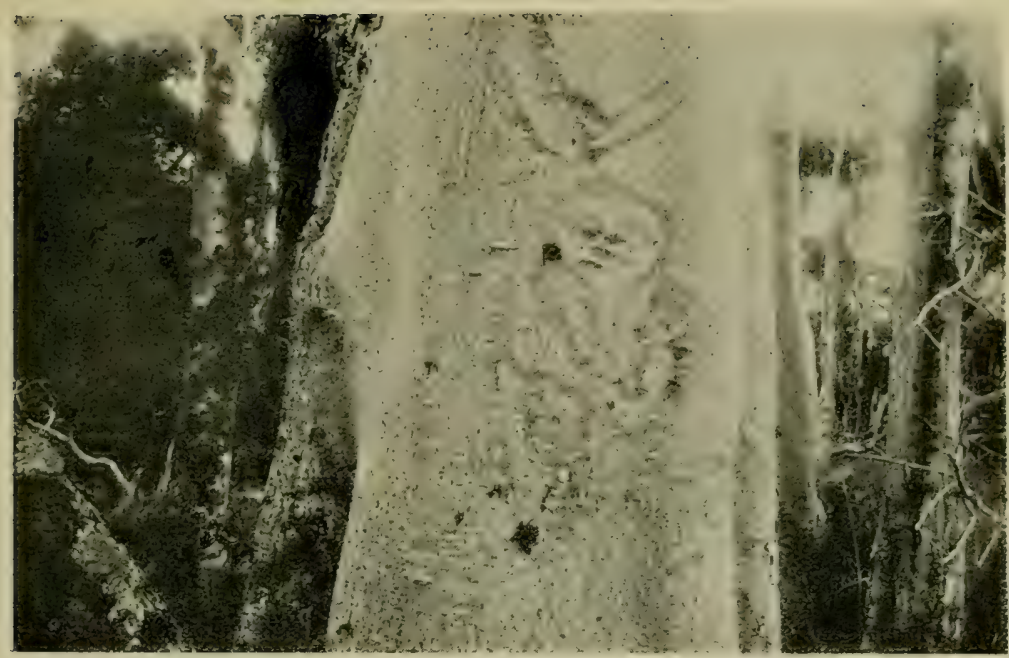

FiG. 92.-Moriori figure with three fingers on bark of kopi-tree (Corynocarpus laevigata). Lowland forest of Chatham Islands.

[l'hoto, L. Cockayne.

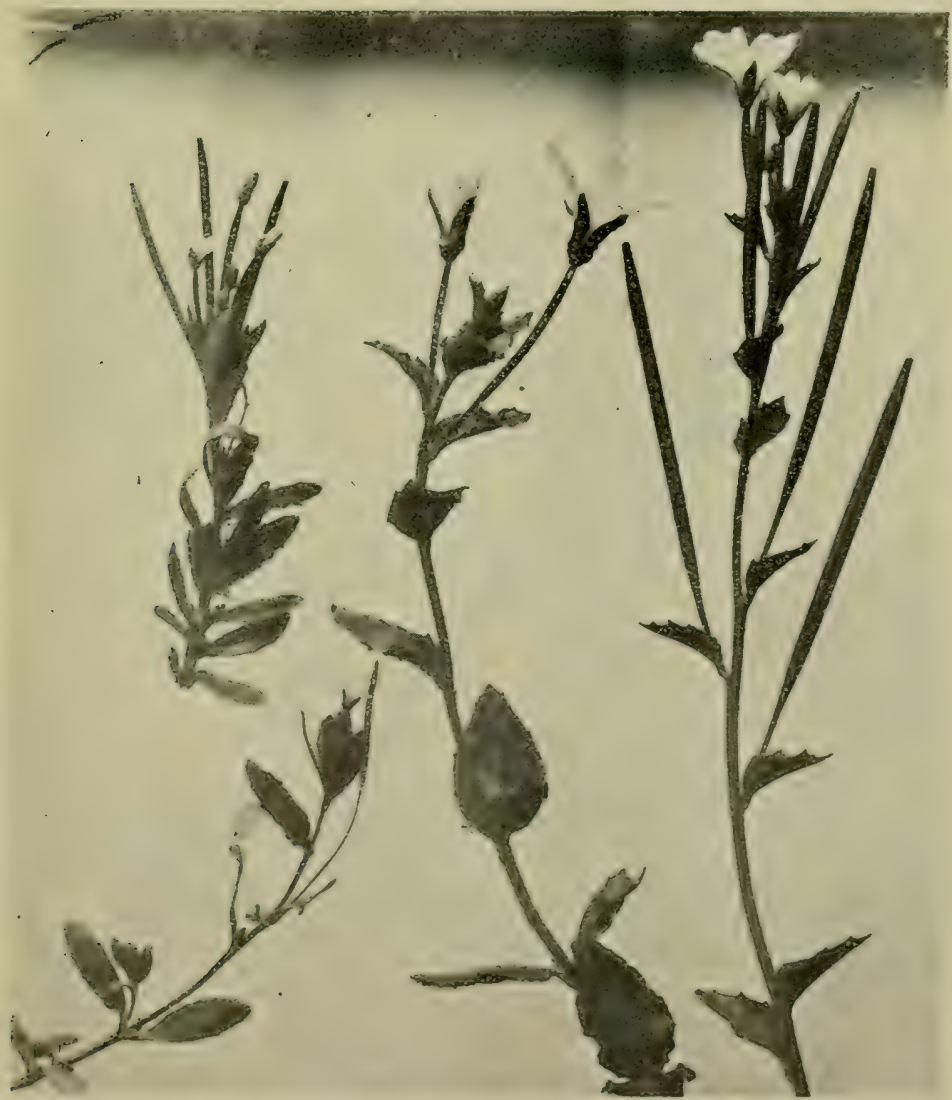

FiG. 93.-Flowering shoots of the mountain willow-herb (Epilobium chlorue- 


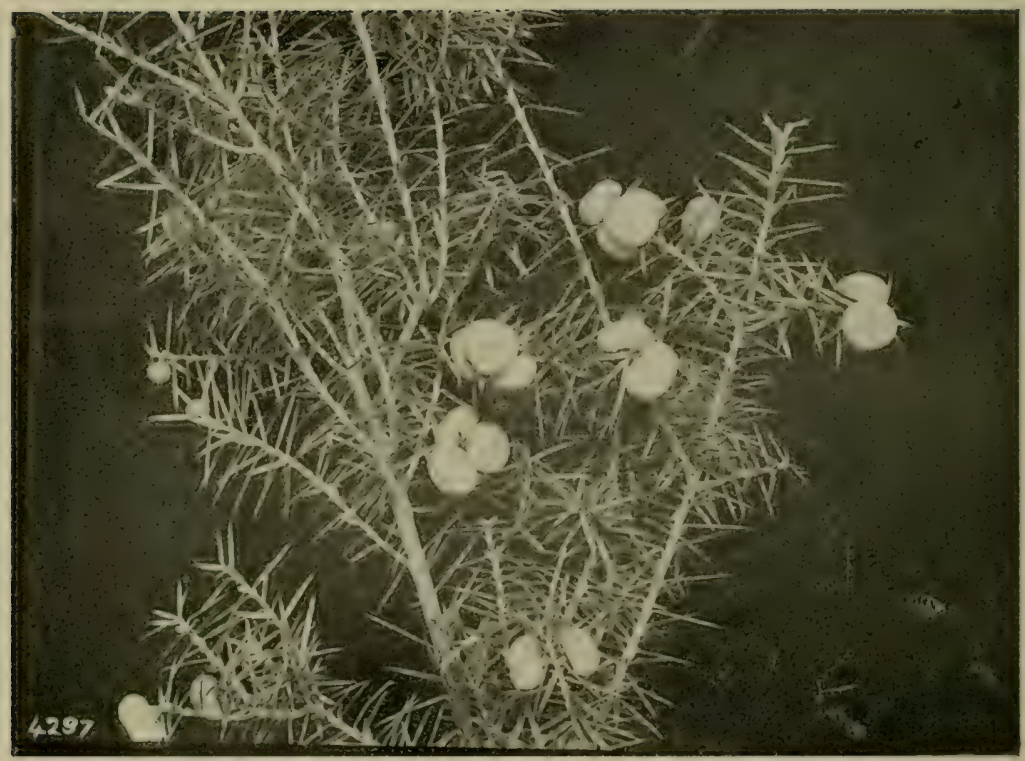

FIG. 94.-Fruiting shoot of Cyathodes robusta of the Chatham Islands; a plant of dry ridges.

[Photo, J. Crosby, Smith.

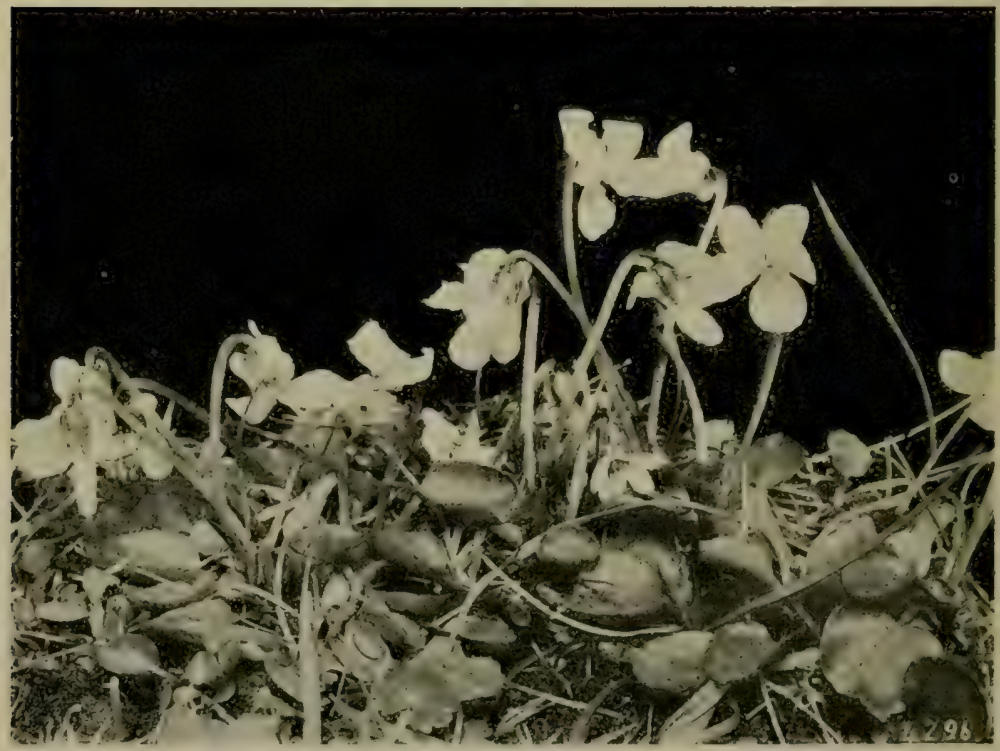

FIG. 95.--The New Zealand violet (Viola Cunninghamii), about life-size.

[Photo, J. Crosb?] Smith. 


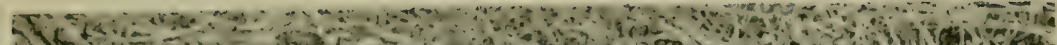

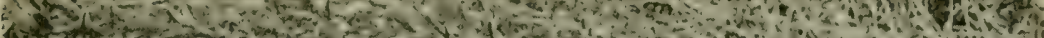
1.6.

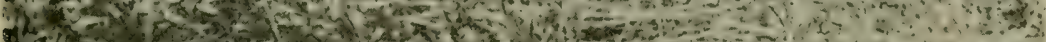

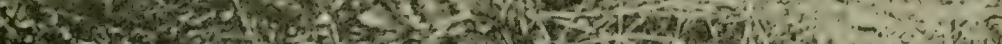

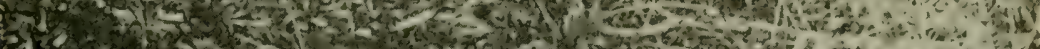
H.

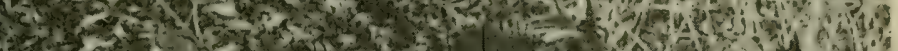

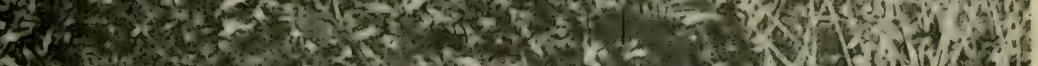
1.

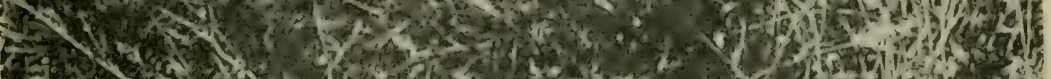

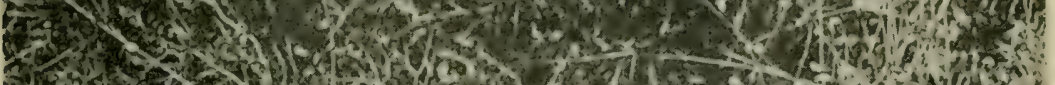

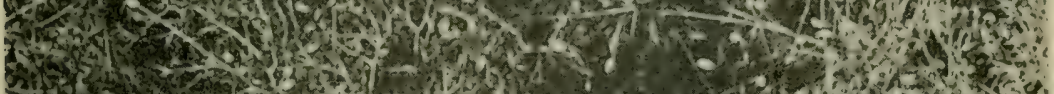

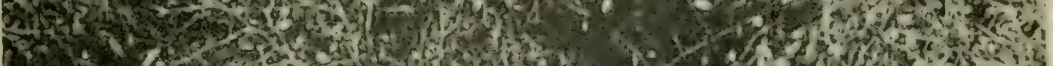
3.

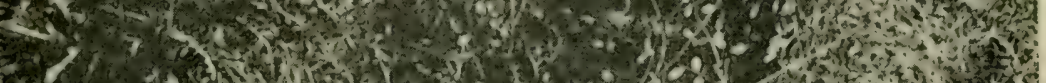

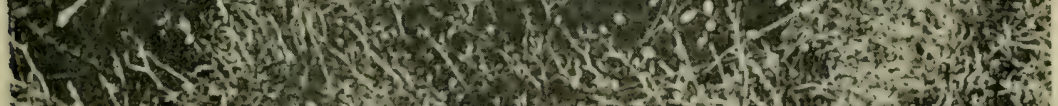

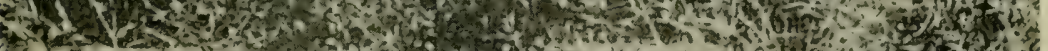
2 2x... E- STH

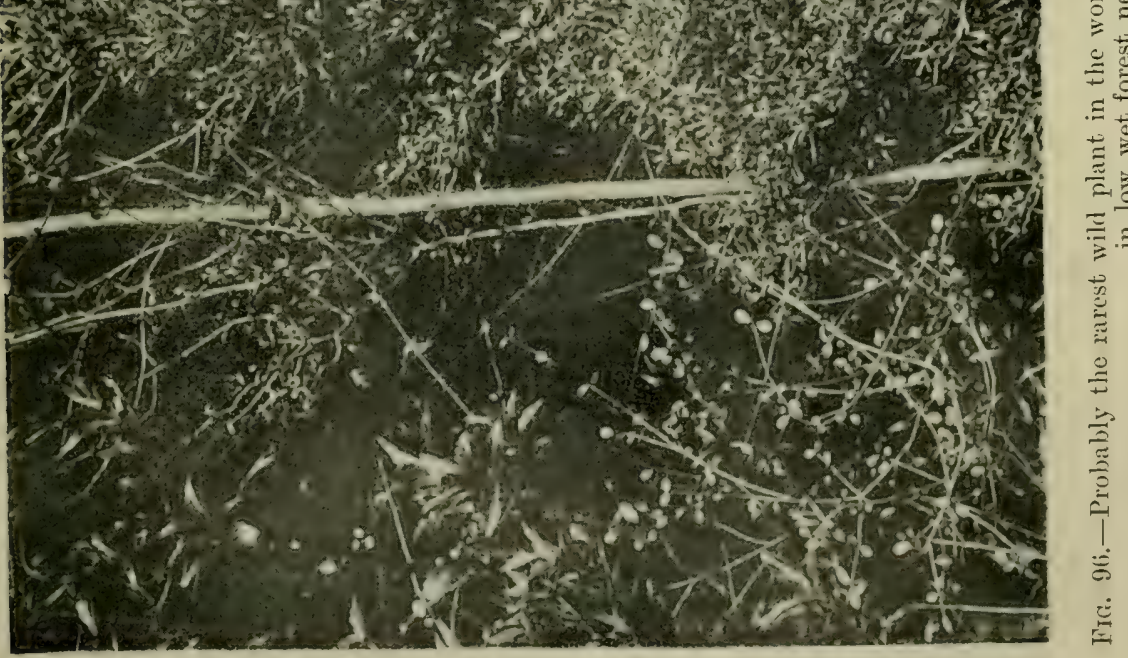




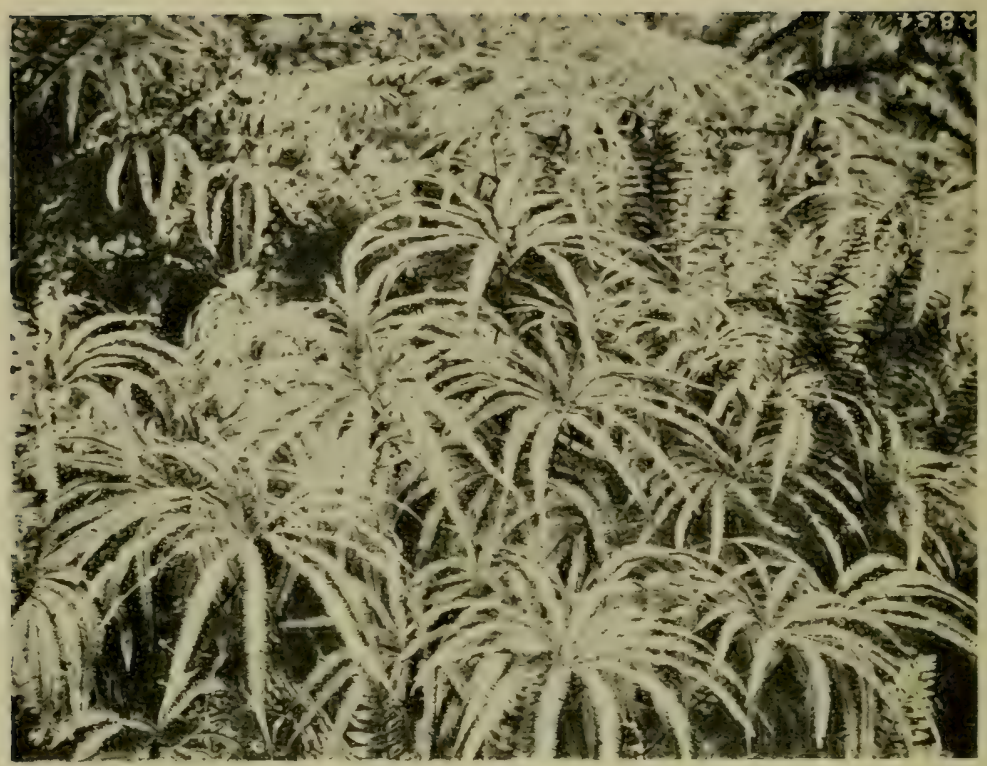

Fri. 97.-The umbrella-fern (filcichenia c'unninghamii) growing in wet forest Lands Depurtmerit.] in Stewart Island.

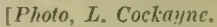

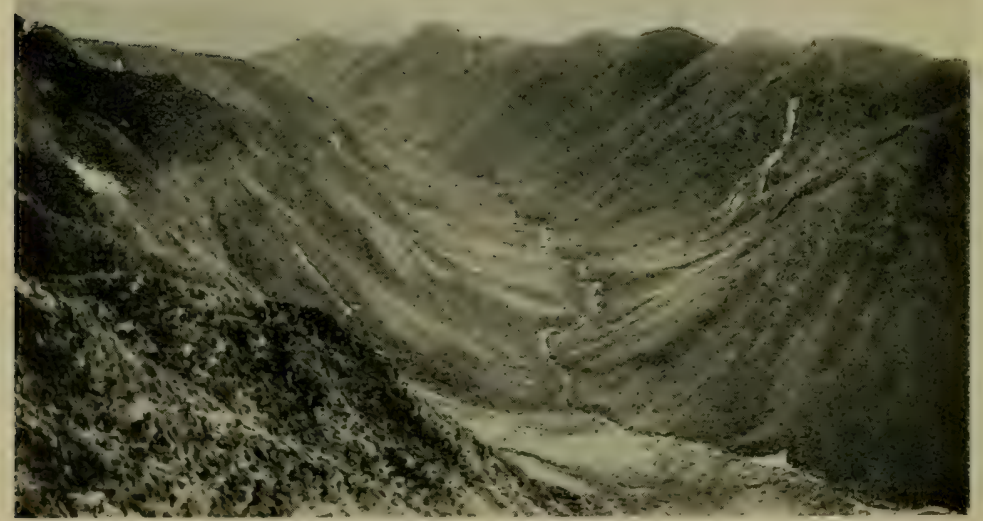

FIG. 98. - The U-shaped Park. Valley, in the Dundas Range of the Tararua Mountains, claimed by G. L. Adkin as a proof of former glaciation in the Tararua Mountains. 
composed of tawa (Beilschmiedia tawa); southern-beech forest is generally absent, Nothofagus Solanderi, when present, being frequently confined to the crest of ridges. The high-mountain flora of Mount Egmont is considerably smaller than that of the Volcanic Plateau or of the Ruahine-Tararua Ranges.

As farmland the soil grows grass amazingly, so that certain areas produce almost unbelievable amounts of cheese and butter. At the Kaupokonui Cheese-factory, for instance, 2,500 tons of cheese are produced from the milk of ten thousand cows grazed on less than 20,000 acres. The mild, moist climate allows camellias, azaleas, and many other flowering-shrubs to grow to a size uncommon elsewhere in New Zealand, and to bloom with the greatest profusion. Near the coast and for some miles inland the immense hedges of the Africau box-thorn (Lycium horridum) in the south-western part of the district are at the present time a physiognomic feature of the landscape.

So little effect has that apparently important natural obstacle, Cook Strait, had upon the wandering of plants that no line of sufficient importance can be drawn to separate the southern North Island flora, and even vegetation, from that of the neighbourhood of the Marlborough Sounds and some portions of northern Nelson. Indeed, the true South Island flora does not begin, so far as the neighbourhood of the coast is concerned, until about latitude $42^{\circ} \mathrm{S}$. is crossed. Thus the following common North Island species extend to the South Island, some reaching as far as Greymouth, or even Banks Peninsula: The nikau-palm (Rhopalostylis sapida), the rewarewa (Knightia excelsa), the pukatea (Laurelia novae-zelandiae), the tawa (Beilschmiedia tawa), the epiphytic Pittosporum cornifolium, the kohekohe (Dysoxylum spectabile), the wharangi (Melicope tematci), the karaka (Corynocarpus laevigata), the titoki (Alectryon excelsum), the northern rata (Metrosideros robusta), the maire (Eugenia maire), the toro (Rapanea salicina), three species of olive (Olea Cunninghamii, $O$. lanceolata, and $O$. montana), the hangehange (Geniostoma ligustirfolium), the kanono (Coprosma grandifolia), two species of Alsenosmia (A. macrophylla and $A$. quercifolia), and the tauhinu (Cassinia leptophylla.

There are a number of plants which are found only in the Ruahine-Cook Botanical District, but they are of restricted distribution, while many of them are confined to the Tararua Mountains 
Senecio compactus, S. Greyi, and Coprosma Buchanani, three locally endemic species, are coastal plants, but they are so rare that to see them all in their habitats would mean a considerable journey.

With regard to the vegetation of the district, there are both taxad and southern-beech forests. The latter occurs in places at almost sea-level. Cook Strait notwithstanding, the forest at Day's Bay, Wellington, and that near the Picton waterworks in the South Island are almost identical. Semi-coastal forest with the kohekohe (Dysoxylum spectabile) (fig. 24) dominant is a feature of many areas. The Cook Strait koromiko (I'eronica salicifolia var. Alkinsonii) is characteristic of coastal rocks, and it extends inland for some miles, where it rapidly takes possession of rock-cuttings and stony banks. The phormium coastal-cliff association differs from that of the East Cape Botanical District. The indigenous induced tauhinu (Cassinia leptopliylla) association is common.

Dairy-farming and grazing are the chief agricultural pursuits. There are permanent pastures of rye-grass on fertile soil-quite an uncommon occurrence elsewhere in New Zealand. There are important areas of indigenous induced New Zealand flax (Phormium tenax).' Maize as a forage crop has its southern limit at Cook Strait. The forglove (Digitalis purpurea) is a bad pasture weed in the Marlborough Sounds part of the district. Danthonia pasture replacing artificial meadow of European grasses is a common occurrence.

It is far easier to fix natural boundaries for the South Island botanical districts than for those of the North Island. This arises principally through the position of the Southern Alps with regard to the westerly winds, charged with moisture, as already explained in Chapter VI. This leads to a natural division into dry and wet districts. In the south of the South Island the south-westerly rains make themselves felt, so that a wet area extends from sea to sea across the island to the south of the dry North Otago Botanical District, where the dry climate reaches it maximum.

There are also local climates to be considered, notably those arising from easterly rains. These bring in, where the ranges are sufficiently high, a local forest-climate along a good deal of the east coast extending from the Seaward Kaikoura Mountains to Banks Peninsula. There are also local forest-climates in gullies and shady places in the eastern ranges. Then there is the Canterbury Plain. itself, with conditions generally hostile to forest. 
The botanical districts of the South Island are distinguished by a good deal of local endemism, which consists in general of more widespread species than are locally endemic in the North Island botanical districts. Also, with the exception of the two Auckland districts considered together, the locally endemic species of the South Island districts are more numerous.

The North-western Botanical District contains about 30 species peculiar to itself, including the beautiful white-flowered Pittosporum Dallii, recently rediscovered by Mr. F. G. Gibbs-this but one of his many important discoveries; the slender Metrosideros Parlinsonii; several species of Aciphylla; a prostrate broom with minute whitish flowers, possibly confined to the coast (Carmichaelia Fieldii); two species of Dracophyllum; two or three forget-me-nots; several gentians; two or three veronicas; about half a dozen species of Celmisia; two groundsels, including the deciduous Senccio Hectori, a most striking shrub, with its large leaves, white flowers, and considerable stature.

An important characteristic is the number of species which reach their southern limit in this district-species some of which are absent elsewhere in the South Island, while some do not occur even in the North Island except in the Auckland Botanical Districts or just beyond their southern boundary-e.g., Lycopodium cernum, Adiantum aethiopicum, Blechnum Fraseri, Astelia Banksii, Schoenus tendo, Pterostylis puberula, and Dracophyllum latifolium. The following are other unexpected North Island plants: Cladium capillaceum, Peperomia Endlicheri, Lepidium incisum, Epacris panciftora, Nertera Cunninghamii, and Gnaphalium subrigidum.

The forest is largely mixed taxad and southern-beech. The mountain southern-beech (Nothofagus cliffortioides) decends to sealevel. There is an extremely rich alpine flora, with extensive herbfields. Stunted southern-beech plays an important part in the subalpine scrub. The subalpine forest is frequently composed of the silver southern-beech (Nothofagus Menziesii). The vegetation of those areas of wet ground known as pakihis much resembles that of portions of the Auckland gumlands, both in species and physiognomy.

The North-eastern Botanical Distriet offers a striking contrast to the district just described. Here forest is absent over wide areas and low tussock-grassland rules. The species confined to the district are mostly those of rock and fell-field, and not of forest or herb- 
ficld. These species number about 32. Several have been described in Chapter V when dealing with rock-vegetation, especially Olearia insignis, Senecio Monroi, Helichrysum coralloides, Veronica Hulkeana, Celmisia Monroi, and Wahlenbergia Matthewsii. Others of special interest are the pink broom (Notospartium Carmichaeliae), and its recently discovered relative, Chordospartium Stevensonii; Gentiana Astoni; Wahlenbergia cartilaginea (like a European crusty saxifrage); Veronica micola; Senecio Christensenii (probably extremely rare); and Raoulia cinerea of the shingle-slips. On the wettest mountains in the south-west of the district the beautiful white-flowered Geum divergens grows on alpine rocks. The great cushions of the vegetablesheep (Haastia pulvinaris) are most characteristic of this district; so, too, the thickets of Cassinia albida.

This district is rapidly becoming of peculiar agricultural importance through the ease with which lucerne can be permanently established, there being no need for special effort to keep down weeds. Malting barley is grown to a fair extent. Chaff is harvested earlier than in any part of New Zealand. Indigenous induced danthonia pasture is common.

The Western Botanical District is readily separated from. the North-western Botanical District by the absence of southern-beech forest except just where the two districts join and in the extreme south, and by the presence of a number of locally endemic plants, some of which are widespread-e.g., Celmisia Armstrongii, Ourisia macrocarpa var. calycina, Ranunculus Godleyanus, and Carmichaelia paludosa.

The mountain-lily (Ranunculus Lyallii) becomes an exceedingly characteristic feature of herb-field, and in wet herb-field are great colonies of Senecio scorzoneroides. The subalpine forest on the western side of the Dividing Range is dominated by the pahau-tea (Libocedrus Bidwillii) (fig. 36) and the mountain-totara (Podocarpus Hallii). On the eastern side of the Dividing Range the subalpine forest is generally of the mountain southern-beech (Nothofagus cliffortioides) type, though in certain localities the true western forest occurs near the sources of the glacier rivers (fig. 36).

Dairy-farming is confined to the very best of the land, on account of the extreme difficulty of establishing permanent pasture, but cattle and sheep are grazed in some of the upland valleys. Paspalum and Lotus major are used as pasture plants to some extent. The 
blackberry (varieties of Rubus fruticosus) both here and in the Northwestern Botanical District is a most aggressive plant when the forest is cleared.

The Eastern Botanical District is not so dry as the Northeastern, consequently the special dry-rock association of Olearia insignis and its accompanying plants (described in Chapter V) is wanting. There are a considerable number of species peculiar to the district, some of which are of most restricted distribution-e.g., Angelica trifoliata (sphagnum bogs of Mount Torlesse); Veronica anomala (Rakaia Gorge); Anisotome patula (limestone rocks, Burke's Pass); Myosotis decora (limestone debris, Trelissick Basin); Helichrysum dimorphum, a scrambling liane, so far found in only two localities near the Waimakariri River at about 1,700 feet altitude. More widespread are Ranunculus Enysii, Dracophyllum acicularifotium, Gentiana serotina, and Celmisia pseudo-Lyallii.

Banks Peninsula might quite well be considered a subdistrict of the Eastern Botanical District, owing partly to certain species being restricted to it--e.g., Veronica Lavaudiana, Celmisia Mackaui, and Senecio saxifragoides: and partly because of its originally widespread forest with totara (Podocarpus totara) dominant, and its small band of northern plants-e.g., the nikau-palm (Rhopalostylis sapida), the karaka (Corynocarpus laevigata), the mariscus-sedge (Mariscus ustulatus), and the New Zealand passion-flower (Tetrapathcea australis).

From the standpoint of its vegetation the Eastern Botanical District is distinguished by isolated, not continuous, forests, which are largely composed of either the black southern-beech (Nothofagus Solanderi) or of totara or matai mixed forest in the lowlands, and of the mountain-beech (Nothofagus cliffortioides) in the mountains. Originally there were small kahikatea (Podocarpus dacrydioides) forests near the coast, of which the already-mentioned Riccarton Bush in Christchurch City (generously donated to the nation by the original owners, the Deans family) is the sole surviving example. The greater part of the district is, or originally was, covered with low tussock-grassland of the usual type, with fell-field at the higher altitudes.

Agriculture on ploughable land consists principally of rotation farming, in which wheat plays an important part. A conspicuous feature of distribution, from the agricultural standpoint, is the inability to successfully grow hard turnips each season owing to the 
ravages of aphides and diamond-backed moths, and consequently winter catch-cropping with forage oats is practised. Owing to the somewhat severe winter, many garden-plants which succeer well farther north, or even farther south, cannot be successfully grown.

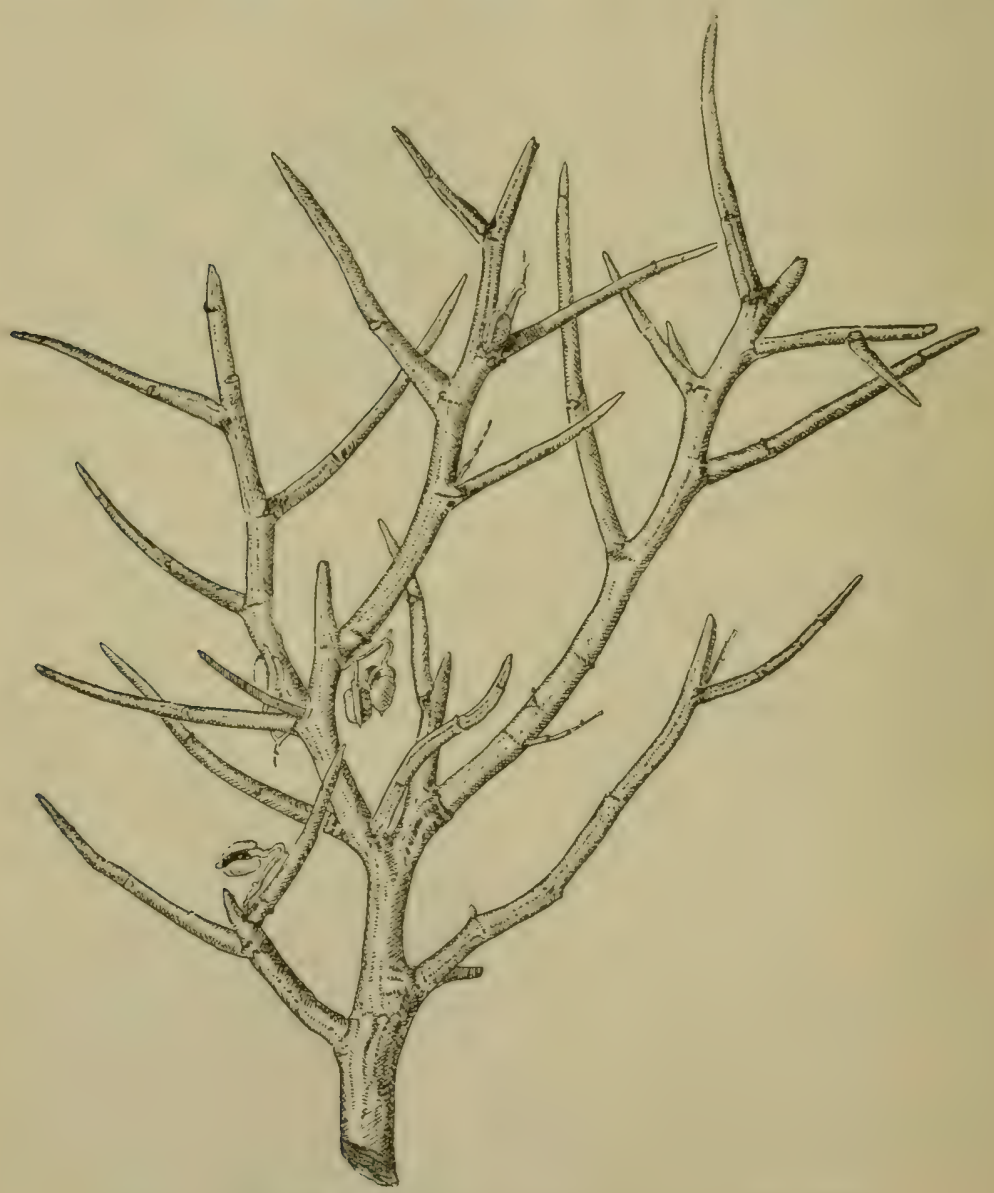

Piece of Carmichaelia Petriei, showing the spinous branchlets, rigid habit, and absence of leaves.

[Esmond Atkinson del.

The North Otago Botanical District is distinguished from all the other districts of New Zealand by the extreme degree of adaptations against drought reached by certain of its plants-e.g., Carmichaelia 
Petriei, Pimelea scriceo-villosa, Myosotis albosericea-as well as the large percentage of such adaptations throughout its flora. There are a considerable number of noteworthy plants confined, or almost so, to the district-e.g., Poa pygmaea, a grass with rigid leathery leaves forming small low cushions, so far found only on the summit of Mount Pisa; one or two buttercups; Acaena Buchanani; two or three species of Carmichaclia; a forget-me-not (Myosotis albosericen), silvery-white with a covering of silky hairs; a dwarf koromiko with thick leaves bluish-green in colour (Veronica Buchanani); and three species of cress (Lepidium).

Forest is absent; at best there are a few patches of trees in sheltered gullies. The depleted condition of much of the grassland has already been described in Chapter $\mathrm{X}$; the subalpine belt, however, frequently is covered with abundance of the broad-leaved snow-grass (Danthonia flarescens), supposed to be a valuable grass for sheep.

In the centre of the district stone-fruits are grown with great success, and grapes will ripen in the open air ; barley and wheat are also cultivated in some parts. The fat-hen (Chenopodium album) is an extremely common weed of ploughed land. The Californian stinkweed (Gilia squarrosa) and the viper's-bugloss (Echium vulgare) are abundant on roadsides.

The Fiord Botanical District is distinguished by a considerable number of species confined, or almost confined, therein. There is also a second class of species which extend to, and are often common in, the adjoining South Otago Botanical District; in fact, where the two districts join it is hard to draw the line between them.

The following are some of the special plants: Two buttercups (Ranunculus Matthewsii and $R$. Baughani)-- the beautiful white $R$. Buchunani, though not confined to the district, is always a most characteristic plant; a willow-herb (Epilobium arcuatum) allied to E. glabollum; the feathery-leaved Anisotome capillifolia, closely related to A. Haastii; one or two gentians; the fine coastal Veronica amabilis; Onisia macrocarpa var. cordata; the splendid tree-daisy (Olearia operina), which forms a dense coastal scrub; a fine celmisia (Celmisia holosericea); two shrubby groundsels (Senecio revolutus and $S$. bifistulosus).

Some of the important plants common to this district and the South Otago Botanical District are - Ranunculus Buchanani; 
Aciphylla pinnatifula; Anisotome intermedia; Dracophyllum Menziesii ; the coastal Myosotis albida; the coastal Gentiana saxosa - this and the two preceding also extending to Stewart Island; a whipcord veronica (Veronica Hectori), V. Petriei, and V. dasyphylla; Ourisia prorepens ; Olearia moschala (which also extends to the southern part of the Western Botanical District); and several celmisias, especially Celmisia ramulosa, C. Brownii, C. Petriei, C. lanceolata, C. Hectori, and $C$. argentea - this last also extending to Stewart Island.

Forest climbs from almost the seashore to the tree-line on the mountains. It is frequently taxad mixed with southern-beech, especially Nothofagus Menziesii and $N$. fusca, but only the former reaches the highest levels. Grassland is virtually wanting except above the forest, where Danthonia crassiuscula may be abundant. There is a dense coastal scrub, made up of veronicas ( $V$. salicifolia var. communis, V. elliptica, and $V$. amabilis - this latter perhaps a hybrid between the other two), Olearia operina, and Senecio rotundifolius.

The South Otago Botanical District depends for its rainfall largely on the southerly downpour. It includes the Southland Plain, as well as much mountainous and hilly country. In its high-mountain flora it has a strong relationship to that of the Fiord District. The number of species restricted to the district are not many: amongst others are Ranunculus Berggreni, Acaena Buchanani var. longe-filamentosa, Carmichaelia virgala (a divaricating shrub), Teronica Poppelwellii, V. annulata, and Celmisia Poppelwellii.

Much of the area was originally forest-clad, a common association of the southern portion being kamahi-rimu forest containing also much southern rata (Metrosideros lucida), the association being very like the ordinary forest of Stewart Island. Tall tussockgrassland with the red-tussock (Danthonia Raoulii var. mubra) was an important feature of the Southland Plain, and still extends thence up the river-valleys and on to the hillsides. Sphagnum bogs are plentiful. A good many plants usually subalpine come down to sea-level.

On ploughable land the agriculture of the district consists of rotation farming, in which spring-sown oats and Aberdeen turnips are conspicuous crops. Dairy-farming is a most important industry. Other features of the district are the ridging of turnips and the general application of burnt lime as a soil-improver. 
The Stewart Botanical District comprises Stewart Island and all the islets adjacent, including Dog Island, at the entrance to the Bluff Harbour. The number of species in the district is about 500 . There are about 18 species restricted, or almost restricted, to the district, the more important of which are--Danthonia pungens; a variety of Uncinia compacta; Uncinia pedicellata (a forest-plant always with purple leaves); Carex longiculmis; a small swamplily with male and female flowers on different plants (Chrysobactron Gibbsii); a tiny plant of the carrot family (Schizeilema Cockaynei); a distinct needle-leaved heath (Dracophyllum Pearsoni); a coastal rock-plant with leaves in rosettes (Anisotome flabellata); a tiny ourisia (Ourisia modesta); a tree-daisy related to Olearia virgata (O. divaricata); a celmisia related to Celmisia petiolata (C. rigida); and the Stewart Island vegetable-sheep (Raoulia Goyeni).

A remarkable feature is the absence of southern-beech (Nothofagus), lacebark (Hoheria), New Zealand broom (Carmichaelia), mountain-ribbonwood (Gaya), celery-pine (Phyllocladus), pigeonwood (Hedycarya), totara (Podocarpus totara) (but P. Hallii is common), the white tea-tree (Leptospermum ericoides), Melicope, Pennantia, Oxalis, and Pimelea arenaria (but the latter is represented by P. Lyallii). The following species, important in Stewart Island, occur also to some extent in the south of the South Island: Carex appressa, Epilobium nerterioides var. minimum, Ourisia Crosbyi, Olearia angustifolia, and Cotula Traillii.

Several plants of subantaretic or Chatham Island affinities occur in this district-e.g., Urtica australis, Suttonia chathanica, Poa foliosa, Veronica odora, and Senecio Stewartiae.

Forest occupies most of the island, and ascends to the scrub-line. A forest-association peculiar to the district is the low swamp-forest of the yellow-pine (Dacrydium intermedium), with its wealth of huge moss and liverwort cushions. Tall tussock-grassland, similar to that of the South Otago Botanical District, occurs in certain wet lowland localities. There is a considerable high-mountain vegetation, although no mountain greatly exceeds 3,000 feet altitude. Bogs are abundant. Lycoportium ramulosum is a common bog-plant. A good many alpine plants occur at sea-level, even some otherwise typically alpinec.g., Celmisia argentea, Donatia novae-zelandiae, and Senecio Lyallii. Coastal scrubs are an important feature of the shore-line; they are closely allied to those of the Fiord Botanical District. 
Besides the botanical districts already dealt with in this chapter there are also those belonging to the outlying islands. Thus the Kermadec Islands form the Kermadec Botanical District; the Chatham Islands, the Chatham Botanical District; and the New Zealand Subantarctic Islands may be divided into the following botanical districts: The Snares, the Lord Auckland, the Campbell, the Antipodes, and the Macquarie. As these districts have received perhaps more than their due share of recognition in Chapter IX, no further details are given here.

As certain of the botanical districts have a good deal in common, those related to one another can be united into groups of a more comprehensive character, here called "botanical provinces," convenient for statistical and other purposes. The New Zealand Botanical Region may be divided into botanical provinces as follows: (1) The Kermadec Botanical Prorince; (2) the Northern Botanical Province, which includes the Three Kings Islands, together with the two Auckland Botanical Districts; (3) the Central Botanical Province, which includes the East Cape, Volcanic Plateau, and Ruahine-Cook Botanical Districts; (4) the Southern Botenical Prowince, which includes all the South Island (except the South Islind portion of the Ruahine-Cook Botanical District), together with Stewart Island; (5) the Chatham Botenical Province, which includes all the Chatham Island group; (6) the Subantarctic Bolanical Protince, which includes all the New Zealand subantarctic islands.

The next point that demands attention concerns the actual travels and methods of travelling of the plants.

A few statistics show clearly that many New Zealand plants have done a good deal of travelling in New Zealand itself. Thus, out of 517 purely lowland species, 249 occur in all the botanical provinces, and 102 of these have managed to reach Stewart Island. There are also 348 additional species which have been able to climb high into the mountains. Other species, again, have done no travelling worth mentioning, while still others are alleged to have come all the way from Australia to New Zealand, or even from South America, or vice versa.

The most important method of travelling is by means of the wind. Many seeds or fruits are so constructed that they can fly long distances. It is a most familiar sight to see thistledown flying high in the air, the down really a crown of hairs attached to the end 
of the light fruit, commonly called the "seed." This method of flying, after the manner of a parachute, is a common feature of plants of the daisy family; also the willow-herbs (Epilobium) and New Zealand jasmines (Parsonsia) travel in this manner. But the distance gained may easily be misjudged, as in the case of the thistle; for thistledown it frequently is, pure and simple, the heavier seed having become detached quite early on.

Seeds and fruits, however, do not require any special flyingapparatus to enable them to be carried for quite a considerable distance by the wind. Where small stones are raised high in the air, as is frequently the case during heavy gales, there is hardly a species of New Zealand plant which cannot have its seeds dispersed to a longer or shorter distance; in fact, except with regard to those plants of entirely sheltered habitats, no special apparatus for dispersal seems to be required-i.e., so long as there is no broad water to cross.

Birds undoubtedly play a considerable part in the dispersal of seeds. Berries they eat, and the seeds, as part of their excreta, are "sown" under favourable conditions. Other seeds or fruits adhere to the feathers or other parts of the bird-the feet, for instance. The fruits of the piripiri (species of Acaena) and of the hooked sedges (Uncinia) are specially suited for distribution by animals. Yet, strange to say, no species of either of these genera occur on the Kermadec Islands, while both the Chatham and the subantarctic islands have each at least one variety of Acaena Sanguisorbae peculiar to the group.

The question of how species travel long distances is of especial moment with regard to those of the high mountains, for they must frequently travel considerable distances over country hostile to their settlement. If the actual high-mountain plants be alone considered, only about 7 per cent. possess succulent seed-containing food attrac. tive to birds, but 23 per cent., including the ferns, are specially fitted for carriage by wind. Add to the above the species having hooked fruits, and the orchids with their minute seeds, and the percentage rises to 36 . But there are a considerable number of species in addition to the above that might readily become attached to birds. so that it seems safe to conclude that one half the species may be widely distributed by means of wind or birds, while the other half are not suitable for dissemination under ordinary circumstances. It 
is interesting to note that with regard to the species common to the lowlands and to the high mountains the number fitted for longdistance travel by aid of birds or wind is greater, 20 per cent. being suitable for carriage by birds and 28 per cent. for carriage by wind.

Water, either of streams, of the sea, or the run-off water of slopes, functions strongly with regard to carriage of seeds. In the mountains snow-avalanches and land-slides must be of considerable moment.

With regard to methods of travel, it should be ever borne in mind that such movement of species must be extremely slow, and that the plant has time unthinkable at its disposal. Also, with regard to the period since there have been plant-formations on the earth with their members close together, it is not a movement of individuals, except in the association, but a movement of the whole association that has to be considered. It resolves itself, in fact, into that most fundamental of biological causes-the struggle for existence; in this case, too, a struggle between communities well equipped to hold their own, and where the weak are well protected.

In considering the possibility of seeds travelling long distances, the arrival at the destination is merely a preliminary to permanent settlement. The seed has first to germinate; then the young plant has to grow; and finally it is exposed to competition with its neighbours. If these things are borne in mind, the prospect of a chance seedling gaining a footing on the soil is small indeed: how small is well illustrated in the case of the primitive plantassociations of New Zealand. Bombarded with the seeds of foreign plants for more than one hundred years, not one of these aliens has become a member of primeval forest, herb-field, grassland, shrubland, or bog!

All species have a more or less discontinuous distribution-i.e., there are always areas, great or small, as the case may be, where the species does not occur. This is the consequence of the species being arranged in associations. If, however, the associations in which a species occurs extend with breaks between them throughout a region, the distribution of that species would be called "contimous." Between such continuity and a species occurring in very few localities there is every degree of transition. The cases about to be noted are where the discontinuity is excessive. Only a few examples are given, but the phenomenon is quite common. 
Pillosporum obcordatum, originally discovered by Raoul near Akaroa, is a low tree, with distinct juvenile and adult forms (fig. 96). It has been recorded only from near Akaroa (Banks Peninsula) and from near Kaitaia (northern Auckland). It is probably extinct at Akaroa, the forest near that town, and, indeed, on most of Banks Peninsula, being now destroyed, and at Kaitaia there are only one or two trees. No tree in the world can be rarer! The seeds of Pittosporum are not suitable either for wind carriage or bird carriage. One may conclude, then, that this species was once of continuous distribution, but that it has been exterminated by more vigorous competitors. Celmisia Traversii is so common on certain mountains of the North-western Botanical District, and of the North-eastern Botanical District near its western boundary, that no one caring for plants could fail to notice one so striking. Farther south it is absent until it appears again many miles away in the Fiord Botanical District, on the mountains near Lake Hauroko, where it was discovered by Mr. J. Crosby Smith. This species is suitable for' wide dispersion by wind. There must be hundreds of stations along the western Southern Alps where it could thrive, and yet it is absent. The explanation that it has had a more continuous distribution and been exterminated cannot well meet this case; nor does one like to suggest that the species may have arisen in both localities. Pittosporum patulum is a fairly common small tree in southern-beech forest in certain parts of the North-western Botanical District. Elsewhere it is found only near Lake Hawea, where it is confined to the same class of forest. This may perhaps be explained on the theory of its being gradually exterminated, or it may be that the class of forest it affects had at one time a much more continuous distribution than is now the case. Ranunculus crithmifolius is a rare shingle-slip plant of the alpine belt of the North-eastern Botanical District. Its only other known habitat is on shingle-slip on the Ilount Arrowsmith Range, Canterbury, where it was discovered some years ago by Mr. R. MI. Laing. One can readily expect shingleslip species to have a precarious existence, so this seems a fairly good example of a species once fairly widespread being now at the verge of extinction. Cotula filformis until a year or two ago had been seen by no living New Zealand botanist, though it was known that Haast collected it on the Canterbury Plain. Thanks, however, to its rediscovery by Mr. C. E. Christensen, it has since proved to be fairly 
common on the Hanmer Plain. In this case, as the species is small and easily overlooked, it may be expected to occur in the intermediate area between the above two localities. Lycopodium cermum, a fine club-moss, with spores easily carried by wind, is extremely common in the North and South Auckland and the northern part of the Volcanic Plateau Districts, but from near Lake Taupo it does not occur again until near the West Wanganui Inlet (North-western Botanical District), where is was discovered last year (1918) by Mr. B. C. Aston. Though the spores of lycopods are so easily distributed by the wind, their germination is not such a common happening, by any means; it seems possible in this case, then, that wind-borne spores are accountable for this southern station of the plant, and that it is a chance comer. The Chatham matipo (Suttonia chathamica), common in the Chathams, also occurs at one or two places, but not abundantly, on the east coast of Stewart Island. The Australian Leucopogon Richei is common on dry ridges in the Chatham Islands, but elsewhere in New Zealand it is known only at a locality not far from the North Cape. A large nettle, Urtica australis, common in Chatham, Lord Auckland, and Antipodes Islands, is known elsewhere only on certain small islands in Foveaux Strait.

The following species are known in only one locality, and, it may be, in only the one station: The small Australian club-moss, Lycopodium Drummondii, has been noted on only a few square yards of boggy ground near Kaitaia, northern Auckland. The boganise (Angelica trifoliata) has been noted at only two stations, not far apart, on the Mount Torlesse Range, Canterbury. Coprosma Buchanani is confined to a few stations, not far distant from one another, on the shores of Cook Strait (Wellington). Certain species already cited in this chapter are confined to the North Cape Promontory. A well-marked variety of Veronica elliptica is confined to Titahi Bay, Wellington. Veronica loganioides is known only from the vicinity of Mount Potts (Canterbury). Veronica Astoni is known only on the Tararua Mountains, where it is fairly common. Poa pygmaea, already mentioned in this chapter, is confined to the summit of Mount Pisa (North Otago Botanical District). Raoulia mubra (fig. 67) is confined to the summits of the Tararua Mountains, where it is fairly common. Logania depressa, which has not been collected or seen since Colenso discovered the species more than sixty-two 
years ago, obviously is extremely rare; its rediscovery is greatly desired, and it is probably to be found only somewhere at the southern end of the Kaimanawa Range. Cases such as the above are generally more readily explained on the supposition that the species are of recent origin than that they are of great age and dying out.

With regard to distribution, it has been, in the past, only the aggregate which has been considered. This has arisen from the facts that varieties are looked upon by many as of little moment ("mere varieties" they are styled), and also that, in the majority of cases, the aggregate has not been studied sufficiently and split up into those component parts (varieties) which, as explained in Chapter $\mathrm{X}$, are the realities, and come "true" from seed, to use the gardeners' expressive term. This matter of coming true from seed can, of course, be definitely proved only by experiment; but here it is assumed that if a distinct race occurs in more than one area, and that there is no suspicion of its being a hybrid, then this race is considered to be pure.

That great aggregate species, the common koromiko (Veronica salicifolia), has been studied recently with some degree of care, and it has come to light that distinct true-breeding races (varieties) have each their special area of distribution. Thus, without troubling the reader with the names proposed for these races, it appears that there is one or more distinct variety for the following areas: The North Auckland Botanical District; Mount Egmont and its environs ; the Egmont-Wanganui Botanical District; the swamps of the River Manawatu; the Otaki Gorge; the southern part of the RuahineCook District and its South Island extension; the part of the South Island east of the Dividing Range generally; the swamps of the Western Botanical District. Then there are the closely allied $V$. gigantea of the Chatham Islands, V. breviracemosa of the Kermadec Islands, and a short-leaved variety originally found in the neighbourhood of the Upper Rangitata in Canterbury, but recently collected on Mount Peel by Mr. H. H. Allan. In a case such as the above, who can doubt the youth of these varieties, or that evolution is still hard at work with the Veronica salicifolia group?

A case where a somewhat greater degree of stability (i.e., of age) comes in is with regard to Leucopogon fasciculatus. No one has suggested, so far, that this species is an aggregate, or "variable," 
to use the common but more incorrect term. Yet in the Auckland Botanical Districts the shrub passes through a distinct juvenile form with leaves much broader than those of the adult (see text-figure below) - a form, too, which persists for a number of years. Farther south both juvenile and adult have the narrow leaves (compare the juvenile forms in the two text-figures), but exactly where the line of separation comes between the two varieties has not been ascertained.

One more example of the distribution of true-breeding races of an aggregate species and the chapter must end, though there are

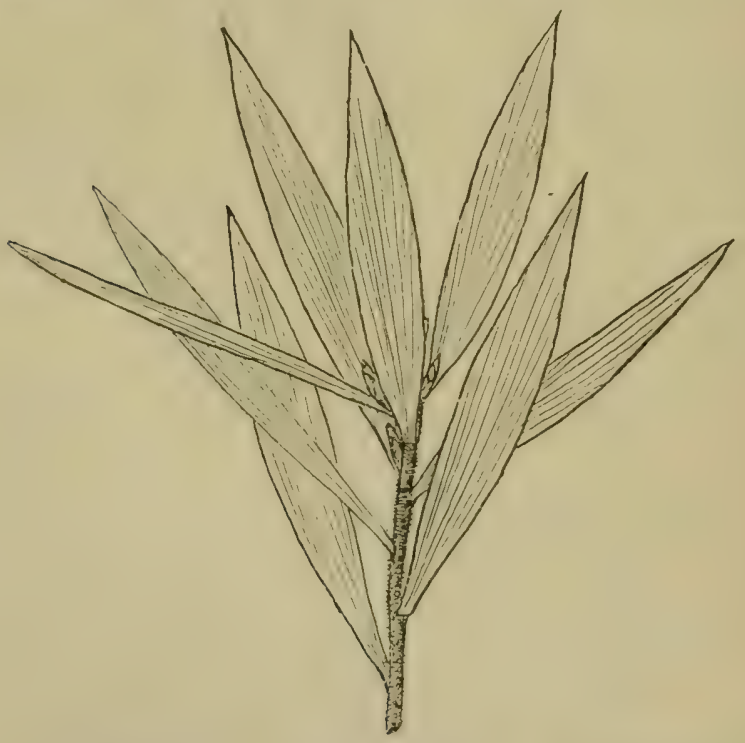

Juvenile form of Leucopogon fasciculatus collected in the North Auckland Botanical District. (Life size.)

[Esmond Atkinson del.

many matters connected with distribution in New Zealand that have been left unsaid. This is the case of the aggregate Celmisia glandulosa, frequently a plant of subalpine bogs or wet herb-field. Generally speaking, throughout the area of its distribution it is represented by a well-marked variety (the "type"); but on Mount Egmont this variety is absent, and in its stead a plant with much broader leaves is alone to be found. Again, in the Clinton Valley (Fiord Botanical District), it is neither of the above varieties which 
occurs, but a much more robust plant with long flower-stalks. In the case of the aggregate $C$. glandulosa the differences appear due to isolation having permitted these two forms of limited distribution to arise.

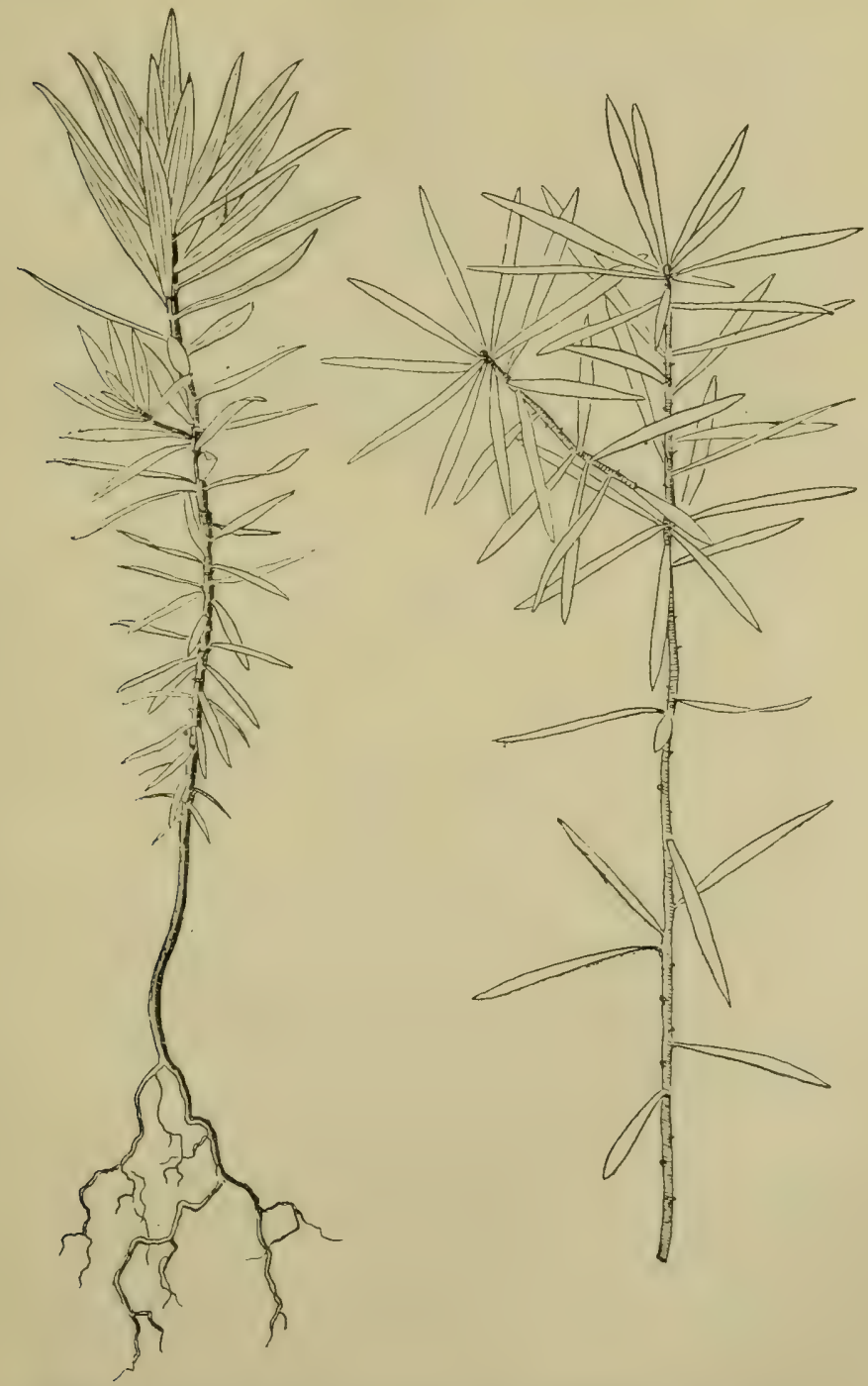

Seedling (on left) and piece of adult (on right) of the narrow-leaved form of Leucopogon fasciculatus, both collected in the Ruahine. Cook Botanical District. (Life size.) 


\section{CHAPTER XIII.}

\section{THE AFFINITIES, ORIGIN, AND HISTORY OF THE FLORA.}

General remarks-Distribution of the kowhai-The endemic element of the New Zealand flora-Different degrees of endemism-The Australian element of the New Zealand flora-The Fuegian element of the New Zealand floraList of species common to New Zealand and subantarctic South AmericaThe Malayan element of the New Zealand flora-The European element of the New Zealand flora-The cosmopolitan element-Relation of the flora of Lord Howe and Norfolk Islands to that of New Zealand-The fossil flora of Antarctica-The New Zealand Tertiary fossil flora-How plants change their form-The history of the New Zealand flora-The New Zealand glacial period.

So far, as recorded in this book, the plants have given fairly definite answers to the questions put to them. Where they have told little of their story it has been through lack of skill on the part of the questioner. Many parts of that story are concealed in their structure or hinted at in their behaviour, and time alone is required to bring to light much that is hidden. But when it comes to seeking information about their birthplaces nothing definite can be learnt from the plants themselves. All they can tell is where their nearest relatives live at the present time. They cannot inform us whether their ancestors crossed the ocean to reach New Zealand, or whether it was over dry land that the journey was made. Perhaps, even, could they speak, we might learn from some of them that their remote ancestors were born on New Zealand soil.

Take the case of the common kowhai (Sophora microphylla) for example. All that this plant can tell about the matter in question is that there are seven or eight different kinds of kowhais, differing but slightly from one another. One of these races, the common kowhai tells us, lives in southern Chile, another graces Juan Fernandez, a third has its home on Easter Island, several inhabit various parts of New Zealand (including the Chathams), and one lives secluded in Lord Howe Island. These different races of the kowhai are known by the aggregate name of Sophora tetraptera. The genus Sophora 
itself is more widespread, occurring, as it does, in many warm countries. S. tetraptera differs from all other members of the genus in certain peculiarities of its flower and fruit. It is placed, therefore, by those botanists who classify plants, in a special division (subgenus) of the genus Sophora, founded for its reception alone, under the name Edwardsia. Now, it is hard to believe that Edwardsia did not at one time or another during the enormously long life of this subgenus, as proved by its wide distribution, live also in other parts of the world, but in such has passed away without leaving a trace behind. Traces of former wanderings of plants are left sometimes as fossils in the rocks, but it is safe to conclude that up to now the history of these wanderings as revealed by the fossil record is most incomplete. Therefore, who can possibly declare that the present distribution of plants in general gives any really reliable evidence as to their place of origin? Eduardsia is usually considered to have come from South America to New Zealand, but Cheeseman has boldly suggested that the contrary occurred. If, however, its home on Lord Howe Island be borne in mind, who can say that it did not come thence to New Zealand, and that its real birthplace may have been in the Malay Archipelago - the almost certain source of so many New Zealand plants?

Notwithstanding the difficulties, as shown above, with which one is confronted, when considering the origin of any flora it is instructive to consider the present distribution and relationships of its species. But it must never be forgotten that when dealing with the origin of a flora, examining how the species originated and seeking the roads by which they travelled, the results arrived at can be a basis for speculation merely.

Leaving out of consideration the lower plants, and taking into account only the seed-plants, the ferns, and the fern-allies, the New Zealand species fall into several distinct groups according to their origin.

These groups are here called: (1) Endemic-i.e., genera and species, or varieties of such, found wild only in New Zealand; (2) Australian-i.e., genera and species found wild in New Zealand and Tasmania or Australia (one or both of these countries); (3) Fuegian-i.e., genera and species found wild in New Zealand and subantaretic South America, or the Falkland Islands, the Crozet Islands, or Kerguelen Land; (4) Malayan-i.e., genera and 
species found wild in New Zealand and the Malay Archipelago or Polynesia (one or both of the two latter); (5) European-i.e., genera and species found wild in New Zealand and Europe; (6) cosmopolitan-i.e., genera and species found wild in New Zealand and also generally in the tropics or subtropics. Each of these divisions may be termed an "element" - e.g., the endemic or Australian elements of the New Zealand flora. In what follows no exhaustive treatment is attempted; such would be out of place in this little book. The aim is merely to give a fair idea of the evidence on which speculations as to the origin and history of the New Zealand flora are based.

Taking 1,780 as a rather low estimate of the total number of species of ferns, fern-allies, and seed-plants of the New Zealand flora, no fewer than 74 per cent. of the species are endemic; or, if the ferns and fern-allies (162 species) and monocotyledons (397 species) be excluded, as both these classes are more widespread, and, speaking generally, more easy of dissemination, the percentage of endemic species amongst the dicotyledons and conifers taken together-i.e., amongst the common trees, shrubs, and herbs (excluding grasses, sedges, rushes, lilies, orchids, pond-weeds, \&c.)is 85 per cent. Thus it appears that a considerable majority of the plants which cannot readily travel long distances are pure New-Zealanders.

These "pure New-Zealanders," or endemic species, are not all of equal rank, so they fall into different classes. Some' are not related at all closely to any other species, but many other species are so closely related to one another that it is merely a matter of personal opinion whether or not they be merged together as aggregate species. Species of the first class may be assumed to be of greater age than those of the second class, excepting the one or other of the latter class which may be the parent. In other words, the majority of the endemic species may with fair confidence be considered of recent origin. A few species, on the other hand, may be of extreme antiquity.

It may be interesting to note the relationships of three or four of the endemic genera and subgenera, and so illustrate different degrees of endemism.

The fern Loxsoma, with its one species, L. Cunninghamii, has its nearest relative in Loxomopsis of Costa Rica and Ecuador. Hectorella, an alpine rock-plant, is of quite doubtful relationship. 
Even its systematic position is uncertain, some placing it in the portulaca family (Poitulacaceae) and others into the chickweed family (Caryophyllaceae). It may have some slight relationship with Lyallia kerguelensis, an endemic species of Kerguelen Land.

A lesser degree of endemism is shown in the case of these genera of the pea family: Carmichaelia, Notospartium, Corallospartium, and Chordospartium. The genus Carmichaelia stands alone in the pea family (Leguminosae), on account of the structure of its seedpod. The genus, however, occurs outside New Zealand, but in one locality only, there being one species $(C$. exsul) indigenous to Lord Howe Island. The other three genera are endemic, and may be considered of recent origin. Corallospartium comes very close to Carmichaelia; Notospartium has the same growth-form as most of the species of the above genera, but its pod is quite different; and Chordospartium has the habit of Notospartium, and its flowers are arranged in the same way, but its pod is that of Corallospartium.

A lower degree still of endemism is exhibited by the genus Traversia. This comes exceedingly close to Senecio, with which, in recent works dealing with the genera of the whole earth, it has been united; but from the standpoint of relative endemism its sole species, T. baccharoides, stands on a much higher plane than the species of Senecio proper, which genus extends over the whole earth.

Endemism of a somewhat lower scale still is exhibited in such cases as the following: Scirpus frondosus, which belongs to the endemic subgenus Desmoschoenus; those species of Veronica belonging to the section Pygmaea, small moss-like alpine cushion-plants; Olearia Forsteri, once placed in a separate genus called Shawia; the species of Fuchsia, once put into a genus named Stimnera; those species of Suttonia which fall into the subgenus Eu-Suttonia.

Considering the great distinctness of certain New Zealand genera and other genera which hardly extend beyond New Zealand (e.g., Celmisia, Aciphylla, and Ruoulia), it is not going very far to suggest that such genera originated in New Zealand itself. For such an endemic element the term "Palcaeozelandic" or "ancient New Zealand" may be used. This element would date for its beginnings to far back in the Tertiary period. It resembles to no small extent the Fuegian element, and it is chiefly guesswork as to which of the two elements certain genera should be assigned. 
The Australian element of the New Zealand flora is not one distinct class, but consists of (1) a true Australian element, (2) a Malayan element, (3) a Fuegian element, (4) a New Zealand element.

Most of the ferns common to New Zealand and Australia belong to the Australian-Malayan element, and quite likely have come to New Zealand from Malaya, and not by way of Australia at all.

Thirty-five genera, or subdivisions of genera, are confined to Australia and New Zealand. Only a few are fairly large Australian genera-e.g., Caladenia, Persoonia, Suainsona, Phebatium, Epacris, and Logaria. Some consist of only one species common to both regions-e.g., Echinopogon, Orthoceras, and Herpolivion. Others consist of one Australian and one New Zealand species-e.g., Amphibromus, Cyrtostylis, Adenochilus, Tounsonia, Achama, and Pernettya. No fewer than 7 of the genera belong to the orchid family. The following are New Zealand genera rather than Australian: Herpolirion, the section Milligunia of the genus Gunnera (10 New Zealand, 1 Australia), Aciphylla (at least 25 New Zealand, 2 Australia), Forstera (3 New Zealand, 1 Australia), Celmisia (55 New Zealand, 1 which is perhaps common to both regions), Craspedia (6 New Zealand, of which 2 may be common to both regions).

Almost in the same class as the above are the following 8 genera found in Australia and New Zealand, together with Norfolk Island, Lord Howe Island, or New Caledonia - one or all of the three: Dichelachne, Pterostylis, Acianthus, Lyperanthus, Pennantia, Pomaderris, Hymenanthera, and Olearia.

The Fuegian-Australian element is represented by 22 genera, or sections of genera, but few would claim that these genera reached New Zealand by way of Tasmania.

Coming next to the species supposed to be identical in the two regions, no comprehensive critical comparisons have been made from both New Zealand and Australian material except in a few cases. In the majority of instances where the species supposedly identical have been examined they have been found amply distinct.

The total number of species supposed to be common to New Zealand and Australia is 290, of which $78^{\circ}$ are ferns or fern-allies ; 97 grasses, sedges, rushes, orchids, water-plants, and a few other monocotyledons; and 115 trees, shrubs, herbs, and semi-woody. plants - these two latter classes taken together being greatly in the 
majority. But the whole of these species are not of pure Australian origin, for they include cosmopolitan, Malayan (nearly all the ferns and their kin), and Fuegian elements. Also, with regard to a good many of the species it is just as reasonable to assign to them a New Zealand origin as an Australian one.

The Fuegian element of the New Zealand flora, although considerably smaller than the Australian element, has given rise to far more speculation. This arises from the fact that though biological geographers have been willing to erect a "land bridge " between northern Australia, Malaya, and New Zealand, many have hesitated before in imagination turning into dry land the profound depths of ocean which lie between New Zealand and Antarctica or South America. At the same time, the presence of this Fuegian element so far distant from its present home has to be explained.

Thanks to a recent publication of the eminent antarctic and sul)antarctic botanical explorer, Dr. Karl Skottsberg, of Upsala (Sweden), an admirable account is available of the relationship of the New Zealand and Fuegian floras, based on that reliable botanist's examination of both New Zealand and Fuegian material. Forty-seven families are common to the two regions, and 68 genera. Regarding these genera Skottsberg thus writes*:--

"We know . . . that, judging from the actual distribution of plants, there is an Australian and New-Zealandic element in Andine and Subantarctic America, that there is an Andine element in New Zealand and Australia, and that there remain genera, or even orders, which are virtually bicentric and form what one might perhaps call the Old Antarctic element. Here are examples of the three groups: (1) Dacrydium, Carices Echinochlaenae, Leptocarpus, Astelia, Lomatia, Embothrium, Orites, Drimys, Aristotetia, Drapetes, Tepualia, Epilobium conjungens, Pseudopanax, Myosotis, Veronica sect. Hebe, Phyllacne, Lagenophora, Cotula sect. Leptinella; (2) Carices bracteosue et aciculares, Enargea, Phrygilanthus, Acaenae Acrobyssinoidecie, Euancistrae et Laevigatae, Gerania chilensia, Discaria, Fuchsia, Azorella, Oreomyrrhis, Pernettya, Jovellana, Ourisia, Plantago sect. Plantaginella; (3) Oreobolus, Carpha, Uncinia, Gaimardia, Marsippospermum, Rosthovia, Libertia, Nothofagus, Laurelia, Nuhlenbechia,

* Notes on the Relations between the Floras of Subantaretic America and New Zealand, "The Plant World," vol. 18, pp. 129-42, May, 1915. 
Colobanthus, Caltha sect. Psychrophila, Drosera sect. Psychophila, Eucryphia, Gunnera, Prionotes, Tetrachondra, Pratia, Donatia, Abrotanella.

"We must certainly remember that the present distribution is often a poor indicator that, for instance, a genus now well represented in New Zealand, with few species in South America, may have been much more plentiful in the latter country in bygone times, or that an Antarctic type may have dereloped many species in one place and few in the other."

As so much interest is taken in the Fuegian element of the New Zealand flora, it seems well to mention all those species of both floras which are supposed to be identical. They are as follows: Agrostis magellanica, a small grass found in the Subantarctic and Fiord botanical divisions; Carex Daminii var. wrolepis, a sedge found in lowland swamps, Chatham Island, and, according to Petrie, in Antipodes Island also ; C. trifida, a tall sedge occurring on the east, south, and south-mest coasts of the South Island, and in Stewart Island and the subantarctic islands; Uncinia macrolepis, a small hooked sedge occurring at rather distant intervals in the high mountains from the North-eastern Botanical District southwards throughout the South Island; Rostliovia magellanica, a rush-like tussock found in bogs near the summits of the hills of Campbell Island; Juncus planifolius, a small grass-like rush common in wet ground in all the botanical provinces except the Kermadec; Colobanthus quitensis, a tiny cushion or rosette plant found in distant stations on the subalpine fell-fields and rocks from Nelson to Otago; C. crassifolius (C'. Billardici of Cheeseman's Manual), a common small grassy rosette-plant occurring from sea-level to the upper subalpine belt in all the botanical divisions except the North and South Auckland and the Kermadec Province; Myosurus aristatus, a minute annual recorded from only a few localities from Wellington to Central Otago, but probably with a much wider distribution; Ranunculus acaulis, a low creeping and rooting herb occurring on the seashore throughout all the botanical provinces except the Kermadec: Carlamine glacialis, a rosette-plant found in Lord Auckland, Campbell, and Macquarie Islands, but as the endemic rariety subcamosa; Crassula moschata, a small succulent mat-forming herb occurring near the sea on peaty ground, rocks, and gravel shores from the northern shores of Cook Strait to Iacquarie Island and the Chathams; Acaena adscendens, 
a semi-woody mat-forming plant confined to Macquarie Island; Geranium sessiliflorum, a rosette-herb occurring in various lowland and especially mountain plant-associations from the Volcanic Plateau to Stewart Island (the "type" does not occur in New Zealand, but only the variety glabrum and other unnaned varieties); Myriophyllum elatinoides, a partly submerged water-plant occurring in lowland to lower-subalpine waters from the South Auckland Botanical District to Stewart Island; Hydrocotyle americana, a creeping and rooting tender herb of the lowland forest-floor from the North Auckland Botanical District to Stewart Island; Azorella Selago, a huge cushion-plant restricted to Macquarie Island; Crantzia lineata, a small lowland and montane ereeping and rooting rush-like plant found in all the botanical provinces except the Kermadec and Subantarctic; Oreomyrrhis andicola, a slender tufted herb occurring in all the botanical provinces except the Kermadec and Subantarctic (the New Zealand and the Fuegian plants belong to different varieties); Gratiola peruviana, a creeping and rooting lowland swampherb occurring throughout the North Island, and in the South Island in the North-western Botanical District; Veronica elliptica, a muchbranched tall shrub occurring in several varieties on the coast from Taranaki and Titahi Bay (Wellington) southwards to Stewart Island (but absent on the greater part of the east coast of the South Island) and the Subantarctic Province; Nertera depressa, a creeping and rooting mat-forming herb found in the lowlands and mountains from the Ruahine-Cook Botanical District through the South Island to Stewart Island and the Lord Auckland Group; Cotula plumosa, a rather stout creeping and rooting herb occurring in the Subantarctic Botanical Province (this species does not occur in subantarctic South America, but in Kerguelen Land only, the flora of which is to a considerable extent Fuegian); Taraxacum magellanicum, a rosette-herb occurring in many parts of New Zealand, but its exact distribution is beclouded through its having been considered in all New Zealand floras as identical with the European dandelion ( $T$. officinale), although it is amply distinct; Selliera radicans, a creeping and rooting mat-forming herb common on the coast in various associations in all the botanical provinces except the Kermadec, Chatham, and Subantarctic.

Besides the above species, the following must be noted, since they are almost identical with Fuegian species-so much so, in fact, that 14-Plants. 
not a few are considered by some botanists as truly identical, or separated only by trivial characters: Hierochloe redolens; Carpha alpina; Gaimardia setacea; Marsippospermum gracile (there are only two species in the genus); Luzula racemosa var. Traversii; Enargea parviftora; Colobanthus subulatus; Ranunculus crassipes; Geum parviflorum; Sophora microphylla and its allies; Oxalis lactea (O. magellanica of Cheeseman's Manual); Coriaria sarmentosa; the NewlZealand varieties of C. thymifolia: Apium prostratum; Tetrachondra Hamiltonii (there are only two species in the genus, and this falls into a family by itself-- the Tetrachondraceae); the genus Jovellana with two species New Zealand and two other species Fuegian; Teronica salicifolia (the Fuegian representative is $V$. Fonchii, of south (hile); Donatia norae-zelandiae (the genus, which contains only two species, falls into a family by itself-Donatiaceae). This list could easily be enlarged by adding species a little more distantly related, or sections of genera, and so on. At any rate, the two lists show that a considerable number of species are common to the two floras, while a consideration of the contrivances of these species for dispersal does not warrant, in the majority of cases, any suggestion that they can have journeyed across a wide ocean such as lies between the two regions at the present time.

With the exception of the ferns and lycopods, many of which are also Malayan or Polynesian species, the Malayan element of the flora makes itself felt rather in the joint possession by Malaya, Polynesia, and New Zealand of certain genera than in that of species. Thus a large percentage of New Zealand trees and shrubs are of Malayan origin. The following list gives some idea of the importance of the Malayan element in this regard, using for the sake of the reader the names of well-known plants, though unless the contrary be stated the species cited is purely a New Zealand one: The kiekie (Freycinetia Banksii); Zoysia pungens (this grass is also Australian and east Asian); the toetoe-grass (Arundo conspicua); all the perching-orchids; the milk-tree (Paratrophis microphylla and the two other species); the parataniwha (Elatostema rugosum); the mangeao (Litsaea calicaris); the tawhero and the kamahi (Weinmannia sylvicola and $W$. racemosa); the various species of Pittosporum; the wharangi (Melicope ternata) ; the kohekohe (Dysoxylum spectabile): the akeake (Dodonaea viscosa) (which also extends beyond New Zealand to Polynesia, Malaya, and many tropical and subtropical 
lands); the hinan and the pokaka (Elaeocarpus dentatus and $E$. Hookeriamus); the mahoe (Nelicytus ramiflorus) (also found in Norfolk Island and part of Polynesia); the pohutukawa and various kinds of rata (Metrosideros tomentosa and the other species of the genus); the maire-tawake (Eugenia maire); the tawapou (Sideroxylon novozealandicum); the hangehange (Geniostoma ligustrifolium); the New Zealand jasmines (Parsonsia heterophylla and P. capsularis); the puriri (Vitex lucens); the mangrove (Avicennia officinalis) (possibly the New Zealand species is distinct from $A$. officinalis, but the matter has not been investigated); the ngaio (Myoporum laetum).

There is a small element in the New Zealand flora consisting either of species identical with European ones or of New Zealand species-endemic it may be - which differ but little from similar species in Europe. For instance, there are the following ferns: Hymenophyllum tunbridgense and Asplenium Trichomanes; but both of these are of widespread distribution throughout most temperate regions. The occurrence of the moonwort (Botrychium lunaria) is of greater interest, since in the Southern Hemisphere it is only Australian, Fuegian, and New Zealand. In the latter region it has been recorded from only one spot-south-western slopes of Mount Torlesse, at 2,700 feet, where it was found many years ago by J. D. Enys, but has not been rediscovered. Carex pyrenaica, a tiny sedge, occurs on many high mountains in Europe, east and west Asia, and subarctic and Pacific North America; it reappears in the Southern Hemisphere in the Australian Alps, and as a rock-plant on certain mountains of the South Island of New Zealand, but as the variety cephalotes. Another sedge, Carex paniculata, is common in many parts of Europe, Asia Minor, and the Canary Islands. It is represented in New Zealand by a series of species, the niggerhead (Carex secta, C. virgata and C. appressa), which approach it so closely that Bentham and others, including Cheeseman at one time, considered that they were varieties of that species. Then, similarly, Carex stellulata is widely distributed in the temperate parts of the Northern Hemisphere, but in the Southern Hemisphere it is known only from Australia and New Zealand, where it appears as a distinct variety named australis. Carex lagopina is another example, and a remarkable case, as in the Southern Hemisphere it occurs only on certain mountains of the South Island of New Zealand. Again, Carex subdola, C. ternaria, and $C$. Gaudichaudiana are very closely allied indeed to the northern 
C. Goodenoughii, but as this is an aggregate species with an almost unlimited number of forms, and is virtually cosmopolitan, the case is not so striking as some of the others. Other sedges which come into this class are Carex Oederi and C. pseudo-cyperus.

The cosmopolitan element may be dismissed with a few words. It is chiefly tropical and subtropical. Its members consist of species of easy distribution and with the power of getting on in the world. Some examples are-the common cudweed (G'naphalium luteo-album); Bidens pilosa; a grass, Oplismenus undulatifolius; the toad-rush (Juncus bufonius); Scirpus cernuus; Solanum nigrum; and the floating duckweed (Lemna minor).

As the floras of Lord Howe and Norfolk Islands are more or less closely related to that of New Zealand, something must be said concerning them.

There are 209 species of ferns, fern-allies, and seed-plants in Lord Howe Island. If the latter alone be considered, 47 are also New Zealand, but of these only 3 are confined to the two floras-e.g., Gahnia xanthocarpa, Uncinia filiformis (but the Lord Howe variety is endemic), and Hymenanthera novae-zelandiae. More interesting is the presence of Coprosma prisca, which by some would be merged into the New Zealand taupata (Coprosma retusce), and a species of Carmichaelia $(C$. exsul), the genus, as already pointed out, being otherwise purely a New Zealand one.

The number of species of ferns, fern-allies, and seed-plants of Norfolk Island is 175 . Of the seed-plants, 49 also occur in New Zealand, but many of these are of wide distribution. Only 2 species are confined to Norfolk Island and New Zealand, but one of these is the New Zealand flax (Phorminm tenax). The endemic Coprosma Baueri is almost identical with the taupata of New Zealand $(C$. retusa).

Having dealt at some length with those living plants whose distribution sheds a faint light on the origin of the New Zealand flora, there only remains a brief consideration of what the fossil plants can tell:

At the present time there are only a few mosses, lichens, and two seed-plants - a grass (Deschampsia antarctica) and a species of Colobanthus - representing ordinary plant-life on the Antarctic Continent. The Swedish Antarctic Expedition showed that a much greater flora must have been present at one time. Thus on Seymour 
Island (virtually part of the continent) a number of fossils of Tertiary age were discovered. These included the following New Zealand genera: Pukatea (Laurelia), now represented by only one Fuegian and one New Zealand species); rewarewa (Knightia), a genus of only 3 species (1 New Zealand, 2 New Caledonia), but the Antarctic plant is related to the New Zealand species and not to the Nèw Caledonian, which belong to a different section of the genus; horopito (Drimys), a genus of 12 species-Fuegian, New Zealand (3 species), Australian, New Caledonian, and Malayan (New Guinea and Borneo, in the mountains); southern-beech (Nothofagus). The occurrence of these fossils is a matter which must be carefully considered when dealing with the origin of the New Zealand flora.

Remnants of an ancient Tertiary flora are not wanting in New Zealand itself. In Otago and Canterbury, as also in other localities, a good many impressions of plants on rock have been collected. Some of these were studied and described by Ettingshausen. $\mathrm{He}$ refers a considerable number to genera of the Northern Hemisphere that no one would ever expect to have been able to reach New Zealand in such numbers. Amongst such genera are oaks (Quercus), alders (Alnus), elms (Ulmus), and maples (Acer). There were also certain of the existing New Zealand genera, and others of a New Zealand type. Judging from Ettingshausen's figures of the fossils, it seems clear that there must be great doubt as to the accuracy of his identifications. If these genera were present, there must have been one universal temperate flora-a happening hardly conceivable with the tropical climate as a barrier. This fossil flora is nevertheless a fact. It teaches clearly that many genera and species have passed atway, just as the present species must in the lapse of the long years pass away also. It is to be sincerely hoped that some one well versed in the flora of New Zealand will thoroughly study these fossils; no purely scientific work is more wanted.

It has already been explained in Chapter II that many plants greatly alter their form according to a change in their enviromment, but such a change of form is usually not permanent. In other cases it is abundantly proved that a species may in course of time be so completely altered, through some ageney not yet known, that a new species has arisen. It is from changes of this kind that all the species of the earth are supposed to have originated. Such species are said to be "evolved" from other species, and the process is called 
"evolution." That evolution is a reality no biologist doubts, though regarding its methods there is great disagreement and no absolute certainty, but quite the contrary. Many theories have been put forth, but three stand out prominently. The first, of which Darwin and Wallace are the illustrious authors, is known as the theory of Natural Selection. It takes the well-known fact that all organisms vary in all directions, and considers that if certain variations, are beneficial they will persist, and by degrees, in the course of an enormous number of generations, become so intensified that a new species will result. As for the unbeneficial varieties, they will in course of time perish through the conflict with the more fitted. This theory is firmly believed in by many*; especially has it a great following amongst zoologists.

In 1901 the eminent Dutch botanist Professor Hugo de VTries put forward his Mutation theory. He showed by numerous farreaching experiments extending over many years that certain varieties, differing markedly from the parent in some hereditary characteristics, appear all of a sudden, and that a new species comes at once into the world without the lapse of long years. If such a species is adapted to its surroundings it will remain; but, if not, it will go to the wall. These de Vriesian species are, of course, not the aggregate species of floras, but the little species mentioned in Chapter XI-the true entities of the plant-world.

A third school, largely botanical, believes that the direct action of the conditions to which a plant or animal is exposed evokes changes in accord with such conditions. This is called the New Lamarckian theory, or the doctrine of the inheritence of acquired characters. For instance, if a plant grows in a wind-swept locality, according to this view, in the course of time its descendants might have the form of wind-swept plants no matter where ther grew. Or if a landplant could be grown successfully in water, it might develop special structures peculiar to water-plants, and these in time would become hereditary. The behaviour of many New Zealand plants could easily be brought forward in support of this theory.

Then, a year or two ago, another Dutch botanist, Dr. Lotsy, read a paper before the Limnean Society of London supporting his belief that virtually all species had arisen through hybridism. Although few would go to so great a length, it seems fairly certain that species do at times arise in that manner, and that the so-called "variability" 
of species is largely a matter of the crossing of little species with one another.

The preceding portion of this chapter, as also C'hapter $\mathrm{X}$, has shown what a varied flora occupies New Zealand, and how diverse is its origin. Now comes the question, How has this wonderful assemblage been enabled to reach and occupy a group of islands surrounded by a vast stretch of ocean? To ask the question is easy enough, but a satisfactory reply is one of great difficulty. As seen from what was said at the beginning of this chapter, data not available at present are urgently needed. To answer the question imagination and conjecture must come into play together with such geological evidence and biological statistics as have been given, and a consideration of means of transit of seeds and spores across hundreds or it may be thousands of miles of landless ocean. Here, too, the opinion of one man is of much less moment than that of the many who have given consideration to this difficult subject. Unfortunately, there is no uniformity of opinion. The authorities on plant and animal distribution are divided into two opposite schools, the one denying the possibility of long-distance transit, and invoking great changes in the land and ocean areas; while the other believes in the comparative permanence of oceans and continents, and in the likelihood of certain classes of animals and plants being conveyed to almost any distance by winds, birds, floating logs, and so on. This latter school generally neglects the question as to the possibility of establishment of an organism even if its seeds or spores arrive intact after long travel, but it assumes that during unthinkable periods of time there must be sufficient arrivals for successful colonization.

Taking the case of New Zealand, the consensus of opinion is that there has been once or twice land connection with Malaya, and here may be suggested also an early connection with Australia. It is over the South American or the Antaretic comnection that the biological battle is waged, for the ocean between New Zealand and Antarctica is, from a little to the south of Campbell Island almost to the Antaretic Circle, perhaps up to 9,000 feet deep. However, the zoological evidence, thanks in part to the researches of Hutton. Benham, and Chilton in this country, is so strongly in favour of a former "land bridge"-evidence not based on a few isolated calse's, but on the distribution of whole groups of the lower animals--that the 
author, though reluctantly, declares himself in favour of great landextension. Moreover, speaking as one who for years has studied plants as they grow wild, the extreme difficulty of a species being able to establish itself in a new land, especially if a stable plantcovering be already present, must never be lost sight of. In support of this statement there is the remarkable fact, already emphasized in Chapter $\mathrm{X}$ but not yet sufficiently known to biological geographers, that in New Zealand, notwithstanding the host of introduced plants (more than 520 species), many of them the most aggressive weeds of the Old World, which in New Zealand thrive amazingly, none are established in any actually virgin plant-association, aquatic and some rock associations excepted. That is, that in those places where man, grazing-animals, and fire have not been, notwithstanding windtransit of millions of seeds for more than one hundred years and constant carriage of such by both indigenous and introduced birds, primitive New Zealand still exists.

The view, then, which may be taken is that New Zealand possessed a primitive flora of her own-the Palaeozelandic-which probably formed part of that of a wide land-area, perhaps united to Antarctica; that at an early date the ancestors of the present subantarctic element came in; that later there was an invasion of tropical Malayan species, and also perhaps of the Australian element, these happenings occurring during a great northern land-extension by way of New Caledonia and the New Hebrides. The reason for assigning an early date to the subantarctic colonization is that the southern-beech (Nothofagus), a typical subantaretic genus, still maintains a few isolated outposts in the North Auckland Botanical District, while elsewhere it is, gencrally speaking, absent in the lowland belt, or, if present, confined to stations unsuitable for tropical rain-forest. According to this view, a "struggle" between the subantarctic and tropical elements is postulated, through which many species of the former were driven into the mountains or the more inhospitable lowland stations. Or, on the other hand, the struggle may have taken place much later, after a cold period, and the present arrangement, even in the North Island, be post-glacial. Then, perhaps in mid-Tertiary times, New Zealand, through depression of the land-surface, was reduced-so geologists assert-to a few small islands, the climate at the same time being much warmer than now. Under such conditions many subantarctic species would go to the 
wall, and the few survivors, except Fuchsia and some others, would be confined to the summits of the hills, faces of rock, and such other stations as offered tolerable conditions-similar stations, indeed, to those occupied even yet at low levels by certain alpine plants. The species of the lowland forest would not be decimated, for on quite small islands at the present time there is a rich forest flora.

Next, as the years passed by in their millions, the land once more slowly rose, and fresh immigrants probably came from the north, the south, and the west. Then, quite recently in its geological history, but really an extremely long time ago, owing either to a change of climate or to rising of the land, or probably to both causes, there came a period when great glaciers filled most of the river-valleys of the South Island, some even extending to the Canterbury Plain. In the North Island the glaciation appears to have been confined to the subalpine and alpine belts (fig. 98), where it still remains on the summit of Mount Puapehu. The increased height of the Southern Alps would lead to a drier climate on the east than at present exists, so that the species of the adjacent lowlands would either perish or move to where conditions were more suitable, or through their innate plasticity assume forms more resistant to drought. Evidently no few of them did so. The evidence for this opinion has been already told in the story of the kowhai (Sophora microphylla). It is revealed, too, by the behaviour of those other trees which at an early stage of their career are drought-tolerating shrubs, but which later become ordinary trees. Such show most clearly the impress of two different environments, neither of which stamps its impression with an indelible stamp. As the glaciers slowly retreated much bare ground would gradually become available for recolonization. Seeds from plants of the lowlands, and from plants of those rocks and peaks which projected above the ice, would be carried to this bare ground. Some would germinate, and in course of time a plant population suitable for the new state of affairs come together. Some of these plants would be ancient enough, though many archaic types must have perished; others would have slowly been evolved under the new conditions. Thus has possibly come about that extreme diversity of form shown by Teronica, Celmisia, and other genera, and it may be that much of the highmountain flora is of quite recent origin. Many of the species of the New Zealand flora must be of recent origin--indeed, species-making must be still in progress. 
Somewhat as pictured above may have been the history of the New Zealand flora up to the coming of the white man, for the aborigines would affect but slightly either the flora or the vegetation. How great the influence of European settlement has been is told with some detail in Chapter IX, where it stands forth plainly that a new flora and a new vegetation are in the making. Thanks, however, to the wisdom of our statesmen, as already shown, many havens of refuge have been provided for the fast-vanishing vegetation, where, too, almost all the species of the flora-one of the most interesting in the world-can remain secure. But is such security assured? Once again must it be urged that the people of New Zealand, to whom these sanctuaries belong, keep them inviolate -true sanctuaries indeed, where, if free from molestation, can rest secure the Palaeozelandic plants, together with their kindred from lands far-distant who after years of wanderings reached these happy isles. 


\section{APPENDIX.}

\section{DIFEERENCES IN NOMENCLATURE.}

THE following table shows the differences in nomenclature (including spelling) of genera, species, and varieties cited in this book from the names of such in Cheeseman's "Manual of the New Zealand Flora" (published in 1906), together with genera, species, and varieties dealt with which have been published since the appearance of the Manual.

\section{Exptanation of the Signs.}

$\dagger=$ Change made in accordance with the International Rules of Botanica! Nomenclature.

\$ Change made by some authority other than the author of this bonk.

* = Change made or approved of by Cheeseman.

$\$=$ Genus, species, or variety published since the appearance of the Nanual, excluding those of which the systematic status is merely altered.

Name as in this Book.

Acaenc Buchanani var. longe-filamentosa. $\ddagger$

, Sanguisorbae var. minor. $\uparrow$ tं*

Aciphylla maxima.

(This appears as a slip in the explanation of fig. 78 , but in the body of the work $\boldsymbol{A}$. Colensoi var. maxima is given. It really matters little whether this plant is treated as a species or a variety.)

Aciphylla pinnatifida.\$‡

Agropyron. $\dagger+$

$\begin{array}{ll}, & \text { pectinatum. } \dagger \\ , & \text { repens. } \dagger \ddagger \\ & \text { scabrum. } \dagger\end{array}$

Angelica montana. $†$

Anisotome.

$$
\begin{array}{ll}
, & \text { acutifolia. } \\
, & \text { antipoda. } \\
, & \text { aromatica. } \\
" & \text { capillifolia. } \$ \text { t* }^{*}
\end{array}
$$

(The * here applies only to the specific name.)

Anisotome carnosula. $\neq$

$$
\begin{array}{ll}
, & \text { Enysii. } \ddagger \\
, & \text { flabellata. } \\
, & \text { Haastii. } \ddagger \\
, & \text { intermedia. } \\
, & \text { latifolia. } \\
, & \text { patula. }
\end{array}
$$

A pium filiforme.

\section{, filifolium.}

(A misprint for filiforme.)
Acaena microphylla var. depressa (in part).

" Sanguisorbae var. antarctica.

Aciphylla Colensoi var, maxima.

Agropyrum.

,, pectinatum.

, repens.

, scabrum.

Angelica Girgidium.

Ligusticum.

$\begin{array}{ll} & \text { acutifolium. } \\ , & \text { antipodum. } \\ \text { aromaticum. } & \text { Haastii (in part). } \\ & \\ & \\ , & \text { carnosulum. } \\ \text { Enysii. } \\ \text { flabellatum. } \\ \text { Haastii. } \\ \text { intermedium. } \\ , \quad \text { latifolium. } \\ \text { patulum. }\end{array}$

Apium prostratum var. filiforme. 
Arthropodium cirratum. $\uparrow$

Asplenium adiantoides.†t*

Shuttleworthianum. $\ddagger$

Astelia montana.

Beilschmiedia taraire. $\dot{\uparrow}$

Blechnum. $\ddagger$

$\begin{array}{ll}, & \text { Banksii. } \ddagger \\ , & \text { rupense. } \ddagger \\ " & \text { discolor. } \ddagger \\ " & \text { durum. } \ddagger \\ " & \text { filiforme. } \ddagger \\ " & \text { fluviatile. } \ddagger \\ , & \text { Fraseri. } \ddagger \\ , & \text { nigrum. } \ddagger \\ , & \text { penna marinum. } \dagger \neq *\end{array}$

(* For specific name only.)

, mlcunicum. +

Cardamine glacialis var. subcarnosa.+*

Carex diandra. $\dagger$ \$

, Goodenoughii.t

.. Oederi.

" pyrenaica var. cephaloles.

, stellulata. $\dagger$ †*

Carmichaelia Fieldii.

$$
\text { , paludosa.\$ }
$$

Cassinia albida. ${ }^{*}$

" fulvida var. montana.ई

(This variety is not yet published.)

Cclmisia glandulosa var. latifolia.\$

, Hookeri.

, intermedia. $\neq$

, lanceolata.\$

, longiflora.

(A misprint for longifolia.)

", Poppelwellii. $\$ \ddagger$

, pseudo-Lyallii.

, rigida.

" verbascifolia. $\dagger$

(This name should be substituted for C. Brownii, which by a slip of the pen appears in this book on pp. 103, 192.)

Chordospartium Stevensonii.\$千*

Chrysobactron.

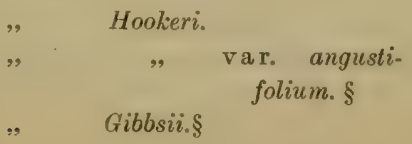

Arthropodium cirrhatum.

Asplenium falcatum.

, flaccidum var. Shuttleworthianum.

Astelia nervosa var. montona (in part).

Beilschmiedia Tarniri.

Lomaria.

, Banksii.

, capensis.

, discolor.

, dura.

, filiformis.

, fluviatilis.

, Fraseri.

, nigra.

, alpina.

, vulcanica.

Cardamine lirsuta var. subcarnosa.

Carex tereliuscula.

"vulgaris.

" flava.

" pyrenaica.

" echinata.

Cassinia Vauvilliersii var. albida.

, fulvide (in part).

Celmisia glandulosa (in part).

", verbascifolia.

" incana var. petiolata.

, longifo'ia.

, Lyallii var. pseudo-Lyallii

, petiolata var. rigida.

, Brownii.

Bulbinella.

"Hookeri.
" $\quad$ (in part).


Chrysobactron Rossii.

Colobanthus crassifolius.

(Appears in Chapter XIII on the authority of Skottsberg.)

Convolvulus fractosaxosa. $\$ \div$

Coprosma Banlisii.

, retusa. $† \ddagger$

Coriaria sarmentosa. $\ddagger$

Cotula Dendyi.\$

, Renwickii.\$

Coxella Dieffenbachii.†*

Craspedia alpina.

Crassula moschata. $\ddagger$

Cyathea kermadecensis.\$!

Cyclophorus serpens.

Danthonia flavescens.

\section{, Raoulii var. rubra.ई}

(This variety is not yet published.)

Dracophyllum acicularifolium.广়

, $\quad$ arboreum.
, $\quad$ paludosum.
, politum.

Dryopteris Thelypteris var. squamulosa. $\ddagger$

Enargea parviflora :

Epilobium arcuatum.\$‡

chloraefolium var. kaikour.
ense.\$
erectum.
nerterioides var. minimum.
pedunculare.

\section{Eschscholzia.†}

(The original spelling of the name.)

Euphrasia tricolor.

Festuca arundinacea. $\neq$ novae-zealandiae.

(Should be spelled zelandiae, as this was the original spelling of the author of the species.)

Gaimardia ciliata.‡*

$$
, \quad \text { pallida. } \neq *
$$

Gaultheria depressa.

Gaya ribifolia.

Gentiana Astoni. $\$ \ddagger$
Bulbinella Rossii.

Colobanthus Billardieri.

Coprosma Colensoi (in part).

\section{, Baueri.}

Coriaria ruscifolia.

Cotula atrata (in part).

Aciphylla Dieffenbachii.

Craspedia uniflora var. lanata.

Tillaea moschata.

Polypodium serpens.

Danthonia Raoulii var. flavescens.

$$
\text { , , (in part). }
$$

Dracophyllum uniflonm var, acicularifolium.

, scoparium var. major.

" " $\quad$ var. paludosum.

, rosmarinifolium var. politum.

Nephrodium Thelypteris var. squamulosum.

Enargea marginata.

Epilobium chloraefolium (in part).

, ' junceum var. macrophyllum.

, nummularifolium var. minimoum.

"nummularifolium var. pedunculare.

Eschscholtzia.

Euphrasia cuneata var. tricolor.

Festuca elatior (in part).

" ovina var. norae-zealandice (probably).

Centrolepis viridis.

, pallida.

Gaultheria antipoda var. depressa.

Gaya Lyallii var. ribifolia. 
Gentiana serotina.\$

Geranium sessiliflorum var. glabrum. +!

Geum divergens.\$干*

Gleichenia alpina. $\ddagger$

Gunnera albocarpa.

Haastia recurva var. Wallii.\$

Halorrhagis cartilaginea. $\dot{\dagger}^{*}$

.. mirrantha.

Helichrysum dimorphum.ई

Histiopteris incisa. $\neq$

Hoheria angustifolia.

" populnea.

, sexstylosa.

Ipomaea pes-caprae $\ddagger$

Jovellana. $\neq$

.r repens. +

, Sinclairii.

Lagenophora pumila.†ं*

Leptopteris hymenophylloides.

$$
\text { , superba. } \ddagger
$$

Leptospermum Nichollsii.\$†

(A garden-plant not found wild. Jot a true species or variety; it does not come true from seed.)

Leucogenes Leontopodium.ț grandiceps. $\ddagger$

Macropiper excelsum. $\ddagger$

Marsippospermum gracile. +

Muehlenbeckia Astoni.\$t

Myosotis albida. ** $^{*}$

" pygmaea var. Traillii.

BIyriophyllum propinquum. $\ddagger$.

$$
\text { , Votschii. } \$ \mp
$$

Nothofagus. $\neq$

$$
\begin{aligned}
& \text { " cliffortioides. } \neq \\
& \text {. fusca. } \ddagger \\
& \text { " Menziesii.† } \\
& \text { " Solanderi.t. }
\end{aligned}
$$

(Note the spelling.)

Nothopanax. $\ddagger$

$$
\begin{array}{ll}
" & \text { anomalum. } \neq \\
" & \text { arboreum. } \ddagger \\
" & \text { Colensoi. } \ddagger \\
, & \text { simplex. } \ddagger
\end{array}
$$

Olearia arborescens. $\dagger+$

$$
\text { " divaricata. } \$
$$

Geranium sessiliflorum.

Gleichenia dicarpa var. alpina.

Gunnera monoica var. albocarpa.

Haloragis alata var. cartilaginea.

$$
\text { , micrantha. }
$$

Pteris incisa.

Hoheria populnea var. angustifolia.

$\begin{array}{lll}, & \quad & \text { var. vulgaris. } \\ , & \quad, & \text { var. lanceolata. }\end{array}$

Ipomaea biloba.

Calccolaria (in part).

$$
\begin{aligned}
& \text {, } \\
& \text {, Sinclairii. }
\end{aligned}
$$

Lagenophora Forsteri.

Todea hymenophylloides.

, superba.

Helichrysum Leontopodium.

" grandiceps.

Piper excelsum.

Rostkovia gracilis.

Myosotis capitata var. albiflora.

, antarctica (in part).

Myriophyllum intermedium.

Fagus.

, cliffortioides.

, fusca.

, Menziesii.

,Solandri.

(Note the spelling.)

\section{Panax.}

", anomalum.

, arboreum.

, Colensoi.

"simplex.

Olearia nitida. 
Olearia lineata.

, pachyphylla.\$.

Oreobolus pectinatus.

Ourisia Crosbyi.ई

, macrocarpa var. calycina.ई

., ., var. cordata. $\$$

, modesta. $\$ \mp$

Oxalis lactea.t

(Appears in Chapter XIII on the authority of Skottsberg.)

Presia scaberula.!

Paratrophis microphylla. $†$

$$
\text { " opaca. †т }
$$

Phorminu Colensoi.Tं

\section{Plagianthus chathamicus. I}

Plantago carnosa (of the "Flora Antarctica").

Polypodium diversifolium. ††

Polystichum $\ddagger$

$$
\begin{aligned}
& \text {, Richardi. } \quad \text { restitum. }{ }^{*} \\
& \text { "The * refers only to the specific name.) }
\end{aligned}
$$

Psamma arenaria.f

Pseudopanax lineare.

Pteridium esculentum. $\ddagger$

Radicula Nasturtium aquaticum. $† \ddagger$

Ranunculus Baughani.§ড়

$$
\text { , lobulatus. }
$$

Raoulia Beauverdii. $\$$

$$
\begin{aligned}
& \text {, cinerea. } \$ \text {. }^{-} \\
& \text {, lutescens. } \text { t* }^{*}
\end{aligned}
$$

Rapanea Urvillei.

Rhopalostylis Cheesemanii.\$†*

Rubus subpauperatus. $\{t$

Samolus repens var. procumbens $\ddagger$

Schizeilema.

$$
\text { var. strictus. } \$ \ddagger
$$

$$
\begin{aligned}
& \text { " Cockaynei.g! } \\
& \text {, nitens. }
\end{aligned}
$$

Scirpus robustus. $\ddagger$

Senecio Christensenï.ई

$$
\text { , scorzoneroides. }
$$

(scorzoneroides is the original spelling.)

Senecio Tumeri. $\$ t^{*}$

Sicyos australis. $\ddagger$

Sideroxylon novo-zelandicum. $\dagger+$
Olearia virgata var. lineata.

Orcobolus pumilio var. pectinatus.

Ourisia macrocarpa (in part).

Oxalis magellanica.

(This name is used throughout the book, except in Chapter XIII.)

Pteris scaberula.

Paratrophis heterophylla.

$$
, \quad \text { Banksii. }
$$

Phormium Cookianum.

(Another name for Phormium tenax.)

Plagianthus betulinus (in part).

Plantago Brownii (in part).

Polypodium Billardieri.

Aspidium.

, Richardi.

, aculeatum var. vestitum.

Ammophila arenaria.

Panax lineare.

Pteris aquilina var. esculenta.

Nasturtium officinale.

Ranunculus insignis var. lobulatus.

Raoulia Monroi (in part).

, australis var. lutescens.

Myrsine Urvillei.

Rhopalostylis Bauerii (in part).

Samolus repens (in part).

Azorella (excluding "A. Selago).

" nitens.

Scirpus lacustris (in part).

Senecio Lyallii var. scorzonerioides.

Sicyos angulata.

Sideroxylon costatum. 
Name as in this Book.

Name as in the Manual.

Siphonidium longiflorum.†

Sophora chathamica.

, grandiflara.

, microphylla.

, prostrata.

Sparganium subglobosum..$_{+}^{+*}$

Sporodanthus Traversii.

(Cheeseman is of opinion that this will ultimately be the accepted name.)

Stilbocarpa robusta.+*

Sutlonia. \$

$\begin{array}{ll}\text {, } & \text { chathamim. } \\ \text {, } & \text { Coxii. } \\ \text {, } & \text { divaricata. } \div \\ \text {, } & \text { lermadecensis. }+\end{array}$

Taraxacum magellanicum. $+*$

Tetrapathaea australis.

Traversia baccharoides.

Uncinia macrolepis.:**

. pediccllata.\$:

Urtica linearifolia.

Veronica annulata.\$

\begin{tabular}{|c|c|}
\hline ", & Astoni. $\$ 7^{*}$ \\
\hline , & breviracemose.s‡ \\
\hline , & Cookiana. \\
\hline , & Dorrien-Smithii.ई \\
\hline , & gigantea. \pm \\
\hline , & glaucophylla. \\
\hline ", & odora $+*$ \\
\hline 9 & Poppeluellii.\$ \\
\hline , & salicifolia var. Atlinsonti.\$ \\
\hline , & ," var. communis.\$๋ \\
\hline ", & var. longeracemosa.§ \\
\hline
\end{tabular}

IV ahlenbergia albomarginata. +*

\section{Mattheusii.§}

zelandiae or zealandiae, according to an author's original spelling of the name. In the Manual zealandiae is used throughout. With few exceptions J. D. Hooker and the earlier writers used zelandiae, while New Zealand authors use zealandiae, which is less correct Latin.
Anagosperma dispermum.

Sophora tetraptera (in part).

$\begin{array}{lll}, & , & \text { var. grandiflora. } \\ , & , & \text { var. microphylla. } \\ , & , & \text { var. prostrata. }\end{array}$

Sparganium antipodum.

Lepyrodia Traversii.

Aralia Lyallii var. robusta.

Myrsine (excluding M. Urvillei and M. salicin $($ ).

, chathamica.

., Coxii.

, divaricala.

, Kermadecensis.

Taraxacum officinale (the "small mountain state").

Passiflora tetrandra.

Senecio geminatus.

(Even if kept in Senecio the specitic name should be baccharoides.)

Uncinia Sinclairii.

Urtica incisa var. linearifolia.

Veronica salicifolia (in part).

" macroura var. Cookiana.

, salicifolia vạr. gigantea.

, Darwiniana (in part).

, elliptica var. odora.

Probably all included in Veronicasalicifolia of the Manual

Wahlenbergia saxicola.

zealandiae. 


\section{N D E X.}

Abrotanella, 7, 208.

Acreici, 152.

Acaena, 169, 195.

., adscendens, 208, 209.

". Buchanani, 191.

", var. longe-filamentosa, 192.

glabra, 107.

,. inermis, 149.

, novae-zelandiae, 157.

, ovina, 154.

". Sinquisorbae, 79, 157, 169, 195.

". , var. minor, 134, 136.

var. pilosa, 149 .

Acienae sect. Acrobyssinoideae, 207.

$$
\text { , "Euncistrae, } 207 .
$$

Acer, 213.

"Treviqatac, 307.

Acianthus, 306.

Aciphylle, 96, 100, 167, 187, 205, 206.

", Colensoi, 88, fig. 56.
,, var. maxima, 113, fig. 78.

, Monroi, 92, 109.

, pinnatifida, 111, 192.

, squarrosa, 32,91 .

". Trailli, 111.

,, Traversii, 141.

Ackrima, 206.

Actinotus, 167.

Adams, James. 97.

Adaptation, definition of term, 25.

Arlaptations, evolution of, 49 .

,, for reducing evaporation, 89.

Adder's-tongue. Ophioglossum.

Adenochilus, 206.

Adiantum rethiopicum, 187.

$$
\text { affine, } 28,80 \text {. }
$$

African box-thorn. Lycinm. horrilum.

Agathis australis, 59, (60, 163, 173, 182. fie. 31.

Agcrutum conyzioirles, 142.

Agropyron pectimutum, 151.

$$
, \quad \text { repens, } 158 .
$$

Agrostis, 96.

$$
\text { scrabrum, 87, } 93
$$

$$
\text { , }
$$

magellanica, 208.

$$
\text { 15-Plants. }
$$

Aka. The climbing species of Metro. sideros.

Akeake. Jodonnen riscosa.

Akepiro. Olearia furfurucen.

Alder. Alnus.

Alectryon excelsum, 43, 185.

Aleurites moluccaner, 142.

Algae, 118, 178.

Allan, H. H., 199.

Alnus, 213.

Alpine avens. Geum uniflorum.

, belt, 99 .

", celery-pine. Phyllocladus alpinus.

" club-muss, I.ycoporlium fustigi. atum.

" evebright. Euphrasia Monroi.

" hard-fern. Blechnum. penna marinum.

" totara. Podocarpus nimalis. (To be substituted for " mountaintotara," the name of $P$. Hollii.)

Alseuosmin, 61, 68.

Altienia, 173.

macrophylla, 60, 185 .

$$
\begin{aligned}
& , \quad \text { macrophylla, } 60, \\
& , \quad \text { quercifolia, } 185 .
\end{aligned}
$$

American water-neer. Eloder canadensis. Amphibromus, 206.

Anabrena. 116.

Angelica, 167.

., montana, $80,81,93,148$, fi:s. 61.

, rosalefolia, 184 .

$\therefore$ trifoliate, 159, 198.

Anise. Anqelica montana.

Anisotome. 96, 167.

, acutifolia, 135.

, antiporla, 133, 134.

". aromatice, 81, 128.

. capillifolia, 191.

. $\quad$ carnosula, 106.

, Enysii, 79.

, fabelluta, 193.

". Harstii, 1!)1.

". intermedin, 192

". latifolic, 133, 189, fig. S8.

.$\quad$ patulu, 79, 159.

, umamed species, 83.

Antaretic piripiri. Acaena Sanguixorbue var. minor.

tree-daisy. Olearia Lyallii,

Antarctica, fossil plants, 213. 
Antaretica, seed-plants, 212.

Antennuria, 64, 177, 178.

Anthoxanthum odoratum. 149.

A pium, 28.

, filiforme, 37,38 .

," prostratum, 38, 39, $142,210$.

A ponogeton distichum, 118.

Aquatic seed-plants, origin of, 117.

Araliacece, 167.

Araliad family. Arraliacene.

Araucaria. 59.

., braziliensis, 173.

" Cunninghamii, 173.

.. excelsa, 173.

". imbricata, 173.

Araucarineae, 173.

Archeria Traversii, 113.

Aristotelia. 307.

,, fruticosa, 18, 71, 77, fig. 40.

"racemosa, 58, 68, 152, 168 .

Arthropodium candidum, 182.

$$
\text { , cirratum, } 39 .
$$

Arundo conspicua, 38, 34, 75, 120, 152,

172,210 , fig. 44.

Ascarina lanceolata, 142, 143.

Asperula, 166.

$$
\text { lucida, 62. }
$$

$$
\text { perpusilla, } 39 .
$$

Asplenium, 174.

$$
\begin{aligned}
& \text {, adiantoides, } 57 . \\
& \text { ", caudutum, } 141 \text {. } \\
& \text { ". flaccidum, } 56 \text {. } \\
& \text { ". obtusatum, } 39,40,142 . \\
& \text {," } \quad \text { var. anomodon, } 79 \text {, } \\
& \text { S0. } \\
& \text { Trichomanes, } 211 .
\end{aligned}
$$

Astelia, 56, 171, 207.

,. Bankisii, 41, 187, 207.

". Cunninghamii, 49, 62 .

,

". montana, 91, 110.

, nervosa, 63, 121.

". Solandri, 49, 79, fị. 27.

, trinervia, 60.

Aston, B. C., 166.

Atriplex, 170.

Atropis, 28.

Billardieri, 31.

," patuln, 38.

, stricta, 38.

Austral-broom. Carmichaelia australis.

Australia. land connection with New Zealand, 215.

Australian glasswort. Salicornia aus. tralis.

," gourd. Sicyos australis.

", heath family. Epacridacene.

" piripiri. Acaena ovina.
Australian\sea-holly. Frynqium vesicu. losum.

, sea-rush. Juncus maritimus var. australiensis.

Autetauranga. Pimelen arenaria.

Avicennia, 28.

Azolla, 174

officinalis, 35, 211, fig. 20.

, rubra, 115.

Azorella, 207.

"S Selagn, 135, 209.

Bacteria, 178.

Banks Peninsula, 81, 189.

Banks, Śrir Joseph, 2. map, 82.

Beard-grass. Polypogon monspeliensis.

Beech family. Fagaceae.

Beilschmiedine, 170.

,$\quad$ taraire, $59,61,182$, fig. 31.
.$\quad$ taxa, $18,60,62,80,18 \%$.

Bell-vine. Calystegin scpium.

Belts of vegetation, 99 .

Benham, 215.

Bidens pilosa, 212.

Bidwill, J. C., 9, 10.

Biological, definition of term, 17. succession, 23.

Black hard-fern. Blechnum nigrum.

, southern-beech. Nothofagus Solanderi.

, tree-fern. Cyathea medullaris.

Blackberry. Rubus fruticosus.

Bladderwort. IJtricularia monanthos.

Blechnum, 174.

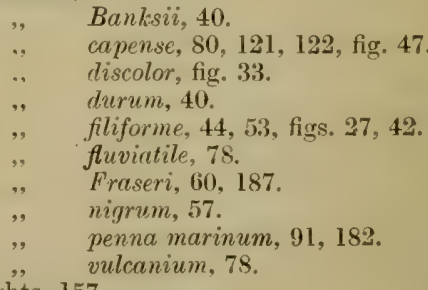

Blights, 157.

Bluebell. Wahlenbergia.

Bluebell family. Campanulaceae.

Blue-grass. Agropyron scabrum.

.. tussock. Por Colensoi.

Boat-leaved tree-daisy. Olearin cymbifolia.

Boehmeria dealbata, 142.

Bog-celmisa. Celmisia glandulosa.

, eushion. Gaimardia ciliata.

, epacris. Epacris pauciftora.

"gentian. Gentiana Tounsom. 
Bog-lily. Chrysobuelron. (See Swamplily.)

, moss. Sphaynum.

", plants, their growth-forms, 125.

", poa. Poa chathamica.

", umbrella-fern. Gleichenia dicarju.

Bogs, 123 et seq., figs. 82, 83, 84 .

, Antipodes Island, 134.

" Chatham Islands, 139, fig. 90.

, physiological dryness, 124 .

Bollons, Captain, 44.

Borrginaceae, 166.

Botanical districts, 180 et seq.

$$
\text { " map, } 181 .
$$

" provinces, 194.

", region, New Zealand, 194.

Botrychium, 174.

$$
\text { lunaria, } 211 .
$$

Bounty Islands, 136.

Box-leaved pimelea. Pimeleu buxifoliu.

Brachycome, 165 veronica (koromilio). Verunim buxifolia.

Sinclairii, 87

Brachyglotis repanda, $43,58,62$.

Bracken-fern. Pteridium esculsntum.

Brassica, 146.

Breathing-roots, 36, 119, figs. 20, 80 .

Broadleaf. Griselinia littoralis.

Broad-leaved cabbage-tree. Cordyline indivisa.

, poa. Poa anceps.

", snow - grass. Danthonia

Bromus, 146. flavescens.

Bronze forget-me-not. Myosolis macranthe.

Broom. Cytisus scoparius.

Buchanan, John, 9, 10.

Buck's - horn plantain. Plantago C'oronopus.

Buckthorn family. Rhamnecere.

Bull-kelp. Durvilluea utilis.

Burning, effect of, in Central Otago, 150, 151.

Bush-lawyer. Rubus australis.

Bushy shrub, 18.

tree, 18, fig. 21 .

Butler, Samuel, 84.

Buttercup). Renunsulus.

Buttereup fomily. Remunculacere:

Cabbage-tree. Corlyline unstrulis.

Caladenia, 206.

Californian stinkweed. Gilia squarrosa.

Callitriche, 117.

thistle. Cnicus arvensis.

Caltha, 170.

", sect. Psychrophila, 20 S.
Calysteyia sepium, 15:.

, Soldanella, 31, fig. 17.

, tuguriorum, 138, 167.

Campanulaceae, 165.

Canadian water-weed. Elodea cunudensis.

Conavaliu obtusifolia, 142, 143.

Candlenut. Aleuriles moluccunu.

Cape broom. Cytisus caudicans.

Cape pond-iveed. A ponogeton distichum. Cardamine glacialis var. subcarnosu, 208.

Carduus pycnocephalus, 151.

Carex, 172, 211, 212.

" acicularis, 172.

" appressa, 193, 211 .

,, breviculmis, 87.

, Colensoi, 87.

" Darvinii var. urolepis, 141, zos.

, diandru, 126.

". Gaudichaudienu, 1:26, :211.

, Goodenoughii, 21:2.

, inversa, 87.

, litorose, 37.

" longiculmis, 193.

, Oederi, $21 \%$.

" paniculata, 211.

, pseudo-cyperus var. fuscicularis, $122,212$.

pumila, 35 .

" pyrenaica var. cephaloles, 17.), 11

" secta, 19, 121, 171, 211.

"semi-Forsteri, 142, 143.

, stellulata, 126, 211.

,, subdola, 211.

," ternaria, 134, 211.

,, trifida, 208.

, virgata, 211 .

Carices aciculares, 207.

, bracteosae, 207.

" Fchinochluenae, 207.

Carmichaelia, 20, 24, 90, 96, 169, 191, $193,205$. ustralis. 35 .

Enysii, 88, 187. exsul, 205, 212. Fieldii, 187.

flagelliformis, 18:. gracilis, 68, 12:2. grandiftore, 68, 78 .

var. dicuricute, 12.2.

Monroi, 88.

nanu, 88.

odorata, 68.

paludosu, 78, 12:, 188.

Petriei, 190, fig. p. 190.

subulata, 7., 88 .

uniflora, 88 .

virgata, 192. 
Carpha, 172, 207.

, alpina, 97, 111, 126, 17:2, 210.

Carpodetus serratus, 58, 169.

Carrot family. Umbelliferae.

Caryo phyllaceae, 170.

Cassinia, 34, 96.

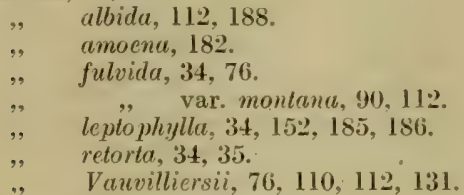

Cassytha, 170.

," paniculata, 74, 18:.

Catsear. Hypochoeris radicula.

Cedronella triphylla, 149.

Celmisit, 96, 103, 165, 187, 205, 206, 217. , argentea, 19, 103, 111, 114, 19:, 193.

Armstrongii, 111, 188, fig. 73.

", bellidioides, 10:3.

", Brownii (verbuscifolia), 103, 111 ,

192.

, coriacea, $103,111$.

, discolor, 109, 111.

", glandulosa, 125, 200.

" , var. latifoliu, 110 ,

$$
200 .
$$

Haastii, 109.

", Hectori, 192.

, holosericea, 191.

, Hookeri, 103.

", hybrids, 103.

, incana, 97, 110, fig. 63.

," intermedia, 92, 109, 111.

, lanceolata, 111, 192.

, laricifolia, 92.

," Lindsayi, 45.

, linearis, 111 , fig. 75 .

, longifolia, 88,91 .

", $\quad$ var. alpina, 125.

, Lyallii, 103, 109.

, Mackaui, 189.

", Monroi, 10, 81, 188.

,, petiolata, 103, 111, 193.

, Petriei, 192.

, Poppelwellii, 192.

, pseudo-Lyallii, 189.

,. ramulosa, 192.

", rigida, 193.

" sessiliflora, 103, 111.

, Sinclairii, 109, 111.

," spectabilis, 92, 103, 109, 157, fig. 62 .

Traversii, 103, 197.

" vernicosa, 133.

", viscosa, 92, 109.
Cenchrus calyculatus, 141.

Centranthus ruber, 155.

Chaetomorpha Darwinii, 31.

Chara, 118.

Chatham akeake. Olearia T'ruversii.

", cranesbill. Geranium Traversii.

" gentian. Gentiana chathamica.

, Islands, 11, 137.

", kowhai. Sophora chathamica.

" lancewood. Pseudopernax chathamicum.

" mahoe. Hymenthera chathamica.

", matipo. Suttonia chathamica.

" ribbonwood. Plagianthus chathamicus.

tree-daisy. Olaria chathumica. tree-heath. Dracophyllum arboreum.

Cheeseman, '1' 1:., 11, 12, 141.

Chenopradiaceae, 170.

Chenopodium, 170.

$$
\text { , album, } 191 .
$$

Cherry-pie. Ageratum conyzivides.

Chickweed family. Curyophyllaceuc.

Chilton, 215.

Chordospartium, 169, 205 .

$$
\text { , Stevensonii, } 188 .
$$

Christensen, C. E., 197.

Christmas tree. Metrosideros tomentosa.

Chrysanthemum Leucanthemum, 155.

Chrysobactron, 96.

$$
\begin{array}{cc}
, & \text { Gibbsii, } 193 . \\
, & \text { Hookeri, 128, 149, 152. } \\
, & \text { var. angusti- } \\
& \text { Rossii, 133, 152. }
\end{array}
$$

Cludiuin, 172.

,, articulatum, 122.

, capillaceum, $76,187$.

, glomeratum, 76, 172.

, junceum, 37.

, Sinclairii, 28, 80, 172.

, teretifolium, $76,122,172$

Cladonia, 134.

Classification, plant-associations, 147,148.

Clicytonia, 170. plants, $159 \mathrm{et} \mathrm{seq.}$

, australasice, 108.

Clematis afoliata, 55, 80, 81 .

, Colensoi, 55.

", hexasepala, 55 .

,. indivisa, 17, 55, 58, fig. 4 .

Clianthus puniceus, 169.

Climbing convolvulus. Calystegia tuguriorum.

") groundsel. Senecio mikanoides.

" hard-fern. Blechnum filiforme. 
C'limbing New \%ealand broum. C'armichaelia gracilis.

, plants, 19, 50 et seq.

", polypody. Polypodium diversifolium.

C'linging climbing - rata. Metrosideros scundens:

C'lub-moss. Lycopodium.

Club-moss family. Lycopodiaceac.

Cnicus urvensis, 155, 158.

('uastal forest, 42 et seq., fig. 24 . ,. scrub, 41, 4:- fig. 23 .

", plants, growth-forms of, 29,30 .

Coccus Cacti, 177.

Cocksfoot. Dactylis ylomerata.

Cortium adlucerens, 31.

Colenso, Rev. W., 7, 148, fig. 5.

Colensou, 8.

physaloides, 165, 182.

Colobunthes, 96, 170, $208,212$.

$\begin{array}{ll}" & \text { Billerdieri, 208. } \\ , & \text { crassifolius, 208. } \\ , & \text { muscoilles, 132, } 136 . \\ , & \text { quitensis, 208. } \\ \text { subulatus, 210. }\end{array}$

Coloration, winter, 114.

Comb wheat-grass. Agropyron pectincetum.

Common anisotome. Anisotome aroma-

, ticu.

, astelia. Astelia nervosa.

" carpha. Carpha alpina.

,

99

,

99

99 celmisia. Celmisia longifolia. climbing - polypody. Polypodium diversifolium.

climbing - rata. Metrosideros hypericifolia.

club-rush. Scirpus nodosus.

convolvulus. Convolvulus erubescens.

coprosma. Coprosma propinqua. cotton-plant. Celmisia specta. bilis.

cudweed. Gnaphalium luteoalbum.

dandelion. 'Taraxacum officinale. dendrobe. Dendrobium $C u n$ ninghamii.

dichronda. Dichrondre reprens. (alpine) donatia. Donutia noverezelondiue.

dwarf broom. Carmichaelia nana.

koromiko. Veronica salicifolia. kowhai. Sophora microphylla. maidenhair. Adiantum affine.

mistletoe. Loranthus micranthus.

mountain - gentian Gentianu bellidifolia.

Common mountain tree-daisy. Olceriu Colensoi.

, New Zealand broom. Carmichuelia subulata. groundsel. Senecio bellidioides.

mistletoe. Loranthus micranthus.

vat-grass. Danthonia semiannularis.

ureobolus. Urcobolus pectinatus. phyllachne. Phyllachne Colensoi. raoulia. Ronulin usstrulis.

scleranth. Scleranthus bifforus. twig-rush. Cladium leretifolium. wates - milfoil. Myriophyllum clatinoides.

whipeord koromiko. Veronicu lycopodioides.

Compositue, 165.

Conspicuousness of white flowers, 101.

Comvolvulacere. 167.

Conrolvulus erubescens, 87.

$$
\text { fruclosuxose }, 10 \% \text {. }
$$

Convolvulus family. Conrolvulaceue.

Cook, C'aptain James, 3, 4.

Cook Strait koromiko. Veronicre sulicifolia var. Atkinsonii.

Cook's scurvy-grass. Lepidium oleruceum.

Coprosme, 18, 43, 59, 96, 165.

\begin{tabular}{|c|c|}
\hline & acerosa, 34. \\
\hline & ucutifolia, 142, 143. \\
\hline 9 & urborea, $18,61,18:$. \\
\hline g & $\begin{array}{l}\text { arooren, } 18,01,182 . \\
\text { areolata, } 166 .\end{array}$ \\
\hline . & Banksii, 63. \\
\hline ," & Baneri, 212. \\
\hline , & Buchenani, 186, 198. \\
\hline , & chathamica, 138. \\
\hline ", & ciliata, 131 \\
\hline , & Colensoi, 63. \\
\hline , & cuneata, $131,134$. \\
\hline , & Cunninghamii, 110,121 . \\
\hline ", & $\begin{array}{l}\text { depressa, 92. } \\
\text { foetidissima, 18, } 62,63,131 \text {, }\end{array}$ \\
\hline & 182. \\
\hline " & grandifolia, 62, 166, 185. \\
\hline , & linarifolia, 18:. \\
\hline " & lucide, 41 . \\
\hline$"$ & mecrocarpe, 180 \\
\hline$"$ & perviflora, 77, 131 . \\
\hline ", & petiolata, $142,143$. \\
\hline ., & Petriei, $149,166$. \\
\hline " & prisce, 212 . \\
\hline ", & repens, 134 . \\
\hline , & $\begin{array}{l}\text { retusa, } 39,43,70,142,212 \text {, } \\
\text { fig. } 41 .\end{array}$ \\
\hline & robustu, $41,77,121,152$ \\
\hline
\end{tabular}


Coprosme rolundifolia, 67.

,r rugosa, 78.

"spathulata, 182.

". tenuicaulis, 63.

Coprosmu, a dye-plant, 166.

Coprosma family. Rubiaceue.

Coral - broom. Corallospartium crassicaule.

Coral-shrub. Helichrysum corulloides.

Corallospartium, 96, 169, 205.

Cordyline, 171. crassicaule, 109.

, australis, 20, 34, 88, 120, 121, $15^{2}, 180$.

indivisu, $182,183$.

Coriaria, 96. indivisu, 182, 183.

"surmentos $u, 75,78,81,88,210$, fig. 46.

thymifolia, 210.

Corokiu buddleoides, 137.

, Coloneaster, 83, 114.

", macrocarpa, 137.

Corynocarpus, 28. , laeviguta, 29, 43, 6:2, 138, 143,185 , 189, fig. 92 .

Corysanthes, 171.

Cotton-plant. Celmisia.

Cottonwood. Cassinia leptophylle.

Cotula, 96, 165.

" atrata, 106.

, coronopifolia, 38.

, Dendyi, 106.

, dioica, 37, 38.

, Featherstonii, 140.

," filiformis, 197.

, lanata, 133.

, plumosa, 133, 209.

, $\quad$ pyrethrifolia, fig. 70 .

, Renwickii, 140.

, Traillii, 193.

, sect. Leptinella, 207.

Couch-grass. Agropyron repens.

Cox, F. A. D., 11.

Coxella, 11, 138, 167.

Dieffenbachii, 141.

Crampton, Dr. C. B., 22.

Cranesbill. Geranium.

Cruntzia, 167.

lineute, 209.

Crape-fern. Leptopteris superbu.

Craspedia, 206.

$$
\text { ", alpina, } 106 .
$$

Crassula moschata, 39, 136, 208.

Creek-fern. Blechnum fluviatile.

Creeping-lawyer. Rubus parvus. ., mountain - foxglove. caespitosa.
Creeping New Zealand calceolaria. Jovellana repens.

, pohuehue. Muehlenbeckia axillaris.

, selliera. Selliera radicans.

Crimson climbing - rata. Metrosideros diffusu.

Cross-pollination, 59.

Cruciferue, 170.

Cudweed. Gnaphalium.

C'ulture in moist air, effect on leaf-form, $7 \cdot 2$.

C'unningham, Allan, $\tilde{5}$

Cunoniaceue, 170.

Richard, 5,6 .

Cursed crowsfoot. Kanunculus sceleratus.

Curtis Islands, 141.

Curved snaketail-grass. Leplurus incurvatus.

Cushion form, 19.

Cushion, liverwort, 64.

., moss, 64, fig. 37.

Cut-leaved alpine buttercup. Rununculus Buchanani.

Cyathea dealbata, 60.

", kermadecensis, 142, 143, tig. 91.

, medullaris, 19.

,. Milnei, 142, 143.

Cyathodes, 7, 96, 167.

, acerosa, 76.

", empetrifolia, 91

", robusta, 141, fig. 94.

Cyclophorus serpens, 28, 174.

Cyperaceae, 171.

Cyperus - sedge. Carex pseudo-cyperus var. fuscicularis.

Cypress-koromiko. Veronica cupressoides

Cyrtostylis, 206 .

Cytisus candicans, 152.

, scoparius, 152.

Dacrydium, 61, 96, 173, 207.

, Biduillii, 97, 123.

," cupressinum, 61, 63, 67, fig. 30.

intermedium, 63, 193.

" intermedium, $63,193$.

Duclylis ylomeruta, 155.

Daisy family. Compositue.

Danthonia. Danthonia pilusa.

Danthonia, 96, 172.

, australis, 92, 94.

"Buchanani, 87.

". crassiuscula, 192.

", flavescens, 94, 109, 191.

, grassland, 149.

, pasture, 184, 186.

" pilusa, 93 . 
Dranthonir pungens, 111, 193.

, Raoulii, 172.

, . var. rubra $19,86,90$, $92,128,192$, fig. 52 .

". semiannularis, 87 .

", $\quad$ var. setifolia,

Daphne, 168.

97, fig. 71 .

Davallia Tasmani, 180.

Dausonia superba, 60, 64, 177, fig. 32.

De Vries, Professor Hugo, 214.

Jeciduous shrubs, 68 .

, tree-groundsel. Senecio Hectori.

trees, 68.

Dendrobium Cunninghamii, 56.

Deptford pink. Dianthus Armeria.

Deschampsia, 96.

$$
\text { ,, antarctica, } 212 .
$$

Desert danthonia. Danthonia Buchanani.

Desmoschoenus, 33, 205.

Deyeuxir, 172.

") setifolia, 125.

Dianthus Armeria, 155.

Diatoms, 118.

Dichelachne, 206.

crinita, 87.

Dichondra. Dichondre repens.

Iichondra repens, 87.

Dicksonia lanata, 60.

Dicotyledons, 171.

$$
\text { squarrosa, 19, } 63 .
$$

Dicranoloma Billardieri, fig. 37.

Dieffenbach, Dr. E., 11.

Digitalis purpurea, 153, 154, 156, 186.

Discaria, 169, 207.

. toumatou, $20,34,67,68,72,76$, $79,88,90,182$, figs. 10,55 .

.. effect of climate on, 67.

effect of moist-air culture, 72.

Dissemination, 194, 195.

Distribution, fell-field, 108.

, high-mountain flora, 97.

", low tussock-grassland, 86 .

, mixed forest, 61 .

, $\quad$ New Zealand forest, 46,47 .

,. $\quad$, plants, 179 et

, trees, 61,62 . seq.

tussock-grassland, 85, 86.

Divaricate tree-daisy. Olearia divaricata.

Divaricating growth-form, 18.

Dodonea viscosa, 43, $160,210$.

Donatia, 208.

", nome-zplendiaes $111,113,114$. $135,193,210$.
Donatiaceae, 210.

Dracophyllum, 96, 109, 113, 167, 187.

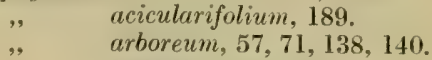

, latifolium, 60, 187.

", longifolium, 41, 131.

,. Menziesii, 192.

, paludosum, 125, 139, fig. 90.

". Pearsonii, 193.

,, politum, 111.

, recurvum, 183.

, rosmarinifolium, 110.

,, subulatum, 75, 91, 183.

,$\quad$ Traversii, 20, 62, 113, 151 .

, Urvilleanum, 74.

Drapetes, 7, 168, 207.

,$\quad$ Dieffenbachii, 168.

Drimys, 307, 213.

, axillaris, 170.

", colorata, 170.

, Traversii, 170.

, Winteri, 170.

Drooping - spleenwort. Asplenium flaccidum.

Drosera, 96, 126, 170.

,, auriculata, 126.

, $\quad$ its insectivorous habit, 126.

," pygmaea, 126.

, sect. Psychophila, 208.

Droseraceae, 170.

Dryness, physiological, 124.

Dryopteris Thelypteris var. squamulosa. 122.

Dun Mountain, 109.

Dune-hollows, 35, 149.

," shrubland, 34,35 .

Dunes, 32 et seq.

,, wandering, 32 , fig. 18 .

D'Úrville, Dumont, 5.

Durvillaea utilis, 30, 132, 136.

Dwarf bedstraw. Asperula perpusilla. $"$ false musk. Mlazus pumilio.

Dysoxylum spectabile, 43, 44, 49, 62, 185, 186,210 , fig. 24.

East Cape Botanical District, 183.

Echinopogon, 206.

groundsel. Senecio Bantisii.

Echium vulgare, 154, 191.

Edelweiss. Leontoporlium, Leucogenes.

Edwardsia, 203.

Egmont buttercup. Ranunculus viviroln. Elaeocarpacene, 168.

Elaeocarpus dentatus, 58, 168, 211.

Hookerianus, 62, 71, 168, 211. fig. p. 70.

Hookerianus, various leaf. forms, 71, fig. p. 70 . 
Elaeocharis, 172.

$$
\text { , sphacelata, } 132 .
$$

Elatostema rugosum, 80, 210 , fig. 48.

Elderberry. Sambucus niger.

Elm. Ulmus.

Eloder canadensis, 118, 15:3.

Elymus arenurius, 34.

Elylranthe, 170.

$$
\text { ," flavida, } 64 .
$$

Emhothrium, 207.

Embryo, 58.

Enarijea, 207.

," parviflora, 182, 210.

Endemism, 204, 205.

," Chatham Islands, 138.
," Sermadec Islands, 142.
Subantarctic Islands, 130.

Enys, J. D., 211.

Epacridaceae, 167.

Epacris, 153, 183, 206.

," perucifolia, 74, 76, 187.

Epilobium; 90, 163, 168, 195.
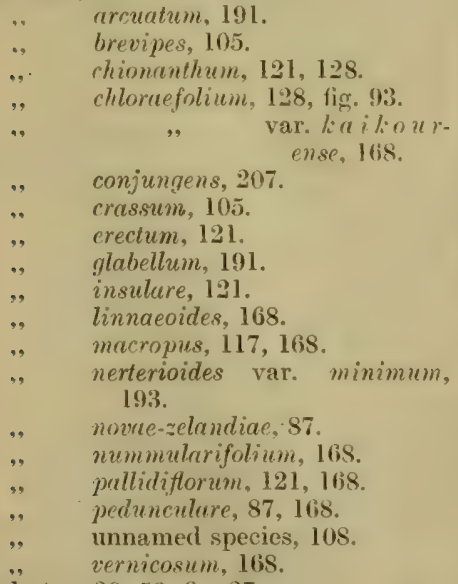

Epiphytes, 20, 56, fig. 27.

\section{Ericaceae, 167.} seedling trees as; 57 , fig. 30 .

Erodium cicutarium, 151.

Eryngium vesiculosum, 38, 157.

Eschscholzia californica, 155.

Eucalyptus, 15:.

Fucryphin, 208 . numerosu, 15:3, fig. 89.

Eugenia, 1 tis.

maire, $168,185,211$.

Euphorbix, 38 .

Euphrorsia, 101, lite.

", Cheesemanii, 101.

Euphrasia cuneatu, 80.

, Monroi, 101, fig. 58.

, repens, 9,38 .

," tricolor, 92, 101, 183, fig. 59.

. zealandica, 101.

Eu-Suttoniu, 305.

Evaporation, adaptations for reducing, 89.

Evergreen canopy-tree, 18.

Everlasting. Helichrysum.

Evolution, theories of, 214.

Exocarpus. 96.

Eyebright. Euphrosin.

Fagaceae, 171.

Faqus, 171.

False edelweiss. Holichrysum bellirlivirles, 87.

, New Zealand (mountain) holly. Olearia macrorlonta.

", snow-grass. Schoenus pauciflorus. Family, definition of term, 164.

Fat-hen. Chenoporlium alhum.

Eell-field, 108, 109, 110, figs. (3:3, 69, 71.

Fern-heath, 78, 15:.

Ferns. Filices.

Fertilization, 58.

Festuca, 96.

" arundinacer, 15\%.

, nozre-zealandire, $86,87,92,93$, $148,172$.

Filices, 174. tussock association, 87 .

Filmy ferns. Hymenophyllum, Trichomunes.

Fimbristylis, 172.

Floating duckweed. Lemna minor.

, water-fern. Azoller rubra.

Flora, definition of term, 14.

". Lord Howe Island, 212.

"Flora Antaretica," 8.

"Flora Novae-Zelandiae," s.

Flor of New Zealand, clements of, 303 , 204.

fossil plants of, 213.

its history, 216 , 느. 21 .

statistics, 204 .

Flora of Norfolk Island, $2: 2:$.

Hlowers of the forest, 58 .

, on juvenile plants, $69,70$.

.. on Subantarctic Islands, 132, 133.

., white, their conspicuousness, $[0]$

Forest, 46 et seq.

, coastal, 42 et seq.

," growth-forms of, 47 .

, kahikatea, 63. 
Forest karaka, 4i.

kauri, 61 .

, Kermadec Islands, 14:3.

", kohekohe, 43.

, Lord Auckland Islands. 130, 131, fig. 86 . mixed, 61.

", southern-beech, 48, 6.t, 65, 177.

, Southland, 62.

" Stewart Island, 62.

,, swamp, 63, fig. 37.

," Westland, lowland, 62.

9 , subalpine, 62 , fig. 36 . upland, 62.

Forest tree-groundsel. Senecio Kirlii.

Forget-me-not. Myosotis.

Forget-me-not family. Boraginaceae.

Forms, persistent juvenile, 69, 70 .

Forster, John George, 4. ,'John Reinhold, 4.

Forstera, 4, 96, 206.

, Biduillii, 10.

Fossil plants, 213.

Foxglove. Digitalis purpurea.

Fragrant tree-daisy. Olearia fragrantissima.

French honevsuckle. Centranthus ruber.

Fresh-water algae, 118.

Freycinetia Binlisi, 28, 44, 51, 62, 63, $173,210$.

Frulania, 177.

Fuchsia, 205, 207.

,. Colensoi, 50, 68.

,$\quad$ excorticata, 50, 68.

Fungi, 177. procumben.s, 68.

Gahnia, 171, 172.

Gaimartia, 307. xanthocarpa, 60, 212.

", ciliata, 125, fig. 81 .

, prellida, 125.

,, setacen, 125, 210

Galega officinalis, 154.

Galium, 166.

Gaultheria, 96, 167.

, antipoda, 79.

," clepressa, 91.

,, oppositifolia, 75, 113.

,, perplexa, 91.

Gaya, 168, 193. rupestris, 113.

," Lyallii, 68, 104.

"ribifolia, $68,104$.

Genera, New Zealand - Australia, 206.

New Zealand - Fuegian, 207.

Geniostoma ligustrifolium, 18, 41, 182, 185, 211.

Gentian. Gentiana.

16-Plants.
Gentiana, 96, 149.

, Astoni, 188.

," bellidifolia, 97, fig. 71 .

,. cerina, 133.

, chathamica. 141.

," corymbiferu, $88,16 \bar{\tau}$.

, $\quad$ lutea, 167.

, saxosa, 38.

, serotina, 18.\%.

,T'ounsoni, 76.

Gentianaceae, 167.

Genus, explanation of term, 163.

Gerania chilensia, 207.

Geraniaceae, 169.

Geranium, 96.

, $\quad$ chathamicum, 140.

, micropliyllum, 87.

,. Robertianum, 149.

, sessiliflonum, 209. var. glutrum, 87 , 209.

Traversii, 140.

Geranium family. Geraniuccue.

Gesneriacene, 166.

Geum, 169.

, divergens, 188.

, parviflorum, 210.

, uniflorum, 104.

Giant fescue. Festuca arundinacea.

" forget-me-not. Myosotidium nobile.

", gahnia. Gahnia xanthocarpa.

, moss. Dausonia superba.

Gibbs, F. G., 187.

Gilia squarrosa, $155,191$.

Glaciation, 217, fig. 98.

Glaucium flavum, 153.

Gleichenia, 174.

$$
\begin{aligned}
& \text {, } \quad \text { alpina, 125, fig. 82. } \\
& , \quad \text { dicarpa, 76, 125, } 139 .
\end{aligned}
$$

Glossy ascarine. Ascarina lucide.

" karamu. Coprosma rolusia.

" plantain. P'lantago Hemittonii.

" tree-daisy. Olearir arborescens.

Gnaphatium, 96.

,$\quad$ lieriense, 40,80 .

, luteo-album, 212.

., Lyyallii, 40.

,. $\quad$ subrigidum, $80,184,187$.

,. $\quad$ trinerve, 40.

Goat's-rue. Galega officinalis.

Golden cottonwood. Cassinia fulvida.

Goosefoot family. Chenopodiaceae.

Gorse. Ulex europaeus.

Gramineae, 172.

Grass family. Treuminerer.

, form, 20.

" lily. Herpolirion norae-zelandiae.

Grassland, 84 et seq. 
Grassland buttercup. Ranunculus multiscapus.

daisy. Brachycome Sinclairii.

Gratiola, 166. danthonia 149 .

, peruviana, $\mathbf{3 5}, \mathbf{2 0 9}$.

Great sowthistle. Sonchus grandifolins.

," spike-rush. Elaeocharis sphacelata.

Green cushion-celmisia. Celmisia bellidioides.

, raoulia. Raoulia Haastii.

" tree-fern: Hemitclia Smithii.

", vegetable-shcep. Raoulia rubra.

Griselinia littoralis, IS, 57, 67, 83, 109, fig. 30 .

, lucida, $41,56,57$.

Groundsel. Senecio.

Growing-place, definition of term, 24 .

Growth-form, definition of term, 17.

, forms, some common New Zea. land, 18, 19, 30.

Gum-tree. Eucalyptus.

Gunnera, 127, 206, 205.

, albocarpa, $\mathrm{so.}$

", arenaria, $3 \tilde{3}$.

, chilensis, 127.

", masafuerue, 127.

", prorepens, 137.

Gyminogramme rutaefolia, 174.

Gymnosperms, 173.

Haast, Sir Julius von, 9, 10.

Haastia, 10, 19, 96.

, pulvinaris, $96,107,108,188$.

," recurva, 96, 107.

, $\quad$," var. Wallii, 96.

" Sinclairii, 96, 107.

Hairy alpine buttercup. Ranunculus insignis.

, climbing-rata. Metrosideros Colensoi.

Hakea acicularis, 153.

Halorrhagis cartilaginea, 182.

micrentha, 128.

Hangehange. Geniostoma ligustrifolium.

Hard-fern. Blechnum.

" shield-fern. Polystichum Richardi.

", tussock. Festuca novae-zealandiae.

, tussock association, 87.

Hard-leaved tree-daisy. Olearia nummularifolia.

Haresfoot clover. Trifolium arvense.

Harestail-grass. Lagurus ovatus.

Hassock.grass. Danthonia australis.

Haumakoroa. Nothopanax simplex.

Heath-like coprosma. Coprosma rugosa. pomaderris. Pomaderris phylicaefolia.
Hector, Sir James, 9, 10.

Hectorella, 96, 204.

Hedycarya, 193.

$$
\text { , arborea, } 170 .
$$

Heketara. Olearia Cunninghamii.

Helenium quadridentatum, 183.

Helichrysum, 96.

$\begin{array}{ll} & \text { bellidioides, } 87,128,149, \\ & \text { fig. } 72 . \\ \text {, } & \text { coralloides, 104, 108, fig. } 77 . \\ \text { dimorphum, 189. } & \text { filicaule, 87. } \\ , & \text { microphyllum, } 105 . \\ \text { Selago, 105. }\end{array}$

Hemitelia Smithii, 63, 131, figs. 7, 86 .

Hemlock storksbill. Erodium cicutarium.

Herb, 20.

", summer-green, 20.

", field, $110,111,132$, fig. $73,74,88$.

Herb-robert. Geranium Robertianum.

Herpolirion, 171, 206.

Hierochloe, 96. novae-zelandice, 91, 127.

$$
\text { , redolens, } 210 .
$$

High-mountain flora, 95 el seq.

$$
\begin{aligned}
& " \quad \text { flowers, 100, 101, } 102 . \\
& \text { " plants in the lowlands, } \\
& \text { " } 113,114 \text {. } \\
& \text {, , growth-forms of, } \\
& \text {, } \quad 100 \text {. low stature of, } 100 \\
& \text { " } \quad \text { their environ. } \\
& \text { ments, } 99 .
\end{aligned}
$$

Hikurangi, Mount, high-mountain flora of, 97.

Hinau. Elaeocarpus dentatus.

Histiopteris incisa, 134, 157.

History of the New Zealand flora, 216, 217,218 .

Hoary mountain-musk. Celmisia intermedia.

" mountain - ribbonwood. Gaya ribifolia.

Hoheria, 168, 193.

" angustifolia, 58, 68, 70.

" populnea, 58 .

, sexstylosa, 58, 68, 70, 184.

" " juvenile blooming of, 70.

Holcus lanatus, 149.

Holloway, Rev. John E., 175.

Homalanthus polyandrus, 142.

Hooked sedge. Uncinia.

Hooker, Sir Joseph D., S, 9, fig. 6.

Horehound. Marrumbium vilgare.

Hormosira Banksii, 31.

Horned poppy. Glaucium flavum.

Horokaka. II esembryanthemum australe.

Hottentot fig. Mesembryanthemum edule. 
Hot-water algae, 11 s.

Hupiro. Coprosma foetidissima.

Hutton, 215.

Hybrid ribbonwood. Plagianthus cymosus.

Hydrocotyle, 121.

americana, 209.

Hymenanthera, $20 \epsilon$.

. chathamica, 138.

, cressifolia, 168.

", dentata var. alpina, 110.

", novae-zelandiae, 212.

Hymenophyllum, 57, 174.

$\begin{array}{ll}, & \text { multifidum, } 134 . \\ \text { pulcherrimum, } 183 . \\ \text { tunbridgense, } 211 . \\ \text { unilaterale, } 182 .\end{array}$

Hypericum Androsaemum, 149.

Hypochoeris radicata, 93, 148 .

Hypolaena lateriflora, 125

Ice-plant. Mesembryanthemum auștrale. , association, 39.

"Illustrations of the New Zealand Flora," 12.

Ink-weed. Phytolacca octandra.

Insectivorous plants, 126, 127.

Inuka. Dracophyllum longifolium.

Ipomaca palmata, 167.

$\therefore \quad$ pes-caprae, 141.

Iridaceae, 171.

Iris family. Iridacene.

Isoetes, 174.

Ivy-tree. Notliopanax arboreum.

Ixerba brexioides, 58, 183.

Jointed rush. Leplocarpus simplex. twig-rush. Cladium articulatum.

Jovellana, 166, 207, 210.

"repens, 80 .

, Sinclairii, 80, 184.

Juncaceae, 171.

Juncus, 171.

" bufonius, 213.

, maritimus var. australiensis, 37.

", planifolius, 208.

Juvenile forms, 69 et sery., fius. 8, 39, 40, 41,42 , text-figs. pp. 70,71 .

Kahakaha. Astelia Solandri.

Kabikatea. Podocarpus dacrydioides.

Kahikatea forest, 63.

Kaikomako. Pennantia corymbosa.

Kaikoura buttereup. Ranunculus lobulatus.

Kamahi. Weinmannia racemosa.

Kanono. Coprosma grandifolia.

Karaka. Corynocarpus laevigata.
Karaka forest, 43, 138.

Karamu. Coprosma lucide.

Karo. Pittosporum crassifolium.

Kaupokonui cheese-factory, 185.

Kauri. Agathis australis.

Kauri forest, 59, figs. 31, 32.

,$\quad$ grass. Astelia trinervia.

Kawaka. Librocedrus Doniana.

Kawakawa. Macropiper excelsum.

Kermadec Islands, 141.

, koromiko. Veronica brevi. racemosu.

, nikau. Rhopalostylis Cheesemanii.

Kidney-fern. Trichomanes reniforme.

Kiekie. Freycinetin Bankisii.

King, Dr. Truby, 153.

King fern. Tondea barbara.

Kirk, Thomas, 11.

Knightia, 213.

," excelsa, 17, 61, 62, 171, 185.

Knotweerl family. Polygonaceae.

Kohekohe. Dysoxylum spectabile.

Kohekohe forest, 43.

Kohuhu. Pittosporum tenuifolium.

Kopi. Corynocarpus laevigata.

Korokio taranga. Corokia buddleoides, C. macrocarpa.

Koromiko. Veronicr.

Koromiko family. Scrophulariaceae.

Korthalsella, 170.

Kowhai. Sophora tetraptera and the other species.

Kowharawhara. Astelia Cunninghamii.

Lacebark. Hoheria.

Lagenophora, 165, 207.

Lagurus ovatus, 149. pumila, 87.

Laing, R. M., 197.

Lancewood. Pseudopenax crassifolium.

Land bridge, 207, 215.

Large-flowered kowhai. Sophora grandiflora.

, New Zealand broom. Curmichaelia grandiflora. , raoulia. Raoulia grandi. flora.

Large-leaved milk-tree. Paratrophis opucu.

pohuchue. Muehlenbeckia australis.

Lauraceae, 170.

Laurel family. Lauraceae.

Laurelia, 207, 213.

:novae-zelandiae, 62, 119, 170, 185, fig. 80.

Lawson, Professor A. A., 176. 
Leaf-form, Aristotclia fruticose, 71 .

,$\quad$ effect of moist-air culture on, 73, fig. 39.

Elaeocurpus Hookerianus, 71. fig. p. 70 .

Veronica salicifolia var. Alkin. sonii, 71, 72, fig. p. 71 .

Leafless clematis. Clematis afoliuta.

Leafy coprosma. Coprosma parviflora.

Leguminosae, 169.

Lemna minor, 212.

Leontopodium alpinum, 104.

Lepidium, 170, 191.

,$\quad$ incisum, 187.

, $\quad$ oleraceum, 170.

, tenuicaule, 32.

Lepidosperma, 172.

Leptocarpus, 207.

laterale, 74 .

Leptopteris hymenophylloides, 57 .

$$
\text { , superba, } 57 .
$$

Leptospermum, 168.

\begin{tabular}{|c|c|}
\hline ," & $\begin{array}{l}\text { ericoides, } 28,35,58,193 . \\
\text { Nichollsii, } 73 .\end{array}$ \\
\hline$\theta^{\prime}$ & $\begin{array}{l}\quad 43,76,79,113,114,121, \\
\quad\end{array}$ \\
\hline & $\begin{array}{l}139 . \\
\text { scoparium, habitats of, } 72 \text {, } \\
\text { fig. } 11 \text {. }\end{array}$ \\
\hline , & $\begin{array}{l}\text { scoparium "Leonard Wil- } \\
\text { son," } 73 \text {, fig. } 43 \text {. }\end{array}$ \\
\hline
\end{tabular}

Lepturus incureatus, 149.

$$
\text { son," } 73 \text {, fig. } 43 \text {. }
$$

ILesson, René Primeverre, 5.

Leucobryum candidum, 60.

Leucogenes, 96, 165.

," grandiceps, 104 .

, Leontopodium, 97, 104, 110, fig. 57, 69.

Leucopogon, $96,167$.

,. fasciculatus, 35, 74, 79, 199, figs. pp. 200, 201.

„. Fraseri, 88, 92, 149, 160.

". Richei, 198.

Leycesteria formosa, 155.

Liane form, 19.

Lianes, erolution of, 50 .

Libertia, 207.

$$
\text { in Umbellifereac, } 167 .
$$

micrantha, 171.

Libocedrus Bidwillii, 62, 65, 67. 151, 173, 182,188 , fig. 36 .

Doniana, 61, 173, 183, 184.

Lichens, 49, 90, fig. 26.

Life-form, 17.

Liliaceae, 171.

Lily family. Litiaceae.

Lime-spleenwort. Asplenium oblusatum var. anomodon.
Limestone, plants confined to, 79 .

Lindsay, Dr. Lauder, 10.

Linum monogynum, 81, 83.

Liparophyllum, 167.

Litsuea, 170.

Gunnii, 126.

," calicaris, 61, 183, 210 .

Little mountain-heath. Pentuchondra pumilu.

, spaniard. Aciphylln Monroi.

Liverwort cushion, 64.

Liverworts, 177.

Lobelia. Pratia. Lobelia.

Lobelia, 96, 165.

,$\quad$ anceps. 40, 142.

" linnueoides, 165.

, Roughii, 107, 165.

Locust-tree. Robinia pseud-racacia.

Logania, 96, 206.

Lomatia, 207.

$$
\text { depressit, } 198 .
$$

Lombardy poplar. Populus fastigiuta.

Long - haired plume-grass. Dicholachne crinita.

Long hard-fern. Blechnum capense.

Long-leaved lacebark. Hoherin sexstylosa.

Jong - stalked willow - herb. Epilobium pedunclare.

Loranthaceae, 170.

Loranthus, 170.

, micranthus, $30,170$.

Lord Auckland Islands, 130.

Lord Howe Island. 212.

Lotsy, Dr., 214.

Lotus hispidus, 183.

$$
\text { major, } 188 .
$$

Low tussock-grassland, 86, 92.

Lowland ribbonwood. Plagianthus betulinus.

Loxomopsis, 204.

Loxsoma, 174.

, Cunninghamii, 182, 204.

Lucerne. Medicago satiza.

Lupinus arboreus, $34,152$.

Luzula, 171.

, campestris, 83, 171 .

Lyall, David, 9.

Lyallia, 9, 205.

" kerguelensis, 205.

Lycium horridum, 185.

Lycopodiaccae, 79, 174.

Lycopodium, 174.

$\begin{array}{ll}, & \text { Billardieri, 4, 57. } \\ , & \text { cernum, 187, } 198 . \\ \text { densum, 74. } & \text { Drummondi, 198. } \\ , & \text { fastigiatum, 64, 183. }\end{array}$


Lycopodium laterale, 127.

, life-history of, $174,175,176$.

, ramulosum, 127, 174, 193.

, , , effect of habitat

, scariosum. 18:. on, 76 .

, varium, 182.

Lygodium articulatum, 54 .

Lyme-grass, Elymus arenarius.

Lyperainthus, 206.

"Mabel Island lily." Arthropodium cirrutum. (See Rock-lily.)

Macquarie Island, 135.

Macrocystis pyrifera, 30, 178.

Macropiper excelsum, $43,44$.

Madder. Rubia tinclorum. var. major, 143.

Magnoliaceae, 170.

Mahoe. Melicytus ramiflorus.

Maidenhair. Adinntum.

Maire-tawake. Eugenin maire.

Maireire. Phebalium nurlum.

Maize, 186.

Makamaka. Acliana rosaefoliu.

Makomako. Aristotelia racemosa.

Mallow family. Malvaceae.

Malvaceae, 168.

Mangeao. Litsaea calicaris.

Mangemange. Lyyjorlium articulatum.

Mangrove. Avicennia officinalis.

"Manual of the New Zealand Flora," 11.

Manuka. Leptospermum scoparium.

Manuka thicket, 73, 152.

", $\quad$ Auckland gumlands, 74.

Nap of Banks Peninsula, 82.

Tolcanic Plateau, 74, 75.

, botanical districts, 181.

Maple. Acer.

Mapou. Rapanea Urvillei.

Hariscus, 172.

ustulatus, 28, 142, 143, 189.

Mariscus-sedge. Mariscus ustulatus.

Marram-grass. Psamma arenaria.

II arrumbium vulgare, $15 t$.

Marsh-pennywort. Hydrocotyle.

Marsippospermum, 96, 207.

$\because$ gracile, 210.

Mat-raoulia. Raoulia tenuicaulis.

Muzus, 166. pumilio, 38.

Merlicago denticulata, 149.

Melicope, 193. sativa, 25,35 .

, ternata, 62, 142, 143, 185, 210.

Nelicytus ramiflorus, 4., $63,142,143,168$, 211.

Melilot. Melilotue arvensis.
Melilotus arvensis. 149.

Menzies, Alexander, 4.

Meryla Sinclairii, 167, 180.

Mesembryanthemum, 28, 39.

Metrosideros, 168. australe, 28, 39, 142. edule, 29.

.. albiflora, 53,60 .

., Colensoi, 53.

,$\quad$ diffusa, 53.

, florida, 19, 53, 57, 62 .

, hypericifolia, 53,63 .

" lucida, 28, 41, 58, 130, 131, 192.

. Parlinsonii, 187.

., robusta, 57, 58, 60, 185.

, scandens, 40, 53, 56, fig. p. 52.

, tomentos $\alpha, 29,39,43,184$, 211, fig. 21.

Microbes, 158, 178. villosa, 141, 142, 143.

Microspore, 58 .

Migratory formation, 22, fig. 12.

Milk-thistle. Silybum Marianum.

Milligania, 206.

Himulus, 166.

, luteus, 153.

, repens, 39 .

Mistletoe. Elytranthe, Korthalsella, Lo. ranthus, Phrygilanthus.

Mistletoe family. Loranthaceae.

, $\quad$ growth-form, 19.

Hitrasacme, 96.

Mixed taxad forest, 61.

Honimiacene, 170.

Monkey-puzzle. Araucuria imbricata.

Ionoao. Dracophyllum subulatim.

Monocotyledons, 171.

Monro, Sir David, 9.

Nontane belt, 99 .

Montia fontana, 39, 117.

Hoonwort. Botrychium.

Ioss cushion, 64, fig. 37 .

Ilosses, 177.

Nountain - akeake. Olearia avicenniaefolia.

(alpine) astelia. Astelia mon$\tan \alpha$.

club-moss. Lycopodium scariosum.

cottonwood. Cassinia Vauvilliersii.

cotula. Cotula pyrethrifolia.

" Hax. Phormium Colensoi.

". foxglove. Ourisia macrophylla.

". ivy-tree. Nothopanax Colensoi.

," korokio. Corokia Cotoneaster.

, lily. Ranunculus Lyallii. 
MLountain-musk. Celmisia.

, neinei. Dracophyllum Traversii.

, pine. Dacrydium Bidwillii.

, piripiri. Acaena Sanguisorbae var. pilosa.

ribbonwood. Gaya Lyallii.

,

, snowberry. Gaultheria depressa. southern - beech. Nothofagus cliffortioides.

tawheowheo. Quintinia acutifolia.

toatoa. Phyllocladus alpinus.

" totara. Podocarpus Hallii. (See also Alpine totara.)

", twitch. Triodia exigua. alpina.

willow-herb. Ei pilobium chlorce-

, wolium. cosit.

Muehlenbeckia, 53, 170, 207.

,, Astoni, 30, fig. 15 .

,, australis, 28, 68, 138.

," axillaris, 68 .

,$\quad$ complexa, 28, 68, fig. 16.

Mueller, Baron von, 11.

Mullein. Verbascum Thapsus.

"Musci Exotici," 5.

Musky tree-daisy. Olearia moschatu.

Mustard family. Cruciferae.

Mutation theory, 214.

Mutton-bird plant. Cotula Featherstonii. scrub, 41.

Myoporum laetum, 43, 142, 143, 211.

Myosotidium, 138, 166.

nobile, 140, 166, fig. 2.

Myosotis, 96, 166, 207.

, albida, 40, 192.

, albosericea, 191.

, amabilis, 97, 184.

,, australis, 102.

," capitata, 133.

, decora, 189.

, Goyeni, 102.

". macrantha, 10:2

," Monroi, 110.

, pulvinaris, 109.

,, pygmaea var. Traillii, 33 .

, saxatilis, 102.

, saxosa, 184.

Myosurus aristrtus, 208.

Myriophyllum, 117.

$\begin{array}{ll}, & \text { elatinoides, 117, } 209 . \\ , & \text { growth-form of, 117. } \\ \text { propinquum, 117. } & \text { robustum, 117. } \\ , & \text { Votschii, 117. }\end{array}$

Myrtaceae, 168.

Votschii, 117.

Myrtle family. Myrtaceae.
Myrtus, 168.

" bullata, 18, 69, 77

", obcordata, 77.

," pedunculata, 18.

, Ralphii, 77.

Myxomycetes, 178.

Names of plants, 159 et seq.

Native holly, 113. (Should be "New Zealand holly.")

Natural order. (Sce Family.)

Nao. Linum monogynum.

Narrow-leaved lacebark. Hoherin angustifolia.

Needle-leaved celmisia. Celmisia laricifolia.

heath. Dracophyllum.

Nephrolepis exaltate, 141.

Nertera Cunninghamii, 18 .

,$\quad$ depressa, 80, 187, 209.

Nettle family. Urticaceae.

New Lamarckian theory, 214.

New Zealand bluebell. Nahlenbergia albomarginata.

, broom. Carmichaelia.
, $\quad$ burr - reed. Sparganium subglobosum.

calceolaria. Jovellana Sinclairii.

flax. Phormium.

holly. Olearia ilicifolia.

honeysuckle. Knightia.

jasmine. Parsonsia heterophylla.

lilac. Veronica Hulkeana.

" musk. Mimulus repens.

, orache. Atriplex Billardieri.

. passion - flower. Tetrapathaea australis.

plantain. Plantago Raoulii.

", screw - pine. Freycinetia Banlisii.

spinach. Tetragonia expansu.

violet. Viola Cunninghamii.

Ngaio. Myoporum laetum.

Niggerhead, Carex secta.

Nikau-palm. Rhopalostylis sapida.

Niniwa. Gaultheria oppositifolia.

Nitella, 118.

Nodding club-moss. Lycopodium varium. Norfolk Island, 212.

", pine. Araucaria excelsa.

North "Island edelweiss. Leucogenes Leontopodium.

evebright. Euphrasia tricolor.

Northern needle - leaved heath. Draco. phyllum Urvilleanum.

rata. Metrosideros robusta. 
Nostoc in Gunnera, 127.

Nothofagus, 18, 48, 64, 65, 96, 171, 184, $193,207,213216$.

cliffortioides, 64, 65, 114, 187, 188,189 , fig. 25 .

, fusca, 64, 65, 109, 192.

", , var. Colensoi, 64.

, Menziesii, 64, 65, 160, 18ב, $187,192$.

Solnnderi, 65, 185, 189.

Nothopanax, 167.

, anomalum, 77, 78.

, arboreum, 60, 63, 142.

, Colensoi, 63, 77.

, simplex, 130, 18:.

Notospartium, 169, 205.

"Carmichaeliae, 188.

Notothlaspi, 96, 205.

," australe, 110.

", rosulatum, 106, 110, fig. 68.

Oak. Quercus.

Odorous tree-daisy. Olearia odorata.

"Oecology of Plants," 15.

Olea, 62.

"Cunninghamii, 185.

, lanccolata, 185.

," montana, 185.

Olearia, 96, 112, 206.

" angustifolia, 41, 193, fig. 22.

, arborescens, 112.

, avicenniaefolia, 62, 77, 80, 160.

,, chathamica, 139.

,. Colensoi, 42, 112, 131, figs. 23, 76.

Cunninghamii, 58.

cymbifolia, 112.

divaricatn, 68, 193.

excorticata, $62,112$.

Forsteri, 83, 205.

fragrantissima, 68.

furfuracea, 74, 184 .

Hectori, 68.

ilicifolia, $62,77,112$.

insignis, 80, 81, 188, 189.

,$\quad$ association, 80.

lacunosa, 62, 112.

lineata, 68. Iyallii,42, 131, 132, 136, figs. 85, 87 , frontispiece.

macrodonta, $62,77,112$, fig. 38 . moschata, 112, 192.
Olive. Olea.

Oliver, IT. R. B., 141.

Onagracede, les.

Ongaunga, Lrtica ferox.

Open Bay Islands, 44.

Ophioglossum, 174.

Oplismenus undulatifolius, 212.

Orache. Atriplex.

Orchid family. Orchiduccue.

Orchidaceae, 171.

Orchids, 56.

, spongy root-tissue of, 56 .

, tuberous, 73.

Oreobolus, 172, 207.

,, pectinatus, 97, $111,125$.

Oreomyrrhis, 207.

, andicole, 209.

Oreostylidium subulatum, 91, 127.

"Origin of Species," 84.

Orites, 207.

Orthoceras, 206.

Oru. Colensoa physaloides.

Ottelia ovalifolia, 118, 183.

Ourisia, 7, 96, 101, 166, 207.

" caespitosa, 101109.

, Cockayniana, 101.

, Crosbyi, 193.

, glandulosa, 101.

", macrocarpa, 101, 110.

", " var. calycina, 101, 188.

", macrophylle, 97, 101, 110, 182,

" fig. 60 .

", modesta, 193.

, prorepens, 101.

, sessiliflorr, 101

Ovule, 58.

Oxalidaceae, 169.

Oxalis, 169, 193.

, corniculata, 87, 169.

, lactea, 210.

" magellanica, $169,210$.

Oxeye daisv. Chrysanthemum Leucanthemum.

Pachycladon, 96, 170.

,. novae-zelandice, 170.

Paesia scaberula, 157.

Pahau-tea. Libocedrus Bidwillii.

Pakihis, plant-coveriner of, 76 .

Palaeozelandic, definition of term, 205.

Pale willow - herb. Eprilobium noraezelandiae.

Palm family. Palmae.

Palmae, 171.

Pandanacere, 173.

Papa-koromiko. Veronica macroura.

Parapara. Pisonia Brunoniana, 1s:3. 
Parataniwha. Elutostema rugosum.

Paratrophis microphylla, 210.

$$
\begin{array}{ll} 
& \text { spaca, } 44 . \\
\text { Smithii, iso. }
\end{array}
$$

Parrot-bill. Clirenthus punicens.

Parsonsin, 195.

", capsuluris, 5t, 211.

, heterophylla, 54, 69, 211, fig. p. 54.

Paspalum dilatatum, 183.

Pastures, upland, 149.

Pea family. Lequminosae.

Peat, 100, 123.

Pendullous club-moss. Lycopodium Billiardieri.

Penguins, 135, fig. 87.

Pennantin, 193, 206.

, corymlosa, 43, 58, 69.

, juvenile blooming, 69 .

Pentachondra, 167.

$$
\text { pumila, 91, 92, } 97 .
$$

Penwiper-plant. Notothlaspi rosulatum.

Peperomia Enllicheri, 187.

Pepper-tree. Drimys.

Perching-kohuhu. Pittosporum cornifolium.

$"$ lilies. Astelia.

" plants, 20,56 , figs. $27,30$.

Pernettya, 96, 167, 206, :07.

Persistent juvenile form $x^{3}, 69,70,71$, fig. 8 .

Persoonia, 206.

Petrie, Donald, 12.

$$
\text { toru, 74, 171, 18:3. }
$$

Phelualium, 206.

$$
\text { nudum, 60, 18:. }
$$

Phormium, 19, 25, 79, 96, 171.

,$\quad$ Colensoi, $28,39,40,41,75$, $81,96,113,151,171$.

, $\quad$ tenax, $25,28,34,59,91,119$, $130,121,171,186,212$.

Phrygilanthus, 170, 207.

Phyllachne, 96, 207.

Phylloclarlus, $173,193$.

$$
\text { Colensoi, 114, } 125 .
$$

, alpinus, 97, 18\%.

", glaucus, 61.

", trichomanoides, 61, 62, 77.

Phylloglossum, 177.

Phytolacca octandra, 18:3.

Pigeonwood. Heilycarya arbored.

Pilularia, 174.

Pimelea, 168.

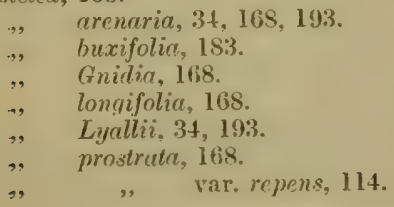

Pimelea sericeo-villosa, 191.

$$
\text { Suteri, } 109 .
$$

Pimelea family. Thymelacareae.

Pinncene, 173.

Pino family. Pinaceae.

Pines. Pinus, Dacrydium, Phyllocladus, Podocarpus.

Pingao. Scirpus frondosus.

Pink broom. Notospartium Carmichaeliae.

Pinus radiatn, 152 .

., Pinaster, 152.

Piripiri. Acaena Sanquisorhae.

Pirita. Tupeia antarctica.

Pisonia Brunoniana, 183.

Pitchy-seed family. Pittosporaceae.

Pitlosporaceae, 169.

Pittosporum, 18, 169, 210.

"Colensoi var. fasciculatum, 63.

,. cornifolium, 56, 185.

", crassifolium, 43, 182, 183, 185.

," Dallii, 187.
," eugenioides, 62, 63.

"' Fairchildii, 180.

," Kirkii, 56.

", obcordatum, 6, 158, 197, fig.

96.

, patulum, 197.

", Ralphii, 184.

", tenuifolium, 63, 169

", umbellatum, 43.

Plagianthus, 168.

, betulinus, $е 8,70$.

" chathamicus, 138.

", cymosus, 68 .

", divaricatus, 37,68 .

Plant-associations, 16, 147 et seq.

, , adventitious, 152.

" $\quad$ " classification of, 145,

147.

, , indigenous induced, 148.

" . $\quad$ induced, 148.

$", \quad$ ", modified, 148, 149.

, community, definition of, 15 .

", formation, climax, 22.

, , meaning of term, 16 .

" migratory, 22.

", names, 159 et seq.

Plantaginacene, 166.

Plantago, 19, 166.

, aucklandica, 166.

, carnosa, 132.

" Coronopus, 149.

, Hamiltoni, 38.

" Raoulii, 40.

" sect. Plantaginella, 207.

Plantain family. Plantaginacere. 
Plastic, definition of term, 21.

Pleurophyllum, 130. criniferum, 133, 134, fig. 88. Hookeri, 133, 135.

Poa, 96, 172. speriosum, 132.

, ancep.s, 79.

, caespitosa, 19, 86, 93, 148, 172, 183.

", chathamica, 140.

, Colensoi, 93.

", foliosa, 132, 135, 136, 193, fig. 85.

", litorosa, fig. 87, frontispiece.

, maniototo, 150 .

, pygmaea, 191, 198.

, ramosissima, 132.

", sclerophylla, 106.

Podocarpus, 61, 96, 173.

, acutifolius, 77.

, dacrydioides, $63,71,189$, fig. 29.

, Hallii, 62, 183, 188, 193.

, nivalis, 97,109 , fig. 51 .

, totara, 61, 160, 183, 189, 193.

Pohuehue. Muehlenberkia.

Pohutukawa. Metrosideros tomentosa.

Pokaka. Elacocarpus Hookerianus.

Pollen-grain, 58.

Pollination, 58, 59.

Polygonaceae, 170.

Polypodium, 174.

Polypody. Polypodium.

Polypogon monspeliensis, 141.

Polystichum Richardi, 5, 83.

, vestitum, 64, 78, 13:, 134, 182 , fig. 35 .

Polytrichum dendroides, 64, 177.

Pomaderris, 169, 206.

, Edgerleyi, 74.

, elliptica, 74.

," phylicaefolia, 35, 74.

Pond-weed. Potamogeton.

Pond-weed family. Potamogetonareae.

Poppelwell, D. L., 111.

Populus fastigiata, 17.

Potamogeton, 116, 173.

, $\quad$ Cheesemanii, 116.

,, ochreatus, $1 \mathbf{1 6 .}$

, pectinatus, 117.

Potamogetonaceae, 173.

Potentilla, 169.

Pratia, 96, 165, 208.

Prickly saltwort. Salsola Kali.

" shield - fern. Polystichum restitum.

Primrose family. Primulaceae.

Primulacene. $16^{7}$

Prionotes. 20R.
Prostrate kowhai. Sophore prostrata.

Proteaceae, 171.

Psamma arenarin, 34, 153.

Pseudopanax, 167, 207.

, chathamicum, 137, 138.

", crassifolizem, 137, 163.

, crassifolium var. trifoliatum, 163.

, crassifolium var. unifoliatum, 77, 121, 163.

" ferox, 137.

". Lessonii, $5,43$.

, lineare, 112

Psilotum, 174, 177.

Pteridium esculentum, 74, 78, 124, 152.

Pteris comans, $\mathbf{1}+3$.

Pterostylis, 171, 206.

, puberula, 187.

Puawananga. Clematis indivisa.

Puheretaiko. Senecio rotundifolius.

Puka. Griselinia lucida, Meryta Sinclairii.

Pukatea. Laurelia novae-zclandine.

Pumice whipcord koromiko. Veronica tetragona.

Pungent heath (sharp-leaved). Leuco. pogon Fraseri.

", mingimingi. Cyathodes acerosa.

Puriri. Vitex lucens.

Purple tree-daisy. Oleuria semidentata.

Putaputaweta. Curpodetus serratus.

Pygmaea, 205.

Pysmy pine. Dacrydium laxifolium.

Quercus, 213.

Quintinia acutifolia, $\mathbf{6 2 .}$.

, serrato, 183.

Raricula Nasturtium aquaticum, 118, 153.

Rain-forest, $47,48,49$, figs. 33,34 .

Ramarama. Myrtus bullala.

"Rambles in New Zealand," 10.

Rangiora. Brachyglottis repunia.

Rangitoto Island, 40, 41.

Ranunculaceae, 170.

Ranunculus, 96, 170.

\begin{tabular}{|c|c|}
\hline \\
\hline \\
\hline \multirow{2}{*}{\multicolumn{2}{|c|}{$\begin{array}{l}\text { acaulis, } 31,208 . \\
\text { iquatilis, } 118,15.3,155 . \\
\text { Baughani, 191. }\end{array}$}} \\
\hline \multirow{2}{*}{\multicolumn{2}{|c|}{ Baurii, 102. }} \\
\hline \multirow{2}{*}{\multicolumn{2}{|c|}{ Berggreni, 192. }} \\
\hline \multirow{2}{*}{\multicolumn{2}{|c|}{ Buchanani, 102, 191.}} \\
\hline & \\
\hline & \\
\hline & \\
\hline & \\
\hline & \\
\hline & \\
\hline & \\
\hline & acaulis, 31, 208. \\
\hline & \\
\hline & \\
\hline & \\
\hline & \\
\hline & \\
\hline , & chordorhi 0 os, 106. \\
\hline ", & crassipes, 210 \\
\hline , & $\begin{array}{l}\text { crithmifotius, } 106,197 \text {, fig. } \\
\text { p. } 107 .\end{array}$ \\
\hline , & Enysii, 103, 189. \\
\hline & gerceniifolius, $] 03$. \\
\hline
\end{tabular}


Ranunculus gracilipes, 103.

Haastii, 106, fig. 5 t.

,9

9

,9

97

99

9

94

,?

,

9

9

,

,

Raoul, Dr. E., 6.

insignis, 102.

lobulatus, 102.

L.yallii, 9, 17, 102, 110, 188, fig. 1.

macropus, 121.

Matthewsii, 102, 191.

Monroi var. dentatus, 103.

multiscapus, 87.

nivicola, 102, 110, 183.

novae-zealandice, 103.

pinquis, 133.

rivularis, 121.

sceloratus, 153.

sericophyllus, 103.

Sinclairii, 103.

Raoulia, 6, 7, 19, 96, 105, 165, 205. australis, $32,75,90$.

" Beaurerdii, 150, 191.

", bryoides, 105, fig. 66.

, Buchanani, 105.

, cinerea, 107, 188.

, cushions, 105.

", eximia, 105, 106, 108, figs. 64, 65 .

,, glabra, 149.

", Goyeni, 1.05, 193.

, grandiflora, 92, 97, 109.

, Hanstii, 90, 114, fig. 54.

" lutescens, 90, 150, fig. 53.

", vibru, 105, 198, fig..67.

, subsericea, $88,149$.

, tenuicaulis, 90, 114, figs. 12, 58, 61.

Rapanea kermadecensis, 143.

"salicina, 185.

, Urvillei, 5, 43.

Rata. Metrosideros.

Raupo. Typha angustifolia.

Raupo family. Typhaceae.

Rautini. Senecio Huntii.

Red climbing-rata. Metrosideros florida.

", heath. Dracophyllum recurva.

" mistletoe. Elytranthe tetrapetala.

", southern-beech. Nothofagus fusca.

", tea-tree. Leptospermum scoparium.

, tussock. Danthonia Raoulii var. rubra.

Reversion shoots, 71 .

Rewarewa. Knightia excelsa.

Rhabdothamnus Solandri, 59, 166.

Rhagodia, 170.

Rhamnaceae, 169.

Rhipogonum scandens, 19, 53, 63, 138, fig. 9.

Rhopalostylis Cheesemanii, 142, 143, 171. , sapida, 4t, 62, 138, 171,

Ribbonwood. Plngianthus.
Riccarton Bush, 189, figs. 28, 29.

Rice-grass. Dichclachne stipoides.

Richard, Achille, 5.

Rimu. Dacrydium cupressinum.

Rimu association, 62, 63.

Piver-bed, its earliest settlers, 90. , shingly, 89 , figs. 12,55 .

River-terrace scrub, 77, 78.

Robinia pseud-acacia, 152.

Rock-akeake. Olearia Forsteri.

$\therefore$ anisotome. Anisotome Enysii.

" bluebell. Wahlenbergia cartilaginea.

" cotton-plant. Celmisia Monroi.

" cudweed. Gnaphalium I.yallii.

", forget-me-not. Myosolis saxatalis.

, groundsel. Senecio Monroi,

., lily. Arthropridium cirratum.

, plants, 79, 104, 105.

, tree-daisy. Olearia insignis.

, vegetation, $39,40,79,80,81$, figs. $49,61,66,67$.

". veronicas, 105 .

Rocky shores, 31.

Rohutu. Myrtus obcordata.

", Myrtus pedunculata. ("Smallleaved myrtle" to replace "rohutu.")

Root buttresses, 48, fig. 29 .

" climber, 19, 52.

" trunks, 57.

Roots, adaptations of, 25.

Rosa rubiginosa, 152, 154.

Rosaceae, 169.

Rose family. Rosaceae.

Rose-leaved anise. Angelica rosaefolia.

Rosette growth-form, 19.

Rostkovia, 171, 207. magellanica, 208.

Rotation of crops, 135.

Rough bracken. Paesia scaberula.

Round-leaved coprosma. Coprosma rotundifolia.

Rubia tinclorum, 166.

Rubiaceae, 165.

Rubus, 51, 169.

," australis, 51, 53, 79, fig. p. 50.

,, cissoides, 51, fig. p. 51 .

, fruticosus, 153, 154, 188.

" parius, 51.

," schmidelioides, 51, 153.

", , var. coloratus, 64, 78.

, subpauperatus, fig. 28.

Rumex, 146.

,. Acetosella, 93, 150, 158.

"neglectus, $31,39$.

Rush family. Juncaceae.

Rusts, 42.

Rye-grass pasture, 186. 
Salicornia, 28.

Salix, 152. australis, 39, 37, 39, fig. 14.

Salsola Kali, 31.

Salt, effect, of, 28, 29.

" grass. Atropi stricto.

", meadow, 38, 149.

, swamp, 37.

Sambucus niger. 149.

Samolus, 28.

$$
\begin{array}{cc}
" & \text { repens, } 167 . \\
" & \quad \text { var. procumbens, } 38 .
\end{array}
$$

Sand-binding plants, 33 .

, convolvulus. Calystegia Soldanella.

", coprosma. Coprosma acerosa.

". vunnera. Gunnera arenaria.

", sedge. Carex pumila.

Saxifragaceae, 169.

Saxifrage family. Saxifragaceae.

Scaevola gracilis, 142.

Scarlet climbing-rata. Metrosideros florida.

Schizeilema Cockaynei, 193.

Schoenus, 172.

$$
\text { nitens, } 117 .
$$

,$\quad$ brevifolius, $74,172$.

,$\quad$ pauciflorus, 127, 172, fig. 83 .

, tendo, $74,17 \%, 187$.

Scirpus, 33, 172.

" americanus, 37 .

, cernuus, 212.

, frondosus, 33, 172, 205.

, nodosus, $142,143$.

, robustus, 37 .

Scleranthus liflorus, 19.

Scoria-koromiko. Veronica spathulata.

" slopes, plants of, 108.

Scramblers, 19, 50, 51 .

Serew-pine family. Pandanaceae.

Scrophulariaceae, 166.

Scrub, definition of term, 76,77 .

" river-terrace, 77.

", subalpine, $111,112,113$, figs. 36 , $50,76,78$.

, use of term in Australia, 76.

Sea-blite. Suaeda maritima.

", club-rush. Scirpus robustus.

" grass. Species of Zostera.

", rush. Juncus maritimus var, australiensis.

", sedge. Carex litorosa.

Sea weeds, 30, 31 .

Sedge. Carex.

Sedge family. Cyperacenc.

Seed-coat, 58.

Seed-plants of Autarctica, 212.

, classification of, 164.

,$\quad$ the introduced, $145,146,147$.
Selliera radicans, $38,209,210$.

Semi-leafless lawyer. Rubus subpuperaius.

Semi-whipcord koromikc. Teronica tetrasticha.

Semi-woody plants, 20.

Senecio, 10, 96, 165, 205.

, antipodus, 134.

, Banksii, 40.

" bellidioides, 19, 88, 149.

, Bidwillii, 113.

, bifistulosus, 191.

," cassinioides, 113.

," Christensenii, 188.

, compactus, 186.

, elaeagnifolius, 113.

, Greyi, 186.

", Hectori, 68, 187.

, Huntii, 139.

.. Kirkii, 56, 60.

, lagopus, 82, fig. 49.

, latifolius, 80, 184.

, lautus, 39.

, Lyallii, 103, 113, 193.

," mikanoides. 155.

, Monroi, 81, 188.

, perdicioides, 3 .

" revolutus, 191.

", rotundifolius, 35, 41, 192.

, saxifragoides, $82,189$.

, scorzoneroides, 103, 188.

,, Stewartice, 132, 136, 193.

, Turneri, 184.

Setchell, Professor W. A., 118.

Sharp-leaved totara. Podocurpus acutefolius.

Shawia, 205.

Shingle-slips, 106, 107, figs. 68,70 .

Shining - spleenwort. Asplenium adiantoides.

Shore-buttercup. Ranunculus acaulis.

" cotula. Cotula dioica.

, cress. Lepidium tenuicaule.

", dock. Rumex neglectus.

, eyebright. Euphrasia repens.

", forget-me-not. Myosotis abida.

", fuchsia. Fuchsia procumbens.

" gentian. Gentiana saxosa.

". groundsel. Senecio lautus.

", hard-fern. Blechnum Banksii.

", koromiko. Veronica elliptica.

" kowharawhara. Astelia Banksii.

", lobelia. Lubelia anceps.

" panax. Pseudopanax Lessonii.

", spleenwort. Asplenium obtusatum.

, stonecrop. Crassula moschata.

Shores, gravelly, 31. 32.

, rocky, 31,32 .

, sandy, 31 . 
Short-flowered cranesbill." Geranium sessiliflorum var. glabrum.

Shrub, 20.

$$
\begin{aligned}
& \text {, bushy, } 18 . \\
& \text { cypress-like, } 20 . \\
& \text { spiny, 20, fig. } 10 . \\
& \text { twiggy, } 18 .
\end{aligned}
$$

Shrub-fuchsia. Fuchsia Colensoi.

Shrubby honeysuckle. Alseusmia macro. phylla.

, nettle. Urtica ferox.

" pohuehue. Muehlenbeckia Astoni.

, ribbonwood. Plagianthus divaricatus.

Sicyos australis, 30, 143.

Sideroxylon novo-zelandicum, 18t, 211.

Silene anglica var. quinquevulnera, 29.

Silky alpine buttercup. Ranunculus sericophyllus.

Silver cushion-celmisia. Celmisia argenter.

, southern-beech. Nothofagus Menziesii.

"tree-fern. Cyathea dealbata.

., tussock. Poa caespitosa.

, tussock association, 86.

Silvery celmisia. (See Silver cushioncelmisia.)

, cotton-plant. Celmisia coriacea.

" sand-grass. Spinifex hirsutus.

silybum Marianum, 153.

Sinclair, Dr. Andrew, 9, 10.

Single crape-fern. Leptopteris hymenophylloides.

Siphonidium longiflorum, 76.

Shinnera, 205.

Skottsberg, Dr. Karl, 207.

Slender bluebell. Wahlenbergia gracilis.

., broom. Carmichnelia flagelli. formis.

everlasting. Helichrysum filicaule.

New Zealand celery. Apium filiforme.

d a is y. Lageno. phora pumila.

tree-fern. Dicksonia squarrosa.

Slender-flowered eyebright. Siphonidium longiflorum.

Slime-fungi. Myxomycetes.

Small craspedia. Craspedia minor.

, mountain club-moss. (See Alpine club-moss.)

, sen-holly. Eryngium vesiculosum.

, vegetable-sheep. Raoulia bryoides.

.. water-milfoil. Myriophyllum Votschii.

white clematis. Clematis hexasepala.
Small-flowered New Zealand jasmine.

Parsonsia capsularis.

Small-leaved cranesbill. Geranium micro. phyllum.

kuhuhu. Pittosporum obcordatum.

myrtle. Myrtus pendunculata.

Smith, J. Crosby, 197.

Smooth-leaved koromiko. Veronica leiophylla.

Snares, 135, figs. 85, 87.

Snowberry. Gaultheria antipoda.

Snow-celmisia. Celmisia viscosa.

" gentian. Gentianu corymbifera.

" groundsel. Senecio scorzoneroides.

Snowy mountain-foxglove. Ourisia macrocurpa.

Solander, Daniel Charles, 2.

Solanum nigrum, 212.

sodomaeum, 183.

Sonchus grandifolius, 140.

Sophora, 68, 70 .

, chathamica, 138.

, $\quad$ grandiflora, 58, 70, 184.

, microphylla, 18, 58, 70, 169, 202, 210 , fig. 8.

,. prostrata, 70.

, tetraptera, 202, 203.

Sorrel. Rumex Acetosella.

Southern-beech. Nothofagus.

Southern-beech forest, 48,64 , fig. 25 .

Southern rata. Metrosideros lucida.

"water-pimpernel. Samolus repens var. procumbens.

Spaniard. Aciphylla Colensoi.

Sparganium subglobosum, 122.

Spear-grass. Aciphylla squarrosa.

Species, definition of term, 162.

Speedwell. Veronica.

Spergularia, 28, 170.

Sphagnum, 122, 123.

, antarclicum var. ericetorum. 139.

Spiderwood. Dracophyllum latifolium.

Spineless piripiri. Acaena inermis.

Spinifex, 28.

,$\quad$ hirsutus, 33, fig. 19.

Spiny shrub, 20.

Spiraea Thunbergi, 58.

Spleenwort. Asplenium.

Spore, definition of term, 55 .

Sporodanthus Traversii, 139.

Spotted catchfly. Silene anglica var. quinquevulnera.

Spreading-orache. Atriplex patula.

Stackhousia minima, 169.

Stackhousiaceae, 169.

Star-lily. 'Arthropodium candidum.

Stellaria decipiens var. angustata, 135. 
Stellaria gracilenta, 150.

, Roughii, 106.

Stephen Island, 44.

Stewart Island, 63, 193.

spaniard. Aciploylla
Traillii.
vegetable-sheep. Raoulia
Goyeni.

Sticta, fig. 26. Goyeni.

Freycinetii, 134

Stilbocarpa, 135, 167.

", polaris, 133, 134.

, robusta, 135.

Stonewort. Chare, Nitella.

Stout dwarf broom. Carmichaelia Monroi. , water-milfoil. Myriophyllum robustum.

Stumpy tree-fern. Dicksonia lanata.

Suaeda maritima, 29, 38.

Subalpine belt, 99 .

, forest, $62,64,113$, figs. 25,35 , 36.

koromiko. Veronica subalpina. ". scrub, 111, 112, 113, figs. 36 , $50,76,78$

Subantaretic islands, 130 et seq. poa. Poa litorosa.

Succession, biological, 23, 79 .

Succulence, 29 topographical, 23.

Suckling-clover. Trifolium minus.

Sunday Island, 141.

Sundew, Droserc.

Sundew family. Droseraceae.

Supplejack. Rhipogonum scandens.

Suttonia, 205.

, chathamica, 138, 193, 197.

, Coxii, 141.

," divaricate, 45, 131.

, kermadecensis, 142.

Swainsona, 96, 107.

, novae-zelandiae, 107, 169.

Swamp-astelia. Astelia nervosa.

, broom. Carmichaelia paludosa.

" coprosmi. Coprosma tenuicaulis. cotula. Cotula coronopifolia.

fern. Dryopteris Thelypteris var. squamulosa.

forest, 63,193 , fig. 79 .

, heath. Dracophyllum paludosum.

, lawyer. Rubus schmidelioides.

", lily. Chrysobactron Hookeri. (The name bog-lily on p. 96 is a slip of the pen.)

matipo. Suttonia Coxii.

tree-daisy. Olearia virgata.

twig-rush. Cladium junceum.

willow-herb. Epilobium pallidi. florum.
Swamps, 119 et seq.

Sweetbrier. Rosa rubiginosu.

Sweet vernal. Anthoxanthum orloritum.

Tall mingimingi. Leucopogon fasciculatus.

, New Zealand broom. Carmichaelia odorata.

,, tussock-grassland, 86, 91, 92, fig. 52.

Tanekaha. Phyllocladus trichomanoides.

Taraire. Bcilschmiedia taraire.

Tarata. Pittosporum eugenioides.

Tarawera eruption, 75 , figs. 44, 45, 46.

Taraxacum magellanicum, 209.

$$
\text { ," officinale, 155, } 209 .
$$

Tauhinu. Cassinia leptophylle.

Tauhinu shrubland, 152.

Tauhinu-korokio. Cassinia retortu.

Taupata. Coprosma retusa.

Tawa. Beilschmierlia taure.

Tawa association, 62.

Tawapou. Sideroxylon nov-zenlundica.

Tawari. Ixerba brexioides.

Tawheoheo. Quintinia serratu.

Tawhero. Weinmannia sylvicola.

Taxaceae, 173.

Taxad, definition of term, 61 .

Taxad family. Taxacene.

Taxus, 61.

Te Nuehau, high-mountain plants of, 97.

Tendril-elimbers, $19,55,56$.

Tepralia, 207.

Teteawaka. Olearia angustifolia.

Tetrachondra, 208.

Hamiltonii, 167, 210.

Tetrachondraceae, 167, 208, 210.

Tetragonia, 28.

$$
\text { ," expansa, 31, } 142 .
$$

Tetrapathaea australis, 56, 189.

Thelymitra, 171.

Thick - leaved hard - fern. IBlechnum

\begin{tabular}{|c|c|c|}
\hline & kohuhu. & Pittosporum \\
\hline & polypody. & Cyclophorus \\
\hline & $\begin{array}{c}\text { serpens. } \\
\text { willow-herb. } \\
\text { crassum. }\end{array}$ & Epilobium \\
\hline
\end{tabular}
durum.

Thin-leaved tree-daisy. Olearia Hectori.

Thomas, Professor A. P. W., 177.

Three Kings karo. Pittosporum Fairchildii.

, milk - tree. Puratrophis Smithii.

Three-nerved cudweed. Gnaphatium trinerve.

Three-ribbed arrow-grass, Sucuelta maritima.

Three-square. Scirms americams. 
Thymelacaceae, 168.

Ti-rauriki. Cordyline pumilio.

Titoki. Alectryon excelsum.

Ti-tree. Cordyline.

Tmesipteris, 174, 175, 176.

" sexual stage, figs. pp. 175, 176.

Toad-rush.' Juncus bufonius.

Toatoa. Phyllocladus glaucus.

Todea barbara, 182.

Toetoe. Arundo conspicua.

Toetoe-whatumanu. Mariscus ustulatus.

Tolpis umbellata, 183.

Toothed medic. Medicago denticulata.

Toro. Rapanea salicina.

Toru. Persoonir toru.

Totara. Podocarpus totara.

Totara association, 62.

Townsonia, 206.

Travers, Henry H., 11.

Travers, IV. T. L., 9.

Traversia, 10, 96,165 .

Tree, bushy, 18. baccharoides, 113, 205.

Tree-coprosma. Coprosma arborea.

, daisy. Olearia.

" fern form, 19.

, ferns, 49 , fig. 7 .

" " most southerly locality for, 131, fig. 86.

, fuchsia. Fuchsia excorticata.

", heath. Dracophyllum arboreum.

", karamu. Coprosma chathamica.

", lupin. Lupinus arboreus.

, moss. Polytrichum dendroides.

, nettle. Urtica ferox.

Trees, deciduous, 68 .

, distribution of, 61,62 .

Triangular hard-fern. Blechnum vulcanicum.

Trichomanes, 57, 174 .

Trifolium, 146. reniforme, $60,174$.

, arvense, 149.

, minus, 149.

, repens, $149,153$.

Triglochin striatum var. filifolium, $3 \mathrm{~S}$.

Triodia exigua, 87, 88, 94 .

Trisetum, 96.

Tuft tree, 20 .

Tuhara. Cladium Sinclairii.

Tumatakuru. Discaria toumatou.

Tupeia antarctica, 20.

Turfy coprosma. Coprosma Petriei. , raoulia. Raoulia subsericea.

Tussock, burning the, 93 .

, grassland, $15,85,86$, figs. 13 , $51,52,55$.

, growth-form, 19.

", of subantarctic islands, 133 , frontispiece.
Tutsan. Hypericum Androsaemum.

Tutu. Coriaria sarmentosa.

Twiggy shrub, 18.

"tree-daisy. Olearia lineata.

Twining climbers, 19, 53, 54, 55.

Typha, 173.

," anqustifolia, 120, 121, 151, 181.

,, $\quad$,, var. Brownii, 121.

,,$\quad$ var. Iuelleri, 121.

Typhaceae, 173.

Ulex europaeus, 152.

Ulmus, 213.

Umbelliferae, 167.

Umbrella - fern. Gleichenia Cunning hamii.

Uncinia, 96, 172, 195, 207.

" compacta, 193.

" filiformis, $21:$.

" macrolepis, 208.

, perlicellata, 193.

Upright calceolaria. Jovellana Sinclairii.

Urtica australis, 193, 198.

"ferox, 28, 171.

" linearifolia, 171.

Urticaceae, 171.

Usnea articulata, 134.

Utricularia delicatula, 127.

$\begin{array}{ll}, & \text { Mairii, } 127 . \\ , & \text { monanthos, } 126 . \\ , & \text { provae-zelandiae, } 127 . \\ , & \text { protre, 127. }\end{array}$

Vancouver, Captain George, 4.

Variety, definition of term, 162.

Vegetable-sheep. Raoulia.

Vegetation, altitudinal belts of, 98, 99. definition of term, 14.

Verbascum Thapsus, 154.

Veronica, 96, 112, 166, 217.

" amabilis, 191, 192.

" annulata, 105, 192.

"anomala, 189.

" Astoni, 198.

" Barkeri, 140.

", Benthami, 133.

, Bollonsii, 45.

" breviracemosa, 142, 199.

"Buchanani, 105, 191.

"buxifolia, 110.

,

,9

,

, chathamica, 140.

, Cookiana, 40, 184.

, cupressoides, 112.

, Darwiniana, 18t.

" Dieffenbachii, 140.

"Dorrien-Smithii, 140.

" elliptica, 41, 42, 132, 184, 192, $198,209$. 
Weronica elliptica, distribution of, 42. epacridea, 105, 107.

Fonckii, 210.

Gibbsii, 105, 107 . gigantea, 137, 199.

Gilliesiana, 105. glaucophylla, 112.

Haastii var. macrocalyx, 107. Hectori, 192.

Hookeriana, 108, 183.

Hulkeana, 80, 81, 188.

insularis, 180.

juvenile leaves of, 71, fig. 39 .

laevis, 183.

Lavaudiana, 81, 189.

leiophylla, 83.

linifolia, 102, fig. 61 .

loganioides, 198.

Lyallii, 108.

lycopodioides, 105, 107, fig. 39.

Mackaui, 189.

macrantha, 104.

macroura, 104, 184.

monticola, 112.

number of species, 166 .

odora, 193.

parviflora, 77.

Petriei, 192.

pimelioides var. minor, 88 .

pinguifolia, 105, 109.

Poppelwellii, 192.

pulvinaris, 109.

Raoulii, 105.

rupicola, 105, 188.

salicifolia, 41, 79, 121, 137, 152, 199,210

var. Atkinsonii, 40 , 186.

var. Atkinsonii, leafform of, 71, fig. p. 71 .

" var. communis, 192. 184.

salicomioides, 124.

sect. Hebe, 207.

spathulata, 108, 183.

subalpina, 112, 151.

tetragona, 183.

tetrasticha, 105, 107.

Traversii, 112.

tumida, 105.

unnamed species, 40.

Vicia, 146. vernicosa, 112

Viola, 168

, Cunninghamii, 128, fig. 95.

Violaceae, 168.

Violet family. Violaceae.
Viper's-bugloss. Echium valgare.

Vitex lucens, 59, 184, 211.

Wahlenbergia, 96.

$\begin{array}{ll}, & \text { albo-marginata, } 87,165 . \\ & \text { cartilaginea, 107, } 188 . \\ & \text { gracilis, } 87 . \\ \text { Matthewsii, 81, } 188 . & \end{array}$

Waiu-atua. Rhabdothamnus Solandri.

Wall, Professor Arnold, 82.

Wandering dunes, 33, fig. 18.

Wanganui River, its rock-vegetation, 80 .

Warming, Professor E., 15.

Water-buttercup. Ranunculus aquatilis.

, chickweed. Montia fontana.

" cress. Radicula Nasturtium aquaticum.

, fern. Histiopteris incisa.

" milfoil. Myriophyllum.

, starwort. Callitriche.

Weed, definition of term, 155 .

Weinmannia racemosa, 18, 63, 65, 100, $170,210$.

, sylvicola, $60,61,182,183$, 210.

, , non-flowering juvenile, 74 .

Welwitschia mirabilis, 173 .

Wet-rock koromiko. Veronica.linifolia.

Whakou, 58.

Wharangi. Melicope ternata.

Whauwhaupaku. Nothopanax anomalum.

Whipcord veronica, 20.

White clematis. Clematis indivisa.

, climbing-rata. Metrosideros albi. flora.

clover. Trifolium repens.

" clover. Irifolium repens.

", cushion-celmisia. Celmisia sessili. flora.

, flowers, conspicuousness of, 101.

, mountain-musk. Celmisia incana.

"tea-tree. Leptospermum ericoides.

White-leaved lawyer. Rubus schmide-

lioides var. coloratus.

Wild celery. Apium prostratum.

, irishman. Discaria toumatou.

" rice. Zizania aquatica.

Willow. Salix.

Willow-herb. Epilobium.

Willow-herb family. Onagraceae.

Wind-pollination, 59 .

Wind-scrub, North Cape, 77.

, Wellington hills, 77.

Wineberry. Aristotelia racemosa.

Winged thistle. Carduus pycnocephalus.

Winter coloration, 114.

Winter's bark. Drimys Winteri.

Wire-rush. Hypolaena lateriflora. 
Wiry matipo. Sutlonire diraricata.

"snowberry. Gaultheria perplexa.

Wood-rush. Luzula.

Yellow alpine buttercup. Ranunculus Godleyanus.

, clematis. Clematis Colensoi.

", eyebright. Euphrasia Cockayniana.

" forget-me-not. IIyosotis australis.

" kowhai. Sophora.

" monkey-flower. Mimulus luteus.
Yellow oxalis. Oxalis corniculata.

: pine Dacrydium intermedium.

Yellow-prickled lawyer. Rubus cissoides.

Yew. Taxus.

Yorkshire fog. Holcus lanatus.

Zanichellia, 173.

Zizania aquatica, 183

Zostera, 28, 173

" nana, 31

tasmanica, 31 .

Zoysia pungens, 210.

Marcus F. Marks, Government Printer, Wellington.-1919. 



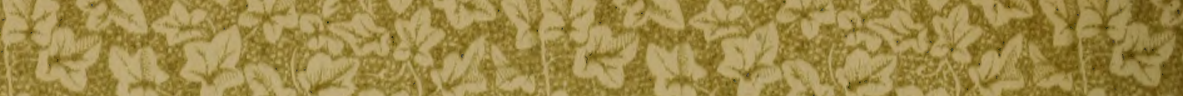

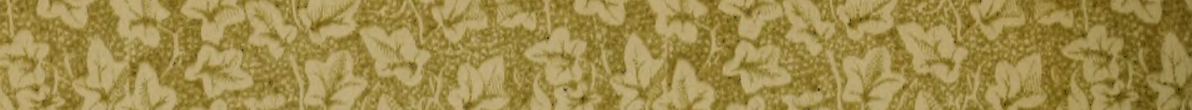

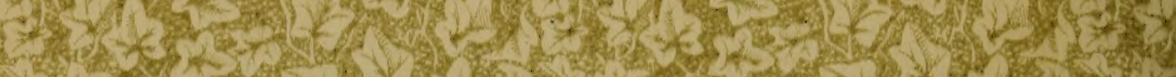

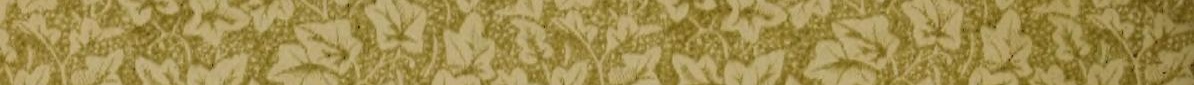

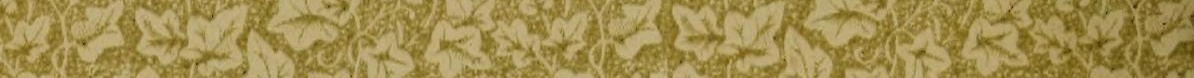

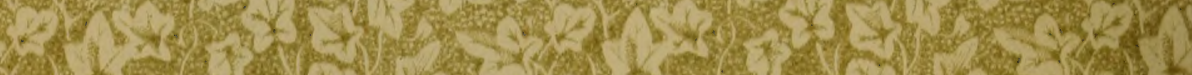

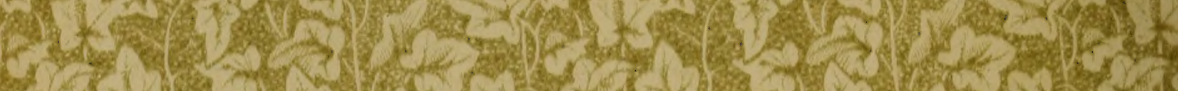

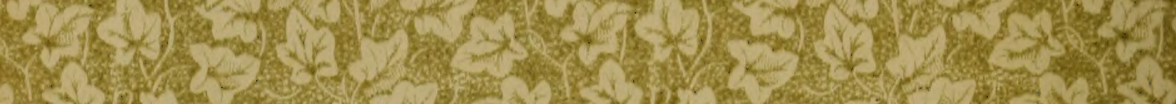

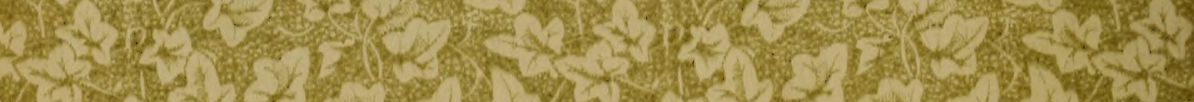

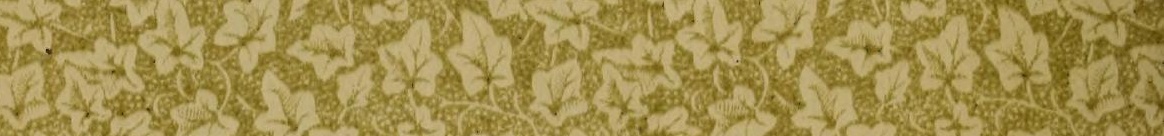

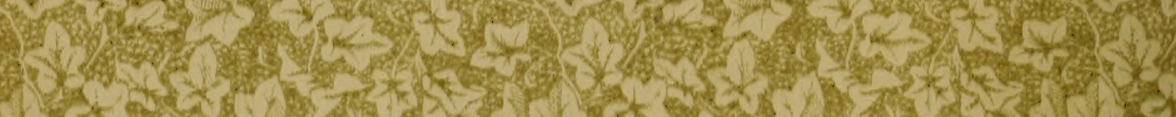

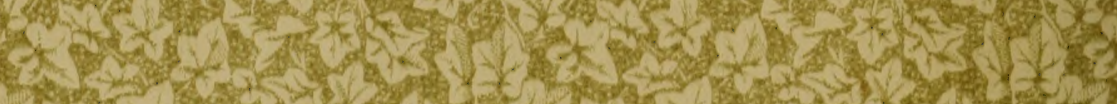

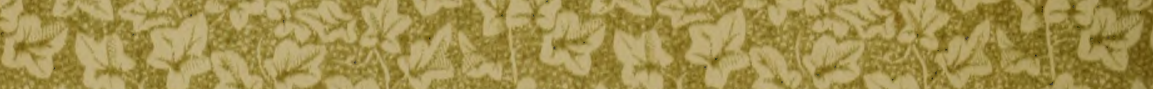
(5)

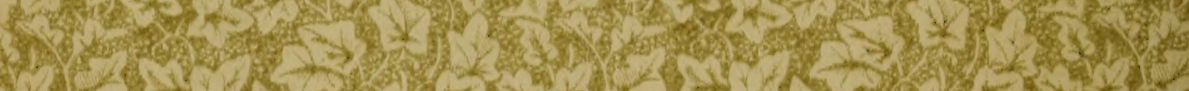

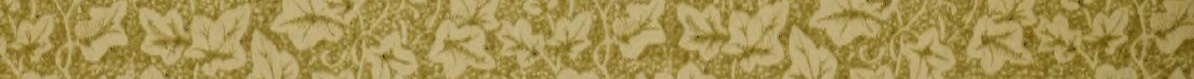

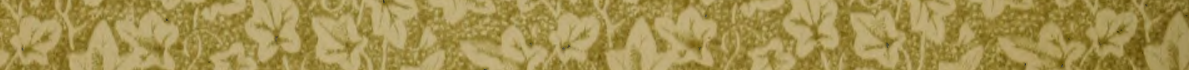

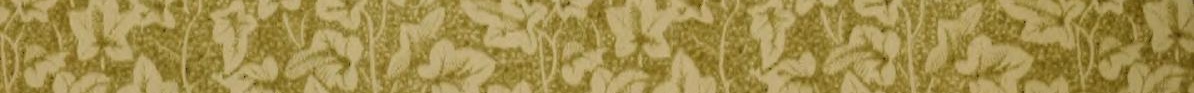

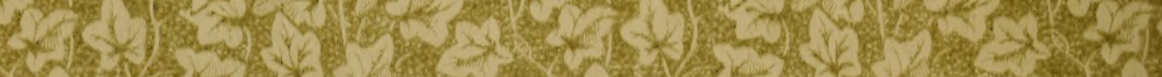

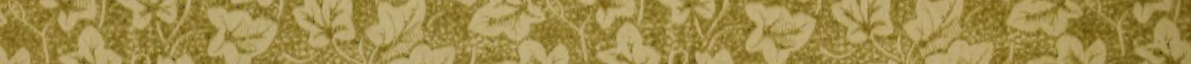

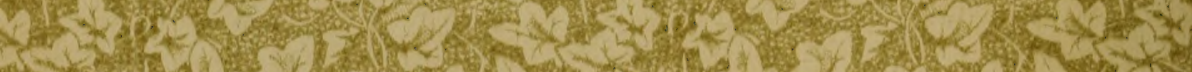

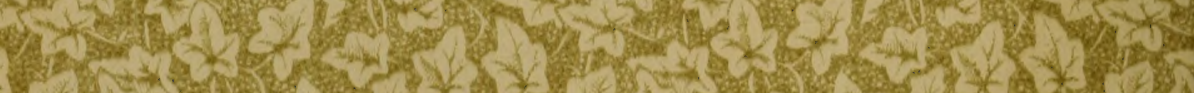

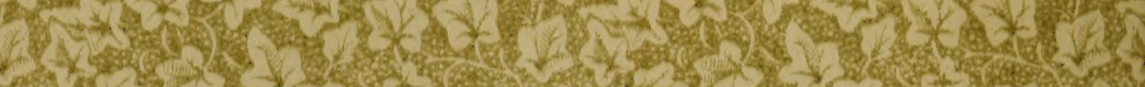

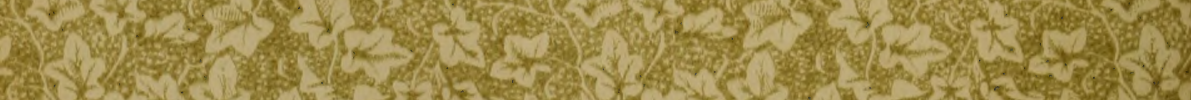
(1)

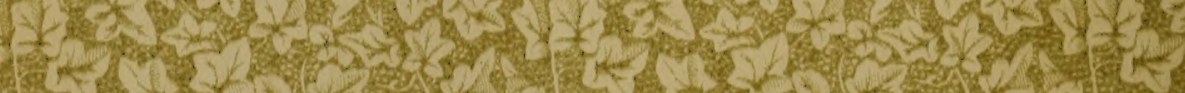

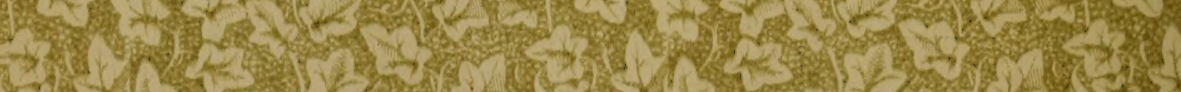

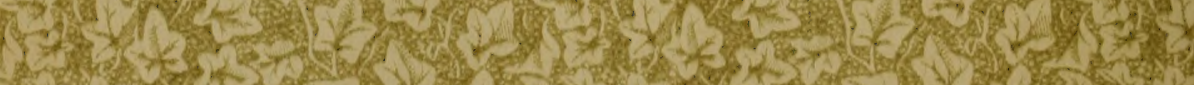
6.

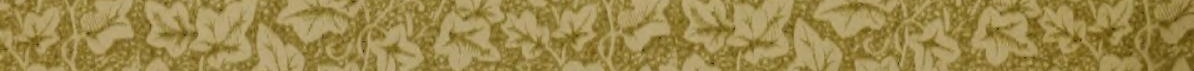

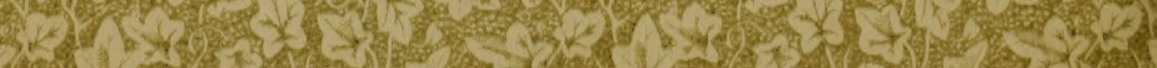

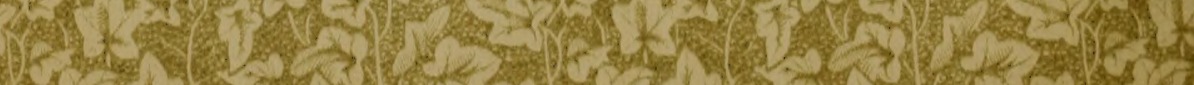

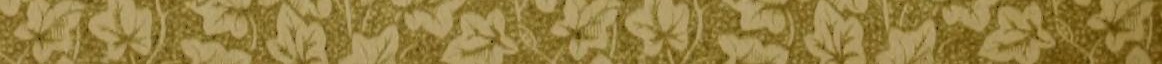


New York Botanical Garden Library

QK $460 . C 58651919$

Cockayne, L./New Zealand plants and thei

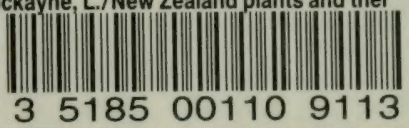

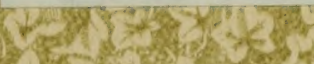

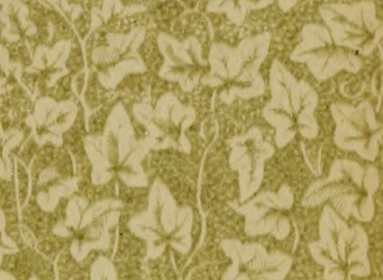

1.tr 3 . 
